\title{
WRR
}

WETENSCHAPPELIJKE RAAD VOOR HET REGERINGSBELEID

\section{Bijdragen aan \\ waarden en normen}

P.T. de Beer en C.J.M. Schuyt (red.) 
De serie 'Verkenningen' omvat studies die in het kader van de werkzaamheden van de WRR tot stand zijn gekomen en naar zijn oordeel van zodanige kwaliteit en betekenis zijn, dat publicatie gewenst is. De verantwoordelijkheid voor de inhoud en de ingenomen standpunten berust bij de auteurs.

De WRR is gevestigd:

Plein 1813, nr. 2-4

Postbus 20004

2500 EA 's-Gravenhage

Telefoon 070-35646 oo

Telefax 07o-356 4685

E-mail info@wrr.nl

Website http://www.wrr.nl 


\section{WRR}

WETENSCHAPPELIJKE RAAD VOOR HET REGERINGSBELEID

\section{Bijdragen aan waarden en normen}

P.T. de Beer, C.J.M. Schuyt (red.) 
ISBN 90-5356-66o-O 


\section{VOORWOORD}

Over waarden en normen wordt zeer uiteenlopend gedacht. Volgens sommigen gaat het bij de discussie over waarden en normen over de grondslagen van onze samenleving, terwijl anderen iedere discussie over waarden en normen zinloos vinden. Sommigen signaleren een schrikbarend verval van normen en waarden, waar anderen vooral stabiliteit en continuïteit zien. Sommigen maken zich vooral druk om het gebrek aan fatsoen van de hedendaagse burger, anderen maken zich zorgen om de botsing tussen culturen en waardestelsels. Sommigen zien de individualiseringstrend als de bron van het kwaad, terwijl anderen juist de volgzaamheid en het gebrek aan individuele verantwoordelijkheid van bepaalde groepen laken.

In zijn rapport Waarden, normen en de last van het gedrag, dat de Wetenschappelijke Raad voor het Regeringsbeleid in december 2003 op verzoek van de regering heeft uitgebracht, probeert de WRR niet alleen enige orde aan te brengen in de grote verscheidenheid aan onderwerpen die onder de noemer 'waarden en normen' ter sprake worden gebracht. De WRR geeft tevens aan wat naar zijn mening de belangrijkste problemen ten aanzien van waarden en normen zijn. Het was hierbij onvermijdelijk dat een groot aantal zaken die in de discussie over waarden en normen aan de orde komen, niet of slechts terloops kon worden behandeld. Mede op verzoek van de regering heeft de WRR daarom getracht ook een bredere discussie over waarden en normen te stimuleren door achttien deskundigen van buiten de WRR te vragen hun licht te laten schijnen op een specifiek aspect of een specifieke invalshoek van de 'waarden- en normenproblematiek'. Deze WRRVerkenning, onder de titel Bijdragen aan waarden en normen, vormt hiervan de neerslag. De bijdragen bestrijken een groot aantal terreinen - van het onderwijs tot de media en van het bedrijfsleven tot de gezondheidszorg - en vertegenwoordigen uiteenlopende standpunten. Van de meeste bijdragen is een eerste versie besproken op een werkconferentie die de WRR op 11 juni 2003 organiseerde. Dank is verschuldigd aan de deelnemers aan deze conferentie voor hun vrijmoedige commentaar op de daar gepresenteerde papers. De tekst van de bijdragen is eind november 2003 gereed gemaakt voor publicatie. De WRR heeft bij het schrijven van zijn rapport dankbaar gebruikgemaakt van inzichten uit deze bijdragen. De verantwoordelijkheid voor de inhoud van deze Verkenning berust echter geheel bij de afzonderlijke auteurs.

Met de publicatie van deze Verkenning Bijdragen aan waarden en normen hoopt de WRR, in aanvulling op het rapport Waarden, normen en de last van het gedrag, bij te dragen aan de verbreding en verdieping van het maatschappelijke debat over waarden en normen. Ik ben de auteurs van deze bijdragen die dit mogelijk hebben gemaakt, hiervoor zeer erkentelijk.

Prof. mr. M. Scheltema

Voorzitter WRR 


\section{INHOUDSOPGAVE}

Voorwoord

$1 \quad$ Inleiding

P.T. de Beer en C.J.M. Schuyt

2 Hoger, harder, sneller... en de prijs die men daarvoor betaalt

G. van den Brink

3 Politiek van preken en praktijken: het 'normen- en waardendebat' als reactie op de 'verplaatsing van de politiek'

G. de Vries

3.1 Inleiding

3.2 De opkomst en verspreiding van het normen- en waardenvocabulaire

3.3 De armoede van het normen- en waardenvocabulaire

3.4 Liberalisme, communitarisme en republikanisme: de rol van de overheid

3.5 De verplaatsing van de politiek

$4 \quad$ Bevrijdende waarden en bindende normen in de publieke moraal

H.E.S. Woldring

4.1 Inleiding: meer dan fatsoen

4.2 Fundamentele waarden

4.3 Normen

4.4 Publieke moraal in een pluralistisch-democratische samenleving

60

4.5 Mogelijkheden tot bijdragen aan de publieke moraal 63

4.6 Inhoudelijke bijdragen aan de publieke moraal 66

$\begin{array}{ll}4.7 & \text { Evaluatie } \\ & 72\end{array}$

5 De aanvaarding en naleving van rechtsnormen door burgers: participatie, informatieverschaffing en bejegening

M. Malsch

5.1 Inleiding

5.2 Maatschappelijke veranderingen in criminaliteit en rechtspleging 79

$\begin{array}{lll}5.3 & \text { De theorie van procedurele rechtvaardigheid } & 81\end{array}$

$\begin{array}{lll}5.4 & \text { Kenmerken van een rechtvaardige procedure } & 84\end{array}$

$\begin{array}{lll}5.5 & \text { Participatie } & 88\end{array}$

$\begin{array}{lll}5.6 & \text { Informatieverschaffing } & 92\end{array}$

$\begin{array}{lll}5.7 & \text { Bejegening } & 95\end{array}$

$\begin{array}{lll}5.8 & \text { Conclusies en aanbevelingen } & 97\end{array}$

$\begin{array}{lll}5.9 & \text { Tot besluit } & 100\end{array}$ 
6 Stadsetiquette: over waarden, normen en collectieve zelfredzaamheid van burgers

R.F.W. Diekstra

6.1 Inleiding

6.2 Achtergrond van de Rotterdamse Stadsetiquette: de rol van geloof in collectieve zelfredzaamheid

6.3 Een korte geschiedenis van de Rotterdamse Stadsetiquette

6.4 Stadsetiquette avant la lettre

6.5 De straatladder

6.6 Het taakanalysemodel

6.7 Stadsetiquette: consensus over waarden en normen

6.8 De Ideale Straat

6.9 Stadsetiquette-experimenten

$\begin{array}{ll}\text { 6.10 Stadsetiquette: proces en product } & 129\end{array}$

6.11 Eigenaarschap

6.12 Het betrekken van jong en oud 130

$\begin{array}{ll}6.13 & \text { Belemmeringen en beperkingen } \\ 6.14 & 131\end{array}$

$\begin{array}{ll}6.14 & 132\end{array}$

$\begin{array}{lll}7 & \text { De dynamische gemeente } & 137\end{array}$

J. van Lidth de Jeude

7.1 Over normen en waarden op lokaal niveau

7.2 Overheid als stimulator van creativiteit: meer kunst op de basisschool

$\begin{array}{ll}\text { 7.3 Over het handhaven en naleven van regels } & 141\end{array}$

$8 \quad$ Opvoeding en de overdracht van waarden en normen $\quad 147$

\section{B. Levering}

8.1 Vooraf

8.2 Over 'ware' morele kennis

8.3 Waar komt dat primitieve beeld van de overdracht van waarden en normen in de opvoeding vandaan?

8.4 Balans van de overheidsbemoeienis met de opvoeding in de afge$\begin{array}{ll}\text { lopen halve eeuw } & 158\end{array}$

8.5 Veranderingen in de omgang tussen ouders en kinderen $\quad 161$

8.6 Anti-vandalismebeleid in Montfoort. Een persoonlijk verhaal $\quad 167$

8.7 Achteraf

9 Gedragsregels op school en de noodzaak die ook daadwerkelijk te handhaven

\section{L.G.M. Prick}

Io De pedagogische opdracht van het onderwijs: aangrijpingspunten en beperkingen 
10.2 Ontwikkelingen in de aandacht voor waarden en normen in het onderwijs

10.3 Waarom opnieuw aandacht voor waarden en normen in het onderwijs?

10.4 Waarden en normen: aanknopingspunten in het onderwijs

10.5 Beperkingen bij de invulling van de pedagogische taak van de school 202

10.6 De rol van de overheid 208

10.7 Ten slotte 211

$\begin{array}{ll}11 & \text { Normoverschrijding en allochtone jongeren }\end{array}$

S. Harchaoui

11.1 Inleiding

11.2 Kenmerken van het Nederlandse debat

11.3 Allochtone criminaliteit als manifestatie van normafwijking 223

11.4 Religieus conservatisme ter illustratie van normafwijking 231

11.5 Gevolgen van een niet in goede banen geleid debat 232

11.6 Convergerende processen: stille en ongeziene emancipatieprocessen

11.7 Conclusie: tijd voor een evenwichtig en helder debat 241

12 De waarde van waarden $\quad 251$

W. Groot en H. Maassen van den Brink

$\begin{array}{lll}12.1 & & 251\end{array}$

12.2 Het dominante economisch marktdenken 254

12.3 De economische betekenis van normen: de waarde van vertrouwen en integriteit $\quad 256$

12.4 Normafwijkend gedrag in het bedrijfsleven en bij de overheid 260

12.5 Economisering van normen en waarden binnen huishoudens 264

$\begin{array}{lll}12.6 & \text { Conclusie } & 269\end{array}$

13 Waarden doen ertoe in de economie 275

$\begin{array}{ll}\text { A. Klamer } & \\ \text { Inleiding } & 275\end{array}$

$\begin{array}{lll}\text { 13.1 } & \text { Inleiding } & 275 \\ 13.2 & \text { Het cultureel-economisch perspectief } & 276\end{array}$

$\begin{array}{lll}\text { 13.3 Met betrekking tot waarden } & 277\end{array}$

$\begin{array}{lll}13.4 & \text { Twee voorbeelden } & 278\end{array}$

13.5 Economische, sociale en culturele waarden $\quad 282$

13.6 De markt en de overheid 286

$\begin{array}{lll}13.7 & \text { De oikos en de derde sfeer } & 289\end{array}$

$\begin{array}{ll}13.8 & \text { Vermenging van de sferen }\end{array}$

13.9 De Nederlandse constellatie 294

$\begin{array}{lr}\text { 13.10 Beleidsconsequenties } & 296\end{array}$

14 Onderzoek het goede: waardebeheer in de gezondheidszorg 301 A. Mol

$\begin{array}{lll}\text { 14.1 Achtergrond } & 303\end{array}$

$\begin{array}{ll}14.2 & \text { Biomedisch en sociaal } \\ & 308\end{array}$ 
14.3 Doelen en middelen 311

$\begin{array}{ll}14.4 & \text { Delibereren en doen } \\ 14.5\end{array}$

$\begin{array}{ll}14.5 & \text { Conclusie } \\ \end{array}$

15 Waardestelsels in en rond de media 325

$\begin{array}{ll}\text { 15.1 Inleiding } & 325\end{array}$

15.2 Waarden en normen binnen de samenleving 327

15.3 De normen van de organisatie waarvoor iemand werkzaam is $\quad 337$

15.4 De mores binnen de beroepsgroep 343

$\begin{array}{ll}\text { 15.5 De privé-normen van het individu } & 347\end{array}$

$\begin{array}{lll}15.6 & \text { Afsluitend } & 350\end{array}$

16 Als de leugen regeert, wie brengt haar dan in omloop? Media, overheid en het debat over waarden en normen 355

O. Scholten

$\begin{array}{lll}16.1 & & 355\end{array}$

16.2 Journalistiek: drie observaties van Weber 356

$\begin{array}{lll}16.3 & 357\end{array}$

16.4 Maatschappelijke context : ICT/internet en journalistiek 358

16.5 Maatschappelijke context: multiculturele samenleving en
journalistiek 360

16.6 Maatschappelijke context: marktdenken $\quad 361$

$\begin{array}{lll}16.7 & \text { Politieke crises en journalistiek } & 362\end{array}$

16.8 Maatschappelijke context: transparantie en journalistiek 364

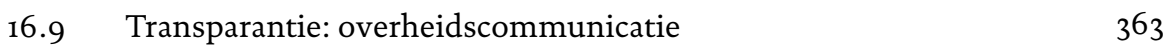

16.10 Media, maatschappelijke verantwoordelijkheid en verantwoording $\begin{array}{ll}\text { afleggen } & 367\end{array}$

$\begin{array}{lll}16.11 & \text { Media en verantwoording afleggen } & 369\end{array}$

16.12 Verantwoordelijkheid en verantwoording afleggen 370

17 Context en verantwoordelijkheid; bijdrage aan het $\begin{array}{ll}\text { normen- en waardendebat } & 383\end{array}$

H.P.M. Adriaansens

$\begin{array}{lll}17.1 & \text { Inleiding } & 383\end{array}$

$\begin{array}{lll}17.2 & \text { Begripsmatige afbakening } 384\end{array}$

17.3 De opkomst van individueel verantwoordelijkheidsbesef als
kernwaarde

17.4 Conflict versus onverschilligheid 386

17.5 Duurzame bevordering van individueel verantwoordelijkheidsbesef 387

17.6 De dimensies van maatschappelijke organisatie: schaal, sturing en samenhang $\quad 388$

17.7 Drie ontwikkelingsprincipes voor sociale infrastructuur 390

$\begin{array}{lll}17.8 & \text { Slot } & 397\end{array}$

$\begin{array}{ll}\text { Over de auteurs } & 401\end{array}$ 
Maatschappelijke discussies roepen soms meer verwarring op dan dat zij verhelderen. De oorzaak daarvan is niet zelden gelegen in het feit dat de deelnemers aan het debat geheel verschillende interpretaties geven aan het onderwerp waarover zij van mening verschillen. Meestal ebben dergelijke discussies na verloop van tijd weg, zonder dat zij tot een duidelijke conclusie, laat staan tot consensus hebben geleid. Blijkbaar is de urgentie van het onderwerp dan afgenomen en dienen zich nieuwe thema's voor het maatschappelijke debat aan. Voorbeelden van dergelijke, weinig vruchtbare debatten in het afgelopen decennium zijn die over individualisering, sociale cohesie, integratie en globalisering. Als men het al niet eens is over wat men onder deze begrippen verstaat, is het niet verwonderlijk dat een discussie daarover al snel in een gesprek tussen doven ontaardt, of, wat misschien een betere vergelijking is, een gesprek tussen mensen die elkaars taal niet spreken.

Ook het maatschappelijke debat over waarden en normen loopt een gedegen

risico dit lot beschoren te zijn. Meer nog dan begrippen als 'individualisering' en 'integratie' leent het begrippenpaar 'waarden en normen' zich immers voor een strikt persoonlijke interpretatie: ieder kan er onder verstaan wat hem of haar van pas komt. De termen zijn zo breed en abstract dat welhaast ieder ongenoegen, ieder heet hangijzer, ieder stokpaardje zich gemakkelijk onder de noemer van 'waarden en normen' laat vangen. Het afgelopen jaar zijn dan ook zulke uiteenlopende zaken als de gebrekkige integratie van allochtonen, de omvangrijke criminaliteit, het toenemende onfatsoen van medeburgers, de 'exhibitionistische zelfverrijking' van topmanagers en de overmaat aan seks en geweld in de commerciële media als waarden- en normenprobleem aan de orde gesteld. En dit vormt dan nog slechts een kleine selectie van wat men allemaal onder 'waarden en normen' kan vatten.

Een van de oogmerken van het rapport Waarden, normen en de last van gedrag, dat de Wetenschappelijke Raad voor het Regeringsbeleid (WRR) in december 2003 heeft uitgebracht, is dan ook om enige terminologische klaarheid te brengen in het waarden- en normendebat. Hiertoe zijn in het rapport uiteenlopende betekenissen van de begrippen waarden en normen geïnventariseerd. Vervolgens heeft de WRR uit het brede scala aan mogelijke interpretaties een keuze gemaakt, waarop hij zich in zijn rapport heeft geconcentreerd. Deze inperking was noodzakelijk om in één rapport het brede thema van waarden en normen op een zinvolle en coherente wijze te kunnen behandelen. Ze heeft echter onvermijdelijk als consequentie dat een aantal onderwerpen die in het kader van de waarden- en normendiscussie de revue zijn gepasseerd, in het rapport van de WRR onbesproken blijft of slechts terloops wordt aangestipt. Te denken valt onder meer aan waarden en normen in relatie tot de opvoeding, in het econo- 
mische verkeer en in medische praktijken. Dat deze onderwerpen in het WRR-rapport weinig of geen aandacht krijgen, betekent geenszins dat de WRR de relevantie en het belang ervan zou willen ontkennen.

Om ook de discussie te stimuleren over de uiteenlopende aspecten van de waarden- en normenproblematiek die buiten het kader van het rapport Waarden, normen en de last van gedrag vallen, heeft de WRR een groot aantal externe deskundigen gevraagd om een discussiebijdrage te schrijven over een specifiek thema dat verband houdt met de 'waarden- en normenproblematiek'. Deze bijdragen treft $\mathrm{u}$ aan in de voorliggende Verkenning, die dan ook de passende titel Bijdragen aan waarden en normen draagt. Overigens bevat deze Verkenning ook een aantal bijdragen over thema's die wel aan de orde komen in het WRR-rapport aan de regering. Bij het schrijven van het rapport heeft de WRR dan ook dankbaar gebruikgemaakt van deze bijdragen, als bron van inspiratie en als tegengeluid om de eigen opvattingen aan te spiegelen. Van de meeste bijdragen aan deze bundel is een eerste versie besproken op een besloten werkconferentie die de WRR op 11 juni 2003 in Den Haag heeft gehouden. Wij willen de deelnemers aan deze conferentie graag danken voor hun stimulerende bijdrage aan de discussie over de daar gepresenteerde papers. In de openingstoespraak van deze conferentie presenteerde Paul Schnabel een aantal cijfers van het Sociaal en Cultureel Planbureau (SCP) over de dominante opvattingen onder de bevolking. Hij confronteert een aantal 'moderne' waarden met meer 'traditionele' waarden en schetst de botsingen die daaruit kunnen voortvloeien. Naar deze bijdrage wordt verwezen in het WRR-rapport Waarden, normen en de last van het gedrag (Schnabel, 2004).

Deze Verkenning opent met een algemene sociaal-culturele beschouwing over de dynamiek in waarden en normen. Gabriël van den Brink baseert zich op cijfers van het SCP om een aantal, ogenschijnlijk tegenstrijdige trends in de waarden en normen van de Nederlandse bevolking in kaart te brengen. Hij constateert dat er, anders dan vaak wordt aangenomen, eerder sprake is van een geleidelijke ophoging dan van een afkalving van normen. Maar juist omdat men hogere eisen stelt, stoort men zich vaker aan anderen die zich niet aan de normen houden. Toenemende zorg over normoverschrijding hoeft dus niet per se het gevolg te zijn van een 'verslechtering' van het gedrag van de gemiddelde burger. Niettemin dient men de toenemende onvrede wel serieus te nemen, stelt Van den Brink. Een periode waarin men steeds toleranter is geworden tegenover 'normafwijkend' gedrag, is inmiddels afgesloten, en sinds het midden van de jaren negentig ligt de nadruk op het streven naar convergentie in de waarden en normen van de Nederlandse bevolking.

De twee hierop volgende bijdragen gaan over de rol van de overheid ten aanzien van waarden en normen. Gerard de Vries is zeer sceptisch over de vraag of de overheid een rol te spelen heeft bij de overdracht en handhaving van waarden en normen. Hij is van mening dat het debat over waarden en normen veeleer de aandacht afleidt van de zaken waar het werkelijk om gaat. In plaats van een 'zinloos waarden- en normendebat' te voeren dient de overheid sociale integratie 
te bevorderen door concrete maatregelen op het terrein van gezondheidszorg, onderwijs, sociale zekerheid, ouderenzorg en milieu. Henk Woldring daarentegen is van mening dat het denken in termen van waarden en normen wel degelijk een belangrijke inspiratiebron kan bieden voor het overheidsbeleid. Hij erkent weliswaar dat het in een liberale democratische samenleving niet aan de overheid is om een specifiek waarden- en normenpatroon op te leggen. Niettemin stelt hij dat verschillende politieke stromingen een belangrijke bijdrage aan het politieke debat kunnen leveren door, ieder vanuit haar eigen levensbeschouwelijke achtergrond, aan te geven op welke fundamentele waarden zij hun stellingname baseren. Hij illustreert dit aan de hand van een vijftal centrale christelijke waarden: rechtvaardigheid, solidariteit, verantwoordelijkheid, duurzaamheid en vrijheid.

De volgende drie bijdragen richten de aandacht op enkele concrete problemen ten aanzien van de relatie tussen normen en gedrag. Marijke Malsch vraagt zich af op welke wijze kan worden bevorderd dat wettelijk vastgelegde rechtsnormen door de burgers worden aanvaard. Hierbij concentreert zij zich op het proces van de rechtspleging. Zij laat zien dat door burgers meer actief te betrekken in de rechtsgang, door hun meer informatie te verschaffen en door een fatsoenlijke bejegening van verdachten kan worden bevorderd dat burgers de uitkomst van het rechtsproces aanvaarden en de kans op herhaling van de wetsovertreding afneemt. Terwijl Malsch zich in haar bijdrage richt op formele, wettelijke normen, beschrijft René Diekstra hoe de overeenstemming over en naleving van informele, sociale normen kan worden gestimuleerd. Hij doet dit aan de hand van de ervaringen met de stadsetiquetten in Rotterdam. Afspraken tussen de bewoners van een buurt of straat onderling over een aantal eenvoudige gedragsregels kunnen het vertrouwen van de burgers in elkaar vergroten en de sociale cohesie versterken. Diekstra geeft echter ook aan dat een dergelijke aanpak alleen werkt in buurten waar nog van enige sociale samenhang sprake is. Stadsetiquette lijkt dus geen oplossing te bieden voor de buurten waar de problemen het grootst zijn. Daar zal veelal direct optreden van de (lokale) overheid nodig zijn.

James van Lidth de Jeude gaat nader in op die rol van de lokale overheid. Hij laat zien hoe met de wijkaanpak in de gemeente Deventer bewoners worden ondersteund, die actief willen proberen verbeteringen in hun wijk aan te brengen. Hij noemt dit de copernicaanse wending in het lokale bestuur: niet het handelen van instituties staat centraal, waarbij dan burgers betrokken worden, maar het handelen van burgers, waarbij instituties betrokken worden. Voorts houdt hij een pleidooi voor meer kunstzinnige vorming in het onderwijs, al vanaf de basisschool. In het concept van 'de brede school' komen zo gemeentelijke initiatieven en activiteiten van leerlingen en andere burgers op het terrein van kunst en sport bij elkaar.

Hierna volgen vier bijdragen waarin de aandacht wordt gericht op de rol van diverse maatschappelijke instituties die zijn betrokken bij de overdracht en handhaving van waarden en normen bij kinderen en jongeren. Bas Levering heeft 
grote twijfels over de zinvolheid van een directe overdracht van waarden en normen in de opvoeding. Simpel gezegd is zijn boodschap dat het weinig zin heeft te praten over waarden en normen, maar dat het vooral een kwestie is van 'goed voorbeeld doet goed volgen'. Als we ons zorgen maken over het gedrag van de jongeren, dan moeten we eerst naar ons eigen gedrag kijken: blijkbaar hebben we hun het verkeerde voorbeeld gegeven. Ook Leo Prick moet weinig hebben van pogingen om waarden en normen direct over te dragen in het onderwijs. Het is veel belangrijker en urgenter dat scholen het gedrag van hun leerlingen direct bijsturen door duidelijke regels voor het gedrag op school te formuleren en deze vervolgens ook te handhaven.

Ria Bronneman-Helmers geeft een historisch overzicht van het denken en het debat over de rol van het onderwijs bij de overdracht van waarden en normen, ook wel aangeduid als de pedagogische opdracht van het onderwijs. Zij laat zien dat de grondwettelijke vrijheid van onderwijs hierbij op de achtergrond steeds een belangrijke rol heeft gespeeld en (mede) verklaart waarom de overheid zich nooit direct heeft gemengd in de waarden- en normenoverdracht in het onderwijs. Evenals Prick is zij van mening dat de meeste winst valt te behalen door de nadruk te leggen op de omgangsvormen op school. Zij wil daarbij echter niet alleen de aandacht richten op het tegengaan van normoverschrijdend gedrag, maar juist ook op het bevorderen van sociaal gedrag, bijvoorbeeld door het organiseren van buitenschoolse activiteiten. Sadik Harchaoui richt zich op normoverschrijdend gedrag van een specifieke groep jongeren, die de laatste tijd in het spotlicht van de belangstelling staat, te weten de allochtone jongeren. Hij plaatst de (vermeende) hoge criminaliteit onder allochtone jongeren in een ander perspectief door erop te wijzen dat in een aantal vormen van criminaliteit die doorgaans minder aandacht krijgen, zoals witteboordencriminaliteit, allochtonen juist ondervertegenwoordigd zijn. Er is ook weinig reden om de hoge criminaliteit onder bepaalde groepen primair als een cultureel bepaald fenomeen te beschouwen, dat direct samenhangt met de etnische herkomst. Harchaoui relateert de criminaliteit onder jonge allochtonen veeleer aan de specifieke sociaaleconomische positie die zij innemen en aan de dominante houding onder de Nederlandse bevolking ten opzichte van allochtonen.

De volgende vijf bijdragen aan deze Verkenning gaan in op de rol van waarden en normen in drie specifieke sectoren van de samenleving. Wim Groot en Henriëtte Maassen van den Brink, en Arjo Klamer beantwoorden de vraag welke rol waarden en normen spelen in de economie. Groot en Maassen van den Brink betogen dat de veronderstelling dat het dominante marktdenken bepaalde nieteconomische waarden en normen erodeert op een misvatting berust. Waarden zijn juist essentieel voor een goed functionerende economie, terwijl een transparante markt normoverschrijdend gedrag kan tegengaan. Huns inziens is er dus geen tegenstelling tussen marktwerking enerzijds en breed gedeelde waarden en normen anderzijds, maar kunnen zij elkaar juist wederzijds ondersteunen. Dat er geleidelijk veranderingen optreden in het dominante waarden- en normenpatroon, waarbij de nadruk verschuift van de collectiviteit naar het individu, 
wordt naar hun mening verklaard door sociale en culturele ontwikkelingen die buiten het economische domein liggen.

De analyse van Klamer staat in een aantal opzichten haaks op die van Groot en Maassen van den Brink. Hij constateert wel degelijk een belangrijke spanning tussen de economische waarden van de markt en andere, sociale en culturele waarden. Zijns inziens dreigen de waarden van de derde sfeer van de civil society in de verdrukking te komen tussen die van de markt enerzijds en de overheid anderzijds. Hij pleit dan ook voor meer aandacht voor deze derde sfeer, waarin het gaat om de informele sociale interacties tussen mensen in het gezin, in verenigingen, vriendenkringen, non-profitorganisaties en dergelijke.

Annemarie Mol vraagt zich af welke rol waarden spelen in de medische sfeer. Bij medische vraagstukken gaat het ogenschijnlijk vaak om louter technische afwegingen. Welke diagnose wordt op basis van de beschikbare medische kennis gesteld? Welke behandelingsmethode is het meest effectief en kostenefficiënt? Hoe dient deze methode te worden toegepast? Het antwoord op dergelijke vragen is altijd in hoge mate waardegeladen, betoogt Mol. Er zijn geen 'neutrale' technische antwoorden op deze vragen te formuleren, aangezien het altijd gaat om de interactie tussen de technologie en de patiënt. Wat technisch 'optimaal' is, hoeft dit in de praktijk niet te zijn, doordat toepassing van de techniek ingrijpende gevolgen kan hebben voor de leefwijze van de patiënt. Hiermee wordt vaak onvoldoende rekening gehouden, waardoor de patiënt gedwongen wordt zich aan te passen aan de techniek. Mol pleit er daarom voor dat bij medische keuzen ook altijd de waarden van de patiënt een belangrijke rol spelen.

Tot slot gaan Arjen van den Berg en Hans Sleurink, en Otto Scholten in op de verantwoordelijkheid van de media bij de overdracht van waarden en normen. In beide bijdragen wordt geconstateerd dat zich de afgelopen decennia belangrijke ontwikkelingen hebben voorgedaan in de media, waardoor deze ook zelf steeds meer onderwerp van maatschappelijke discussie zijn geworden. Te denken valt bijvoorbeeld aan de toenemende concurrentie tussen de media, onder meer door de opkomst van commerciële radio en tv, de (toenemende) verwevenheid tussen journalistiek en politiek en de opkomst van een nieuw medium als internet. Deze ontwikkelingen roepen de vraag op naar de verantwoordelijkheid van de media voor de wijze waarop zij de burgers informeren en amuseren. Media kunnen niet langer pretenderen dat zij slechts een neutrale boodschapper zijn en niet verantwoordelijk kunnen worden gesteld voor de aard en de inhoud van de informatie en het amusement dat zij de lezer, kijker en luisteraar aanbieden. De grondwettelijke vrijheid van meningsuiting en vrijheid van drukpers leggen echter strikte beperkingen op aan de mogelijkheden van de overheid of de rechter om de media ter verantwoording te roepen. Van den Berg en Sleurink hebben hun hoop gesteld op ondersteuning van de positie van de burger in zijn rol als informatieconsument. Door media-educatie zou de burger kunnen leren om meer tegenwicht te bieden tegen de invloed van de media. Scholten verwacht meer van het verantwoording afleggen door de media zelf. Hij pleit er niet voor dat de overheid voor- 
schrijft op welke wijze de media verantwoording afleggen over hun doen en laten, maar dat hierover een maatschappelijk debat wordt gevoerd met alle betrokken partijen: burgers, bedrijfsleven, overheid en de media zelf. Daarnaast pleit hij voor een grotere afstand tussen politici en journalisten.

De Verkenning wordt afgesloten met een algemene beschouwing over de rol van instituties bij de overdracht en handhaving van waarden en normen. Hans Adriaansens zet uiteen dat in het algemeen aan drie voorwaarden moet worden voldaan om instituties hun uit maatschappelijk oogpunt gewenste rol te laten vervullen. Deze voorwaarden betreffen de schaal, de sturing en de samenhang. Adriaansens pleit voor kleinschaligheid binnen grotere verbanden, om de herkenbaarheid van de institutie bij de deelnemers te vergroten. Sturing door de overheid dient niet gebaseerd te zijn op gedetailleerde regels, maar op het bieden van ruimte binnen bepaalde welomschreven kaders. De samenhang binnen instituties dient niet te worden bevorderd door te streven naar gelijkheid, maar door een 'cultuur van verschil' te stimuleren die ieder de gelegenheid biedt zich naar eigen voorkeuren en capaciteiten te ontplooien. In aansluiting op diverse andere bijdragen aan deze Verkenning stelt ook hij zich op het standpunt dat het er in het kader van het waarden- en normendebat niet om gaat een moreel appèl op de burger te doen, maar om de maatschappelijke en institutionele (rand)voorwaarden te creëren die bevorderen dat burgers zich meer conform de breed gedeelde waarden en normen gaan gedragen. 


\title{
HOGER, HARDER, SNELLER... EN DE PRIJS DIE MEN DAARVOOR BETAALT
}

\author{
G.van den Brink
}

Het huidige debat over normen en waarden wordt door velen in verband gebracht met het onbehagen in de politiek dat vorig jaar aan het licht getreden is. In tal van huishoudens, organisaties, bedrijven, onderwijsinstellingen en televisieprogramma's is deze kwestie aan de orde van de dag. Toch vrees ik dat maar weinigen beseffen hoezeer het vraagstuk van de normen en dat van het onbehagen met elkaar verstrengeld zijn. Daarom wil ik mijn visie op die samenhang in drie etappes uiteenzetten. Na een korte beschouwing over het onbehagen in de politiek noem ik zes andere sectoren van het sociale leven waar vergelijkbare vormen van onvrede een rol spelen. Dat zal het grootste en tevens meest empirische gedeelte van dit essay uitmaken. ${ }^{1}$ Vervolgens wil ik een algemenere theorie formuleren over de samenhang tussen normatieve ontwikkeling en maatschappelijk onbehagen. Ten slotte een filosofisch onderdeel over de vraag hoe men het proces van modernisering in dit opzicht zou kunnen zien. Nog één opmerking voordat ik terzake kom. Als ik over normen spreek doel ik niet op morele richtlijnen, idealen of wijsgerige beginselen. Het gaat mij in de eerste plaats om de feitelijke gedragsregels, alledaagse maatstaven en gangbare verwachtingen die in het leven van gewone Nederlanders een rol spelen.

Laat ik beginnen met het onbehagen in de politiek. Dat burgers steeds minder vertrouwen in de politiek hebben, blijkt onder meer uit de dalende opkomst bij verkiezingen. Bij de Tweede Kamer valt die daling nog wel mee. Sinds het afschaffen van de stemplicht gaat circa tachtig procent van de kiezers naar de stembus. Maar bij verkiezingen voor de gemeenteraad komt dat aandeel de laatste jaren heel wat lager uit (65\%), terwijl het bij provinciale verkiezingen nog veel erger is (50\%), om maar te zwijgen over de verkiezingen voor het Europees Parlement, waarbij de opkomst niet hoger dan een derde komt (35\%). Los van het opkomstpercentage is ook de trouw van kiezers aan één politieke stroming of partij sterk achteruitgegaan. Dat blijkt onder andere uit het grote aantal zwevende kiezers en de vele kiezers die per ronde van partijvoorkeur veranderen. Deze laatste groep vormt bijna de helft van het electoraat (46\%). Blijkbaar heeft een steeds kleiner deel van de bevolking stabiele politieke overtuigingen. Dat is trouwens niet zo vreemd, omdat de programmatische en ideologische scheidslijnen tussen de partijen veel minder sterk zijn dan in de jaren zestig of zeventig. Vanaf 1994 hebben we zelfs twee kabinetten meegemaakt waarin socialisten en liberalen - die traditioneel lijnrecht tegenover elkaar stonden - een coalitie vormden. Daarmee werd de politiek steeds meer tot een vorm van beheer die niets met tegenstellingen of strijd te maken heeft. Ter illustratie daarvan wijs ik op de verregaande afkalving van het partijlidmaatschap in figuur 2.1 (partij). Terwijl midden jaren zestig nog bijna tien procent van het Nederlandse electoraat was aangesloten bij een politieke partij, is dat momenteel geen drie procent. In feite 
zijn partijen alleen nog interessant voor professionals die een loopbaan in het politieke bedrijf of het openbaar bestuur zoeken. Met gewone burgers hebben de partijen niets van doen.

Maar dit verhaal heeft ook een keerzijde. Dat de meeste burgers weinig enthousiast zijn over traditionele politiek betekent niet dat zij een afkeer van de politieke democratie hebben. Integendeel. Hun steun voor het democratisch stelsel en de daarbijbehorende vrijheden nam de afgelopen decennia alleen maar toe. Het merendeel van de bevolking interesseert zich voor de politiek en zegt het nieuws op dat gebied te volgen. Er is eveneens een groeiend aantal mensen dat in het openbaar zijn mening geeft of een ingezonden brief schrijft naar de krant. Kijkt men naar de politiek in ruime zin, en niet alleen naar het proces van parlementaire besluitvorming, dan ziet de zaak er veel positiever uit. Ik wil het niet te mooi voorstellen. Er is nog altijd een substantieel deel van de bevolking dat cynische gevoelens heeft, weinig democratisch denkt en graag een sterke leider ziet. In een onderzoek voor de WRR heb ik het profiel van deze groep geschetst en hen beschreven als bedreigde burgers (Van den Brink 2002: 76-86). Zij kenmerken zich door een laag inkomen, weinig opleiding en een afwerende houding tegenover de moderne dynamiek. Ze hebben vaak conservatieve en autoritaire voorkeuren. Maar minstens zo veelzeggend vind ik dat deze voorkeuren de afgelopen dertig jaar aanmerkelijk verminderd zijn. Uit figuur 2.1 kan men aflezen dat autoritair leiderschap vanaf 1970 door steeds meer Nederlanders afgewezen wordt (demo).

\section{Figuur 2.1 Politiek en democatie 1970-1995}

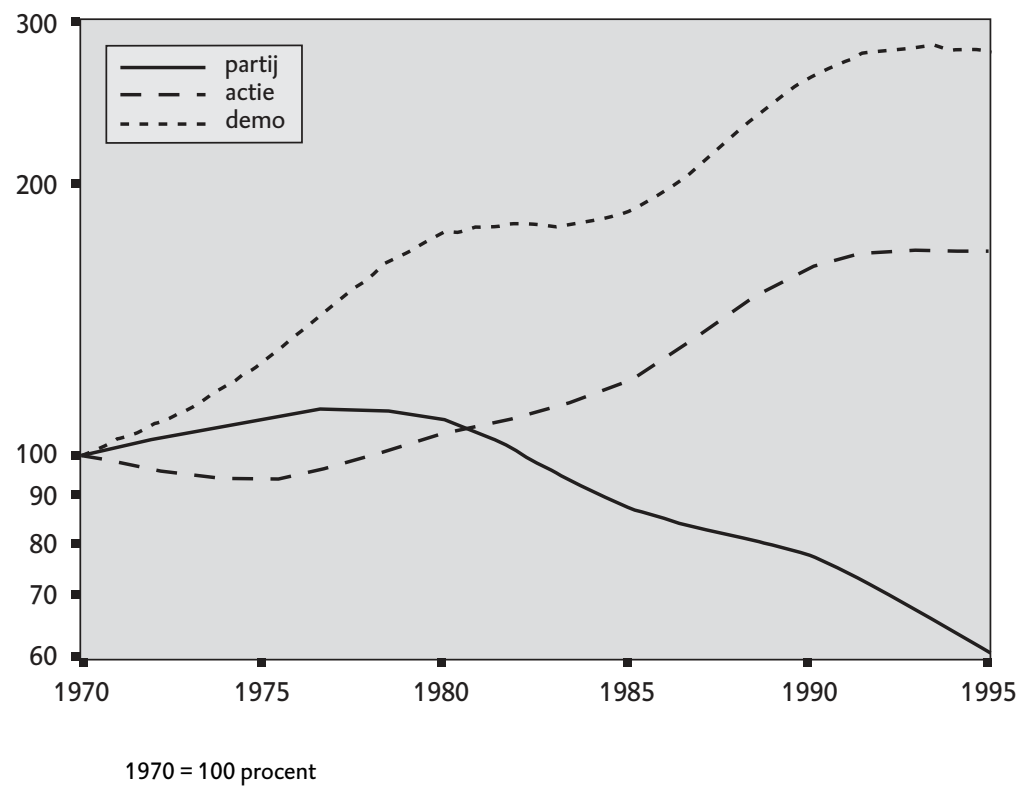

En daar komt nog iets anders bij. Er zijn steeds meer burgers die het juist vinden dat men zelf politieke activiteit ontplooit. Ter illustratie daarvan wijs ik op de derde curve in figuur 2.1. Deze heeft betrekking op de instemming met alterna- 
tieve acties zoals het houden van zitdemonstraties tegen een onrechtvaardige wet, een schoolbezetting uit protest tegen grotere klassen of een wilde staking tegen massaontslag (actie). De steun voor dit soort buitenparlementaire vormen van politiek neemt in de loop der jaren toe. Ook groeit het aantal burgers dat zelf aan dergelijke acties deelgenomen heeft of steun geeft aan verenigingen en organisaties met een ideële doelstelling. Het ledental van organisaties als het Wereldnatuurfonds, Greenpeace of Natuurmonumenten kende vanaf de jaren zeventig een spectaculaire groei en dat geldt eveneens voor de hoeveelheid geld die naar ideële doelen gaat. In mijn onderzoek naar de politieke habitus heb ik ook het sociaal-culturele profiel van deze bedrijvige burgers geschetst. Ze hebben doorgaans een hoge opleiding en een dito inkomen, ze tonen grote belangstelling voor de publieke zaak maar volgen professionele politici met de nodige reserve. Deze groep vormt in elk opzicht het tegendeel van de bedreigde burgers en maakt circa twintig procent van de bevolking uit. Ten derde is er nog een tussengroep van berustende burgers. Zij stellen zich meer afwachtend op en vormen ongeveer de helft van de bevolking. Aldus kan men niet zeggen dat er op politiek gebied alleen maar onbehagen is. Er bestaat wel onvrede, maar daarnaast hebben wij hogere verwachtingen. En er zou ook wel eens een verband tussen die twee tendensen kunnen zijn. Wellicht nam het onbehagen toe omdat onze ambities toegenomen zijn. Dit is in elk geval de these die ik in dit essay wil verdedigen en die niet alleen op de politiek maar ook op vele andere sectoren van de maatschappij betrekking heeft. Om dat aan te tonen zal ik zes van die sectoren in kort bestek behandelen. ${ }^{2}$

\section{Relatievorming en privé-leven}

Als eerste neem ik relatievorming en privé-leven. Op dat gebied zijn de verwachtingen de afgelopen decennia duidelijk omhoog gegaan. Dat blijkt onder meer uit de kwaliteiten en verlangens die in Nederlandse contactadvertenties vermeld worden (Zeegers 1988: 181-224). Tot het midden van de jaren zestig lag de nadruk sterk op praktische aspecten van het huwelijk. De adverteerders gaven vooral informatie over hun financiële positie, huishoudelijke situatie of het beroep dat zij uitoefenden. Ook met betrekking tot een toekomstige partner stonden deze kenmerken voorop. Over persoonlijke kwaliteiten of interesses deelde men niet veel mee. Maar in de daaropvolgende decennia zien we dat veranderen, met als gevolg dat het eisenpakket sterk in het teken van affectieve en psychologische kwaliteiten komt te staan. Hoewel mannen en vrouwen midden jaren tachtig hun financiële of huishoudelijke situatie niet onvermeld laten, schenken zij veel meer aandacht aan persoonlijke aspecten zoals uiterlijk voorkomen, een bepaalde belangstelling of een gevolgde opleiding. En dat geldt niet alleen voor de manier waarop kandidaten zichzelf aanprijzen, maar ook voor de verwachtingen die zij met betrekking tot een eventuele partner koesteren. Ter illustratie van deze trend - die men in de literatuur als een teken van emotionalisering of psychologisering ziet - verwijs ik naar de ontwikkeling van wensen op het gebied van de persoonlijkheid in figuur 2.2. Zowel bij mannen als bij vrouwen nam de aandacht voor dit soort kenmerken in de loop der jaren toe (perso). Met andere woorden: het proces van relatievorming onderging de afgelopen decennia een opvallende verandering, waarbij nieuwe respectievelijk hogere aspiraties een voorname rol spelen. 
Deze hogere verwachtingen gelden ook nadat een relatie totstandgekomen is. Dat kunnen we bijvoorbeeld afleiden uit de manier waarop de Nederlandse bevolking tegen seksuele trouw aankijkt. Als gevolg van de sterk toegenomen vrijheden denken velen dat de zeden op dit gebied erg los geworden zijn. Maar dat is beslist niet het geval. Vanaf 1970 leggen onderzoekers van het Sociaal en Cultureel Planbureau de gedachte voor dat een enkel avontuurtje geen kwaad kan in een goed huwelijk. Dertig jaar geleden steunde 57 procent van de bevolking deze opvatting, maar sindsdien neemt dat aandeel telkens af met als gevolg dat deze gedachte eind jaren negentig door driekwart van de ondervraagden verworpen werd. Anders gezegd: zolang een relatie duurt stellen verreweg de meeste Nederlanders seksuele trouw op prijs en dat aandeel ging in de loop der jaren niet omlaag maar uitdrukkelijk omhoog. Op dat punt zien we dus een geleidelijke ophoging van normen, ofwel een dalende tolerantie tegenover normovertredingen, zoals men uit de betreffende curve in figuur 2.2 kan afleiden (over).

\section{Figuur 2.2 Huwelijksleven 1965-1995}

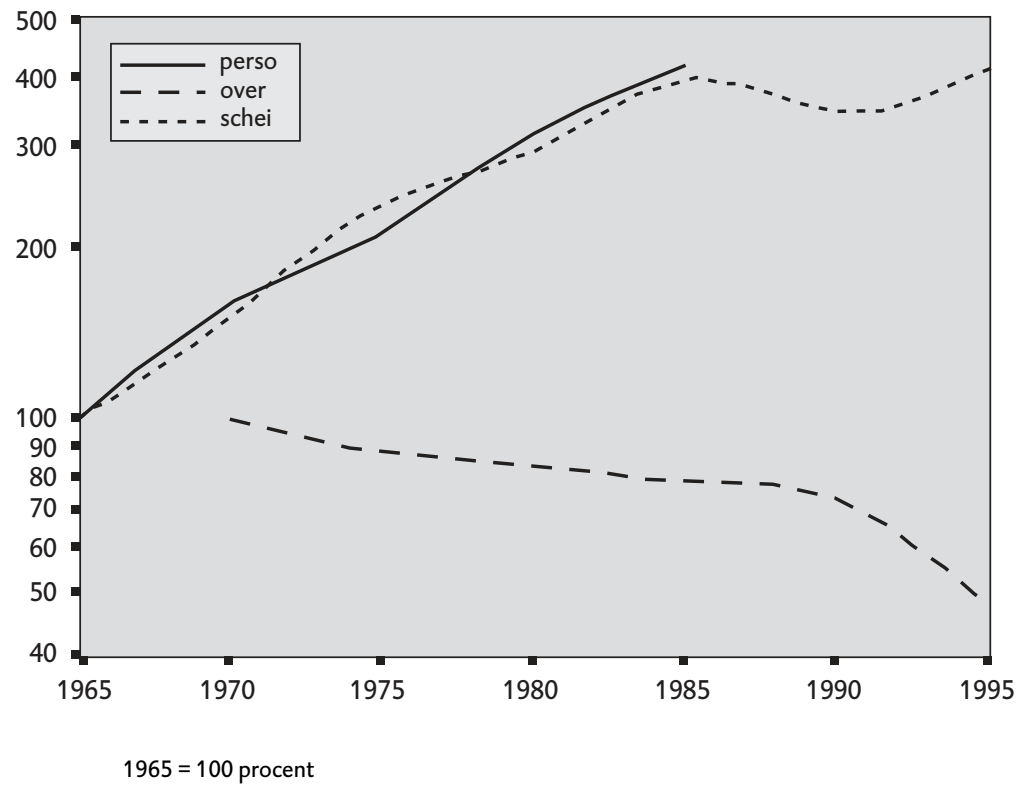

Maar het verhaal heeft ook een keerzijde. Het feit dat partners op tal van punten in de loop der jaren hogere verwachtingen zijn gaan koesteren, betekent niet dat hun relaties veel stabieler zijn. Vrijwel alle indicatoren wijzen op het tegendeel. Veel jongeren stellen het aangaan van een vaste relatie in eerste instantie uit. Dat geldt ook voor het moment waarop ze overgaan tot gezinsvorming. Bijgevolg ligt de gemiddelde leeftijd waarop een Nederlandse vrouw voor het eerst moeder wordt momenteel op dertig jaar. Verder heeft het ongehuwde samenwonen zich de afgelopen twintig jaar sterk uitgebreid. Men heeft steeds minder behoefte om zich vast te leggen op een formeel huwelijk en geeft de voorkeur aan samenwonen of andere flexibele leefvormen. Bovendien groeit het aandeel van de bevolking dat helemaal geen vaste relatie wil en als single door het leven gaat respectie- 
velijk alle tijd en energie in een eigen carrière stopt. En ten slotte komt het veel vaker tot een vorm van echtscheiding, zoals blijkt uit de betreffende curve in figuur 2.2 (schei). Met andere woorden: we constateren opnieuw een paradoxale ontwikkeling. Terwijl de normen en verwachtingen inzake een huwelijksrelatie in de loop der jaren geleidelijk omhooggingen, tekent zich op het niveau van de huwelijkse praktijk een zekere erosie af. In mijn opvatting horen deze twee ontwikkelingen bij elkaar. Juist omdat partners hogere verwachtingen van elkaar hebben, groeit de kans op teleurstelling en echtscheiding. Dat zien we ook aan de motieven van mensen die besluiten uit elkaar te gaan. De voornaamste klachten houden in dat men uit elkaar groeit, dat men niet goed kan praten of dat men niet genoeg aandacht voor elkaar opbrengt. Het gewicht van dit soort affectieve en psychologische problemen nam in de loop der jaren toe, terwijl klassieke motieven zoals lichamelijk geweld minder vaak een rol spelen.

\section{Werk en werkverhoudingen}

Vergelijkbare tendensen zien we op het gebied van werk en werkverhoudingen. Zoals bekend ondergaat onze economie vanaf de Tweede Wereldoorlog een geleidelijke maar beslissende verandering. Daarbij denk ik niet zozeer aan de groeiende welvaart - hoewel ook dat verschijnsel gepaard gaat met hogere verwachtingen - maar vooral aan het toenemende belang van soorten dienstverlening. De agrarische sector liep sterk achteruit en omvatte midden jaren negentig nog maar enkele procenten van de werkzame beroepsbevolking. Maar ook het aandeel van de industrie verminderde. In 1960 verdiende 44 procent van de werknemers zijn brood in deze sector en midden jaren negentig was dat nog maar een kwart. Daar staat tegenover dat verschillende vormen van dienstverlening zich sterk uitbreidden met als gevolg dat nu circa 70 procent van alle werknemers zijn brood in deze branche verdient. Deze verschuiving is relevant omdat ze een heel andere houding vooronderstelt. In de traditionele landbouw en industrie speelden uithoudingsvermogen en lichamelijke kracht een grote rol, maar bij moderne dienstverlening komt het vooral op sociale en communicatieve competenties aan. Bijgevolg worden er andere en hogere eisen gesteld bij werving van nieuw personeel. Ter illustratie van deze tendens verwijs ik naar figuur 2.3. Onderzoek naar personeelsadvertenties laat zien dat werknemers in de loop der jaren steeds vaker aan sociaal-normatieve eisen moeten voldoen (Moelker 1992: 8o-81). Daarbij gaat het om kwaliteiten als loyaliteit, eigen initiatief of het vermogen om met andere samen te werken (norm). Opmerkelijk is dat deze tendens niet alleen geldt voor hogere functionarissen maar ook voor functies op lager en middenniveau. In feite gingen de sociale en normatieve eisen over de gehele linie omhoog. Wel trad er een zeker onderscheid op. Bij lagere functies moesten werknemers vaker aan collectieve normen voldoen, terwijl de vereisten bij hogere functies betrekking hadden op het functioneren als individu.

Een belangrijk punt is evenwel dat het aandeel van die hogere functies in de loop der jaren stijgt. Het aandeel van de lagere functies maakt tussen 1960 en 1995 nauwelijks verandering door, maar dat van de hogere functies neemt behoorlijk toe (van $15 \%$ tot $37 \%$ ), terwijl het middenniveau evenredig daalt (van $56 \%$ naar $35 \%$ ). 


\section{Figuur 2.3 Arbeidsverhoudingen 1955-1995}

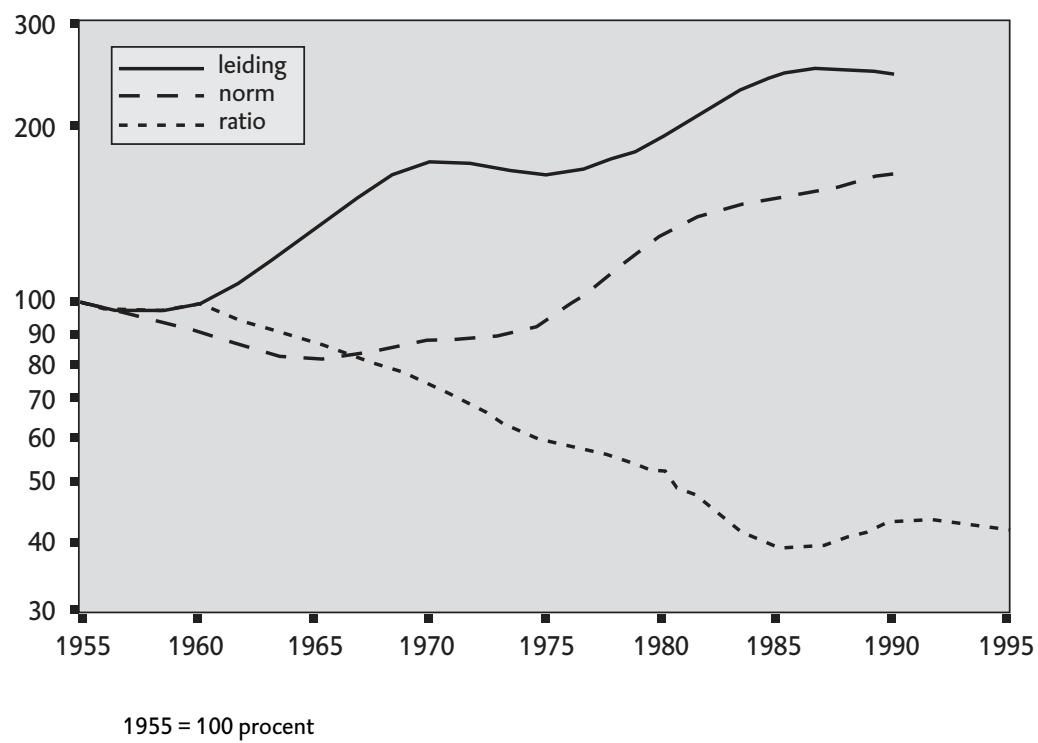

Aan figuur 2.3 kan men aflezen hoe het aandeel van leidinggevende functies zich in de loop der tijd ontwikkeld heeft (leiding). Dat zijn banen die op het vlak van ervaring, zelfstandigheid en opleidingspeil de nodige eisen met zich meebrengen. In het algemeen gingen de kwalificaties van veel Nederlanders omhoog. Inmiddels heeft circa een kwart van alle werknemers een wetenschappelijke opleiding of hogere beroepsopleiding (De Beer 2002: 19-67). Hoewel de productiviteit in traditionele zin in deze periode niet gestegen is, behoort Nederland tot de wereldtop als het gaat om de productiviteit per tijdseenheid. Een ander belangrijk punt lijkt mij te zijn dat de betekenis van arbeid gestegen is. Zo vertegenwoordigen werk en beroep midden jaren negentig voor 63 procent van de Nederlanders een belangrijke waarde, terwijl dat aandeel eind jaren zeventig nog maar 53 procent was.

Anders gezegd: zowel de eisen die aan moderne werknemers worden gesteld als de verwachtingen van werknemers bij hun beroepsuitoefening gaan geleidelijk omhoog. Maar daarvoor wordt eveneens een prijs betaald: er vindt in de Nederlandse economie een permanente uitstoot van arbeidskrachten plaats met als gevolg dat er nu al bijna twintig jaar een hoog niveau van werkloosheid is. De ernst van dit verschijnsel wordt gemaskeerd als men uitsluitend let op werknemers met een ww-uitkering. Het gaat evengoed om mensen die van de bijstand leven, vervroegd uittreden of in de WAO terechtkomen. Hanteert men een dergelijke brede definitie van werkloosheid, dan is duidelijk dat dit verschijnsel een structureel karakter heeft. De ratio van het aantal actieven en inactieven neemt dan ook voortdurend af (figuur 2.3, ratio). Sinds het midden van de jaren tachtig zit ongeveer een kwart van de beroepsbevolking zonder werk thuis. Dat is opmerkelijk, omdat de werkgelegenheid in Nederland vanaf 1985 flink verbeterde. Een en ander kan volgens het Sociaal en Cultureel Planbureau op twee 
manieren verklaard worden. Ten eerste deed de werkgelegenheidsgroei van de laatste twintig jaar zich vooral bij hogere functies en in de sector dienstverlening voor. Degenen die altijd in sectoren als de industrie of de bouw gewerkt hadden, kwamen daarvoor niet meer in aanmerking, wat een blijvende verhoging van het aantal langdurig werklozen tot gevolg had. De positie van deze werknemers op de arbeidsmarkt is erg zwak, omdat ze weinig opleiding hebben en/of van allochtone afkomst zijn. Ten tweede lopen degenen die wél werken eveneens een hoger risico. Dat geldt met name voor mensen die moeten werken onder stress of hoge werkdruk en die met de gevolgen van flexibilisering of reorganisatie geconfronteerd worden. Van hen komt een onevenredig groot deel in de wAO terecht (SCP 1998: 401-403). Langs beide wegen betalen wij in Nederland een prijs voor de hoge eisen die in een moderne economie aan werknemers gesteld worden. In die zin treffen we de paradox van vooruitgang en verslechtering ook in het economisch leven aan.

\section{Onderwijs}

Bij het onderwijs stellen we vergelijkbare processen vast. Daar is in elk geval sprake van stijgende verwachtingen. In de jaren vijftig en zestig kwam slechts een derde van de kinderen in het voortgezet onderwijs terecht. Verreweg de meesten gingen na de lagere school uit werken. Sinds die tijd nam de belangstelling voor middelbaar en hoger onderwijs voortdurend toe, met als gevolg dat midden jaren negentig bijna de helft van de Nederlandse bevolking een vorm van hoger onderwijs gevolgd heeft. Een ander opmerkelijk gegeven is dat deze toename zeer geleidelijk verloopt (figuur 2.4, hoog). Ze wordt nauwelijks beïnvloed door omstandigheden op economisch of politiek gebied en vormt een vrijwel autonome ontwikkeling. Wel is bekend dat het opleidingsniveau van de ouders grote invloed heeft op de onderwijsloopbaan van hun kinderen. In het wetenschappelijk onderwijs en het hoger beroepsonderwijs treft men relatief veel kinderen van hoogopgeleide ouders aan, terwijl de ouders van leerlingen in voorbereidend beroepsonderwijs of mavo relatief weinig opleiding gevolgd hebben (Bronneman-Helmers 2002: 120). Wellicht moeten we dit opvatten als een zichzelf versterkende ontwikkeling en wel in die zin dat hoger onderwijs het meest aantrekkelijk is voor kinderen die door hun hoogopgeleide ouders al het nodige culturele en intellectuele kapitaal in huis hebben. In dat geval moet het streven naar een steeds hoger opleidingspeil vooral uit de toegenomen onderwijsparticipatie in de jaren zestig en zeventig verklaard worden.

Toch kan men de hogere verwachtingen niet alleen aan het ambitieniveau van de ouders toeschrijven. Het onderwijssysteem draagt er eveneens toe bij. Men is afgestapt van de klassikale werkwijze waarbij alle leerlingen dezelfde hoeveelheid vaste leerstof moesten doorwerken. Men schenkt meer aandacht aan de specifieke moeilijkheden en mogelijkheden van individuele leerlingen. Bovendien is het accent verschoven van parate kennis naar cognitieve vaardigheden en zelfstandig werken. Als gevolg daarvan ging het abstractieniveau omhoog en werd een goede taalvaardigheid belangrijker. Het hogere ambitieniveau komt ook in de schooladviezen tot uitdrukking. Recent onderzoek van het SCP maakt 
duidelijk dat steeds meer leerlingen een havo- of vwo-advies meekrijgen, terwijl het aandeel van de mavo- of vbo-adviezen evenredig daalt. Opmerkelijk genoeg correspondeert deze toename niet met een betere onderwijsprestatie van de leerlingen. De CITO-scores bleven in de loop van de jaren negentig op hetzelfde niveau. Verder blijkt het hogere advies niet altijd een garantie voor succes: na drie jaren in het voortgezet onderwijs schuift een aanzienlijk deel van de leerlingen door naar een lager schooltype. Ook in die zin zorgen hooggespannen verwachtingen niet zelden voor teleurstelling (Bronneman-Helmers 2002: $94-95,128,158)$.

\section{Figuur 2.4 Onderwijs 1970-1995}

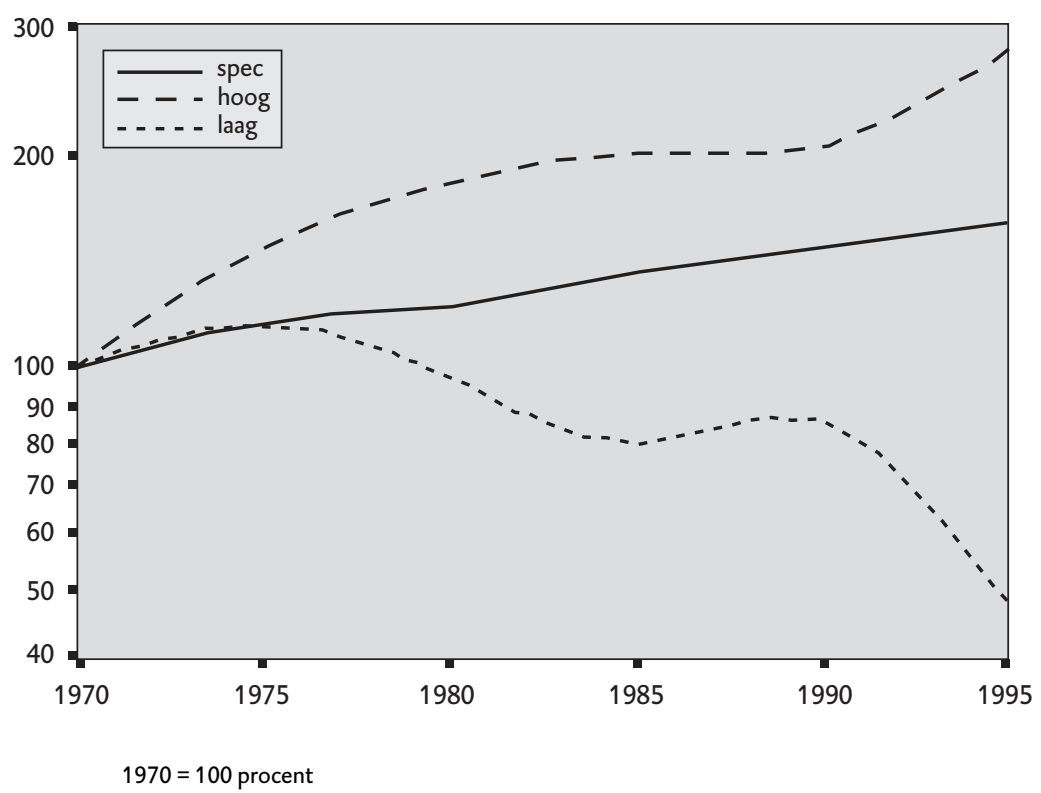

Ik zou dan ook de stelling willen verdedigen dat de selectieve werking van het onderwijs versterkt is. Juist doordat er hogere eisen aan leerlingen gesteld worden - zowel sociaal als cognitief - stijgt het aandeel van hen die uit de boot vallen. Ter illustratie daarvan wijs ik op de gestage toename van het aantal kinderen dat naar het speciaal onderwijs gaat. Aan de betreffende curve in figuur 2.4 laat zich aflezen dat dit aandeel vanaf 1970 voortdurend stijgt (spec). Dat is opmerkelijk omdat men in dezelfde periode tal van onderwijskundige verbeteringen doorvoerde, bedoeld om de uitval zoveel mogelijk te beperken. Doornbos noemt zaken als de verkleining van de klasssen in het basisonderwijs, het tegengaan van zittenblijven, introductie van kindgerichte onderwijsmethoden, opkomst van het schooladvieswerk, een meer objectieve beoordeling, et cetera. Maar dat alles heeft niet geleid tot een kleiner aantal leerlingen dat speciale zorg nodig heeft. Integendeel. Het speciaal onderwijs krijgt steeds meer kinderen, terwijl de gewone basisschool in toenemende mate met gedragsproblemen en leerachterstanden kampt (Doornbos 1991: 16-21). Ik denk dat we dit als een keerzijde van hogere normen moeten zien. Als men de lat zowel sociaal als cognitief steeds een 
beetje hoger legt, groeit onvermijdelijk het aantal leerlingen dat in kennis of gedrag niet aan de verwachtingen voldoet. Overigens zien we bij het voortgezet onderwijs hetzelfde. Sinds 1990 nam het aantal zorgleerlingen daar sterk toe, zowel in absolute als in relatieve zin. En ook dat vloeit voort uit de hogere eisen die op vele fronten aan jongeren gesteld worden (Bronnenman-Helmers 2002: 152).

\section{Goed en kwaad}

Ten vierde het domein dat bij dit alles een centrale plaats inneemt: houdingen tegenover goed en kwaad. Laten we eerst vaststellen dat de opinie van veel Nederlanders op dit gebied aanmerkelijk veranderd is. Dat blijkt uit het antwoord dat ze geven op de vraag of zeden en gedrag in Nederland verbeterd dan wel verslechterd zijn. In 1970 waren de reacties nog gelijk verdeeld: 31 procent was van mening dat zeden en gedrag vooruitgingen, 30 procent meende dat er achteruitgang was en 39 procent ontwaarde een wisselende ontwikkeling. Die opinies zien er dertig jaar later toch heel anders uit! Nog maar een heel klein deel van de bevolking meent dat er zedelijke vooruitgang is (6\%), terwijl een kwart over wisselingen spreekt (25\%). Maar het aandeel van degenen die vinden dat het slechter wordt, nam sterk toe en maakt meer dan tweederde deel van de hele bevolking uit (69\%). In figuur 2.5 vindt men deze laatste ontwikkeling in beeld gebracht (slechter). Dit strookt met de wijze waarop de publieke opinie veranderde. Met name in de jaren negentig vond menigeen dat Nederland verloederde en dat een herstel van waarden en normen geboden is.

De vraag is evenwel hoe men deze ontwikkeling moet opvatten. De genoemde uitspraken hebben immers betrekking op de samenleving als geheel en dat oordeel valt niet altijd samen met de eigen normen. Bovendien kan het ook best zijn dat deze uitspraken een positie in het openbare debat weergeven, terwijl het feitelijke gedrag van heel andere normen afhangt. Men zou beide interpretaties op grond van empirisch materiaal kunnen verdedigen. Bij de eerste is vooral een effect van de secularisatie in het geding. Zoals bekend maakte het proces van ontkerkelijking in Nederland vanaf de jaren zeventig een versnelling door. Daarbij daalde het percentage Nederlanders dat bij een kerk aangesloten is van 67 procent in 1970 tot nog maar 26 procent in het jaar 2000 (figuur 2.5, kerklid). Verder daalde - bij degenen die hun kerk trouw bleven - de frequentie van het kerkbezoek. Daar komt dan nog eens de ontzuiling bij, wat betekent dat de kerkelijke leer inzake goed en kwaad veel minder impact op het politieke of maatschappelijke denken heeft. Met andere woorden: het morele gezag van de kerken is vanaf eind jaren zestig ondermijnd en de meeste burgers maken voortaan zelf uit wat ze onder goed en kwaad verstaan.

Maar betekent deze ontwikkeling nu ook dat de burgers aan morele verwarring onderhevig zijn of dat ze maar wat aan rotzooien? Gezien de cijfers dringt zich juist de omgekeerde conclusie op. Ik illustreer dat aan de hand van twee stellingen die sinds 1970 regelmatig door het SCP aan de bevolking worden voorgelegd. De eerste luidt: 'Er zijn zo veel verschillende opvattingen over wat goed en wat 


\section{Figuur 2.5 Zeden en gedrag 1970-1995}

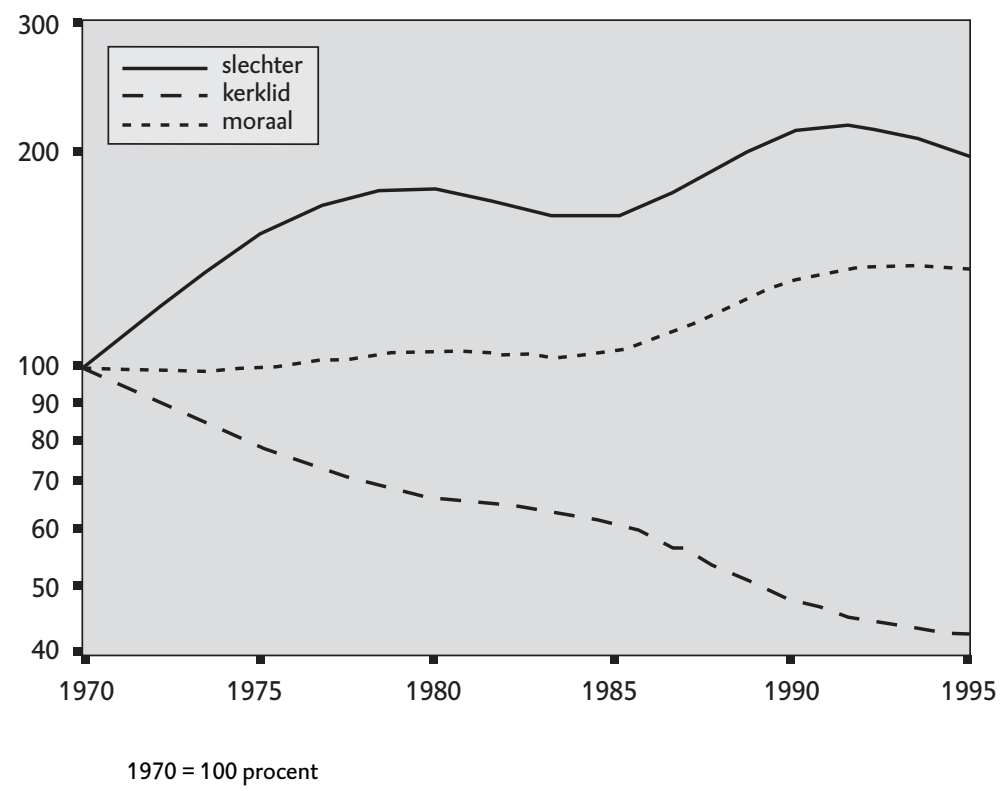

slecht is, dat je soms niet meer weet waar je aan toe bent.' De tweede luidt: 'Alles verandert heden ten dage zo snel dat men vaak nauwelijks meer weet wat goed en wat slecht is.' De eerste stelling wijst op morele verwarring ten gevolge van maatschappelijke diversiteit, de tweede op onzekerheid als gevolg van maatschappelijke dynamiek.

Omdat Nederland de afgelopen dertig jaar zowel diverser als dyamischer geworden is, ligt de verwachting voor de hand dat steeds meer burgers op moreel gebied de weg kwijt zijn. Maar het tegendeel is het geval. Een steeds groter deel van alle Nederlanders zegt dat ze heel goed kunnen onderscheiden tussen goed en kwaad. De toegenomen maatschappelijke diversiteit en dynamiek heeft daar kennelijk geen invloed op. Bovendien weten we dat dit in hoge mate met het onderwijspeil correspondeert. Als er in ons land verwarring op moreel gebied bestaat, dan concentreert die zich bij de burgers met een bescheiden opleiding (Van den Brink 2002: 62-76). Ik zou dan ook de stelling willen verdedigen dat de morele standaarden de afgelopen decennia niet omlaag maar juist omhoog gingen (figuur 2.5, moraal). Dat zou zelfs het onbedoelde maar daarom nog niet onwenselijke gevolg van de secularisatie kunnen zijn: pas wanneer oordelen over goed en kwaad niet langer het voorrecht van pastoor, dominee of andere morele specialisten is, kunnen gewone burgers zich een eigen oordeel vormen. En dat zou weer een verklaring vormen voor het feit dat ze veel kritischer tegen de samenleving als geheel aankijken. In die zin wijst hun oordeel over de zedelijke verloedering niet alleen op de groei van allerlei probleemgedrag - een groei die op zichzelf onmiskenbaar is - maar ook op een geleidelijke ophoging van de eigen normen. 


\section{Emancipatie van de vrouw}

Een voorname ontwikkeling is ook de emancipatie van de vrouw. Deze werkt in de meest uiteenlopende domeinen van het leven door. Zo is de traditionele achterstand van meisjes op het gebied van onderwijs de afgelopen decennia geheel verdwenen en zelfs in een voorsprong omgezet. De verwachtingen groeiden navenant. In 1970 meende al een groot deel van de bevolking (73\%) dat school voor meisjes net zo belangrijk is als voor jongens en dit aandeel nam in de loop der jaren alleen maar toe. Verder kregen Nederlandse meisjes meer vrijheden op seksueel gebied. Veelzeggend is de vraag of respondenten er moeite mee hebben dat een meisje voor haar huwelijk seksuele gemeenschap heeft als ze van een jongen houdt. In 1970 wilde slechts 20 procent haar daarin vrijlaten, maar midden jaren negentig wil 77 procent dat doen. Bovendien vindt een steeds groter deel van de Nederlanders het ook goed als dat meisje niet van een jongen houdt. Een en ander illustreert dat de bewegingsvrijheid van vrouwen in relatief korte tijd aanzienlijk toegenomen is. Het zou echter onjuist zijn om de betekenis van de emancipatie tot het privé-leven te beperken.

Minstens zo belangrijk is dat veel meer vrouwen aan het arbeidsproces zijn gaan deelnemen. Daartoe moest eerst worden gebroken met de norm dat moeders met kleine kinderen in principe thuis blijven. Die norm is inmiddels geheel en al geërodeerd. Midden jaren zestig maakte nog 81 procent bezwaar tegen de gedachte dat een moeder zou gaan werken zolang zij voor kleine kinderen te zorgen heeft. Maar in 1970 is dat aandeel gehalveerd en in 1995 maakt nog maar een kleine minderheid van 9 procent bezwaar tegen moeders die gaan werken (figuur 2.6, moeder). Deze normatieve wijziging correspondeert met de praktijk. In dezelfde periode nam de arbeidsparticipatie onder vrouwen toe van 25 procent rond 1970 tot meer dan 50 procent aan het einde van de eeuw (figuur 2.6, arbeid). Uit de lite-ratuur weten we dat het lang niet altijd om fulltimebanen gaat. Toen de werkgelegenheid rond 1985 weer begon te groeien, ging een aanzienlijk deel van deze groei naar deeltijdbanen toe. Het zijn vooral vrouwen die een paar dagen per week gaan werken. Niettemin nam de vrouwelijke beroepsbevolking relatief snel toe en hebben vrouwen vandaag de dag meer verschillende bezigheden dan voorheen.

Hoewel velen deze ontwikkeling als een vooruitgang opvatten, heeft zij toch ook nadelige gevolgen. Daarbij denk ik vooral aan de toenemende combinatiedruk. Vrouwen die gaan werken nemen nog altijd een groot deel van het huishouden voor hun rekening. Het aandeel dat meerdere taken combineert, steeg dan ook van 15 procent midden jaren zeventig tot 45 procent in het jaar 20oo. Hoewel mannen in absolute zin minder tijd besteden aan huishouden of zorg voor kinderen, gaat ook bij hen de combinatiedruk omhoog en wel van 25 procent tot 49 procent (Breedveld 2001:15). Het lijkt hierbij te gaan om een algemene ontwikkeling die zich aan alle burgers opdringt. Zo maakt opleiding wel verschil - in die zin dat mensen met een hoge opleiding vaker taken (moeten) combineren dan mensen met een lage opleiding - maar voor beide groepen gaat de combinatiedruk omhoog (figuur 2.6, druk). Deze toename geldt zelfs voor werklozen, ook 
Figuur 2.6 Vrouwenemancipatie 1970-1995

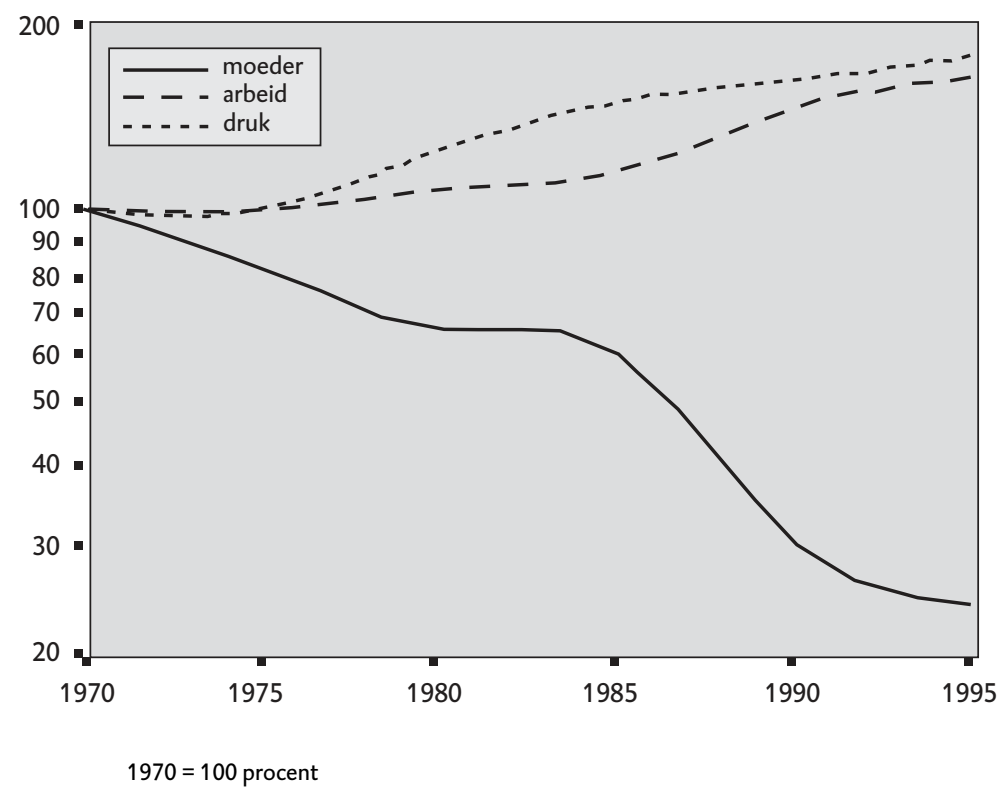

al worden die er minder door geplaagd dan mensen die een betaalde baan hebben. Natuurlijk kan men deze tendens niet alleen verklaren uit het feit dat vrouwen zijn gaan werken. Tal van andere factoren spelen hierin mee. Maar de figuur van de huisvrouw - die een groot deel van haar tijd in of rond het huis doorbracht en zelf haar bezigheden kon indelen - bracht bepaalde marges met zich mee. Nu deze marges wegvallen moet een groter aantal taken over meer mensen verdeeld worden, terwijl de daarvoor beschikbare tijd veelal minder is. Dat vormt in elk geval een van de factoren die in het hedendaagse bestaan voor stress zorgen.

\section{Openbare orde}

De openbare orde is het laatste domein dat in dit verband om aandacht vraagt. Velen menen dat Nederland wat dit betreft door verloedering getroffen wordt. Er zijn steeds meer klachten over agressie en andere vormen van asociaal gedrag. Hoewel ik de normatieve kant van dit verschijnsel niet ontken, wil ik de aandacht vestigen op enkele ontwikkelingen die er sterk toe bijdragen. Zo heeft het maatschappelijk verkeer in elk opzicht een geweldige intensivering ondergaan. Dat uit zich onder andere in een toename van de ruimtelijke mobiliteit. In 1970 legde de gemiddelde Nederland per jaar ruim 5.50o kilometer af, maar inmiddels komt dat aantal reeds boven de 10.000 kilometer uit (figuur 2.7, verkeer). Deze ontwikkeling is relevant, omdat Nederland sinds jaar en dag een hoge bevolkingsdichtheid heeft. Men zou kunnen zeggen: hoe meer bewegingen op een beperkt oppervlak, des te groter de kans op botsingen. Het is daarom bepaald niet vreemd dat bijvoorbeeld de intensivering van het wegverkeer tevens een toename van agressie tot gevolg heeft. Op economisch, sociaal en informatief gebied deden zich vergelijkbare ontwikkelingen voor. Wij kwamen de afgelopen decennia steeds vaker in aanraking met anderen met wie wij in hoog tempo geld, goederen, dien- 
sten, berichten en opvattingen uitwisselen. Het is haast onvermijdelijk dat daarbij irritaties en misverstanden aan het licht treden. Dat geldt temeer wanneer het verkeer zich niet in besloten kring maar in relatief anonieme en grootschalige omgevingen afspeelt.

\section{Figuur 2.7 Criminaliteit 1970-1995}

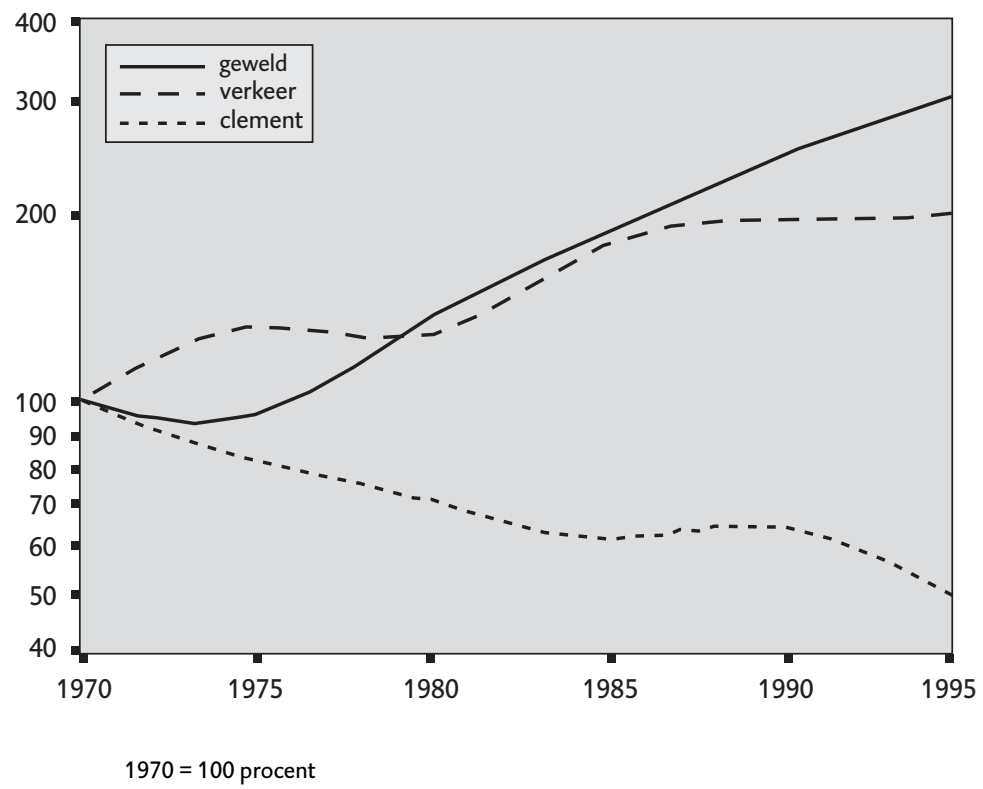

Daarmee is duidelijk dat deze intensivering van het maatschappelijk verkeer behalve evidente voordelen ook een risico behelst. Ze brengt onder andere een stijging van het aantal geweldsdelicten mee. De afgelopen drie decennia steeg het aantal misdrijven tegen het leven met een factor vijf, terwijl het aantal gevallen van mishandeling verdrievoudigde (figuur 2.7, geweld). Vormen van vandalisme namen nog veel sterker toe en stegen tussen 1970 en 1995 met een factor tien! Alleen de omvang van seksuele misdrijven bleef min of meer constant. Deze cijfers hebben betrekking op de geregistreerde criminaliteit en mogen niet zonder meer gelijkgesteld worden met de daadwerkelijke ontwikkeling. Op grond van een eerder onderzoek naar agressief gedrag bij jongeren meen ik dat het om een combinatie van twee processsen gaat. Enerzijds gaat het aantal geweldsdelicten per 100.000 inwoners vanaf 1970 daadwerkelijk omhoog. Anderzijds nemen de zorgen over deze ontwikkeling tegen het einde van de jaren tachtig toe. De media besteden er meer aandacht aan, de politie gaat actiever opsporen en men brengt verbeteringen in de registratie aan. Als gevolg hiervan neemt het aantal geweldsdelicten in de statistiek vanaf 1990 extra sterk toe. Dat spoort met een toenemend gevoel van onveiligheid onder de bevolking. Daarin zit weliswaar een subjectieve component, maar het is niet juist om te beweren dat het alleen maar een kwestie van grotere gevoeligheid zou zijn. Er is vanaf de jaren zestig wel degelijk iets aan de hand (Van den Brink 2001: 37-52). 
Intussen roept deze ontwikkeling de nodige reacties op. We zien dat burgers een veel hardere houding tegenover criminelen aannemen. Ter illustratie daarvan verwijs ik naar de stelling dat men criminelen niet zozeer moet straffen maar moet proberen te veranderen. In 1970 was nog 74 procent van de respondenten het met deze stelling eens, maar dat aandeel neemt in de loop der jaren steeds meer af en komt momenteel op ruim een derde uit. Een en ander wijst op een harder maatschappelijk klimaat (figuur 2.7, clement). Deze tendens strookt met recent onderzoek van het SCP, waaruit blijkt dat een groeiend deel van de burgers voor zwaardere straffen en het bouwen van meer gevangenissen is (SCP 2002: 675-678). Verder valt op dat de steun voor een meer repressieve aanpak van asociale elementen vanaf midden jaren tachtig sterk steeg. Dat is af te leiden uit het antwoord op de stelling dat men maatschappelijke problemen het beste kan oplossen door asociale en misdadige elementen uit de samenleving te verwijderen. In eerste instantie nam de steun voor deze opvatting onder Nederlanders af, maar vanaf 1985 neemt deze weer toe tot het aanvankelijke niveau. Dat is opmerkelijk, omdat verschillende andere factoren die vaak met deze repressieve habitus verband houden (zoals voorkeur voor nationalisme, sterke leiders of autoritaire politiek) in dezelfde periode niet toegenomen zijn. Kennelijk maakt de voorkeur voor een harder optreden tegenover asociale gedragingen zich uit zijn oude conservatieve context los. Een en ander komt momenteel in brede lagen van de bevolking voor en kan niet meer als een typisch 'rechtse' opvatting gezien worden.

\section{Andere verwachtingen}

Daarmee ben ik bij het tweede, meer theoretische gedeelte van deze bijdrage. Naar mijn indruk vertonen de zojuist geschetste ontwikkelingen een algemeen patroon dat vier elementen telt. Ten eerste zien we op uiteenlopende domeinen van het maatschappelijk leven een proces van toenemende verwachtingen. Langzaam maar zeker gaan de normen, de idealen of de kwaliteitseisen in de loop van twintig of dertig jaar omhoog. Op politiek gebied hebben burgers vooral hogere verwachtingen als het om hun eigen inbreng gaat. $\mathrm{Zij}$ willen duidelijk gehoord worden, leggen zich niet voetstoots bij het oordeel van bestuurders neer, willen zich ook graag inzetten voor de publieke zaak en hechten grote waarde aan een democratische werkwijze. In het privé-leven is meer aandacht ontstaan voor de persoonlijke en gevoelsmatige aspecten van het huwelijk. Wij koesteren hogere verwachtingen op het gebied van seksuele trouw en hechten meer waarde aan een gezamenlijke belangstelling. De vooruitgang op economisch vlak omvat niet alleen een hoger welvaartspeil, we zien ook dat het aandeel van de hogere functies stijgt, terwijl steeds meer Nederlanders in de sector dienstverlening werken. Als gevolg daarvan moeten werknemers meer sociale en normatieve vaardigheden in huis hebben. Op onderwijsgebied stellen we eveneens een aantal stijgende lijnen vast. De deelname aan middelbare en hogere vormen van onderwijs nam toe. Verder stelt men hogere eisen aan de leerlingen, bijvoorbeeld taalvaardigheid of het vermogen tot zelfstandig werken. Op moreel gebied zien we - ondanks secularisatie en ontzuiling - eenzelfde ontwikkeling. Er zijn steeds meer mensen die voor zichzelf een onderscheid tussen goed en kwaad maken en er zijn steeds 
minder mensen die aan morele verwarring onderhevig zijn. Ook de vrouwenemancipatie bracht vooruitgang mee. De bewegingsvrijheid van vrouwen nam de afgelopen decennia belangrijk toe, niet alleen in economisch maar ook in sociaal en seksueel opzicht. Alleen het domein van de openbare orde wijkt enigszins af van dit patroon. In de onderlinge omgang van burgers tekent zich een zekere verruwing af die niet strookt met de these van hogere verwachtingen. Niettemin blijft het een feit dat er in de loop der jaren meer aandacht voor dit probleem ontstaat, terwijl politie en justitie veel actiever optreden. Zelf denk ik dat wij gevoeliger geworden zijn voor allerlei vormen van overlast en dat wij hogere eisen aan het sociale verkeer stellen dan enkele decennia terug.

Aldus zien we in zeer uiteenlopende sectoren van het maatschappelijk leven een proces van normatieve ophoging. ${ }^{3}$ Het is een verschuiving die heel geleidelijk verloopt en daarom nauwelijks doordringt tot het bewustzijn van de betrokkenen, maar niettemin na verloop van tijd aanwijsbaar is. Zou men de huidige ambities vergelijken met die van dertig jaar terug, dan springen de niveauverschillen in het oog. Ik geef dat in figuur 2.8 met een vette zwarte curve weer. Zij illustreert dat de maatschappelijke norm geleidelijk steeds hoger wordt (Afstand A). Uiteraard wijkt de empirische ontwikkeling altijd van een dergelijke curve af-zoals uit het verloop van eerdere figuren blijkt - maar qua type komt zij daarmee overeen. Uit deze figuur blijkt eveneens welke problemen kunnen voortvloeien uit zo'n ontwikkeling. Daarbij gaat mijn aandacht naar drie potentiële problemen uit.

\section{Figuur 2.8 Norm en onbehagen}

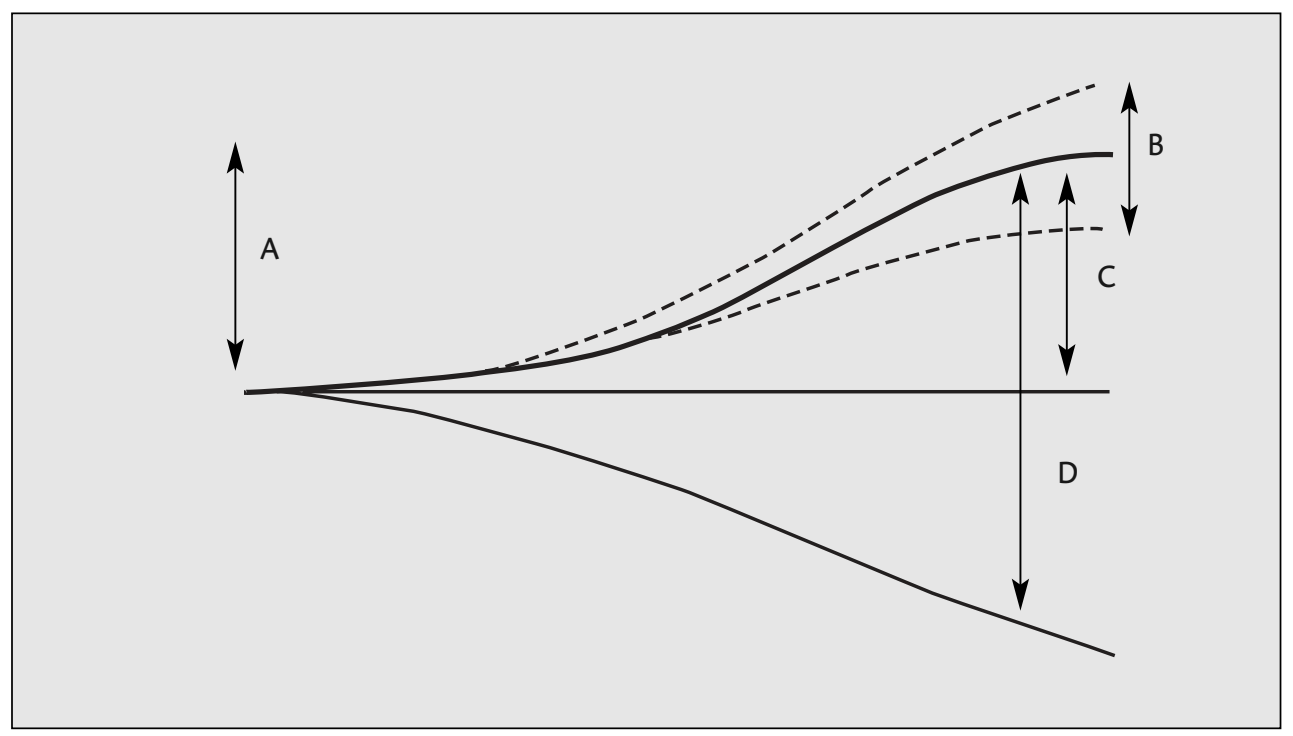

Om te beginnen kan het ophogen van de norm een grotere spreiding met zich meebrengen. Dat proces - in bijgaand diagram door de beide gestippelde curven aangeduid - zou men als een vorm van normatieve diffusie kunnen opvatten (Afstand B). Vervolgens kan het ophogen van de norm een andere perceptie van 
bestaande gedragingen tot gevolg hebben. Hoewel dat gedrag op zichzelf niet veranderd is, ervaren de betrokkenen het als een verslechtering, juist omdat zij hogere normen aanleggen (Afstand C). Een dergelijk proces van relatieve verslechtering geef ik in figuur 2.8 met de middelste curve aan. Ten slotte is het mogelijk dat de hogere norm samengaat met een verslechtering van het gedrag in objectieve zin, wat in figuur 2.8 met de laagste curve wordt aangegeven (Afstand D). Dan gaat het niet slechts om een andere perceptie van het gedrag maar treedt er een vorm van selectie op. Aldus kan men het onbehagen op diverse wijzen opvatten.

\section{Diffusie, perceptie, selectie}

Komt de onvrede uit een proces van diffusie, perceptie of selectie voort? In aansluiting op het voorgaande wil ik laten zien dat ze alledrie een rol spelen. Om te beginnen deden zich in Nederland processen van diffusie voor. Dit houdt in dat het normbesef minder scherp wordt doordat de variatie aan gedragingen toeneemt. De ontwikkelingen op het gebied van relatievorming zijn daar een voorbeeld van. Tot ver in de jaren zestig kenden wij in ons land maar een beperkt aantal leefvormen. Daarbij was het formele huwelijk tussen man en vrouw veruit dominant. Het seksuele verkeer werd geacht zich af te spelen binnen dat huwelijk en er was weinig ruimte voor afwijkende voorkeuren of gedragingen. Sindsdien nam de variatie aan leefvormen sterk toe. Wij kunnen tegenwoordig kiezen uit een vaste of lossere verbintenis, al dan niet bezegeld door een huwelijk, al dan niet tussen leden van hetzelfde geslacht, al dan niet leidend tot kinderen, et cetera. Hoewel het traditionele kerngezin een taai leven leidt, kan men het niet langer opvatten als norm of dwingend opleggen. Daarvoor is de spreiding op het gebied van de relatievorming veel te groot en er zijn geen tekenen dat dit binnen afzienbare termijn zal veranderen.

Een vergelijkbare situatie zien we op moreel gebied. Hoewel burgers steeds vaker zeggen dat ze in staat zijn om onderscheid te maken tussen goed en kwaad, lopen hun opvattingen inhoudelijk gezien nogal uiteen. In elk geval is er momenteel geen instantie meer die voor een algemeen geldige norm staat. Met de komst van migranten wordt de reeds bestaande variatie nog eens extra uitvergroot. Met betrekking tot het gedrag in de openbare ruimte stellen we evenzeer vergaande normatieve variatie vast. Het zou kunnen dat burgers in hun oordelen over openbaar gedrag veel sterker overeenstemmen dan op het eerste gezicht lijkt. Maar de moeilijkheid is dat deze normen zelden expliciet en collectief gemaakt worden. In elk geval vinden veel Nederlanders het erg moeilijk om elkaar aan te spreken op dat soort gedragsregels. Bijgevolg staat de publieke ruimte in het teken van een verregaande liberaliteit: in feite nam de variatie zodanig sterk toe dat het onderscheid tussen normaal en abnormaal voor menigeen volslagen duister is. Genoemde voorbeelden contrasteren duidelijk met de situatie van enkele decennia terug, toen collectieve normen inzake huwelijk, moraliteit of openbaar gedrag niet alleen vrij strikt waren, maar ook van bovenaf gesanctioneerd werden. Dat zou men als een eerste moeilijkheid op het gebied van normen en normhandhaving kunnen zien. 
Een tweede moeilijkheid staat niet met diffusie maar met perceptie in verband. Het geleidelijk ophogen van de verwachtingen kan tot gevolg hebben dat men de bestaande realiteit met andere ogen gaat bezien. En ook dat doet zich op verschillende terreinen voor. Ik denk daarbij vooral aan het onderwijs waar men over toenemende problemen klaagt. Steeds meer kinderen zouden last hebben van leer- of gedragsstoornissen. In elk geval komen steeds meer leerlingen in het speciaal onderwijs terecht, terwijl het aantal zorgleerlingen in het voortgezet onderwijs eveneens toeneemt. Toch is het niet waarschijnlijk dat het percentage kinderen met ADHD of vergelijkbare stoornissen dramatisch stijgt. Veel waarschijnlijker lijkt mij dat de normen in het onderwijs geleidelijk omhooggingen, met als gevolg dat een groter aantal kinderen daar niet langer aan voldoet. We zien derhalve wel een verslechtering, maar mogen niet vergeten dat deze relatief is. Eenzelfde proces vermoed ik achter de toegenomen gevoelens van onveiligheid onder de bevolking. Er is wel degelijk een werkelijke toename van criminaliteit, maar tegelijkertijd werden we de afgelopen dertig jaar gevoeliger voor lichtere vormen van overlast. Juist doordat er in het sociale verkeer meer aandacht is gekomen voor respect en gelijkwaardigheid, stijgt de kans dat iemand zich verkeerd bejegend voelt. De omgang met vrouwen en andere 'minderheden' wijst op hetzelfde: bepaalde gedragingen die vroeger vrij normaal waren, worden vandaag de dag als kwetsend opgevat. Anders gezegd: de onvrede neemt toe, omdat we hogere normen aanleggen. Een vergelijkbare verklaring zou ik willen geven voor het onbehagen van de burgers in de politiek. Juist doordat hun politieke interesse toegenomen is, doordat zij grote waarde aan het democratische proces hechten en velen zich willen inzetten voor de publieke zaak - ervaren veel burgers de houding van het bestuur als arrogant. Het betekent niet dat Nederland in objectieve zin veel slechter wordt bestuurd dan dertig jaar terug, maar wel dat de kwaliteit van het bestuur achterblijft bij de verwachtingen die moderne burgers inmiddels van de politiek hebben.

Een laatste mogelijkheid is uiteraard dat er inderdaad een verslechtering van het gedrag optreedt. Dit betekent dat de afstand tussen norm en gedrag niet alleen groter wordt (zoals bij een relatieve verslechtering), maar dat norm en gedrag zich in tegengestelde richting ontwikkelen. Dat heeft in het algemeen een scherpere selectie tot gevolg, omdat degenen die zich misdragen steeds slechter passen bij de eisen die in het betreffende domein gesteld worden. Ik geef drie voorbeelden. Ten eerste de toename van langdurige werkloosheid en arbeidsongeschiktheid in het economische domein. Dat verschijnsel is het gevolg van een dubbele ontwikkeling. Enerzijds gaan de cognitieve, normatieve en sociale eisen met betrekking tot werknemers omhoog, anderzijds verdwijnen allerlei soorten van industriële nijverheid uit Nederland. Bijgevolg treedt een massale en langdurige uitstoot van arbeidskrachten op. Het is evident dat het hierbij niet zozeer om perceptie maar om een vorm van selectie gaat. Het bedrijfsleven stoot de betrokken werklozen en arbeidsongeschikten af waardoor hun levensomstandigheden objectief verslechteren. Dat proces van uitstoting zien we eveneens bij de meer ernstige vorm van criminaliteit. Veel van deze delinquenten zijn niet bereid (en vaak ook niet in staat) om zich te voegen naar de normen van het maatschappelijke verkeer. 
Ze dragen een hele geschiedenis van ruzies en conflicten met zich mee, die al in het gezin van herkomst of de eigen buurt begint, doorgaat in het onderwijs of de werkkring en eindigt bij een van de schemergebieden in de hedendaagse maatschappij. Ook bij hen is er meer aan de hand dan een verslechtering in relatieve zin. Terwijl de maatschappelijke normen worden aangescherpt, leggen deze delinquenten zich op het overtreden van die normen toe. Ook hen stoot de samenleving uit - hetzij figuurlijk doordat ze een onderwereld opzoeken, hetzij letterlijk doordat ze in de gevangenis terechtkomen. Als derde voorbeeld van een verslechtering in absolute zin noem ik echtscheiding. Hoewel die toename mede samenhangt met hogere verwachtingen inzake het privé-leven, is het niet juist om haar tot een proces van perceptie te beperken. Het verbreken van een vaste relatie brengt in objectieve zin allerlei verslechteringen mee, niet alleen voor de partners maar ook voor de eventuele kinderen. Mensen die scheiden lopen in menig opzicht extra risico en voor kinderen vormt echtscheiding een factor die nadelige gevolgen voor hun persoonlijk leven heeft.

Samenvattend meen ik dat het vraagstuk van de zogeheten verloedering op drie wijzen met de geleidelijke ophoging van normen te verbinden is. Ten eerste kunnen hogere verwachtingen met een toename van de variatie samengaan. Een dergelijk proces van diffusie brengt met zich mee dat de norm weliswaar hoger maar ook minder helder wordt. Ten tweede leiden hogere verwachtingen tot een andere waarneming van bestaande gedragingen. Een dergelijke verandering in de perceptie brengt met zich mee dat men een verslechtering van het gedrag ervaart, zonder dat dit gedrag in objectieve zin veranderd is. Ten derde kan het gedrag in absolute zin verslechteren, wat dan (zeker in combinatie met opgehoogde normen) een scherpere selectie van betrokkenen tot gevolg heeft. Aldus roept een hoger normatief niveau in drie opzichten moeilijkheden op. ${ }^{4}$ Deze uitkomst moge paradoxaal lijken, maar zij doet zich in het proces van modernisering regelmatig voor. Ik meen zelfs dat ze inherent is aan de hedendaagse samenleving en dat elke vorm van modernisering dit soort paradoxen kent. Het lijkt mij goed deze gedachte van een korte uitleg te voorzien.

\section{Modernisering}

Het laatste, meer filosofische gedeelte van mijn essay handelt over het proces van modernisering in algemenere zin en de voorname rol die normen in dat verband spelen. Zoals bekend is dit proces op zeer diverse wijzen opgevat. Sommige auteurs, zoals Friedrich Nietzsche en Michel Foucault, benadrukken dat de moderne cultuur sinds de Verlichting in het teken van een subtiele onderwerping staat. Wij leven in een maatschappij waarin de vitale krachten in toenemende mate gedisciplineerd en gerationaliseerd worden. Dat brengt weliswaar bepaalde zekerheden mee, maar ook een verlies aan eigenheid of zelfstandigheid. Andere auteurs, zoals Sigmund Freud en Norbert Elias, houden er een meer positieve filosofie op na. Zij erkennen weliswaar dat natuurlijke aandriften in de moderne cultuur worden ingetoomd, maar benadrukken dat een dergelijk streven juist vrijheid en beschaving brengt. En er zijn ook auteurs, zoals Max Weber of Emile Durkheim, die op een meer neutrale wijze de functionaliteit van normen en 
waarden benadrukken. Normen zijn noodzakelijk voor de integratie van individuen en groepen in de samenleving als geheel. Gemeenschappelijk aan deze visies lijkt mij evenwel dat ze modernisering in de eerste plaats als een proces van integratie opvatten: individuen en groeperingen worden opgenomen in een groter geheel en als gevolg daarvan nemen hun verschillen af. In feite werkt de hegeliaanse dialectiek nog sterk in dergelijke visies door. Ze erkennen weliswaar dat er verschillen zijn, maar uiteindelijk loopt het historische proces op een vorm van synthese uit waarin de oppositie opgeheven is. Hoewel ik een dergelijke beweging niet ontken, wil ik aandacht vragen voor het feit dat processen van modernisering vaak ook het omgekeerde laten zien. Daarmee bedoel ik dat de fase van integratie door een fase van differentiatie gevolgd wordt, wat op den duur niet tot het opheffen maar juist tot het aanscherpen van de verschillen leidt.

Het zojuist gepresenteerde diagram vormt daar een illustratie van. Daaraan kan men aflezen dat zich in de loop van enkele decennia meerdere van elkaar afwijkende gedragslijnen ontwikkelen. De gedragsvariatie neemt toe, terwijl de normen geleidelijk naar boven gaan. Als gevolg van dit laatste treden er - in relatieve dan wel in absolute zin - ook verslechteringen op. De vraag is evenwel vanuit welk gezichtspunt men deze veranderingen evalueert. Wie zich op het gezichtspunt van de norm zelf stelt, kan bepaalde gedragingen goed of slecht noemen. Hoe groter de afstand tussen gedrag en norm, des te slechter zal men het gedrag vinden. Maar de socioloog denkt niet in termen van goed of slecht. Hij wil vooral vaststellen in hoeverre de variatie toegenomen is - en dan niet alleen de variatie op het gebied van normen, maar ook op dat van de gedragingen en zelfs in de relatie tussen normen en gedragingen. Bovendien is van belang dat er behalve variatie ook processen van selectie aan het werk zijn. Juist het feit dat in elk maatschappelijk domein zeer specifieke eisen aan het gedrag gesteld worden, brengt met zich mee dat sommige individuen zich daar thuis voelen, terwijl andere dat veel minder doen en een andere omgeving opzoeken. Bij die selectie spelen de instituties een voorname rol, omdat zij eisen voor een langere periode vastleggen. Daarnaast kan selectie een minder georganiseerde vorm aannemen. Soms treedt een onverwachte inperking van de variatie op en blijkt dat reeds lang bestaande gedragsvormen in korte tijd irrelevant worden.

Op deze wijze bepaalt de sociale omgeving welk gedrag blijft voortbestaan en na verloop van tijd het uitgangspunt voor een nieuwe serie variaties wordt. Met andere woorden: het zojuist beschreven proces vormt geen eenmalige ontwikkeling en kan zich meerdere keren achter elkaar voordoen. Mijn vermoeden is dan ook dat het zich in de geschiedenis van de moderniteit al vele keren heeft voorgedaan en typisch voor de moderne samenleving is. Figuur 2.9 geeft deze opeenvolging schematisch weer. In deze opvatting komt modernisering neer op het samengaan van variatie en selectie, met deze aantekening dat het proces van differentiatie zich veelal spontaan voltrekt en na verloop van tijd door een moment van selectie gevolgd wordt. Dit impliceert een evolutietheoretische interpretatie van de moderne geschiedenis (Gould 1996: 149-181). Deze ziens- 


\section{Figuur 2.9 Selectie en variatie}

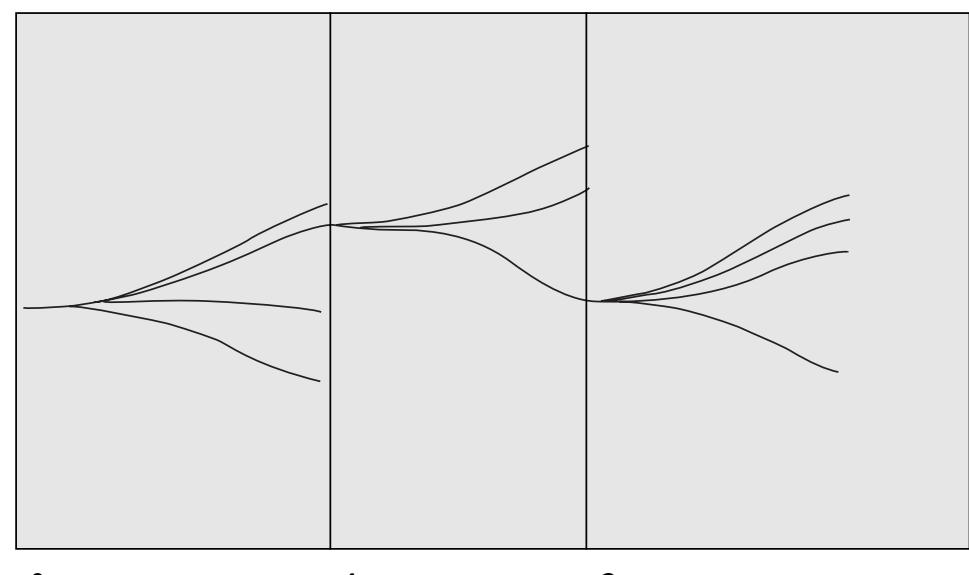

to

t1

t2

wijze erkent dat er vormen van integratie zijn, maar wijst erop dat die telkens door nieuwe vormen van differentiatie gevolgd worden. Zij vormt daarmee het tegendeel van een hegeliaanse dialectiek die de betekenis van differentiatie uiteindelijk in het moment van integratie legt.

Wat is nu - los van levensbeschouwelijke voorkeuren - de meerwaarde van een dergelijke evolutionistische benadering? Ik noem drie voordelen die mij in verband met het vraagstuk van norm en onbehagen relevant lijken. Ten eerste kunnen we ons op die manier bevrijden van de beruchte vraag of modernisering nu tot vooruitgang of tot achteruitgang leidt. Op grond van deze theorie zijn beide interpretaties te verdedigen. Verwijzend naar het ophogen van de normen kan men zeggen dat het in de moderne maatschappij steeds beter gaat. We hebben daar in het eerste deel van mijn bijdrage ook diverse voorbeelden van gezien. Maar omdat dit proces steeds gepaard gaat met vormen van relatieve of absolute verslechtering, kan men even goed zeggen dat het in de moderne maatschappij steeds slechter gaat. De pessimist en de optimist hebben dus alletwee gelijk, juist omdat zij op een normatieve wijze naar gedrag kijken. In mijn analyse stel ik slechts voortdurende variatie vast die periodiek of permanent door selectie ingeperkt wordt. Daarbij is de cruciale vraag of er een zekere afstemming ontstaat tussen de verschillende individuen en hun gedragsrepertoire enerzijds en de eisen die vanuit het sociale milieu aan hen gesteld worden anderzijds. De overlevingskansen van individuen of gedragingen die op geen enkele wijze aan de eisen van een sociale omgeving tegemoetkomen, zijn volgens deze theorie gering. Deze visie behelst een meer waardevrije benadering die we ook uit de biologie kennen. Het is dan ook geen toeval dat figuur 2.9, als het een kwartslag wordt gedraaid, het bekende patroon van een evolutionaire boomstructuur laat zien (zie figuur 2.10). Met het vorderen der tijd treedt voortdurend variatie en selectie op, maar zonder dat de uitkomst nu in termen van achteruitgang of vooruitgang op te vatten is. 


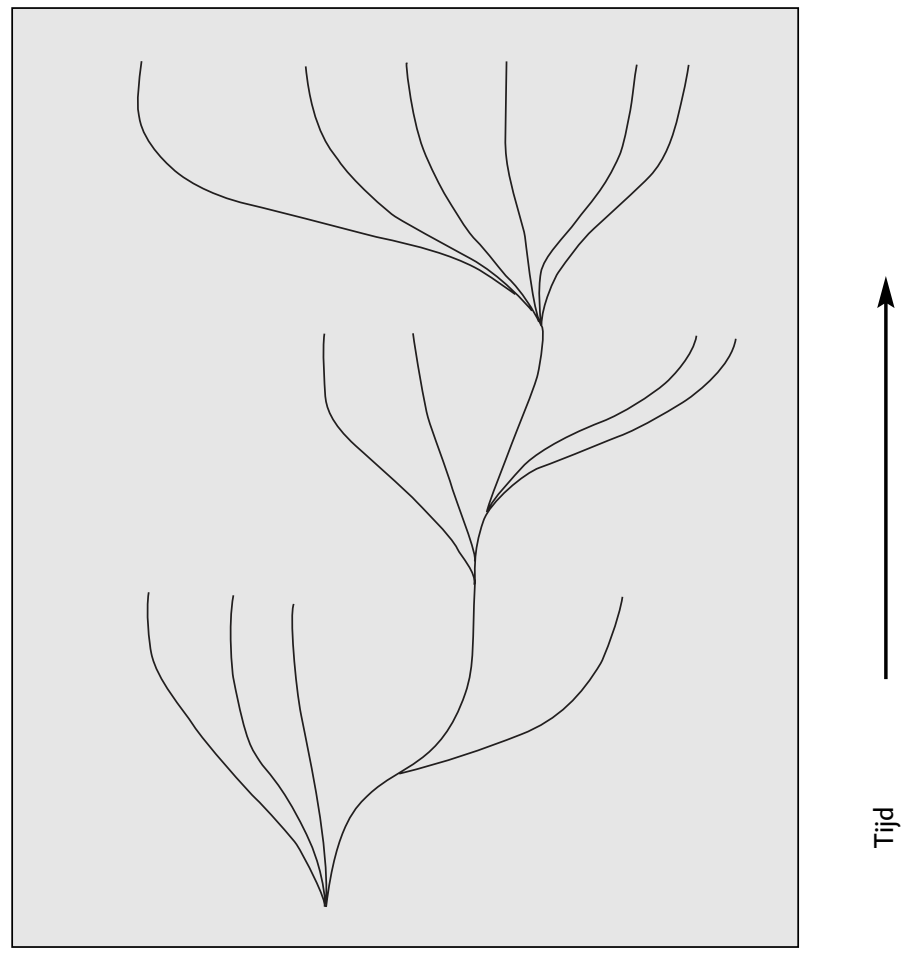

Een tweede voordeel van deze benadering lijkt mij dat het verschijnsel van de transgressie er van meet af aan in opgenomen is. Deze term verwijst naar het doelbewust overtreden van alom aanvaarde normen, vaak gepaard gaande met intense (lichamelijke) ervaringen. Voorbeelden daarvan zijn gevaarlijke sporten zoals parachutespringen, bezoek aan houseparty's en het gedrag van voetbalhooligans. Het enthousiasme van de deelnemers aan een dergelijk evenement is doorgaans omgekeerd evenredig aan de goedkeuring onder toeschouwers. Bijgevolg is men geneigd om het overtreden van de norm op te vatten als een betreurenswaardig feit, als iets wat eigenlijk verboden is of met de moderne samenleving conflicteert. In werkelijkheid vormen het overtreden van de norm enerzijds en modernisering anderzijds één onlosmakelijk geheel. Juist omdat de modernisering een voortdurende ophoging van normen kent, roept zij telkens een vorm van transgressie op. Dat maakt nu juist de dialectiek van de Verlichting uit.

Moderniteit betekent niet alleen dat problemen worden opgelost, het betekent evenzeer dat er telkens nieuwe problemen bij komen. Verlichting betekent niet alleen dat men het gedrag normaliseert, maar ook dat daardoor nieuwe afwijkingen ontstaan. Het betekent niet alleen dat bepaalde delen van het sociale leven gerationaliseerd worden, maar ook dat daardoor nieuwe vormen van irrationaliteit ontstaan (Geldof 1996: 142-201). Met andere woorden: het stellen van een norm brengt automatisch het abnormale met zich mee. Dat is niet alleen in logisch maar ook in historisch en sociologisch opzicht zo. Cultuur-historisch beschouwd zou men dit zelfs als een specifieke trek van het Westen kunnen 
opvatten. In veel Aziatische culturen zijn problemen iets waarvan men zich bevrijden moet, terwijl veel Afrikanen weten hoe men problemen overleeft. Maar het Westen brengt telkens nieuwe problemen aan het licht om vervolgens te zoeken naar een oplossing. Dat brengt een onafgebroken innerlijke onrust met zich mee die even vermoeiend als kenmerkend voor de moderne levenshouding is.

Een derde voordeel van deze analyse is dat ze een beschrijving biedt van de plotselinge omslagen die we in de geschiedenis van de moderniteit regelmatig kunnen vaststellen. Het proces van toenemende variatie roept vroeg of laat haar eigen grenzen op. Naar mijn indruk is dat precies wat op dit moment de Nederlandse samenleving overkomt. Vanaf de jaren zestig stellen we op tal van terreinen een proces van differentiatie vast. Enerzijds neemt het aantal gedragsvarianten toe, anderzijds loopt ook de spanning op tussen normen en afwijkende gedragingen. Tot het moment waarop een bepaalde maat overschreden wordt en het proces weer in de omgekeerde richting gaat. Dat moment lijkt voor Nederland tegen het einde van de jaren negentig bereikt. Op dat tijdstip begonnen - zonder dat iets of iemand daar de hand in had - plotseling allerwege stemmen op te gaan dat de ontwikkeling 'doorgeslagen' was. Men begon weer aan te dringen op gedragsregels, op een beter normbesef, op krachtig optreden van de overheid, et cetera. Met als gevolg dat we nu over de hele breedte van de samenleving over waarden of normen aan het debatteren zijn en wel op een manier die men twintig jaar geleden nog voor onmogelijk gehouden had. Toch is een dergelijke omslag niet uniek. Deze deed zich in de geschiedenis van de afgelopen twee eeuwen regelmatig voor, waarbij opvalt dat perioden van toenemende variatie of liberalisatie vaak zo'n jaar of dertig aanhouden en dan door een periode van normherstel gevolgd worden. ${ }^{5}$ Een en ander wijst erop dat er in de moderne samenleving subtiele vormen van homeostase aan het werk zijn, en wel in die zin dat er vaak een dynamisch evenwicht bestaat tussen het proces van integratie en de krachten die verdere differentiatie bevorderen. 


\section{NOTEN}

$1 \quad$ Alle in deze tekst genoemde cijfers zijn (tenzij anders wordt vermeld) afkomstig uit het gegevensbestand Culturele veranderingen van het Sociaal en Cultureel Planbureau. Mijn dank gaat uit naar Paul Dekker en Joep de Hart die een speciaal werkbestand ter beschikking stelden waarmee de ontwikkeling van ruim dertig variabelen over de periode 1960-200o kon worden gereconstrueerd. Het is misschien goed erop te wijzen dat ik deze tekst uitdrukkelijk als een essay beschouw. Ik probeer één bepaalde gedachte te ontwikkelen om te zien wat haar implicaties zijn. Vandaar dat ik uiteenlopende maatschappelijke sectoren vanuit eenzelfde gedachte onderzoek en dit met grafieken illustreer. Maar ik beweer natuurlijk niet dat overal dezelfde processen gaande zijn of dat men die processen onder één noemer kan terugbrengen.

3 Overigens is het gebruik van termen als hoger of lager hier een conventionele zaak. Men kan normatieve ontwikkelingen even goed beschrijven in termen van vermeerdering als in termen van vermindering. Om een voorbeeld te noemen: de een zal homoseksueel gedrag in de openbare ruimte opvatten als een aantasting van klassieke fatsoensnormen, de ander zal het als een vorm van emancipatie zien. Niettemin heb ik een voorkeur voor begrippen als ophoging, omdat ze ons eraan herinneren dat de moderne maatschappij vaak hoge eisen stelt aan het individu en zijn of haar gedragingen. Hoewel een vierde mogelijkheid - namelijk de erosie van normen - in dit essay onbesproken blijft, is het duidelijk dat bepaalde normen wel degelijk aan slijtage onderhevig zijn. Ik zal daar in een volgende publicatie voor de WRR nog uitvoerig op terugkomen.

$5 \quad$ Men denke aan de verzuiling van het sociaal-politieke leven tegen het einde van de negentiende eeuw (als reactie op de liberale dynamiek in eerdere decennia) en aan de vormen van autoritaire politiek in de jaren dertig (die een reactie op de revolutionaire dynamiek aan het begin van de twintigste eeuw vormden). 


\section{LITERATUUR}

Beer, P. de (2001) Over werken in de postindustriële samenleving, Den Haag: Sociaal en Cultureel Planbureau.

Breedveld, K., en A. van den Broek (2001), Trends in de tijd. Een schets van recente ontwikkelingen in tijdsbesteding en tijdsordening, Den Haag: Sociaal en Cultureel Planbureau.

Brink, G. van den (2001) Geweld als uitdaging. De betekenis van agressief gedrag bij jongeren, Utrecht: NIZW.

Brink, G. van den (2002) Mondiger of moeilijker? Een studie naar de politieke habitus van hedendaagse burgers, WRR Voorstudies en achtergronden, nr. 115, Den Haag: Sdu Uitgevers.

Bronneman-Helmers, H. (2002) Voortgezet onderwijs in de jaren negentig, Den Haag: Sociaal en Cultureel Planbureau.

Doornbos, K. (1991) Samen naar school. Aangepast onderwijs in gewone scholen, Nijkerk: Uitgeverij Intro.

Geldof, K. (1996) 'Economie, exces, grens: Michel de Certeaus genealogie van de moderniteit', blz. 142-201 in: K. Geldof en R. Laermans (red.) Sluipwegen van het denken. Over Michel de Certeau, Nijmegen: Sun.

Gould, S. (1996) De gok van de evolutie. Misvattingen over evolutie, vooruitgang en honkbal, Amsterdam: Contact.

Moelker, R. (1992) Zou hij onze nieuwe werknemer kunnen zijn? Veranderingen in gevraagde kwalificaties als weerspiegeling van veranderingen in de betekenis van prestatie. Een inhoudsanalyse van personeelsadvertenties, De Lier: Academisch Boeken Centrum.

SCP (1998) Sociaal en cultureel rapport 1998. 25 jaar sociale verandering, Den Haag: Sociaal en Cultureel Planbureau.

SCP (2002) Sociaal en cultureel rapport 2002. De kwaliteit van de quartaire sector, Den Haag: Sociaal en Cultureel Planbureau.

Zeegers, W. (1988) Andere tijden, andere mensen. De sociale representatie van identiteit, Amsterdam: Bert Bakker. 
G. de Vries

\section{$3.1 \quad$ INLEIDING}

Alledaagse ergernissen, daar draait het normen- en waardendebat uiteindelijk om. De CDA-website www.normenenwaardendebat.nl maakt het in één oogopslag duidelijk. Bezoekers kunnen er hun stem uitbrengen voor de 'nationaleergernissen-top-10’. Er kan uit zeventien kandidaten worden gekozen. Ze worden keurig alfabetisch geordend gepresenteerd: van agressief gedrag, discriminatie en drugsgebruik, via gebrek aan respect voor de politie, hondenpoep, luid mobiel bellen en niet opstaan voor ouderen, tot zwartrijden en zwerfvuil. Het geheel vormt een groslijst van wat burgers zoal hindert als zij hun huis verlaten en zich op straat, in het openbaar vervoer of andere publieke ruimten begeven. Nuchter moet worden vastgesteld dat dit soort ergernis kennelijk op ruime schaal voorkomt.

Ergernissen die direct of indirect naar maatschappelijke structuren of culturele contexten verwijzen zijn niet in de lijst op de CDA-website opgenomen. Het normen- en waardendebat richt zich op de manieren waarop mensen individueel met elkaar omgaan, of liever gezegd: op gedrag van anderen dat als teken van een ergerlijk gebrek aan beschaving wordt ervaren. De misnoegens over asociaal gedrag worden op een onsociale manier gepresenteerd. Referenties naar onrecht, armoede en ongelijkheid zijn afwezig, evenals elke directe verwijzing naar het feit dat in Nederland mensen met sterk uiteenlopende culturele en religieuze achtergronden leven. De mogelijkheid om te stemmen op ongelijke kansen op werk, gebrekkige opvang voor daklozen of uitzicht op een moskee wordt niet geboden. Hoewel door het CDA de urgentie van de normen- en waardenproblematiek wordt benadrukt, lijkt de tijd toch stil te hebben gestaan. Met uitzondering van luid mobiel bellen worden immers louter gedragingen genoemd die ook dertig of veertig jaar geleden reeds door velen als ergerlijk werden ervaren.

Het normen- en waardendebat verplaatst de genoemde ergernissen naar de publieke sfeer. Het antwoord van politici op de ergernissen die burgers ervaren wanneer zij sommige medeburgers ontmoeten bestaat er niet uit dat zij de bezem ter hand nemen en de straat schoon vegen of een tijdje met conducteurs meelopen om hen te ondersteunen bij hun werk op een 'risicolijn'. De ergernissen over agressief gedrag en zwerfvuil worden op een bijzondere manier gearticuleerd, namelijk door bezorgdheid te uiten over het feit dat kennelijk 'normen en waarden' niet meer vanzelf spreken, dat sommige individuen en groepen te weinig 'geïntegreerd' zijn en dat er een gebrek aan 'sociale cohesie' in het land is. Het debat richt zich vervolgens op de vraag wat hiervan de oorzaak is - waarbij abstracte termen als 'individualisering' en 'commercialisering' de ronde doen - 
en op de vraag langs welke wegen het tij kan worden gekeerd. Welke rol dient de overheid te hebben? Welke rollen komen gezinnen, scholen, kerken, buurten en bedrijven toe? En welke rol heeft de politiek bij het versterken van zulke maatschappelijke verbanden die, zoals cultuursocioloog Zijderveld op de genoemde website meldt, "belangrijk zijn voor het herbeleven van normen en waarden”?

Wat als alledaagse ergernis begon, is daarmee in enkele stappen een tamelijk abstract politiek probleem geworden. Zaken die aanvankelijk weinig of niets met elkaar gemeen hadden, zijn onder een noemer gebracht. Wie nooit van het normen- en waardendebat gehoord heeft, zal moeite hebben om de vraag te beantwoorden wat agressief gedrag en hondenpoep, of discriminatie en zwerfvuil met elkaar te maken hebben en misschien zelfs denken dat hem een grap of puzzel wordt voorgelegd. Hij zal zich misschien verwonderd afvragen of de vragensteller soms denkt dat bij uitstek hondenbezitters zich agressief gedragen, of tegenwerpen dat ook in buurten waar afval niet op straat maar keurig in vuilnisbakken wordt gedeponeerd, mensen wonen die hun landgenoten discrimineren omdat zij homoseksueel zijn of een donkere huid hebben. Het normen- en waardendebat maakt aan zulke twijfels een einde. Eenmaal gearticuleerd in het vocabulaire van dit debat verschijnen wat geïsoleerde, ergerniswekkende verschijnselen waren als voorbeelden van een en dezelfde problematiek. Agressief gedrag, hondenpoep, discriminatie en zwerfvuil worden alle als uitvloeisels van één maatschappelijke probleem gepresenteerd, namelijk het probleem van het niet langer vanzelf spreken van 'normen en waarden'. Voor dat probleem moeten politiek en samenleving nu oplossingen zoeken. Wat als gemopper in de huiselijk kring, bij de slager of in de bedrijfskantine begon, is een publieke zaak geworden.

Die transformatie spreekt niet vanzelf. Toen Montesquieu in 1729 ons land bezocht, oogstte de politieke constellatie van de Hollandse republiek zijn diepe bewondering. De Franse filosoof en rechtsgeleerde ergerde zich echter mateloos aan de gierigheid van de Hollanders, aan de voortdurende geld-uit-de-zak-klopperij waarmee hij werd geconfronteerd en hij verbaasde zich over een vrouw die, terwijl het gezin toekeek en - zoals Montesquieu opmerkt - haar man zijn tijd verdeed, elke ochtend dertig koppen thee dronk om haar verzwakte maag vervolgens met eau de vie te verkwikken. Toen Diderot in 1773 een vergelijkbare tocht maakte, viel hem op dat de Hollandse mannen slechte tanden hadden - een gevolg, vermoedde hij, van onder meer het vele roken - en merkte hij op dat Hollanders zelden bij elkaar op bezoek gingen. Als zij geen zaken met elkaar deden, zouden de Hollanders geen contact met elkaar hebben, concludeerde de Franse filosoof. Geconfronteerd met verslavingsproblematiek (thee, tabak), agressie jegens buitenlanders, verzakelijking en vereenzaming, repten Montesquieu en Diderot met geen woord over normen en waarden. Dat zich hier problemen aandienden waarop de Hollandse politiek een antwoord zou moeten zoeken, kwam al helemaal niet in hen op. Dat is niet verwonderlijk. De middelen om dit soort gedachten te uiten hadden de genoemde filosofen van de Verlichting niet. De terminologie waarvan het normen- en waardendebat zich bedient, was in de achttiende eeuw eenvoudigweg nog niet beschikbaar. 
Het begrip 'norm' kenden Montesquieu en Diderot. Afgeleid van het Latijnse norma dat oorspronkelijk naar winkelhaak of rechte hoek verwijst, was norm gaandeweg wet, regel, maatstaf of richtsnoer gaan betekenen. Als wiskundig begrip komt het voor in de Encyclopédie van d'Alembert en Diderot. De gedachte dat er sociale normen zouden bestaan die typerend zijn voor een bepaalde samenleving en die het gedrag van de inwoners van die samenleving reguleren, kwam echter pas aan het eind van de negentiende eeuw in omloop. Zij wordt gangbaar als ontdekt wordt dat allerlei gebruiken, zeden en gewoonten, alsmede geestesziekten en misdadigheid onverwachte statistische regelmatigheden vertonen.

Ook 'waarde' is een begrip dat pas in die eeuw gangbaar wordt. Lotze introduceert het rond 1840 in de filosofie van het Duitse idealisme. Hij ontleent de term aan de politieke economie die enkele decennia daarvoor was begonnen om theorieën te formuleren over economische waarden die een soort eigen leven leiden, los van de zaken of dingen waarvoor moet worden betaald. Waarden hebben filosofisch echter een problematische status, zo realiseert Lotze zich: zij bestaan niet objectief zoals feiten, maar zijn evenmin subjectief. Seiendes ist, Werte gelten, zo vat Lotze hun status samen. Veel navolgers voor zijn gedachten vindt hij aanvankelijk echter niet. Pas na Nietzsches provocerende denkbeelden over de Umwertung aller Werte komt het begrip 'waarde' hoog op de filosofische agenda te staan. In de handen van Nietzsche blijkt het waardebegrip namelijk een krachtig wapen te zijn voor het bestrijden van gangbare, hooggeschatte denkbeelden over ethiek, moraal en religie. Het is ironisch te moeten vaststellen dat een begrip dat nu wordt ingezet als antidotum tegen commercialisering en individualisering, zijn carrière begon in de economie en het filosofisch nihilisme.

Het nieuwe vocabulaire waarin over (maatschappelijke) normen en waarden wordt gesproken leidt tot verschuivingen in de manier waarop maatschappelijke problemen worden gepercipieerd. De nieuwe terminologie verleent specifieke betekenissen aan wat in haar wordt uitgedrukt. Om een indruk te krijgen van die lading is het nuttig om kort de geschiedenis van de gebruikte termen te beschrijven. Daaraan is het eerste deel van dit hoofdstuk gewijd. Het zal een verleden van veel vallen en opstaan en van toenemende begripsverwarring blijken te zijn. Aan het einde van de ontwikkeling kan men zich zelfs in gemoede afvragen waarover iemand spreekt die de genoemde termen gebruikt. Wie dat constateert komt vervolgens voor de vraag te staan wat politici doen wanneer zij desalniettemin de genoemde termen bezigen om alledaagse ergernissen tot een algemeen, publiek probleem te transformeren. Wat zijn de effecten van dit taalgebruik? En wat brengt politici ertoe om de in veel opzichten verwarrende terminologie van het normen- en waardendebat te blijven gebruiken als zij maatschappelijke problemen voor het voetlicht willen brengen? Op die beide laatste vragen gaat het slot van dit hoofdstuk in. 


\subsection{DE OPKOMST EN VERSPREIDING VAN HET NORMEN-EN WAARDENVOCABULAIRE}

Aan het einde van de negentiende eeuw wordt onderkend dat de samenleving een aanzienlijk ingewikkeldere constellatie vormt dan aanvankelijk was gedacht. De negentiende eeuw wordt gekenmerkt door een 'lawine van gedrukte getallen'. Talrijke statistische bureaus ontstaan in deze tijd. Steeds meer gegevens worden verzameld en vastgelegd, de belangstelling gaat allang niet alleen meer uit naar betaalde belasting en aantallen rekruten. De verzamelde gegevens wijzen uit dat zelfmoord, criminaliteit, prostitutie, geestesziekten en tal van andere vormen van deviant gedrag opmerkelijk stabiele patronen kennen. Welke krachten schuilen daarachter, zo begint de intellectuele wereld zich af te vragen. Waardoor wordt het maatschappelijk handelen van mensen geleid? De ontdekking dat de samenleving in veel opzichten een onbekende is zal rond 1900 de aanzet geven tot het ontstaan van een nieuw soort wetenschap, de sociologie. In dezelfde tijd groeit het besef dat een weerwoord moet worden geformuleerd op het nihilisme. Het idee dat samenlevingen met een normen- en waardenprobleem kunnen worden geconfronteerd vindt zijn wortels in het dubbele besef dat menselijke gedragingen mede bepaald worden door vooralsnog duistere maatschappelijke krachten en dat ook een rechtvaardiging van menselijk handelen in termen van de waarden die richtinggevend zouden moeten zijn, allesbehalve vanzelf spreekt.

Het antwoord op het nihilisme wordt door Duitse neokantiaanse filosofen gezocht in theorieën die speculatief een fundering zouden moeten bieden voor absolute, objectief geldende waarden. De gedachten gaan daarbij uit naar waarden als waarheid, familie en vaderland. De situatie waarin men zich manoeuvreert is filosofisch gesproken echter weinig bemoedigend. De absolute waarden die gezocht worden, moeten immers aan tegenstrijdige eisen voldoen. Zij zouden tegelijk objectief en irreëel zijn. Waarden bestaan niet op de manier waarop fysieke objecten er zijn en zij kunnen dus niet simpelweg worden waargenomen; zij zijn a priori, maar zouden toch niet subjectief zijn. Waarden gelden, had Lotze verklaard, maar waaraan zij die bijzondere status ontlenen was raadselachtig. De waardetheorieën zouden hierop het antwoord moeten geven. De pogingen om absolute waarden te bepalen lopen echter op niets uit en enkele decennia later wordt de onmogelijkheid van de hele onderneming algemeen onderkend.

Waardetheorieën verdwijnen daarna van het filosofische toneel. Filosofen die vanaf dat moment nog over waarden spreken, hebben het over iets wat subjectief is en waarmee filosofisch nauwelijks garen valt te spinnen. Degenen die alsnog in de traditie van Kant pogingen wagen om universele kaders voor normatieve beoordelingen van handelingen te formuleren, zetten hun kaarten niet meer op waarden, maar op normen. Zulke filosofische normen zijn echter formele, procedurele regels. $\mathrm{Zij}$ vertellen niet concreet hoe we behoren te handelen, noch houden ze ons voor wat we belangrijk en dus van waarde zouden moeten vinden. Zij specificeren - bijvoorbeeld in de uitwerking die Habermas geeft - op welke manieren we bereid zouden moeten zijn ons handelen ter discussie te stellen. 
Het hoeft weinig betoog dat tussen zulke normen en respect voor de politie of ergernis over zwerfvuil een diepe kloof gaapt.

Het gemak waarmee in publieke discussies met het begrip 'waarde' wordt geschermd mag dus wel enige verbazing wekken. Dat dit begrip niet tegelijk met de filosofische waardetheorieën het veld heeft geruimd is te danken aan twee ontwikkelingen. In de eerste plaats is het begrip 'waarde' in zwang gebleven als een weinig precieze en in veel opzichten zelfs verwarrende aanduiding voor ongeveer alles wat niet tot de fysieke wereld behoort, maar toch het bespreken waard wordt geacht. Waarde wordt in de loop van de twintigste eeuw een catch all-term voor alles wat in de filosofische traditie eerder behandeld was onder uiteenlopende noemers als rechten, deugden, verplichtingen, het goede, het ware en het schone. Wat filosofen in de Verlichting geleerd hadden te onderscheiden, wordt door deze term weer onder een - vage - noemer gebracht. Veel inhoud heeft het begrip echter niet. Het ontleent zijn betekenis in de eerste plaats aan wat niet wordt bedoeld: feit, natuur, materie. Het verwijst naar wat de gegeven, objectieve, materiële, niet-menselijke wereld van feiten en dingen te boven gaat. Met geest, cultuur en idee verbonden komt het tegenover lichaam, natuur en realiteit te staan. Waarde is het te vondeling gelegde kindje van het Duitse idealisme waarover het alledaagse spraakgebruik zich heeft ontfermd. Dat bleef zich erover ontfermen, ook toen de moeder zelf al lang en breed het toneel had verlaten.

De tweede ontwikkeling die het lot van het begrip 'waarde' heeft bepaald is de opkomst van de sociale wetenschappen. Onder invloed van de neokantiaanse filosofen situeert Max Weber aan het begin van de twintigste eeuw het begrip 'waarde' in het centrum van zowel zijn inhoudelijke sociologische werk als zijn wetenschapsfilosofie. In tegenstelling tot zijn filosofische collega's maakt Weber zich geen zorgen over het bestaan van absolute of objectieve waarden. Zijn vergelijkende godsdienstsociologie leert hem dat er zeer uiteenlopende waardestelsels bestaan. Ook met de filosofische vraag op basis waarvan waarden 'gelden' maakt Weber korte metten: dat bepaalde waarden gelden is voor hem een gegeven dat karakteristiek is voor een samenleving of cultuur. Wie geïnteresseerd is in de vraag waarom zij gelden, moet de geschiedenis van zo'n samenleving of cultuur bestuderen.

Weber past zijn inzichten ook toe op zijn eigen cultuur en op de wetenschap die hij bedrijft. Hij onderkent dat ook de waarden die de cultuurwetenschappen leiden relatief zijn en dat als zich nieuwe maatschappelijke problemen voordoen, de cultuurwetenschappen hun begrippenapparaat zullen aanpassen. Daarin onderscheiden de cultuurwetenschappen zich volgens Weber precies van de natuurwetenschappen: zij zijn 'waardebetrokken'. Waarde is voor Weber daarmee een begrip dat het kruispunt vormt van de belangstelling die de onderzoeker 'als cultuurmens' heeft en de bijzondere aard van de samenlevingen die hij bestudeert. Wie uitlegt dat het confucianisme door bepaalde waarden wordt gekarakteriseerd, vertelt niet alleen iets over het Chinese denken, maar laat tegelijk zien wat ons, als leden van de hedendaagse cultuur, daarin interesseert. 
De subtiliteit waarmee Weber het begrip 'waarde' in de sociologie introduceert, slijt evenwel in het latere gebruik. De waardebetrokkenheid van de onderzoeker waarop Weber wees, verdwijnt uit het zicht. Waarden worden al snel opgevat als gegevenheden die op een quasi-natuurwetenschappelijke manier kunnen worden vastgesteld, als attitudes of disposities die individuen tijdens hun socialisatie hebben verworven. Hele samenlevingen worden nu zelfs geacht een empirisch beschrijfbare normatieve structuur te hebben die in termen van gedeelde waarden kan worden geëxpliciteerd.

Eenmaal op deze koers beland, zijn simpele politieke conclusies te trekken. Wanneer mensen zich onmaatschappelijk gedragen, hebben zij zich kennelijk de maatschappelijk gangbare waarden onvoldoende eigen gemaakt. Zij moeten tijdens hun socialisatie dus onvoldoende hebben opgelet. Wie onmaatschappelijk gedrag wil bestrijden, zal dus middelen zoeken om mensen beter bij de les te houden. Dat in het normen- en waardendebat veelvuldig naar de rol van scholen en gezinnen wordt verwezen, hoeft ons dus niet te verbazen. In die instituties wordt immers geacht de primaire socialisatie, de overdracht van waarden, plaats te vinden.

\subsection{DE ARMOEDE VAN HET NORMEN- EN WAARDENVOCABULAIRE}

De redenering dat onmaatschappelijk gedrag effectief te bestrijden is door de rol van kerninstituties als scholen en gezinnen te versterken mag door haar eenvoud aanspreken, intellectueel gesproken is zij echter nogal armoedig. Zij maakt zoals we zagen gebruik van een filosofisch twijfelachtige terminologie en is zoals we zullen zien ook sociologisch gesproken buitengewoon oppervlakkig. Wie op een objectiverende, quasi-natuurwetenschappelijke manier over waarden wil spreken en Webers wetenschapsfilosofische subtiliteiten dus negeert, moet namelijk de conclusie trekken dat moderne samenlevingen beslist niet door gedeelde normen en waarden kunnen worden gekarakteriseerd. Het is Webers tijdgenoot Durkheim, die welbewust een sociologie voorstond die naar de natuurwetenschappen was gemodelleerd, die dit overtuigend heeft laten zien.

Durkheim kiest de sociale statistieken die in de negentiende eeuw met grote ijver verzameld waren, als uitgangspunt voor zijn beschouwingen. $\mathrm{Zij}$ maakten duidelijk dat het maatschappelijke leven regelmatigheden kent die het alledaagse bewustzijn ontgaan. Durkheim stelt nuchter vast dat, hoezeer de zelfmoordenaar er ook van overtuigd mag zijn dat hij een volstrekt individueel gemotiveerde, unieke daad uitvoert, het jaarlijkse percentage zelfmoordenaars in een samenleving opmerkelijk stabiel is. Wat een puur individuele keuze lijkt, blijkt aan sociale wetmatigheden onderworpen te zijn. Wat dwingt mensen in samenlevingen tot handelen, wat bindt hen, vraagt Durkheim zich daarom af. Het antwoord formuleert hij onder meer in termen van een contrast tussen 'mechanische' en 'organische' solidariteit. 
Mechanische solidariteit valt aan te treffen in kleine, overzichtelijke, traditionele gemeenschappen, betoogt Durkheim. Religie en rituelen spelen hier een belangrijke ondersteunende rol. In dit soort gemeenschappen reproduceert het individuele bewustzijn het collectieve bewustzijn (conscience). Er kan inderdaad van 'gedeelde normen en waarden' gesproken worden. Moderne, industriële samenlevingen hebben volgens Durkheim echter een aanzienlijk ingewikkeldere structuur. De organische binding die daar aan te treffen valt is niet gebaseerd op gedeelde normen en waarden, maar op arbeidsdeling en functiescheiding. Zoals hart en longen aan het voortbestaan van een lichaam kunnen bijdragen juist omdat zij qua opbouw en functie verschillen, zo geldt dat ook voor de uiteenlopende delen van het sociale lichaam. In complexe samenlevingen bestaat geen directe overeenkomst tussen individueel en collectief bewustzijn en sociale cohesie is er niet gebaseerd op een overkoepelende consensus. Het vereist ingenieuze onderzoekstechnieken om wat mensen in zulke samenlevingen bindt in beeld te brengen, aldus Durkheim, die daarin meteen het bestaansrecht van de sociologie had gevonden.

Het verwijt van conservatisme en nostalgie dat regelmatig gemaakt wordt jegens degenen die de discussie over normen en waarden hoog op de politieke agenda plaatsen, is vanuit Durkheims perspectief bezien dus volstrekt terecht. Wie over gedeelde normen en waarden spreekt en daarbij denkt aan normen en waarden die de leden van een samenleving bewust proberen hoog te houden, refereert impliciet naar een type samenleving dat al lang niet meer bestaat. Hij mag een traditionele dorpsgemeenschap op het oog hebben, maar kan het niet hebben over geïndustrialiseerde, stedelijke samenlevingen. Wanneer in het normen- en waardendebat over de maatschappij en de gemeenschap gesproken wordt, gaat het dus hooguit om een verbeelde - zo niet: ingebeelde - gemeenschap.

Zeker, mensen hebben opvattingen en hun meningen kunnen met behulp van vragenlijsten worden verzameld en desgewenst in termen van gangbare normen en waarden worden gerapporteerd. Dat kan ook in moderne, complexe samenlevingen. Vastgesteld kan dan bijvoorbeeld worden dat terwijl in 1991 nog 28 procent van de Nederlanders meende dat het gezin eronder lijdt als de vrouw werkt, dit percentage in 1998 is opgelopen tot 38 . Wat kan daaruit worden afgeleid over de sociale cohesie in Nederland, over de manier waarop sociale binding plaatsvindt of over de manier waarop Nederlanders zich feitelijk gedragen? Het eerlijke antwoord is simpel: eigenlijk helemaal niets.

Waarden en normen binden op zichzelf genomen namelijk niet. Mensen die dezelfde normen en waarden aanhangen, kunnen toch over concrete zaken van mening verschillen en als het op keuzes aankomt heel verschillende wegen inslaan. Dat wordt duidelijk als we ons even op een gemeenschap richten waarin belangrijke normen en waarden expliciet worden gedeeld: de wetenschap. Aan waarheid wordt in de wetenschap de hoogste waarde toegekend en er bestaat overeenstemming over belangrijke methodologische normen. Als echter louter het onderschrijven van de waarde van waarheid voldoende zou zijn om een 
succesvol onderzoeker te worden, zou ieder kind wetenschap kunnen bedrijven. Dat is uiteraard niet zo. Het beamen van de waarde van waarheid vertelt onderzoekers namelijk niet wat zij concreet moeten doen of vinden. Onderzoekers die oprecht de waarheid nastreven kunnen toch diepgaand van mening verschillen over elk detail van een theorie of over de manier waarop een experiment moet worden uitgevoerd en de uitkomsten ervan moeten worden geïnterpreteerd. Ook methodologische normen vertellen onderzoekers niet wat ze moeten denken of doen, zoals een simpel voorbeeld duidelijk kan maken. In de natuurwetenschappen is een algemeen onderschreven methodologische regel dat serieus te nemen experimenten reproduceerbaar moeten zijn. In concrete gevallen ontstaan er echter niet zelden lange en diepgaande discussies over de vraag of experiment $A$ wel als een herhaling van experiment B kan worden opgevat. Wanneer een onderzoeker een experiment reproduceert maar tot andere bevindingen komt, is niet ogenblikkelijk duidelijk wat moet worden geconcludeerd. Er ontstaat ruimte voor discussie: moeten de verschillen in de uitkomsten geweten worden aan fouten bij het uitvoeren van een van de experimenten, aan verschillen in de uitvoering van deze zo op het oog toch gelijke experimenten, of aan andere, nog onbekende factoren? De methodologische norm van reproduceerbaarheid onderschrijven legt niet vast welke conclusie getrokken moet worden.

Wat zo met betrekking tot waarheid en reproduceerbaarheid kan worden vastgesteld, geldt ook buiten de wetenschap: waarden en normen leveren geen directe richtlijnen op voor gedrag. Dat mensen dezelfde waarden aanhangen, impliceert niet dat zij conflictloos samenleven. Iedere partij in het Midden-Oostenconflict heeft vrede hoog in het vaandel staan, maar ondanks dat vallen er vrijwel dagelijks doden. Ook meer specifieke waarden leiden niet automatisch tot overeenstemming in gedrag. Nadat algemeen aanvaard is dat tolerantie een belangrijke waarde is, kunnen we toch van mening blijven verschillen of een bepaalde houding of gedragswijze als tolerantie dan wel als onverschilligheid moet worden uitgelegd. Normen garanderen al evenmin overeenstemming in feitelijk gedrag. Mensen die zonder aarzeling de norm aanvaarden dat we in het openbaar vervoer moeten opstaan voor ouderen, kunnen vervolgens heel wel verschillend oordelen over de vraag of de man of vrouw die net de tram binnenkwam nu wel of niet zo'n oudere is. Tussen waarden en normen enerzijds en feitelijk gedrag anderzijds staat steeds een oordeel en is dus ruimte voor verschillen in interpretatie.

Rapportages over de in een samenleving gangbare normen en waarden moeten dus met de nodige scepsis worden bezien. Het percentage Nederlanders dat desgevraagd van mening is dat gezinnen eronder lijden als de vrouw werkt, neemt in de jaren negentig toe. De arbeidsparticipatie van gehuwde vrouwen neemt in diezelfde periode ook toe. Dat is geen tegenstrijdigheid. Het een heeft simpelweg weinig met het ander te maken. Hoe kwetsend ook voor het in de loop van de twintigste eeuw gangbaar geworden zelfbesef dat ervan uitgaat dat we handelen op basis van bewust aangehangen normen en waarden, het is een eenvoudige waarheid: uit wat mensen denken en vinden kan niet zonder meer worden afgeleid hoe zij zich maatschappelijk gedragen. Het zelfbesef dat ons misleidt is geënt 
op de alledaagse situatie waarin we een eenvoudig doel hebben dat we zeggen te zullen nastreven. Dan kan inderdaad van ons verwacht worden dat we ons conform het uitgesproken voornemen gedragen. Wie zegt de trein te zullen nemen, heeft iets uit te leggen als hij toch in de auto stapt. Zo'n simpele relatie tussen een doel en een handeling is echter eerder uitzondering dan regel. Waarden en normen - en meer algemeen gesproken: regels - voor handelen zijn niet een soort geestelijke hefbomen of instructies die de menselijke machine in beweging zetten. Mensen oordelen en interpreteren. Dat geldt ook als zij zich zeggen te laten leiden door normen en waarden. Desgevraagd zullen ze de enquêteur antwoorden dat gezinnen eronder lijden als de vrouw werkt, maar er in alle eerlijkheid bij denken dat dit gelukkig niet voor hun eigen gezin geldt, of zich realiseren dat het tweede inkomen niet kan worden gemist. De volgende morgen gaat moeder dan ook weer naar haar werk.

\subsection{LIBERALISME, COMMUNITARISME EN REPUBLIKANISME: DE ROL VAN DE OVERHEID}

Waarde is een vaag begrip, een fossiel uit een inmiddels verlaten filosofisch verleden; de gedachte dat de samenleving door consensus over normen en waarden bijeen wordt gehouden is sociologisch onhoudbaar. Politici die over 'normen en waarden' spreken bedienen zich dus van begrippen waarvan men zich in gemoede kan afvragen wat hun betekenis nog kan zijn.

Aan academische scherpslijperij hebben politici echter weinig boodschap. Zij kunnen erop wijzen dat, hoewel de gebruikte terminologie wellicht bezwaren heeft, de zaak waarom het uiteindelijk draait toch aandacht verdient. Er bestaat immers in ruime kring ergernis over gebrek aan beschaafd gedrag. En of we het probleem nu in termen van gemeenschappelijke normen en waarden formuleren of niet, is het niet een primaire taak van de overheid om samenleven mogelijk te maken, de gemeenschap te beschermen en beschaving te bevorderen?

Met hoeveel retorisch talent ook uitgesproken, niet iedereen zal de suggestie dat de overheid de genoemde rol toekomt ogenblikkelijk beamen. De klassieke liberaal wijst haar zelfs categorisch af. In het klassieke liberale politieke denken staan immers individuen die belangen en voorkeuren hebben voorop. Zij worden geacht hun handelen in de eerste plaats via markten te coördineren. De staat heeft in de liberale opvatting slechts een rol bij het faciliteren van marktmechanismes en bij het corrigeren van die gevallen waarin de markt evident faalt. Het recht is daarvoor dan het geëigende middel. De politiek heeft in deze opvatting dus een beperkte functie: zij moet langs de weg van partijprogramma's en parlementaire verkiezingen individuele preferenties bundelen en op basis van zo geaggregeerde voorkeuren de rol van de staat bij het faciliteren en zo nodig corrigeren van marktwerking initiëren en controleren. Voor de klassieke liberaal geldt Thatchers befaamde uitspraak There is no such thing as society: er bestaan slechts individuen (en, zo voegde Thatcher er niet geheel consequent aan toe, gezinnen) die elkaar 
op markten treffen. Wie andere vormen van sociale cohesie zoekt, moet die maar in de privé-sfeer organiseren. De samenleving, sociale cohesie, of zo men wil solidariteit, is voor een liberaal geen zaak voor politiek en overheid.

Ook communitaristen zijn terughoudend als het gaat om de rol van de politiek. Voor hen staan echter niet zoals bij de liberaal het individu en zijn keuzes centraal, maar de gemeenschap en de deugden die van leden van een gemeenschap mogen worden verwacht. Communitaristen leggen de nadruk op het sociale karakter van het menselijk leven, van identiteiten, relaties en instellingen. Sociale cohesie en solidariteit moet in de ogen van communitaristen primair op dit niveau tot stand worden gebracht. Zoals de liberaal de rol van de politiek primair ziet in het faciliteren van markten, zo vormt voor de communitarist het stimuleren van instituties die gemeenschapszin bevorderen een voorname taak van de politiek. In tegenstelling tot de liberaal meent de communitarist dus dat de overheid mag moraliseren. De uitvoering van het op de ontwikkeling van deugden gerichte beleid wordt echter primair als een taak van het gezin, de school, kerken, buurtgemeenschappen en eventueel bedrijven gezien. De overheid dient te bevorderen dat de genoemde instituties hun maatschappelijke rol kunnen vervullen.

Omdat 'deugd' inmiddels een ietwat oudbakken klank heeft, wordt deze term in veel communitaristische geschriften door normen en waarden vervangen. Filosofisch gesproken is dat curieus. Het communitarisme beoogt terug te grijpen op een vorm van ethiek die door het Duitse idealisme, dat de bron van het normenen waardenvocabulaire vormde, werd verdrongen. Ook in een ander opzicht valt veel vertegenwoordigers van het communitarisme een zekere intellectuele zorgeloosheid te verwijten. De in het voetspoor van Durkheim geformuleerde sociologische kritiek dat wie over normen en waarden spreekt zijn onderwerp beperkt tot gemeenschappen die door mechanische solidariteit worden gekenmerkt, en het dus niet over moderne samenlevingen kan hebben, wordt nogal eens simpelweg genegeerd.

Het communitarisme is ruim vertegenwoordigd in de Nederlandse politiek. In tamelijk zuivere vorm valt het aan te treffen binnen het CDA, met Hirsch Ballin als spraakmakende representant. De Partij van de Arbeid kent al sinds Vorrink een expliciete communitaristische traditie, die in Wöltgens een belangrijke hedendaagse woordvoerder vindt. Zelfs de VVD heeft er blijk van gegeven gevoelig voor het denken van deze stroming te zijn. Zo betoogden de auteurs van het Teldersstichting-rapport Tussen vrijblijvendheid en paternalisme-Bespiegelingen over communitarisme, liberalisme en individualisering zelfs dat het niet alleen mogelijk, maar ook wenselijk is dat politici moraliseren. Het communitarisme zou liberalen kunnen inspireren tot een hernieuwde kijk op de eigen stroming, aldus de auteurs. Zij stonden daarin niet alleen. Bolkestein heeft in 1996 gepleit voor het opnemen van een verwijzing in het VVD-beginselprogramma naar de fundamentele waarden van het christendom (een verwijzing die in 1980 betrekkelijk geruisloos was verdwenen). In recente debatten over de multiculturele samenleving hebben de Nederlandse liberalen er al evenzeer blijk van gegeven 
een expliciet inhoudelijke conceptie van de Nederlandse gemeenschap voor te staan. Nederlandse liberalen zijn dus aanzienlijk minder streng in de liberale leer dan Thatcher.

Terwijl liberalen en communitaristen als het op maatschappelijke integratie aankomt aan overheid en politiek dus een beperkte rol toekennen, zijn republikeinen (een begrip dat in deze context niet tegenover de monarchie staat) van oordeel dat de politiek wel degelijk de taak toekomt het maatschappelijke proces als geheel te constitueren. De politiek is in deze opvatting de sfeer waarin burgers gezamenlijk een gemeenschap vormen. 'Gemeenschap' is daarbij (net als in het communitarisme) een morele notie: volgens de republikeinse opvatting zijn burgers in hun politieke handelen gericht op wat goed voor de gemeenschap is. Naast individuele preferenties en de marktfaciliterende rol van de staat, put de politiek in deze opvatting dus ook uit een derde bron: een idee over wat goed is voor de samenleving als geheel, het besef dat maatschappelijke integratie niet alleen via de markt en het staatsrecht, maar ook langs de weg van solidariteit tot stand moet worden gebracht.

Ook de republikeinse opvatting van politiek kan in Nederland op brede steun rekenen. Zij ligt zelfs feitelijk verankerd in de grondwet, die expliciet aan de Nederlandse overheid de taken toewijst om maatregelen te treffen ter bevordering van de volksgezondheid, te zorgen voor bestaanszekerheid en voor onderwijs, de bewoonbaarheid van het land te bevorderen en het milieu te beschermen en te verbeteren. Praktisch niemand in Nederland betwist dus dat de politiek er ook is voor de samenleving, dat solidariteit moet worden georganiseerd en dat politiek en overheid hierbij een voorname rol hebben. Waar in veel andere landen de politieke ruimte wordt opgespannen door ideologische tegenstellingen tussen liberalisme, communitarisme en republikeins denken, zijn de verschillen tussen de politieke partijen in Nederland in dit opzicht gering. De ideologische driehoek is bijna tot een punt gereduceerd. De tegenstellingen tussen de belangrijkste partijen beperken zich tot de vraag welke mengverhouding tussen individu, maatschappelijk middenveld (gemeenschappen) en politiek wenselijk en uitvoerbaar is.

Uit de republikeinse gedachte dat het een taak van de politiek is om solidariteit te organiseren volgt evenwel niet dat deze taak vervuld moet of zelfs maar kan worden door het nastreven van overeenstemming over normen en waarden. Discussies over de genoemde mengverhouding die gevoerd worden in termen van normen en waarden zijn dan ook misplaatst. De eerdergenoemde kritiek op het normen- en waardenvocabulaire treft namelijk ook de onderwerpen die de grondwet aanwijst als onderwerp van overheidszorg. De waarde van volksgezondheid en van de bescherming van het milieu onderschrijven vertelt ons niet hoe die fraaie doelen praktisch gerealiseerd moeten worden. Wie expliciet geformuleerde politieke doelen - zoals bescherming van het milieu of bevorderen van de volksgezondheid - verwart met het nastreven van maatschappelijke consensus over normen en waarden, maakt dus een categoriefout. Zijn denken wordt gevangen gehouden door het beeld waarin normen en waarden het handelen 
sturen, en waarin overeenstemming over normen en waarden garandeert dat ieders gedrag binnen de aanvaarde kaders zal blijven. Dat beeld is veel te simpel. Het doet onrecht aan de complexiteit van sociale binding. Het is bovendien strijdig met de basisgedachte van democratie, namelijk dat het door het volgen van behoorlijk democratisch overleg mogelijk is geordend en vreedzaam samen te leven, ook waar de meningen fundamenteel verschillen.

\subsection{DE VERPLATSING VAN DE POLITIEK}

Normen en waarden hebben niet de rol die hun in veel hedendaagse discussies wordt toegedicht, ze kunnen die rol in moderne, geïndustrialiseerde samenlevingen zelfs niet hebben. Politici die zich toch van dit vocabulaire bedienen, krijgen wellicht applaus van de tribune, maar op de keper beschouwd verplaatsen zij slechts lucht. De ergernissen van degenen die zij vertegenwoordigen over onbeschaafd gedrag, die de aanleiding vormden voor het spreken over normen en waarden, worden er niet door weggenomen.

Deze situatie roept ten minste drie vragen op. De eerste is: op welke manier komt sociale integratie dan wel tot stand, als het niet langs de weg van gedeelde normen en waarden is? Wat is de basis voor beschaafd gedrag? De tweede vraag luidt: waarom heeft de discussie over normen en waarden dan toch zo'n hoge vlucht kunnen nemen? De laatste kwestie die om een reactie vraagt is: wat zijn de effecten van het blijven discussiëren over maatschappelijke vraagstukken in de termen die horen bij het normen- en waardendebat?

Op de eerste vraag is geen kort, goed antwoord mogelijk. Sterker nog, de eerlijkheid gebiedt te zeggen dat wie zich niet in weinigzeggende slagzinnen wil uiten, het antwoord op deze vraag schuldig moet blijven. Over de manier waarom mensen zich hun moedertaal eigen maken, bestaan verschillende wetenschappelijk serieus te nemen theorieën. Over de manier waarop wij ons beschaafd gedrag eigen maken, tasten we echter in het duister. Wat te constateren valt is dat samenlevingen feitelijk wonderen van sociale integratie zijn, waarin dagelijks ontelbare handelingen op een adequate manier worden gecoördineerd. Wie aan het maatschappelijk verkeer wil deelnemen moet een soort evenwichtskunstenaar zijn. Hij moet in staat zijn om te gaan met subtiele balansen. Hedendaagse samenlevingen vragen bijvoorbeeld historisch gesproken hoge niveaus van zelfbeheersing en agressieregulatie; tegelijkertijd worden het nemen van initiatieven, assertiviteit en het bewust aangaan van competitie toegejuicht. Zulke ambivalenties kunnen op diverse terreinen worden geconstateerd. Zo worden met het oog op de gezondheid talrijke gedragingen aangeleerd die hygiëne bevorderen; wie zich daar echter al te zeer door laat leiden, lijdt aan smetvrees en wacht behandeling. Uiteraard gaat onze politieke interesse uit naar de gevallen waarin de coördinatie van handelen mislukt en waarin het gedrag van sommigen de ergernis van anderen wekt. Theoretisch gesproken is het slagen van de coördinatie in het overgrote deel van de gevallen een harder te kraken noot. 
Op de een of andere manier slaagt het merendeel van de mensen erin zich de competenties of de habitus eigen te maken die hen in staat stelt deel te nemen aan het maatschappelijk verkeer. Zij maken zich beschaving eigen, dat wil zeggen zij weten zich te gedragen. Hoewel zij in staat zullen zijn om onder verwijzing naar morele codes hun gedrag te rechtvaardigen, gaat het daarbij om een vorm van kennis waarvan men zich zelden expliciet bewust is. Behalve competenties moet echter ook de materiële omgeving op een adequate manier zijn ingericht. Wie geleerd heeft dat beschaafde mensen hun vuilnis niet op straat gooien, zal over een vuilnisbak willen beschikken die regelmatig wordt geleegd. Zonder die voorziening, zal het genoemde beschaafde gedrag slechts een kort leven zijn beschoren.

De manier waarop mensen tot beschaafde subjecten worden geconstitueerd is op zijn zachtst gezegd complex en wie denkt haar onder verwijzing naar kerninstituties met enkele slagzinnen te kunnen afdoen, misleidt zichzelf en zijn gehoor. We kunnen zulk gedrag wel langs verschillende dimensies proberen te ordenen.

Samenlevingen onderscheiden zich van elkaar en ten opzichte van hun eerdere stadia in de eerste plaats door de domeinen van het gedrag waarvoor publieke verantwoording kan worden gevraagd. Naast traditionele thema's rond geweld, dood en seks zijn nieuwe domeinen opgekomen: gezondheid, persoonlijke ontwikkeling, zorg voor de directe omgeving en omgang met anderen. Beschaving uit zich allang niet meer uitsluitend door beheerst gedrag, tafelmanieren, door lichaamsverzorging en het in acht nemen van hygiëne, maar ook door de bereidheid zich te ontwikkelen en het ruimte weten te bieden aan anderen. Samenlevingen verschillen in de tweede plaats in de praktijken waarin de subject-constitutie feitelijk gestalte krijgt. Soms maken preken, instructie of voorlichting deel uit van zulke praktijken, vaker wordt het beoogde effect bereikt door oefeningen, door controle, door het maken van indelingen van mensen, door het zichtbaar maken van individueel gedrag, of langs andere wegen tot stand gebracht. Wie de geschiedenis van de seksualiteit beziet, moet wel concluderen dat de inventiviteit van opvoeders weinig grenzen lijkt te hebben. Ten slotte verschillen samenlevingen in de manier waarop de verantwoording moet worden afgelegd - van biecht tot groepsgesprek en maoïstische zelfkritiek - en de doelen en vormen van rationaliteit die in het geding zijn.

Ondanks deze enorme verscheidenheid valt een grove trend vast te stellen. Vanaf de negentiende eeuw zijn overheden zich in toenemende mate gaan bemoeien met de manieren waarop individuen als beschaafde subjecten en morele personen worden geconstitueerd. In veel opzichten heeft modern bestuur het karakter gekregen van wat Foucault aanduidt met de term governmentality, 'the conduct of conduct'. Nadat eerst onderwijs, gezondheidszorg en sociale zekerheid overheidstaken werden, is na de Tweede Wereldoorlog onder meer milieubescherming daaraan toegevoegd. Die bemoeienis heeft geleid tot praktijken waarin op subtiele en soms minder subtiele manieren mensen geleerd wordt zich te gedragen als individuen die geacht worden een zekere ontwikkeling te hebben, hun 
gezondheid te bewaken en hun omgeving als voorwerp van hun zorg te zien. De scholier weet wat hem te doen staat als er examen moet worden gedaan; de patiënt weet dat hij niet verbaasd hoeft op te kijken als de arts hem vraagt zich uit te kleden; het gebruik van vuilniszakken is bekend. Dat alles is gerealiseerd zonder al te veel uitdrukkelijke instructie: door klaslokalen en medische praktijken op een bepaalde manier in te richten en door het vuilnis op een vaste dag in de week op te halen. Als iets de integratie van de samenleving en het beschaafde verkeer van mensen mogelijk maakt, is het dit ragfijne en uitgebreide netwerk van voorzieningen en praktijken.

De enorme toename van deze praktijken heeft evenwel geleid tot een tweede trend: de toenemende verzelfstandiging ervan. Hoewel overheden in belangrijke mate de financiering van voorzieningen verzorgen, is de praktische vormgeving ervan in de eerste plaats een zaak van professionals en uitvoeringsinstanties geworden. Slechts in bijzondere gevallen en in situaties waarin de financiering in het geding komt, spreken de overheid en de politiek zich er uitdrukkelijk inhoudelijk over uit. Feitelijk is een groot deel van de constitutie van individuen als morele subjecten daarmee onttrokken aan de democratische controle. Het overgrote deel van de feitelijke maatschappelijke integratie vindt plaats buiten de sfeer waarop de politiek directe greep heeft. Dat geldt dus niet alleen voor die domeinen waar de politiek zich traditioneel reeds terughoudend opstelt, de markteconomie en de privé-sfeer, maar ook voor de terreinen waar de overheid wel expliciet (bijvoorbeeld grondwettelijk) geacht wordt taken te hebben. Het vormt een gegeven dat in de Nederlandse discussies over de 'verplaatsing van de politiek' ten onrechte weinig aandacht heeft gehad.

De politiek is door beide genoemde ontwikkelingen in een lastig parket gekomen. Enerzijds worden in lijn met het republikeinse denken aan de overheid taken toegekend op het terrein van het vormgeven van maatschappelijke solidariteit. De verwachtingen zijn hooggespannen en de domeinen waarvoor de overheid verantwoordelijkheden worden toegedicht zijn in de loop van de twintigste eeuw aanmerkelijk uitgebreid. Vooralsnog lijkt er aan die ontwikkeling geen einde te komen. Tegelijkertijd moet geconstateerd worden dat de feitelijke invloed van de politiek op de uitvoering van deze taken gering is. Niet politici, maar professionals en uitvoeringsinstanties maken als het erop aankomt de dienst uit.

Het opleven van het normen- en waardendebat in het afgelopen decennium kan begrepen worden als een uitvloeisel van de paradoxale situatie waarin de politiek zo terechtgekomen is. Het debat kan gezien worden als een verwoede poging om het verloren gegane terrein terug te winnen en de maatschappelijke integratie expliciet tot onderwerp van politieke discussie en beleid te maken. Veel kans van slagen heeft die poging niet, zoals uit het voorgaande duidelijk mag zijn. De termen waarin het debat gevoerd wordt zijn zoals we gezien hebben weinigzeggend en de doelstelling maatschappelijke integratie te bewerkstelligen door overeenstemming over normen en waarden is onrealistisch. Sociale integratie berust 
niet op gedeelde normen en waarden, en een normen- en waardencrisis zal zulke samenlevingen zonder veel problemen kunnen opvangen. Feitelijk liggen de (interne) bedreigingen voor moderne samenlevingen op een heel ander vlak. Maatschappelijke integratie komt pas echt in gevaar wanneer de elektriciteitsvoorziening langere tijd uitvalt en het vuil een aantal weken niet wordt opgehaald.

Het belangrijkste effect van het huidige normen- en waardendebat is dan ook precies tegengesteld aan wat politici die het onderwerp maatschappelijke integratie hoog op de publieke agenda plaatsen zeggen te beogen. Het normen- en waardendebat onttrekt de manier waarop die integratie in complexe samenlevingen feitelijk totstandkomt aan de democratische discussie. Een overheid die in lijn met het republikeinse denken zich het bevorderen van maatschappelijke integratie ten doel stelt, moet haar grondwettelijk vastgelegde taken ter harte nemen: de volksgezondheid bevorderen, voor adequate voorzieningen voor onderwijs, sociale zekerheid en ouderenzorg zorgen, het milieu beschermen. Zij moet de voorzieningen instandhouden die onderdeel vormen van het ragfijne netwerk van praktijken dat de basis vormt voor sociale integratie. Wanneer de politiek de manier waarop maatschappelijke integratie in moderne maatschappijen praktisch totstandkomt onder democratische controle wil brengen, zal de overheid zich intensiever met professionele organisaties dienen bezig te gaan houden dan tot dusverre het geval is. De bestaande trend waarbij professionals een hoge mate van zelfbestuur wordt toegekend (waarvoor de regelingen rond het medische beroep exemplarisch zijn) zou daarbij opnieuw bezien moeten worden. Een politiek stelsel dat besluit voor sociale integratie essentiële voorzieningen en praktijken te liberaliseren of over te dragen aan semi-autonome professionele organisaties, om zich vervolgens te vermoeien met het voeren van een zinloos normen- en waardendebat, maakt zichzelf overbodig. Het graaft zijn eigen graf. 


\section{LITERATUUR}

Anderson, B. (1995) Verbeelde Gemeenschappen, Amsterdam: Uitgeverij Jan Mets. Bourdieu, P. (1989) Opstellen over smaak, habitus en het veldbegrip, Amsterdam: Van Gennep.

Bovens, M. et al. (1995) De verplaatsing van de politiek, Amsterdam: Wiardi Beckmann Stichting.

Collins, H.M. (1985) Changing Order, Londen: SAGE Publications.

Dassen, P. (1999) De onttovering van de wereld-Max Weber en het probleem van de moderniteit in Duitsland, 189o-1920, Amsterdam: Uitgeverij G.A. van Oorschot.

Diderot, D. (1994) Over Holland - Een journalistieke reis 1773-1774, Amsterdam: Uitgeverij Contact.

Durkheim, E. (1897) Le Suicide, Parijs: Alcan.

Durkheim, E. (1902) De la division du travail social, zième Edition, Parijs: Alcan.

Elias, N. (1969) Über den Prozeß der Zivilisation, Bern/München: Francke Verlag.

Foucault, M. (1979) The History of Sexuality Volume 1, Londen: Penguin Books.

Foucault, M. (1991) Governmentality, in: C.G.G. Burchell and P. Miller (eds.), The Foucault Effect, Chicago: The University of Chicago Press.

Groenveld, K., G.A. van der List, P.B. Cliteur, R. Hansma en A.A.M. Kinneging (1995) Tussen vrijblijvendheid en paternalisme - bespiegelingen over communitarisme, liberalisme en individualisering, Den Haag: Prof. Mr. B.M. Teldersstichting.

Habermas, J. (1981) Theorie des kommunikativen Handelns, Frankfurt a.M.: Suhrkamp Verlag.

Habermas, J. (1994) Volkssouveränität als Verfahren, in: J. Habermas, Faktizität und Geltung, Frankfurt a.M.: Suhrkamp Verlag.

Hacking, I. (1990) The Taming of Chance, Cambridge: Cambridge University Press.

Koenis, S. (1997) Het verlangen naar gemeenschap - Over moraal en politiek in Nederland na de verzuiling, Amsterdam: Van Gennep.

Kuhn, T. S. (1970) The Structure of Scientific Revolutions, 2nd enlarged edition, Chicago: Chicago University Press.

MacIntyre, A. (1984) After Virtue, 2nd edition, Notre Dame, Indiana: University of Notre Dame Press.

Mertens, J.J.H., R. Pieterman, C. J. M. Schuyt, en G. de Vries (2003) Pech moet weg, Amsterdam: Amsterdam University Press.

Montesquieu (1949) Oeuvres complètes, Vol. 1, Parijs: Gallimard (Bibliotheque de la Pléiade).

Schnädelbach, H. (1983) Philosophie in Deutschland, 1831-1933, Frankfurt a.M.: Suhrkamp Verlag.

SCP (2000) Sociaal en Cultureel Rapport 200o, Nederland in Europa, Den Haag: SCP.

Vries, G. de (1999) Zeppelins - Over filosofie, technologie en cultuur, Amsterdam: Van Gennep.

Weber, M. (1968) Gesammelte Aufsätze zur Wissenschaftslehre, Tübingen: J.C.B. Mohr $<$ Paul Siebeck>.

Wittgenstein, L. (1969) Philosophische Untersuchungen, Frankfurt a.M.: Suhrkamp Verlag. 


\title{
4 BEVRIJDENDE WAARDEN EN BINDENDE NORMEN IN DE PUBLIEKE MORAAL
}

\author{
H.E.S. Woldring
}

\subsection{INLEIDING: MEER DAN FATSOEN}

In 2002 heeft Balkenende als politiek leider van het CDA en later als ministerpresident het thema 'waarden en normen' op de politieke agenda geplaatst. Met de slagzin 'Fatsoen moet je doen' leek hij aanvankelijk vooral de strijd aan te binden tegen gebrek aan respect, wellevendheid en fatsoen in het publieke domein (vooral in het verkeer en openbaar vervoer). In zijn in april 2002 verschenen boek Anders en beter blijkt echter reeds dat Balkenende (2002a: 51-62) het thema 'waarden en normen' breder en dieper wil aanpakken. Hij betoogt dat elke samenleving een eigen cultuur heeft, die bepaalde waarden en normen bevat die op alle terreinen van de samenleving aan de orde zijn en derhalve ook op alle beleidsterreinen.

In de aanpak van het probleem van waarden en normen wil Balkenende (2002b: 35/2633-2645) drie sporen volgen: 1) inventariseren van de ervaringen, zorgen en problemen van burgers in hun woon-, werk- en leefomgeving, 2) inventariseren van de initiatieven die burgers en maatschappelijke organisaties zelf ondernemen om waarden en normen vorm te geven (en die door bewindspersonen op hun diverse beleidsterreinen kunnen worden versterkt) en 3) een inhoudelijke verdieping van waarden en normen. Die inhoudelijke verdieping heeft betrekking op de volgende vragen. Over welke fundamentele waarden en normen gaat het debat of behoort het te gaan? Op welke manier kan men waarden en normen expliciet maken? En op welke manier kunnen bepaalde waarden en normen samenbindend werken? Het eerste en tweede spoor hebben betrekking op empirisch onderzoek. Het derde spoor heeft vooral betrekking op een filosofische en ethische reflectie. Ik zal mij tot dat derde spoor beperken, teneinde te voldoen aan het verzoek van de WRR: het leveren van een discussiebijdrage over de relatie tussen westerse waarden en christelijke waarden. Ik zal deze discussiebijdrage toespitsen op twee vragen.

I Welke bijdragen kunnen vanuit christelijk-levensbeschouwelijke visies worden geleverd aan een inhoudelijke verdieping van het debat over fundamentele waarden en normen?

2 Op welke wijze kan die inhoudelijke verdieping bijdragen tot een versterking dan wel correctie van 'gedeelde waarden en normen' (publieke moraal) in de samenleving?

Teneinde deze vragen te beantwoorden, zal ik in de volgende paragrafen aandacht besteden aan de volgende onderwerpen: fundamentele waarden (par. 4.2), normen (par. 4.3), de publieke moraal in een pluralistisch-democratische samenleving (par. 4.4), mogelijkheden tot bijdragen aan de publieke moraal (par. 4.5) 
en inhoudelijke bijdragen aan de publieke moraal (par. 4.6): rechtvaardigheid, solidariteit, verantwoordelijkheid, duurzaamheid en vrijheid. Een korte evaluatie (par. 4.7) volgt als slot.

\subsection{FUNDAMENTELE WAARDEN}

Waarden zijn fundamenteel als zij onontbeerlijk zijn voor het morele leven van individuele mensen en de samenleving als geheel. Aldus de ethicus Vos (1995: 100-118), die vervolgens vijf fundamentele waarden bespreekt: leven, weldadigheid, rechtvaardigheid, waarachtigheid en vrijheid. Die waarden staan niet los van elkaar, maar zij moeten in hun onderlinge samenhang worden geïnterpreteerd en simultaan worden gepraktiseerd. Ik geef een enigszins vrije, samenvattende beschrijving van die fundamentele waarden.

a Leven. Deze waarde betekent dat men respect behoort te hebben voor het bestaan van anderen en dat men nog niet geborenen en hen die in hun laatste, broze bestaansfase verkeren behoort te beschermen, opdat mensen in vrede en met toekomstverwachting kunnen samenleven. Problemen als abortus, euthanasie, agressie, zinloos geweld, ontwikkelingssamenwerking, oorlog en vrede ontlenen hun belang aan de waarde die aan het leven wordt gehecht. Die problemen worden echter niet opgelost met een eenvoudig beroep op de fundamentele waarde van het leven, omdat in het menselijke handelen die waarde slechts in samenhang met andere waarden kan worden begrepen en behoort te worden gerealiseerd.

b Weldadigheid. Aan deze waarde ligt ten grondslag een gezindheid van welwillendheid die tot uitdrukking komt in het verlenen van hulp. Leven is een basale waarde, maar omdat mensen kwetsbaar en beperkt zijn, is hulp als uiting van weldadigheid onmisbaar. In extreme situaties, waarin bijvoorbeeld sprake kan zijn van abortus of euthanasie, kan het beëindigen van het leven een uiting zijn van welwillende hulp. Vandaar dat leven geen absoluut-fundamentele waarde is; die waarde kan in uitzonderlijke gevallen worden gerelativeerd door en aangevuld met welwillendheid. De fundamentele waarde van welwillendheid kan in bepaalde situaties worden vertaald in waarden als zorg, liefde en solidariteit.

c Rechtvaardigheid. Deze waarde wordt vaak geassocieerd met gelijkwaardigheid, gelijke behandeling van gelijke gevallen, ieder het hare/zijne geven en 'Wat gij wil dat u geschiedt, doe een ander evenzo'. Bij rechtvaardigheid gaat het om het eerlijk verdelen van schaarse goederen en diensten. $\mathrm{Zij}$ volgt op de waarden van leven en welwillendheid, omdat rechtvaardigheid dient ter beantwoording van vragen: hoe te leven en hoe welwillend te zijn.

d Waarachtigheid. Deze waarde heeft betrekking op het spreken van waarheid en het houden van beloften. Deze waarde komt na leven, welwillendheid en 
rechtvaardigheid, omdat altijd waarheid spreken anderen (bijv. onderduikers) in gevaar kan brengen. Hoewel dus geen absolute waarde, is zij in samenhang met de genoemde waarden fundamenteel. In elke samenleving is zij onontbeerlijk, omdat zij mogelijk maakt wat noodzakelijk is: samenwerking, aangaan van relaties, nakomen van overeenkomsten, wederzijds respect en het beantwoorden aan gewekte verwachtingen. Waarachtigheid bewerkt continuïteit in de samenleving, trouw, besef van verantwoordelijkheid en duurzaamheid van onze leefwereld.

e Vrijheid. Deze waarde ligt ten grondslag aan het kiezen van een eigen levensrichting en inrichting van het leven. Evenals andere waarden is vrijheid niet absoluut. De vrijheid van de één kan de vrijheid van de ander in de weg staan. Ook al wordt de grens van vrijheid vaak gelegd bij het geen schade toebrengen aan anderen, in positieve zin krijgt vrijheid haar ontplooiing in samenleven met anderen en wederzijds respect. Vrijheid zonder welwillendheid kan leiden tot egocentrisme. Omgekeerd kan welwillendheid die weinig ruimte laat voor vrijheid leiden tot paternalisme en intolerantie. Vrijheid zonder rechtvaardigheid en waarachtigheid kan gemakkelijk ontaarden, maar het omgekeerde geldt eveneens.

De genoemde fundamentele waarden - leven, welwillendheid (zorg, liefde, solidariteit), rechtvaardigheid (gelijkwaardigheid, eerlijk delen), waarachtigheid (trouw, besef van verantwoordelijkheid, duurzaamheid) en vrijheid (wederzijds respect, tolerantie) - zijn niet uit de lucht komen vallen. De meeste komen reeds in Oud-Griekse en -Romeinse (en andere) culturen voor, evenals in diverse religieuze en seculiere levens- en wereldbeschouwingen en filosofische theorieën die sindsdien westerse en niet-westerse culturen hebben beïnvloed. Hoewel vooral wederzijds respect en tolerantie in oude tijden niet geheel afwezig waren, hebben die waarden in het Westen sinds de achttiende eeuw geleidelijk meer erkenning gekregen. Zoals reeds werd opgemerkt heeft geen van de genoemde waarden een claim van absoluutheid. Iemand die één fundamentele waarde nakomt, handelt daarom nog niet goed en iemand die die ene waarde niet nakomt handelt alleen daarom niet per se slecht. Verantwoord handelen betekent dat men handelt op grond van een beargumenteerde samenhang van die waarden.

Op de keper beschouwd zijn de genoemde fundamentele waarden niet meer dan vage noties die weliswaar een richting van handelen aangeven, maar die tevens voor verschillende interpretaties vatbaar zijn. Vos $(1995: 167,169)$ noemt die waarden 'morele informatiedragers': ook al gebruikt men in verschillende levensen wereldbeschouwelijke (godsdienstige en seculiere) visies voor waarden dezelfde woorden, vanuit die verschillende visies krijgen die waarden verschillende theoretische interpretaties en praktische uitwerkingen.

We kunnen die waarden ook aanduiden als beginselen, uitgangspunten of oriëntatiepunten. Zij zijn nooit op een voltooide manier gerealiseerd. Zij zijn normatief omdat zij wijzen in een richting van wat men in acht behoort te nemen; als 
zodanig behoren zij aan het handelen richting te geven. Terecht schrijft Heyde (1994/95: 110) dat de reden van die beginpositie of oriënterende normativiteit van waarden ligt in onze condition humaine, onze menselijke bestaansvoorwaarde. Menszijn is geen onmiddellijk gegeven maar een opgave, iets wat wij tot stand moeten brengen. Steeds weer moeten wij waarden herontdekken en ons eigen maken. Waarden zijn dan ook geen idealen, belangen of doelen om na te streven - ook al kan men naar aanleiding van bepaalde waarden komen tot het formuleren van nastrevenswaardige idealen, belangen en doelen.

\subsection{NORMEN}

Waarden krijgen hun uitwerking in gedragsregels of normen (afkomstig van het Latijnse norma, meetlat). Normen bevatten altijd bepaalde waarden, maar waarden gaan niet op in normen. Anders gezegd, waarden zijn nog geen normen, maar waarden worden uitgewerkt in normen. De normen van een gemeenschap zijn uitermate belangrijk, omdat geen samenleving zonder gedragsregels kan bestaan.

Op grond van de rede, goddelijke openbaring of tradities heeft men in het verleden aan normen vaak een universele strekking verbonden. Normen zijn echter veel minder universeel dan men in vroegere tijden aannam. Normen reguleren het gedrag van mensen in een samenleving en ze verwijzen naar een sociaal verwachtingspatroon, maar ze blijken in de loop van de tijd veranderingen te ondergaan. Ook verschillen normen per cultuurkring, zonder dat wij gemakkelijk kunnen zeggen dat normen van de ene cultuur beter of minder zijn dan die van een andere cultuur. Naarmate wij die veranderingen en verschillen nader bekijken, kan een kritische bezinning ontstaan op de vraag: wat fundeert normen eigenlijk en waar komen ze vandaan? Aan welke normen hechten wij waarde en waarom vinden wij bij nader inzien bepaalde normen waardevol en andere niet of niet meer? Met het stellen van die vragen komt het subjectieve waardebesef van mensen naar voren.

Ook al gaan waarden niet op in normen, waarden gaan ook niet op in subjectieve gevoelens. In de eerste plaats omdat gevoelens - hoe zuiver en verheven ze ook mogen zijn - vaak te weinig gedisciplineerd en niet constant genoeg zijn om de basis te kunnen vormen van gemeenschappelijke of gedeelde waarden in het maatschappelijk leven; wie zich in het samenleven met anderen slechts door subjectieve gevoelens laat leiden, komt vaak teleurgesteld en gedesillusioneerd uit. In de tweede plaats omdat waarden in morele, juridische, sociale, economische en religieuze normen worden uitgewerkt, die niet slechts zijn te herleiden tot subjectieve gevoelens. In de derde plaats omdat waarden niet volledig immanent zijn; dat wil in dit verband zeggen dat ze slechts ten dele besloten liggen in het subjectieve leven van individuele mensen. Waarden hebben namelijk ook iets objectiefs of iets wat het subjectieve transcendeert, omdat ze zich voordoen in allerlei situaties en herkenbaar zijn voor meerdere mensen. Zo bestaan er 
gedeelde of maatschappelijke waarden. Bovendien gaan waarden langer mee dan subjectieve gevoelens, omdat waarden zijn ingeweven in religieuze en seculiere levensbeschouwingen die vaak lange tradities hebben en bovensubjectieve contexten van interpretaties vormen.

Ook al zijn er gedeelde of maatschappelijke waarden, zij worden op grond van verschillende levensbeschouwelijke interpretaties vaak verschillend uitgelegd en in praktisch handelen verschillend uitgewerkt. Vandaar dat tussen de immanente of subjectief geïnterpreteerde waarden en de 'transcendente' of geobjectiveerde waarden een spanning bestaat. Elk mens probeert weleens bepaalde waarden in haar/zijn eigen belang uit te leggen en in praktijk te brengen, maar de objectivering van waarden brengt de erkenning met zich mee dat waarden niet alleen maar subjectief zijn. Bovendien kan die objectivering bijdragen tot een kritische reflectie op en een vernieuwing van subjectieve en levensbeschouwelijke interpretaties van waarden. Het vervolgens evalueren van geobjectiveerde waarden en de uitwerking ervan in normen, maakt het denken over waarden en normen boeiend en dynamisch.

Enerzijds kan men zeggen dat normen als gedragsregels duidelijker te formuleren zijn dan waarden en dat zij daarom 'harder' en dwingender zijn dan de waarden die eraan ten grondslag liggen. Omdat waarden uitwerking krijgen in normen, kan men anderzijds zeggen dat waarden duurzamer zijn dan normen, die van tijd naar tijd veranderen. De uitwerking van waarden in normen geeft aan dat waarden hun zeggingskracht behouden. Met het veranderen van sociale omstandigheden kunnen normen worden geherformuleerd. Elke tijd vraagt om een herontdekking van waarden, die in geherformuleerde normen worden uitgewerkt. Die herformulering is een taai, maar ook een gedifferentieerd proces. Taai, omdat individuele mensen vaak weinig kunnen beginnen tegen de dwang van geïnstitutionaliseerde normen. Die normen bevatten namelijk vaak maatschappelijke en/of godsdienstige vooroordelen. Als zodanig kunnen die normen los raken van de waarden, maar om via een herontdekking van waarden tot een herformulering van normen te komen is een collectief en aanhoudend streven nodig. Gedifferentieerd, omdat de dwang van sociale, morele en juridische normen verschillend is. Individuele mensen en kleine collectiviteiten kunnen sociale en morele normen herformuleren in hun eigen levenssfeer; die herformuleringen en bijpassende praktijk kunnen vervolgens effecten hebben op de herformulering van normen in andere sectoren van de samenleving. Bij juridische normen is dat veel moeilijker. Individuele mensen en kleine collectiviteiten kunnen wel proberen juridische normen te herformuleren, maar zij kunnen die geherformuleerde normen niet zonder ernstige maatschappelijke en civielrechtelijke (soms ook strafrechtelijke) consequenties in praktijk brengen. Bovendien vereisen juridische herformuleringen langdurige procedures en een officiële besluitvorming. Maar dit alles gebeurt regelmatig, omdat waarden uiteindelijk boven de (juridische) normen van de gemeenschap uitgaan. Ook al zijn normen in het algemeen bedoeld om waarden uit te werken, hoog te houden en te beschermen, zij kunnen die waarden ook verduisteren. Normen kunnen door middel van een te uitgebreide regelgeving 
waarden misvormen. Normen kunnen echter ook eroderen en dientengevolge waarden doen vervagen.

Hoe komen we tot een herontdekking van waarden? Een mogelijk antwoord is: wanneer bestaande normen tekortschieten in het reguleren van gedrag (hetzij vanwege een overmatige regelgeving, hetzij vanwege erosie), wanneer mensen normen niet meer begrijpen of ertegenop botsen vanuit een concrete ervaring van protest tegen lijden of onrecht. Dan kan men waarden herontdekken. Die zijn weliswaar vager dan normen, maar zonder besef van waarden kan geen normatief denken ontstaan. Die herontdekking heeft betrekking op een persoonlijke en vaak collectieve betrokkenheid, levensbeschouwelijke visies en moreel engagement. Als zodanig zijn waarden volgens Van Peursen (1993/94: 125-128) moeilijker te definiëren dan normen, maar zijn zij des te reëler en echter!

Het formuleren en herformuleren van normen heeft echter niet slechts een utilitaire betekenis. Als het goed is behoren normen te worden nageleefd omdat ze een uitwerking zijn van waarden die mensen aanvaarden als intrinsiek goed en niet omdat ze voor de betrokkenen nuttig zijn. De overweging van nuttigheid kan gemakkelijk met zich meebrengen dat normen worden beschouwd als verkeersregels of als iets wat slechts uitwendig is. Anders dan verkeersregels hebben normen een moreel surplus; ze zijn meer dan middelen of instrumenten met het oog op het verwerkelijken van bepaalde preferenties en doelen. Indien normen niet worden aanvaard als uitwerkingen van waarden die op zichzelf goed zijn, maar slechts worden beschouwd als instrumenten die nuttig zijn, dan fungeren normen niet meer als een kritische instantie ter beoordeling van feitelijke situaties; dan fungeren normen slechts als instrumenten ter realisering van feitelijke doelstellingen, bijvoorbeeld van eigenbelang of groepsbelangen (Heyde 1994/95: $110)$.

Normen zijn dus gerechtvaardigd omdat en voorzover men een beroep kan doen op waarden. Het herformuleren van normen vindt zijn rechtvaardiging in de herontdekking van waarden, die een vastgelopen situatie kan openbreken. Die herontdekking werkt bevrijdend, niet omdat dan de problemen zijn opgelost, maar omdat zij stimuleert tot een ervaring van menselijke vrijheid die het aanvaarden van geherformuleerde normen en een nieuwe manier van leven mogelijk maakt.

\subsection{PUBLIEKE MORAAL IN EEN PLURALISTISCH-DEMOCRATISCHE SAMENLEVING}

Dat waarden verschillend worden uitgelegd en in praktisch handelen verschillend worden uitgewerkt, is een oud en bekend verschijnsel en actueel in een pluralistisch-democratische samenleving en rechtsstaat: op het grondgebied en binnen de grenzen van de rechtsstaat leven burgers die participeren in verscheidene 'autonome' gemeenschappen en organisaties, elk met haar eigen rechten, 
vrijheden en verantwoordelijkheden (sociale pluraliteit) en die bovendien verschillende seculiere of religieuze levens- en wereldbeschouwingen aanhangen (levensbeschouwelijke pluraliteit). Die pluralistische democratie wordt echter georganiseerd volgens levensbeschouwelijk neutrale of formele regels en procedures (bijvoorbeeld geformuleerd in de Kieswet). Die formele organisatie betekent dat burgers en overheid democratische regels en procedures correct behoren te volgen.

Formele democratische regels die in wetten zijn beschreven blijken echter niet slechts formeel te zijn. Er zijn fundamentele waarden die ten grondslag liggen aan dat formele concept van democratie, bijvoorbeeld waarden die gestalte hebben gekregen in: a) wettelijk beschermde rechten van leven, vrijheid van meningsuiting, drukpers en vereniging, gelijkheid van burgers voor de wet, het recht van politieke participatie, rechten en plichten van burgers en maatschappelijke organisaties ten opzichte van elkaar en de samenleving als geheel; en b) morele, nietwettelijk vastgelegde waarden als tolerantie, wederzijds respect, samenwerking en de verantwoordelijkheid van burgers en maatschappelijke organisaties voor het bevordering van het gemeenschappelijk welzijn. Die wettelijk en niet-wettelijk vastgelegde waarden zijn te herleiden tot de reeds besproken fundamentele waarden, die ik in dit verband basale of minimumwaarden noem, omdat zij aan democratische regels ten grondslag liggen. Het bestaan en de erkenning van die basale of minimumwaarden brengt met zich mee dat een zuiver formeel concept van democratie niet bestaat. Zeker, er bestaan wel formele democratische regels en procedures, maar zij vooronderstellen bepaalde basale waarden die het functioneren van die regels mogelijk maken.

Omdat burgers er verschillende, omvattende seculiere of religieuze levensbeschouwingen en 'brede' morele opvattingen op na houden, kunnen zij op grond van die overtuigingen en daaraan ontleende morele waarden als leven, rechtvaardigheid, naastenliefde, zorg en verantwoordelijkheid, die formele democratische regels en procedures (en de eraan ten grondslag liggende minimumwaarden) voorzien van beargumenteerde of theoretische onderbouwingen. Ondanks de verscheidenheid van levensbeschouwelijke visies en theoretische onderbouwingen kan het functioneren van een democratische samenleving alleen maar vitaal blijven indien burgers ook bepaalde morele opvattingen en gedragingen gemeenschappelijk hebben. Dat willen zeggen dat zij bewust of onbewust basale waarden delen in het naleven van democratische regels en andere wetten en in het uitwerken van niet-wettelijk vastgelegde waarden in hun handelen. Met andere woorden: een sociaal en levensbeschouwelijk pluralistische, democratische samenleving kan niet zonder een 'smalle' publieke moraal (afgeleid van het Latijnse mores, zeden en gewoonten), die wordt gevormd door in meerdere of mindere mate algemeen aanvaarde opvattingen en gedragingen in de samenleving. In die opvattingen en gedragingen zijn bepaalde gemeenschappelijke waarden en normen vervat, die in belangrijke mate door tradities, wetten, vanzelfsprekendheden en levensbeschouwingen worden bepaald. 
Enerzijds bevat de publieke moraal dus de genoemde minimumwaarden die tot uitdrukking komen in wettelijke rechten, vrijheden en plichten van burgers en maatschappelijke verbanden ten opzichte van elkaar en de staat, en omgekeerd in rechten, vrijheden en plichten van de staat ten opzichte van burgers en maatschappelijke verbanden. Anderzijds heeft de publieke moraal ook betrekking op niet-wettelijk vastgelegde morele waarden als tolerantie, wederzijds respect voor de overtuiging en meningen van anderen en verantwoordelijkheid voor het algemene welzijn (inclusief vaderlandsliefde, eerbied voor zijn geschiedenis en cultuur); dit 'deel' van de publieke moraal bevat morele waarden en normen die wettelijk niet kunnen worden georganiseerd, maar die wel bijdragen tot de morele kwaliteit van het samenleven van mensen.

De publieke moraal bevat dus wettelijk en niet-wettelijk vastgelegde waarden en normen, waartussen een wisselwerking bestaat: het wel of niet naleven van wettelijk vastgelegde waarden en normen kan gevolgen hebben voor de vitaliteit dan wel slijtage van niet-wettelijke of morele waarden en normen. Het omgekeerde kan ook het geval zijn: het wel of niet aan slijtage onderhevig zijn van morele waarden en normen kan gevolgen hebben voor het wel of niet naleven van wetten.

Een vitale publieke moraal is van belang voor de sociale integratie in de samenleving. Omdat de publieke moraal uit wettelijk en niet-wettelijk vastgelegde waarden en normen bestaat, kunnen we spreken van een wettelijk georganiseerde sociale integratie in de samenleving en van een niet-wettelijke of morele integratie in de samenleving; die morele integratie kan ook (morele) cohesie worden genoemd. Derhalve identificeer ik wettelijk georganiseerde sociale integratie niet met morele cohesie. Weliswaar heeft een wettelijk georganiseerde sociale integratie morele implicaties, omdat die sociale integratie niet kan bestaan zonder enige morele steun van de burgers; anders zou sociale integratie slechts worden afgedwongen. Anderzijds wordt een morele integratie (of cohesie) gefaciliteerd door een wettelijk georganiseerde sociale integratie. De keerzijde is dat de wettelijk en de niet-wettelijk vastgelegde waarden en normen van de publieke moraal dermate aan slijtage onderhevig kunnen raken, dat zij de sociale integratie en morele cohesie bedreigen en zelfs op sociale en morele desintegratie kunnen uitlopen.

De kernvraag is: hoe kan in een sociaal en levensbeschouwelijk pluriforme, democratische samenleving de 'smalle' publieke moraal worden versterkt dan wel gecorrigeerd? Mijn antwoord is dat zowel wettelijke als niet-wettelijke waarden en normen van de publieke moraal vanuit levensbeschouwelijke visies en daarin vervatte 'brede moraalopvattingen' beargumenteerde of theoretische onderbouwingen nodig hebben. De verdergaande strekking van dit antwoord is dat die levensbeschouwelijke onderbouwingen moeten beklijven tot de gemeenschappelijke erkenning (consensus) van de wettelijke en niet-wettelijke waarden en normen, op grond waarvan mensen met elkaar kunnen samenleven ondanks de verscheidenheid van of tegenstellingen tussen hun levensbeschouwelijke 
overtuigingen. Indien die overeenstemming niet actief wordt ondersteund door burgers vanuit hun levensbeschouwelijke inzichten en morele motieven, dan wordt de publieke moraal ondermijnd, loopt bijgevolg het naleven van wetten gevaar en verschraalt de morele kwaliteit van de samenleving. De volgende, in de inleiding reeds geformuleerde vraag moet wel zijn: op welke wijze kan de inhoudelijke verdieping van het debat over fundamentele waarden en normen (op grond van levensbeschouwelijk beargumenteerde onderbouwingen) bijdragen tot een versterking of correctie van 'gedeelde waarden en normen' in de publieke moraal? Deze vraag wordt in de volgende paragraaf beantwoord.

\subsection{MOGELIJKHEDEN TOT BIJDRAGEN AAN DE PUBLIEKE MORAAL}

De publieke moraal bevat wettelijke en niet-wettelijke waarden en normen waarover een consensus bestaat of waarover op een faire manier naar een consensus kan worden gestreefd. Die consensus omvat basale waarden en normen, omdat zij algemeen (kunnen) worden aanvaard (ondanks de omvattende levensbeschouwingen die burgers aanhangen). Ik noem die consensus echter niet een grootste gemene deler van diverse levensbeschouwelijke en morele opvattingen, omdat burgers die basale waarden en normen kunnen interpreteren en uitwerken (krachtens de levensbeschouwingen die zij hebben) in meeromvattende concepten, teneinde de publieke moraal te onderbouwen en te versterken; bijdragen daartoe worden ook geleverd vanuit kerken, politieke partijen, onderwijsinstellingen en andere maatschappelijke organisaties (zie Van der Graaf 2003). Dat proces van onderbouwen en versterken zal ik op twee manieren toelichten, namelijk langs a) een institutionele en $b$ ) een procedurele weg.

a De institutionele weg heeft betrekking op de gedifferentieerde gemeenschappen in een sociaal-pluralistische samenleving, ook wel 'intermediaire instituties' genoemd: gemeenschappen of instituties die een plaats hebben tussen de overheid en de burgers en die van groot belang zijn voor individuele burgers en voor de vitaliteit van de civiele samenleving. Enerzijds is van belang dat door middel van die intermediaire instituties morele waarden en normen en maatschappelijke deugden worden overgedragen die de persoon van de burger constitueren en die haar/hem houvast geven. Anderzijds bevorderen intermediaire instituties de betrokkenheid van hun participanten bij de samenleving als geheel; zij informeren en mobiliseren die participanten ten behoeve van hun functioneren in de samenleving (zie Selznick 1992: 517-518).

Waarden en normen kunnen en mogen niet aan burgers worden opgelegd, door de overheid noch door andere instituties, maar zij kunnen wel worden geleerd en geïnternaliseerd. Dat proces van leren en internaliseren vindt volgens Etzioni plaats in gedifferentieerde gemeenschappen en in de samenleving als geheel, met als uiteindelijke doel het vormen van een moreel sterke samenleving. Etzioni (1996: 175-179) noemt die gedifferentieerde gemeenschappen de 'morele infrastructuur' van een samenleving, die bestaat uit gezinnen, scholen en andere 
gemeenschappen. In het gezin leren kinderen bepaalde morele waarden. Het onderwijs op scholen bouwt verder aan de morele ontwikkeling van de persoonlijkheid van leerlingen, eventueel corrigerend. Ook andere gemeenschappen behoren die morele vorming te versterken. In de 'gemeenschap van de gemeenschappen' (de samenleving als geheel) krijgt de internalisering van morele waarden en deugden een verbreding die verder gaat dan die van de gedifferentieerde gemeenschappen en die tot uiting behoort te komen in maatschappelijk aanvaardbaar gedrag. Hoe is die verbreding mogelijk als morele waarden inhoudelijk worden gevormd en overgedragen in gedifferentieerde gemeenschappen en op grond van verschillende levensbeschouwelijke overtuigingen?

b Via de procedurele weg kan men trachten die vraag te beantwoorden, zoals bijvoorbeeld John Rawls heeft gedaan. Hij erkent weliswaar het bestaan van omvattende filosofische en levensbeschouwelijke visies (en daarop gebaseerde omvattende opvattingen over democratie en rechtvaardigheid), maar hij vreest hun onderlinge strijd die mensen in verwarring kan brengen en die hen het gemeenschappelijke kan doen vergeten. Hij wil de invloed van levensbeschouwelijke en filosofische visies op het publieke leven minimaliseren om een bepaalde basis van overeenstemming of een 'onderliggende basis van consensus' over politieke rechtvaardigheid veilig te stellen: een rationele consensus die het resultaat is van rationele compromissen tussen mensen die verschillende overtuigingen hebben (Rawls 1985: 223-251; 1993: 144-151). Rawls erkent dat vanuit omvattende levensbeschouwelijke visies meer over rechtvaardigheid kan worden gezegd, maar dat 'meer' valt buiten de door hem beoogde consensus. En juist dat 'meer' kan interessant zijn in verband met het zoeken naar de mogelijke betekenis van meeromvattende opvattingen van rechtvaardigheid, die in een democratische samenleving door middel van diverse gemeenschappen worden overgedragen.

Philip Selznick, een criticus van Rawls, verdedigt een ander procedureel concept van rechtvaardigheid, dat hij combineert met een inhoudelijk concept van rechtvaardigheid. Wat zijn procedureel concept van rechtvaardigheid betreft verwijst Selznick naar Aristoteles' idee van het goede leven. Selznick weet dat veel contemporaine filosofen zich verzetten tegen die gedachte van Aristoteles, omdat zij vrezen dat de idee van het goede leven burgers bij voorbaat zou binden aan bepaalde doelen die zouden moeten worden nagestreefd en aan een bepaalde manier van leven die aanbevelenswaardig zou zijn. Selznick betoogt echter dat het streven van de overheid naar het goede leven nog niets zegt over de middelen, doelen en resultaten. Volgens hem kunnen burgers in een democratische en pluralistische samenleving met elkaar over die onderwerpen een publiek debat aangaan. Onder het motto 'zoeken naar het goede leven' kunnen zij hun keuzen maken en hun doelen en belangen met elkaar bespreken en beoordelen. Dit betekent niet meer, maar ook niet minder dan gezamenlijk zoeken naar een wenselijk maatschappelijk leven ter bevordering van individueel en algemeen welzijn. Selznick (1992: 148-151) wil geen blauwdruk geven van een rechtvaardige samenleving of van het goede leven, maar hij verdedigt dat in het zoeken naar het goede 
leven rechtvaardigheid richtinggevend behoort te zijn, opdat het individuele en algemene welzijn wordt bevorderd.

Wat zijn inhoudelijke concept van rechtvaardigheid betreft, wil Selznick rechtvaardigheid niet slechts afleiden uit bestaande wetten of slechts interpreteren als het verminderen van onderdrukking, het vermijden van destructieve conflicten of ieder het zijne geven volgens procedurele regels. Hij vindt die opvattingen te minimaal, omdat de belofte die de idee van rechtvaardigheid in zich heeft, eraan ontbreekt. Het inhoudelijke van rechtvaardigheid heeft volgens Selznick betrekking op de erkenning door de overheid van de 'autonomie' van gedifferentieerde gemeenschappen. Met die erkenning bevordert de overheid niet alleen de sociale voorwaarden voor een actieve participatie van burgers, maar bevordert zij ook hun morele capaciteiten daartoe. Rechtvaardigheid moet volgens hem dan ook binnen die gemeenschappen worden uitgewerkt, opdat de kwaliteit van leven van de burgers wordt bevorderd en de vitaliteit van de civiele samenleving wordt versterkt. Daarom schrijft Selznick (1992: 363): “De waarde van een gemeenschap wordt afgemeten aan de bijdrage die zij levert aan het welzijn van unieke en verantwoordelijke mensen."

Dat burgers, sociale instituties en de staat hun verantwoordelijkheid met betrekking tot rechtvaardigheid realiseren, is volgens Selznick (1992: 369) een kwestie van beschaving. Indien de burgers zelf hun morele verantwoordelijkheid kunnen realiseren, dan moet de staat zich zoveel mogelijk terughoudend opstellen.

Kunnen zij dit niet, dan komt de overheid een regulerende functie toe die zij niet kan uitvoeren zonder een visie op het goede leven van de burgers in de samenleving. Hoewel de overheid aan de burgers geen morele opvattingen kan en mag opleggen, kan zij de morele verantwoordelijkheid van burgers wel bevorderen door middel van wet- en regelgeving. Het beleid van de overheid wordt echter bepaald door democratische debatten en besluitvorming, waarin rechtvaardigheid en andere componenten van de publieke moraal vanuit verschillende levensbeschouwelijke visies worden geïnterpreteerd en uitgewerkt (uitgebreider in Woldring: 2002: 87-104).

Ook al kunnen mensen overtuigd zijn van de exclusieve waarheid van hun geloof of levensbeschouwing, het uitwerken van waarden in maatschappelijke normen is een zoekproces dat mede wordt bepaald door maatschappelijke en politieke omstandigheden en de dialoog met anderen. Ieder kan haar/zijn bijdragen leveren tot het (her)ontdekken van fundamentele waarden en tot het (her)formuleren van normen, teneinde het beleid van de overheid via democratische debatten en besluitvorming te beïnvloeden. In dat debat kan men levensbeschouwelijke argumentaties expliciet maken zonder claim van exclusiviteit. Een voorbeeld van misplaatste exclusiviteit is de opmerking van B. van der Vlies van de SGP (2002, 35/2614) tijdens een debat in de Tweede Kamer: "Dat het debat over waarden en normen steeds min of meer stokt, geeft aan dat een levensoriëntatie die niet religieus gefundeerd is, geen antwoorden kan geven op de vraag wat de mens behoort te doen." Deze opmerking impliceert een diskwalificatie van niet-reli- 
gieuze levensbeschouwingen die fundamentele waarden bevatten en op eigen wijze (theoretisch en praktisch) uitwerken.

\subsection{INHOUDELIJKE BIJDRAGEN AAN DE PUBLIEKE MORAAL}

Ik kom tot de andere, in de inleiding geformuleerde vraag: welke bijdragen kunnen vanuit christelijk-levensbeschouwelijke visies worden geleverd aan een inhoudelijke verdieping van het debat over fundamentele waarden en normen? Ter beantwoording van deze vraag zal ik mij beperken tot enkele fundamentele waarden die niet alleen in de christen-democratie, maar in verscheidene christelijke tradities een belangrijke plaats hebben, namelijk rechtvaardigheid, solidariteit, verantwoordelijkheid, duurzaamheid en vrijheid. Ondanks onderlinge verschillen hebben die tradities bepaalde kerngedachten gemeenschappelijk.

\section{Rechtvaardigheid}

In joodse en christelijke tradities wordt rechtvaardigheid in verband gebracht met het reddende handelen van God. In het Oude en Nieuwe Testament wordt het volk Israël onderwezen in zijn verplichtingen ten aanzien van weduwen, wezen, armen, vreemdelingen en anderen die een kwetsbare plaats in de samenleving hebben. De basis van die verplichtingen om recht te doen aan die mensen is de herinnering aan Gods reddende handelen: hij had ooit de Israëlieten bevrijd uit de slavernij in Egypte. Die herinnering verandert de bipolaire relatie van rechtvaardigheid tussen mensen ('Geef ieder wat haar/hem toekomt' of 'Wat gij wilt dat u geschiedt, doe een ander evenzo') in een tripartite relatie: 'Geef ieder wat haar/hem toekomt zoals God jegens u deed’ (Reinders 1996: 163-166). In christelijke tradities krijgt het reddende handelen van God bovendien gestalte in de figuur en het evangelie van Jezus van Nazareth die mensen oproept niet alleen zorg te dragen voor armen en kwetsbaren, maar zich ook te bevrijden van ideologische machten van het kwaad. Die oproep tot rechtvaardigheid vraagt om navolging; mensen behoren rechtvaardigheid te dienen. Die oproep kan nooit dienen als een sanctionering van de bestaande maatschappelijke orde, maar hij wil die orde wakker schudden. Ook de overheid behoort dat beroep in haar beleid zichtbaar te maken, opdat het algemene welzijn wordt bevorderd. Met andere woorden: rechtvaardigheid is niet slechts een private, maar ook een publieke zaak en als zodanig behoort zij voor de identiteit van de staat bepalend te zijn en voor het beleid van de overheid normerend.

Omvattende christelijke levensbeschouwingen kennen dus de fundamentele waarde van rechtvaardigheid, die in 'brede' opvattingen van moraal worden uitgewerkt. In een publiek debat over rechtvaardigheid zullen vertegenwoordigers van christelijke tradities op grond van hun 'brede' opvattingen van moraal beargumenteerd onderbouwde bijdragen kunnen leveren. Op basis van het tripartiete model, waarin rechtvaardigheid niet slechts een kwestie is van verdelende en corrigerende rechtvaardigheid en evenmin gelijk is aan de regel van de wet, behoren zij bijdragen te leveren tot het streven tot versterking van reddend 
handelen dat door liefde wordt geïnspireerd. Die opvatting van rechtvaardigheid betekent ook: omzien in rechtvaardigheid. Dat wil zeggen dat burgers met betrekking tot hun handelen, de overheid met het maken van wetten en de rechter met zijn uitspraken behoren om te zien naar de effecten voor de groepen en personen op wie die handelingen, wetten en uitspraken betrekking hebben; met name behoren zij zorg te dragen voor de effecten van handelingen, wetten en rechterlijke uitspraken voor maatschappelijk kwetsbare mensen. Op grond van hun 'brede' opvattingen over moraal behoren christenen in hun bijdragen aan een publiek debat te appelleren aan de belofte die het streven naar rechtvaardigheid bevat en die dat streven dynamiek geeft.

\section{Solidariteit}

Dat mensen zorg voor elkaar behoren te hebben is niet voor iedereen vanzelfsprekend. Toch kennen we het woord 'solidariteit' of 'saamhorigheid': mensen behoren bij elkaar en zijn met elkaar verbonden. Indien iemand zich met een ander solidair verklaart, dan kan zo'n verklaring van solidariteit berusten op een keus en op subjectieve gevoelens. Zou solidariteit echter niet bij voorbaat zwak zijn, indien zij slechts gebaseerd zou zijn op subjectieve keuzen en gevoelens?

Het woord 'solidariteit', afgeleid van het Latijnse rechtsbegrip in solidum, duidt op een juridische verantwoordelijkheid waarbij verschillende personen niet elk voor een deel maar elk voor het geheel instaan. Solidariteit vindt haar oorsprong in de fundamentele onderlinge afhankelijkheid van mensen - mensen die op elkaar aangewezen zijn, die een eenheid vormen en die gezamenlijk voor een taak staan. In de traditie van het jodendom en christendom wordt de mens getypeerd als naar het 'beeld van God' geschapen. Die typering brengt tot uitdrukking dat de mens iets van een mysterie heeft en dat zijn identiteit derhalve niet adequaat te definiëren is. Dat wil niet zeggen dat wij niets over de mens kunnen zeggen. Zo lijkt die mysterieuze typering een hoge roeping te impliceren: Gods liefde voor en solidariteit met de mensen doen een appèl op de mens tot navolging in naastenliefde, solidariteit en dienstbaarheid. Die typering lijkt ook in te houden dat elk mens uniek is en een onvervreemdbare menselijke waardigheid bezit. Tegelijkertijd impliceert die onvervreemdbare waardigheid iets universeels: alle mensen maken deel uit van de menselijke soort of de mensheid. Als zodanig bestaat tussen mensen een ontologische saamhorigheid.

Die saamhorigheid van de mensheid blijkt reeds in oude bijbelverhalen, waarin verteld wordt dat God met de mensen een verbond heeft gesloten en dat verbond meermalen heeft herhaald en bevestigd. In het christendom wordt als een hoogtepunt van dat verbond beschouwd de figuur en de boodschap van Jezus. In Jezus kreeg de liefde van God voor de mensheid gestalte - een liefde die oproept tot het geven van antwoord: liefde tot God en tot de medemensen, omdat zij allen naar Gods beeld zijn geschapen. In die opvatting is Gods solidariteit met de mensen het fundament van de solidariteit van mensen onderling. 
In een publiek debat over solidariteit zullen vertegenwoordigers van christelijke overtuigingen hun eigen argumentatie geven, die gebaseerd is op hun 'brede' opvatting van solidariteit die door liefde moet worden geactualiseerd. Opdat liefde niet in vaagheid verzandt, kan die argumentatie worden aangevuld met de gedachte dat mensen met hun naasten in gemeenschappen leven en slechts in gemeenschappen kunnen bestaan waarin liefde kan worden geconcretiseerd.

In christelijke tradities is solidariteit dus een fundamentele waarde die mensen behoort te verenigen in de uitvoering van een plan waarin zij gezamenlijk zijn geëngageerd. In navolging van Walgrave (1960: 112-113) zal ik die fundamentele morele waarde op drie manieren onder woorden brengen.

1 Waar een mens voor een noodzakelijke levensopgave staat die hij alleen niet of niet goed kan volbrengen, mag hij rekenen op de hulp van anderen.

2 Anders gezegd, waar een mens voor een levensopgave staat die voor hem noodzakelijk of dienstig is, maar die hij alleen niet aankan, zijn anderen verplicht hem naar vermogen te helpen. De eerste formulering gaat uit van de ik-formule: ik heb jou nodig, dus is het mijn recht dat jij mij helpt. De tweede formulering gaat uit van een jij-formule: jij hebt mij nodig, dus is het mijn plicht dat ik jou help.

3 Beide formuleringen vullen elkaar aan en worden overkoepeld door een wijformule: waar alle mensen voor een levensopgave staan, die geen enkel mens alleen aankan, daar zijn wij in solidum verplicht elkaar door gemeenschapsvorming te helpen om die levensopgave te vervullen. Solidariteit is derhalve direct gericht op het gezamenlijk bevorderen van het algemeen welzijn.

\section{Verantwoordelijkheid}

Dat mensen worden beschouwd als verantwoordelijke wezens, impliceert dat zij niet slechts instinctief handelen en dat zij opdrachten niet slaafs behoren uit te voeren. Mensen behoren verantwoordelijkheid te dragen, uiteraard overeenkomstig hun verstandelijke en psychische vermogens. De mens wordt wel een subject genoemd, dat naar subjectiviteit verwijst en dat in de oorspronkelijke zin van het Griekse woord hypokeimenon betekent 'het onderliggende', 'het onderworpene' - niet slechts in de betekenis van onderworpen zijn aan wetten, maar subjectiviteit verwijst veeleer naar het dragende en het ontvankelijke. De mens als subject betekent dan ook: openstaan voor..., instaan voor... en uitgaan naar... Ook als burger staat een mens open voor wat er in de samenleving en de politiek gebeurt en draagt hij verantwoordelijkheid. Velen beseffen dat ook. Dat besef van verantwoordelijkheid gaat zelfs vooraf aan het maken van politieke keuzen. Dat besef gaat ook vooraf aan de gedachten en ideeën die burgers hebben over de wereld; het gaat vooraf aan de bijdrage die zij willen leveren aan de vormgeving van hun samenleving. Verantwoordelijkheid kan men burgers niet aanpraten; men kan die slechts beseffen en dragen. Hoewel veel burgers in politiek opzicht marginaal functioneren, dragen zij desondanks politieke verantwoordelijkheid. We kunnen de idee van het dragen van politieke verantwoordelijkheid verder uitwerken. Sinds lange tijd wordt het terrein van de staat res publica genoemd, letterlijk: publieke zaak of publiek terrein, ook wel vertaald als publieke rechts- 
gemeenschap of staat. In de res publica van onze tijd participeren burgers en oefenen zij door middel van een kiesstelsel invloed uit op de politiek. Zij brengen hun stem uit en schorten daarmee hun oordeel over veel concrete politieke vraagstukken op. Zij dragen een stuk verantwoordelijkheid over aan volksvertegenwoordigers, zonder hun verantwoordelijkheid te verliezen; menselijke verantwoordelijkheid is onvervreemdbaar. Daarom is de staat (res publica) volgens De Boer (1993: 9-13, 27-30) te typeren als een 'republiek van verantwoordelijkheid'. Verantwoordelijkheid bevat 'woord' en 'antwoord', die met elkaar samenhangen. Mensen als subjecten staan er open voor antwoord te geven als ze worden aangesproken. Mensen behoren zich te verantwoorden voor hun daden. In christelijke tradities behoren zij antwoord te geven op het woord van het evangelie en van medemensen: streven naar rechtvaardigheid en het tot uitdrukking brengen van solidariteit in de samenleving en in maatschappelijke verbanden.

Verantwoordelijkheid heeft niet alleen betrekking op het handelen van individuele mensen, maar ook op dat van collectiviteiten (staten en maatschappelijke organisaties). In het evangelie is reeds sprake van collectieve daden en verantwoordelijkheden. In het Oude Testament trekken profeten van leer tegen collectieve misstanden bij het volk Israël en met name tegen de sociale lagen van rijken en landeigenaren en tegen beroepsgroepen van regeringsambtenaren en rechters; het in praktijk brengen van rechtvaardigheid en solidariteit en het algemene welzijn waren in gevaar. Het latere optreden van Jezus ligt in de lijn van die profeten. Kritiek op collectieve handelingen en gebrek aan collectieve verantwoordelijkheid impliceert niet dat persoonlijke verantwoordelijkheid buiten schot blijft. Vandaar dat De Valk (1967: 6) met betrekking tot het besef van collectieve verantwoordelijkheid terecht opmerkt: "Het zich bewust zijn van het feit dat het leven in maatschappelijk verband voor mensen niet slechts betekent dat hij bepaalde verplichtingen heeft jegens de groepen waarvan hij deel uitmaakt, doch tevens dat dit hem in meerdere of mindere mate medeverantwoordelijk maakt voor het doen en laten van deze groepen."

In een publiek debat over verantwoordelijkheid zullen vanuit christelijke tradities en hun 'brede' opvattingen over moraal eigen bijdragen worden geleverd. Zowel persoonlijke als collectieve verantwoordelijkheid behoort gericht te zijn op verbetering van de morele kwaliteit van leven in diverse maatschappelijke verbanden en in de samenleving als geheel. Als zodanig behoren zij bij te dragen tot het duurzaam welzijn van mensen.

\section{Duurzaamheid}

De waarde van duurzaamheid wordt ook wel rentmeesterschap genoemd. Een rentmeester was in de Oudheid niet alleen iemand die het financieel beheer had over de bezittingen van een rijke familie, maar ook iemand die in opdracht van de eigenaar de verantwoordelijkheid had voor de leiding en het beheer van het familiebedrijf. Hij behoorde toezicht te houden op het tijdig zaaien, maaien en oogsten, de verzorging van het vee en het onderhoud van de stallen, het bijhouden van de wijngaard en het functioneren van de persen, het personeel en de rela- 
ties met schuldeisers en afnemers. Met andere woorden, hij was verantwoordelijk voor het doen van keuzen en het nemen van beslissingen voor een rechtvaardig beleid en daarin voor een zorgvuldig en evenwichtig beheer van alle sectoren van het bedrijf. De aandacht voor de ene sector mocht niet ten koste gaan van andere sectoren. Als hij alle sectoren van het bedrijf tot hun recht liet komen en daarvan verantwoording kon afleggen aan de eigenaar, werd hij een rechtvaardige rentmeester genoemd.

De rentmeester is een figuur die enkele keren in het Nieuwe Testament ter sprake komt. De goede rentmeester wordt beschreven als iemand die het personeel geeft waar het recht op heeft (en soms meer dan dat), die zijn fouten rechtvaardig weet te herstellen, die verder het gehele bezit van de eigenaar zo beheert dat het rendement oplevert. Van de slechte of onrechtvaardige rentmeester wordt gezegd dat hij slaven en slavinnen slaat, rechtvaardige regels van het economisch verkeer met schuldenaars overtreedt, op zijn eigen genoegens en voordeel uit is of het vermogen van de eigenaar erdoor jaagt.

Het beeld van een goede of rechtvaardige rentmeester kan worden aangevuld met de functie van een wachter. Aldus Houtepen (1995: 80), die vervolgt: "De rentmeester als wachter houdt toezicht op het reilen en zeilen van mens en dier, houdt de tekenen der tijden in het oog, waakt waar anderen slapen en kondigt tijdig gevaren aan. Zorg staat bij zo'n rentmeester hoger in zijn vaandel dan winst of efficiency. Het kreupele dier en het verloren schaap krijgen zelfs meer aandacht dan de vette ram en de veelbelovende lammetjes. De wachter is niet een handelsagent, die loert op de hoogste prijs, noch een huurling, die niet echt om de spullen geeft, maar iemand die zorg draagt als plaatsbekleder, vicarius Dei, die ook voor God rekenschap moet afleggen voor zijn beleid. Ons is een opdracht, mandaat en roeping gegeven, waarin we getest zullen worden, geen vrijbrief of blanco cheque die we naar eigen bevind van zaken kunnen invullen."

De verantwoordelijkheid van de rentmeester of het rentmeesterschap heeft in onze tijd een meer uitgebreide betekenis gekregen: mensen zijn verantwoordelijk voor een zorgvuldig en duurzaam beheer van de wereld waarin zij leven, voor de mensen met wie zij omgaan en voor de zaken die aan hun zorgen zijn toevertrouwd. In een publiek debat over duurzaamheid zal vanuit 'brede' christelijke opvattingen over moraal de oorspronkelijke gedachte van rentmeesterschap naar voren worden gebracht. Dat wil zeggen dat de rentmeester geen eigenaar is, dat hij het vruchtgebruik van de schepping heeft en dat hij anderen daarin laat delen, zonder de schepping in haar veelzijdigheid en vitaliteit aan te tasten. Kortom, de mens is geen heerser maar beheerder, geen machthebber maar gemachtigde, geen meester maar rentmeester (Goudzwaard 1976: 255).

\section{Vrijheid}

De idee van vrijheid is in de theorieën van veel politiek filosofen en rechtsfilosofen na de Renaissance nadrukkelijk aanwezig, maar de manier waarop zij vrijheid uitwerken is problematisch. Een kenmerk van het filosofisch denken na de 
Renaissance over de verhouding tussen mens en samenleving is namelijk, dat 'er geen waarde hoger is dan het individu' (Berlin 1969: 137) of dat de mens wordt beschouwd als een 'zichzelf definiërend subject' (Taylor 1975: 6). Vooral representanten van liberale theorieën omtrent moraal en politiek schrijven hun vrijheidsconcepten die individualistische basis toe. Vervolgens verbinden zij vrijheid met bepaalde burgerrechten, politieke participatierechten en economische rechten van eigendom, handel en concurrentie. Die economische 'vrijheidsrechten van de markt' hebben verstrekkende gevolgen voor de samenleving - niet slechts in de economische sector, maar ook in andere sectoren van de samenleving.

Ook in joodse en christelijke tradities neemt vrijheid een belangrijke plaats in. Vrijheid betekent in die tradities allereerst: zich vrijmaken van de dwang van afgoden en in verbondenheid met God een 'nieuw leven' beginnen. Als zodanig is vrijheid een relationeel concept dat in de eerste plaats betrekking heeft op de bron van inspiratie en de levensrichting die men kiest. Vervolgens heeft vrijheid betrekking op bevrijding uit een situatie van onderdrukking en rechteloosheid (bijvoorbeeld bevrijding uit de slavernij in Egypte). Vrijheid betekent een gerichtheid op nieuwe mogelijkheden en een nieuwe toekomst. Die bevrijding uit... en vrijheid tot... komen voort uit een goddelijk handelen dat door liefde en rechtvaardigheid wordt gekenmerkt. Die goddelijke liefde en rechtvaardigheid houden een oproep in tot navolging van liefde en rechtvaardigheid tot medemensen, opdat ieder mens in relatie met anderen vrijheid kan realiseren. Daarom is in joodse en christelijke tradities vrijheid ook een relationeel concept dat op medemensen is gericht. In het kader van die tradities wordt vrijheid bedreigd als de mens zich als individu van die relationaliteit losmaakt.

In joodse en christelijke tradities heeft vrijheid niets te maken met individualistische opvattingen, noch met de idee van autonomie van Immanuel Kant, die haar opvatte als de onvoorwaardelijke gehoorzaamheid aan de morele wet van de rede die iemand zichzelf oplegt. Tegenover deze opvatting van autonomie staat de opvatting van heteronomie, die betekent dat morele waarden uit een andere bron afkomstig zijn dan de menselijke rede, bijvoorbeeld uit het evangelie. Er is niets tegen de idee van heteronomie, mits morele waarden niet door middel van dwang worden opgelegd, maar uit vrije wil worden erkend en aanvaard als rechtvaardig en goed.

Als relationeel concept is de essentie of authenticiteit van vrijheid te karakteriseren als een moreel engagement met anderen en de verscheidenheid van sociale gemeenschappen waarin zij participeren. Daarom is vrijheid niet alleen van toepassing op individuele mensen, maar ook op gemeenschappen die hun eigen rechten en verantwoordelijkheden hebben. $\mathrm{Zij}$ die in gemeenschappen gezag uitoefenen geven niet alleen leiding aan individuele participanten, maar ook aan die gemeenschappen. Burgers hebben hun individuele en groepsvrijheden te verdedigen en tegelijkertijd hebben zij leiding en gezag te aanvaarden. Vrijheid en gezag behoeven dus niet tegengesteld aan elkaar te zijn. Het uitoefenen van gezag noch het gehoorzamen aan gezag is irrationeel of inhumaan; beide zijn met 
redelijke argumenten te verdedigen. Indien de rechtsstaat vorm wil geven aan het vrijheidsbeginsel, dan zijn rechtsstatelijke gezagsinstanties nodig zowel ter garandering van vrijheidsrechten als ter bevordering van de manier waarop burgers met die rechten omgaan. In evangelische zin heeft gezag niet primair een heersende, maar een dienende functie. Het woord 'autoriteit' (gezag) komt van het Latijnse werkwoord augére, dat 'doen groeien' of 'doen toenemen' betekent. Dat wil in dit verband zeggen dat het uitoefenen van gezag de normatieve dimensie heeft om burgers te doen groeien tot moreel volwassen en verantwoordelijk handelende personen, opdat zij hun vrijheid optimaal kunnen realiseren. Ook gezag is dus een fundamentele waarde.

In een publiek debat over vrijheid kan men verwachten dat op grond van christelijke tradities en 'brede' opvattingen over moraal kritiek wordt geuit op concepten van individualistische vrijheid. Men zal naar voren brengen dat in die concepten vrijheid wordt gebaseerd op een visie op het individu als een doel op zichzelf. Men zal betogen dat die concepten ver verwijderd zijn geraakt van de authentieke betekenis van vrijheid als een relationeel begrip dat gekenmerkt wordt door een moreel engagement met medemensen en met gedifferentieerde gemeenschappen. Men zal beargumenteren dat vrijheid nooit en nergens kan worden gerealiseerd buiten gemeenschappen noch zonder legitiem gezag en leiding die soms met gelegitimeerde dwang gepaard gaan. Weliswaar worden concepten van individualistische vrijheidsopvattingen vaak aangevuld met waarden als rechtvaardigheid en verantwoordelijkheid - bijkomende waarden om uitwassen van individualistische vrijheid in de praktijk te corrigeren. Daarentegen wordt met de genoemde authentieke vrijheid een manier van leven bedoeld die rechtvaardigheid en verantwoordelijkheid niet als bijkomende waarden beschouwt, maar als inbedding van vrijheid. Die inbedding in waarden als rechtvaardigheid, verantwoordelijkheid, liefde, zorg en trouw is bedoeld om vrijheid kracht te geven én, in het geval van misbruiken, onder kritiek te plaatsen.

\subsection{EVALUATIE}

De twee in de inleiding geformuleerde vragen heb ik beantwoord: op grond van omvattende christelijk-levensbeschouwelijke visies en 'brede' opvattingen over moraal kunnen beargumenteerde bijdragen worden geleverd tot het tegenwoordige publieke debat over waarden en normen die deel uitmaken van de publieke moraal. Men kan de vraag stellen of een praktische morele consensus op de 'werkvloer' van de samenleving en maatschappelijke verbanden niet belangrijker is dan een theoretisch-filosofische discussie over normen, waarden en een morele consensus. Weliswaar heeft filosofisch onderzoek de onvervangbare taak door middel van analyse en argumentatie een bijdrage te leveren tot verheldering van die onderwerpen, maar het zou inderdaad tekortschieten indien het niet op de praktijk gericht zou zijn; dat wil zeggen indien dat filosofisch onderzoek geen of onvoldoende argumenten zou bevatten die bruikbaar zijn voor een versterking of correctie van de publieke moraal op de 'werkvloer'; daar gaat het uiteindelijk 
om. Filosofisch onderzoek heeft niet slechts als doel theoretisch-morele kennis te vermeerderen, maar het heeft vooral een praktisch doel, opdat - zoals Aristoteles (1990, II, 2, 1103b26-28) reeds opmerkt - “wij er beter van worden, anders zou ons onderzoek van geen nut zijn”. Hoewel ik straks ook nog enkele factoren zal noemen die de publieke moraal kunnen ondermijnen, heb ik in het bovenstaande met name 'brede' opvattingen over moraal besproken die kunnen bijdragen tot een versterking van een publieke moraal. Ter voorkoming van mogelijke misverstanden, zal ik hier nog iets nader op ingaan.

Het bestaan en voortbestaan van een pluralistisch-democratische samenleving is afhankelijk van de politieke participatie van burgers en hun sociale participatie in diverse gedifferentieerde maatschappelijke verbanden. Velen beschouwen hun omvattende levensovertuiging en 'brede' opvattingen van morele waarden niet alleen als inspirerend voor hun privé-leven, maar ook voor hun manier om mede vorm te geven aan de samenleving. Die bijdrage tot vormgeving aan de samenleving kan plaatsvinden in en door middel van maatschappelijke verbanden met een levensbeschouwelijke grondslag. In katholieke en protestantse tradities in Nederland verdedigt men het recht op die levensbeschouwelijk geïnspireerde, sociale participatie op grond van de ideeën van subsidiariteit en soevereiniteit in eigen kring: de rechten, vrijheden en verantwoordelijkheden van burgers in maatschappelijke verbanden behoren ten volle te worden erkend, evenals de rechten, vrijheden en verantwoordelijkheden van die verbanden zelf, maar altijd binnen de context van de samenleving als geheel en binnen de grenzen van de wetten van de rechtsstaat. Subsidiariteit en soevereiniteit in eigen kring hebben niets te maken met 'autonome' gemeenschappen of geïsoleerde geloofsrichtingen die los zouden staan van de samenleving als geheel. Met soevereiniteit in eigen kring, respectievelijk subsidiariteit is onverbrekelijk haar pendant verbonden, universaliteit in eigen kring: de rechten, vrijheden en verantwoordelijkheden van maatschappelijke verbanden (en van haar participanten) behoren ook ten gunste van de samenleving als geheel te worden uitgewerkt. Soevereiniteit in eigen kring zonder die pendant blijft in zichzelf gekeerd, terwijl een univeralistische opvatting van de samenleving als geheel geen recht doet aan de sociale gedifferentieerdheid van de samenleving (Dooyeweerd 1963: 45, 78-80). Soevereiniteit in eigen kring en subsidiariteit mogen derhalve nooit dienen ter rechtvaardiging van handelingen die slechts georiënteerd zijn op geïsoleerde groepswaarden, maar behoren bij te dragen tot de sociale integratie en morele cohesie in de samenleving.

Als voorbeeld noem ik bijzondere scholen met een levensbeschouwelijke grondslag. Op katholieke, protestantse, joodse en islamitische scholen wordt in godsdienstlessen en andere vakken onderwijs gegeven overeenkomstig de waarden van de betreffende richting, opdat de leerlingen ook als goede burgers in de samenleving kunnen participeren. Ondanks uitwassen (die overal voorkomen en die vaak overbelicht worden) hebben veel bijzondere scholen gedurende meer dan honderd jaar bewezen bij te dragen aan de integratie van diverse bevolkingsgroepen in de samenleving. Dat oud-minister Van Boxtel (2002) pleit voor 
afschaffing van bijzondere scholen omdat zij de integratie in de samenleving zouden belemmeren, geeft blijk van gebrek aan kennis van zaken. Dat bijzondere scholen vanwege hun grondslag soms allochtone kinderen weigeren is dermate uitzonderlijk, dat Van Boxtels voorstel eerder lijkt voort te komen uit vooroordelen dan uit respect voor een sociaal- en levensbeschouwelijk-gedifferentieerde, democratische samenleving en daarin bestaande 'brede' opvattingen over moraal.

Niet slechts vooroordelen zijn bedreigend voor de erkenning van 'brede' opvattingen over moraal die ten grondslag liggen aan de publieke moraal in een democratische samenleving, maar ook ideeën die dermate algemeen verbreid zijn dat zij sluipenderwijs de publieke moraal ondermijnen. In de eerste plaats noem ik het probleem van het individualisme, dat uitgaat van de idee dat de mens autonoom is en een doel op zichzelf. Ik onderscheid dat individualisme van individualisering: de afnemende afhankelijkheid van het individu van maatschappelijke verbanden, de vrijheid en verantwoordelijkheid van ieder haar/zijn eigen levensrichting te kiezen en haar/zijn leven naar eigen inzicht in te richten en persoonlijke ontplooiingsmogelijkheden na te streven. Mensen zijn zelfstandiger en mondiger geworden - onomkeerbare processen. Wanneer de idealen van individualisering echter niet meer betekenen dan het maximaliseren van eigen rechten, vrijheden en belangen, dan verliest vrijheid haar authentieke, relationele betekenis die samenhangt met waarden als rechtvaardigheid, solidariteit en verantwoordelijkheid voor anderen. Dan verwordt individualisering in de praktijk tot individualisme, dat bijgevolg gemakkelijk leidt tot egoïsme, sociale desintegratie of verval van gemeenschapsbesef.

In de tweede plaats noem ik de invloed van het postmodernisme, dat niets moet hebben van politieke visies met fundamentele morele waarden voor de samenleving als geheel. Morele waarden worden volgens postmoderne filosofen altijd bepaald door subjectieve opvattingen. Mensen participeren nu eenmaal in bepaalde groepen die hun morele uitspraken bepalen. Die groepen zijn contingent; ze zijn toevallig in de loop van de geschiedenis ontstaan. Er hadden ook andere groepsvormen kunnen ontstaan en dan waren er andere morele waarden en opvattingen geweest. Achter die opvattingen terugvragen naar de waarheid ervan, heeft volgens postmoderne filosofen geen zin. De waarheid van elke morele opvatting is relatief, hoewel men in een democratische samenleving door middel van open discussies wel tot een morele consensus kan komen over bijvoorbeeld rechtvaardigheid en onrechtvaardigheid. Indien bij het zoeken naar een consensus slechts subjectieve opvattingen gelden en geen onderzoek wordt gedaan naar gemeenschappelijke fundamentele waarden en normen van de publieke moraal, dan dreigt de publieke moraal te worden aangevreten door morele vrijblijvendheid.

In de derde plaats noem ik het gedoogbeleid van een overheid die toelaat dat wetten worden overtreden. Gedogen kan een kwestie van noodzaak zijn, wanneer de overheid niet over adequate middelen beschikt om tegen misstanden op te treden. Ook kan gedogen voortkomen uit prudentiële overwegingen en het 
gebruikmaken van discretionaire bevoegdheden. Indien gedogen echter voortkomt uit een gebrek aan regeerkracht en vooral indien burgers met de wet- en regelgeving een loopje nemen en zichzelf en elkaar er niet op aanspreken, dan worden gedragingen en opvattingen van 'dat moet toch kunnen' in de publieke moraal bevorderd. Voeg hierbij de genoemde vooroordelen, het individualisme en de morele vrijblijvendheid en men ziet dat fundamentele waarden en normen van de publieke moraal en bijgevolg de sociale integratie en morele cohesie op de tocht komen te staan. Opzettelijk? Welnee, waarschijnlijk zijn veel mensen zich er in hun onnadenkendheid niet eens van bewust.

Hannah Arendt (1958: 5) heeft opgemerkt dat een van de meest opvallende kenmerken van onze tijd onnadenkendheid is: vergaande zorgeloosheid, hopeloze verwarring of gezapige herhaling van 'waarheden' die lege gemeenplaatsen zijn geworden. In een ander verband heeft Arendt (1994: 288) onnadenkendheid getypeerd als een 'banaal kwaad'. Hoewel het door haar bedoelde 'banale kwaad' (van kritiekloze meelopers in nazi-Duitsland) oneindig veel ernstiger was dan het onnadenkend omgaan met vooroordelen, individualisme, morele vrijblijvendheid en marchanderen met regels, zijn deze verschijnselen echter zo alledaags geworden dat ze door velen niet eens meer worden opgemerkt als vormen van kwaad. Dat kwaad moet in zijn alledaagsheid echter worden ontmaskerd, teneinde de ernst ervan onder ogen te zien. Het opbotsen tegen dat alledaagse kwaad kan stimuleren tot het inzicht dat het besef van bepaalde fundamentele waarden en normen aan erosie onderhevig is, een beargumenteerde herformulering ervan noodzakelijk kan zijn en het herontdekken van aan normen ten grondslag liggende waarden bevrijdend kan werken. Indien burgers en maatschappelijke verbanden hun persoonlijke en collectieve morele verantwoordelijkheid onvoldoende realiseren, ligt er een taak voor de overheid, niet om morele opvattingen voor te schrijven, maar wel om dat probleem aan de orde te stellen. En dat is gebeurd! 


\section{LITERATUUR}

Arendt, H. (1958) The Human Condition, Chicago/Londen: University of Chicago Press.

Arendt, H. (1994) Eichmann in Jerusalem. A Report on the Banality of Evil, New York etc.: Penguin (herz. ed.).

Aristoteles (1990) The Nicomachean Ethics, Cambridge, Mass./Londen: Harvard University Press.

Balkenende, J.P. (2002a) Anders en beter. Pleidooi voor een andere aanpak in de politiek vanuit een christen-democratische visie op de samenleving, overheid en politiek, Soesterberg: Aspekt.

Balkenende, J.P. (2002b) Handelingen Tweede Kamer, 18 december 2002.

Berlin, I. (1969) ‘Two Concepts of Liberty', in: I. Berlin, Four Essays on Liberty, Londen etc.: Oxford University Press.

Boer, Th. de (1993) Tamara A., Awater en andere verhalen over subjectiviteit, Amsterdam: Boom.

Boxtel, R. van (2002) Interview, GPD-kranten, 6 april 2002.

Dooyeweerd, H. (1963) Vernieuwing en bezinning. Om het reformatorisch grondmotief, Zutphen: Van den Brink.

Etzioni, A. (1996) The New Golden Rule. Community and Morality in a Democratic Society, New York: Basic Books.

Goudzwaard, B. (1976) Kapitalisme en vooruitgang. Een eigentijdse maatschappijkritiek, Assen/Amsterdam: Van Gorcum.

Graaf, J. van der (2003) Normen op hun waarde geschat, Heerenveen: Groen.

Heyde, L. (1994/95) 'U bent toch verzekerd? Over de "nutteloosheid” van normen', Wijsgerig perspectief op maatschappij en wetenschap, 35,4 .

Houtepen, A. (1995) 'Christelijk geloof, humanisme en de intrinsieke waarde van het milieu', Christen Democratische Verkenningen, 1995, 2.

Peursen, C.A. van (1993/94) 'Normen binden. Waarden maken vrij', Wijsgerig Perspectief op maatschappij en wetenschap, 24, 1.

Rawls, J. (1985) 'Justice as Fairness: Political Not Metaphysical', Philosophy and Public Affairs, 14.

Rawls, J. (1993) Political Liberalism, New York: Columbia University Press.

Reinders, J.S. (1996) 'The Golden Rule between Philosophy and Theology', blz. 163-166 in: A. Bondolfi c.s. (red.), Ethik, Vernunft und Rationalität, München: Lit Verlag.

Selznick, Ph. (1992) The Moral Commonwealth. Social Theory and the Promise of Community, Berkeley etc.: University of California Press.

Taylor, C. (1989) Hegel, Cambridge etc.: Cambridge University Press.

Valk, J.M.M. de (1967) Maatschappelijke verantwoordelijkheid, Rotterdam: Universitaire Pers.

Vlies, B. van der (2002) Handelingen Tweede Kamer, 18 december 2002.

Vos, H. (1995) Filosofie van de moraal. Inzicht in moraal en ethiek, Utrecht: Het Spectrum.

Walgrave, J.H. (1960) 'Verantwoording en uitbouw', blz. 9-128 in: J.A. Ponsioen e.a. (red.), Welvaart, welzijn en geluk. Een katholiek uitzicht op de Nederlandse samenleving, deel I, Hilversum/Antwerpen: Paul Brand.

Woldring, H.E.S. (2002) Kernbegrippen in de politieke filosofie. Een herwaardering, Bussum: Coutinho. 


\title{
5 DE AANVAARDING EN NALEVING VAN RECHTS- NORMEN DOOR BURGERS: PARTICIPATIE, INFORMATIEVERSCHAFFING EN BEJEGENING
}

\author{
M. Malsch
}

\section{$5.1 \quad$ INLEIDING}

Wetten en andere rechtsregels bevatten normen waarover in een democratisch proces overeenstemming is bereikt. Deze normen worden geacht in het algemene belang te zijn; in het proces van wetgeving dat heeft geleid tot de aanvaarding van deze normen, heeft dit 'algemene belang' de aandacht gekregen die het behoeft. Dit neemt niet weg dat in individuele gevallen burgers kunnen kiezen voor nietnaleving van bepaalde normen, omdat dit hun eigenbelang beter dient dan het zich houden aan de wet. Als voor de hand liggend voorbeeld kan genoemd worden de naleving van verkeersregels. Door rood licht rijden, sneller rijden dan toegestaan is of achter het stuur gaan zitten met een glaasje te veel op is verleidelijk als men weet dat de kans op controle gering is en het alternatief, zoals het bellen van een taxi of even wachten, niet aantrekkelijk is. Dit neemt niet weg dat waarschijnlijk ieder van deze wetsovertreders overtuigd is van het nut van algemene regels die dronken rijden en andere verkeersmisdrijven verbieden. Nietnaleving van dit soort rechtsnormen komt dus veelvuldig voor, terwijl tegelijkertijd de daders ervan meestal wel de bedoeling van deze normen onderschrijven.

Ook andere typen van rechtsnormen dan die zijn neergelegd in de verkeerswetgeving worden regelmatig overtreden zonder dat de daders het bestaan van een wet die dat gedrag verbiedt expliciet afwijzen. Mishandelingen, (pogingen tot) doodslag of moord, diefstallen, inbraken, fraude en zedenmisdrijven worden algemeen afgekeurd, maar de verboden daarop worden niet algemeen nageleefd: een substantieel deel van de criminaliteit die door de rechtbank wordt behandeld, betreft dit soort misdrijven.

Dit betekent dat voor de naleving van rechtsnormen niet te veel gerekend kan worden op de internalisering van deze normen en het uit dien hoofde zich aan de wet houden. Deze normen worden weliswaar onderschreven, maar de nakoming ervan laat veelal te wensen over. In veel gevallen zijn de overtreders van deze normen van mening dat hun situatie zodanig afwijkt van wat gangbaar is dat zij 'gerechtigd' zijn om de wet te overtreden. Sykes en Matza (1957) onderscheiden vijf 'neutraliseringstechnieken' die dienen als rechtvaardiging voor overtreding van de wet. Met deze neutraliseringstechnieken praten daders van strafbare feiten hun gedrag goed en wordt afkeuring door anderen of het eigen schuldgevoel 'geneutraliseerd'. Zij ontkennen bijvoorbeeld hun verantwoordelijkheid voor het delict of voor de gevolgen ervan, of zeggen dat er geen schade of nadeel is geleden. Sommigen rechtvaardigen zichzelf omdat zij alleen van mensen stelen die het kunnen missen, of zij veroordelen diegenen die een oordeel over hen vellen. 
De rechter moet het daarbij vaak ontgelden, of daders vinden dat dit feit eigenlijk niet strafbaar zou moeten zijn. Ook wordt door daders wel gesteld dat onder de beroerde leefomstandigheden waaronder zij leven er geen andere keuzemogelijkheid is dan het overtreden van de wet om zo de zorg voor het gezin veilig te kunnen stellen. De daders deden het niet voor zichzelf, maar voor hun gezin (Janssen 2003). Daarnaast zijn er delicten die in een impuls worden gepleegd, zoals sommige gevallen van mishandeling of doodslag: de dader ontsteekt naar aanleiding van een gebeurtenis in woede en valt het slachtoffer aan. Ook in deze situatie is internalisering van normen onvoldoende om iemand te weerhouden van strafbaar gedrag. Hetzelfde geldt als daders psychisch gestoord zijn: in die gevallen zal internalisering van rechtsnormen eveneens haar uitwerking missen.

De voorlopige conclusie uit het bovenstaande is dat voor naleving van rechtsnormen de internalisering ervan vaak niet voldoende is. Bovendien is internalisering van normen moeilijk vast te stellen en maar in zeer beperkte mate te sturen. Daadwerkelijke internalisering betekent immers dat de normen als het ware onderdeel worden van het geheel van waarden en normen van de persoon zelf. In een pluriforme, postmoderne samenleving als de Nederlandse anno 2004 valt een eis als deze moeilijk te realiseren. Dit betekent dat er meer aandacht moet komen voor andere factoren die van invloed zijn op de aanvaarding en naleving van rechtsnormen, zoals het vertrouwen dat wordt gesteld in het rechtssysteem en de legitimiteit van de autoriteit die tot nakoming van rechtsnormen dwingt. Naast de overheid als meer abstracte vorm van autoriteit, moet hierbij met name worden gedacht aan de politie, het Openbaar Ministerie en de rechter. Legitimiteit van deze autoriteiten kan onder meer tot gevolg hebben dat de normen die zij uitvaardigen als vanzelfsprekend worden nageleefd. Hun autoriteit wordt in het geval dat zij als 'legitiem' worden ervaren, niet of nauwelijks ter discussie gesteld. Legitimiteit van verschillende overheidsorganen is tegenwoordig echter niet meer vanzelfsprekend, maar moet worden gevonden en onderhouden. Mede daarom is er toenemende aandacht voor het vertrouwen dat wordt gesteld in de overheid en in organen van rechtspleging, de wijze waarop autoriteiten met burgers communiceren, de participatie van burgers in overheidsbeslissingen en de bejegening van burgers door autoriteiten (WRR 2002; Hertogh 2003). Al deze factoren zijn van belang voor de aanvaarding en de legi-timiteit, en daarmee voor de naleving, van rechtsnormen.

In deze bijdrage wordt ingegaan op de verschillende verbanden tussen legitimiteit enerzijds en de aanvaarding en naleving van rechtsnormen anderzijds. Eerst wordt kort ingegaan op recente maatschappelijke veranderingen in de criminaliteit en de reacties daarop van politie, Openbaar Ministerie en de rechter. Deze korte omschrijving heeft met name betrekking op de Nederlandse situatie. Daarna wordt de theorie van Procedural Justice (procedurele rechtvaardigheid) behandeld en wordt een drietal onderwerpen besproken die van essentieel belang zijn voor de legitimiteit van politie, justitie en de rechter. Het gaat daarbij om participatie van de burger in de rechtspraak, om informatieverschaffing aan de burger en om bejegening van de burger door het strafrechtssysteem. De normen 
zoals die zijn neergelegd in Nederlandse wetten en andere rechtsregels, zijn niet onderwerp van discussie. Het gaat in deze bijdrage uitsluitend over de aanvaarding en de naleving van deze rechtsnormen door de burger, de redenen hiervoor, en de omstandigheden waaronder aanvaarding en naleving kunnen worden bevorderd. Daarbij staat het strafrecht centraal, maar zal op verschillende plaatsen ook aandacht worden besteed aan de andere rechtsgebieden.

\subsection{MAATSCHAPPELIJKE VERANDERINGEN IN CRIMINALITEIT EN RECHTSPLEGING}

De aard van de criminaliteit verandert en deze wordt gewelddadiger. Daders beginnen bovendien vaak al op jongere leeftijd met het overtreden van de wet (DAJS 2001). Doordat in toenemende mate toezicht door ouders en leraren ontbreekt en tegelijkertijd de verleidingen van de wereld van de volwassenen, zoals drank, seks en de genietingen die worden geboden via reclame, film en televisie alomtegenwoordig zijn, gaan jongeren op steeds vroegere leeftijd over tot crimineel gedrag. Ook in de wereld van de (jong)volwassenen vinden veranderingen plaats die hen verleiden tot criminaliteit. Een van de belangrijkste maatschappelijke veranderingen van de afgelopen jaren is die van een toenemende individualisering (WRR 20O2). Niet alleen binnen gezinnen, maar ook bij arbeidsverhoudingen, in het openbare leven en in de politieke of sociale participatie tekent zich deze individualisering af. Dankzij welvaart en een gemiddeld hogere opleiding zijn mensen minder afhankelijk geworden van hun directe sociale omgeving. Zij kunnen zich beter verplaatsen en beschikken over meer informatie, waardoor zij ook beter zelfstandig kunnen oordelen (WRR 2002: 98). Vrijheid en zelfontplooiing zijn belangrijk geworden bij het aangaan van bindingen, niet alleen in verhouding tot de directe omgeving, maar ook in relatie tot de overheid. Burgers hebben vaak hoge verwachtingen van overheidsinstanties en stellen hoge eisen (WRR 2002: 99). Tegelijkertijd voelen zij zich vaak minder gebonden door regels en geboden van buitenaf. Dit leidt tot een toenemend aantal conflicten, zowel tussen burgers onderling als tussen burgers en het bevoegd gezag.

Sommige auteurs constateren dat als gevolg van deze en andere tendenties er een groeiend onbehagen ontstaat onder de bevolking of bepaalde bevolkingsgroepen (De Roos 2001; Van den Brink 2001; Boutellier 2002). Dit onbehagen houdt verband met een nieuwe, ruime keuzevrijheid die als drukkend wordt ervaren. Het teloorgaan van de 'grote verhalen' en de veel ruimere mogelijkheden tot zelfontplooiing heden ten dage leiden tot een vergrote keuzevrijheid. Een vergroot gevoel van eigenwaarde en een egogerichte mondigheid hebben vaak frustratie en een gekwetstheid van superioriteitsgevoelens tot gevolg. Vooral bij jongeren die sociaal tekortkomen kan dit tot geweldsuitbarstingen leiden (Van den Brink 2001). Deze neiging tot geweld wordt nog gevoed door een 'vitalisme' dat door Boutellier (2002) wordt gedefinieerd als “... een gemene deler voor tal van fenomenen die kenmerkend zijn voor de hedendaagse samenleving, zoals de dominantie van de markt met haar nadruk op ondernemerszin, risiconeming en 
concurrentie. Of men kan denken aan de jeugdcultuur en de mediawereld, aan de sportbeoefening en aan het uitgaansleven om de verleiding van snelle, expressieve en emotiegerichte activiteiten te onderkennen" (Boutellier 2002: 2). Mensen kunnen en willen steeds meer en daarmee botsen ze ook sneller op anderen, die dan voornamelijk als lastige blokkades worden beschouwd. Frustraties zijn het gevolg.

In het proces van individualisering, dat samenhangt met de toenemende nadruk op consumptie, bestaan volgens Bauman (1993) steeds minder algemeen geldende ethische codes. Moraliteit moet dan ook steeds meer gevonden worden in de individuele verantwoordelijkheid van ieder mens in zijn samenleven met andere mensen, maar dat proces is nog niet goed op gang gekomen. De toenemende individualisering is ook af te lezen aan een zekere mate van normatieve verzelfstandiging van burgers. Met het verdwijnen van de sociale druk van ouders, dominees, onderwijzers en ander morele gezagsdragers heeft ook een proces van toenemende morele verzelfstandiging van burgers plaatsgevonden. Zij maken nu veelal zelf uit wat hun mening is over bepaalde maatschappelijke vraagstukken en laten zich niet meer primair leiden door de normen die autoriteiten uitdragen.

Veel onvrede wordt veroorzaakt door of geprojecteerd op politie, justitie en de rechter. De 'witte beweging' in België die begon als reactie op de zaak-Dutroux en het gebrekkige functioneren van politie en justitie aldaar, vond zijn pendant in de Nederlandse 'stille marsen' (Boutellier 2002). Compassie met slachtoffers en een diffuse vorm van ontevredenheid over politie en justitie waren de aanleiding tot deze marsen. Incidenten met 'zinloos geweld', die volgens velen door politie voorkomen hadden kunnen worden, gecombineerd met straffen die te laag werden gevonden en die bovendien onvoldoende waren gemotiveerd, vormden een achtergrond voor deze onvrede. Er werden bovendien in ongeveer dezelfde periode vragen gesteld bij de nevenfuncties van sommige leden van de rechterlijke macht. Deze nevenfuncties zouden de onpartijdigheid van rechters in negatieve zin beïnvloeden, terwijl er tegelijkertijd weinig openbaarheid bestond over deze nevenfuncties (Ruijs 2001). Recent is ook onvrede naar buiten gekomen over de gebrekkige inzet van politie en justitie bij veel criminaliteit die hun ter kennis komt en die vaak blijft liggen. Er is voor gepleit om het opportuniteitsbeginsel ten aanzien van bepaalde delicten anders in te zetten (WRR 2002), in die zin dat vervolging bij ernstiger delicten nu de eerste optie zou moeten worden en sepot pas in bijzondere omstandigheden in aanmerking komt.

De hier beschreven tendenties staan niet op zichzelf. Zij houden nauw verband met een algemene wijziging in de verhouding tussen autoriteiten en burgers sinds de jaren zestig. Autoriteiten worden niet meer beschouwd als boven elke kritiek verheven, burgers worden kritischer en laten zich niet meer zo eenvoudig de wet voorschrijven. De klassieke professionals kunnen ter staving van hun verhaal niet meer volstaan met te wijzen op hun autoriteit, maar moeten hun diagnoses en beslissingen op begrijpelijke wijze uitleggen en onderbouwen. Leerlingen, studenten, patiënten en cliënten komen met gerichte vragen over de informatie die hun wordt aangeboden en verlangen een adequaat antwoord. 
Geconfronteerd met deze verwachtingen worden veel professionals ertoe gedwongen om meer en beter te communiceren met de burger en om meer aan de verwachtingen van de gebruikers van hun diensten te voldoen (Malsch \& De Bakker 2003; Hertogh 2003).

Ook ten aanzien van de rechterlijke macht tekent een dergelijke ontwikkeling zich steeds duidelijker af, zij het dat dit type veranderingen dáár als een van de laatste plaatsvindt. Er is binnen de rechterlijke macht een toenemende aandacht voor cliëntvriendelijkheid en openheid. Er worden voorlichtingsfunctionarissen bij rechtbanken, hoven en parketten aangesteld en er vinden klanttevredenheidsonderzoeken plaats. Ondanks deze ontwikkelingen binnen het strafrecht worden gerechtelijke procedures door de deelnemers nog steeds vaak als bureaucratisch ervaren, vindt men de rechter afstandelijk en ontoegankelijk en worden procesdeelnemers soms te weinig op de hoogte gesteld van de voortgang in hun zaken (Wemmers 1996; Van der Kam 2000; Prisma 2002; Malsch 2003c). De participatie van burgers in het strafrechtssysteem is, zoals hieronder zal worden toegelicht, nog steeds marginaal. Hierin onderscheidt het rechtsbedrijf zich overigens niet van sommige andere sectoren, zoals bijvoorbeeld de politiek of de gezondheidszorg (Schoo 2003). Ook in de politiek is de gewone burger zonder academische opleiding steeds meer afwezig. De werkelijk belangrijke zaken worden in achterkamertjes geregeld waartoe niet direct betrokkenen geen toegang hebben (Schoo 2003).

De hier kort omschreven veranderingen in criminaliteit en rechtspleging zijn van directe invloed op de vraagstukken van legitimiteit en nakoming van rechtsnormen. In zijn algemeenheid kan worden gesteld dat er als gevolg van de ontwikkelingen die hierboven zijn beschreven tegenwoordig een geringere a priori bereidheid bestaat om rechtsnormen te aanvaarden en na te leven (Luhmann 1978) en dat de rol van communicatie tussen autoriteit en publiek daarmee belangrijker is geworden. Legitimiteit van justitiële autoriteiten is niet meer zo vanzelfsprekend als vroeger, maar moet worden gezocht, gewonnen en onderhouden.

\subsection{DE THEORIE VAN PROCEDURELE RECHTVAARDIGHEID}

Moderne maatschappijen kunnen niet zonder regels en zonder autoriteiten die de nakoming van die regels afdwingen. In deze regels worden de inrichting van de staat en de verantwoordelijkheid, plichten en bevoegdheden van autoriteiten en burgers neergelegd. In situaties die grote onzekerheid met zich meebrengen, zoals dreigingen van buitenaf of rampen, worden aan autoriteiten ingrijpendere bevoegdheden toegekend dan in relatief rustige situaties. Zo is de bevolking onder de dreiging van bijvoorbeeld terrorisme sneller bereid ingrijpende bevoegdheden van de overheid en nieuwe wetgeving die die ingrepen legitimeert, te aanvaarden dan zonder die dreiging. In zijn algemeenheid vormen de creatie van nieuwe regels en de versterking van de bevoegdheden van politie en justitie een geëigend antwoord op situaties van conflict en crisis (Tyler \& Lind 1992). 
Wettelijke regels en bevoegdheden van autoriteiten om regels af te dwingen zijn echter niet voldoende voor de naleving van rechtsnormen. Het blijkt dat mensen die regels toch steeds weer overtreden, ook als zij daarmee de kans lopen te worden gestraft. Het leven van alledag laat zich niet in regels vangen en tal van gebeurtenissen en incidenten roepen overtreding van regels op. Pas een volledige controle van alle handelingen van alle subjecten zou afdoende zijn om iedereen te dwingen om zich conform de regels te gedragen, en dit is zelfs in de verst doorgevoerde politiestaat (die niemand wil) niet mogelijk. Daarom berust elke conceptie van een juridisch systeem op een zoveel mogelijk vrijwillige medewerking van burgers aan de normen die het recht stelt. De vraag is dus niet primair of rechtsregels alle mogelijke vormen van ongewenst of zelfs crimineel gedrag dekken en of autoriteiten de mogelijkheid hebben om nakoming af te dwingen, de vraag is veel meer hoe burgers kunnen worden gemotiveerd om uit zichzelf rechtsnormen na te leven (Tyler 1990). De algemene bevinding van het onderzoek naar procedurele rechtvaardigheid (Procedural Justice) is dat het antwoord op de vraag waarom mensen autoriteiten gehoorzamen of de wet naleven, veel meer te maken heeft met de procedures waarlangs beslissingen totstandkomen dan met de uitkomst van die beslissingen (Tyler \& Lind 1992). De term 'procedures' moet in dit verband breed worden opgevat: hieronder vallen alle contacten tussen professionals en burgers waarbij die professionals bepaalde bevoegdheden ten aanzien van burgers uitoefenen. Zowel aanhoudingen door de politie van verdachten en verhoren van getuigen als de behandeling van zaken tijdens strafzittingen kunnen onder deze procedures vallen. Onder het begrip 'procedures' worden in dit advies dus niet primair de formele regelingen van processen gevat, maar veeleer de inrichting van alle contacten tussen autoriteiten en burgers in hun diverse hoedanigheden.

In theorieën over rechtvaardigheid zijn twee stromingen te onderkennen. De eerste en oudste stroming richt zich op de rechtvaardigheid van de uitkomst van beslissingen van autoriteiten. Geeft die uitkomst een gelijke of billijke verdeling tussen partijen te zien, dan wordt die uitkomst als 'rechtvaardig' beschouwd (Distributive Justice). De gedachte hierachter is dat mensen na de beslissing van een autoriteit gaan vergelijken wat zij hebben gekregen met wat anderen in ongeveer dezelfde situatie hebben gekregen. Valt dit oordeel negatief uit, bijvoorbeeld omdat men vindt dat men beduidend minder heeft ontvangen dan anderen, dan leidt dit tot ontevredenheid over de autoriteit. Is er wel een gelijke of billijke verdeling totstandgekomen, dan zijn de deelnemers tevreden over de beslissende autoriteit. Het centrale probleem bij deze rechtvaardigheidstheorie is dat het moeilijk is om vast te stellen wat precies een gelijke of billijke verdeling is. Geen twee gevallen zijn immers hetzelfde en de ene persoon is 'behoeftiger' dan de andere (Wasserman 1997). Met name in het strafrecht is het moeilijk om uit te maken of een straf proportioneel is aan de ernst van het feit, meer nog dan in civiele zaken waarin het vaak draait om de hoogte van een schadevergoeding die iets eenvoudiger is vast te stellen. Bij het ontbreken van een hard criterium om te bepalen of de uitkomst rechtvaardig is, vallen partijen dan ook terug op indicaties voor de onpartijdigheid en zorgvuldigheid van de rechter of een andere beslis- 
sende autoriteit. Daarmee komt dan de procedure die de autoriteit hanteert meer in zicht.

De andere stroming binnen de rechtvaardigheidstheorieën schenkt dan ook meer aandacht aan de procedure die is gehanteerd om tot een beslissing te komen (Procedural Justice; Leventhal 1976; Lind \& Tyler 1988; Thibaut \& Walker 1975; Tyler \& Lind 1992; Röhl \& Machura 1997). Als procedures aan bepaalde eisen voldoen, leiden zij tot tevredenheid van de deelnemers, zelfs als de uitkomst van de procedure op zich tegenvalt. Factoren als de beleefdheid, de onafhankelijkheid en het respect dat een autoriteit uitstraalt worden door partijen als aanwijzing gezien dat eerlijke procedures worden gevolgd om tot een beslissing te komen. Men gaat ervan uit dat in dat geval ook de uitkomst wel rechtvaardig zal zijn. Het onderzoek naar procedurele rechtvaardigheid heeft aangetoond dat het voor de tevredenheid van partijen in een procedure over het algemeen belangrijker is dat zij correct en rechtvaardig worden behandeld dan dat zij een groot geldbedrag binnenkrijgen. Overigens zijn de resultaten van het onderzoek op dit punt niet geheel eenduidig. Vooral in veldonderzoek is ook wel het tegenovergestelde gevonden, namelijk dat de uitkomst een substantieel grotere invloed heeft op de tevredenheid van procesdeelnemers dan de kenmerken van de procedure (Schuyt et al. 1978; Genn 1999; Minekus 2003). Als verklaring voor deze discrepanties is wel gesteld dat het belang van proefpersonen bij de uitkomst van een beslissing in een experiment veel geringer is dan bij personen die in een echte zaak zijn betrokken (Minekus 2003). De laatsten zouden zich dus meer richten op de uitkomst - datgene wat zij hebben binnengehaald - en zouden het dus belangrijker vinden om hun eis toegewezen te krijgen dan om correct te worden bejegend. Veel onderzoek naar procedurele rechtvaardigheid heeft gebruikgemaakt van experimenten waarin de proefpersonen geen daadwerkelijk belang hadden bij de uitkomst. Dit staat in tegenstelling tot veldonderzoek waarbij de onderzochte personen in echte zaken zijn betrokken en dus een reëel belang hebben bij de beslissing van de rechter. De centrale conclusie van het onderzoek naar procedurele rechtvaardigheid is echter dat kenmerken van de procedure over het geheel genomen toch belangrijker zijn voor het oordeel over de rechtvaardigheid dan kenmerken van de uitkomst.

Het onderzoek naar de theorie van procedurele rechtvaardigheid is niet alleen van belang voor de tevredenheid over beslissingen van een autoriteit. Ook de acceptatie van die beslissingen en de naleving ervan en van rechtsnormen in het algemeen worden verhoogd door kenmerken van een rechtvaardige procedure. Tyler (1990) onderzocht de naleving van wetten met behulp van interviews met een omvangrijke steekproef van burgers. Die interviews werden op verschillende tijdstippen herhaald. Een deel van de respondenten werd in de tussentijd in een gerechtelijke procedure betrokken. Het bleek dat zij die de gehanteerde procedures rechtvaardig vonden, de beslissingen van de rechter en andere professionele procesdeelnemers legitiemer vonden en dit leidde ertoe dat zij ook beter de wet naleefden. Dit effect was sterker bij een positief oordeel over de rechtvaardigheid van de procedure dan bij een positief oordeel over de rechtvaardigheid van de 
uitkomst. Ook Sherman vond dat, als verdachten rechtvaardig en met respect werden behandeld, zij later minder vaak in contact kwamen met de politie (Sherman 2002). Deze onderzoeksresultaten lijken erop te duiden dat er een direct verband is tussen de rechtvaardigheid van een behandeling of procedure en de naleving van rechtsnormen.

\subsection{KENMERKEN VAN EEN RECHTVAARDIGE PROCEDURE}

Welke kenmerken van procedures zijn van belang voor het oordeel over de rechtvaardigheid ervan? Thibaut en Walker $(1975,1978)$ legden in hun 'instrumentele model van procedurele rechtvaardigheid' de nadruk op de invloed die procesdeelnemers (kunnen) hebben op de procedure die wordt gehanteerd om tot een beslissing te komen, en daarnaast ook de invloed die zij kunnen uitoefenen op die beslissing. Procescontrole, de eerste vorm van invloed die partijen kunnen hebben, heeft vooral te maken met de vraag of zij zelf bewijs kunnen inbrengen in de procedure en of zij hun argumenten naar voren kunnen brengen op een zitting ten overstaan van de rechter. Beslissingscontrole verwijst enerzijds naar een directe inbreng in beslissingen en anderzijds naar de mogelijkheid om hoger beroep in te stellen en dus de beslissing van de eerste rechter aan te vechten.

De algemene bevinding van onderzoek naar verschillende typen procesmodellen is dat partijen procescontrole belangrijker vinden dan invloed op de uiteindelijke beslissing. Accusatoire procesmodellen, waarin partijen een substantiële invloed op het proces hebben, leiden bovendien tot betere beslissingen en tot meer tevredenheid van partijen dan inquisitoire procesmodellen, waar partijen veel minder invloed hebben op de procesvoering (Thibaut \& Walker 1975; Crombag \& Van Koppen 2002). Accusatoire procesmodellen zijn met name te vinden in de Angelsaksische landen, en inquisitoire procesmodellen met name in continentaal West- en Midden-Europa, waaronder Nederland, in Zuid-Europa en in landen in Latijns-Amerika. Hierbij hebben we het met name over het strafrecht; binnen het civiele recht zijn vormen van procescontrole veel vanzelfsprekender, omdat daar de partijen altijd het meeste bewijs verzamelen en aan de rechter voorleggen.

Procesdeelnemers blijken dus een sterke voorkeur te hebben voor accusatoire procesvormen. In dit type proces kunnen zij zelf beslissen welke informatie en welk bewijs zij aan de rechter voorleggen en kunnen zij hun eigen advocaat kiezen. Ook kunnen zij zelf beslissen of zij getuigen oproepen of deskundigen inschakelen en wie dit zijn. Zij krijgen een substantiële mogelijkheid om hun argumenten op de zitting naar voren te brengen. Bij inquisitoire processen is de inbreng van partijen veel geringer en worden er veel meer restricties opgelegd aan het zelf inschakelen van getuigen en deskundigen. Er is op de zitting vaak minder tijd voor partijen om hun standpunt toe te lichten dan in accusatoire processen (Malsch \& Nijboer 1999; Van Koppen \& Penrod 2003; Crombag \& Van Koppen 2003). Vergelijkend onderzoek naar deze twee typen van procedures heeft laten zien dat zelfs partijen die hun zaak hadden verloren de uitkomst nog in zekere 
mate rechtvaardig vonden als deze via een accusatoire procedure was verkregen. Dit was niet het geval bij een inquisitoire procedure; daar overheerste dan ongenoegen over de beslissing. Dit tekent het belang dat wordt gehecht aan inbreng in procedures en procescontrole (Thibaut \& Walker 1975; Crombag \& Van Koppen 2003).

In de hier beschreven instrumentele versie van de theorie van procedurele rechtvaardigheid wordt procescontrole als belangrijk voor partijen beschouwd, omdat deze zich er zo van kunnen verzekeren dat de rechter alle informatie ontvangt die nodig is om een rechtvaardige beslissing te kunnen nemen. En beslissingscontrole wordt van belang geacht omdat deze tot op zekere hoogte aan partijen de mogelijkheid geeft om een uitkomst te accepteren die hun gewenst voorkomt, en als zij een in hun ogen niet-correcte uitspraak hebben gekregen deze voor te leggen aan een hogere rechter. Het instrumentele aspect van het model van Thibaut en Walker blijkt uit het feit dat procedures slechts als middel tot een doel worden beschouwd, namelijk het verkrijgen van een zo gunstig mogelijke beslissing. In deze theorie heeft de rechtvaardigheid van de procedure dus voornamelijk de functie van het verkrijgen van een zo rechtvaardig mogelijke uitkomst. Thibaut en Walker besteden veel minder aandacht aan overwegingen die partijen kunnen hebben om de relatie met de autoriteit(en) ook op langere termijn goed te houden, waarbij rechtvaardige procedures ook een waarde op zichzelf kunnen krijgen. Zij gaan er automatisch van uit dat de meeste procesdeelnemers slechts één keer voor de rechter verschijnen. Het is de vraag of die aanname terecht is: zij mag dan misschien voor de meeste procespartijen gelden, zij geldt zeker niet voor de advocaten die optreden voor de partijen. Advocaten zien veel vaker een rechter en zullen daarom zeker geïnteresseerd zijn in het handhaven van goede verhoudingen met de rechterlijke macht en de andere professionele procesdeelnemers. Maar ook procespartijen of burgers in het algemeen kunnen om verschillende redenen belang hechten aan rechtvaardige procedures om geschillen op te lossen, los van de uitkomst waartoe zij leiden.

In theorieën die gekarakteriseerd kunnen worden als 'relationele modellen van procedurele rechtvaardigheid' hebben procedures niet primair een instrumenteel karakter, maar hebben zij een zelfstandige betekenis in het licht van de waarden die binnen de desbetreffende groep worden gehanteerd. Uit kenmerken van procedures kan immers worden afgeleid hoe deelnemers worden gewaardeerd binnen een groep, waarbij men onder 'groep' elke enigszins bestendige combinatie van personen waarbinnen relaties bestaan kan verstaan, variërend van een gezin tot de maatschappij. Het Group-Value Model (Tyler \& Lind 1992) stelt dat mensen zich bij hun oordeel over procedures vooral laten leiden door hun contact met de beslissende autoriteiten of instanties die de procedures hanteren. Zij stellen een groter belang in het op de langere termijn goed houden van hun relaties met autoriteiten dan in het koste wat kost gelijk krijgen of het 'binnenhalen' van een grote som geld. Deze theorieën gaan er dus van uit dat procesdeelnemers, als lid van een groep, de kans hebben om vaker in een procedure te worden betrokken of meermalen met bepaalde instellingen of autoriteiten te worden gecon- 
fronteerd. Een prettig verlopende procedure en een coöperatieve instelling van procesdeelnemers is in die situatie gewenster dan in het geval van een eenmalige betrokkenheid in een procedure. Het gaat hierbij ook niet uitsluitend om één autoriteit of één instantie; de verhoudingen van burgers tot een veelheid van autoriteiten en instanties zijn relevant binnen deze tak van de theorie van procedurele rechtvaardigheid.

Het Group-Value Model van Tyler en Lind (1992) veronderstelt dat mensen van nature sterk gericht zijn op identificatie met een groep. Een reden hiervoor is dat anderen het individu bevestiging van het zelfbeeld kunnen verschaffen. Waar groepsidentiteit de externe kenmerken van een groep definieert, geven procedures de interne kenmerken van een groep weer. Door het ontwerpen van procedures geeft een groep zichzelf vorm en geeft zij blijk van haar waarden en doelstellingen. Een procedure die in overeenstemming is met de individuele en de groepswaarden resulteert volgens deze theorie in een positief oordeel over de rechtvaardigheid bij de groepsleden. Hoewel normen en waarden per groep en per individu kunnen verschillen, bestaan er volgens Tyler en Lind fundamentele waarden die gericht zijn op de instandhouding van de groep die voor alle groepen gelden. Lind en Tyler noemen in dit verband groepssolidariteit, maatschappelijk aanzien, het waarborgen van het lidmaatschap van de groep, de mogelijkheid om ten volle te kunnen deelnemen aan het sociale leven in de groep en het instandhouden van relaties met de autoriteiten binnen de groep (Tyler \& Lind 1992; Van der Leij 2002, 2003). Met de term 'groep' refereren Tyler en Lind aan de gehele maatschappij, of aan 'de rechtsgenoten'. Het is natuurlijk de vraag in hoeverre in deze tijd van individualisering een dergelijke gelijkstelling nog relevantie bezit. De algemene identificatie met de maatschappij is waarschijnlijk minder stevig dan in de tijd dat deze theorieën werden opgesteld. Dit neemt niet weg dat veel mensen in de huidige maatschappij deze groepswaarden waarschijnlijk nog steeds onderschrijven.

Tyler en Lind onderscheiden drie factoren die mensen gebruiken om de rechtvaardigheid van procedures te bepalen. Deze factoren zijn toegesneden op de interacties van groepsleden met de autoriteit(en) binnen een groep. De eerste factor is de waardering die iemand als lid van een groep geniet. Groepsleden willen deze waardering in de interactie met een autoriteit bevestigd zien. De autoriteit kan die geven door het groepslid op een beleefde en waardige manier te behandelen en zijn rechten te respecteren. De tweede factor is het vertrouwen dat gesteld kan worden in de goede intenties van de autoriteit. Die goede intenties houden in dat de autoriteit oog heeft voor de behoeften van het individu en rekening houdt met diens opvattingen. De derde factor is de onpartijdigheid die autoriteiten en instanties betrachten in hun besluitvorming. Zij baseren zich in het geval van onpartijdigheid op de feiten in de zaak, laten zich niet leiden door vooroordelen en zijn oprecht en betrouwbaar. Vooringenomenheid van een autoriteit kan een grote bedreiging vormen voor het zelfbeeld van een groepslid (Tyler \& Lind 1992; Van der Leij 2002, 2003). 
Voldoet de autoriteit niet aan deze 'vereisten', dan heeft dit volgens Tyler en Lind tot gevolg dat het betreffende groepslid de gebruikte procedure als onrechtvaardig zal beschouwen. Daardoor kunnen de tevredenheid over en de steun aan die autoriteit verminderen. Bovendien heeft het optreden van een autoriteit gevolgen voor de houding van groepsleden ten opzichte van andere autoriteiten. Uit onderzoek komt naar voren dat een onheuse bejegening van slachtoffers van strafbare feiten door de politie kan leiden tot een verslechtering van de verhouding tussen slachtoffers en de strafrechtspleging in haar geheel (Wemmers 1996). Dit kan uiteindelijk een bedreiging vormen voor de loyaliteit en de verbondenheid van het individu met de samenleving. Een vertrouwensbreuk met de autoriteiten binnen de samenleving kan bij slachtoffers onder andere leiden tot een verminderde aangiftebereidheid (Conaway \& Lohr 1994; Wemmers \& Winkel 1997) en zelfs tot normovertredend gedrag (Wemmers 1996; Ter Voert 1997). Een effectieve bestrijding van de criminaliteit wordt op die manier ondergraven. Kortom, het gebruik van rechtvaardige procedures is een belangrijk element voor een effectieve uitoefening van gelegitimeerd gezag.

Het belang van het gebruik van rechtvaardige procedures geldt met name voor de direct betrokken procesdeelnemers, zoals partijen in een civiel geding en verdachten in een strafprocedure. Eisen van een rechtvaardige procedure gelden echter óók voor bijvoorbeeld getuigen die een verklaring moeten afleggen bij de rechter-commissaris of ter zitting (Van der Leij 2002, 2003). Maar niet alleen procesdeelnemers, ook belangstellenden die op een publieke tribune zitten of een proces volgen via de media trekken hun conclusies over de rechtvaardigheid van procedures en baseren hun oordeel over autoriteiten en rechtsregels hierop (Aubert 1971; Röhl \& Machura 1997; Malsch 2003c). Dus ook voor anderen dan de directbetrokkenen is het van belang dat procedures rechtvaardig zijn: dit vergroot de legitimiteit van de wet en de autoriteiten die deze toepassen, en de effectiviteit van het juridische systeem wordt er indirect door beïnvloed.

Naast de verschillende groepen theorieën die hierboven zijn besproken en die zich richten op enerzijds de instrumentele functie van een rechtvaardige procedure en anderzijds de rol die procedures kunnen hebben om groepswaarden tot uitdrukking te brengen, is er ook een theorie die sterk de nadruk legt op het expressieve aspect van deelname in procedures. De Expressive Theory stelt dat procedures niet alleen dienen om een verdeling tot stand te brengen tussen de partijen, maar eveneens om participatie en het zelf kunnen presenteren van argumenten mogelijk te maken (Röhl 1997). Deze theorie, die de zelfexpressieve waarde van procescontrole centraal stelt, poneert dat het participeren in een procedure en het naar voren brengen van het eigen standpunt tegenover een rechter op zichzelf al tot tevredenheid van procesdeelnemers kunnen leiden. Het onthouden van deze mogelijkheid aan procesdeelnemers wordt door velen van hen als een straf ervaren. Onderzoek heeft uitgemaakt dat de mogelijkheid om de eigen mening en argumenten naar voren te kunnen brengen en de gelegenheid die een partij krijgt om de eigen kant van het verhaal te vertellen, zeer belangrijke factoren zijn bij het oordeel over de rechtvaardigheid van procedures (Tyler \& 
Lind 1992). Het belang hiervan staat zelfs los van de gelegenheid die deze vorm van participatie biedt om de uitkomst te beïnvloeden. Voice, dus de expressie van de eigen argumenten en standpunten, heeft derhalve een zelfstandige waarde, los van de beslissingscontrole die het kan genereren. Het is zelfs niet ondenkbaar dat een verdachte die zonder proces wordt vrijgesproken toch ontevreden naar huis gaat, omdat hij niet zijn day in court heeft gehad - niet zijn zegje heeft kunnen doen ten overstaan van een rechter (voor een voorbeeld hiervan, zie Van Rossum 2003; Röhl 1997).

De theorie van procedurele rechtvaardigheid heeft verschillende factoren naar voren gebracht die van belang zijn gebleken voor oordelen over de rechtvaardigheid van procedures en die daarmee invloed hebben op acceptatie van beslissingen van autoriteiten en de naleving van rechtsnormen. Opvallend is hierbij dat er weinig demografische verschillen zijn gevonden tussen burgers in de mate waarin zij waarde hechten aan verschillende aspecten van procedurele rechtvaardigheid; opleiding, inkomen, woonplaats, leeftijd en geslacht maken niet veel uit voor dit oordeel. Hieronder zal op een drietal concepten uit de theorie van procedurele rechtvaardigheid, te weten participatie, informatieverschaffing en bejegening, nader worden ingegaan. Er zal daarbij ook aandacht worden geschonken aan de vraag in hoeverre in Nederlandse juridische procedures aan deze vereisten wordt voldaan.

\section{$5 \cdot 5$ PARTICIPATIE}

De term 'participatie' heeft in brede zin de betekenis van 'deelnemen'. Toegepast op strafrechtelijke procedures zijn veel vormen van deelname door procespartijen denkbaar, variërend van het - slechts - naar voren kunnen brengen van het eigen standpunt (voice) tot het deelnemen in de uiteindelijke beslissing in een zaak. In deze paragraaf wordt aandacht geschonken aan de participatie van verschillende typen niet-professionele procesdeelnemers, onder wie verdachten, getuigen en slachtoffers in het strafproces. Deze participatie kan in verschillende fasen van het strafproces plaatsvinden: tijdens de aanhouding door de politie, bij de verhoren door verschillende functionarissen, op de zitting en tijdens de tenuitvoerlegging van de sanctie. Ook wordt kort ingegaan op de participatie van leken in het beslissingsproces van rechters: de inzet van lekenrechters en van rechter-plaatsvervangers.

\section{Procescontrole door verdachten}

Procescontrole is van belang voor oordelen over de rechtvaardigheid van procedures. Procesdeelnemers, onder wie verdachten, die zelf hun argumenten naar voren kunnen brengen en een duidelijke inbreng hebben in het proces accepteren de uitkomst beter, zo is hierboven bij de bespreking van de theorie van procedurele rechtvaardigheid reeds betoogd. Om hun argumenten naar voren te kunnen brengen moet hun daartoe de gelegenheid worden geboden door de autoriteiten die de beslissing nemen in een zaak. Het blijkt dat accusatoire procesvormen die 
gelegenheid beter bieden dan inquisitoire procesvormen, zoals die te vinden zijn in bijvoorbeeld het Nederlandse strafproces. Hieronder wordt besproken welke kenmerken van de Nederlandse strafprocedure participatie mogelijk maken of juist bemoeilijken.

De Nederlandse procescultuur in strafzaken heeft een aantal geheel eigen kenmerken: snel (althans wat de zittingen betreft), redelijk efficiënt en informeel, en met een grote nadruk op het vooronderzoek. De wortels van deze procescultuur liggen in de ontstaansgeschiedenis ervan; de gevolgen van deze procescultuur zijn in de dagelijkse rechtspraktijk te vinden (Malsch \& Nijboer 1999). In ons type strafproces wordt het meeste onderzoek in een zaak vóór de zitting verricht. De rechter krijgt een lijvig dossier en beperkt zich meestal tot een toetsing van alle processen-verbaal die daarin zitten in samenspraak met de verdachte zonder zelf actief bewijs te verzamelen. In Nederland kan een zaak waarin een moord ten laste is gelegd die weinig publiciteit heeft gegenereerd, in twee uur worden 'afgedaan'. Dit is in de meeste andere landen ondenkbaar. De geringe tijd die in Nederland voor elke zaak wordt uitgetrokken betekent dat er relatief ook minder tijd is voor de 'partijen' om hun standpunten op de zitting naar voren te brengen.

Getuigen worden in Nederlandse strafzaken meestal in de fase vóór de zitting gehoord en ook deskundigen worden meestal in die fase al geraadpleegd. De processen-verbaal van verhoor en de deskundigenrapporten maken deel uit van het dossier en de getuigen en deskundigen worden meestal niet ter zitting opgeroepen. De verdediging heeft verschillende mogelijkheden om getuigen in te schakelen en rapportage door deskundigen te verzoeken, maar deze verzoeken zijn altijd afhankelijk van de toestemming van de officier van justitie, rechter-commissaris of zittingsrechter (Hielkema 1996). Advocaten zijn in Nederland niet erg actief in het zelf inschakelen van deskundigen. Zij zijn wel actiever in het oproepen of doen oproepen van getuigen, maar hun verzoeken daartoe aan de officier van justitie of de rechter worden lang niet altijd ingewilligd. Ook op het gebied van de betaling van expertise is de positie van het Openbaar Ministerie en de verdediging niet gelijk: vergoeding van kosten van deskundigen die worden opgeroepen door de advocaten is niet in alle gevallen eenvoudig te verkrijgen, omdat de verdediging moet aantonen dat het deskundigenoordeel noodzakelijk is, terwijl de officier van justitie dit niet hoeft. Het Nederlandse strafproces laat dus een vrij geringe mate van procescontrole zien voor de verdediging, zeker in vergelijking met veel landen met een accusatoire procesvorm waar voor de verdediging meer mogelijkheden bestaan om getuigen op de zitting te horen en deskundigenbewijs te verzamelen en te presenteren (Van Koppen \& Penrod 2003).

\section{Getuigen en slachtoffers}

Niet alleen verdachten hebben behoefte aan inbreng in het proces, ook getuigen willen een verdergaande vorm van 'participatie' dan alleen het afleggen van een verklaring. Onderzoek onder getuigen heeft laten zien dat zij het van belang vinden om, als zij worden opgeroepen om een verklaring af te leggen, vragen aan de verhorende autoriteit te kunnen stellen en hun wensen kenbaar te kunnen 
maken. Getuigen vinden het niet erg belangrijk om invloed te hebben op de uiteindelijke beslissing in de strafzaak. Zij zijn, met andere woorden, niet gericht op invloed op de uitkomst van de strafzaak, maar zij zijn wel gericht op de mogelijkheid om vragen te stellen en wensen te uiten. Het Nederlandse strafproces geeft hun daar weinig mogelijkheden toe (Van der Leij 2002, 2003).

Getuigen die slachtoffer zijn willen vaak niet op de zitting een verklaring afleggen, omdat hen dit weer in directe confrontatie brengt met de verdachte. Er zijn echter getuigen die dit juist wél wensen, en hiervoor is inmiddels aandacht gekomen vanuit de wetgever en vanuit initiatieven in het land. Deze initiatieven bieden het slachtoffer de gelegenheid om te spreken op een zitting over de gevolgen die het strafbare feit voor hem of haar heeft gehad. Er is veel discussie ontstaan over deze vorm van inbreng van een niet-professionele procesdeelnemer in een strafzaak. Er zitten veel haken en ogen aan het voorstel en de ervaringen in het buitenland hebben laten zien dat Victim Impact Statements (vis: zo worden slachtofferverklaringen in het Engels genoemd) geen of slechts een minimale invloed hebben op het oordeel van de rechter. Ook de tevredenheid van slachtoffers over het proces lijkt er niet substantieel door te worden beïnvloed. De eerste bevinding, dat uitspraken van rechters niet veranderen als er een slachtofferverklaring in het dossier zit, neemt een van de bezwaren tegen slachtofferverklaringen weg, te weten dat het vonnis door een factor zou gaan worden bepaald die een grote 'toevalligheidswaarde' heeft, namelijk kenmerken en reacties van slachtoffers (De Keijser \& Malsch 2002; Kool \& Moerings 2003). Andere bezwaren tegen het spreekrecht, zoals bijvoorbeeld het risico van secundaire victimisatie (negatieve gevolgen van hernieuwde confrontatie met het misdrijf), blijven echter bestaan. Desalniettemin vormt het voorgestelde spreekrecht een methode om participatie van een niet-professionele procesdeelnemer te bevorderen. Door velen is echter een voorkeur geuit om de slachtofferverklaringen in een schriftelijke vorm toe te laten en niet in een mondelinge, zoals in het wetsontwerp is voorgesteld (Kool \& Moerings 2001; De Keijser \& Malsch 2002). Deze schriftelijke vorm verdient sterke aanbeveling.

\section{Inbreng van leken in de rechtspraak}

Men kan mogelijkheden tot participatie ook op een wat hoger niveau dan dat van de individuele zaken beschouwen: in hoeverre hebben leken inbreng in de strafrechtspraak door rechters? Het blijkt dat het Nederlandse strafproces op dit niveau evenmin veel inbreng van leken toelaat (Malsch 2003d). Het Nederlandse strafrechtssysteem kent een zeer sterke professionele cultuur. Nederlandse rechters worden benoemd voor het leven en kunnen niet worden ontslagen op grond van de inhoud van de beslissingen die zij nemen. Invloed van gewone burgers op de benoeming van rechters is afwezig. Rechters zijn, met een klein aantal uitzonderingen, juristen. Nederland kent bovendien geen jury's, al hebben deze in de negentiende eeuw wel een aantal jaren gefunctioneerd. Er wordt in Nederland slechts zeer bescheiden gebruikgemaakt van lekenrechters. De lekenrechtspraak heeft in Nederland bovendien voornamelijk betrekking op de deelname van deskundige leken, en wel aan bijzondere vormen van rechtspleging. Deze vorm 
van lekenrechtspraak is bijvoorbeeld te vinden in de pachtkamers, de militaire strafkamers, de penitentiaire kamer van het hof Arnhem en voorheen de Raden van Beroep voor de Sociale Verzekeringen. Het gaat hier steeds om bijzondere vormen van rechtspleging (Bovend'Eert 2002; Roos, 2002; Malsch 2003d). De 'leken' die hier een bijdrage leveren aan de rechtspraak zijn allen benoemd met het oog op hun deskundige, maar niet-juridische inbreng in deze procedures. Daarnaast kent Nederland het systeem van de rechter-plaatsvervanger. Rechterplaatsvervangers, die in gewone zaken rechtspreken, zijn echter allen juristen. Met rechtspraak door leken heeft de inzet van lekenrechters en van rechterplaatsvervangers weinig te maken. 'Echte' leken, en daarmee wordt gedoeld op personen die geen academische achtergrond hebben, zijn afwezig in de Nederlandse rechtspraak. En het ziet er, gezien het sterk professionele karakter van de Nederlandse rechtspraak, ook niet naar uit dat zij snel zullen terugkeren als rechter of als lid van een jury (Malsch 2003d).

De afwezigheid van een volwaardige mogelijkheid tot participatie in de rechtspraak betekent dat leken weinig mogelijkheden hebben om invloed op rechterlijke beslissingen uit te oefenen en deze te controleren. Dit kan de ervaren afstand tot de rechterlijke macht vergroten en daarmee de bereidheid verkleinen om rechterlijke beslissingen en rechtsnormen na te leven. Er zijn echter verschillende maatregelen denkbaar om de afstand tussen rechters en burgers te verkleinen zonder dat over moet worden gegaan tot lekenrechtspraak, zoals bijvoorbeeld een grotere openbaarheid van de strafrechtspleging, meer uitleg en een betere motivering van beslissingen en maatregelen die de toegankelijkheid van de rechtspraak vergroten (Malsch et al. 2003). Deze maatregelen leiden ertoe dat er meer communicatie totstandkomt tussen de juridische professionals en de rechtsgenoten. Een goede communicatie lijkt immers steeds meer een essentiële voorwaarde te worden voor het behoud van legitimiteit en vertrouwen in het rechtssysteem, welke in sterk verband staan met de naleving van rechtsnormen (WRR 2002; Hertogh 2003).

\section{De participatie in andere vormen van afdoeningen}

De reguliere strafrechtsprocedure biedt dus relatief weinig mogelijkheden tot participatie van procesdeelnemers en leken-belangstellenden. Naast of in plaats van deze reguliere afdoening zijn in de loop der jaren echter procedures ontstaan waarin strafbare feiten op een andere wijze worden afgedaan. Procedures die vaak als alternatief voor een 'volle' (strafrechtelijke of civielrechtelijke) procedure gelden en waarbij partijen gezamenlijk tot een oplossing van hun geschil komen, bieden diverse mogelijkheden waarbij de inbreng van procesdeelnemers veel groter is dan in reguliere afdoeningen. Hierbij kan worden gedacht aan procedures als mediation, dading, maar ook de buitengerechtelijke afdoeningen door politie en Openbaar Ministerie zoals transacties, HALT-afdoeningen of het regelen van een schadevergoeding door een schadebemiddelaar tussen verdachte en slachtoffer (Malsch \& Carrière 1996; Cleiren 2001; Hildebrandt 2003). Zowel het consensuele element als de participatie van procesdeelnemers is bij dit type procedures veel groter dan bij de reguliere strafrechtelijke afdoeningen door de 
rechter; de verdachte komt bijvoorbeeld met het slachtoffer of met de officier van justitie overeen om een schadevergoeding of een schikking te betalen, waarmee de zaak is afgedaan. De openbaarheid van zitting en uitspraak, de onafhankelijkheid van de beslisser, het onschuldbeginsel en andere aspecten van het fair trialprincipe zijn echter grotendeels afwezig in deze procedures. Aan het 'procesbeginsel' wordt meestal niet voldaan (Hildebrandt 2003).

Tot slot kan worden gewezen op de ontwikkelingen van restorative justice, waarbij verzoening tussen dader en slachtoffer centraal staat en niet primair of uitsluitend de vergoeding van schade, al zal dat in veel gevallen wel gebeuren. 'Herstelrecht', zoals restorative justice in Nederland ook wel wordt genoemd, vindt met name plaats in bijeenkomsten waarbij de verdachte en zijn familie of andere naasten, en het slachtoffer met familie of andere naasten het feit, de gevolgen van het strafbare feit en een mogelijke afdoening bespreken. De oorsprong van dit type recht is te vinden in landen met een belangrijke aboriginal bevolkingsgroep, zoals Australië, Nieuw-Zeeland, Canada en de Verenigde Staten (Malsch 2000; Leest 2001). In Nederland wordt aan de beweging voor herstelrecht onder meer vorm gegeven door de zogenoemde 'Echt Recht'-conferenties. Op een aantal plaatsen in Nederland worden experimenten met herstelrecht uitgevoerd. Er is inmiddels ook een tijdschrift met de naam Herstelrecht. Over het algemeen zijn de schrijvers van mening dat nog niet van een paradigmawisseling binnen het Nederlandse strafrecht kan worden gesproken, daarvoor bevinden deze 'nieuwe' vormen van afdoening zich (nog) te veel in de marginaliteit (Groenhuijsen 2002). Wel geven de initiatieven diverse mogelijkheden voor participatie van nietprofessionele procesdeelnemers in de procedure en de besluitvorming over zaken die veel verder gaan dan in een 'reguliere' strafprocedure mogelijk is. De tevredenheid over de procedures en de nakoming ervan liggen ook veel hoger (Malsch \& Carrière 1996).

\subsection{INFORMATIEVERSCHAFFING}

Informatieverschaffing over procedures en beslissingen kan op vele momenten en door verschillende functionarissen in een proces plaatsvinden: door politie, officieren van justitie en (zittings)rechters en andere functionarissen, over de gang van zaken tijdens het onderzoek en op een zitting, maar ook over de uitkomsten van processen. Over het algemeen zijn niet-professionele procesdeelnemers, zoals verdachten, getuigen en partijen in een civiel geschil, geïnteresseerd in het verloop van een proces en verwachten zij informatie daarover van de professionele procesdeelnemers. Ook buitenstaanders zijn vaak geïnteresseerd in hoe het rechtssysteem werkt en welke beslissingen het produceert. De wijze waarop het systeem zichzelf naar buiten presenteert is hierbij van groot belang, evenals de bereidheid van de juridische professionals om de beschikbare informatie te verspreiden. En ten slotte heeft algemene, feitelijke informatie over welke zaken worden berecht en welke straffen worden opgelegd, zoals hieronder zal worden betoogd, invloed op de opinies van gewone burgers over het strafrechtssysteem. 
Wemmers (1996) vond in haar onderzoek dat slachtoffers die als benadeelde partij zijn betrokken in een strafprocedure, graag geïnformeerd willen worden over de voortgang van de procedure. Ook achtten haar respondenten het van belang om vragen te kunnen stellen en om wensen te kunnen uiten. Het Openbaar Ministerie en de politie bleken in Wemmers' onderzoek de slachtoffers niet altijd voldoende op de hoogte te houden van de voortgang van hun zaken. Dit leidde vaak tot ontevredenheid over politie en justitie bij de slachtoffers. Van der Leij (2002) constateerde dat getuigen het van belang vinden om vragen te kunnen stellen en daarmee informatie te verkrijgen over de procedure. De mogelijkheden die hun hiervoor door de verhorende instanties werden verschaft, waren van invloed op de tevredenheid over de procedures. Helaas moest Van der Leij constateren dat zowel rechters-commissarissen als zittingsrechters onvoldoende gelegenheid boden aan getuigen om vragen te stellen en wensen te uiten.

Onderzoek van de Britse Home Office (Chapman et al. 2002) vond dat, als aan burgers feitelijke en eenvoudig te begrijpen informatie wordt verschaft over aantallen misdrijven die worden gepleegd en de straffen die worden opgelegd, hun attitudes ten opzichte van en het vertrouwen in het strafrechtssysteem in positieve zin veranderen. Dit onderzoek richtte zich niet op de directbetrokkenen in het strafrecht, zoals slachtoffers en getuigen, maar had het algemene publiek als doelgroep. Aan 1022 burgers werd een vragenlijst voorgelegd over hun kennis van criminaliteit, straffen en het strafrechtelijk systeem. Na invulling werd hun informatie verstrekt over het Britse strafrechtssysteem en de straffen die worden opgelegd, door middel van een boekje, een seminar of een video. De informatie ging onder meer over het feit dat bepaalde delicten tegenwoordig minder vaak worden gepleegd dan vroeger, maar ook over de straffen die worden opgelegd en hoe het strafrechtelijke systeem werkt. Ook werden gegevens verschaft over de kans om slachtoffer te worden: dat die kans groter is voor jonge mannen dan voor oudere mensen, terwijl de laatsten juist de meeste angst hebben voor criminaliteit. Alle drie vormen van informatie verstrekten eenvoudig toegankelijke kennis aan de respondenten. Noodzakelijkerwijze was de informatie enigszins simpel gehouden en ontdaan van ingewikkeldheden die het strafrechtelijke systeem omgeven.

De kennis over criminaliteit, straffen en het strafrechtelijke systeem van de respondenten bleek voorafgaand aan het experiment over het algemeen erg mager te zijn. Zij die ooit in contact waren geweest met het strafrechtssysteem scoorden iets beter dan diegenen die nooit in een zaak betrokken waren geweest, maar gemiddeld was de kennis minimaal te noemen.

Enige tijd nadat zij deze informatie hadden gekregen, werden de respondenten opnieuw geïnterviewd om vast te stellen of hun kennis en hun attitudes zich hadden gewijzigd (Chapman et al. 2002). Nadat zij de informatie hadden gekregen, bleken de respondenten inderdaad meer vragen goed te beantwoorden dan daarvoor, en deze stijging was het grootst bij hen die van tevoren het minst wisten. Opvallend was dat beter geïnformeerde mensen een hogere waardering 
bleken te hebben voor het strafrechtssysteem. Het bezoeken van het seminar leidde tot de grootste verandering in attitudes, gevolgd door het lezen van het boekje. Het zien van de video leidde tot de minst sterke wijziging van attitudes. Van de video werd gevonden dat deze een enigszins vertekend beeld van criminaliteit en straffen gaf; dit was minder of nauwelijks het geval bij het boekje en het bijwonen van het seminar.

Een kwart van de respondenten bleek na het ontvangen van de informatie een minder punitieve attitude te hebben ontwikkeld. Een groot deel van de respondenten wijzigde hun mening in die zin dat zij de hoogte van de straffen die worden opgelegd meer onderschreven; zij vonden minder vaak dat er te laag wordt gestraft. Ook het vertrouwen in het strafrechtssysteem steeg als gevolg van de ontvangen informatie. Het percentage respondenten die zeiden er vertrouwen in te hebben dat het strafrechtssysteem de mensen die strafbare feiten plegen ook inderdaad berecht, steeg van 38 naar 6o. De mening van de respondenten over het doel van straffen veranderde niet sterk als gevolg van de informatie die werd verspreid. De angst om zelf slachtoffer te worden nam echter af. De Home Office concludeerde uit dit onderzoek dat het verschaffen van informatie positieve effecten heeft op de angst voor criminaliteit, op de percepties van opgelegde straffen en op het vertrouwen in het strafrechtssysteem. Degenen met de meest extreme attitudes bleken het meest bereid tot wijziging ervan. Overigens maken de onderzoekers zelf het voorbehoud dat niet slechts het verschaffen van feitelijke informatie de deelnemers bracht tot het veranderen van hun attitudes. Het gehele proces van benaderen van personen, het uitnodigen om deel te nemen aan het onderzoek, het ontvangen van een boekje of video of het mogen bijwonen van een seminar, leidt waarschijnlijk tot positievere attitudes ten opzichte van politie, justitie en de rechterlijke macht, en niet slechts de ontvangen informatie. Ook het feit dat de respondenten werden betaald voor hun deelname kan een belangrijke rol hebben gespeeld. De effecten van informatieverschaffing vermengen zich hier dus waarschijnlijk met de effecten van een positieve bejegening.

Cognitieve aspecten en de relatie met het oordeel over het strafrechtelijk systeem zijn eveneens onderzocht door Hough en Roberts (1999). Zij vonden dat gebrekkige kennis over criminaliteit en straf samengaat met een negatief oordeel over straffen en rechters. Bovendien gaat een geringe kennis vaak gepaard gaat met het oordeel dat er te licht wordt gestraft en met een laag niveau van vertrouwen in het systeem. Eenzelfde soort effect werd gevonden door Mattison \& MirrleesBlack (2000) in het jeugdrecht. Mirrlees-Black (2001) constateerde dat er een verband is tussen onjuiste percepties van het strafrechtssysteem en de straffen die worden opgelegd enerzijds en een gering vertrouwen in het strafrechtssysteem anderzijds.

Ook de Nederlandse rechterlijke macht wordt zich steeds meer bewust van het belang van informatieverschaffing. Er worden websites opengesteld met informatie over de gang van zaken binnen gerechten. Op deze websites wordt een deel 
van de jurisprudentie gepubliceerd. Verschillende gerechten hebben voorlichtingsfunctionarissen aangesteld. Steeds meer mensen zijn overtuigd van het belang van een goede motivering van rechterlijke uitspraken (Huls 200o) en de begrijpelijkheid van uitspraken (Nolta 1997; Ensink \& Nolta 1998; Tak 2002). Gezien het hierboven aangehaalde Engelse onderzoek lijkt immers overdracht van feitelijke kennis over criminaliteit en de werking van het strafrechtssysteem van essentieel belang te zijn voor het vertrouwen in het systeem en de legitimiteit ervan. En deze zijn op hun beurt, zoals uit de bespreking hierboven van de literatuur over procedurele rechtvaardigheid bleek, uitermate relevant voor acceptatie en naleving van wetten en rechterlijke uitspraken.

\subsection{BEJEGENING}

Het aspect van een correcte bejegening van procesdeelnemers heeft binnen de literatuur over procedurele rechtvaardigheid een centrale plaats gekregen. Procedures waarbinnen de deelnemers met respect worden bejegend door een onpartijdige en onafhankelijke rechter leiden tot een grotere tevredenheid. Bovendien werken procesdeelnemers dan beter mee en zijn zij ook ten opzichte van andere autoriteiten coöperatiever dan in het geval dat zij onheus worden bejegend

(Wemmers 1996). De vriendelijkheid van de rechterlijke autoriteiten is in dit verband ook van belang. Van der Leij (2002) vond in zijn onderzoek onder getuigen een correlatie tussen de vriendelijkheid van de rechter en de bereidheid om in toekomstige procedures opnieuw mee te werken. Deze bevinding is met name zo belangrijk omdat het strafrechtssysteem voor een zeer belangrijk deel afhankelijk is van de aangiften en de medewerking van slachtoffers en omstanders; zonder dat zou veel criminaliteit nooit aan het licht komen, laat staan dat zaken zouden kunnen worden 'opgelost' of door een rechter zouden kunnen worden berecht. En hoe minder zaken in het strafrechtelijk systeem ter hand worden genomen, hoe groter de kans dat burgers het recht in eigen hand nemen, uitmondend in eigenrichting.

De Amerikaanse onderzoeker Sherman, die veel onderzoek heeft gedaan naar de legitimiteit van het strafrechtssysteem en de bejegening van procesdeelnemers, constateerde dat verdachten en daders van strafbare feiten sterk beïnvloed worden door de wijze waarop politie, justitie en de rechterlijke macht optreden. Als de politie tijd nam om naar zowel verdachte als slachtoffer te luisteren, als de verdachte niet met geweld werd aangehouden en geen handboeien omkreeg, bleek dat slechts 25 procent van hen recidiveerde. Dit percentage was 40 bij diegenen die op minder respectvolle wijze werden aangehouden (Sherman 2002). Shermans algemene bevinding is dat een rechtvaardige behandeling van verdachten en partijen een groter vertrouwen in het strafrechtssysteem teweegbrengt en een terugval in criminaliteit grotendeels voorkomt. Ook Tyler (1990) constateerde dat diegenen die van mening waren dat zij niet rechtvaardig waren behandeld, zich minder verplicht voelden om de wet na te leven. Niet alleen in het strafrecht is er een relatie tussen een correcte en respectvolle behandeling, in 
bijvoorbeeld het belastingrecht of binnen de gezondheidszorg valt deze relatie eveneens te constateren. Makkai \& Braithwaite (1994) geven het voorbeeld van inspecteurs voor de volksgezondheid die verpleeghuizen bezoeken. Daar waar zij zonder enig respect aan verpleegkundigen kenbaar maakten dat zij regels hadden overtreden, leidde dit tot een geringere bereidheid bij de verpleegkundigen om in de toekomst richtlijnen na te leven dan in het geval dat de inspecteurs hun ongenoegen op een wat respectvollere wijze lieten blijken.

Braithwaite suggereert in zijn standaardwerk Crime, shame and reintegration (1989) dat de schaamte die mensen voelen op het moment dat zij worden betrapt op foutief gedrag, in sommige gevallen kan leiden tot hernieuwd foutief gedrag, maar in andere gevallen een verbetering van gedrag tot gevolg heeft. Tot welke van deze twee uitkomsten schaamte leidt, hangt sterk af van de reacties van de omgeving, inclusief die van politie, justitie en de rechterlijke macht. Bejegening speelt dus een centrale rol bij de vraag welk effect schaamte heeft voor toekomstig gedrag. Als de persoon van de dader in zijn geheel wordt afgewezen en niet slechts zijn daad, treedt uitsluiting op. Uiteindelijk kan de dader hierdoor in een vicieuze cirkel belanden. Buitensluiting werkt als een self-fulfilling prophecy: omdat de dader zich uitgestoten voelt, zijn er ook weinig remmen om hem van slecht gedrag af te houden. Vaak zullen daders in zo'n situatie dan ook contact zoeken met andere groepen waar zij zich wel door geaccepteerd voelen en het ligt voor de hand dat dit criminele groeperingen zijn. Bij integratie richt de afkeuring zich daarentegen niet op de persoon in zijn geheel, maar wordt alleen de daad afgekeurd. Tegelijkertijd wordt getracht om de dader niet een stigma op te plakken en hem zijn werk, huis en gezin te laten behouden, om verder afglijden te voorkomen. Het effect van bejegening en de schaamte die daardoor bij verdachten wordt teweeggebracht, is dus van groot belang voor het toekomstig gedrag. De conclusie die Braithwaite en anderen verbinden aan de hier beschreven effecten van schaamte is dat het van belang is om de dader geïntegreerd te houden in de maatschappij en buitensluiting te voorkomen. 'Sancties' als dader-slachtofferbemiddeling, taakstraffen die de dader binnen de maatschappij houden, schadevergoeding en verzoening verdienen vanuit die optiek dan ook de voorkeur. Het spreekt voor zich dat die voorkeur bij veel delicten niet of moeilijk kan worden verwezenlijkt. Dit neemt niet weg dat een faire oplegging en uitvoering van straf, evenals een respectvolle bejegening en behandeling in detentie door de justitiële autoriteiten, van essentieel belang zijn voor het gedrag van de veroordeelde na het uitzitten van de straf.

Sherman (1993) concludeert dat de perceptie van fairness van straffen van groot belang is voor het toekomstig gedrag van veroordeelden. Een respectvolle bejegening en behandeling tijdens de straf kan ertoe bijdragen dat aan de dader schaamte over het feit toelaat, hetgeen een essentiële voorwaarde is voor inzicht in en het nemen van verantwoordelijkheid voor het misdrijf (Sherman 1993; Kelk 1994; Janssen 2003). Een niet-rechtvaardige behandeling in detentie kan tot verzet tegen autoriteiten leiden, maar ook tot geweld en verzet tegen anderen in de situatie dat de oorspronkelijke ongenoegens niet tegen autoriteiten kunnen 
worden geuit (Sherman 1993). Het risico bestaat dan dat de neutraliseringstechnieken die door Sykes en Matza (1957) zijn beschreven en die in de inleiding kort zijn genoemd, hun werk de gehele gang door het strafproces blijven doen.

Schaamte is volgens de hier genoemde auteurs essentieel voor het voorkómen van recidive, en dit proces van zich schamen wordt tegengegaan door verzet en de neutraliseringstechnieken.

Ook in het civiele recht is er een relatie gevonden tussen een rechtvaardig proces en een correcte bejegening enerzijds en de nakoming van de rechterlijke beslissing anderzijds. In verschillende typen civiele gedingen is in Amerikaans onderzoek gevonden dat, als partijen het proces fair vonden, ze meer bereid waren om de uitspraak uit te voeren, ook als zij hadden verloren (zie voor een overzicht: Paternoster et al. 1997). Nakoming van civielrechtelijke uitspraken is, evenmin vanzelfsprekend als de nakoming van strafrechtelijke uitspraken en rechtsnormen. Nederlands onderzoek toonde aan dat de in een civiel geding toegewezen eis in meer dan de helft van de zaken na drie jaar nog niet door de gedaagde was voldaan (Van Koppen \& Malsch 1992). Aspecten van procedurele rechtvaardigheid zijn derhalve ook in het civiele recht van belang voor de naleving van de rechterlijke uitspraak. Het is waarschijnlijk dat ook binnen het bestuursrecht dergelijke effecten optreden.

\subsection{CONCLUSIES EN AANBEVELINGEN}

Legitimiteit en vertrouwen in de overheid en in de rechterlijke macht zijn heden ten dage niet meer vanzelfsprekend. Voor de naleving van rechtsnormen kan er niet meer op worden vertrouwd dat zij zijn geïnternaliseerd en uit dien hoofde als vanzelfsprekend worden nageleefd. Onze hedendaagse maatschappij wordt daarvoor te veel gekenmerkt door individualisering, door heterogeniteit van de bevolking en door de verleidingen van alledag die uitnodigen tot bepaalde vormen van criminaliteit. Aan de andere kant is het ook niet wenselijk om een waterdicht systeem van rechtshandhaving te ontwerpen waarbij elke normoverschrijdende gedraging direct kan worden waargenomen en berecht: dit zou leiden naar een politiestaat. Daarom zijn er methoden nodig om vrijwillige medewerking van burgers aan rechtsnormen te verkrijgen, ook als niet duidelijk is of iedereen op elk moment elke rechtsnorm onderschrijft.

De literatuur over procedurele rechtvaardigheid beschrijft essentiële kenmerken van procedures die leiden tot tevredenheid van de deelnemers. Procedures worden binnen groepen gehanteerd om conflicten op te lossen, maar ook om gemeenschappelijke waarden in tot uitdrukking te brengen. Dit kunnen 'procedures' zijn die door de politie worden gehanteerd om conflicten op straat op te lossen, maar ook verhoorprocedures of de procedures die de rechter hanteert. Het in deze bijdrage besproken onderzoek heeft laten zien dat rechtvaardige procedures niet alleen tot tevredenheid bij de deelnemers leiden, maar ook de acceptatie en de naleving van beslissingen bevorderen. Het is zelfs zo dat de algemene 
houding ten opzichte van autoriteiten door rechtvaardige procedures in positieve zin wordt beïnvloed.

Vanzelfsprekend vormt een rechtvaardige procedure slechts een van de factoren waarop burgers hun acceptatie van autoriteiten en de naleving van rechtsnormen baseren; er zijn in de criminologie talloze factoren beschreven die van invloed zijn op regelovertredend gedrag. Toch biedt het onderzoek naar procedurele rechtvaardigheid belangrijke aanknopingspunten voor een verbetering van de verhouding tussen autoriteiten en burgers die van belang zijn voor zowel de rechtspraktijk als voor andere maatschappelijke segmenten waarbij de overheid in contact staat met burgers.

Het eerste aspect van de theorie van procedurele rechtvaardigheid dat van belang is voor tevredenheid en naleving van normen, kan worden samengevat onder het begrip participatie. Procesdeelnemers willen vaak graag hun argumenten naar voren kunnen brengen op een zitting ten overstaan van een rechter. $\mathrm{Zij}$ willen vragen kunnen stellen en wensen kunnen uiten. Dit is de vorm van participatie die zij het belangrijkste vinden. Daarnaast stellen zij het ook op prijs om zelf bewijs naar voren te kunnen brengen en om hun eigen advocaat te kunnen kiezen. Het in deze bijdrage besproken onderzoek heeft dan ook laten zien dat accusatoire procesvormen, waarin participatiemogelijkheden in ruimere mate aan de verdediging zijn toegekend, hoger worden gewaardeerd dan inquisitoire procesvormen, zoals het Nederlandse strafproces tot op zekere hoogte kan worden gekarakteriseerd. Dit leidt tot de volgende aanbevelingen.

- Zorg voor voldoende gelegenheid tijdens de opsporingsfase, in de fase van de vervolging en tijdens het onderzoek ter terechtzitting, voor procesdeelnemers om argumenten naar voren te brengen, vragen te stellen en wensen te uiten.

- Geef slachtoffers de mogelijkheid om een schriftelijke slachtofferverklaring op te stellen die in het dossier wordt gevoegd.

- Doe onderzoek naar de participatie van lekenrechters in de noordse staten en in Duitsland en de toepasbaarheid hiervan in het Nederlandse rechtssysteem.

\section{Toelichting}

Vanzelfsprekend kan niet iedere niet-professionele procesdeelnemer evenveel 'recht' doen gelden op deze vormen van participatie. Een getuige mag niet tijdens het verhoor zijn of haar mening naar voren brengen, maar moet verklaren over wat hij of zij heeft waargenomen en ondervonden. Er is niet altijd voldoende tijd om iedere procesdeelnemer gelegenheid tot spreken te geven. Toch geven nieuwe, individuele initiatieven binnen de rechtszaal om wél de getuige te laten vertellen wat de gevolgen van een strafbaar feit zijn geweest, aan dat rechters het belang van deze vorm van voice inzien en vinden dat dit mogelijk moet zijn.

In de tweede plaats blijkt informatieverschaffing van invloed te zijn op legitimiteit van en tevredenheid over juridische professionals. Als procesdeelnemers 
naar behoren worden geïnformeerd over een procedure waarin zij zijn betrokken, zijn zij meer tevreden over hun behandeling dan als zij niet of gebrekkig worden geïnformeerd. Tevredenheid over procedures leidt vaak tot een grotere naleving van normen. Gewone burgers zijn vaak zeer wel in staat om juridische onderscheidingen te vatten, als hun deze maar worden uitgelegd (Finkel 1995).

Informatieverschaffing vervult echter ook een belangrijke rol voor het grote publiek. Dit is vaak eveneens geïnteresseerd in het verloop van procedures en de beslissingen die er vallen. In dit advies is gewezen op een onderzoek van de Britse Home Office waaruit blijkt dat, als aan burgers feitelijke informatie over de afdoening van zaken en de opgelegde straffen wordt verstrekt, zij hun attitude in positieve zin wijzigen ten opzichte van het strafrechtssysteem en straffen in het algemeen. Zij onderschrijven meer de straffen die worden opgelegd en vinden minder vaak dat er te laag wordt gestraft. Bovendien vergroot informatie hun vertrouwen in het strafrechtssysteem en reduceert het hun angst voor criminaliteit. Dit tekent het belang van goede, objectieve informatie die wordt verspreid onder de bevolking en waarop burgers hun mening kunnen baseren. Het verschil met berichtgeving door de media is dat de informatie die wordt verspreid een 'algemeen' karakter heeft en zich niet beperkt tot één of een aantal specifieke, in het oog springende zaken. Bovendien is in het onderzoek van de Home Office getracht om de informatie zo objectief en neutraal mogelijk te houden, iets wat in de berichtgeving door de media niet altijd het geval is. Deze bevinding leidt tot de volgende aanbevelingen.

- Organiseer seminars waarin feitelijke informatie wordt verschaft aan het publiek over de berechting van zaken en de straffen die worden opgelegd.

- Verstrek feitelijke informatie aan het publiek over de werking van het strafrechtssysteem en de straffen die worden opgelegd in de vorm van een boekje.

- Gerechten dienen zelf adequate informatie te verschaffen over de gang van zaken binnen gerechten.

- Rechterlijke beslissingen dienen adequaat en begrijpelijk te worden gemotiveerd.

- De op zittingen en in rechterlijke uitspraken gehanteerde taal dient begrijpelijk te zijn voor niet-juristen.

- Verspreid op grotere schaal dan nu gebeurt jurisprudentie in geanonimiseerde vorm via het internet en via andere media.

\section{Toelichting}

In het onderzoek van de Home Office werden de seminars en het boekje met informatie als de beste methoden van informatieverschaffing genoemd. Van de video werd gevonden dat deze een enigszins vertekend beeld gaf. Dit neemt niet weg dat in principe het verschaffen van informatie via een video ook nuttig kan zijn. 
Een derde aspect van procedurele rechtvaardigheid dat invloed blijkt te hebben op tevredenheid, acceptatie en naleving van normen is de bejegening van procesdeelnemers. Een correcte bejegening is van groot belang gebleken voor verschillende procesdeelnemers: verdachten die door de politie worden aangehouden, getuigen die door politie, rechters-commissarissen en zittingsrechters worden verhoord, verdachten die tijdens een openbare zitting worden berecht, veroordeelden die in de gevangenis te maken krijgen met gevangenispersoneel (Tyler \& Lind 1992; Sherman 1993; Wemmers 1996; Van der Leij 2002, 2003; Vruggink 2003; Janssen 2003). Procesdeelnemers willen met respect worden bejegend. Rechters die vriendelijk zijn en informeren naar hoe het met getuigen gaat, kunnen op grotere medewerking rekenen dan botte rechters (Wemmers 1996; Van der Leij 2002, 2003). Daarnaast is het van belang dat rechters (de schijn van) partijdigheid vermijden en de procesdeelnemers het gevoel geven dat zij gewaardeerde leden zijn van de maatschappij. De theorievorming over de rol van schaamte laat zien dat de benadering van verdachten in de rechtszaal schaamte met zich mee kan brengen en dat die schaamte twee richtingen kan uitwerken: een integrerende richting en een richting waarbij de verdachte zich buitengesloten voelt en zich daarom verzet en zich in de toekomst minder aan de regels houdt (Braithwaite 1989; Sherman 1993). De mate van integratie houdt vervolgens verband met het toekomstig gedrag van de veroordeelde (Braithwaite 1989; Sherman 1993) Deze bevindingen leiden tot de volgende aanbevelingen.

- Politiefunctionarissen, officieren van justitie en rechters dienen verdachten, getuigen en partijen bij de behandeling van zaken met respect te bejegenen.

- Politiefunctionarissen, officieren van justitie en rechters dienen in hun communicatie met verdachten, partijen en getuigen deze procesdeelnemers zo min mogelijk te 'isoleren': integratie van verdachten en veroordeelden na een proces en een eventuele straf is het meest geholpen met een correcte bejegening tijdens het proces en de straf.

- Personeel van penitentiaire inrichtingen dient verdachten en veroordeelden met respect te bejegenen en zo open mogelijk met hen te communiceren.

\subsection{TOT BESLUIT}

Het Nederlandse strafrechtssysteem wordt gekenmerkt door een grote mate van professionaliteit. Er is weinig inbreng van leken waardoor er weinig aansporing bestaat om het systeem begrijpelijk te houden voor de niet-jurist. Uitleg van beslissingen en communicatie met de rechtsgenoten krijgen nog weinig plaats binnen ons strafrecht. Hierdoor dreigt het systeem in te boeten aan legitimiteit en neemt het vertrouwen van de bevolking af, wat kan leiden tot een verminderde naleving van rechtsnormen. Een correcte bejegening en een adequate informatieverschaffing zijn van essentieel belang om vertrouwen en legitimiteit te waarborgen, maar zij vormen slechts een deel van het verhaal. Het andere deel van het verhaal wordt gevormd door participatiemogelijkheden voor de burger in het strafrecht, omdat er slechts dan enige zekerheid bestaat dat de afstand tot de professionals wordt gereduceerd. Die participatie dient als vanzelfsprekend plaats 
te vinden in de procedure (voice, kenbaar maken van wensen, vragen kunnen stellen); maar het is niet uitgesloten dat ook participatie in de beslissing moet worden gestimuleerd, in procedures zoals bemiddeling en dading. Als uiterste kunnen eventueel vormen van lekenrechtspraak verder worden uitgebouwd (Cleiren \& De Roos 2002). 


\section{LITERATUUR}

Aubert, V. (1952) Enkele sociale functies van wetgeving, in: B. Peper \& K. Schuyt, Proeven van rechtssociologie: uit het werk van Vilhelm Aubert (46-74), Rotterdam: SWU/UPR, 1971.

Bauman, Z. (1993) Postmodern ethics, Oxford: Blackwell.

Bol, M.W. (1995) Gedragsbeïnvloeding door strafrechtelijk ingrijpen, Arnhem: Gouda Quint.

Boutellier, H. (2002) De veiligheidsutopie. Hedendaags onbehagen en verlangen rond misdaad en straf, Den Haag: BJu.

Bovend'Eert, P.P.T. (2002) 'Burgers, democratie en rechtspraak', Nederlands Juristenblad, 34: 1700-1701.

Braithwaite, J. (1989) Crime, shame and reintegration, Cambridge: Cambridge University Press.

Brink, G. van den (2001) Geweld als uitdaging: de betekenis van agressief gedrag bij jongeren, Utrecht: NIZW.

Chapman, B., C. Mirrlees-Black \& C. Brawn (2002) Improving public attitudes to the criminal justice system: the impact of information, Londen: Home Office Research, Development and Statistics Directorate.

Cleiren, C.P.M. (2001) Geding buiten geding. Een confrontatie van het geding voor de strafrechter met strafrechtelijke ADR-vormen en mediation, Arnhem: Gouda Quint.

Cleiren, T., \& T. de Roos (2002) ‘Democratisering van het strafproces?’ blz. 171-188 in: K. Boonen, C.P.M. Cleiren, R. Foqué \& Th.A. de Roos (red.), De weging van 't Hart. Idealen, waarden en taken van het strafrecht, Deventer: Kluwer.

Conaway, M.R., \& S.L. Lohr (1994) 'A longitudinal analysis of factors associated with reporting violent crimes to the police', Journal of Quantitative Criminology, 1: 23-39.

Crombag, H.F.M., \& P.J. van Koppen (2002) 'Rechtvaardigheid', blz. 775-786 in: P.J. van Koppen, D.J. Hessing, H.L.G.J. Merckelbach, \& H.F.M. Crombag (red.), Het recht van binnen. Psychologie van het recht, Deventer: Kluwer.

Directie Algemene Justitiële Strategie (DAJS) (2001) Justitie over morgen: een strategische verkenning, Den Haag: Ministerie van Justitie.

Ensink, T., \& J. Nolta (1998) 'De toegankelijkheid van rechtspraak', Tijdschrift voor Taalbeheersing, 3: 193-216.

Feeley, M.M. (1979) The process is the punishment. Handling cases in a lower criminal court, New York: Russell Sage Foundation.

Finkel, N.J. (1995) Commonsense Justice: jurors' notions of the law, Cambridge: Harvard University Press.

Genn, H. (1999) Paths to justice: what people do and think about going to law, Oxford: Hart Publishing.

Groenhuijsen, M. (2002) 'Enkele centrale denkbeelden van Montesquieu en van Beccaria in relatie tot het legaliteitsbeginsel in strafzaken' blz. 21-48 in: K. Boonen, C.P.M. Cleiren, R. Foqué \& Th.A. de Roos (red.), De weging van 't Hart: Idealen, waarden en taken van het strafrecht, Deventer: Kluwer.

Hertogh, M.L.M. (2003) 'Het maatschappelijk vertrouwen in “onze” rechtsstaat', Nederlands Juristenblad, 11: 550-552. 
Hielkema, J. (1996) Deskundigen in Nederlandse strafzaken, Den Haag: Sdu.

Hildebrandt, M. (2003) 'Mediation in strafzaken: afdoening buiten recht? Over de meerwaarde van het juridische', Delikt \& Delinkwent, 4: 353-374.

Hough, M., \&J. Roberts (1999) 'Sentencing trends in Britain: public knowledge and public opinion', Punishment and Society: The International Journal of Penology, 1: 11-26.

Huls, N.J.H. (200o) 'Het interne en externe natraject van rechterlijke uitspraken', blz. 133-146 in: M.L.M. Hertogh \& L.E. de Groot-van Leeuwen (red.), Na de uitspraak: gevolgen van geschillenbeslechting, Den Haag: Elsevier.

Janssen, J. (2003) 'Van zitting tot zitten. Schuld en schuldgevoelens in de strafrechtelijke keten', blz. 65-76 in: M. Malsch (red.), De burger in de rechtspraak. Ervaringen en percepties van niet-professionele procesdeelnemers, Den Haag: Elsevier juridisch (Recht der Werkelijkheid).

Keijser, J.W. de, \& M. Malsch (2002) 'Is spreken zilver en zwijgen goud? Spreekrecht en het ontstemde slachtoffer', Delikt \& Delinkwent, 1: 5-20.

Kelk, C. (1994) De menselijke verantwoordelijkheid in het strafrecht, Arnhem: Gouda Quint.

Kool, R., \& M. Moerings (2003) 'Schriftelijke slachtofferverklaring of spreekrecht?' Trema, 2: 50-55.

Koppen, P.J. van, \& M. Malsch (1992) 'Hoe de verliezer wint: executie van civiele vonnissen', Nederlands Juristenblad, 34: 1101-1104.

Koppen, P.J. van, \& S.D. Penrod (red.) (2003) Adversarial versus Inquisitorial Justice: Psychological Perspectives on Criminal Justice Systems, New York: Kluwer/Plenum.

Leest, J. (2001) 'Het heft weer in eigen hand. Herstellend recht-conferenties in de praktijk', Tijdschrift voor Herstelrecht, 1: 4-11.

Leij, J.B.J van der (2002) Bejegening op maat: de behandeling van getuigen in strafzaken, Deventer: Gouda Quint.

Leij, J.B.J van der (2003) 'Van instrument naar deelnemer? De bejegening van getuigen in strafzaken', blz. 95-116 in: M. Malsch (red.), De burger in de rechtspraak. Ervaringen en percepties van niet-professionele procesdeelnemers, Den Haag: Elsevier juridisch (Recht der Werkelijkheid).

Leventhal, G.S. (1976) 'Fairness in social relationships' in: J. Thibaut, J. Spence \& R. Carson (red.), Contemporary topics in social psychology, Morristown (NJ): General Learning Press.

Lind, E.A., \& T.S. Tyler (1988) The social psychology of procedural justice, New York: Plenum Press.

Luhmann, N. (1978) Legitimation durch Verfahren, Darmstadt/Neuwied.

Makkai, T., \& J. Braithwaite (1994) 'Reintegrative shaming and compliance with regulatory standards', Criminology, 32: $361-385$.

Malsch, M. (2000) 'Zedenmisdrijven en conflictbemiddeling', blz. 91-104 in: R.H. Haveman, F.P. Ölcer, Th.A. de Roos \& A.L.J. van Strien (red.), Seks, zeden en strafrecht, Deventer: Gouda Quint.

Malsch, M. (red.) (2003a) De burger in de rechtspraak. Ervaringen en percepties van nietprofessionele procesdeelnemers. (Special van Recht der Werkelijkheid), Den Haag: Elsevier.

Malsch, M. (2003b), 'Door het oog van verdachte en dader: ervaringen en meningen over de gang door het strafproces', blz. 41-52 in: M. Malsch (red.), De burger in de 
rechtspraak. Ervaringen en percepties van niet-professionele procesdeelnemers, Den Haag: Elsevier.

Malsch, M. (2003c) 'De burger in de rechtspraak: samenvatting en conclusies', blz. 135-146 in: M. Malsch (red.), De burger in de rechtspraak. Ervaringen en percepties van niet-professionele procesdeelnemers, Den Haag: Elsevier.

Malsch, M. (2003d) 'De leek als rechter en de rechter als leek', Justitiële Verkenningen, 1: 47-61.

Malsch, M., \& R.M Carrière,. (1996) 'Dading en bemiddeling: geschikt voor het strafrecht?' Recht der Werkelijkheid, 1: 25-38.

Malsch, M., \& J.F. Nijboer (red.) (1999) Complex cases: perspectives on the Netherlands criminal justice system, Amsterdam: Thela Thesis.

Malsch, M., \& E. de Bakker (2003) 'Niet-professionele procesdeelnemers over de rechtspraak: inleiding', blz. 3-12 in: M. Malsch (red.), De burger in de rechtspraak. Ervaringen en percepties van niet-professionele procesdeelnemers, Den Haag: Elsevier.

Malsch, M., F. van den Berg, I. de Bruijn, J. de Keijser \& H. Nijboer (2003) 'De ideale rechtbank: openbaarheid en gerichtheid op de buitenstaander', blz. 117-134 in: M. Malsch (red.), De burger in de rechtspraak. Ervaringen en percepties van nietprofessionele procesdeelnemers, Den Haag: Elsevier.

Mattison, J., \& C. Mirrlees-Black (2000) Attitudes to crime and criminal justice: findings from the 1998 British Crime Survey, Home Office Research Study No. 200, Londen: Home Office.

Minekus, W. (2003) 'Over verliezers en zondebokken: procesbeleving en attributietheorie in het civiele recht', blz. 13-40 in: M. Malsch (red.), De burger in de rechtspraak. Ervaringen en percepties van niet-professionele procesdeelnemers, Den Haag: Elsevier juridisch (Recht der Werkelijkheid).

Mirrlees-Black, C. (2001) Confidence in het criminal justice system: findings from the 2000 British Crime Survey, Home Office Research Findings No. 137, Londen: Home Office.

Nolta, J.V. (1997) Taal in toga: over toegankelijke (straf)rechtstaal, Deventer: Kluwer.

Paternoster, R., R. Bachman, R. Brame \& L.W. Sherman (1997) 'Do fair procedures matter? The effect of procedural justice on spouse assault', Law \& Society Review, 31: $163-204$.

Pol, U. van de (1986) Openbaar terecht. Een onderzoek van het openbaarheidsbeginsel in de strafrechtspleging, Dissertatie, Amsterdam: vu.

Prisma (2002) Open voor publiek. Klantwaarderingsonderzoek in zes rechtbanken, Amersfoort: Prisma.

Rijksen, R. (1958, 1961) Meningen van gedetineerden over de strafrechtspleging, Assen: Van Gorcum.

Röhl, K.F., \& S. Machura (red.) (1997) Procedural justice, Aldershot: Ashgate.

Röhl, K.F. (1997) 'Procedural justice: introduction and overview', blz. 1-36 in: K. F. Röhl \& S. Machura (red.), Procedural justice, Aldershot: Ashgate.

Roos, Th.A. de (2001) 'Openbaarheid en publiciteit', blz. 149-156 in: C.J. de Poot \& M. Malsch (red.), Bivakmuts, politiepet en toga, Den Haag: Boom Juridische uitgevers.

Rossum, W. van (2003) 'De "legal iceberg” opnieuw bekeken. Turks familiegoud in een nauwelijks gewonnen zaak', blz.77-94 in: M. Malsch (red.), De burger in de recht- 
spraak. Ervaringen en percepties van niet-professionele procesdeelnemers, Den Haag: Elsevier juridisch (Recht der Werkelijkheid).

Ruys, P. (2001) Wij zien u wel in de rechtszaal. Klassenjustitie in Nederland? Soesterberg: Aspekt.

Schoo, H.J. (2003) 'Nooit meer normaal', de Volkskrant, 3 mei 2003.

Schuyt, C.J.M., A. Jettinghoff, E. Lambregts \& F. Zwart (1978) Een beroep op de rechter.

Een verkennend onderzoek naar de ervaringen van burgers met rechtspraak in het sociale-verzekeringsrecht, met name in zake de Ziektewet, de Werkeloosheidswet en de Wet op de Arbeidsgeschiktheidsverzekering, Deventer: Kluwer.

Sherman, L.W. (1993) 'Defiance, deterrence, and irrelevance: a theory of the criminal sanction', Journal of Research in Crime and Delinquency, 30: 445-473.

Sherman, L.W. (2002) 'Trust and confidence in criminal justice', NIJ Journal, 248: 23-31.

Sykes, G.M., \& D. Matza (1957) 'Techniques of neutralization: a theory of delinquency', American Sociological Review, 1: 664-670.

Tak, P.J.P. (2002) 'Lekenrechtspraak kan legitimiteit strafrechtspleging bevorderen', Nederlands Juristenblad, 34: 1703-1704.

Thibaut, J., \& L. Walker (1975) Procedural justice: a psychological analysis, Hillsdale: Wiley.

Thibaut, J., \& L. Walker (1978) 'A theory of procedure', California Law Review, 66: $541-566$.

Tyler, T.S. (1990) Why people obey the law, New Haven: Yale University Press.

Tyler, T.R., \& E.A. Lind (1992) 'A relational model of authority in groups', Advances in Experimental Psychology, 25: 115-191.

Voert, M.J. ter (1997) 'Vertrouwen in het strafrechtsysteem en normvervaging', blz. 93-101 in: K. Wittebrood, J.A. Michon \& M.J. ter Voert (red.), Nederlanders over criminaliteit en rechtshandhaving, Deventer: Gouda Quint.

Vruggink, J. (2003) 'Het is ook maar een baan. Daders over spelers in het strafproces', blz. 53-64 in: M. Malsch (red.), De burger in de rechtspraak. Ervaringen en percepties van niet-professionele procesdeelnemers, Den Haag: Elsevier juridisch (Recht der Werkelijkheid).

Wasserman, D. (1997) 'The procedural turn: social heuristics and neutral values', blz. 37-58 in: K.F. Röhl \& S. Machura (red.), Procedural justice, Aldershot: Ashgate.

Wemmers, J.M. (1996) Victims in the criminal justice system, Den Haag/Amsterdam/ New York: woDC/Kugler Publications.

Wemmers, J.M., \& F.W. Winkel (1997) ‘Hulp aan slachtoffers', blz. 622-638 in: P.J. van Koppen, D.J. Hessing \& H.F.M. Crombag (red.), Het hart van de zaak: psychologie van het recht, Deventer: Gouda Quint.

Wetenschappelijke Raad voor het Regeringsbeleid (WRR) (2002) De toekomst van de nationale rechtsstaat, Rapporten aan de Regering nr. 63, Den Haag: Sdu Uitgevers. 


\title{
6 STADSETIQUETTE: OVER WAARDEN, NORMEN EN COLLECTIEVE ZELFREDZAAMHEID VAN BURGERS
}

\author{
R.F.W. Diekstra
}

\subsection{INLEIDING}

Ergens in Rotterdam in een buurthuis. Er zit een zestigtal buurtbewoners in de centrale zaal die al een tijd lang onder leiding van een opbouwwerker praten over wat ze met elkaar in de buurt willen gaan doen om te zorgen dat het er allemaal wat vriendelijker en veiliger aan toegaat. Op een gegeven moment staat een oudere man op en vraagt het woord. "De mensen", zo begint hij, "hebben altijd wel wat over elkaar te zeggen, maar ze moeten eens leren om naar zichzelf te kijken." Dan vertelt hij een opmerkelijk verhaal. Tijdens de koopavond van de voorafgaande week was hij op het plein voor het winkelcentrum in de buurt en zag dat een aantal jongens - "volgens mij waren het Marokkanen, maar dat heb ik dus niet gezegd" - op hun scooters tussen het winkelend publiek aan het scheuren was. Hij vond dat gevaarlijk, was op de jongens afgestapt en had ze beleefd gevraagd dat elders te gaan doen. Terwijl hij nog met de jongens stond te praten, had een mevrouw zich bij hem gevoegd en was hem bijgevallen in zijn kritiek op de jongens. Die waren daarop inderdaad afgedropen. "Maar wat raad je me wat!" ging de man verder, "een minuut of tien later, ik was nog steeds op het plein, zag ik diezelfde mevrouw op haar fiets met een kind achterop tussen de mensen doorslingeren. Ik naar haar toe en tegen haar zeggen: 'Mevrouw, dat kunt u niet maken..!' Nou geef ik je te raden wat ze terug zei...? 'Bemoei je met je eigen zaken, man!'”

De zaal reageert opgewonden lachend. Daarop vraagt de opbouwwerker aan de man wat hij de vrouw heeft geantwoord. "Ik?” antwoordt de man. "Ik was zo perplex dat ik geloof ik niks gezegd heb. Wat had ik moeten zeggen?"

Dan gebeurt er iets opmerkelijks. "Die mevrouw”, zegt de man met zijn vinger wijzend, "is hier vanavond ook." Verbazing in de zaal. Daarop vraagt de opbouwwerker of dit inderdaad zo is. Ietwat schuchter maar ook moedig meldt de vrouw zich en bevestigt het verhaal van de man in grote lijnen. Enige tijd later, als de grote groep opgesplitst is in een aantal kleine 'werkgroepen', stel ik mijn groepje, waarin ook de betreffende man en de vrouw, voor om de vraag wat de man had kunnen zeggen als vertrekpunt van gesprek te nemen. De aanwezigen stemmen daar enthousiast mee in. We brainstormen vervolgens over allerlei mogelijke reacties en besluiten daarvan een aantal uit te spelen. De reactie die op algemene acceptatie kan rekenen, is die waarbij de man de vrouw uitlegt dat hij zich door haar aan te spreken met zijn eigen zaken bemoeit. Want de openbare ruimte is van iedereen, dus ook van hem, en als andere mensen zich daar onveilig gedragen, dan bemoeit hij zich dus met zijn eigen veiligheid, zijn eigen zaak dus, als hij daar wat aan wil doen. En door zich op die manier met zijn eigen zaak te bemoeien, dient hij ook andermans zaak, het algemeen belang, de veiligheid van iedereen die in die ruimte verkeert.

Ik zal de reactie van een aantal van de aanwezigen en vooral van de vrouw in kwestie op die 'oplossing' niet gauw vergeten. Het was alsof er een hele bak munten in haar hoofd doorviel. 
Ze gaf eerlijk toe dat ze er nog nooit zo over gedacht had. "Gek hè”, zei ze hoofdschuddend in een soort van verwonderende verzuchting.

Een van de ervaringen die in de pilotstudie Rotterdamse Stadsetiquette (Diekstra et al. 2002) werd opgedaan, is dat burgers zich vaak weinig bewust zijn van de (mogelijke) gevolgen die hun gedrag in de publieke ruimte voor anderen heeft. Als er overlast gevend of onveilig of onbeleefd gedrag wordt vertoond, is dat in heel veel gevallen geen kwestie van onwil of opzet, maar simpel van gebrek aan bewustzijn van de relatie tussen de eigen actie en het gevolg voor anderen. Veel burgers nemen verschijnselen in de publieke ruimte, die manifestaties of symptomen van hun eigen gedrag zijn en/of dat van hun straat- of stadsgenoten, niet als zodanig waar (zie figuur 6.1).

Een andere ervaring is dat veel burgers, waarschijnlijk zelfs de meerderheid, grote moeite hebben om effectief, laat staan respectvol te reageren op aangesproken worden op eigen gedrag en de gevolgen daarvan. Het eerste, gebrek aan bewustzijn, verklaart ongetwijfeld een deel van het tweede, niet adequaat reageren op aangesproken worden, maar is slechts een deel van het verhaal. Want ook een onduidelijke 'innerlijke' afbakening tussen waarden, normen en gedrag in de privé-sfeer en in de publieke ruimte speelt in deze bij veel burgers een rol. Nog een andere ervaring is dat veel burgers het niet gemakkelijk vinden of zelfs gevaarlijk om anderen, ook als het buren zijn, aan te spreken op hun gedrag. In de straten rondom het Verschoorplein in de Tarwewijk, deelgemeente Charlois, een van de pilotgebieden van de Stadsetiquette, gaf maar liefst 66 procent van de ondervraagde bewoners aan het belangrijk te vinden dat mensen dit jegens elkaar doen, maar tegelijkertijd vonden ze het zo gevaarlijk dat ze het zelf liever niet doen. Daarbij speelt ongetwijfeld een rol dat velen ook niet weten hoe effectief iemand aan te spreken. Tijdens zogenaamd participerend toneel (toeschouwers kunnen op ieder moment instappen om een bepaalde rol in of over te nemen) in het kader van de pilotstudie bleek dit keer op keer.

De meest gebruikte eerste aanspreekwijze van burgers is er een die gemakkelijk agressie uitlokt (“Zeg hé, schei daar eens mee uit man!”). Respectvoleffectieve manieren zijn in het bestaande repertoire van veel burgers niet aanwezig, hetgeen ongetwijfeld samenhangt met problematische modellen en gebrek aan sociali-satie of oefening. Mede als gevolg daarvan maken veel burgers te weinig onderscheid tussen situaties waarin het adequaat is om een persoon individueel aan te spreken en situaties waarin het onverstandig of ronduit gevaarlijk is om 'in je eentje' anderen aan te spreken. Zo geldt voor bepaalde overlastsituaties of criminele voorvallen dat, als getroffen burgers mogelijke daders aanspreken, ze dat altijd samen met een aantal medebewoners moeten doen om het risico op escalatie en een eventuele dramatische afloop zo klein mogelijk te maken. Er zijn overigens straten, zo bleek tijdens de pilotstudie, waarin bewoners op zodanige manier met elkaar samenwerken 
Figuur 6.1 Een foto van ons gedrag

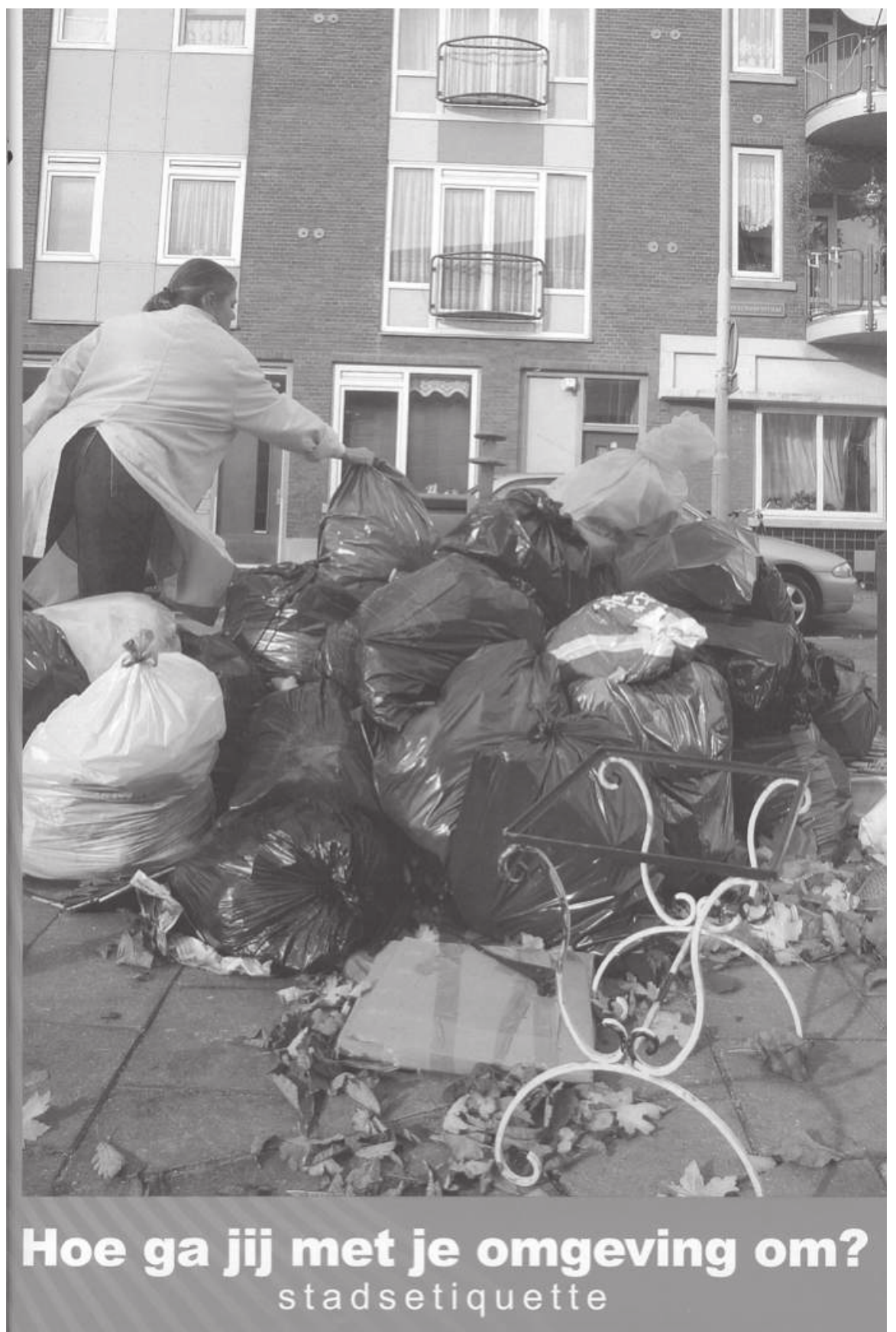

Een foto van een vuilnisstapeling in de Tarwewijk (deelgemeente Charlois). Op de vraag aan burgers wat de foto uitbeeldt, komen in eerste instantie uitsluitend antwoorden als 'vuile troep', 'zooitje vuilniszakken' en dergelijke. Door ze te wijzen op het onderschrift ('Hoe ga jij met je omgeving om?'), komen vervolgens ook antwoorden die verwijzen naar het gedrag van mensen. Zoals een bewoner het op een bepaald moment treffend formuleerde: "Dat is een foto van ons gedrag." 
dat er een duidelijk positief effect op gevoelens van veiligheid van uitgaat; onder meer omdat ze de gewoonte hebben om gezamenlijk tegen (dreigende) onveilige situaties op te treden.

\subsection{ACHTERGROND VAN DE ROTTERDAMSE STADSETIQUETTE: DE ROL VAN GELOOF IN COLLECTIEVE ZELFREDZAAMHEID}

Het Rotterdamse project, inmiddels programma, Stadsetiquette (Diekstra et al. 2002) is ontwikkeld tegen de achtergrond van en geïnspireerd door het werk van de psycholoog Albert Bandura aan de universiteit van Stanford met betrekking tot collectieve zelfredzaamheid. Ruim twintig jaar geleden gebruikte Bandura als eerste de term 'belief in collective self-efficacy', geloof in collectieve zelfredzaamheid (Bandura 1995). De term staat voor het geloof dat mensen in een bepaalde gemeenschap of groep hebben in hun vermogen en bereidheid om door samenwerking toekomstige problemen op te lossen of doelen te bereiken die ook voor hen individueel belangrijk zijn. Aanvankelijk vond het onderzoek naar geloof in collectieve zelfredzaamheid enerzijds en gedrag anderzijds vooral plaats met betrekking tot onderwijssituaties. Daaruit bleek onder meer dat het geloof in collectieve zelfredzaamheid (kortweg Cr-factor) van docententeams een belangrijke voorspeller is van schoolprestaties van kinderen, vooral kinderen uit minderheidsgroepen of kansarme groepen (Bandura 1993). Ook bleek dat de Crfactor van een docententeam een belangrijke bepaler is voor de manier waarop zowel team als individuele docenten met werkstress omgaan. Hoe sterker de Crfactor, hoe effectiever een team met werkstress omgaat en hoe minder negatieve of gezondheidsbedreigende gevolgen eruit resulteren.

Pas betrekkelijk recentelijk heeft het begrip ook ingang gevonden in het denken van beleidsmakers en onderzoekers van (sociale) leefbaarheid in steden in de Verenigde Staten. Belangrijkste prikkel daarvoor was de publicatie van een onderzoek door een psychiater, een psycholoog en een pedagoog in het tijdschrift Science (Sampson et al. 1997). Zij hadden 343 buurten in Chicago onderzocht om onder andere antwoord te vinden op de vraag waarom buurten die qua bevolkingssamenstelling en sociale achterstand identiek zijn, toch zo sterk kunnen verschillen in de frequentie van misdrijven en geweldsincidenten, vooral gepleegd door jongeren en jonge volwassenen. Een belangrijk deel van het antwoord bleek te vinden in de verschillen tussen buurten in (geloof in) collectieve zelfredzaamheid (zie tekstbox 6.1).

\section{Tekstbox 6.1 Collectieve zelfredzaamheid van de straat}

Neem eens de straat of buurt waar $\mathrm{u}$ woont in gedachten en beantwoord dan de volgende vragen. Is het volgens u 'zeer waarschijnlijk', 'waarschijnlijk', 'onduidelijk', 'onwaarschijnlijk' of 'zeer onwaarschijnlijk' dat de mensen in uw straat in actie zullen komen als ze zien dat (1) (uw) kinde- 
ren van school spijbelen en in de buurt rondhangen; (2) kinderen graffiti op een gebouw aan het spuiten zijn; (3) kinderen zich onbeschoft tegen een volwassene gedragen; (4) er een vechtpartij in de straat plaatsvindt; (5) een belangrijke voorziening in de buurt vanwege bezuinigingen met sluiting wordt bedreigd? Als u op de meerderheid van de vragen met 'waarschijnlijk' of 'zeer waarschijnlijk' kunt antwoorden, dan woont u vrijwel zeker in een straat of buurt waar de omgang tussen de bewoners vriendelijk is, waar de meerderheid van hen zich (mede)verantwoordelijk voelt voor de gang van zaken in de straat en zich daarnaar gedraagt, waar een relatief hoge mate van sociaal vertrouwen bestaat en waar het veilig is voor jong en oud. En dat laatste dan dus niet omdat er veel blauw op straat is of omdat de mensen die er wonen of komen nu zo veel braver zijn dan de rest van de bevolking. En ook niet omdat de straat zo veel mooier is dan andere straten of dat de inwoners van hetzelfde 'ras' of dezelfde culturele of sociaal-economische achtergrond zijn. Elk van die factoren heeft op zich minder invloed dan het feit dat in de straat de collectieve zelfredzaamheid of $\mathrm{Cr}$-factor hoog is.

Zo blijkt dat in arme, 'zwarte' wijken waar weinig misdaad en geweld is, mensen op elkaar kunnen rekenen als het gaat om het (gezamenlijk) optreden tegen gebrek aan respect, overlast en misdaad. Ze slaan er ook veel eerder de handen in elkaar als het gaat om het behoud van bepaalde voorzieningen of het verkrijgen van fondsen van de overheid of andere instanties voor activiteiten in hun straat of buurt. De onderzoekers vergeleken de invloed van 'klassieke' factoren van criminaliteit, zoals ras, etniciteit en sociaal-economische positie, met (geloof in) collectieve zelfredzaamheid. Ze constateerden dat de laatste "the single most important determinant of a neighbourhood's violent crime rate" was. Opmerkelijk genoeg bleek dat ook Bandura's stelling dat "collective selfefficacy requires merging diverse self-interests in support of common core values and goals" (Bandura 1995: 37), door buurtbewoners in vrijwel dezelfde termen werd onderschreven. Op de vraag aan bewoners van bepaalde buurten waarom daar nauwelijks sprake was van samen doen of samenwerken ten behoeve van leefbaarheid, luidde het algemene antwoord: "people in this neighbourhood do not share the same values” (Sampson et al. 1997).

Op het eerste gezicht lijkt het nagenoeg een 'open deur' te stellen dat er een verband bestaat tussen het delen van bepaalde waarden en de daarbijbehorende normen enerzijds en het geloof in collectieve zelfredzaamheid in een gemeenschap anderzijds. Toch is het bij nadere beschouwing allerminst duidelijk hoe men zich dit verband moet voorstellen. Is het één procesmatig gezien een voorwaarde voor het ander? Maar dan toch bepaald geen voldoende voorwaarde. Want mensen in een bepaalde buurt kunnen heel wel bepaalde waarden delen en toch niet gezamenlijk actief zijn ten behoeve van de leefbaarheid daar. Zo zullen in vrijwel iedere straat bewoners schoonheid, in de zin van geen zwerfvuil, als waarde delen, maar dat betekent allerminst dat ze individueel met betrekking tot die waarde actief zijn in hun straat, laat staan met elkaar daarvoor actie ondernemen.

Hiermee raken we aan de essentie van wat inmiddels de methode of benadering van de stadsetiquette is gaan heten. Die essentie is: het creëren of faciliteren van 
de voorwaarden waaronder burgers in een bepaald gebied met elkaar gemeenschappelijke belangen vaststellen en manieren van omgang met elkaar en met de overheid en andere instanties ontwikkelen en onderhouden om die belangen voorzover dat in hun vermogen ligt actief te behartigen. De geschiedenis van en de ervaringen met de stadsetiquette-benadering tot nu toe tonen inderdaad aan dat waarden, normen, omgangsafspraken en (geloof in) collectieve zelfredzaamheid daarin de cruciale (proces)begrippen zijn.

\subsection{EEN KORTE GESCHIEDENIS VAN DE ROTTERDAMSE STADSETIQUETTE}

In het najaar van 1999 formuleerde de gemeente Rotterdam haar beleid voor de periode 2000-2010 in een nota die de titel Rotterdam op koers: stedelijke visie 2010 meekreeg. Behalve plannen op fysiek en economisch terrein bevatte de nota ook een sociaal beleidsplan met als titel Een stad voor elkaar (Diekstra 1999). Daarin werden als zwaartepunten drie beleidsterreinen aangewezen, te weten jeugd, veiligheid en kwetsbare groepen. In de paragraaf over jeugd was een tabel opgenomen met een opsomming van gewenste eindtermen van ontwikkeling, dat wil zeggen van datgene wat jongeren bij voorkeur in hun bagage moeten hebben als ze op de drempel van de volwassenheid verschijnen. Een aantal van die 'eindtermen' beschrijft houdingen en vaardigheden die zonder voorbehoud als elementen van verantwoord burgerschap of van een sociale etiquette kunnen worden aangeduid (zie tabel 6.1). ${ }^{1}$

\section{Tabel 6.1 Essentiële vereisten voor of eindtermen van een gezonde ontwikkeling}

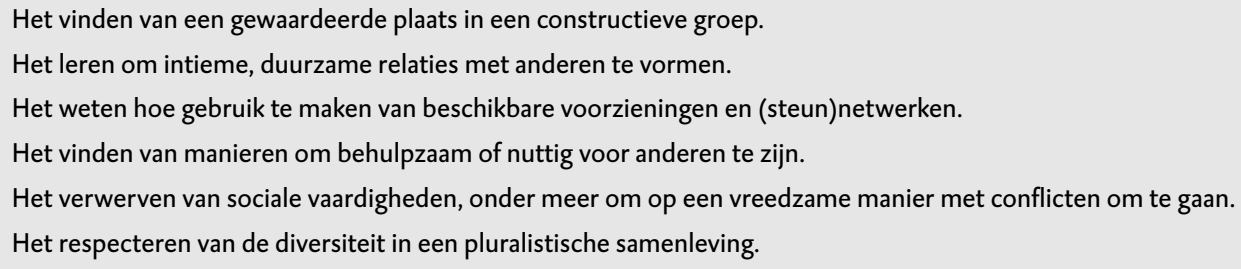

Tijdens een openbare discussie van politici, raadsleden, burgers en vertegenwoordigers van allerlei organisaties over het sociale hoofdstuk in de stedelijke visie werd het gebruik van zulke eindtermen voor het jeugdbeleid door veel van de aanwezigen met instemming begroet. "Maar waarom”, riep op een bepaald ogenblik een van de aanwezigen, "formuleren we zulke gedragsregels alleen voor jongeren en niet ook voor volwassenen?" "Het is hoog tijd dat er ook een etiquette voor volwassenen komt", was de reactie van iemand anders. Waarop iemand riep: "Precies, we moeten in Rotterdam een stadsetiquette hebben!" Op dat moment was de geboorte van het idee Stadsetiquette een feit, hoewel niemand een duidelijk beeld had van wat er nu precies onder verstaan moest worden en wat de rol van de overheid in deze zou moeten of kunnen zijn. Even- 
min was er zicht op het draagvlak bij de burgers in de stad voor zoiets als een stadsetiquette.

Het was vermoedelijk vanwege die onzekerheden omtrent wat tegelijkertijd als een 'sexy' concept werd ervaren, dat het college van Burgemeester en Wethouders van de stad op voorstel van wethouder Herman Meijer (GroenLinks) besloot om de auteur, als psycholoog en gedragsdeskundige, de opdracht te geven een verkennende studie en in het verlengde daarvan eventueel enkele stadsetiquette 'experimenten' uit te voeren. Deze pilotstudie, uitgevoerd in de periode september 2001-december 2002, beoogde antwoord te geven op de volgende vragen.

- Zijn er gebieden in de stad waar burgers, al dan niet met behulp van instanties/organisaties, zoiets als een stads- of straatetiquette hebben ontwikkeld?

- Hoe is dat gebeurd, wat zijn kritische succes- of faalfactoren voor ontwikkeling en voortbestaan?

- Is stadsetiquette, opgevat als herstel van fatsoenlijke en verantwoordelijke omgang in de publieke ruimte, in het algemeen een thema voor de burgers van Rotterdam?

- Wat zijn, in buurten of straten waar (nog) geen stadsetiquette bestaat, voorwaarden en effectieve methoden voor het ontwikkelen van zo'n etiquette en wat is de rol van de overheid, respectievelijk instanties daarin of welke dient deze te zijn?

Met opzet werd bij de aanvang van de studie geen duidelijke definitie of afbakening van het begrip 'stadsetiquette' gehanteerd, maar werd de formulering van een breed gedragen omschrijving benaderd als een van de mogelijke opbrengsten van de studie. Overigens stonden twee kenmerken van meet af aan vast, althans gezien vanuit de opdrachtgever. In de eerste plaats zou stadsetiquette moeten gaan om omgangsafspraken in de publieke ruimte en uitdrukkelijk niet in de privé-sfeer. Ten tweede zouden die omgangsafspraken door de burgers zelf gewenst, geformuleerd en onderhouden moeten (kunnen) worden. In de vorming van stadsetiquette zou dus sprake moeten zijn van een 'bottom-up/topsupport'-proces.

In het volgende zal op enkele van de voornaamste bevindingen met betrekking tot elk van de drie onderzoeksvragen worden ingegaan. Aansluitend zullen de implicaties van die bevindingen voor stadsetiquette als 'methodiek' ten behoeve van sociale integratie en collectieve zelfredzaamheid worden beschreven. Ten slotte zal tegen de achtergrond daarvan worden uiteengezet wat de toekomst van stadsetiquette is binnen het huidige Rotterdamse Collegeprogramma.

\subsection{STADSETIQUETTE AVANT LA LETTRE}

Als iets een goed idee lijkt, als tegelijkertijd (nog) niet erg duidelijk is hoe dit idee vormgegeven zou kunnen of bij voorkeur moeten worden, dan is doorgaans de meest vruchtbare eerste stap om na te gaan of anderen dit idee of iets wat erop 
lijkt, ook al gehad hebben. En vooral wat ze ermee gedaan hebben. In het kader van de pilotstudie werd daarom in heel Rotterdam gespeurd naar straten of buurten waar bewoners een 'etiquetteachtig' initiatief hadden genomen en ontwikkeld. Daarbij werd onder andere gebruiktgemaakt van de informatie waarover het campagnebureau Opzoomer Mee beschikte. ${ }^{2}$ In totaal werden elf van dergelijke buurten of straten gevonden, waarmee overigens niet gezegd is dat daarmee al dergelijke initiatieven in de stad waren verzameld. Van die initiatieven werd een nauwkeurige beschrijving gemaakt, onder meer door middel van interviews met initiatiefnemers of -dragers.

De volgende criteria werden gehanteerd om een initiatief als etiquette-initiatief aan te merken.

1 Het initiatief moet door de bewoners zelf zijn genomen. In een later stadium kan het initiatief eventueel wel ondersteuning hebben ontvangen van professionele organisaties.

2 Het initiatief is gericht op het in gezamenlijkheid opstellen van omgangsregels voor en door bewoners, of dit is een neveneffect van het initiatief.

De omgangsregels hebben als doel de leefbaarheid voor alle bewoners van een straat of woongebied te vergroten en niet slechts voor een beperkte groep bewoners. Met de elf initiatieven werd een viertal conferenties belegd waaraan initiatiefnemers of -dragers deelnamen in de functie van wat werd aangeduid als 'burgerexperts'. Doel van die conferenties was de kennis en ervaringen van de burgerexperts bijeen te brengen, te bespreken, vast te leggen en samen te voegen tot een body of knowledge die gebruikt zouden kunnen worden bij experimenten met stadsetiquette in andere gebieden. De verslaglegging van de verschillende initiatieven leverde belangrijke inzichten op in de ontstaans- en voortbestaansgeschiedenis van een stads- of straatetiquette (zie voor een voorbeeld tekstbox $6.2)$.

\section{Tekstbox 6.2 “Gaan we zo met elkaar om?”}

Een dag in het voorjaar van 1994, ongeveer negen uur in de avond. In een huis in de Korenaardwarsstraat in Rotterdam-West zit een aantal bewoners bij elkaar voor wat, naar later zal blijken, de eerste is van een reeks van straatvergaderingen. Aanstichters van de bijeenkomst zijn twee bewoonsters van de straat, een van Nederlandse en een van Kaapverdische afkomst. Al langere tijd is er veel onrust in de straat. Tot's avonds laat, niet zelden een uur of elf, twaalf, spelen, schreeuwen, gillen de kinderen in de straat. Ze voetballen met leren ballen die regelmatig tegen ramen en op auto's terechtkomen. De getroffen volwassenen reageren daar met verontwaardiging en agressie op. Agressie die weer agressie oproept. Er worden voortdurend racistische opmerkingen gemaakt - de ongeveer dertig gezinnen in de straat zijn afkomstig uit tien verschillende culturen - en het gescheld loopt af en toe ook uit op een handgemeen. 'Een grote bek en je vuisten gebruiken' lijkt de gedragscode bij uitstek te zijn die de straatbewoners - volwassenen en kinderen - elkaar aan het bijbrengen zijn. 
Op een dag is voor twee moeders de limiet bereikt. Hoewel ze elkaar nauwelijks kennen, komen ze in een gesprek tot de conclusie dat het zo niet langer kan. Als ze iets niet willen, is het dat hun kinderen op deze manier opgroeien. Ze beseffen dat er waarschijnlijk nog lange tijd niets zal gebeuren als de bewoners zelf niet in actie komen en besluiten een straatvergadering te beleggen. Hun doel is een kritische massa van bewoners te mobiliseren om het tij te keren. Ze realiseren zich dat de manier waarop die eerste bijeenkomst verlopen zal, wel eens beslissend kan zijn voor de volgende jaren van de straat. Ze realiseren zich ook dat respect voor ieders standpunt en grieven de voorwaarde is voor de bereidheid gezamenlijk naar oplossingen te zoeken. Daarom besluiten ze 'neutrale' hulp van buiten in te roepen. Ze wenden zich tot de bewonersorganisatie en verzoeken om een heel goede gespreksleider. In een straat met zo veel verschillende culturele achtergronden staat het sturen van brieven gelijk aan vragen om problemen. Die worden niet gelezen of zelfs als afstandelijk en beledigend ervaren. Daarom besluiten ze, in overleg met de gespreksleidster, iedereen persoonlijk uit te nodigen en daarbij heel goed uit te leggen waar het om gaat. Die manier van uitnodigen vindt een brede weerklank, vooral bij de volwassenen met kinderen.

De bijeenkomst begint met ieder van de aanwezigen de gelegenheid te geven tegen elkaar te zeggen, te schelden desnoods, wat hen dwarszit. Zoals een van de initiatiefneemsters later zou zeggen: “Eerst werd er veel gescholden en geschreeuwd; gelukkig kon iedereen dat goed." Dan gebeurt er iets waarvan, zoals zo vaak bij belangrijke sociale veranderingen, pas veel later duidelijk wordt dat het een cruciaal moment is geweest. De Kaapverdische initiatiefneemster staat op, richt zich tot de aanwezigen en zegt dan ondanks haar gebrekkige Nederlands op voor niemand mis te verstane wijze: "Ik heb een vraag: gaan we zo in de straat met elkaar om? Is dit wat we willen? Voeden we onze kinderen zo met elkaar op? Is dit nou een voorbeeld voor de toekomst? ...” En toen werd het stil.

Een vruchtbare stilte, zo blijkt. Het resterende deel van de bijeenkomst wordt besteed aan de vraag ‘Hoe kunnen we dit gaan omkeren?' Het levert drie duidelijke afspraken op.

- Geen leren ballen meer in de straat.

- Door de week als de kinderen naar school gaan is het vanaf negen uur's avonds rustig in de straat. De kinderen hoeven niet naar binnen, maar iedereen mag tegen de kinderen zeggen en die ook tegen elkaar: “Hé, denk erom, mag het wat rustiger?” In de weekenden en vakanties is het tijdstip tien uur.

- Geen racistische taal in de straat.

In feite wordt er nog een vierde afspraak gemaakt, misschien wel de meest belangrijke. De volwassenen stemmen ermee in dat ze elkaar en elkaars kinderen op deze afspraken mogen aanspreken. Weliswaar op een zo beleefd en respectvol mogelijke manier, maar toch. Nog diezelfde avond bedenken de deelnemers dat afspraken maken één ding is, maar afspraken op de rails houden een heel ander. Ze realiseren zich dat om de afspraken langdurig aanvaard te krijgen zoveel mogelijk bewoners van de straat zich als 'mede-eigenaar' en dus ook 'medehandhaver' van de afspraken moeten zien. Dat geldt niet alleen voor de volwassenen maar ook voor de kinderen. Daarom wordt besloten ook met de kinderen een straatvergadering te beleggen, die enige weken later plaatsvindt. Verder beseffen de deelnemers aan die eerste vergadering dat het niet zo handig is om uitsluitend afspraken te maken over wat niet meer gedaan wordt of niet meer mag. Daarom wordt besloten om de afspraak niet meer met leren ballen in de straat te spelen te completeren met de 
overeenkomst dat wel met plastic ballen gespeeld mag worden. Die zullen vervolgens gezamenlijk worden gekocht en aan elk gezin worden uitgedeeld.

Het is inmiddels voorjaar 2001 geworden. Samen met enkele ambtenaren en wethouder Herman Meijer (GroenLinks) zit ik (Diekstra) op een avond met beide initiatiefneemsters bij een van hen thuis. Aanwezig zijn ook verschillende kinderen van toen, nu inmiddels jongeren. Het gesprek gaat over hoe het in de straat gegaan is sedert die eerste vergadering, zeven jaar geleden.

In het relaas van de aanwezige bewoners springen drie dingen duidelijk in het oog. In de eerste plaats is het niet alleen gelukt de gemaakte afspraken overeind te houden, maar is het ook gelukt er in de loop van de tijd nog enkele aan toe te voegen. Zoals de regel dat de bewoners elkaar groeten in het voorbijgaan en dat nieuwe bewoners in de straat een soort introductie krijgen. Niet alleen worden ze door de anderen verwelkomd; ze krijgen ook uitleg over de omgangsafspraken in de straat. Een belangrijke voorwaarde voor deze ontwikkeling lijkt te zijn geweest dat bewoners sedert die avond in 1994 met regelmaat contactactiviteiten, plezierige activiteiten zoals feesten en spelen, met elkaar hebben georganiseerd.

Het tweede dat opvalt is dat er in de straat op een voor iedereen zichtbare plaats een klok is opgehangen die tegelijkertijd zowel een symbool is van als een hulpmiddel bij het 'sociale contract' dat jong en oud in de straat met elkaar hebben gesloten. De klok, een kostbare installatie, is er gekomen dankzij een gezamenlijke actie van bewoners die onder meer een subsidie heeft opgeleverd. De kinderen en jongeren kunnen zien en elkaar erop wijzen wanneer het tijdstip is aangebroken om een paar toontjes lager te spelen en overlast voor anderen te voorkomen. Gek genoeg hebben de bewoners de aanwezigheid van de klok regelmatig moeten verdedigen tegenover bewoners van andere straten en de media. De klok werd niet zelden uitgelegd als de uitdrukking van een dwingend opgelegde avondklok of spertijd, zoals die in oorlogstijd gebruikelijk was.

Het derde opvallende gegeven is de manier waarop op 'niet meedoen' en 'afspraken overtreden' wordt gereageerd. Niet alleen tolereren de meer actieve bewoners dat er gezinnen of stellen in de straat zijn die zich afzijdig houden. Het weerhoudt ze er ook niet van de 'niet-actieven' toch iedere keer weer uit te nodigen. Op den duur blijkt die strategie soms effect op te leveren, in die zin dat bepaalde bewoners na een aantal keren afwezigheid of een aantal weigeringen alsnog instappen. Ook het wijzen op (overtreding van) de afspraken verloopt gewoonlijk beheerst, mede door het besef dat een ideale straat nu eenmaal niet tot de mogelijkheden behoort.

Hoe groot de verandering tussen 1994 en 2001 is, blijkt uit niets zo duidelijk als uit de uitspraak van een van de bewoonsters: "Als ze me zeven jaar geleden, vóór de klok, gevraagd hadden of ik zou willen verhuizen uit deze straat, had ik geantwoord: 'Liever gisteren dan vandaag'. Als ze me nu vragen of ik hier weg zou willen, is mijn antwoord: 'Ik hoop dat als ik hier ooit weg moet, dat in een kist is."” (Diekstra 2001)

Samenvattend leverden de gegevens van de elf geïdentificeerde initiatieven de volgende inzichten op met betrekking tot het ontstaan en voortbestaan van die initiatieven.

- Er blijkt doorgaans een incident of een reeks incidenten (binnen de eigen straat 
of wijk, maar soms ook elders, bijvoorbeeld een dode als gevolg van zinloos geweld ergens in het land) nodig te zijn voor een kleine groep bewoners om zich ertoe te zetten zich met elkaar te verenigen om de leefbaarheid in de straat te verbeteren of te voorkomen dat die afglijdt tot een niveau dat elders allerlei problemen en 'ongein' oplevert.

- Dit groepje bewoners - het voortrekkersgroepje - blijkt vervolgens in staat een draagvlak te creëren bij anderen in de straat of buurt. Daarbij hoeft het niet per se te gaan om de meerderheid van de bewoners. Ongeveer een op drie blijkt voldoende als draagvlak om een duidelijk en duurzaam effect te sorteren. Belangrijke onderdelen van deze draagvlakcreatie zijn het persoonlijk benaderen van medebewoners voor deelname aan of het (mede) organiseren van gezamenlijke activiteiten, zoals spelen voor de kinderen, straatfeesten, schoonmaak- of 'opknap'-activiteiten en (overleg)bijeenkomsten.

- Bij het ontstaan van initiatieven is een gemeenschappelijke doelstelling of motivatie van belang. In het algemeen waren dat de 'kinderen', vaak geformuleerd als het zorgen voor een goede en veilige opgroeisituatie voor de kinderen ter plaatse.

- Veelal wist de groep initiatiefnemers al vroeg in het initiatief steun te krijgen van werkers, instellingen of de (deel)gemeente, hetzij in de vorm van personele, hetzij in de vorm van financiële ondersteuning of van beide.

- Binnen meerdere initiatieven werden naast de volwassenen ook de kinderen en jongeren in de straat of buurt bij het initiatief betrokken en kregen ze daarin een eigen actieve en volwaardige rol.

- Het blijken vooral, zij het niet uitsluitend, vrouwen te zijn die in dergelijke initiatieven een actieve voortrekkersrol of een bindende rol vervullen. De betrokkenheid van mannen bij het initiatief blijkt een belangrijke stimulans voor jongens en mannen om deel te nemen aan straatactiviteiten.

- Ook na jaren blijkt dat in de meeste gevallen de oorspronkelijke initiatiefnemers en voortrekkers nog altijd de centrale figuren zijn. Het regelen van opvolging is geen gemakkelijke kwestie.

Naast deze gemeenschappelijke kenmerken is er ook een aantal opmerkelijke verschillen tussen de initiatieven. Zo zijn er maar betrekkelijk weinig straten als de Korenaardwarsstraat. Dat wil zeggen, er zijn maar weinig straten waar het proces is begonnen met het maken van afspraken, waarna ook andere ontwikkelingen hebben plaatsgevonden die de gemaakte afspraken ondersteunen en nieuwe doen ontstaan, zoals het organiseren van straatactiviteiten. In de meerderheid van de initiatieven is de ontwikkelingsgang omgekeerd geweest. Via het organiseren van straatactiviteiten, zoals een straatfeest, meestal in het kader van deelname aan de Opzoomercampagne, ontstond een basis van 'kennen en gekend worden'. Dat leidde tot meer gezamenlijke activiteiten, waaruit zich dan bepaalde omgangsafspraken ontwikkelden, zoals de ervaring dat het akkoord is elkaars kinderen aan te spreken op overlast gevend gedrag. Omdat die bleken te werken, werd het weer gemakkelijker andere gezamenlijke activiteiten te ontwikkelen, zoals schoonmaak- of straatversieractiviteiten of speeldagen voor de kinderen, op basis waarvan weer nieuwe omgangsafspraken gemaakt konden worden. 
Overigens bleken er naast overeenkomsten met betrekking tot omgangsafspraken ook aanzienlijke verschillen te bestaan tussen straten met betrekking tot omgangsafspraken, zowel wat betreft aard als aantal. Die verschillen hebben niet zozeer te maken met verschillen in waarden (zie hierna) als wel met verschillen in kenmerken van bewoners en fysieke kenmerken van de straat. Zo zijn afspraken over veiligheid en wederzijdse verantwoordelijkheid voor een deel sterk bepaald door de vraag of er in de straat veel gezinnen met jonge kinderen zijn.

Voorts bleken er grote verschillen te bestaan tussen initiatieven in termen van de omvang van het woongebied dat ze bestrijken. Nu eens is het een gedeelte van een grote straat, dan weer een hele straat, maar dan wel van beperkte omvang, en dan weer een groepje van straten, bijvoorbeeld rondom een park(je) of een andere openbare gebruiksruimte. Voor de onderzochte initiatieven geldt dat 'straat' vrijwel zonder uitzondering wordt gedefinieerd als het gebied dat de betrokkenen als hun 'buurt' beschouwen. Dat wil zeggen het gebied in de directe omgeving van hun huis waarvan ze de bewoners regelmatig tegenkomen, op de straat of in publieke ruimten rondom de straat en waarover ze biografische informatie hebben of naar hun mening 'eigenlijk zouden moeten hebben'.

Er bleken ook aanzienlijke verschillen tussen de initiatieven te bestaan wat betreft de mate waarin ze succesvol zijn in het verkrijgen van middelen van de overheid of van instellingen en maatschappelijke organisaties voor hun activiteiten. Anders gezegd, de mate van collectieve zelfredzaamheid in de omgang met externe partijen loopt sterk uiteen.

Een bijkomende, maar bepaald niet onbelangrijke observatie is ten slotte dat sommige initiatieven bedolven blijken te raken onder hun eigen succes. Ze trekken zodanig de aandacht van de buitenwereld en de media dat de initiatiefnemers voor van alles en nog wat worden uitgenodigd, variërend van voordrachten op lokale, nationale en internationale symposia tot reeksen interviews en reportages in de media. Ook trekken stoeten politici, beleidsmakers en andere geïnteresseerden voorbij. Hoewel die aandacht enerzijds als 'belonend' wordt ervaren, legt ze anderzijds niet zelden een zodanig beslag op de tijd en de energie van initiatiefnemers dat die regelmatig tegen 'burn-out' aan hangen.

\subsection{DE STRAATLADDER}

Hoewel, zoals in het voorafgaande beschreven, de ontwikkelingstrajecten van de 'etiquette'-straten een grote mate van diversiteit vertonen, blijken de in dit opzicht succesvolle straten op de lange duur een aantal kenmerken te delen, zowel wat betreft ervaren effecten als waarschijnlijke effectfactoren. De ervaren effecten kunnen kernachtig worden omschreven als 'vriendelijker, veiliger, verantwoordelijker'. Zoals in de Korenaardwarsstraat geldt in het algemeen in de etiquettestraten dat de bewoners de sfeer en de omgang met elkaar als vriendelij- 
ker, veiliger en verantwoordelijker ervaren. Het is daarbij opmerkelijk dat die drie grootheden elkaar voortdurend versterken of instandhouden. Als bewoners elkaar vriendelijker of hoffelijker bejegenen, roept dat een gevoel van veiligheid op. Bezien vanuit Bandura's sociale leertheorie (Bandura 1995) is dat overigens niet alleen maar 'een kwestie van gevoel', maar ook van daadwerkelijk veiliger gedrag. Mensen die elkaar groeten, hebben een lagere drempel om elkaar bij dreigende of onveilige situaties om hulp te vragen en bij te staan dan mensen die elkaar negeren, ondanks het feit dat ze in elkaars directe nabijheid wonen en leven. Omgekeerd geldt dat hoffelijke of 'erkentelijksheids'-reacties bij veilig gedrag de waarschijnlijkheid doen toenemen dat die reacties ook in de toekomst worden vertoond.

Het gaat hier om het zogenoemde 'zebrapadfenomeen', naar het opsteken van de hand of een ander gebaar van erkentelijkheid van de overstekende voetganger jegens de automobilist die zijn wagen 'veilig' voor het zebrapad tot stilstand brengt. Dit gebaar doet de waarschijnlijkheid dat de automobilist ook een volgende keer stopt, toenemen. Een automobilist die enige malen achter elkaar meemaakt dat zijn stoppen niet gesignaleerd wordt, stopt vervolgens minder vaak voor een zebrapad (Diekstra en Kroon 2003). Hetzelfde geldt voor (ander) verantwoordelijk gedrag. Wanneer de ene bewoner de andere aanspreekt omtrent (dreigende) overlast, zoals bijvoorbeeld de vuilniszakken te vroeg op straat zetten zodat ze opengetrokken kunnen worden door (huis)dieren, de aangesprokene vervolgens daarop adequaat reageert (vuilniszak weer naar binnenhaalt) en daarvoor hoffelijk wordt bedankt, neemt de waarschijnlijkheid van overlast verminderend gedrag toe.

De ontwikkelingstrajecten van de opgespoorde etiquettestraten kunnen modelmatig worden voorgesteld met behulp van de zogenaamde 'straatladder'. De straatladder (zie tabel 6.2) specificeert de posities die straten hetzij serieel, hetzij (deels) simultaan doorlopen bij de ontwikkeling van een relatief onvriendelijke of zelfs vijandige omgeving naar een omgeving met een hoge mate van sociale samenhang en collectieve zelfredzaamheid, zowel intern als extern. De in de tabel weergegeven straatladder is ontwikkeld op basis van een door Duyvendak en Van der Graag (2001) in het kader van hun onderzoek naar het Opzoomeren in Rotterdam geformuleerde contactladder (Diekstra en Janssens 2003).

Op de straatladder bevindt stadsetiquette als kenmerk van of 'beweging in' een straat zich op sporten hoog op de ladder (sport 8 en hoger). De implicatie daarvan is dat voor de ontwikkeling en vooral voor het onderhoud van een etiquette in een straat of buurt de voorafgaande fases doorlopen of sporten beklommen zijn. De ontwikkeling van de Korenaardwarsstraat laat zich inderdaad goed met behulp van de straatladder typeren. Binnen relatief korte tijd is de straat van sport 1 van de ladder (agressie/conflicten in de straat) via sport 5 (twee vrouwen maken contact met elkaar over de problemen in de straat) tot sport 8 (samenwerken met betrekking tot het regelen van gedrag/omgang in de straat) en na nog enige tijd zelfs tot sport 9 (samenwerken met betrekking tot zorg voor straat) 'opgeklom- 


\section{Tabel 6.2 Straatladder}

\begin{tabular}{|c|c|c|c|c|}
\hline \multirow[t]{2}{*}{ Trede } & \multirow[t]{2}{*}{ Kenmerk $^{1}$} & \multirow[t]{2}{*}{ Werkwijze } & \multicolumn{2}{|c|}{ Voorwaarden } \\
\hline & & & straat & omgeving \\
\hline 10. $(+7)$ & $\begin{array}{l}\text { Straat maakt gemeenschappelijke agenda } \\
\text { met instellingen en sluit sociaal contract } \\
\text { dat wederzijdse inspanningen regelt en } \\
\text { ondersteunt }\end{array}$ & $\begin{array}{l}\text { Contractbenadering } \\
+ \\
\text { Stadsetiquette } \\
+ \\
\text { Opzoomeren }\end{array}$ & & \\
\hline 9. $(+6)$ & $\begin{array}{l}\text { Samenwerken met betrekking tot zorg } \\
\text { voor straat (en andere publieke ruimtes) }\end{array}$ & $\begin{array}{l}\text { Stadsetiquette } \\
+ \\
\text { Opzoomeren }\end{array}$ & & \\
\hline 8. $(+5)$ & $\begin{array}{l}\text { Samenwerken met betrekking tot het } \\
\text { regelen van gedrag/omgang in de straat }\end{array}$ & $\begin{array}{l}\text { Stadsetiquette } \\
+ \\
\text { Opzoomeren }\end{array}$ & & \\
\hline 7. $(+4)$ & $\begin{array}{l}\text { Samenwerken met betrekking tot } \\
\text { (het organiseren van) straatactiviteiten }\end{array}$ & Opzoomeren & & \\
\hline 6. $(+3)$ & $\begin{array}{l}\text { Actief contact maken/zoeken } \\
\text { (op groepsbasis), aan straatactiviteiten } \\
\text { deelnemen }\end{array}$ & Opzoomeren & & \\
\hline 5. $(+2)$ & $\begin{array}{l}\text { Actief contact maken/zoeken } \\
\text { (op individuele basis) }\end{array}$ & Opzoomeren & & \\
\hline 4. $(+1)$ & Niet vermijden van contact & & & \\
\hline 3. $(0)$ & Onverschilligheid & $\begin{array}{l}\text { mogelijkheid van } \\
\text { Opzoomeren }\end{array}$ & & \\
\hline 2. $(-1)$ & Vermijding & & & \\
\hline 1. $(-2)$ & Agressie/doelbewuste onveiligheid & $\begin{array}{l}\text { Overheidsinterventies } \\
\text { tbv van veiligheid en } \\
\text { overlast }\end{array}$ & & \\
\hline
\end{tabular}

(Aanpassing van Contactladder van de hand van het Verwey-Jonker Instituut ten behoeve van MMS-Straten (René Diekstra en Johan Janssens , jan. 2003))

1 Kenmerk = overheersende kenmerk van omgang in straat naar het oordeel van de bewoners 


\section{DE STRAATLADDER}

+7 Samenwerken met instellingen en diensten

+6 Samen zorgen voor de straat

-5 Leefregels afspreken en in stand houden

+4 Samen straatactiviteiten organiseren

+3 Meedoen aan straatactiviteiten

+2 Actief contact maken

+1 Niet vermijden van contact

0 Onverschilligheid

1 Vermijding

2 Agressie

Straatladder zoals die in gesprek-

ken met bewoners wordt gehanteerd.

Bron: Mensen maken de stad, ontwerp figuur Van Putten

men'. Voor het voortbestaan en de verdere uitbreiding van de etiquette is echter noodzakelijk geweest dat ook de sporten 6 en 7 werden doorlopen of alsnog werden aangebracht. Zo werd de Korenaardwarsstraat, zoals gezegd, een Opzoomerstraat. Ook de meeste andere etiquettestraten waren Opzoomerstraten, niet zelden al langere tijd voordat ze (ook) etiquettestraten werden.

De conclusie hieruit is dat straten hun eigen specifieke ontwikkelingstraject langs de straatladder hebben, afhankelijk van de daar bestaande potenties en beperkingen. Voor sommige straten geldt dat ze pas een volgende fase of sport bereiken als alle voorafgaande doorlopen zijn. Andere straten daarentegen slaan al ontwikkelend een of meer sporten over, maar houden hun hoogste sport meestal alleen vol als de 'overgesprongen' sporten vervolgens toch worden gerealiseerd.

De straatladder als ontwikkelingsmodel roept twee belangrijke vragen op. In de eerste plaats de vraag wat maakt of wat nodig is om een straat een bepaalde sport te doen bereiken en te doen volhouden. En daarmee samenhangend: kunnen alle straten alle sporten vroeg of laat bereiken? Wat betreft de laatste vraag laat de 
empirie zien (zie ook Sampson et al. 1997) dat lang niet alle straten of buurten in staat zijn om de ladder volledig te beklimmen en de collectieve zelfredzaamheid te bereiken die de bovenste sport van de ladder kenmerkt.

Voor het beantwoorden van beide vragen is van belang een model te hebben dat de ontwikkeling van straten als de Korenaardwarsstraat verklaart of ten minste straten 'diagnosticeert' op een wijze die aanknopingspunten biedt voor handelen door burgers, beleidsmakers en uitvoerders. In het volgende zullen we een dergelijk model uiteenzetten. Tegen de achtergrond daarvan zullen de ervaringen en opbrengsten van de twee experimenten kort beschreven worden.

\subsection{HET TAAKANALYSEMODEL}

Vatten we de stads- of straatetiquette in de Korenaardwarsstraat op als een casus, en wel een succesvolle casus tot op heden, hoe kan dit succes dan conceptueel worden gesystematiseerd? Er zijn verschillende manieren waarop die vraag beantwoord kan worden. In het kader van de pilotstudie is dit steeds gebeurd door gebruikmaking van het zogenaamde taakanalysemodel. Dit model, oorspronkelijk ontwikkeld in het wetenschappelijk onderzoek naar werkstress en arbeidsuitval (zie Diekstra et al.1994), is ook bruikbaar gebleken bij andere maatschappelijke vraagstukken, zoals het (dis)functioneren van sociale grootheden als straten en wijken (Diekstra 1999). Vertrekpunt is de-inmiddels empirisch uitgebreid onderbouwde - veronderstelling dat het ontstaan en voortbestaan van sociale of individuele problemen (klachten, symptomen, stoornissen) de resultante is van de discrepantie tussen enerzijds ( 1 ) de taken en/of problemen waarvoor een individu, een gezin, straat of andere gemeenschap zich gesteld ziet en anderzijds (2) de beschikbare materiële middelen om aan die taken/problemen het hoofd te bieden, (3) de beschikbare sociale ondersteuning voor die taken/problemen, (4) de autonomie, regelmogelijkheden of zelfstandige beslissingsruimte waarover individu/ groep/samenleving beschikt om te kiezen op welke wijze aan de taken/problemen het hoofd te bieden, (5) de beschikbare houding en vaardigheden ten aanzien van de taken/problemen, (6) de fysieke en psychische weerbaarheid/kwetsbaarheid van individu/groep of samenleving en ( 7 ) de wijdere sociaal-economische, sociaalculturele en ruimtelijke context waarin individu, gezin, groep of samenleving de taken/problemen het hoofd moet bieden (zie tabel 6.3).

Hoe groter de discrepantie tussen factor (1), de taken/problemen, enerzijds en de factoren (2) tot en met (7) anderzijds, hoe groter de kans op disfunctioneren van individu, gezin, straat of gemeenschap. Anders gezegd, hoe groter de kans op disfunctionele of ongezonde spanningen of stress.

Gebruikmakend van het model kunnen we stellen dat er in de Korenaardwarsstraat in de periode vóór 1994 al langere tijd sprake was van problemen die bewoners individueel met de hun persoonlijk ter beschikking staande middelen en vaardigheden niet rechtstreeks konden oplossen of verminderen. Derhalve was er 


\section{Tabel 6.3 Het taakanalysemodel}

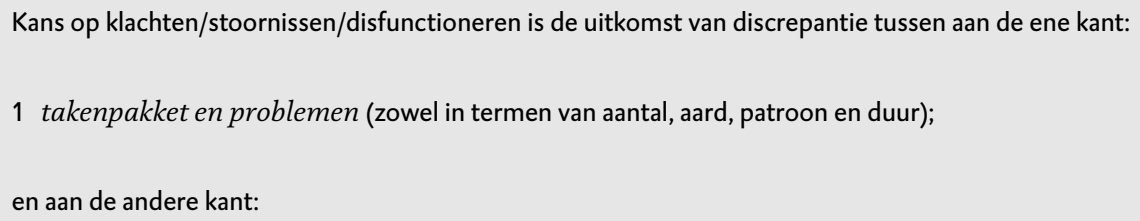

2 beschikbare materiële middelen (financiële, technische, institutionele, ruimtelijke, personele) voor het hoofd bieden aan taken/problemen;

3 beschikbare sociale steun, waarbij onderscheid tussen emotionele/affectieve, informationele en 'voorbeeld'steun (beschikbaarheid van goede/attractieve rolmodellen);

4 beschikbare autonomie of beslismogelijkheden met betrekking tot manieren en middelen om aan de taken/problemen het hoofd te bieden;

5 houding met betrekking tot taken/problemen (uitdaging versus bedreiging, zinvol versus zinloos, etc.) en beschikbare vaardigheden (taalvaardigheid, communicatieve en culturele vaardigheden, probleemoplossingsvaardigheden, beroepsvaardigheden, etc);

6 fysieke en psychische weerbaarheid/kwetsbaarheid (algemene gezondheidstoestand van individu, gezin, groep of volk, genetisch bepaalde kwetsbaarheden, leeftijd/ouderdom, handicaps, etc.);

7 de wijdere socio-economische, socioculturele of ruimtelijke context waarin taken/problemen moeten worden vervuld (zoals de grootte van straat of wijk, de culturele samenstelling, de 'turnover' (wisseling) van bewoners, mate van veiligheid, de aard van publieke en recreatieve ruimte).

een hoge en steeds verder oplopende mate van stress in de straat die het gedrag van groepen bewoners, kinderen en volwassenen nadelig beïnvloedde en tengevolge daarvan gemeenschappelijke belangen of waarden in toenemende mate schaadde (zoals een goed ontwikkelingsklimaat voor de kinderen en voldoende veiligheid). Het waren dan ten slotte de laatste druppels, in de vorm van vervelende incidenten, die enkele bewoners met grote emotionele betrokkenheid en met communicatieve en probleemoplossingsvaardigheden in beweging brachten. Zij realiseerden zich dat deze problemen alleen konden worden opgelost door het organiseren van voldoende sociale activiteit en steun (zie factor 3 ) in de straat, zowel in affectieve zin (de betrokkenheid van zoveel mogelijk bewoners, volwassenen en kinderen) als in 'voorbeeld'-zin (bereidheid om het goede voorbeeld te geven). Ze realiseerden zich ook dat ze sociale steun, in de zin van informatieve steun, van buitenaf nodig hadden en benaderden daarvoor de bewonersorganisatie, vanwaaruit een opbouwwerkster zich beschikbaar stelde als gespreksleidster. ${ }^{4}$

Die informationele (factor 3) en personele steun (factor 4) zijn vermoedelijk van cruciale betekenis geweest voor het tot bloei brengen van het burgerinitiatief. Het in gang gezette proces leidde bij een grote groep bewoners tot het ontwikkelen van een nieuwe houding ten aanzien van de straat en van elkaar en tot het identificeren van bepaalde vaardigheden (uitgedrukt in omgangsafspraken) die nodig zijn om problemen in de toekomst te voorkomen (factor 5). Voorts werd aan degenen die betrokken waren ook duidelijk dat bepaalde materiële voorzieningen 
nodig of wenselijk waren ter ondersteuning van de nieuwe houding en vaardigheden (het vervangen van leren door plastic ballen, het ophangen van de klok) en ze ondernamen daarvoor stappen, onder andere het verwerven van subsidies (materiële steun van buitenaf, factor 4). Tegelijkertijd besloten ze ook een 'cultuur' (factor 7 ) in de straat te ontwikkelen die de autonomie van individuele bewoners (factor 2) niet aantast. Want non-participatie werd niet 'gestraft', maar participatie wel gestimuleerd en beloond. Ten slotte realiseerden de meeste betrokkenen zich dat voor het onderhoud en de eventuele ontwikkeling van de omgangsregels een continuering van sociale contacten, uitwisseling en steun in alle drie varianten (emotioneel/affectief, informationeel en voorbeeld) noodzakelijk was. Dus werden gezamenlijke activiteiten, zoals straatfeesten en -spelen, onder andere in het kader van de Opzoomercampagne georganiseerd, werden af en toe vergaderingen belegd en kregen nieuwe bewoners van de straat een 'introductie' door de andere bewoners in de straat (factor 3 en 5 ).

Dit alles leide ertoe dat in 2001 (tijdstip van de interviews) de discrepantie tussen taken en problemen in de straat (factor 1), want die laatste waren er natuurlijk nog altijd ('niemand is perfect') enerzijds, en de beschikbare middelen, mogelijkheden, steun, houding, vaardigheden en 'cultuur' anderzijds (factor $2 \mathrm{t} / \mathrm{m} 7$ ), aanzienlijk geringer was dan vóór die belangrijke avond in 1994. Dit gold vooral voor de taak die bij veel bewoners boven aan de lijst van prioriteiten stond, namelijk het creëren van een zo goed mogelijke ontwikkelingssituatie voor hun kinderen. Op die taak (ook factor 1) of op die common core value (Bandura 1995) hebben de bewoners elkaar indertijd gevonden. Voor die taak hebben ze zich de middelen, mogelijkheden en vaardigheden of competenties verschaft om de obstakels daarvoor zoveel mogelijk op te ruimen. Als gevolg daarvan is de ongezonde stress in de publieke ruimte grotendeels verdwenen en heeft deze plaatsgemaakt voor een sfeer die door de meeste bewoners, jong en oud, als weldadig wordt ervaren.

Zo is de Korenaardwarsstraat een treffende demonstratie van Bandura's hypothese dat toename van (geloof in) collectieve zelfredzaamheid leidt tot een afname van disfunctionele stress in de groep of gemeenschap (Bandura 1995).

\subsection{STADSETIQUETTE: CONSENSUS OVER WAARDEN EN NORMEN}

Maar de Korenaardwarsstraat is nog in een ander opzicht een illustratie van Bandura's concept van (geloof in) collectieve zelfredzaamheid. Zoals eerder opgemerkt vereist collectieve zelfredzaamheid de samenvoeging of versmelting van uiteenlopende persoonlijke belangen ten gunste van gemeenschappelijke waarden of doelen. De zelfgeïnitieerde etiquette in de Korenaardwarsstraat ontstond in een proces waarin bewoners hun gemeenschappelijke interesses identificeerden, articuleerden en reguleerden. Ze werden zich ervan bewust door bij elkaar te komen, ze spraken ze ten opzichte van elkaar uit en ze kwamen regels overeen die hun collectieve waarden in voldoende mate realiseerden. 
De definitie van waarde die door de cultuursocioloog Hofstede is geformuleerd, lijkt hier uitgesproken van toepassing: een waarde is 'een collectieve neiging om een bepaalde gang van zaken te verkiezen boven andere'. Een waarde is als het ware 'een gevoel met een richting'. Schoonheid, bijvoorbeeld, is een waarde op een gevoelsdimensie die loopt van vuil naar schoon. Als er in een straat een brede neiging bestaat om schoon te verkiezen boven vuil, dan is schoonheid een straatwaarde. Daarmee is overigens nog niet vastgelegd wat in de praktijk van het alledaagse straatleven de norm is voor schoon of vuil. Eenvoudig gezegd, hoe lang de vuilniszakken op straat mogen staan voordat ze worden opgehaald, kan duidelijk verschillen tussen twee straten die allebei schoonheid een belangrijke waarde noemen. Dat leidt tot twee conclusies. Een is dat straten dezelfde waarden kunnen aanhangen, maar verschillende normen kunnen hanteren voor wanneer aan die waarden voldaan is. Om die reden kunnen straten voor dezelfde waarde verschillende afspraken of regels hebben. De tweede conclusie is, en dat is de meest belangrijke, dat mensen om elkaar te begrijpen en met elkaar samen te leven in de publieke ruimte, zowel elkaars waarden als normen moeten kennen en delen.

Op welke waarden vonden de bewoners van de Korenaardwarsstraat elkaar aanvankelijk? Voor alle helderheid: de bewoners spraken zelf in het geheel niet over waarden en normen in de straat. Zij hadden het gewoonweg over 'Hoe gaan we hier met elkaar om?’ Zo gauw we het hier dus hebben over waarden en normen, verwijderen we ons van de wijze waarop de mensen in de straat met elkaar communiceerden. Dat betekent overigens niet noodzakelijk dat we ons daarmee verwijderen van hun belevingen of van datgene dat ze geantwoord zouden hebben op de vraag welke waarden zij in de omgang met elkaar belangrijk vinden. Hoe het ook zij, als we proberen de waarden die achter de door de bewoners gemaakte afspraken verondersteld kunnen worden, van namen te voorzien, ontstaat het volgende beeld.

Een van die waarden was in ieder geval waardigheid of respect ('geen racistisch taalgebruik'). Een ander was weldadigheid (dat wil zeggen elkaar geen schade toebrengen of voorkomen dat dit gebeurt: 'niet meer met leren ballen voetballen' en 'na negen uur 's avonds geen lawaai meer op straat'). Een derde, zowel impliciet als expliciet, was vrijheid ('Bewoners die niet (direct) meedoen, negeren of straffen we niet, naar blijven we uitnodigen'). We kunnen er in feite ook nog rechtvaardigheid, in de zin van reciprociteit ('Wat gij niet wilt dat u geschiedt, doe dat ook een ander niet...') aan toevoegen. Deze vier waarden - waardigheid, weldadigheid, vrijheid en rechtvaardigheid - zijn ook de vier die wel als de relationele versie van de vier kardinale deugden worden beschouwd (Fokkink 200o; Gravesteijn en Diekstra 2003).

\subsection{DE IDEALE STRAAT}

Een van de vragen die aan de burgerexperts werden gesteld was om met elkaar de afspraken/regels van de 'Ideale Rotterdamse Straat' op te stellen. Tijdens een 
tweetal bijeenkomsten bogen de experts zich over die vraag, waarbij gebruik werd gemaakt van de zogenaamde Icodrome of Team Syntegrity-benadering (Beer 1994). Daaruit kwamen de thema's en (mogelijke) omgangsafspraken die in tabel 6.4 zijn opgesomd.

\section{Tabel 6.4 De Ideale Straat}

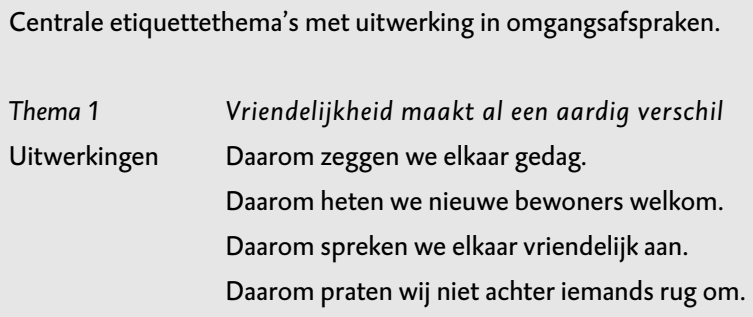

Centrale etiquettethema's met uitwerking in omgangsafspraken.

Thema $1 \quad$ Vriendelijkheid maakt al een aardig verschil

Uitwerkingen Daarom zeggen we elkaar gedag.

Daarom heten we nieuwe bewoners welkom.

Daarom spreken we elkaar vriendelijk aan.

Daarom praten wij niet achter iemands rug om.

\section{Thema $2 \quad$ Wij rekenen op elkaars respect}

Uitwerkingen Daarom kunnen we het oneens zijn zonder ruzie te maken.

Daarom accepteren we elkaars verschillende gebruiken.

Daarom proberen we problemen in onderling overleg op te lossen.

\section{Thema 3}

Uitwerkingen
Wij geven kinderen regels met voldoende speelruimte

Daarom houdt de buurt rekening met kinderen.

Daarom leren we kinderen rekening te houden met de buurt.

Daarom doen ouders en buurtgenoten hun best om op te letten.

Daarom is overleg met ouders over wat hun kinderen mogen hier mogelijk.

\section{Thema 4}

Uitwerkingen

\section{Schoon is gewoon}

Daarom gooien wij onze troep in de prullenbak.
Daarom kunnen we de baas van een hond die op de stoep poept daarop aanspreken.

Daarom zetten we ons vuil pas buiten op de dag dat het wordt opgehaald.

Daarom houden wij onze eigen stoep schoon.

\section{Thema 5}

Heel is heel normaal

Uitwerkingen

Daarom komen wij in actie als we vernielingen zien of horen.

Daarom gaan wij zorgvuldig om met de spullen in onze buurt.

Thema 6 Veilig is ons heilig

Uitwerkingen

Daarom staan we elkaar bij in een bedreigende situatie.

Daarom kijken we niet de andere kant op bij onraad, maar halen we hulp.

Daarom werken we samen aan veiligheid.

Thema 7

Wederzijds respect trekt

Uitwerkingen
Daarom mogen wij elkaar rustig aanspreken op overlast.

Daarom vragen wij iedereen in de vakken te parkeren. 
In de gekozen etiquettethema's voor de ideale straat laten zich opnieuw de genoemde vier relationele waarden herkennen. De uitwerkingen bij elk thema zijn niet noodzakelijkerwijze gelijk aan de concrete omgangsafspraken zoals ze in een straat gemaakt worden. De uitwerkingen zijn eerder te beschouwen als de 'normen' waaraan de concrete omgangsafspraken voor een bepaald thema ontleend kunnen worden.

De burgerexperts bleken zich er overigens maar al te duidelijk van bewust dat het één ding is om thema's en omgangsafspraken te maken, maar een heel ander om die breed geaccepteerd en onderhouden te krijgen. Behalve het feit dat dit een zeker niveau van regelmatig contact tussen straatbewoners vergt, vraagt het ook nog om iets anders. Dat wordt het meest duidelijk als we kijken naar thema 7 en in het bijzonder de uitwerking: 'Daarom mogen we elkaar rustig aanspreken op overlast'. De meerderheid van de experts gaf aan dat 'rustig' aanspreken niet gemakkelijk is, dat lang niet iedereen dat kan en dat ook lang niet iedereen zich 'rustig' laat aanspreken. Met andere woorden: voor deze, overigens heel centrale omgangsafspraak geldt dat veel bewoners de noodzakelijke of wenselijke vaardigheden niet in hun repertoire hebben en het dus gewoon nog moeten leren om elkaar fatsoenlijk en effectief aan te spreken, evenals fatsoenlijk en effectief reageren op aangesproken worden.

Kortom, stadsetiquette is niet alleen maar een proces van bewustwording, consensus en samenwerking. Het is ook een proces van uitbreiding of 'bij'-schaving van het gedragsrepertoire van de straatbewoner.

\subsection{STADSETIQUETTE-EXPERIMENTEN}

Het voorafgaande maakt duidelijk dat de vraag of straten een straatetiquette kunnen ontwikkelen, niet a priori met 'ja' beantwoord kan worden. In feite is het juister de vraag te stellen welke sporten op de straatladder straten kunnen bereiken, en dat kan maar hoeft niet de 'etiquette-sport' te zijn. Het beantwoorden van die vraag vereist het maken van een 'portret' van de straat. Zo'n portret omvat een analyse of diagnose van de straat in termen van taken/problemen enerzijds en middelen/mogelijkheden anderzijds. Het is heel goed mogelijk dat een portret laat zien dat, ook al is er een bepaalde groep bewoners enthousiast voor stadsetiquette, dit helemaal niet hoeft te betekenen dat stadsetiquette er ook mogelijk is.

Dit is ook een van de conclusies uit de twee experimenten met stadsetiquette in gebieden waarin daar (nog) geen sprake van was. Het eerste experiment, op de Mathenesserweg, is tot op zekere hoogte als mislukt te beschouwen. Het heeft niet geleid tot de ontwikkeling van een stadsetiquette, ondanks het feit dat er een groep van bewoners was, die 'ervoor wilde gaan'. Achteraf beschouwd was in het betreffende gebied de discrepantie tussen taken/problemen enerzijds en de middelen/mogelijkheden van bewoners onderling anderzijds eenvoudig te groot. 
Er was in het gebied sprake van ernstige onveiligheid (o.a. als gevolg van drugsgebruik en -handel en de nabijheid van de Keylerweg), van ernstige chronische vervuiling mede als gevolg daarvan, van een onderbezetting van de politie die de eerste jaren niet zou zijn opgeheven en van een bevolking die in toenemende mate mobiel werd. Bovendien waren er te weinig 'bindende' taken in de positieve zin van het woord. Zoals Müller (2003) in zijn bespreking van de Rotterdamse Stadsetiquette terecht opmerkt, is het gebied 'kinderarm'.

Maar het was juist vanwege de ernstige (veiligheids)problemen en de moeilijkheidsgraad van de buurt dat de Mathenesserweg als een uitdaging voor de stadsetiquette werd beschouwd en die uitdaging ook werd aangenomen door bewoners en uitvoerders. Vastgesteld moet echter worden dat de discrepantie tussen de vigerende taken/problemen enerzijds en tussen wat bewoners met elkaar konden mobiliseren en uitrichten anderzijds te groot bleef, waardoor de stadsetiquette-exercitie al tijdens de opstart voortdurend door (veiligheids)incidenten in de wielen werd gereden. In feite bleek tijdens de exercitie dat bewoners bezig waren met behulp van de stadsetiquette zich te zetten aan de aanpak van problemen die tot de opdracht van overheid en instellingen behoren, maar die zij lieten liggen of althans onvoldoende uitvoerden. Daarbij kwam nog dat het ook moeilijk was om de deelgemeente en de in het gebied werkzame instellingen en hun uitvoerders op een lijn te krijgen voor wat betreft steun aan de etiquette-exercitie. Gaandeweg de exercitie bleek namelijk dat deze vergt dat de deelgemeente en de in het gebied werkzame instellingen en hun uitvoerders bereid zijn hun agenda in het gebied beter op elkaar af te stemmen, maar vooral ook om de vaststelling en uitvoering van die agenda als een co-constructie met bewoners te benaderen. Wat ook een rol heeft gespeeld is dat de werkers, met name de opbouwwerkers in het gebied die na de opstartfase de 'fakkel' moesten overnemen, zich te weinig profileerden als 'sociale wevers' en te zeer als belangenbehartigers. Op dat laatste terrein lag ook hun voornaamste competentie.

Op basis van de ervaringen op de Mathenesserweg werd de tweede stadsetiquette-exercitie, in de straten rondom het Verschoorplein (Tarwewijk Charlois), substantieel anders aangepakt. Behalve dat er voorafgaand aan de exercitie een bewonersonderzoek werd uitgevoerd naar draagvlak, taken/problemen en potentiële actieve betrokkenheid, werd ook van meet af aan een helder onderscheid gemaakt tussen taken/problemen van bewoners waar zij zelf iets aan kunnen doen enerzijds en taken/problemen van overheid en instellingen anderzijds. Voorts werd er vooraf een breed draagvlak georganiseerd bij de deelgemeente en de instellingen en hun werkers. Daarnaast was er in het gebied een opbouwwerker werkzaam die bereid was zich tot 'sociale wever' om te laten smeden en ook na de opstartfase het proces verder te blijven ondersteunen. Hierna worden drie van de voornaamste conclusies uit beide exercities kort beschreven. 


\subsection{STADSETIQUETTE: PROCES EN PRODUCT}

Stadsetiquette, zo blijkt uit de exercities (zie Diekstra et al. 2002: 35-36), is niet alleen een product, de omgangsafspraken of -normen, maar het is vooral ook een proces. Een proces van bewustwording van de rol en de betekenis van eigen gedrag voor de leefbaarheid en van ervaring en vaardigheid in het elkaar aan kunnen spreken op zaken en in het samenwerken met betrekking tot gemeenschappelijke belangen of waarden. Beide, proces en product, moeten in samenhang ontwikkeld en onderhouden worden. Het invoeren van een stadsetiquette in een bepaald gebied staat immers gelijk aan het invoeren van een nieuwe, andere omgangscultuur tussen burgers onderling en tussen burgers enerzijds en overheid en instellingen anderzijds. Dit betekent dat het niet als een project moeten worden gelanceerd en beheerd en gefinancierd, maar als een programma van onbepaalde duur.

\subsection{EIGENAARSCHAP}

Stadsetiquette gaat om omgangsafspraken en samenwerking tussen burgers in hun eigen straat of buurt. Zij zijn de civil scientists, degenen die weten welke gemeenschappelijke belangen ze met elkaar hebben of kunnen hebben en welke de voor hen aanvaardbare en hanteerbare omgangsafspraken en gedragingen daartoe zijn. Zij zijn, kortom, tegelijk schepper en eigenaar van de etiquette. Voorzover anderen, zoals overheid, diensten en maatschappelijke instellingen bij het etiquetteproces betrokken zijn, zijn ze behulpzaam bij dat proces. Dit betekent een voortdurende subtiele dans op het slappe koord tussen afstand houden en steun verlenen. Het betekent ook dat het tempo van het proces het tempo van de betrokken bewoners is en niet dat van de jaarplanning of de evaluatiemomenten van diensten en instellingen.

De meest effectieve garantie dat de betrokken burgers eigenaar blijven van de etiquette is het bestaan en het 'steunen op aanvraag' van een kerngroep van burgers uit de straat of buurt die als 'eersten onder gelijken' fungeert. Anders gezegd, een straatetiquette is niet goed mogelijk als er niet een kerngroep van burgers bestaat of geformeerd kan worden die als initiator en conservator werkzaam wil zijn. Het is van groot belang dat in zulke 'sterspelers' veel wordt geïnvesteerd, zonder dat dit tot (proto)professionalisering leidt.

Bij het maken van straatportretten voorafgaand aan het entameren van stadsetiquette in een buurt of straat waar deze (nog) niet bestaat, is het identificeren van zulke burgers een cruciaal punt van aandacht. Functioneert zo'n kerngroep eenmaal, dan is het van wezenlijk belang om ervoor te helpen zorgen dat taken en middelen/mogelijkheden in een hanteerbaar evenwicht gehouden worden. De ervaring met de 'burgerexperts' laat zien dat het aanbieden van deskundige coaching daarbij een dankbaar aanvaarde en zinvolle ondersteuning is. 


\subsection{HET BETREKKEN VAN JONG EN OUD}

Jongeren, en vooral kinderen, zijn een belangrijke en inspirerende motor van stadsetiquette. Ze zijn belangrijk omdat ze als groep goed te bereiken zijn, vooral via de basisschool. Ze zijn verder belangrijk omdat ze stadsetiquette ook achter de voordeur brengen wanneer hun ouders, om welke reden dan ook, niet of zelden participeren. Op die manier fungeren ze ook vaak als een prikkel voor ouders om op een gegeven moment toch te besluiten aan bepaalde straatactiviteiten mee te doen. Voorts zijn kinderen belangrijk omdat zij, vaak nog meer dan volwassenen, weten wat er wel en niet goed gaat in de straat. Zij maken immers voor een groot deel van hun vrije tijd met andere kinderen gebruik van de straat en de omliggende gebieden. De suggesties voor veranderingen in gedrag en omgangsafspraken waar kinderen mee komen, zetten daarom vaak voor de sociale leefbaarheid de nodige zoden aan de dijk. Bovendien zijn het vaak de kinderen die als geen ander ervaren waar en hoe volwassenen in een straat zich problematisch of conflictueus gedragen. Daarnaast zijn kinderen ook vaak een bron van conflicten en irritaties tussen straatbewoners. Kortom, als kinderen gemotiveerd worden voor en betrokken worden bij het verbeteren van de omgang en de samenwerking in de straat, heeft dit een aanzienlijk effect op de sociale leefbaarheid.

In de Rotterdamse pilot zijn kinderen vooral bij de stadsetiquette betrokken via hun scholen. Daar vonden onder andere 'lagerhuis'-debatten plaats, waarin ze met elkaar omgangsafspraken voor de straat verzonnen en bespraken. Die werden vervolgens concreet vormgegeven in affiches en borden met afspraken en in activiteiten, zoals het als schoolklas schoonvegen van de straat.

Het betrekken van kinderen is verder ook om nog een andere, voor de hand liggende reden van cruciaal belang. Jong geleerd is oud gedaan. Als kinderen houdingen en vaardigheden aanleren, die hen voorbereiden op een actief en betrokken burgerschap, neemt de kans sterk toe dat we in de toekomst generaties zullen hebben voor wie deelname aan een straatetiquette en aan zorg voor de straat gewoon zal zijn. De school lijkt de context bij uitstek om die gedragspatronen te socialiseren.

Het lesprogramma Levensvaardigheden dat door de GGD Rotterdam in de periode 1996-2001 is ontwikkeld en op zijn effecten onderzocht, toont aan dat dit daadwerkelijk mogelijk is. Het programma is bedoeld voor leerlingen in het voortgezet onderwijs (binnenkort is er ook een programma voor het basisonderwijs), en is gemodelleerd naar het programma Skills for Life van de Wereldgezondheidsorganisatie in Genève (Gravesteijn en Diekstra 2003). Het programma wordt door eigen leerkrachten aan de leerlingen gegeven. Die leerkrachten krijgen daarvoor een speciale training (zie tekstbox 6.3).

In de toekomst zouden de scholen die hun leerlingen rekruteren uit gebieden waarin een stadsetiquette wordt ontwikkeld of al loopt, daarom bij voorkeur programma's als Levensvaardigheden als een regulier onderdeel van hun curriculum en cultuur moeten kennen. 


\section{Tekstbox 6.3 Het programma Levensvaardigheden}

De vaardigheden waarin leerlingen middels het programma Levensvaardigheden worden getraind zijn de volgende.

- Zelfbewustzijn en empathie.

- Een positief zelfbeeld vormen en bewust worden van jezelf en de anderen.

- Omgaan met gevoelens, stress en conflicten.

- Creatief denken en kritisch denken.

- Onderscheidingsvermogen, leren nadenken over goed en slecht, waardig-onwaardig, et cetera.

- Leren van je fouten.

- Beslissingen nemen en problemen oplossen.

- Communicatie- en relatievaardigheden.

- Samenwerken, hulp vragen en geven.

Uit het effectonderzoek blijkt dat zowel op de korte als op de lange termijn de leerlingen die Levensvaardigheden hebben gevolgd in vergelijking met de leerlingen die de lessen niet hebben gevolgd:

- een significant groter geloof in hun persoonlijke effectiviteit en een significante toename in hun zelfwaardering ervaren;

- significant minder spanning ervaren bij het uiten van negatieve emoties;

- significant vaker de intentie hebben hun sociale en emotionele vaardigheden te gebruiken;

- een significante verbeteringen in hun relatie met klasgenoten rapporteren (zie verder Gravesteijn e.a. 2004).

\subsection{BELEMMERINGEN EN BEPERKINGEN}

Hoewel de pilot, vanwege opzet en duur, hierin geen volledig inzicht heeft kunnen bieden, is wel duidelijk geworden dat er belemmeringen voor en beperkingen aan het instrument Stadsetiquette zijn. Wat belemmeringen betreft, gaat het vooral om de volgende.

- Als de bevolkingsmobiliteit in een bepaald gebied hoog is, lukt het vermoedelijk niet om zonder een zware inzet van professionals de etiquette gaande te houden. Gezien de schaarsheid van middelen lijkt het dan realistischer om de ambities (de beoogde treden op de straatladder) lager te stellen.

- In gebieden waarin een stadsetiquette is ontwikkeld en geïnitieerd met behulp van professionals, met name als het gaat om een qua bevolkingssamenstelling heterogeen gebied, is een lange adem van diensten, werkers en bewoners vereist voordat de etiquette voldoende tot cultuur is geworden. De follow-up van de pilot rondom het Verschoorplein (medio 2003) laat zien dat bij het ontbreken of inzakken daarvan, de winst van een stadsetiquette-exercitie snel kan verdampen en dat het veel moeite kost deze weer terug te winnen.

- Het onderhoud van een stadsetiquette vergt een cultuuromslag bij diensten en 
instellingen ('de ring rondom de straat'). Kern van die omslag is dat deze diensten de agenda van de straat, de behoeften en vragen van burgers, tot een van de prioriteiten van hun beleid maken en hun budgettering zodanig inrichten dat ze ook snel in staat zijn op legitieme behoeften of vragen in te spelen. Wanneer de cultuuromslag niet (snel) lukt, wordt de etiquette voortdurend bedreigd door de stress van incidenten of botsingen tussen instellingen en burgers.

- Het is voorts van essentieel belang dat ook stadsbreed het belang van stadsetiquette voortdurend op de agenda wordt gehouden. Een nuttige manier daarvoor lijkt te zijn een stel van stadsbrede omgangsregels (minder specifiek dan die voor een straat) vast te stellen en die periodiek onder de aandacht van de hele stedelijke gemeenschap te houden.

\subsection{SLOT: DE TOEKOMST VAN STADSETIQUETTE}

Op basis van de informatie en ervaringen uit en opbrengsten van de pilotstudie en op basis van krantenenquêtes en een gemeentebrede 'Stadsdialoog over Stadsetiquette' (op 18 december 2001) heeft het huidige college van Burgemeester en Wethouders van Rotterdam besloten tot een stedelijk programma 'Mensen maken de Stad', dat in de periode 2003-2006 de ambitie heeft om door combinatie van Opzoomeren en stadsetiquette in een groot aantal straten sociale integratie, sociale cohesie en collectieve zelfredzaamheid op ten minste sport 6 van de straatladder en in een zeer aanzienlijk aantal straten zelfs op sport 8 tot 10 te brengen (zie tabel 6.5).

In de programmabeschrijving (Mensen maken de Stad, 2003) worden de aanpak, methodiek en effectmeting gedetailleerd beschreven. Daarbij wordt onder andere ook aangegeven dat de sleutelfiguren in de (uitvoerings)ondersteuning van bewoners de opbouwwerker, jeugd- en jongerenwerker en buurtagent zijn. Voor de eerste twee categorieën wordt een op het programma toegesneden opleidingsen coachingstraject opgezet. Daarbij is de focus vooral gericht op competenties ten behoeve van herstel van gescheurd en het helpen vervaardigen van gewenst sociaal weefsel tussen mensen en kinderen in hun directe woon- en leefomgeving. 
Tabel 6.5 Doelstellingen Rotterdams collegeprogramma 'Mensen maken de Stad': straataanpak

\begin{tabular}{|c|c|c|c|}
\hline $\begin{array}{l}\text { Acti- } \\
\text { viteit }\end{array}$ & Beoogd effect & $\begin{array}{l}\text { Meetbare } \\
\text { outputdoelstelling }\end{array}$ & $\begin{array}{l}\text { Target (0-situatie en } \\
\text { streefwaarde) }\end{array}$ \\
\hline (a) & $\begin{array}{l}\text { Toename van aantal bewoners in straten die } \\
\text { elkaar kennen en door elkaar gekend worden; } \\
\text { die met elkaar contact onderhouden en } \\
\text { deelnemen aan straatactiviteiten. }\end{array}$ & $\begin{array}{l}\text { Groei van aantal stra- } \\
\text { ten die deelnemen } \\
\text { aan Opzoomeren. }\end{array}$ & $\begin{array}{l}1600 \text { straten (of clusters } \\
\text { daarvan), waaronder } \\
\text { zoveel mogelijk straten } \\
\text { in hotspot-wijken } \\
(0 \text {-situatie }=900)\end{array}$ \\
\hline (b) & $\begin{array}{l}\text { Toename van straten en van aantal bewoners } \\
\text { per straat, zowel volwassenen, jongeren als } \\
\text { kinderen, die aan gezamenlijke activiteiten } \\
\text { deelnemen, omgangsafsafspraken met betrek- } \\
\text { king tot vriendelijk, verantwoordelijk en veilig } \\
\text { gedrag hebben, onderschrijven en uitvoeren, } \\
\text { en zich in hun straat vertrouwd en voor hun } \\
\text { straat verantwoordelijk voelen. }\end{array}$ & $\begin{array}{l}\text { Toename van aantal } \\
\text { straten (of clusters } \\
\text { daarvan) die naast } \\
\text { Opzoomeren ook } \\
\text { deelnemen aan stads- } \\
\text { etiquette (subgroep } \\
\text { van a). }\end{array}$ & $\begin{array}{l}250 \text { straten (of clusters } \\
\text { daarvan), waarvan een } \\
\text { deel in hotspot-wijken } \\
(0 \text {-situatie }=3)\end{array}$ \\
\hline (c) & $\begin{array}{l}\text { Toename van straten/buurten waarin tussen } \\
\text { bewonersinitiatieven/-organisaties enerzijds en } \\
\text { overheid/diensten anderzijds een contract is } \\
\text { gesloten met betrekking tot wie waar verant- } \\
\text { woordelijkheid voor draagt en hoe verantwoor- } \\
\text { delijkheden worden afgestemd en in samen- } \\
\text { werking/complementair worden uitgevoerd. }\end{array}$ & $\begin{array}{l}\text { Toename van aantal } \\
\text { straten (of clusters } \\
\text { daarvan) die naast } \\
\text { Opzoomer ook stads- } \\
\text { etiquette hebben en } \\
\text { in het kader daarvan } \\
\text { afspraken met de over- } \\
\text { heid/diensten hebben } \\
\text { omtrent taakverdeling } \\
\text { en waarin die taakver- } \\
\text { deling duurzaam wordt } \\
\text { onderhouden (sub- } \\
\text { groep van b). }\end{array}$ & $\begin{array}{l}150 \text { straten (of clusters } \\
\text { daarvan), waarvan } \\
\text { zo veel mogelijk straten } \\
\text { in hotspot-wijken } \\
(0 \text {-situatie }=10)\end{array}$ \\
\hline
\end{tabular}




\section{NOTEN}

1 Deze eindtermen werden ontleend aan Great Transitions, een publicatie van de Carnegie Corporation of New York (1995).

2 Met dank aan Johan Janssen, campagneleider Opzoomer Mee.

3 Kenmerk = overheersend kenmerk van omgang in straat naar het oordeel van de meerderheid van de bewoners.

4 Die opbouwwerkster was Ingrid Heijst, thans directeur van de stichting Delphi in de deelgemeente Delfshaven. 


\section{LITERATUUR}

Bandura, A. (1993) 'Perceived self-efficacy in cognitive development and functioning', Educational Psychologist, 28: 117-148.

Bandura, A. (red.) (1995) Self-efficacy in changing societies, Cambridge University Press.

Beer, S. (1994) Beyond Dispute: the Invention of Team Syntegrity, New York: Wiley \& Sons.

Brooks-Gunn, J., G. Duncan en L. Aber (red.) (1997) Neighbourhood Poverty: Context and Consequences for Children. Conceptual, methodological and policy Approaches to studying Neighbourhoods, Volume 2, New York: Russell Sage Foundation.

Carnegie (1995) Great Transitions. New York: Carnegie Corporation of New York.

Diekstra, R.F.W., P. de Heus, M.W. Schouten, I.L.D. Houtman (1994) Werken onder druk: Een onderzoek naar omvang en factoren van werkstress in Nederland, Den Haag: Vuga Uitgeverij/Ministerie van Sociale Zaken en Werkgelegenheid.

Diekstra, R.F.W. , G.A.P. Spierings, A.Vlaanderen (1995) Keerpunten. Naar een geestelijk gezond jeugdbeleid, Rotterdam: GGD, beleidsprogramma preventief jeugdbeleid.

Diekstra, R.F.W., M. Kroon (1997) 'Cars and behaviour: psychological barriers to car restraint and sustainable urban transport', blz. 147-16o in: R. Tolley (red.), The greening of urban transport, Chichester/New York: Wiley.

Diekstra, R.F.W. (1999) Een stad voor elkaar. Uitgangspunten van het sociaal beleid van de gemeente Rotterdam tot het jaar 2010, Rotterdam: Projektbureau GSB-sociaal.

Diekstra R.F.W. (2001) 'Stadsetiquette: aansprekend gedrag in de publieke ruimte', blz. 91-111 in: R.P. Hortulanus, J.E.M. Machielse (red.), Jong Geleerd, Oud Gedaan? Het sociaal debat, Deel 5 .

Diekstra, R.F.W., M. van Toor, M. den Ouden, M. Schweitzer (2002) 'Vriendelijker, Verantwoordelijker en Veiliger. Stadsetiquette: van idee naar programma, Verslag van een pilot', Rotterdam: Rapport Bestuursdienst directie SCZ.

Diekstra R.F.W., J. Janssens (2003) 'Mensen maken de Stad. .. zo gaan we dat doen in Rotterdam', Plan voor de Straataanpak, Gemeente Rotterdam: Bestuursdienst.

Duyvendak, J.W., P. van der Graag (2001) Opzoomeren, Stille Kracht? Een onderzoek naar de kwaliteiten van het Opzoomeren in Rotterdam, Utrecht: Verwey-Jonker Instituut.

Fokkink, P. (200o) Integriteit en Verantwoordelijkheid in het Openbaar Bestuur. Syllabus, Universiteit Twente.

From Neurons to Neighbourhoods: The Science of Early Childhood Development, The National Academies Press, 2000.

Gravesteijn, C., R.F.W. Diekstra (2004) Waardig en Vaardig in het leven, Lisse: Swets \& Zeitlinger.

Gravesteijn, C., R.W.F. Diekstra, E.J. de Wilde, E. Koren (2004) ‘Effekten van een vaardigheidsprogramma voor adolescenten', Tijdschrift Kind en Adolescent [te verschijnen].

Hofstede, G. (1991) Allemaal Andersdenkenden. Omgaan met cultuurverschillen, Amsterdam: Uitgeverij Contact.

Müller, Th. (2003) 'Je moet de groeten hebben', Tijdschrift voor de Sociale Sector, april 2003: 10-15. 
Raad voor Maatschappelijke Ontwikkeling (2002) Geen woorden maar daden. Bijdrage aan het normen- en waardendebat, Den Haag: RMO.

Sampson, R.J., S.W. Raudenbush, F. Earls (1997) 'Neighborhoods and violent crime: A multilevel study of collective efficacy', Science, 277 (Aug. 15): 918. 


\title{
7 DE DYNAMISCHE GEMEENTE
}

\author{
J.van Lidth de Jeude
}

\subsection{OVER NORMEN EN WAARDEN OP LOKAAL NIVEAU}

De vraag of het in onze samenleving slechter gesteld is met de waarden en normen dan vroeger is moeilijk te beantwoorden. Eén ding is echter wel duidelijk: de samenleving is veel dynamischer, hectischer en opener geworden. Bij de vraag welke rol de gemeente kan spelen bij de overdracht van bepaalde waarden en normen en de handhaving daarvan, is het dan ook vooral dit aspect van 'de dynamische samenleving' waar ik op in wil gaan.

\section{De dynamische samenleving}

In de tweede helft van de twintigste eeuw is de dynamiek in de (Nederlandse of westerse) samenleving enorm toegenomen. Door het wegvallen van de zuilen namen interacties toe, werden zekerheden minder 'zeker' en waarden en normen minder vanzelfsprekend. Door de ontwikkeling van de media (tv, ICT) werd de hoeveelheid informatie verveelvoudigd, door de toegenomen welvaart ging men meer reizen, door het hogere gemiddelde opleidingsniveau namen de ontwikkelingsmogelijkheden toe en door technische hulpmiddelen kwam tijd vrij voor interactie. De positieve effecten hiervan zijn een meer open samenleving, met grotere individuele ontplooiingsmogelijkheden, toename van de mogelijkheden om van materiële en culturele welvaart te genieten. De keerzijde van de medaille is de toename van (individuele) onzekerheden, verlies aan gemeenschapszin en een toename aan materiële competitie met maatschappelijke verharding, dropouts en agressie. De rol van de (lokale) overheid op het punt van normen en waarden moet aansluiten bij de dynamiek van de samenleving. Dat betekent geen blauwdrukken of centrale sturing, maar het stimuleren van gewenste ontwikkelingen en bij het handhaven van normen het tot stand brengen van partnerschap tussen de overheid en de andere actoren in de samenleving.

\section{Dynamiek}

Een zich dynamisch ontwikkelend systeem kent meestal verschillende soorten dynamiek. De gewone 'lineaire' dynamiek, dat wil zeggen dat de veranderingen in de ontwikkelingen van het systeem tengevolge van beïnvloeding van het systeem van dezelfde orde van grootte zijn als de mate van beïnvloeding. Niet-lineaire dynamiek, wat inhoudt dat kleine 'oorzaken' grote gevogen kunnen hebben, waarbij een toename van beïnvloeding zeer grillige veranderingen kan geven en het systeem derhalve onvoorspelbaar is. Een derde vorm van dynamiek is de 'attractor' ofwel de aantrekker: dat wil zeggen dat de 'loop' van het systeem moeilijk te beïnvloeden is en dat eigenlijk alleen effect gesorteerd kan worden als de 'attractor' door een andere wordt vervangen. De meeste complexe systemen bevatten alle drie de vormen van dynamiek. Bij een evenwichtig dynamisch systeem leidt dat tot een complex adaptief systeem, 
dat wil zeggen een systeem dat door leren en evalueren tot 'hogere' ontwikkeling komt.

\section{De rol van de lokale overheid bij normen en waarden}

In deze bijdrage geef ik geen compleet beeld van de rol van de lokale overheid bij normen en waarden, maar beperk ik mij tot twee in mijn ogen belangrijke aspecten. Hoe kan de lokale overheid positieve waarden als creativiteit, gemeenschapszin, schoonheid en affiniteit met de natuur stimuleren? Hoe kunnen mensen ondersteund worden bij het leren leven met onzekerheden? Hoe kunnen andere vormen van intelligentie dan de cognitieve tot ontplooiing komen? Dit mondt uit in een pleidooi voor meer kunst op de basisschool.

De samenwerking tussen de overheid (politie, justitie, toezichthouders) en de andere actoren op buurt- en wijkniveau bij het handhaven van normen. In dit deel (onder)scheid ik de normen van de waarden, in die zin dat mijns inziens verscheidenheid in waarden alleen maar waardevol is, maar normen gebaseerd op diverse waarden wel eenduidig moeten zijn of worden. Hierbij pleit ik voor een handelwijze conform de Deventer wijkaanpak. Dit is een aanpak waarin de burgers centraal staan, een eigen verantwoordelijkheid hebben en waarin burgers en overheidsinstanties samenwerken.

\subsection{OVERHEID ALS STIMULATOR VAN CREATIVITEIT: MEER KUNST OP DE BASISSCHOOL}

De kwaliteit van een samenleving en de houding ten opzichte van waarden en normen worden niet alléén bepaald door de welvaart (economisch en financieel) en het democratische gehalte (kritische pers en participatie), maar vooral ook door de plek die de kunst inneemt in de samenleving. Het wegvallen van de zuilen heeft enerzijds vanzelfsprekende culturele inbeddingen doen wegvallen en anderzijds de dynamiek verhoogd, wat zowel positieve gevolgen heeft, namelijk grotere individuele verscheidenheid en ontplooiingsmogelijkheden, maar ook de onzekerheid voor mensen heeft vergroot.

Meer aandacht voor kunst in de opvoeding en op school kan zowel de culturele verschraling compenseren als kinderen mogelijkheden bieden om te leren omgaan met onzekerheden in het leven. Bovendien kan aandacht voor kunst in een multiculturele samenleving de ontmoeting tussen culturen versterken en op positieve wijze bijdragen aan de identiteit van individuen in een multiculturele context. Daarnaast kan de ontwikkeling van kinderen beter gestimuleerd worden als rekening wordt gehouden met de verschillende 'soorten' intelligenties waar kinderen over kunnen beschikken.

Ten gevolge van de wetenschappelijke ontwikkelingen (bijv. de mechanisering van het wereldbeeld), de industrialisering en de economisering vormt de cognitieve benadering van intelligentie de boventoon. Hieraan kleven verschillende 
nadelen. Ten eerste het zelfversterkende effect: mechanisering, industrialisering en economisering versterken de cognitieve benadering van intelligentie, die op haar beurt weer de mechanisering, industrialisering en economisering versterkt. Daarnaast is het voor heel veel kinderen die grotere mogelijkheden hebben in andere aspecten van intelligentie, jammer dat hun weinig mogelijkheden geboden worden die andere aspecten te versterken en zullen hun mogelijke kwaliteiten ondergewaardeerd worden in hun sociaal functioneren.

Er zijn verschillende vormen van intelligentie te onderscheiden (vgl. H. Gardner 1984: 73-277).

De verbaallinguïstische intelligentie. Deze intelligentie gebruikt men als men in, met en over woorden denkt. Mondelinge en geschreven taal zijn symbolen waarin deze intelligentie zich uitdrukt en ontwikkelt. Leerlingen die gevoelig en ontvankelijk zijn voor talige informatie, zijn sterk in deze vorm van intelligentie.

Logisch-mathematische intelligentie. Men gebruikt deze intelligentie om te denken in, met en over cijfers en verbanden. Kinderen met deze intelligentie vinden het leuk uitkomsten te kwantificeren, verbanden vast te stellen, abstract te denken etc. Ook het creëren van, denken over en oplossen van problemen, het analyseren van objecten en situaties en het gebruikmaken van abstracte symbolen zijn typerend voor deze intelligentie.

Visueel-ruimtelijke intelligentie. We gebruiken deze intelligentie om in en over visuele voorstellingen te denken. Tekenen, beeldhouwen, het arrangeren van objecten en navigeren zijn hier uitdrukkingen van. Een leerling die hierin sterk is, neemt de werkelijkheid waar via beelden en kleuren en geeft blijk van kunstzinnige talenten. De leerling kan bijvoorbeeld goed schilderen of tekenen, is goed met klei, zand en papier en bouwt bijvoorbeeld eigen speelgoed of maquettes. Met andere woorden: deze leerlingen zijn sterk in het vormgeven of het combineren van kleuren. Vaak zijn ze ook goed in het vinden van de weg.

Muzikaal-ritmische intelligentie. We gebruiken deze intelligentie om in, met en over muziek te denken. Het kan het bespelen van instrumenten, liedjes zingen, muziek leren, het componeren van melodieën en het waarderen van muziek omvatten. Leerlingen die snel melodietjes oppikken, veel neuriën, op de tafel trommelen en graag een muziekinstrument spelen laten affiniteit met deze intelligentie zien. Soms werken ze met ezelsbruggetjes of rijmpjes om iets te onthouden en vinden ze het prettig met muziek op de achtergrond te werken.

Lichamelijke-kinesthetische intelligentie. We gebruiken deze intelligentie om te denken in, over en met bewegingen en gebaren. Het leren op basis van en door fysieke ervaringen is typerend hiervoor. Een leerling die hierin uitblinkt, heeft een goede controle over het eigen lichaam (lichaamsbesef, grove en/of fijne motoriek). Een dergelijk kind valt op in de gymles, is goed in klimmen en heeft een goede coördinatie, wat zich uit in het goed kunnen jongleren, voetballen, goochelen of dansen. 
Naturalistische intelligentie. Leerlingen met deze intelligentie voelen zich sterk aangetrokken tot planten, dieren, landschappen en natuurlijke fenomenen. Ze hebben oog voor ecologie; de wederzijdse afhankelijkheid van planten, dieren en omgeving. Daarmee is verbonden het vermogen om snel overeenkomsten en verschillen waar te nemen en te classificeren. Ze observeren en hebben naast oog voor detail ook interesse in grotere gehelen (bijv. het weer, het milieu, de natuurbescherming).

Interpersoonlijke intelligentie. Interpersoonlijke intelligentie houdt het natuurlijke vermogen tot empathie in. Leerlingen die hierin sterk zijn, genieten van werken met, zorgen voor en leren met anderen. Hun wereld ligt in het communiceren, het contact hebben en het betrokken zijn met anderen. Deze leerlingen hebben een goed ontwikkeld vermogen om zich te verplaatsen in een ander en zijn gevoelig in het oppikken van sociale signalen uit hun omgeving. Ze vinden het leuk om samen te werken en ervaringen uit te wisselen en leren het best door middel van interactie. Het zijn groepsmensen, ze maken makkelijk vrienden en krijgen op school waarschijnlijk veel waardering voor hun sociale karakter, mits ze niet bazig worden.

Intrapersoonlijke intelligentie. Zoals de interpersoonlijke intelligentie zich naar buiten richt, naar andere individuen, zo richt de intrapersoonlijke intelligentie zich naar binnen, naar iemands eigen innerlijke belevingswereld, zijn stemmingen en gevoelens. Een leerling met een sterk ontwikkelde intrapersoonlijke intelligentie stelt zich graag wat op de achtergrond, kan verlegen zijn, leeft in een eigen wereld en houdt van dagdromen. Dit kind houdt ervan na te denken over eigen gevoelens, ideeën, stemmingen en de dingen die hem bezighouden. Het heeft het vermogen de eigen persoonlijkheid, inclusief de minder goede karaktereigenschappen, te respecteren en te waarderen. Het houdt van afzondering, stilte, contemplatie, reflectie en van de gelegenheid om innerlijk ervaringen en gedachten te verkennen. Het is gevoelig voor poëzie en filosofie. Het neemt zijn omgeving scherp waar en kan daar last van hebben (te veel voelsprieten).

Om andere aspecten dan mechanisering, industrialisering en economisering in de samenleving te versterken en om kinderen in staat te stellen ook andere eigenschappen dan cognitieve intelligentie te ontplooien (zowel belangrijk voor individuen als voor de samenleving), moet meer aandacht gegeven worden aan kunst op de basisschool. Voor we toekomen aan de beantwoording van de vraag hoe, volgt nog één praktisch aspect namelijk: dagindeling en de brede school.

\section{Dagindeling en de brede school}

Tussen 1980 en nu is de participatie van vrouwen in betaald werk gestegen van veertig procent naar zeventig procent. Dit is - in sommige opzichten helaas - niet gepaard gegaan met een even grote toename van het aandeel van mannen in het huishouden. Voor tweeverdieners en alleenstaande ouders betekent dit dat het combineren van werk en privé steeds meer problemen oplevert. Dit heeft geleid tot een enorme toename van (de behoefte aan) voor-, tussen- en naschoolse 
opvang, onder andere gerealiseerd in zogenaamde brede scholen waar overigens naast onderwijs en opvang vaak nog sprake is van een scala van andere sociaalculturele activiteiten voor jong en oud. Al deze opvang buiten schooltijd geeft grote mogelijkheden voor kwaliteitsopvang in de vorm van kunst en sport.

\title{
Meer kunst
}

Het stimuleren van kunst op de basisschool kan op drie manieren. Ten eerste meer aandacht aan kunst in de opleiding, dat wil zeggen op de PABO's (en ROC's). Dit moet ertoe leiden dat de basisschoolleraren én meer openstaan voor andere vormen van intelligentie dan de cognitieve én over meer vaardigheden beschikken om bij de leerlingen die andere vormen te ontwikkelen. Ten tweede kan nog veel meer dan nu al vaak gebeurt, gebruikgemaakt worden van kunstenaars, kunstdocenten bij нво еn Мво, kunststudenten bij нво еn мво, muziekschooldocenten enz., om die in te zetten bij (additionele) activiteiten in het basisonderwijs. Ten derde zouden (om te beginnen) vijfduizend docenten (muziek, drama, beeldend) ingezet kunnen worden om zowel in het onderwijs als in de 'opvang' buitenschools (maar wel op school of aan school gelieerde opvang) een rol te spelen. Door samenwerking tussen РABO's en НВО-instellingen voor kunstonderwijs kan ook de kwaliteit van het eerste en het derde punt bevorderd worden.

\subsection{OVER HET HANDHAVEN EN HET NALEVEN VAN DE REGELS}

\section{Normen en waarden in historisch perspectief}

Het is goed te beseffen dat het bij normen en waarden om een steeds terugkerend thema gaat. Een opvallende gelijkenis vertonen de volgende passages, waarbij de eerste van Erasmus is (zo'n vijfhonderd jaar geleden) en de tweede uit de Volkskrant van 28 december 2002 komt van de hand van Bas van Stokkom.

\begin{abstract}
"Zoals het niet past dat er in het gezin wulpse taal gehoord wordt, zo past het evenmin daarin wellustige schilderijen te hebben. Het zwijgende schilderij is immer zeer welsprekend en geleidelijk kruipt het in de geest van de mensen naar binnen. En welk soort schandelijkheid beelden heden ten dage de schilders en beeldhouwers niet uit? Met dat soort geneugten versieren sommigen hun woonvertrekken, alsof de jeugd gebrek heeft aan prikkels tot het kwaad. Waarom ontbloot je op een schilderij die ledematen die je uit schroom verbergt? En als je het niet veilig oordeelt voor de zedigheid van je zonen en dochters als ze die zouden zien, waarom wil je dan dat je kinderen die steeds voor ogen hebben" (Erasmus 1508).
\end{abstract}

\footnotetext{
"Te midden van nonchalante mensen worden attentie en wellevendheid ontmoedigd. Door intieme dingen te vertellen worden we ongewild deelgenoot van delicate of compromitterende private ervaringen. Ook bij opzichtige vormen van body performance inclusief piercings en tatoeages kun je vraagtekens plaatsen. Met name halfnaakte meisjes die in videoclips op popzenders optreden hebben een voorbeeldwerking. Door de erotiserende kleding verplaatst de aandacht zich naar hun seksuele gebruikswaarde” (Van Stokkom 2002).
} 
Belangrijker dan deze commentaren op de zedelijkheid zijn mijns inziens de opmerkingen over normen en waarden bij het omgaan met elkaar. Erasmus pleit in zijn geschriften voor de dialoog tussen mensen, voor het zelfstandig nadenken van mensen, tegen een autoritaire uitleg van de bijbel en voor solidariteit met de armen. Ter illustratie hiervan een passage uit Lof der Zotheid.

\begin{abstract}
"En onlangs woonde ik persoonlijk, zoals zo vaak, een theologisch dispuut bij en hoorde daar wat volgt. Iemand vroeg waar in de Schrift de beslissende passage voorkomt volgens welke een ketter bekeerd moet worden door de brandstapel in plaats van door een dialoog. Daarop hield een vijandige grijsaard hem verontwaardigd voor - reeds zijn hoogmoedige wenkbrauwen verrieden de theoloog: 'Dat heeft de apostel Paulus geboden, want hij zegt: Haereticum hominem post unam et alteram correptionem devita!' Niemand begreep het, want het betekent: 'Een mens, die scheuring maakt, moet gij, na hem een en andermaal terechtgewezen te hebben, afwijzen.' De grijsaard smeet intussen met donderende stem deze zin er steeds maar weer uit, zodat men zich al begon af te vragen of hem misschien iets was overkomen, tot eindelijk het raadsel werd opgelost: 'devita' (wijs af) had zich in zijn vindingrijke hoofd in twee woorden (de vita) gesplitst, wat dan evenwel "van het leven" betekent, en fluks had hij aangevuld 'moet men hem beroven'. Nu lachten sommigen, maar anderen vonden deze slimme vondst goed theologisch” (Erasmus 1508).
\end{abstract}

Ik citeer in dit verband ook weer Bas van Stokkom.

"Een fatsoenlijke samenleving heeft behoefte aan grenzen. Het gaat bij zelfbeheersing niet om de aloude christelijke betekenis van zelfontkenning, maar van zelfrelativering. Het gaat om een herontdekking van het menselijk tekort: het leren omgaan met onzekerheden, het ontwikkelen van scepsis en zelfspot, en bovenal het vermogen om eigen en andermans machtsaanspraken te doorzien. Maar dat is niet genoeg. We hebben ook de plicht elkaar goed te behandelen. De Amerikaanse rechtsgeleerde Stephen Carter wijst er in zijn boek Civility. Manners, morals and the etiquette of democracy op dat beschaving twee aspecten heeft: generositeit, ook wanneer dat kosten met zich meebrengt, en vertrouwen, ook wanneer er risico's zijn. Opoffering betekent dingen doen of nalaten, ook als we dat liever niet zouden willen: het opgeven of opschorten van bepaalde wensen, mijn kalmte bewaren als ik alle reden heb boos te zijn, een buurman groeten die ik eigenlijk niet mag. Luisteren en anderen laten uitpraten is ook een opoffering: we moeten meningen aanhoren die we niet delen en soms verafschuwen, en we staan open voor de mogelijkheid van andermans gelijk. Het gaat om kleine giften: helpen, even oppassen, elkaar aanspreken, concessies bieden. Daardoor kunnen sociale betrekkingen van spanningen worden ontdaan, kunnen fouten worden hersteld en wordt samenwerking gegenereerd. Kleine vormen van geven en vergeven zijn de smeerolie van het openbare leven" (Van Stokkom 2002).

De inhoud van onze gemeenschappelijke waarden en normen was enkele decennia geleden directer dan nu vanwege het verdwijnen van de verzuiling en de verzorgingsstaat, waarbij onder meer door religieuze en andere verbanden, bijvoorbeeld 'de rode familie', een grotere saamhorigheid bestond. De laatste twintig jaren zijn zelfredzaamheid en individualisering kernbegrippen geworden, met als gevolg dat sociale controle en traditionele gezagsverhoudingen zijn verdwenen. Dat heeft ook grote voordelen. De vroegere groepsnormen konden ook verstikkend en geestdodend werken. Maar volgens P.H. Donner, de huidige 
minister van Justitie, leidt deze ontzuiling tot een verzwakking van wat bindt: gemeenschappelijke waarden, algemene belangen en een herkenbare maatschappelijke identiteit.

Ten slotte: ik vind het vanzelfsprekend hanteren van de term waarden en normen in één adem op veel plaatsen 'ongepast'. Waarden mogen sterk verschillen per groep of per individu. Dat is zelfs wenselijk, het maakt de samenleving levendig en interessant. De normen - gebaseerd op waarden - moeten echter zodanig overeenstemmen dat intermenselijk verkeer op een goede wijze kan plaatshebben. Het probleem is ook meestal niet dat de geaccepteerde normen in de verschillende groepen erg zouden verschillen, het probleem is dat binnen groepen subgroepen en individuen zich niet houden aan de algemene geaccepteerde normen. Over hoe daarmee om te gaan gaat de volgende paragraaf.

\section{Een analyse van Gabriël van den Brink}

Onlangs heeft de filosoof Gabriël van den Brink hierover een interessante analyse gegeven. Daarbij heeft hij zichzelf de vraag gesteld of, en zo ja op welke wijze, de ontwikkelingen van de laatste decennia gekeerd kunnen worden, zodat er weer sprake is van fatsoen, sociale controle en het naleven van regels. Volgens hem valt het tij nog te keren, maar daarvoor is een nieuwe cultuur noodzakelijk. Die

cultuur heeft hij verwoord in de vorm van een tiental nieuwe geboden. Ik ga niet op alle tien geboden in, maar enkele daarvan zijn zodanig interessant en actueel dat ik deze kort wil toelichten (Van den Brink 2002). Een van de geboden is dat we onze gedragsregels van het sociale leven expliciet moeten maken. Voor iedereen moet helder zijn wat wel en wat niet mag. Het publieke domein komt soms over als een jungle waarin alles schijnt te mogen, waarbij verschillende regels gelden afhankelijk van tijd en plaats. In feite is dit een pleidooi voor transparante regels waarmee niet gemarchandeerd wordt. De grens van wat geaccepteerd wordt, moet niet hoger of anders liggen op zondagmiddag bij een voetbalwedstrijd dan op iedere andere middag.

Een ander gebod sluit daarop aan door de verantwoordelijkheid voor het toezicht op de naleving van gedragsregels op een ondubbelzinnige manier te regelen. Voor wat betreft de openbare ruimte is dit aspect vaak zeer diffuus en wordt door verschillende organisaties geregeld.

Verder pleit Van den Brink voor 'prepressie' (een combinatie van preventie en repressie), voor het formuleren van doelen, voor heldere verantwoordelijkheid, voor toezicht en handhaving, voor opvoeding (het doorleven van regels en niet van bovenaf opleggen), voor de juiste schaal (mensen moeten elkaar 'kennen'), voor proportionaliteit bij de correctie van wangedrag, voor de pedagogische dimensie bij het handhaven van regels, voor betrokkenheid (een juiste verhouding tussen liefde en gestrengheid) en voor het versterken van de mogelijkheden van burgers conflicten op te lossen of daarbij in te grijpen. Ten slotte stelt Van den Brink dat we ernaar moeten streven dat er een betere afstemming moet zijn over de regels die gelden in de verschillende domeinen. Gelden er op school, bij 
het uitgaansleven, binnen de sportclub niet vaak verschillende regels? (Van den Brink 2002).

\section{De Deventer wijkaanpak}

De analyse van Van den Brink lezende kwam ik tot het besef dat zijn pleidooi voor het expliciteren van regels, de discussie daarover en het versterken van de mogelijkheden van burgers conflicten op te lossen of daarbij in te grijpen verankerd is in de Deventer wijkaanpak. De Deventer wijkaanpak is gebaseerd op de copernicaanse wending. Niet het handelen van de instituties staat centraal, waarbij burgers betrokken worden, maar het handelen van de burgers staat centraal, waarbij instituties worden betrokken. Het jaarlijks panellen per straat en de discussies in de wijkteams over de prioriteiten van menskracht van de instellingen zijn regelmatig pure discussies over normen, over de inhoud van de normen, over het belang van de handhaving daarvan en over sociale controle of cohesie. Niet voor niets is hieruit een florerend buurtbeheerbedrijf ontstaan, genaamd Cambio. Een mooi voorbeeld is het net afgeronde proces waarbij burgers en ondernemers 50 procent van de inzet van de Deventer afdeling toezicht hebben bepaald. Bij deze afdeling werken 60 mensen: 40 stadswachten en 20 milieu- en parkeerinspecteurs. Samen goed voor 60 x 1600 uren op jaarbasis. De helft daarvan, 48 .ooo uur, is verdeeld over de zes Deventer wijken. De bedoeling was en is dat, net zoals in de wijkaanpak algemeen, bij de verdeling van de inzet ook discussie ontstaat over de regels en situaties als zodanig en over 'wat kunnen de mensen er zelf aan doen', zodat ook hier weer discussies ontstaan over normen en waarden.

\section{Vermaatschappelijking van de politie}

De trend steeds meer met prestatiecontracten tussen overheid en politie te werken heeft ook grote nadelen. De suggestie ontstaat dat de politie (en justitie) voor veiligheid en orde moeten zorgen in plaats van dat het moet gaan om een gezamenlijke opdracht. Goede ontwikkelingen in dat verband zijn: het steeds meer territoriaal gericht gaan werken (politie en wijkteams), de interactie tussen politie en burgers in de vorm van peilstokacties (politie geeft burgers gelegenheid hun ureninzet te bepalen), klantengroepen (politie overlegt regelmatig met burgers) et cetera. Deze ontwikkelingen doen recht aan de gezamenlijke verantwoordelijkheid en stimuleren inhoudelijke discussies over waarden en normen. 


\section{LITERATUUR}

Brink, G. van den (2002) Toezicht en betrokkenheid, Christen Democratische Verkenningen, blz. 15-22, december 2002, Wetenschappelijk instituut voor het CDA, Den Haag.

Erasmus, D. (1508) Lof der Zotheid, vertaald door J.B. Kan, ed. 1912, Utrecht, Het Spectrum: z.j.

Gardner, H. (1984) Frames of Mind, the theory of multiple intelligences. Londen: Heinemann.

Stokkom, B. van 'Een fatsoenlijke samenleving heeft behoefte aan grenzen', de Volkskrant, 28 december 2002, Open Forumpagina. 


\title{
8 OPVOEDING EN DE OVERDRACHT VAN WAARDEN EN NORMEN
}

\author{
B. Levering
}

\subsection{VOORAF}

Een twintigtal jaren was het stil geweest rond de problematiek van waarden en normen in de opvoeding. In die periode gold het zelfs als een truttig onderwerp, dat herinnerde aan de moraliserende houding op allerlei gebied die men voorgoed achter zich had gelaten. Het proces van individualisering, dat in de jaren zestig in een stroomversnelling was geraakt, had inderdaad bewerkstelligd dat algemene aanspraken op het morele gebied verstomden. Iedereen moest het zelf maar uitzoeken. Theoretisch pedagogen zagen na 1970 resoluut af van de formulering van een algemeen opvoedingsdoel (Levering 1986). De theoretische pedagogiek bleef wel geïnteresseerd in normatieve kwesties, maar trok zich terug op metaethisch niveau (Steutel 1984; Van Haaften 1986).

Eind jaren tachtig werd er door politici weer voor het eerst over gesproken. Tegen de achtergrond van de gestegen jeugdcriminaliteit spraken de toenmalige minister-president Lubbers en minister van Justitie Hirsch Ballin opvoeders en pedagogen aan om weer waarden en normen over te dragen. Minister van Onderwijs Ritzen sloot zich daar later bij aan door de discussie over de pedagogische opdracht van de school te openen. Het ging om overdracht van waarden en normen en hernieuwde aandacht voor morele opvoeding in de strijd tegen de jeugdcriminaliteit. Hier deed zich een probleem voor. Als de opdracht tot voorkoming van jeugdcriminaliteit bij de opvoeding wordt neergelegd, wordt de opvoeding namelijk schromelijk overvraagd. Het verschijnsel jeugdcriminaliteit is ingebed in een complex van maatschappelijke oorzaken waarin de opvoeding slechts een bescheiden rol vervult. Dat betekent natuurlijk niet dat opvoeders geen verantwoordelijkheden op het gebied van de morele opvoeding zouden hebben. Het betekent ook niet dat het wel goed zit met de morele opvoeding door de Nederlandse ouder. Leerkrachten - in het basisonderwijs en in het voortgezet onderwijs - klagen, ook vandaag de dag, dat heel veel ouders op dat gebied veel te veel verantwoordelijkheden richting school schuiven.

Een verzoek om een discussiebijdrage te leveren voor het te schrijven WRRrapport over waarden en normen in Nederland vormt voor een pedagoog een mooie uitdaging, maar veroorzaakt toch ook enige aarzeling. De problematiek van de overdracht van waarden en normen is een bij uitstek pedagogisch onderwerp, maar ondanks het feit dat de jaren negentig bol gestaan hebben van discussies over het onderwerp, lijken er maar weinig echte vorderingen te zijn gemaakt. En als het om de problematiek gaat die er steevast mee verbonden wordt, de toestand van de jeugd, zijn er al tal van adviezen uitgebracht. In dergelijke adviezen is de verhouding tussen wetenschap en politiek in het geding en daarover 
moet in dit vooraf kort iets worden gezegd. Er zijn natuurlijk wetenschappers die zich door het politiek bestuur laten inhuren om voorgenomen overheidsbeleid empirische legitimatie te verschaffen. Dit heeft bijvoorbeeld in de onderwijskunde geleid tot veel onderzoek dat zich al te trouw in het verlengde van dat overheidsbeleid opstelde. Deze bijdrage zal kritisch zijn. Ook is het van belang te onderstrepen dat het empirische materiaal dat door wetenschappelijk onderzoek wordt aangeleverd, niet als zodanig tot (politiek-)normatieve standpunten leidt. Aan normatieve standpunten kan de wetenschap de politiek niet helpen. Anders gezegd: de normatieve standpunten waarmee de wetenschapper de politiek verrijkt had hij in het algemeen al voordat hij aan het onderzoek begon. Dit laatste kan met het volgende voorbeeld worden verduidelijkt.

In juni 1993 werd onder de titel 'Het gaat goed/slecht met de jeugd' aan de universiteit van Leiden een debat georganiseerd naar aanleiding van het verschijnen van twee landelijke rapporten over de toestand van de Nederlandse Jeugd. Ter tafel lagen Jongeren op de drempel van de jaren negentig van de Universiteit Utrecht en het Sociaal en Cultureel Planbureau en Jeugd in ontwikkeling van de Wetenschappelijke Raad voor het Regeringsbeleid. De discussie tussen de Leidse hoogleraren R.F.W. Diekstra en G.A. Kohnstamm was het felst. Beide rapporten kenden vergelijkbare feitelijke uitkomsten. Met tachtig procent van de Nederlandse jeugd blijkt het goed te gaan. Met twintig procent gaat het slecht. Het verschil in opvatting tussen Diekstra en Kohnstamm reikte verder dan de vraag of het nu veel of weinig is, als we moeten constateren dat het met eenvijfde deel van onze jeugd niet goed gaat. De door de redacteur van de WRR-voorstudie, Diekstra, naar aanleiding van de cijfers voorgestelde maatregelen waren ingrijpend. Hij achtte de oprichting van een Nationaal Centrum voor Opvoeding en Ontwikkeling geboden. In het voortgezet onderwijs zou een leerlingenvolgsysteem voor psychosociale problemen moeten worden ingevoerd. De overheidsbemoeienis zou zich, gezien de ernst van de problemen, niet tot preventieve interventie moeten beperken, maar ook postventieve of correctieve interventie werd door Diekstra noodzakelijk geacht.

Kohnstamm wilde hier niets van weten. Hij had, zoals dat onder wetenschappers gebruikelijk is, vanzelfsprekend methodologische kritiek op het rapport van Diekstra en achtte de uitkomsten ervan op die gronden aanvechtbaar. Maar dat was niet zijn belangrijkste kritiek. Ook zijn opvatting dat monitoring van psychosociale problemen, in tegenstelling tot die van lichamelijke problemen of schoolvorderingen, gevaarlijk is, omdat daarbij normatieve kwesties in het geding zijn, staat uiteindelijk niet op zichzelf. Het is evident dat Kohnstamms opvatting over de vraag of de overheid zich al dan niet actief met jongeren met psychosociale problemen zou moeten bemoeien steunt op een liberaal idee over de inrichting van de samenleving. Het bijzondere hiervan is dat hierdoor zichtbaar wordt dat zo'n sociaal-politieke stellingname voorafgaat aan de interpretatie van het empirische feitenmateriaal. 
we nu als een communitaristische zouden kenmerken, te verbergen. "Zolang er op de wereld nog één ontheemde rondloopt, kan ik niet gelukkig zijn”, zei Diekstra, en liet zich daarmee onomwonden kennen als een soort moderne seculaire pastor. En dat betekent dat het verzamelde feitenmateriaal, waarin eenvijfde deel van de Nederlandse jongeren te kennen gaf dat het niet goed met hen ging, niets zegt over de politieke vraag of de overheid daarmee al dan niet bemoeienis dient te hebben. Over die vraag wordt op een ander niveau beslist.

Dit stuk is geschreven vanuit de overtuiging dat de overheid een bijdrage dient te leveren aan het waarden- en normendebat in de opvoeding, maar dat haar rol daarin niet moet worden overschat. Het oorspronkelijk voornemen van het kabinet-Balkenende I over dit onderwerp leek aan die overschatting te lijden. Een brede discussie over waarden en normen heeft natuurlijk pas echt zin wanneer na bereikte consensus de overdracht ervan een vanzelfsprekendheid zou zijn. In de eerste plaats probeer ik te achterhalen wat 'ware' morele kennis is en ontwikkel op grond daarvan een kritiek op bestaande theorieën van morele ontwikkeling en opvoeding. In de tweede plaats probeer ik te laten zien dat overdracht van waarden en normen nu juist geen vanzelfsprekende zaak is en probeer ik te achterhalen waar dat primitieve beeld van waarden- en normenoverdracht vandaan komt. Ook besteed ik daarbij aandacht aan de houdbaarheid van algemene opvoedingsdoelen. Vervolgens maak ik de balans op van de overheidsbemoeienis met de opvoeding in de afgelopen halve eeuw. Door daarna aandacht te besteden aan veranderingen in de omgang tussen ouders en kinderen kan het lastig begaanbare gebied van de waarden- en normenoverdracht en de morele opvoeding op originele manieren worden betreden. Het wijzen van die originele ingangen is meer dan eens niet gebaseerd op resultaten van afgerond wetenschappelijk onderzoek, maar toont soms juist de noodzaak ervan, zoals dat in een discussiebijdrage past. Vervolgens wil ik aandacht besteden aan de spanning tussen theorie en praktijk door terug te gaan naar mijn ervaringen als welzijnswethouder met een anti-vandalismeproject in een kleine Nederlandse gemeente aan het begin van de jaren negentig. Slechts zelden krijgt een wetenschapper zo de kans om theorieën in de praktijk te toetsen. Slechts zelden wordt de weerbarstigheid van het overheidsbedrijf zo goed zichtbaar. Ten slotte zet ik mijn bevindingen op een rij.

\subsection{OVER 'WARE' MORELE KENNIS}

Er zijn veel objecten van sociaal-wetenschappelijk onderzoek die door wetenschapstheoretische discussies of andersoortige theoretische richtingenstrijd onzichtbaar zijn geworden. Dat probleem is wat het gebied van de waarden- en normenoverdracht in de opvoeding betreft - wellicht zonder dat hij het zichzelf bewust was - in $195^{8}$ definitief opgelost door de Britse filosoof Gilbert Ryle. Op zoek naar de ware aard van morele kennis schreef hij een analyse onder de welluidende titel On forgetting the difference between right and wrong. Het was Ryle opgevallen - de originele wijze van redeneren past in de toen in zwang zijnde 
ordinary language-benadering - dat het vreemd is om te zeggen dat je het verschil tussen goed en kwaad vergeten bent. Dus stel dat je op het nakomen van een belofte wordt aangesproken, dan is het niet goed voorstelbaar dat je zegt: "O sorry, ik was even vergeten dat je je aan je beloften moet houden."

Ryle werkt in zijn analyse de verschillende vormen van kennis en de mogelijkheid om deze te vergeten systematisch af. Het zal duidelijk zijn dat we propositionele kennis kunnen vergeten. Het klinkt ongelooflijk maar het is mogelijk om te vergeten dat Groningen de hoofdstad van Groningen is. Door het vergeten van feiten en namen veranderen we overigens niet als persoon, ook al beginnen we er tussen ons vijftigste en zestigste flink problemen mee te krijgen. Als ik vergeet dat Groningen de hoofdstad van Groningen is, blijf ik gewoon Bas Levering die niet meer weet dat Groningen de hoofdstad van Groningen is. Ook vaardigheden kunnen we vergeten, al noemen we het in het algemeen niet zo en spreken we in dat geval liever over verleren. Ondanks de plechtige belofte en aanmoediging van onze ouders dat, als we ooit na veel inspanning de kunst van het fietsen, zwemmen of schaatsen machtig zouden zijn geworden, die kunst nooit meer zouden verleren, is de werkelijkheid een stuk weerbarstiger en onaantrekkelijker. Maar ook door het verleren van vaardigheden veranderen we niet als persoon. Ik ben gewoon nog altijd Bas Levering die ooit heel aardig schaatsen kon, maar nu nog nauwelijks op die dingen kan blijven staan. Maar morele kennis kun je niet vergeten en dat vindt zijn oorzaak in het gegeven dat 'ware' morele kennis met affecties verbonden is. Morele kennis zit me zo aan het lijf gebakken dat ik niet anders kan handelen dan volgens de morele attitude die me in mijn ontwikkeling zo eigen is geworden. Echte morele kennis bestaat uit het houden van het goede en het verachten van het kwade.

Theodor W. Adorno heeft ooit in verband met opvoeding en geweld gezegd dat we kinderen weerzin tegen geweld zouden moeten bijbrengen. En, als we morele kennis vergeten, als we er in de loop van ons leven andere opvattingen over waarden en normen op na gaan houden en die ook praktiseren, dan kunnen we zeggen dat we veranderen als persoon.

Het is onbetwist zo dat de morele kennis waarmee affecties verbonden zijn de 'ware morele kennis' genoemd kan worden, in die zin dat de band tussen denken en doen er het sterkst is. Op zoek naar het antwoord op de vraag "Hoe zorg ik ervoor dat mijn kind zich moreel gaat gedragen?” zouden ouders dus bij die vorm moeten uitkomen. Kinderen doen die vorm van morele kennis op onder invloed van integere ouders die zelf affectief moreel gedrag aan de dag leggen. Voorleven noemen we dat. De meeste mensen herkennen die grote invloed van het morele doen en laten van hun ouders pas achteraf, op latere leeftijd. Soms was er ook een lerares die door haar hele doen en laten niet één maar meer leerlingen tot de liefde voor dat ene aanvankelijk zo onaantrekkelijke vak had verleid. De analyse van Ryle is overtuigend maar in zekere zin ook misleidend. Ook andere vormen van morele kennis spelen in de opvoeding een rol. 
Propositionele kennis van goed en kwaad speelt natuurlijk een rol. Weten wat goed is en niet goed, wat mag en niet mag, speelt een belangrijke rol in ons doen en laten. Maar de band tussen propositioneel moreel weten en moreel doen is uiterst zwak. Er is het merkwaardige verschijnsel van de morele zwakte. Je weet wat je in een bepaalde situatie hoort te doen, je hebt ook zelf de morele overtuiging dat dit in dit geval de beste morele handeling is, je bent ook vrij om het te doen, en toch... doe je het niet. We spreken hier niet over vormen van wilszwakte, waar we ons onmiddellijk een levendige voorstelling van kunnen maken. Dat menselijke dat niemand vreemd is doortrekt de hele geschiedenis van de westerse mens. De geest is gewillig, maar het vlees is zwak. Vormen van wilszwakte zijn voorstelbaar en fungeren zelfs in meer of mindere mate als excuus als we niet in staat zijn geweest om de morele overtuiging in handelen om te zetten. Er zijn wat dat betreft ook grote culturele verschillen: in bepaalde streken wordt de zogenoemde crime passionel ook wettelijk anders behandeld dan in andere. En ook historisch zijn er grote variaties die, als je uitgaat van een toename van beheersing van driften door de eeuwen heen, zichtbaar worden. Maar morele zwakte - handelen tegen je eigen beste morele oordeel in, terwijl je vrij bent om aldus te handelen - houdt iets onbegrijpelijks, terwijl we weten dat het bestaat. Kortom, propositioneel moreel weten speelt in het morele handelen wel een rol, maar de band met het handelen is uiterst zwak (vgl. Levering 1988).

Ook vaardigheden zijn in het morele weten van groot belang. Zonder voldoende morele knowhow is moreel handelen zelfs onmogelijk. Regels kunnen expliciet, als propositionele kennis, worden aangeleerd, maar het effect daarvan is beperkt. In het algemeen doen kinderen de praktische morele kennis van regels gewoon op. Mensen zijn ook niet in staat alle regels die ze dag in dag uit volgen te expliciteren. De sociale werkelijkheid is te beschouwen als een samenstel van cultuurgebonden impliciete regels die we ons al doende eigen maken. De regels van een gezelschapsspel leer je ook door het eens mee te spelen en niet, of oneindig veel moeilijker, door de binnenkant van de doos te bestuderen. De band met het handelen is in het geval van de vaardigheid om regels te volgen (de praktische morele kennis van regels) sterker dan die van propositionele kennis, maar heeft toch ook zwakke kanten. De zwakke kanten zijn te vinden in het karakter van de regels zelf. Regels kunnen worden overtreden. Het volgen van regels kan mislukken. Vaardigheden spelen in dit verband ook nog op een andere manier een rol in het morele handelen. Voor het volgen van regels is in voorkomende gevallen een bepaalde mate van zelfcontrole vereist. Dit geldt ook voor het overwinnen van wilszwakte en morele zwakte. Opvoeders spelen een rol in het aanleren van regels en het trainen van zelfcontrole.

De sterkste band tussen moreel weten en moreel handelen bestaat in de affecties. Het is - afgezien van het moreel handelen uit gewoonte - zelfs verdedigbaar dat moreel handelen op grond van propositionele kennis alleen mogelijk wordt gemaakt door het affectieve aspect. Het is dan niet de morele kennis als zodanig, maar bijvoorbeeld de esthetiek van de morele redenering die de brug tussen denken en handelen slaat. In die zin had Ryle weer het grootste gelijk van de 
wereld met de uitkomst van zijn analyse dat de 'ware' morele kennis affectief van aard is. Maar de schoonheid heeft ook haar lelijke kanten. Morele opvoeding op affectieve basis ligt gevaarlijk dicht tegen indoctrinatie aan. Gelukkig kan Ryle vaststellen dat morele miseducatie niet goed denkbaar is. We kunnen kinderen niet opvoeden tot een moraliteit waar we zelf niet in 'geloven'. Zoals we eerder vaststelden is de kracht van morele opvoeding, voorzover ze bestaat, gelegen in de consistentie in spreken en handelen van de opvoeder. Voor de Afrikaanse kindsoldaten biedt dat weinig soelaas.

De analyse van Ryle brengt ons niet alleen in het hart van het gebied tussen moreel weten en moreel doen, waar de morele opvoeding en de zogenoemde overdracht van waarden en normen hun aangrijpingspunten moeten vinden, maar zij is ook in staat de verduisterende wetenschappelijke richtingenstrijd tussen theorieën over morele ontwikkeling en opvoeding te verhelderen. De lange tijd ook in Nederland dominante theorie van de Amerikaanse psycholoog Lawrence Kohlberg kan weliswaar niet zonder meer worden geïdentificeerd met de zwakke band tussen propositionele morele kennis en handelen, in de fundering van zijn theorie van het moreel redeneren hanteert hij wel degelijk uitgesproken het uitgangspunt: "He who knows the good, chooses the good" (Kohlberg 1981), dat ik hier nu juist bekritiseer. De theorie van Kohlberg heeft gewis aantrekkelijke kanten, en het heldere model van de morele ontwikkelingsstadia dat op grond daarvan is ontwikkeld en dat iedere pedagoog en psycholoog in opleiding in Nederland minstens een keer of drie krijgt aangeleerd, heeft zeker heuristische waarde. De zwakke kant van het verhaal dat een theorie van de moraliteit op cognitieve basis nu eenmaal eigen is, werd echter veel te weinig belicht. In Nederland zijn in het welzijnswerk en onderwijs sinds halverwege de jaren tachtig allerlei projecten met de op de theorie van Kolhlberg gebaseerde dilemma-methode gestart (vgl. Mink et al. 1986), maar als het om de empirische evaluaties van die projecten gaat, is er vooral discussie ontstaan over de kwaliteit van de evaluatiemethoden. De indruk bestaat dat de morele opvoedingsmethoden alleen maar werken als ze worden ingebed in een bredere aanpak van samenlevingsopbouw, maar dat brengt nu juist meteen de al te smalle basis van de dilemma-methode in het zicht. Het doet het belang dat wordt toegeschreven aan de mogelijkheid van overdracht van waarden en normen sterk verwateren. Als over morele dilemma's praten een manier is om ervoor te zorgen dat mensen met elkaar praten is daar natuurlijk niets op tegen, maar voordat je al te enthousiast wordt over 'de morele-dilemma-aanpak' moet je je wel afvragen of het onderwerp van gesprek niet om het even welk ander onderwerp had kunnen zijn. De fundamentele fout in het kohlbergiaanse denken zou wel eens kunnen zijn dat de gewone moraliteit helemaal niet 'dilemmisch' is en dat het empirisch onderzoek dat ooit de gegevens voor de theorie aanleverde op verkeerde uitgangspunten was gebaseerd.

Een andere theorie die door de analyse van Ryle onder kritiek komt te staan is die welke in het verlengde ligt van het denken van Ludwig Wittgenstein. Het gaat daarbij weliswaar om een theorie van praktischere soort, de uitwerking die zij op 
sommige plaatsen in een deugdenbenadering heeft gekregen doet haar weer bij het concrete niveau wegtrekken. De problematiek van het aanleren en opdoen van regels, die zich ook in het verlengde van het denken van Wittgenstein heeft ontwikkeld, zullen we pas later aan de orde stellen. Die problematiek is aparte aandacht waard, omdat de indruk bestaat dat de hele revival van het waarden- en normendebat in de opvoeding en de roep om weer waarden en normen over te dragen nu juist betrekking heeft op de wens dat kinderen zich weer aan regels gaan houden en op de vraag hoe we dat kunnen bewerkstelligen. Dat men zich echter van die overdracht juist een verkeerde voorstelling maakt, is in de huidige publieke discussie over waarden en normen cruciaal.

Het gewichtigste probleem waar we met de huidige wens tot hernieuwde overdracht van waarden en normen tegenaan lopen, is dat ouders kinderen regels willen aanleren waar ze zichzelf niet aan houden. De analyse van Ryle liet zien waarom dat niet lukt en dat wisten we ook wel, maar het stond ons misschien niet zo helder voor de geest. Het normoverschrijdende gedrag van volwassenen aan het begin van de eenentwintigste eeuw is schrikbarend. Ouders realiseren zich maar al te goed dat ze hun kinderen niet voor het rode voetgangerslicht kunnen leren wachten als ze er zelf, zelfs in het bijzijn van de kinderen, steevast doorheen rennen. Ze formuleren het voor zichzelf ook als probleem. Het klinkt natuurlijk flauw om tegen de politiek te zeggen dat, als je je druk maakt over de morele opvoeding van de kinderen, je je eerst druk zult moeten maken over de opvoeding van de opvoeders, maar het is niet anders. Het normoverschrijdende gedrag van de overheid zelf is in dit verband als verdubbeling van deze problematiek ook al heel vaak aan de orde gesteld. Opnieuw is het niet anders.

We wisten het allemaal allang, maar lijken het steeds weer te vergeten. Kijk maar eens hoe mooi die belangrijkste conclusie ruim een jaar geleden in het prijswinnend essay van het tijdschrift Pedagogiek - een van de algemene landelijke wetenschappelijke pedagogiektijdschriften - werd verwoord. Dat Jan Marten Praamsma met die kerngedachte een prijs wist te winnen onderstreept dat het dan wel om een pedagogische waarheid als een koe mag gaan, maar dat die zo gemakkelijke vergeten wordt dat zelfs pedagogen het nodig en bijzonder vinden om eraan te worden herinnerd.

\footnotetext{
"Wie zich zorgen maakt over de moraal van de jeugd moet niet in de eerste plaats kijken naar onderwijs en opvoeding, maar naar de wereld van de volwassenen, naar de dragende moraal van de samenleving. Daarbinnen worden onze kinderen groot. Onderwijs en opvoeding zijn slechts instrumenten in het doorgeven van die moraal. De samenleving moet de jeugd een oprechte moraal voorleven. Dat wil in onze tijd zeggen dat ze vraagtekens moet durven zetten bij haar eigen moraliteit. Daarmee is het een zaak van maatschappelijk en politiek belang. Volwassenen kunnen daarbij onmogelijk blijven staan bij het opnieuw accentueren van het belang van waarden en normen op zich. Ze zullen kleur moeten bekennen en duidelijk moeten maken om welke waarden en normen het dan wel gaat. Ze moeten hun eigen politieke en maatschappelijke handelen tegen het licht durven houden. En zich de vraag stellen of daaraan inderdaad de waarden ten grondslag liggen die we ook aan onze kinderen mee zouden willen meegeven. De zogenaamde 'pedagogische
} 
opdracht' die zo graag wordt doorgeschoven naar het domein van onderwijs en opvoeding is daarmee een opdracht van de samenleving in haar volle breedte" (Praamsma 2002).

\subsection{WAAR KOMT DAT PRIMITIEVE BEELD VAN DE OVERDRACHT VAN WAARDEN EN NORMEN IN DE OPVOEDING VANDAAN?}

Waarden kunnen een rol spelen in reflectie op gedrag - en daarin kunnen ze een heel belangrijke rol spelen -, maar waarden kunnen niet worden overgedragen. Dat geldt ook voor normen, die vaak als geconcretiseerde waarden (wat dit ook moge zijn) worden begrepen. Een klassiek model van overdracht van waarden en normen (het gaat hier inderdaad om een negentiende-eeuws model) is het freudiaanse. Een dergelijk model hebben de meeste leken, politici incluis, nog altijd voor ogen als ze aan de overdracht van waarden en normen denken. Het freudiaanse model is ook van een aantrekkelijke eenvoud. Het ik moet bemiddelen tussen het driftleven en de normerende aanspraken van de buitenwereld en wordt daarin geleid door het opper-ik. Dat opper-ik bestaat uit het ideaal-ik (wat en wie ik wil worden) en het geweten. De waarden en normen in het geweten bestaan aanvankelijk slechts als de geboden en verboden van de ouders in mij. Het geweten ontstaat door internalisatie van de geboden en de verboden van de ouders. Het geweten is zo een van de sturingsinstanties van mijn gedrag, zo neemt men aan.

Op ruimere historische schaal gezien gaat het hier om een modern beeld van overdracht van waarden en normen in de opvoeding. Er moet een tijd geweest zijn dat de overdracht van de cultuur een vanzelfsprekende zaak was. Vaak wordt aangenomen dat opvoeding pas is ontstaan toen de samenleving zo ingewikkeld was geworden dat overdracht van de cultuur niet meer vanzelf ging. In de historisch-pedagogische literatuur wordt dat wel het ontstaan van de pedagogische kwestie genoemd. Aan het einde van de Middeleeuwen werd zo een nieuw samenstel van vragen systematisch gesteld: "Wat moet hoe en wanneer worden overgedragen en hoe moeten kinderen worden gemotiveerd?” Met de ontdekking van de noodzaak van opvoeding en van de opvoedbaarheid was ook het motivatieprobleem geboren. Werd de middeleeuwse mens nog volkomen van buitenaf aangestuurd (laten we het sprekende beeld van David Riesman van het wetboek aanhouden), de moderne mens krijgt een geweten ingeplant dat als een kompas voor de oriëntatie van binnenuit zorgt. Als de leek over morele opvoeding of overdracht van waarden en normen spreekt, heeft hij nog altijd het beeld van het in te planten kompas voor ogen. Het probleem van onze postmoderne tijd lijkt te zijn dat mensen niet langer op een intern kompas varen, maar zich in hun doen en laten voortdurend oriënteren op anderen. We zijn, om met Riesman te spreken, radarmensen geworden.

Ik denk dat dit heldere en overtuigende beeld bijstelling behoeft. Het beeld veronderstelt dat er ooit een vorm van geslaagde waarden- en normenoverdracht heeft bestaan. Het verhaal gaat er bijvoorbeeld van uit dat in de jaren vijftig, die 
gewis de meest stabiele en veilige periode uit de vaderlandse geschiedenis vertegenwoordigen, sprake was van geslaagde gewetensvorming in die zin dat mensen zich keurig volgens de in het geweten ingeplante waarden en normen zouden hebben gedragen. Bij nader inzien behoeft dit beeld nadrukkelijk bijstelling. De reden dat mensen zich in de jaren vijftig schijnbaar volgens de ingeplante waarden en normen gedroegen was uiteindelijk omdat zij daarbij voortdurend door een stabiele homogene omgeving werden ondersteund. Het kind op straat werd ook door de buurvrouw aan de normen herinnerd die zijn eigen moeder hem voorhield en ook een paar straten verderop werd er door willekeurige volwassenen in die zin nog naar hem omgezien. Ik herinner me nog levendig hoe mijn ouders in die jaren vijftig terug van hun eerste vakantie naar het buitenland, het reisje langs de Rijn, zich vrolijk maakten om die oom die een bierglas van een terrastafel had meegenomen. Ik begreep er helemaal niets van. Mensen die zich altijd zo keurig volgens de waarden en normen gedroegen die zij mij voorhielden, hadden zich er in dat verre buitenland niet aan gebonden gevoeld. (De Britse ethicus Richard M. Hare sprak ooit in verband met een mogelijke verklaring voor het merkwaardige verschijnsel van 'morele zwakte' van taking a moral holiday). Voorzover de succesvolle overdracht van waarden en normen ooit heeft bestaan, werd ze inderdaad gerealiseerd door een stabiele gedeelde moraal in de samenleving. De staat van het geweten echter is altijd al zorgelijk geweest (vgl. Levering 2003).

In de pedagogiek weten we al heel lang dat waarden- en normenoverdracht niet volgens het negentiende-eeuwse model van het ingeplante geweten verloopt. Het spreken over opvoeding geschiedt er al meer dan een eeuw niet meer in termen van beïnvloeden. Dat is ook de eeuwige terminologische verwarring die optreedt in de discussie tussen pedagogen aan de ene kant en psychologen en sociologen aan de andere kant. Die terminologische verwarring lag bijvoorbeeld ten grondslag aan de Nederlandse titel van het boek The nurture assumption van de Amerikaanse psychologe Judith Harris: Het misverstand opvoeding. Het verschijnen van dat boek in 1998 deed veel stof opwaaien, omdat het met het empirisch gestaafde bewijs kwam voor de schokkende bewering dat ouders in vergelijking met leeftijdgenoten nauwelijks invloed op de ontwikkeling van kinderen hebben. Hoe groot de invloed van peers ook moge zijn - niets nieuws onder de zon natuurlijk, opvoeders hebben zich altijd druk gemaakt om de invloed van verkeerde vrienden op hun kinderen - bij opvoeden gaat het om iets anders.

Meer dan een eeuw geleden stelde de Utrechtse pedagoog J.H. Gunning vast dat, als je je niet de medewerking van het kind weet te verwerven, je het in de opvoeding wel vergeten kan. Een halve eeuw later gaf de Utrechtse pedagoog Martinus J. Langeveld een positieve draai aan deze beperking door vast te stellen dat morele ontwikkeling, afgezien van de waarden en normen die het kind onwillekeurig van zijn omgeving overneemt, verwerkelijking van waarden door het kind is en dat zij dat ook moet zijn. Vorig jaar nog, weer meer dan vijftig jaar later, kwam Wiel Veugelers in zijn oratie Waarden en normen in het onderwijs tot een wel zeer omslachtige herbevestiging van dit uitgangspunt zonder ook maar met één woord aan de genoemde traditie te refereren. 
Morele opvoeding zal zich moeten oriënteren op datgene wat kinderen in de samenleving van morgen nodig hebben om moreel te kunnen overleven. Morele opvoeding kan alleen daarom al geen overdracht van waarden en normen zijn omdat de huidige waarden en normen ontoereikend zijn om de morele vragen in de toekomst aan te kunnen. In de pedagogiek van Langeveld ging het al sinds 1945 om zelfuerantwoordelijke zelfbepaling, een wel heel precieze pedagogische uitwerking van het kantiaanse autonomie-ideaal. Langeveld kan dan ook doorgaan voor een echte moderne pedagoog, die met de manier waarop hij inhoud gaf aan het opvoedingsdoel volkomen klaar was voor de uitwerking van het moderne burgerschapsideaal. Naast zelfverantwoordelijke zelfbepaling, een volwassen leven leiden vanuit een zelfstandige eigen keuze van waarden, verwachtte hij van de volwassene constructief deelgenootschap aan het maatschappelijk leven. Er is weinig fantasie voor nodig om in deze opvoedingsdoelformulering de actieve burger te herkennen die volwaardig in de moderne democratie kan meedraaien. Als dat vandaag de dag allemaal te bereiken zou zijn, zou een groot deel van het nieuwe kabinet en de Staten Generaal de komende vier jaar rustig achterover kunnen leunen. In de formulering van het opvoedingsdoel door Langeveld is de individualisering, die we vooral later zo belangrijk zijn gaan vinden, al volledig begrepen. Zijn opvoedingsdoelformulering is meer dan vijftig jaar na dato op de keper beschouwd slechts op een beperkt aantal punten achterhaald. Kinderen verwerven de karakterologische stabiliteit in het algemeen in onze tijd een kleine tiental jaar later dan Langeveld in de jaren vijftig aannam - zo rond hun dertigste in plaats van rond de aanvankelijke wettelijke volwassenheidsleeftijd van 21 jaren - en ook daarna kunnen er nog wisselingen optreden in het gekozen pakket van waarden. Niet alleen de verhouding met de ouders is veranderd, ook de verhouding met de overheid is ingrijpend gewijzigd. Burgerlijke ongehoorzaamheid is sinds de jaren zestig tot het repertoire van de werkelijk volwassene gaan behoren. (Noteer overigens dat Langeveld gehoorzaamheid nadrukkelijk onderscheidde van volgzaamheid en definieerde als het volgen van zelf erkend gezag.)

Als er vandaag de dag een opvoedingsdoel zou moeten worden gedefinieerd - we stelden eerder vast dat theoretisch pedagogen het wat dat betreft na 1970 bewust hebben laten afweten - zou de formulering van Langeveld nog heel goed dienst kunnen doen. Het is dan vooral de praktische uitwerking die aan het begin van de eenentwintigste eeuw het verschil zou moeten uitmaken. Dat lijkt aantrekkelijk maar het biedt ook zicht op een groot probleem dat de hele discussie over waarden en normen doortrekt. Als waarden zo algemeen of zo abstract zijn dat ze een halve eeuw later nog altijd tot uitgangspunt kunnen dienen, dan moeten we ons afvragen welke functie zij precies in het denken over de praktijk hebben. Als we er werkelijk alle kanten mee op kunnen, moeten we er natuurlijk grote vraagtekens bij plaatsen en niet alleen bij de betekenis van een algemeen opvoedingsdoel als waarde, maar bij de waarde van overdracht van waarden en normen in het algemeen. Langevelds opvoedingsdoel heeft echter wel degelijk een zeker onderscheidend vermogen dat van praktisch belang is. Je zou kunnen zeggen dat de nog algemenere waarden van de typisch westerse joods-christelijke traditie erin tot uitdrukking zijn gebracht. Het waren die waarden die Frits Bolkestein in 
1991 inspireerden om vanuit Zürich de Nederlandse natie toe te spreken over de onverzoenlijkheid ervan met de waarden van de islamitische cultuur, waarmee hij de discussie over de houdbaarheid van de multiculturele samenleving opende. Langeveld had in het kader van de doorbraakbeweging eind jaren veertig, begin jaren vijftig, die joods-christelijke waarden geseculariseerd en voor het humanistisch georiënteerde volksdeel acceptabel gemaakt. Waar de confrontatie van de waarden van de westerse ik-cultuur met zijn accent op persoonlijke verantwoordelijkheid met de waarden van de islamitische wij-cultuur in de praktijk tot problemen leidt, wordt juist een theoretische tegenstelling op de spits gedreven.

Die toepasbaarheid van Langevelds opvoedingsdoel in onze tijd wordt ook op andere plaatsen bevestigd. Het zou om een kwestie van accenten gaan (vgl. De Winter 1995). En als er op grond van dergelijke uitgangspunten een analyse gemaakt wordt van wat er in de afgelopen halve eeuw allemaal is veranderd in de omstandigheden waaronder in Nederland wordt opgevoed, neemt de Raad voor Maatschappelijke Ontwikkeling een gat in de pedagogische infrastructuur waar. Ook de centraal in de remedie en de aanbeveling staande zogenoemde aansprekende pedagogische infrastructuur past in de typisch Nederlandse pedagogische traditie, met een opvoeding die kinderen en jeugdigen aanspreekt, omdat zij aansluit bij hun belevingswereld, jeugdigen aanspreekt op hun verantwoordelijkheid en medeburgerschap, en burgers, instellingen en overheden aanspreekt op hun gedeelde opvoedingsverantwoordelijkheid. Er is maar weinig fantasie voor nodig om te zien dat in deze aanpak getracht wordt om de overdracht van waarden en normen weer mogelijk te maken door een stabiele omgeving te scheppen, door gaten in de pedagogische infrastructuur op te vullen. Het zal duidelijk zijn dat, als we hier al over het geweten spreken, dat niet gezien wordt als een met normen gevulde interne instantie die zijn rechtstreekse gedragscorrigerende werk doet. Het geweten fungeert hier veel meer als overlegorgaan, maar ook die functie was bij Langeveld al te vinden.

De volledig beregelde en gecontroleerde maatschappij past niet bij de Nederlandse cultuur. De Noord-Amerikaanse samenleving bijvoorbeeld is traditioneel vele malen sterker gecontroleerd dan de Nederlandse. De hoge boetes die er in de Verenigde Staten staan op het op straat gooien van afval zijn hier te lande vooralsnog ondenkbaar. Ook het RMO-advies van 2001 gaat nog altijd uit van het idee dat, als we elkaar maar aanspreken het op den duur wel weer goed komt. De grootste fout die we in de afgelopen decennia hebben gemaakt, lijkt het advies te zeggen, is dat we met dat aanspreken zijn gestopt. Overheidsbeleid, lokaal, provinciaal en landelijk, is alom uit op het herstel van sociale cohesie. Het is de vraag of het hierbij gaat om een eigentijdse remedie of om een terugverlangen naar een samenleving die niet meer bestaat en ook niet meer kan bestaan. Maar laten we aan de hand van de analyse van E.A. Godot in het begin 2003 gepubliceerde Hoezo pedagogisch? eens de balans opmaken van wat er in de afgelopen vijftig jaar in de betrokkenheid van de overheid bij de opvoeding is veranderd. 


\subsection{BALANS VAN DE OVERHEIDSBEMOEIENIS MET DE OPVOEDING IN DE AFGELOPEN HALVE EEUW}

Een algehele balans van de overheidsbemoeienis met de opvoeding in de afgelopen halve eeuw laat zien dat ze is toegenomen en afgenomen. Er is vandaag de dag meer en minder overheid in pedagogische zaken in vergelijking met vijftig jaar geleden. Voor het ontstaan van dat gedifferentieerde beeld is een aantal oorzaken aan te wijzen. Als het om de afname van overheidsbemoeienis gaat, is in de eerste plaats het gegeven van belang dat burgers in toenemende mate op hun strepen staan als het om hun privacy gaat. Er is in Nederland in de pedagogiek overigens altijd een grote weerstand tegen staatsopvoeding geweest. Het recht van ouders om hun kinderen naar eigen inzicht op te voeden is geen gedelegeerd recht, maar een oorspronkelijk recht en ligt in het verlengde van de fundamentele individuele burgerlijke vrijheden en rechten. Dat is ook de reden dat er wel wat aan de hand moet zijn wil de rechter overgaan tot ontzetting uit de ouderlijke macht. De vrijheid van onderwijs en het recht om door de overheid gesubsidieerd onderwijs naar eigen levensbeschouwelijk inzicht in te richten liggen in het verlengde van de ouderlijke opvoedingsverantwoordelijkheid. Het is zeer de vraag of het systeem van verzuiling een oplossing is voor de problemen van de multiculturele samenleving van het begin van de eenentwintigste eeuw. Maar het idee dat de overheid in den brede de verantwoordelijkheid voor de opvoeding van de ouders zou kunnen overnemen is, los van de vraag of het wenselijk is, gebaseerd op een primitief beheersingsoptimisme.

In de tweede plaats is voor de afname van de overheidsinvloed op pedagogisch gebied het tanende geloof in de maakbaarheid van de samenleving van belang. Allerlei goedbedoelde compensatieprogramma's hebben ronduit gefaald, onderwijsvoorrangsbeleid is mislukt, projecten gericht op mentaliteitsverandering hebben geen enkel effect gehad, enzovoort. Maatschappelijke problemen en sociale ongelijkheid worden door opvoeding en onderwijs eerder gereproduceerd dan weggewerkt. Schools cannot compensate for society. Dat is een bittere pil. Daarom kunnen we onze pretenties maar beter bijstellen. Uiteraard blijven die desillusies in de opgewekte beleidsretoriek altijd onhoorbaar.

In de derde plaats lijkt voor 'de maakbaarheid van de samenleving' 'de maakbaarheid van het eigen private levensgeluk' in de plaats te zijn gekomen. Dat nieuwe geloof neemt veelal de vorm aan van een consumentisme. Tezamen met het geloof in de effectiviteit en rechtvaardigheid van de markt leidt dat tot een situatie waarin de relatie tussen professionals en opvoeders er een wordt tussen aanbieders en afnemers. 'U vraagt en wij draaien' is de filosofie. Overheidsinstanties en maatschappelijke organisaties worden daarmee naar de tweede lijn gedegradeerd. Ouders zijn eerder geneigd om commerciële bladen, websites en consultants te raadplegen dan zich tot de traditionele instanties te wenden. De oplagecijfers van 'vakbladen voor ouders' zoals J/M en Ouders van Nu zijn indrukwekkend. Traditionele damesbladen als Libelle en Margriet beginnen terrein te verliezen aan het sterk groeiende Psychologie Magazine. 
In de vierde plaats is een oorzaak van de afgenomen overheidsinvloed in opvoedingsaangelegenheid te vinden in het gegeven dat ouders hoger opgeleid en mondiger zijn dan twintig jaar geleden. Zij slikken de adviezen van professionals niet langer voor zoete koek. En als het om de opvoeding gaat lijkt werkelijk iedereen deskundige te zijn. De status en autoriteit van pedagogische professionals - of het nu om leerkrachten, opvoedingsondersteuners of maatschappelijk werkers gaat - is achteruitgehold. Het vragen van een second opinion is niet alleen in de medische sector de gewoonste zaak van de wereld geworden. Pedagogen doen er goed aan zich strikt aan de beroepscode te houden, want ook in deze sector rukt in Nederland de Amerikaanse claimcultuur op. Wanneer je problemen ondervindt in de opvoeding kun je eigenlijk beter je moeder, buurvrouw of vriendin om wijze raad vragen. Zo gaat het in de praktijk dan ook vaak. De professionals worden veelal afgestuurd op de 'sociaal zwakke' groepen.

De uitkleding van de verzorgingsstaat kan worden genoemd als de vijfde en laatste oorzaak van de afname van de overheidsbemoeienis met de opvoeding. Er wordt inderdaad minder geld gereserveerd voor beleidsterreinen als welzijn, onderwijs en hulpverlening dan zo'n twintig jaar geleden. Vandaar dat bijvoorbeeld veel residentiële zorg plaats heeft gemaakt voor ambulante hulpverlening. Vandaar dat veel kinderen en jongeren in de oude volkswijken hun eigen honk hebben verloren en nu noodgedwongen hun toevlucht moeten nemen tot de coffeeshops. Vandaar dat men van overheidswege de doorstroming naar hogere schooltypen wil beperken. Uit financiële overwegingen komt het erop aan een efficiënte leerweg te bewandelen. In individuele gevallen is het positieve effect van omwegen en doodlopende zijpaden in de schoolcarrière gemakkelijk aan te tonen.

De oorzaken van de toename van overheidsbemoeienis met opvoeding en onderwijs zijn verwant, maar liggen toch op een heel ander vlak. In de eerste plaats is met het wegvallen van een gedeelde publieke moraal onder burgers slechts de zorg om non-morele waarden als gezondheid, veiligheid en leefbaarheid overgebleven. Publieke inspanningen concentreren zich daarom op de aanpak van criminaliteit, het voorkomen van overlast, het bevorderen van de sociale cohesie. Dat alles heeft een overheersend technisch karakter gekregen en gaat eigenlijk alleen maar om het vinden van medicijnen tegen de meest storende maatschappelijke kwalen.

In de tweede plaats maakt de overheid zich bijvoorbeeld om onze gezondheid wel uitermate druk. De overheid spaart zich kosten noch moeite om burgers duidelijk te maken dat roken slecht is voor de gezondheid, dat veilig vrijen een absolute must is, dat we voorzichtig moeten zijn met vuurwerk, dat we enkel met mate van drank mogen genieten, dat we niet te vet moeten eten, enzovoort. Het is niet moeilijk om het economische motief aan dit schijnbaar nobele overheidsstreven af te lezen.

In de derde plaats heeft het ontstaan van een multiculturele samenleving meer overheidsbemoeienis noodzakelijk gemaakt. Nieuwkomers moeten de Neder- 
landse taal en cultuur leren. Er zijn zogenaamde prismagroepen op scholen en er is een inburgeringsplicht voor volwassenen. De concentratie van sociaal(-economisch) zwakke groepen allochtonen in bepaalde wijken en het leven tussen twee culturen veroorzaakt opvoedingsproblemen en onderwijsachterstanden. De overheid initieert sociaal-cultureel beleid om de integratie van verschillende bevolkingsgroepen te bevorderen. Volgens sommigen is de sociaal-culturele achterstand vooral aan de economische achterstand te wijten.

De toename van de overheidsbemoeienis met de opvoeding wordt in de vierde plaats veroorzaakt door het feit dat er een steeds grotere en daarmee machtigere beroepsgroep van pedagogische professionals ontstaan is. Binnen een hechte infrastructuur van pedagogische instituties en organisaties - die is er tussen de door de RMO (2001) geconstateerde gaten evenzeer - behartigen die professionals eigen institutionele belangen. Ze proberen hun eigen voortbestaan te verzekeren door hun werkterrein te verdedigen en waar mogelijk uit te breiden. Volgens sommigen liggen bijvoorbeeld de schattingen van het aantal daklozen in Nederland door het op dat terrein actieve Leger des Heils vier keer te hoog. Het zou om twintigduizend in plaats van tachtigduizend gaan.

Pedagogen staan bekend om hun zorgelijke blik. Eerst worden er problemen aangekaart of bedacht, zo nodig gecreëerd, om ze vervolgens op te lossen. Evenals in het geval van andere beroepsgroepen kenmerkt het pedagogische circuit zich door een zichzelf versterkende beroepsideologie. Als bijvoorbeeld blijkt dat pedagogische interventies niet de gewenste resultaten opleveren - zoals met bepaalde vormen van opvoedingsondersteuning -, dan wordt niet besloten om er maar een punt achter te zetten, maar om er met nog meer geld en energie tegenaan te gaan. Het is deze dynamiek die inderdaad leidt tot die gestaag uitdijende projectencarrousel. Het is niet alleen de overheid die nieuw beleid initieert, maar vooral ook de beroepsgroep zelf.

In de vijfde en laatste plaats wordt de toename van overheidsbemoeienis veroorzaakt door het grote economische belang van arbeidsparticipatie door mannen en vrouwen. Door de concentratie op 'werk, werk en nog eens werk' is er de overheid veel aan gelegen om mensen naar de arbeidsmarkt toe te leiden en in het verlengde daarvan de opvang van kinderen te faciliteren. Ook bijstandsmoeders worden tot solliciteren gedwongen, want het uitgangspunt is dat kinderen niet in de weg mogen staan van een betaalde baan.

Het is niet gemakkelijk om al deze ontwikkelingen onder een of twee noemers te brengen, maar er zijn wellicht toch een paar algemene lijnen te ontdekken. Politiek-filosofisch bezien ontstaat het volgende beeld. De afname van overheidsbemoeienis wordt voortgestuwd door een liberaal-burgerlijk ideaal van negatieve vrijheid. De overheid moet zich zo weinig mogelijk bemoeien met de opvoeding van mijn kind. De goed opgeleide, geëmancipeerde, mondige burger eist maximale vrijheid om zijn kind naar eigen goeddunken en in de overeenstemming met de eigen levensstijl op te voeden en te scholen. Thuisonderwijs (home-schooling) 
is daarvan wellicht het meest radicale voorbeeld. De toename van overheidsbemoeienis maakt deel uit van een ontwikkeling waarbij burgers steeds meer garanties en diensten van de overheid gaan eisen. De overheid moet ervoor zorgen dat het weer veilig wordt op straat, dat de buurt weer meer een geheel wordt, dat ik mijn werk en zorg voor de kinderen kan combineren, dat de overlast door de jeugd afneemt, dat kindermishandeling wordt aangepakt, enzovoort. Kortom, enerzijds eisen burgers in het algemeen en ouders in het bijzonder een terugtredende overheid en roepen luidkeels: 'Laat mij en mijn kinderen met rust!' Anderzijds eisen zij een optredende overheid, vooral als het om de kinderen van anderen gaat: om de mishandelde, verwaarloosde, criminele en overlast veroorzakende kinderen.

Een gedetailleerde analyse van toename en afname van overheidsbemoeienis met opvoeding naar type zou wel eens kunnen opleveren dat de directe overheidsinterventie in opvoedings- en onderwijssituaties is afgenomen. Vadertje staat is voorzichtiger geworden met de ontheffing uit de ouderlijke macht, met de residentiële opvang van moeilijk opvoedbare kinderen, enzovoort. De indirecte maatschappelijk-institutionele bemoeienis is echter toegenomen. Met indirecte overheidsbemoeienis wordt bemoeienis bedoeld via instituties op het gebied van de kinderbescherming, jeugdwelzijn, opvoedingsondersteuning, opvoedingsvoorlichting, voogdijraden, jeugdzorg, kinderopvang, peuterspeelzaalwerk, voor- en vroegschoolse educatie, huiswerkbegeleiding, brede school, verlengde schooldag, vensterschool, enzovoort. Dit heeft natuurlijk alles te maken met die al eerdergenoemde projectencarrousel en het ontstaan van een machtige pedagogische beroepsgroep en infrastructuur. Vanuit een maatschappijtheoretisch perspectief zou men kunnen stellen dat tussen de private en publieke levenssfeer een zich wijzigend maar blijvend krachtig maatschappelijk middenveld bestaat vanwaaruit allerhande maatschappelijk-pedagogische initiatieven worden ondernomen. Uiteraard zijn het dan vooral de goed opgeleide, welgestelde burgers die hun initiatieven afvuren op de wat minder gefortuneerde ouders en hun kinderen. Ook de Bond van Grote Gezinnen (opgericht naar Belgisch voorbeeld) is daarvan een van de merkwaardige nieuwe voorbeelden. Maar of die klok terug te zetten is, valt toch ernstig te betwijfelen.

\subsection{VERANDERINGEN IN DE OMGANG TUSSEN OUDERS EN KINDEREN}

Om de mogelijkheden van waarden- en normenoverdracht in de opvoeding na te gaan moet nadrukkelijk de veranderde verhouding tussen ouders en kinderen aan de orde worden gesteld. Er zijn maar weinig wetenschappelijke pedagogische termen in het alledaagse taalgebruik doorgedrongen en de meest pregnante onder die termen is nog van een socioloog ook. Dat de opvoedingsverhouding in de afgelopen halve eeuw is veranderd van een bevelshuishouding in een onderhandelingshuishouding weten leken ook als ze nog nooit van Abram de Swaan hebben gehoord. Hoe dat precies gegaan is in de periode tussen jaren vijftig en zeventig beschrijft Godot in Hoezo pedagogisch? (229-232). Het kleiner worden 
van de gezinnen, na het operationeel worden van effectieve anticonceptie, was daarbij van grote invloed. De gegroeide welvaart en met name de veranderende economische verhouding tussen jeugdigen en volwassenen stonden geen autoritaire verhoudingen meer toe. Voor pedagogen is het leerzaam om te moeten constateren dat het niet hun aansprekende ideeën zijn geweest die het hele pedagogische klimaat in de jaren zestig veranderden, maar dat de economie de doorslag gaf. Zoals gezegd, rekening houden met de stem van het kind was al aan het begin van de twintigste eeuw hét pedagogische credo geworden, de verhouding tussen ouders en kinderen bleef nog lang autoritair, al is dat niet noodzakelijk synoniem met kil. Vanaf de jaren zeventig kunnen verreweg de meeste ouders goed met hun kinderen overweg, blijkt uit allerlei onderzoek. Het zogenoemde generatieconflict lijkt echt in de jaren zestig uitgevochten. Een van de laatste beletselen, die alles met waarden en normen te maken heeft en die een goede relatie tussen ouders en kinderen in de weg stond, is weggenomen. Ouders leggen kinderen wat dat betreft namelijk geen duimbreed meer in de weg. Was het voor de jeugd van de jaren zestig zaak zo jong mogelijk het ouderlijk huis te verlaten om in vrijheid te kunnen doen wat ouders verboden, de jeugd van de jaren negentig is het huis niet meer uit te krijgen. En de keuze tussen wonen op een klein duur kamertje en thuis verzorgd te worden als hotelgast met een eigen vertrek met de vrijheid om te ontvangen wie je maar wilt, lijkt snel gemaakt.

Als het om waarden en normen en de opvoeding gaat, is er in de afgelopen vijftig jaar inderdaad veel veranderd. In de jaren zestig en zeventig is niet alleen een grotere maatschappelijke betrokkenheid ontstaan, maar ook een grotere ikgerichtheid. Hedonisme en consumentisme hebben zich steeds dieper in het hart van het Nederlandse individu genesteld en gaandeweg is het calvinistische syndroom van het niet kunnen genieten definitief overwonnen. Met het jarennegentigcredo 'We want it all and we want it now' is een van de meest fundamentele ambities van de opvoeding geweld aangedaan: het leren uitstellen van de behoeftebevrediging. Want dat was echt het eerste wat we ooit deden, kinderen helpen zindelijk te worden, kinderen leren hun kakkie op te houden. Dat credo heeft in de jaren negentig de hele cultuur onder druk gezet. Opnieuw was het de booming economie die maatschappelijk-culturele kaders in zijn voegen deed kraken. Was in de jaren zestig en zeventig het onderwijs de route geworden naar gegarandeerd maatschappelijk succes, in de jaren negentig liep je de kans als je hard studeerde je belachelijk te maken. En nog leiden de als moeilijk bekend staande studies een kwijnend bestaan. 'We want it all and we want it now' betekende ook alles zeggen wat je voor de mond komt. Geen rekening houden met anderen is ook al storend als maar een paar individuen het doen en het is nog besmettelijk ook. Walkman en mobiele telefoon zijn volstrekt geaccepteerde ordeverstoorders geworden.

Kinderen moeten regels leren, want ze gaan niet vanzelf rekening houden met anderen. Kinderen zijn van huis uit egocentrisch, dat weet iedere ontwikkelingspsycholoog, en dat rekening houden met anderen lukt alleen maar onder een zekere dwang. De fout die een hele generatie in de jaren zestig maakte is dat ze 
met het terecht afschaffen van de regels die onlegitimeerbare autoritaire relaties instandhielden, de regels überhaupt afschaften. De denkfout die aan deze fout ten grondslag lag was dat het verband tussen twee soorten regels, tussen regulatieve regels en constitutieve regels, niet werd gezien. Regulatieve regels regelen bestaand gedrag in termen van geboden en verboden, maar ze zijn vaak verbonden met constitutieve regels die sociale praktijken zoals beloven, prijzen, geven, ontvangen, afscheid nemen, een gesprek voeren, en ga zo maar door, mogelijk maken. Als je, zoals dat in de jaren zestig gebeurde, het geven van een hand bij het voorstellen afschaft, omdat je van oordeel bent dat het ritueel bij een ouderwetse vorm van onderdanigheid hoort, dan moet daar wel iets voor in de plaats komen, want anders raken we echt onthand. Kenningsmakingsrituelen zijn er om de ontmoeting soepel te laten verlopen. Als de bijbehorende regels individualiteit wegconformeren is er iets mis, maar als het goed is maken regels individualiteit juist mogelijk. Juist en alleen in de subtiele individuele toepassing van de regel kan ik mijzelf laten zien.

Twee jaar geleden heb ik in een interview in Trouw een pleidooi mogen houden voor een hernieuwde aandacht voor etiquette in de opvoeding (vgl. Kreulen 2001). Op dat interview is een zeer levendige discussie gevoerd in het opvoedingsdebat dat nog altijd op de website van Trouw terug te vinden is. In verschillende bijdragen aan de discussie is goed terug te lezen hoeveel mensen de discussie over regels aangrijpen om oude autoritaire verhoudingen te herstellen. Die ondertoon, die in de brede roep om herstel van waarden en normen doorklinkt, moet nauwkeurig van de band worden verwijderd en dat kan ook. Want het is volstrekt helder waarover we spreken. Regels zijn er niet om ouders greep op de kinderen te geven, maar om kinderen greep op de wereld te geven. Bij het aanleren van de regels zien we natuurlijk wel naar het kind om. De panische angst die een hele generatie beving in de jaren zestig als het om jonge kinderen handjes leren geven ging, dat de kinderziel definitief schade op zou lopen, is op een bepaalde manier niet helemaal ongegrond. Sommige kinderen houden niet van kusjes geven, zoals andere kinderen van naar andijvie kijken al onpasselijk worden. Op bepaalde punten kunnen en moeten er uitzonderingen worden gemaakt. De pedagogische waarheid, dat het in de opvoeding altijd om het individuele kind gaat en dat algemene opvoedingsregels dus moeilijk te formuleren zijn, geeft het vak in de ogen van velen een zwak aanzien. Voor opvoeders is er altijd de spanning tussen het tegemoetkomen aan de wensen en mogelijkheden van het individuele kind, waarin soepel met de regels wordt omgesprongen, en de gelijke rechten die kinderen onderling op grond van diezelfde regels opeisen. De eeuwige strijd over het tijdstip van gaan slapen zou op individuele basis beslist moeten kunnen worden, omdat ook de kinderen onderling inzien dat de een meer slaap nodig heeft dan de ander.

In een recent interview in Trouw (Kreulen 2003) heb ik het gedogen in de opvoeding verdedigd. De term 'gedogen' was natuurlijk gekozen tegen de achtergrond van 'Enschede' en 'Volendam', maatschappelijke drama's veroorzaakt door een maatschappelijk gedoogbeleid van de verkeerde soort. Natuurlijk moet er niet 
met veiligheidsregels gesjoemeld worden, al moet ook worden gezegd dat er in de manier waarop er sindsdien over handhaving van regels is gesproken, wel erg veel eenzijdige verantwoordelijkheid bij de overheid is gelegd. De burger die in een café een flipperkast voor een nooduitgang ziet staan moet de eigenaar aanspreken en als het obstakel niet verwijderd wordt, moet hij de zaak verlaten. Maar die vorm van gedogen wordt niet bedoeld. De maatschappelijke vorm van gedogen die we met het oog op de opvoeding in beschouwing moeten nemen, is de typisch Nederlandse vorm van gedogen, die verschillende wijzen van leven naast elkaar mogelijk maakt. Daarnaast betekent gedogen in de opvoeding dat we ook nog op een andere manier soepel zijn in de toepassing. Kinderen moeten in het aanleren van regels fouten kunnen maken; anders leren ze ze nooit echt. De oude bijbelse norm dat het nastreven van het goede en het daarbij fouten maken prevaleert boven het risicoloos fouten vermijden, getuigt van groot maatschappelijk en pedagogisch inzicht. Kinderen moeten ook fouten mogen maken om de grenzen van de eigen mogelijkheden te leren kennen.

Dat de ins en outs van het gedogen in de opvoeding niet zo eenvoudig te begrijpen zijn, moge blijken uit de opiniepeiling die Bureau Interview naar aanleiding van het Trouw-interview op 4 maart 2003 uitzette.

1 Denkt $\mathrm{u}$ dat gedogen een effectieve manier is in de opvoeding van kinderen? Ja $20 \%$, nee $69 \%$, weet niet / geen mening $11 \%$

2 Vindt $\mathrm{u}$ dat gedogen tot maatschappelijke problemen leidt? Ja $71 \%$, nee $18 \%$, weet niet / geen mening $11 \%$

3 Bent $\mathrm{u}$ het eens met de stelling dat regels bestaan om kinderen greep te laten krijgen op de wereld?

Ja $75 \%$, nee $20 \%$, weet niet / geen mening $5 \%$

De kans bestaat dat de inleiding op de vragen onvoldoende helder was. Immers, inhoudelijk zijn 1 en 3, 'gedogen in de opvoeding' en 'het belang van regels voor de kinderen in plaats van voor de opvoeders', sterk met elkaar verbonden. Vraag 2, die een verband legt met de verkeerde vorm van maatschappelijk gedogen, zet de geënquêteerden wellicht op een verkeerd spoor. Als de geënquêteerden het allemaal wel goed begrepen hadden, is er nog veel werk aan de winkel.

Onze herwaardering van regels met het pleidooi voor etiquette in de opvoeding is dus beslist geen poging tot restauratie van oude verhoudingen. We mogen ook in de opvoeding nooit terug naar de tijden van 'regels zijn regels'. Als we spreken over een zekere dwang, dan is niet bedoeld dat regels onbediscussieerbaar zijn. Regels moeten altijd beargumenteerd kunnen worden op grond van een zekere bedoeling. Regels moeten ervoor zorgen dat we rekening houden met of omzien naar anderen en kunnen daarop ook beoordeeld worden. Soms kunnen regels inhoudelijk niet nader beargumenteerd worden en soms zijn ze ook echt arbitrair. Dat is lastig in discussies met kinderen die in de fase zitten dat ze kettingen van 
waaromvragen stellen tot de waaromvraag waarop geen enkel ander antwoord past dan 'Daarom!' Daarvoor nog waren ze er zo gemakkelijk ingegleden onder het zingen van het onsterfelijke liedje: '... Zo zijn onze manieren, manieren. Zo zijn onze manieren.'

Aan de ene kant geldt er dus een 'nooit meer terug naar de autoritaire opvoedingsverhoudingen van de jaren vijftig'. Aan de andere kant heeft de democratisering van de opvoedingsverhoudingen sinds de jaren zestig allerlei onvermoede problemen opgeleverd. Ik ben het met Tijs Goldschmidt (1998) eens dat, als het bijvoorbeeld om de analyse van pestgedrag onder kinderen gaat, langdurig gedragsbiologisch onderzoek geboden is. 'Leraartje pesten' bijvoorbeeld lijkt erg veel op de manier waarop jonge chimpansees het gezag van de oudere apen op de proef stellen. Een halve dag naar de dierentuin is genoeg om dit gegeven en nog een groot aantal andere in waarnemingen bevestigd te krijgen. De jonge chimps zijn werkelijk voortdurend aan de gang om de oudere te pesten. Op grond van zijn bevindingen bekritiseert Goldschmidt het leerstofjaarklassensysteem, omdat daar de natuurlijk hiërarchie van ouder en jonger ontbreekt. Al die leeftijdgenoten in dezelfde groep, die dan ook nog oncreatief moeten luisteren, dat is vragen om pesterijen. Maar ook van het verzoeningsritueel dat bij chimpansees uiteindelijk op het pestgedrag volgt, zouden we het een en ander kunnen leren. Want natuurlijk krijgt zo'n kleine chimp van zo'n hele grote op een gegeven moment een geweldige hengst en dan is het afgelopen, of nog niet helemaal. Als de kleine weer overeind is gekrabbeld zal hij in zichtbare onderdanigheid de grote benaderen om vergiffenis te vragen. En als het goed is, krijgt hij van de grote vervolgens een aai over de bol en dan is het echt afgelopen, of liever gezegd, dan begint het hele verhaal weer van voren af aan. En opnieuw en opnieuw.

De vraag is of vergiffenis schenken wel in relaties van gelijken past. Zeker is dat het in hiërarchische relaties echt een plaats heeft. God kan vergiffenis schenken en inderdaad de priester namens hem of de pater familias als zijn verre plaatsvervanger. Vergiffenis vragen onder gelijken gaat de meeste mensen niet gemakkelijk af. Onder gelijken is het niet gemakkelijk om je ongelijk te bekennen. Egalitaire verhoudingen bemoeilijken het ongelijk bekennen, want dat toegeven is ongelijkheid accepteren. Dit geldt voor verhoudingen tussen mensen in het algemeen en binnen egalitaire opvoedingsverhoudingen in het bijzonder. Dat geen ongelijk bekennen kan een gewoonte worden. Er is in dat verband ook een dramatisch verlies aan ritueel. Als ik in Italië een stomme fout in het verkeer maak en ik steek mijn handen in de lucht, kan het zijn dat ik onder begeleiding van een quasihautaine blik en een brede armzwaai vrij baan krijg. Als ik dat in Nederland doe is de kans groot dat de mond blijft schelden en de middelvinger in de lucht blijft steken. Ik generaliseer hier, maar dat mag. Het gaat om de onverwachte maar mogelijke problematische gevolgen van de egalisering van verhoudingen in het algemeen en van de opvoedingsverhoudingen in het bijzonder.

Een van de grote problemen van het debat over waarden en normen is dat participanten claimen zowel theoretisch als praktisch de wijsheid in pacht te hebben. 
Naast de ouderwetse opvatting dat pesten op school er gewoon bij hoort, die door een ethologische benadering als die van Goldschmidt nieuw leven ingeblazen zou kunnen krijgen, is er de opvatting dat pesten, opgevat als structureel lichamelijk, geestelijk of seksueel geweld tussen leerlingen onderling, wat partijen, mechanismen en gevolgen betreft vergelijkbaar is met kindermishandeling. In dat geval niet van volwassenen ten opzichte van kinderen, maar tussen kinderen onderling (vgl. Van de Meer 2002). In de jaren tussen Lubbers en Balkenende heeft Nederland te maken gekregen met nieuwe vormen van geweld. Op de reeks incidenten die men als zinloos geweld is gaan betitelen is echter nog niet veel meer dan sprakeloosheid en collectief ongeloof gevolgd. Psycholoog Bob van der Meer zei op 29 april 2003 tegen de Volkskrant dat een schietpartij als in het Duitse Erfurt, waarbij een leerling volkomen onverwacht achttien medeleerlingen en leerkrachten om het leven bracht, ook in Nederland voorstelbaar is. Van der Meer legde een direct verband tussen dergelijke verschrikkelijke gebeurtenissen en pesten op school. Het directe verband is natuurlijk niet wetenschappelijk aangetoond. Van der Meer houdt zich al bijna 25 jaar met dat onderwerp bezig. Het is zijn onderwerp. Tot nu toe is het nog niet gelukt om scholen te verplichten een beleid op het gebied van pesten te formuleren en uit te voeren. En toch blijft het de vraag of dat wel moet. Net als het de vraag blijft of een verbod op slaan in de wet moet worden opgenomen. Net als het de vraag is of de gedragscode op school, die leerkrachten verbiedt om kinderen van een zekere leeftijd op schoot te nemen om te troosten, wel zo'n goed idee was. Het is de vraag omdat de hele benadering steunt op een overschatting van wat je met beleid, wet en regel bereiken kan. Het is de vraag omdat men weer even vergeet dat regels van deze soort tot ontduiking aanleiding geven en juist het verkeerde gedrag dat je in de gaten zou willen houden naar het verborgene verbant. Het is de vraag omdat het allemaal lijkt te steunen op het uitgangspunt dat ouders en leerkrachten het niet zelf afkunnen en het bevordert niet dat de lerarenopleidingen leraren af gaan leveren die die kwaliteiten wel hebben.

Naast egalisering is er in Nederland de afgelopen dertig jaar sprake geweest van een sterke feminisering van de verhoudingen. Nieuwe aandacht voor de oude verschillen tussen jongens en meisjes is geboden. Ontkennen dat in het jongetje zijn hele leven het testosteronkanon blijft bulderen heeft geen zin (vgl. Biddulph 1999; Delfos 2001). Maar er moet natuurlijk ook aandacht zijn voor onderzoek als dat van Marianne Junger, die onder meer tot de conclusie komt dat fysieke agressie een vorm van gedrag is die bij baby's spontaan ontstaat en in het algemeen vanaf het vierde à zesde levensjaar weer afneemt. Junger veronderstelt dat het de ouders zijn die kinderen zo tussen twee en zes het fysieke gedrag afleren. Haar voorlopige conclusie, dat fysieke agressie al heel vroeg in het leven zichtbaar wordt en daarom ook heel vroeg in het leven moet worden afgeleerd, is van groot pedagogisch belang. Agressiviteit als gewoonte. We moeten gewoon goede gewoonten aanleren en slechte gewoonten afleren. Zou het zo eenvoudig zijn? Er moet natuurlijk ook aandacht zijn voor onderzoek dat een verband legt tussen agressiviteit en voedingssupplementen in fastfood bijvoorbeeld. Het is helemaal niet eenvoudig, want het overzicht ontbreekt. 
We moeten in ieder geval waken voor de totaalaanspraken van de marskramers in projectenland. Aan de ene kant dreigt theoretische eenzijdigheid, aan de andere kant theoretische vervlakking. Ooit sprak Kohlberg heerlijk helder badinerend van de bag of virtues in zijn afwijzing van de deugdenbenadering en zijn verdediging van zijn cognitivistische benadering (vgl. Kohlberg 1981). Later heeft hij dat allemaal genuanceerd en het is natuurlijk ook verstandig om als uitgangspunt te nemen dat, zoals wij het noemden, in morele opvoeding zowel kennis als vaardigheden en affecties in het geding zijn. Projecten die ooit gestart zijn op grond van eenzijdige wetenschappelijke uitgangpunten als de kohlbergiaanse zijn allang verwaterd en vermengd met andere benaderingen. Daaruit blijkt dat de kohlbergiaanse benadering ook in de praktijk volstrekt niet op eigen benen kan staan. We moeten hoe dan ook oppassen dat termen als 'waarden- en normenoverdracht' en 'morele opvoeding' niet worden 'misbruikt' als legitimatie van op zichzelf lovenswaardige projecten voor samenlevingsopbouw. Dergelijke projecten moeten ook op grond van die specifieke doelstellingen worden geëvalueerd. De noodzaak tot nauwgezet evalueren is er ook bij een geheel andere aanpak als die in de penitentiaire inrichting Den Engh en die in de Glen Millschool, waar delinquente jongeren via een gerichte, militair aandoende, groepsaanpak worden voorbereid op de terugkeer in de maatschappij. Dat in dat verband ten onrechte over 'opvoeding' wordt gesproken is zeker. Of de jongens na de behandeling inderdaad het gewone vrije leven weer aankunnen moet precies worden nagegaan. Daarbij is van groot belang - het is een open deur, maar het blijft een hele belangrijke - dat de verschillende disciplines goed samenwerken. Wat dreigt is dat practici zich op terreinen begeven waar het hen aan de vereiste theoretisch expertise ontbreekt, terwijl de experts zich hebben teruggetrokken in de ivoren toren van het wetenschappelijk onderzoek, en beiden geen goed woord voor elkaar over hebben.

Dat het allemaal niet eenvoudig is heb ik zelf aan den lijve ervaren. Als wethouder Welzijnszaken van een kleine Nederlandse gemeente was ik begin jaren negentig betrokken bij een anti-vandalismeproject. Ik deed er in 1994 op een congres over preventie van gedragsstoornissen verslag van (vlg. Levering 1994). Met al mijn inhoudelijke bagage moest ik aanzien dat disciplines langs elkaar heen werkten, zich stevig vastklampend aan de opvattingen die ze al hadden voordat de ellende begon. Hier volgt wat ik destijds optekende.

\subsection{ANTI-VANDALISMEBELEID IN MONTFOORT. EEN PERSOONLIJK VERHAAL}

In het stadje Montfoort, een vijftiental kilometer ten zuidwesten van Utrecht, kampte men in het begin van de jaren negentig met een vervelend jeugdvandalismeprobleem. Zelf waren wij er een jaar of vijftien eerder komen wonen. In zekere zin was vijftien kilometer toen nog ver van de stad. Als ik een brood ging kopen, twee straten verderop, liet ik met opzet de voordeur openstaan. Dat kon daar toen nog en dat wilde ik weten ook. Tegenwoordig woont heel Nederland in de 
grote stad en doen we allemaal aan inbraakpreventie. Postmodernisme in het Groene Hart van Holland.

Het jeugdvandalisme in Montfoort was niet echt uitzonderlijk. De dingen die er gebeurden, gebeurden in andere plattelandsgemeenten in de omgeving ook. Graffiti, allerhande vernielingen, het lastigvallen van voorbijgangers, diefstal uit tuinen en schuurtjes, drank- en softdruggebruik in het park. In Montfoort was het allemaal alleen een graadje erger. Dat kon ook in de jaarverslagen van de politie worden nagelezen.

Op 1 mei 1990 werd ik gekozen tot wethouder van deze gemeente met 12.500 inwoners, ongelijk verdeeld over twee kernen, bestuurd door een gemeenteraad van vijftien leden, met een dagelijks bestuur bestaande uit een burgemeester en twee wethouders. Dit verhaal gaat over mijn mislukte anti-vandalismebeleid in die vier jaar. Want hoewel ik graag zou verhalen van al die geslaagde bestuurlijke acties waaraan ik in die periode een bijdrage heb mogen leveren, zal ik mij tot het anti-vandalismebeleid beperken. Wetenschappelijk gezien zijn nu eenmaal de mislukkingen het interessantst.

De politierapporten boden vanuit preventieoogpunt een vertrouwd beeld. De vaak zeer jonge jongeren die vaker met de politie in aanraking kwamen, bleken meer dan eens uit gezinnen afkomstig die arm waren aan beschermende factoren. Retrospectief was het niet moeilijk om eventuele oorzaken van problematisch en antisociaal gedrag op te sporen. Die jongen die vrijdagavond door vader uit huis werd gezonden, met de mededeling niet voor zondagavond terug te keren, omdat vader in het weekend rust aan zijn hoofd wilde, kan moeilijk kwalijk genomen worden dat hij tussenliggende nachten buitenshuis doorbracht. Maar in voorspellende zin en in het individuele geval valt er van de oorzaken van antisociaal gedrag maar bitter weinig te zeggen. Niet alleen omdat ongunstige omstandigheden lang niet in alle gevallen tot ongewenste gevolgen leiden, maar ook omdat gunstige omstandigheden geen garantie lijken te bieden voor het voorkómen van ongewenste gevolgen. Ook wat dat betreft vormde de situatie in Montfoort geen uitzondering.

Wat de toenmalige beleidscontext betreft is het volgende van belang. De gemeenteraad had zojuist tot de instelling van uitvoerend jongerenwerk in de hele gemeente besloten. Sinds de gemeentelijke herindeling van 1989, waarbij het dorp Linschoten en het stadje Montfoort waren samengevoegd, was een geslaagde poging gedaan om het welzijnsbeleid van beide kernen op elkaar af te stemmen. Een van de resultaten was dat er in Montfoort nu ook actief aan Jeugdwelzijnswerk gedaan zou gaan worden, een situatie die in Linschoten al bestond. De oude Montfoortse gemeenteraad had altijd in meerderheid een forse weerstand tegen open jongerenwerk gehad. De confessionele meerderheid organiseerde haar eigen jongerenwerk in haar eigen instellingen. Daarnaast verwachtte men van de preventieve werking van het open jongerenwerk niet veel. Zo zei een van de raadsleden in dit verband ooit tegen mij: "Ach Bas, geef die tachtigduizend 
gulden toch gewoon aan mij. Dan zal ik de schade betalen die jaarlijks wordt aangericht en dan weet ik zeker dat ik nog geld overhoud ook." Jongerenwerk, dat door velen louter gezien wordt als vorm van vandalismebestrijding en waar men eigenlijk juist wat dat betreft niets van verwacht, gaat niet onder een al te goed gesternte van start.

Ik zat dus als welzijnswethouder met een groot probleem. Ik wilde het functioneren van het jeugd- en jongerenwerk niet laten afrekenen op het eventueel mislukken van het anti-vandalismebeleid. Het jeugdvandalismeprobleem was immers in de eerste plaats een openbare-ordeprobleem. En op het terrein van de openbare orde heeft in een Nederlandse gemeente de burgemeester een eerste en unieke verantwoordelijkheid. Zo kwamen we overeen dat we langs twee lijnen zouden werken. Burgemeester en politie, ondersteund door de afdeling bestuurszaken, probeerden de problemen te lijf te gaan door de opzet van een buurtpreventieproject. De wethouder welzijn, ondersteund door de afdeling welzijn, ging gesprekken aan met allerhande instellingen die met de problemen van doen hadden. Die gesprekken dienden een dubbel doel. In de eerste plaats ging het natuurlijk om de uitwisseling van ideeën met directbetrokkenen. In de tweede plaats ging het om netwerkontwikkeling. ${ }^{1}$

De heldere taakverdeling tussen de twee afdelingen zou vanzelfsprekend gepaard gaan met een voortdurende uitwisseling van ervaringen. Van die vorm van samenwerking kwam echter weinig terecht, omdat al snel bleek dat de visies op het probleem niet alleen verschilden, maar zelfs diametraal tegenover elkaar stonden. De verantwoordelijken voor de openbare orde stonden een krachtig repressief beleid voor. De verantwoordelijken voor het welzijnsbeleid toonden zich geïnteresseerd in achtergronden en stonden een beleid voor dat als meer pedagogisch te kenschetsen was. Op repressief terrein was er al het een en ander uitgeprobeerd. De hekken die de ene dag voor de binnentuinen van het scholencomplex waren geplaatst, bleken de volgende dag eenvoudig omgetrokken. De in de school geplaatste camera's bleken op die nachten te draaien dat er toevallig niets onrechtmatigs gebeurde. Het gemeentebestuur zat met de handen in het haar. Er leek niet veel meer te resten dan de wijk directer bij de aanpak van de problemen te betrekken.

In het verenigingsgebouw Sint Joseph kwamen op uitnodiging van de burgemeester de bewoners van de meest geplaagde wijk bij elkaar om over de problemen te praten. In het gesprek werden de uitkomsten van een enquête die eerder in de wijk was uitgezet, tot uitgangspunt gekozen. Het werd een zeer emotionele bijeenkomst. We zijn de inbreuken op het gewone leven in het algemeen zo gewoon gaan vinden dat we concrete verhalen nodig hebben om de wanhoop in het individuele geval te begrijpen. In een enkel geval zagen bewoners geen andere oplossing dan verhuizen. Het gebrek aan aanspreekbaarheid ervoer men als het meest moedeloosmakend. Het gemeentebestuur kreeg de volle laag. Hoe lang waren de klachten nu al bekend en wanneer gebeurde er nu eindelijk iets? Voor politie en justitie had men ook al geen goed woord over. Als je belde kwamen ze 
niet en als er eindelijk iemand gepakt werd, ging de raddraaier vrijuit of stelde de uiteindelijk opgelegde straf in de ogen van de bewoners niets voor. Men legde de verantwoordelijkheid voor de eigen veiligheid onverkort bij de overheid. Het resoluut afschuiven van de verantwoordelijkheid werd relatief vaak gepraktiseerd door ouders van notoire onruststokers. Als je je realiseert dat dit in het verlengde ligt van de ervaren onmacht, is het minder merkwaardig dan het op het eerste gezicht lijkt. Hoe het ook zij, toch toonde een vijftigtal wijkbewoners zich bereid om een of andere bijdrage aan een buurtpreventieproject te leveren.

De gesprekken met instellingen onthulden eenzelfde tweespalt in visies op de jeugdvandalismeproblematiek als binnen de muren van het stadskantoor zichtbaar waren geworden. Er waren mensen die vonden dat je er gewoon meteen bovenop moest slaan. Er waren er ook die om aandacht voor andere aspecten van de problemen vroegen. Niet zelden zaten deze twee scherp onderscheiden categorieën in personen vredig naast elkaar in eenzelfde bestuur. De pedagogische houding die men in sommige gevallen aan de dag legde was gemeten naar de overlast vaak bewonderenswaardig. Hier en daar werd met spijt gesproken over een niet te begrijpen verharding. Een oude rot in het vrijwilligersvak verzuchtte: "Ik kan ze niet meer bereiken; vroeger scholden ze tenminste nog op me." Aan de andere kant werden successen gemeld van een stevigere aanpak. Bij de bibliotheek werd het pasjessysteem strikt gehandhaafd en de voorzitter van het bestuur hield de jonge onruststokers hoogstpersoonlijk met zijn hond op afstand.

Het verschil in visie, dat een bovenlokale betekenis heeft, leek door de stelligheid waarmee de onderscheiden standpunten worden geformuleerd echt onoverbrugbaar. Binnen de muren van het stadskantoor was het verschil in visie zo hardnekkig dat het de ontwikkeling van samenhangend beleid al aan de basis frustreerde. De werking van het verschil in visie kwam scherp tot uitdrukking in de manier waarop er tegen het zogenoemde HALT-project werd aangekeken. Het idee van de toepassing van alternatieve straffen bleek beide kampen aan te spreken. De hardliners waardeerden de HALT-aanpak echter vanwege de effectiviteit, terwijl de pedagogisch geïnspireerden er vooral iets in zagen vanwege het idee van de zinvolle straf. Een onderzoekster die op grond van haar succesvolle begeleiding van een HALT-project in Almelo en haar ervaring met jongeren die met de politie in aanraking kwamen door de ene afdeling werd aanbevolen, kwam bij een andere afdeling niet verder dan één gesprek.

In de gesprekken met instellingen bleek dat er een grote eenheid van gedachte bestond over de verantwoordelijkheid die de ouders van de overlast bezorgende jongeren in dit verband toekomt. Maar in de visie op de wijze waarop de ouders zouden moeten worden aangesproken vonden we weer hetzelfde verschil in visie terug. Er waren mensen die met een ongekende verbetenheid over de verantwoordelijkheid van de ouders spraken. Er waren er ook die ervoor waarschuwden de ouders niet in de beklaagdenbank te zetten, zowel om redenen van ineffectiviteit als om morele redenen. Dat falen als ouder een van de ergste dingen is die 
een mens kan overkomen, weten we natuurlijk ook uit andere bronnen. Hier bleek het, hoe vreemd dat op het eerste gezicht misschien ook lijkt, zowel uit de buitengewone felheid van het intolerante als uit de bijzondere mildheid van het tolerante oordeel.

De afdeling Bestuurszaken schreef de 'Integrale beleidsnota criminaliteitspreventie. Tweesporenbeleid: Buurtpreventie en Sociale Vernieuwing'. Van het tweede spoor, de sociale vernieuwing, is weinig terechtgekomen. Het belang van de wijk bleek het verjagen van de vandalen, of die nu uit de buurt zelf afkomstig waren of niet, of die nu elders een buurt onveilig zouden maken of niet. De bij het buurtpreventieproject betrokken bewoners lieten zich als hardliners kennen. De binnentuinen van het scholencomplex waren al door hoge hekken afgesloten om het rondhangen daar te voorkomen. $\mathrm{Nu}$ overwoog men met de portieken hetzelfde te doen.

Inmiddels is de overlast door jeugdvandalisme in Montfoort een stuk draaglijker geworden dan het in de afgelopen jaren is geweest. Het enige opvallende verschil met die afgelopen jaren is dat er nu een andere wethouder voor welzijnszaken zit. $\mathrm{Om}$ nu de gunstige ontwikkeling daaraan toe te schrijven gaat toch te ver. Ook kan het verminderen van de overlast in de hele gemeente niet worden toegeschreven aan het geslaagde buurtpreventieproject in die ene wijk. Sommige sociologen hebben verklaringen die pedagogen de indruk geven nutteloos werk te verrichten. Die zien jeugdvandalisme als generatiegebonden fenomeen. Als een aantal jongens uit de groep aan de vriendin raakt, is het overlast gevende gedrag meer dan eens snel verdwenen. Niet zelden is de vandaal van veertien op zijn 28 ste veranderd in een brave burgerman, die zich al zorgen begint te maken over het gedrag van zijn eigen kinderen.

\subsection{ACHTERAF}

Inmiddels zitten er extra sloten op de deuren van ons huis in Montfoort en zijn er voor het winkelpand van de juwelier ter stede betonblokken in een passende kleur gestort tegen de zogenaamde ramkraken die inmiddels in zwang gekomen zijn. Bij de bushalte tegenover het stadskantoor is een Jop gebouwd. De houten wanden van de openbare fietsenstalling die ernaast staat zijn verwijderd, zodat iedereen kan zien wat er gebeurt. Tussen Hoorn en Enkhuizen houden zogenaamde treinterroristen van een jaar of zeventien huis als uitkomst van een 'brisante mix van maatschappelijk onvermogen', zoals de Volkskrant commentarieert.

De persoonlijke ervaring met het Montfoortse anti-vandalismebeleid leerde ons veel over de manier waarop ouders zich al dan niet voor hun pubers verantwoordelijk weten, maar vooral ook dat je er met gedegen wetenschappelijk inzicht in de problematiek niet bent. De verschillende opvattingen over wat we met de problematiek van overdracht van waarden en normen in de opvoeding aan 
moeten zijn zeer hardnekkig, op alle niveaus. Of het nu gaat om de sociaal-filosofische tegenstellingen en de vraag of de overheid überhaupt een taak heeft in kwesties van deze soort - zoals we die bijvoorbeeld in het begin van deze studie bij Diekstra en Kohnstamm tegenkwamen - of om de verschillen in inzicht in de manier waarop we onze jeugd hoe dan ook mores kunnen leren - zoals we die bijvoorbeeld én onder Montfoortse burgers én onder Montfoortse gemeenteambtenaren én onder Montfoortse gemeentebestuurders aantroffen - het lijkt een onmogelijke taak om alle neuzen één kant op te krijgen, om die vreselijke uitdrukking toch maar te gebruiken. De opvattingen van de eerste soort zijn meestal impliciet, die van de tweede expliciet, maar beide soorten zijn inderdaad zeer persistent. Het feit dat er in de afgelopen tien à vijftien jaar, ondanks alle aandacht voor de problematiek, zo weinig vorderingen zijn gemaakt, heeft dus een structurele oorzaak.

De zorg voor de samenleving als geheel en de volgende generatie in het bijzonder kan niet tot het probleem van de overdracht van waarden en normen worden gereduceerd. Het plan voor het dichten van de gaten in de pedagogische infrastructuur suggereert toch te veel dat we er weer een blijvende eenheid van kunnen maken. Wellicht moet het postmoderne karakter van onze samenleving in het beleid meer als uitgangspunt worden genomen dan tot nu toe gebeurde. De onderlinge betrokkenheid van de jaren vijftig komt niet terug en die van de jaren zeventig ook niet. In multi-etnische wijken leven verschillende groepen keurig langs elkaar heen. Maar het verblijf in de publieke ruimte moet veiliger en vriendelijker kunnen. Er is hoe dan ook veel werk aan de winkel. We moeten nu eens en voor altijd duidelijk maken dat, als het om morele opvoeding en ontwikkeling gaat, de lang alom aangehangen kohlbergiaanse benadering en de deugdenbenadering eigenlijk uiterst zwak zijn. De sterke, op affecties gerichte benadering, die nog altijd onderbelicht gebleven is, vraagt om een grote persoonlijke betrokkenheid. De zwakte van de theorie van Kohlberg en van de deugdenbenadering doortrekt de projecten die op de uitgangspunten van die theorieën gebaseerd zijn. Vaak gaat het daarbij ook helemaal niet om projecten morele opvoeding of overdracht van waarden en normen, maar om lovenswaardige projecten die de opbouw van de samenleving in het algemeen moeten dienen. Dat moeten de subsidiegevers zich dan wel realiseren, want dat is dan ook de doelstelling waarop dergelijke projecten moeten worden geëvalueerd.

Cruciaal in ons verhaal is het uitgangspunt dat we niet over waarden- en normenoverdracht moeten zeuren als we onze eigen praktijk van waarden en normen niet op orde hebben. Fatsoen moet je inderdaad doen, maar dat moet je dan ook echt doen. We moeten snappen en accepteren dat onze verslonsde samenleving geen nette burgers kan voortbrengen. De noodzakelijk algehele Opzoomeractie kost meer opoffering dan een vrije zaterdag.

Het hele idee van waarden- en normenoverdracht is gebaseerd op een negentiende-eeuwse vergissing. Dat mensen zich ooit aan normen hielden, betekent niet dat de overdracht ervan gelukt was. Dat mensen zich aan die normen hiel- 
den, werd gerealiseerd doordat ze voortdurend werden ondersteund door een homogene cultuur van een bepaalde normatieve orde. Doordat die homogeniteit nu niet meer bestaat is op een schrijnende manier zichtbaar geworden dat het inplanten van een intern moreel kompas hoe dan ook onmogelijk is.

Dat het bij morele opvoeding en ontwikkeling om verwerkelijking van waarden door het kind gaat, weten pedagogen al meer dan een halve eeuw. Hoe komt het toch dat ze dat nog altijd niet aan de rest van de wereld hebben kunnen duidelijk maken? De moderne democratische persoonlijkheid vormde in die pedagogiek al sinds jaar en dag het opvoedingsdoel, maar juist dat volwassenheidsbeeld staat door het gedrag dat een groot aantal van de Nederlandse volwassenen aan de dag legt onder grote druk.

We maakten de balans op van de overheidsbemoeienis met de opvoeding in de afgelopen halve eeuw. We constateerden dat daarin verschillende krachten werkzaam zijn geweest. Er is een afname van overheidsbemoeienis op grond van het liberaal-burgerlijke ideaal van de negatieve vrijheid. Er is een toename van overheidsbemoeienis omdat de burger van het overheidsbedrijf waar voor zijn belastinggeld eist. De terugtredende en de optredende overheid strijden om de voorrang. Het voorlopige resultaat van deze merkwaardige mix is dat de directe overheidsbemoeienis is afgenomen, terwijl de indirecte overheidsbemoeienis is toegenomen. Wat de directe overheidsbemoeienis betreft zouden veel van de zo op hun privacy gestelde ouders in voorkomende gevallen gediend zijn met het terloopse opvoedingsadvies dat ooit op consultatiebureaus zo gewoon was.

Opgestuwd door de groeiende welvaart is de relatie tussen ouders en kinderen in diezelfde halve eeuw fundamenteel veranderd. De meeste ouders en kinderen kunnen goed met elkaar overweg. Ze hangen dezelfde waarden en normen aan en daarom hoeven kinderen niet langer het huis uit om hun morele vrijheid te verwerven. Van de ooit zo kenmerkende calvinistische ingetogenheid is nagenoeg niets meer over. Een groot deel van de kinderen groeit in een sfeer van onmatigheid op. Dat is geen sfeer waarin je rekening leert houden met anderen. Daarin moet dan ook expliciet worden geïnvesteerd. Doordachte omgangsregels moeten als elegante gewoonten worden aangebracht, opdat en zodat mensen (weer) naar elkaar omzien. Om te ontdekken hoe dat kan en moet dient de scope van het sociaal-wetenschappelijk onderzoek sterk te worden verbreed en bijvoorbeeld ook biologie en ethologie te omvatten. Alleen op die manier kan sterke theorie ontwikkeld worden die geschikt is om met creatieve praktijk verbonden te worden.

Ouderschap behelst voor de ambitieuze tweeverdieners van onze tijd een loodzware taak, maar de overheid kan de opvoeding niet van hen overnemen. De overheid moet zuinig zijn met regels, maar moet niet terughoudend zijn in het ouders wijzen op hun opvoedingsverantwoordelijkheid. Soms moet er toch een regel bij. De verplichting om ervoor te zorgen dat als ouders uit elkaar gaan als eerste wordt vastgelegd hoe het met de kinderen verder zal gaan, moet zo snel 
mogelijk worden opgenomen in de wet. Scheiding is statistisch gezien allang een normaal verschijnsel, maar voor kinderen wordt het nooit normaal als ouders uit elkaar gaan (vgl. Spruijt et al. 2003).

En al is de band tussen moreel denken en redeneren en handelen dan nog zo zwak, er moet over waarden en normen gesproken blijven worden. In het meest ontkerkelijkte land van de wereld zal dat vooral ook in de school moeten gebeuren door goed opgeleide betrokken leerkrachten. Ook daarin moet worden geïnvesteerd. Want wie naast de ouders de kinderen in deze morele doolhof de weg moet wijzen, moet wat dat betreft van wanten weten. 


\section{NOOT}

I We spraken met de besturen, directies en medezeggenschapsraden van scholen, de beheerder van de kantine in de sporthal, vertegenwoordigers van de beide jongerencentra, de ondernemersvereniging, vertegenwoordigers van de binnenen buitensportverenigingen, het bestuur van de openbare bibliotheek, bestuur en beheerder van het verenigingsgebouw, het maatschappelijk werk en met de politie. 


\section{LITERATUUR}

Adorno, Th.W. (1970) Opvoeding tot mondigheid, Utrecht/Antwerpen: Het Spectrum. Biddulph, S. (1999) Jongens, hoe voed je ze op? Rijswijk: Elmar.

Bogt, T. ter en C. van Praag (m.m.v. P. Krabbe) (1992) Jongeren op de drempel van de jaren negentig, Rijswijk: Sociaal en Cultureel Planbureau.

Delfos, M. (2001) 'De ontmannelijking van de man. Opvoeden met de biologische stroom mee in plaats van tegen de biologische stroom in', Pedagogiek in Praktijk Magazine, 1, 1: 8-13.

Diekstra, R.F.W. (red.) (1992) Jeugd in ontwikkeling. Wetenschappelijke inzichten en overheidsbeleid, WRR Voorstudies en achtergronden, nr. 75, Den Haag: Sdu Uitgevers.

Godot, E.A. (2003) Hoezo pedagogisch? Amsterdam: SwP.

Goldschmidt, T. (1998) 'De biologie van het pesten. Onbevooroordeeld etholoog node gemist op het schoolplein', NRC Handelsblad, 16 mei.

Gunning, J.H. (1940) Keur uit de werken, Groningen/Batavia: Wolters.

Haaften, A.W. e.a. (1986) Ontwikkelingsfilosofie. Een onderzoek naar de grondslagen van ontwikkeling en opvoeding, Muiderberg: Coutinho.

Hare, R.M. (1981) Moral thinking. Its levels, method and point, Oxford: Clarendon Press.

Harris, J. R. (1998) Het misverstand opvoeding. Over de invloed van ouders op kinderen, Amsterdam: Contact.

Junger, M. (2003) 'Agressie op jonge leeftijd', Pedagogiek in Praktijk Magazine, 3, 14: 16-19.

Kohlberg, L. (1981) 'From is to ought and how to commit the naturalistic fallacy and get away with it in the study of moral development', blz.101-189 in: L. Kohlberg, The philosophy of moral development. Moral stages and the idea of justice, San Francisco: Harper and Row.

Kreulen, E. (2001) 'Een kind komt egocentrisch ter wereld', Trouw, 8 mei.

Kreulen, E. (2003) 'Nee is nee en soms toch “ja”' (n.a.v. Hoezo pedagogisch?), De verdieping, Trouw, 4 maart.

Langeveld, M.J. (1945/1979) Beknopte theoretische pedagogiek, Groningen: Wolters (Noordhoff).

Levering, B. (1983) 'De kunst van het schouderophalen. Een voor- en nawoord over morele opvoeding', Pedagogische verhandelingen, 6,4: 54-95.

Levering, B. (1986) 'Opvoedingsdoel in diskrediet', blz. 74-97 in: B. Levering \& J. van Weelden (red.), Over het bijzondere van de orthopedagogiek, Groningen: Wolters Noordhoff,

Levering, B. (1994) 'Ze pakken je je hele leven af'- Preventie van gedragsstoornissen in maatschappelijk perspectief, 'Voordat het te laat is. Preventie en aanpak van gedragsproblemen', Najaarscongres van de Vereniging O\&A, Amsterdam: RAI, 12 november 1994 .

Levering, B. (1996) Mogelijkheden en onmogelijkheden van morele opvoeding. Verkorte weergave van de bijdrage aan de studiedag 'Vrij en ongebonden' op 26 november 1996 in Eindhoven, 's-Hertogenbosch: Brabants Steunpunt Jeugdwelzijn.

Levering, B. (2003) 'De zorgelijke staat van het geweten', blz. 145-172 in: J. Vugt (red.), De actualiteit van het geweten, Budel: Damon. 
Meer, B. van der (2002) 'Pesten op school. Een goed bewaard groepsgeheim', Pedagogiek in Praktijk Magazine, 2, 8, 10-14.

Mink, F. e.a. (1996) Waarden en normen vrij en ongebonden. Het Lieshouts model, 's-Hertogenbosch: Brabants Steunpunt Jeugdwelzijn.

Mink, F. e.a. (1996) Waarden en normen vrij en ongebonden. Dilemma's en activiteiten, 's-Hertogenbosch: Brabants Steunpunt Jeugdwelzijn.

Praamsma, J.M. (2002) 'Te veel van het goede', Pedagogiek. Wetenschappelijkforum voor opvoeding, vorming en onderwijs, 22, 4-8.

Riesman, D. (1950) The lonely crowd. The changing of the American character, New Haven: Yale University Press.

Raad voor Maatschappelijk Ontwikkeling (2001) Aansprekend opvoeden. Balanceren tussen steun en toezicht, Den Haag: RMO-advies 18.

Ryle, G. (1958) 'On forgetting the difference between right and wrong', blz. 147-159 in: A.I. Melden, Essays in moral philosophy, Seattle/Londen: University of Washington Press.

Spruijt, E., H. Kormos en C. Burggraaf \& A. Steenweg (2003) Het verdeelde kind, Utrecht: Universiteit Utrecht.

Steutel, J.W. (red.) (1984) Morele opvoeding. Theoretisch-en historisch-pedagogische opstellen, Meppel/Amsterdam: Boom.

Veugelers, W.M.M.H. (2003) Waarden en normen in het onderwijs. Zingeving en humanisering: autonomie en sociale betrokkenheid, Utrecht: Universiteit voor Humanistiek.

Winter, M. de (1995) Kinderen als medeburgers. Kinder- en jeugdparticipatie als maatschappelijk opvoedingsperspectief, Utrecht: De Tijdstroom. 


\title{
9 GEDRAGSREGELS OP SCHOOL EN DE NOODZAAK DIE OOK DAADWERKELIJK TE HANDHAVEN
}

\author{
L.G.M. Prick
}

\section{Het Franse centralisme}

Waar het gaat om de problemen rond het thema normen en waarden in het onderwijs, is het verhelderend de Nederlandse situatie te vergelijken met die in Frankrijk, waar sprake is van strikte centralistische sturing. Scholen voor voortgezet onderwijs in Frankrijk kennen, naast de directeur onderwijs, een directeur beheerszaken die uitsluitend verantwoordelijk is voor de organisatie van de school als leefgemeenschap. De school kent dus twee bazen, de ene voor het onderwijs en de andere voor alle materiële voorzieningen, die in Frankrijk ook meer om het lijf hebben dan in Nederland, omdat de leerlingen er iedere dag een warme maaltijd geserveerd krijgen. Beide directeuren werken gedurende hun loopbaan achtereenvolgens op verschillende scholen in verschillende streken. Dit betekent dat niet alleen de inrichting van het onderwijs, maar ook de richtlijnen voor de manier waarop leerlingen zich dienen te gedragen overal in Frankrijk nagenoeg dezelfde dienen te zijn. Dit centralisme geldt overigens niet alleen voor het onderwijs, maar ook voor andere sectoren, zoals binnenlands bestuur en gendarmerie. De mobiliteit onder het hogere kader zorgt ervoor dat overal volgens centraal opgestelde directieven het werk wordt gedaan. Zo gaat het in Frankrijk. Diametraal tegengesteld hieraan is de situatie in Nederland.

\section{Het eigen karakter van de Nederlandse school}

Kenmerkend voor het Nederlandse onderwijs is de autonomie van de school en, daarbinnen, de autonomie van de leraar. De autonomie van de scholen betreft zowel de organisatie van het onderwijs als de inrichting van de school als leef- en werkgemeenschap. Scholen bepalen dus zelf de regels volgens welke leerlingen zich dienen te gedragen. Omdat geen sprake is van gescheiden verantwoordelijkheden van twee directeuren, zijn directie en leraren in Nederland tegelijkertijd verantwoordelijk voor zowel het onderwijs als voor een ordelijke gang van zaken in de school. Omdat de school de gedragsregels zelf opstelt, hebben zij ook iets betrekkelijks. Dit geldt temeer waar men over die regels, over wat al dan niet als fatsoenlijk of beleefd wordt ervaren, steeds meer verschillend is gaan denken.

\section{Diversificatie van de maatschappij}

In het verleden was er maar weinig verschil tussen de schoolregels en de opvattingen van de afzonderlijke leraren over hoe leerlingen zich dienen te gedragen. De afgelopen decennia is dit geleidelijk veranderd. Volwassenen in het algemeen, en dus ook leraren, zijn steeds meer onderling van mening gaan verschillen over de eisen die je aan jongeren mag stellen, over de vraag wat wel en niet hoort en in hoeverre het wenselijk is corrigerend op te treden en ook over de wijze waarop dit dan eventueel zou moeten worden gedaan. Daarmee zijn de gedragsregels waaraan leerlingen zich dienen te houden steeds meer afhankelijk geworden van de opvattingen daarover van de betrokken docent. Dit is niet alleen verwarrend 
voor de leerlingen, het is ook zeer belastend voor de leraren. Die moeten immers hun gedragsregels aanvaard zien te krijgen, waarbij zij altijd maar weer moeten opboksen tegen afwijkende opvattingen van collega's. Dat probleem is niet van vandaag of gisteren; het is wel steeds prominenter geworden met de voortschrijdende diversificatie, waarbij je als leraar steeds minder een beroep kunt doen op algemeen aanvaarde, van huis uit meegekregen regels. De situatie op veel scholen valt wat dit betreft te vergelijken met een voetbaltoernooi waarbij de ene scheidsrechter niet moeilijk doet over buitenspel, een ander een beetje buitenspel door de vingers ziet en een derde de regel strikt hanteert. Een dergelijk gebrek aan duidelijkheid is belastend voor scheidsrechter en spelers, draagt niet bij tot een goede sfeer, noch tot een goede onderlinge verstandhouding, want iedere beslissing, van ieder van die drie scheidsrechters, wordt aangevochten omdat die als onredelijk wordt ervaren. Gedragsregels op een school zijn in wezen niet anders dan de spelregels die daar gelden en vereisen dan ook eenzelfde consequente toepassing.

Overigens doet zich het verschijnsel van verschillen in inzicht met betrekking tot gedragsregels niet overal in dezelfde mate voor. Scholen met een duidelijke signatuur kennen op dit vlak, als gevolg van de gemeenschappelijke achtergrond van leraren én leerlingen, in de regel meer consensus dan gemiddeld het geval is.

\section{Cultuur in het onderwijs}

Een factor die de discussie rond gedragsregels in het onderwijs bemoeilijkt, is dat de omgangsvormen in scholen, als gevolg van de leeftijdsopbouw van de leraren, sterk gedomineerd worden door de cultuur van de jaren zeventig. Als volwassene moest je, conform de toen geldende tijdgeest, vooral tolerant zijn. Het belangrijkste pedagogische beginsel luidde 'moet kunnen', en je mocht al helemaal niet autoritair zijn. De vraag waarom iets verboden was, mocht daarom niet worden beantwoord met 'omdat dat nou eenmaal niet mag', of 'omdat zoiets niet hoort of niet fatsoenlijk is'. Het verbod diende met redenen omkleed te worden. Omdat omgangsregels lang niet altijd rationeel zijn te verdedigen, kan dit leiden tot absurditeiten. Een leraar verbiedt petjes, gevraagd naar de reden: ik wil je in de ogen kunnen kijken. Resultaat: petje achterstevoren mag wel. Met als uiteindelijk resultaat dat in de schoolregels komt te staan dat petjes in de klas uitsluitend achterstevoren mogen worden gedragen.

Niet alleen scholen maken rare sprongen met het petje. Hetzelfde geldt voor het St. Gregorius College in Utrecht en, in zijn voetspoor, NRC Handelsblad. Deze krant wijdt een redactioneel commentaar aan het gegeven dat die school door de Commissie Gelijke Behandeling in het gelijk is gesteld met haar verbod van hoofddoekjes. In het leerlingenstatuut van de betreffende school staan kledingvoorschriften die een verbod bevatten van, aldus de krant: "kledingstukken die met een niet-katholieke of niet-christelijke levensovertuiging kunnen worden geassocieerd. Met name worden genoemd: een cap, pet, hoofddoekje, burqa, chador, djelleba en niqaab." De krant vindt het blijkbaar gewoon dat het traditionele autochtone hoofddeksel pet nu ineens wordt getypeerd als niet te rijmen 
met het christelijke of katholieke karakter van de school, terwijl het hier om een omgangsregel gaat, om de vraag of iets al dan niet als fatsoenlijk, beleefd, passend bij de situatie wordt ervaren. Het voorbeeld illustreert de verwarring daarover bij zowel de school als bij de commentator. Het illustreert ook iets anders: de problemen rond gedragsregels zijn de laatste jaren in het onderwijs nog eens extra toegenomen als gevolg van het feit dat scholen in toenemende mate te maken krijgen met leerlingen afkomstig uit andere culturen. Hun in het oog springende, afwijkende opvattingen hebben als gunstig effect gehad dat scholen steeds meer zijn gaan beseffen dat er op dit terrein daadwerkelijk iets dient te gebeuren.

Kortom, soms is er sprake van onbekendheid met of het ontbreken van regels met betrekking tot omgangsvormen, maar voorzover ze wel algemeen bekend zijn en deel uitmaken van het schoolreglement, hebben leraren er toch moeite mee die te handhaven. Dit nu is het gevolg van de specifieke positie van de leraren in het Nederlandse onderwijs. Voor wat betreft de inrichting van het onderwijs zijn zij, naar internationale maatstaven gemeten, ongekend autonoom. Het is daarom niet wonderlijk dat zij een vergelijkbare autonomie vanzelfsprekend vinden waar het gaat om secundaire aspecten van hun beroep zoals het toezien op orde in de school.

Hoewel veel leraren het zullen zien als een aantasting van hun autonomie, ontkomen scholen er niet aan duidelijke regels op te stellen en van de leraren te eisen dat zij die ook handhaven, want wanneer in een school vanzelfsprekende leefregels niet meer gelden, wordt die school een chaos en in een chaos kun je niet werken. Zo'n school is dus gewoon een slechte school.

\section{Onderwijskundige ontwikkelingen}

Dat de laatste tijd in het onderwijs de discussies over normen en waarden zijn opgelaaid heeft te maken met bovengeschetste ontwikkeling van diversificatie. Deze leidt niet alleen in de school maar in alle sectoren van het maatschappelijk leven tot onduidelijkheid en verschillen in inzicht, waardoor excessen zoals het verschijnen van leerlingen op school in een niqaab, een gezichtssluier, nodig zijn om iedereen te doen beseffen dat bezinning op normen en waarden noodzakelijk is om tot algemeen aanvaarde gedragsregels te komen. De behoefte daaraan in het onderwijs wordt versterkt door twee andere ontwikkelingen. In de eerste plaats de andere inrichting van het voortgezet onderwijs waarbij leerlingen zelfstandig werken en waarbij ze niet te maken hebben met het gezag van één bepaalde docent. De regels die gelden in het studiehuis kunnen moeilijk afhankelijk worden gesteld van de leraren die er op dat moment toevallig rondlopen. Daar komt nog een versterkend effect bij uit geheel onverwachte hoek: het lerarentekort. Het handhaven van eigen gedragsregels kost leraren veel energie. Leraren zijn het hele lesuur lang doende met de orde te bewaren. Talloos zijn de verhalen over zij-instromers die het al na een paar weken of maanden voor gezien houden. Zij hebben gekozen voor het beroep van leraar en niet voor dat van politieagent, zo kunnen hun beweegredenen om het onderwijs weer snel te verlaten, worden 
samengevat. Die zij-instromers hebben trouwens gezien hun leeftijd in de regel ook geen last van het 'moet kunnen'-syndroom. Zij vinden gewoon dat leerlingen zich behoorlijk dienen te gedragen.

Willen scholen personeel krijgen en binnenboord houden, dan zullen zij dat personeel een aanvaardbaar werkklimaat moeten bieden. Scholen moeten daarom niet alleen duidelijkheid verschaffen omtrent de gedragsregels waar leerlingen zich aan dienen te houden, zij dienen er ook serieus werk van te maken die regels te handhaven.

\section{Het onderwijsaanbod}

Dat scholen de laatste jaren in toenemende mate worden geconfronteerd met gedragsproblemen van jongeren is niet alleen het gevolg van maatschappelijke ontwikkelingen of de verdeling van de verantwoordelijkheden binnen onze scholen, maar heeft ook te maken met het onderwijs zelf, met de vraag welke kennis en vaardigheden scholen geacht worden de leerlingen bij te brengen.

Voor veel leerlingen, vooral te vinden in de laagste regionen van het voortgezet onderwijs, heeft de school zijn functie allang verloren. De leerstof die ze er voorgeschoteld krijgen, bevestigt alleen maar hun onvermogen en ontneemt hen daarmee het laatste restje zelfvertrouwen. De school heeft hun niets te bieden. Dat is overigens niet de schuld van die scholen, maar het gevolg van de maatschappijvreemde opdracht waar de politiek die scholen mee heeft opgezadeld. Zo getuigt het pakket basisvorming van een wereldvreemd wensdenken van mensen wier ideaalbeeld van de verheffing van de arbeider is blijven steken in de jaren vijftig. Het huidige onderwijs sluit niet aan bij de behoeften en vermogens van veel leerlingen. Dit geldt vooral voor de leerlingen die aangewezen zijn op de vbo-varianten binnen het vmbo, maar omdat opinieleiders als politici, journalisten, wetenschappers en beleidsambtenaren hun kinderen daar in de regel niet hebben zitten, is er nauwelijks aandacht voor. Wel voor de problemen die die jongeren op straat veroorzaken, want daar worden we allemaal mee geconfronteerd, maar niet voor de onderwijsinhoudelijke oorzaken ervan.

De laatste jaren is er steeds meer aandacht voor de maatschappelijke problemen die hier het gevolg van zijn. De oplossing wordt gezocht in strenge en ook kostbare heropvoedingsinternaten die ontspoorde jongeren terug op het rechte pad dienen te brengen. Het beleid zou gericht moeten zijn op de voorkoming daarvan.

Voor de jongeren waar het hier om gaat, en dat geldt zowel allochtoon als autochtoon, is het grote struikelblok in haast alle gevallen een gebrekkige kennis van de taal. Dit gebrek vormt een handicap bij vrijwel alle vakken die ze in het vmbo krijgen voorgeschoteld. Daardoor worden deze leerlingen op school voortdurend geconfronteerd met hun tekorten en worden hun eventuele kwaliteiten niet zichtbaar. 
Voor deze leerlingen moeten er scholen komen waar vakmensen hen een vak leren waar zij later de kost mee kunnen verdienen. Dit draagt meer bij tot de ontwikkeling van het zelfbewustzijn van deze jongeren dan nog meer van het soort lesstof waar ze op de lagere school ook al niet mee uit de voeten konden.

\section{Een speciale functionaris}

Wanneer in scholen in het verleden werd gesproken over normen en waarden, werden lijsten opgesteld van hoogdravende, vage noties waar iedereen zich in kon vinden, zoals: respect voor de ander, tolerantie ten aanzien van elkaars geloofsovertuiging, bereidheid naar anderen te luisteren. Dit kon iedereen op zijn eigen manier uitleggen en dus kon iedereen zich daar ook in vinden. Maar als gevolg van geschetste ontwikkelingen gaan scholen steeds meer over tot het opstellen van praktische regels zoals niet met de voeten op de stoelen, niet schreeuwen in de kantine, op je beurt wachten, geen rotzooi op de grond gooien. Nieuw daarbij is het inzicht dat die regels alleen maar zin hebben als ze ook daadwerkelijk worden gehandhaafd. Wat dit betreft zouden de scholen een voorbeeld kunnen nemen aan de Franse situatie voor wat betreft de scheiding van verantwoordelijkheden.

Naast de directeur onderwijs zou er op elke school een functionaris moeten komen die verantwoordelijk is voor de regelgeving en de handhaving daarvan en die uit hoofde van zijn functie iedereen, leraren én leerlingen, op hun rol daarin kan aanspreken. 


\title{
10 DE PEDAGOGISCHE OPDRACHT VAN HET ONDERWIJS: AANGRIJPINGSPUNTEN EN BEPERKINGEN
}

\author{
R. Bronneman-Helmers
}

\subsection{INLEIDING}

Scholen hebben een pedagogische opdracht. ${ }^{1}$ Daarover is iedereen het wel eens. Maar over de vraag wat die pedagogische opdracht precies inhoudt lopen de meningen sterk uiteen. Tegenover degenen die van mening zijn dat het onderwijs zich in de eerste plaats moet richten op de overdracht van kennis en vaardigheden staan anderen die vinden dat opvoeden juist de kerntaak van het onderwijs is.

Momenteel richt de discussie zich zowel op de noodzaak om in het onderwijs meer aandacht te schenken aan waarden, normen en gedragsregels als op het belang van een goed pedagogisch klimaat binnen de school. Voor beide verlangens geldt dat ze worden ingegeven door een groeiende ergernis over antisociaal en normoverschrijdend gedrag, niet alleen van kinderen en jongeren, maar ook van volwassenen. Binnen sommige scholen speelt het probleem dat er als gevolg van dit gedrag nauwelijks nog goed les kan worden gegeven. Buiten de school is sprake van een groeiende maatschappelijke onvrede over onveiligheid in het algemeen en vandalisme en criminaliteit door jongeren in het bijzonder. De huidige vraag naar meer aandacht voor de pedagogische taak van het onderwijs wordt dus vooral gevoed door negatieve sentimenten. Als remedie voor dit maatschappelijk ongenoegen zouden scholen naast hun onderwijstaak meer aan opvoeding moeten doen.

Deze beperkte, functionele zienswijze op de pedagogische taak van het onderwijs wordt echter, zoals gezegd, lang niet door iedereen gedeeld. Niet alleen onder pedagogen, ook in het onderwijs zelf zijn velen de opvatting toegedaan dat onderwijs en opvoeding onlosmakelijk met elkaar verbonden zijn. De pedagogische en didactische opdracht van het onderwijs zijn in die visie niet van elkaar te scheiden. Sterker nog, bij onderwijs gaat het niet in de eerste plaats om overdracht van kennis en vaardigheden die je later nodig zou kunnen hebben, maar om persoonlijkheidsvorming van kinderen en jongeren met het oog op hun toekomstige participatie in de samenleving.

In paragraaf $10.2 \mathrm{zal}$ allereerst worden ingegaan op een aantal ontwikkelingen in de aandacht voor waarden en normen in het onderwijs. Vervolgens wordt in paragraaf 10.3 wat meer ingezoomd op de recente belangstelling voor de pedagogische taak van het onderwijs. Mogelijke aanknopingspunten voor een versterking en explicitering van de pedagogische opdracht van het onderwijs komen in paragraaf 10.4 aan de orde. In paragraaf 10.5 zal vervolgens duidelijk worden dat er ook de nodige beperkingen en belemmeringen zijn bij de invulling van die 
opdracht. De rol van de overheid komt in paragraaf 10.6 aan bod, waarna de bijdrage in paragraaf 10.7 met een korte slotbeschouwing zal worden afgesloten.

\subsection{ONTWIKKELINGEN IN DE AANDACHT VOOR WAARDEN EN NORMEN IN HET ONDERWIJS}

Tot het midden van de jaren zestig van de vorige eeuw waren religie en levensbeschouwing richtinggevend in het onderwijs. In het verzuilde onderwijsbestel was het min of meer vanzelfsprekend dat de waarden en normen van de verschillende religieuze en levensbeschouwelijke groeperingen weerspiegeld werden in de onderwijspraktijk van alledag. Ouders kozen voor een school die aansloot bij hun levensovertuiging of hun pedagogische visie. Het onderwijsbeleid van de overheid was in die jaren overwegend juridisch/administratief en distributief van aard, dat wil zeggen vooral gericht op de planning en bekostiging van scholen met een verschillende levensbeschouwelijke of pedagogische identiteit. De onderwijskundige kennis was geconcentreerd in wat destijds het rijksschooltoezicht werd genoemd (tegenwoordig de inspectie van het onderwijs).

Medio jaren zestig kwam daar verandering in. Het onderwijs kwam in dienst te staan van de maakbare samenleving. Gelijke kansen en emancipatie van achterstandsgroepen werden belangrijke doelstellingen; door middel van structuurveranderingen in het onderwijs (zoals de middenschool) moesten de doelstellingen van het zogenoemde constructieve onderwijsbeleid dichterbij worden gebracht. Waarden en normen als gelijkheid, zelfontplooiing en mondigheid werden belangrijke richtsnoeren voor het onderwijs. Rond de scholen werd een omvangrijke onderwijsverzorgingsstructuur in het leven geroepen, waarin deskundigheden op het terrein van de leerplanontwikkeling, de toetsontwikkeling en de pedagogische ondersteuning in aparte instituten werden gebundeld.

Begin jaren tachtig verloren de ideologische noties die aan het constructieve onderwijsbeleid ten grondslag lagen, geleidelijk aan glans. De samenleving bleek uiteindelijk minder maakbaar dan gedacht. In reactie op de economische crisis gingen financieel-economische en bestuurlijke overwegingen het onderwijsbeleid domineren: doelmatigheid (in de vorm van schaalvergroting en kortere leerwegen) en autonomie (in de vorm van meer beleidsvrijheid voor de onderwijsinstellingen op financieel gebied) werden belangrijke waarden.

Inhoudelijk kwam het onderwijs in het teken te staan van de kwalificatie-eisen zoals die vanuit de arbeidsmarkt werden geformuleerd. Deze omslag in waarden bleef niet zonder gevolgen voor het gedrag. De vanuit emancipatorische overwegingen nagestreefde mondigheid evolueerde in de loop van de jaren tachtig geleidelijk tot een individualistisch en economisch geïnspireerde assertiviteit, niet alleen onder jongeren maar in de samenleving als geheel. 
Begin jaren negentig kwam er een reactie. Uit onvrede met de toenemende individualisering en verzakelijking in de samenleving en de daarmee gepaard gaande afbrokkeling van gemeenschapszin en gezamenlijk gedragen waarden en normen vroeg de minister van Onderwijs en Wetenschappen, Ritzen, voor het eerst expliciet aandacht voor de pedagogische opdracht van het onderwijs. Ook andere politici - Hirsch Ballin en Lubbers - riepen op tot een bezinning op de rol van waarden en normen in de samenleving. In het najaar van 1993 werd het Platform Pedagogische Opdracht van het Onderwijs ingesteld, dat twee jaar de tijd kreeg om een brede maatschappelijke discussie over de pedagogische taak van het onderwijs te organiseren. Tot richtinggevende uitspraken over waarden en normen binnen het onderwijs kwam het Platform overigens niet. Daarvoor was - en is er nog steeds - te veel ambivalentie in het denken over waarden en normen in het onderwijs. Aan de ene kant zijn er velen die vinden dat de school aandacht moet schenken aan normen en waarden om problemen als normvervaging, vandalisme en criminaliteit te voorkomen, aan de andere kant bestaat er een grote angst voor moraliseren en staatspedagogiek. Het Platform kwam dan ook niet veel verder dan de aanbeveling om "universele waarden, die de grondslag vormen van een democratische en humane samenleving en gelden als gemeenschappelijk cultuurgoed" een prominente plaats te geven in te ontwerpen schoolcodes en onderwijsprogramma's (PPOO 1995: 27). In het onderwijs werden diverse projecten in gang gezet om het schoolklimaat te verbeteren: de campagne 'de veilige school' en allerlei projecten tegen het pesten. Het onderwijsbeleid werd in de jaren negentig gekenmerkt door een toenemende overheidsbemoeienis met de onderwijskundige inrichting van het onderwijs: de basisvorming, de vernieuwing van de bovenbouw van het vmbo en de vernieuwing van de tweede fase van het havo/vwo (profielen en het studiehuis). Bij deze vernieuwingen stonden de onderwijsinhouden en de didactische aanpak centraal; van een pedagogische visie was nauwelijks sprake.

Anno 2004, ruim tien jaar nadat vanuit de politiek voor het eerst expliciet aandacht werd gevraagd voor de pedagogische taak van het onderwijs, staat de vraag naar de mogelijke bijdrage van het onderwijs aan de overdracht en handhaving van waarden en normen opnieuw in de belangstelling. Wederom is het de politiek die de pedagogische opdracht aan de orde stelt. De voedingsbodem is echter een andere dan begin jaren negentig. De multiculturele samenleving en de manifest geworden spanningen tussen verschillende bevolkingsgroepen liggen er aan ten grondslag, maar ook een groeiende ergernis over normoverschrijdend gedrag van jongeren zowel binnen de school als in de publieke ruimte. Voor de oplossing van beide maatschappelijke problemen wordt, zoals gebruikelijk, al snel naar het onderwijs gekeken.

Wat leert deze korte historische terugblik? In de eerste plaats dat de waarden en normen die aan het onderwijs worden voorgehouden, in de loop der tijd nogal kunnen veranderen. Waarden en normen zijn bovendien niet alleen tijdgebonden, maar ook plaatsgebonden en groepsgebonden. In de tweede plaats is het opmerkelijk dat er eigenlijk pas sinds kort expliciet aandacht wordt gevraagd voor 
de pedagogische opdracht van het onderwijs. Vroeger was het kennelijk vanzelfsprekend dat er in het onderwijs sprake was van overdracht van waarden en normen. De samenleving was destijds ook een stuk overzichtelijker en het gedrag van jongeren riep mogelijk ook minder problemen op. In de derde plaats valt op dat de politiek niet alleen richtinggevend is bij het formuleren van nieuwe doelen en waarden, maar ook aan de bel trekt indien er na verloop van tijd in de samenleving ongewenste gedragsreacties optreden. In de vierde plaats moet worden geconstateerd dat het onderwijs de afgelopen decennia weliswaar sterk is beïnvloed door nieuwe onderwijskundige en didactische inzichten, maar dat de aandacht voor het meer normatieve pedagogische aspect sterk op de achtergrond is geraakt. Wat ten slotte opvalt is dat de discussie over waarden en normen in het onderwijs zich vaak op een hoog abstractieniveau afspeelt. De algemene verlegenheid in discussies over waarden en normen wordt in dit verband nogal eens toegeschreven aan artikel 23 van de grondwet (vrijheid van onderwijs) en de daarmee samenhangende angst voor staatspedagogiek. Vermoedelijk zijn de toegenomen culturele pluriformiteit, het postmoderne waarderelativisme en de politieke correctheid van de afgelopen decennia als verklarende factoren minstens zo belangrijk.

\subsection{WAAROM OPNIEUW AANDACHT VOOR WAARDEN EN NORMEN IN HET ONDERWIJS?}

Er zijn, het is hiervoor al opgemerkt, twee redenen waarom er momenteel opnieuw aandacht wordt gevraagd voor overdracht van waarden en normen in het onderwijs. In de eerste plaats het groeiende onbehagen over wat inmiddels 'het multiculturele drama' is gaan heten: de gebrekkige integratie van een aantal etnische minderheidsgroepen in ons land. In de tweede plaats de toenemende ergernis over het normoverschrijdende gedrag van een deel van de jeugd.

\section{Cultuurverschillen en de moeizame integratie van etnische minderheden}

De integratie van sommige etnische minderheidsgroepen - met name Turken, Marokkanen en Antillianen - verloopt moeizaam, niet alleen in termen van hun positie in het onderwijs (grote achterstand in basisvaardigheden) en op de arbeidsmarkt, maar ook in sociaal-cultureel opzicht (een grote afstand tot moderne westerse opvattingen, weinig omgang met autochtonen en een sterke identificatie met de eigen groep (Dagevos et al. 2003). Hoewel er wel enige vooruitgang wordt geboekt, is de onderwijsachterstand van Turkse en Marokkaanse leerlingen nog steeds aanzienlijk. Deels komt dat doordat onder autochtone leerlingen het opleidingsniveau nog steeds stijgt. Daarnaast is er als gevolg van (huwelijks)migratie sprake van een voortdurende instroom van nieuwe, veelal laaggeschoolde migranten die de Nederlandse taal niet beheersen. Met de kinderen van de huwelijksmigranten komt er jaarlijks een nieuwe aanwas aan kansarme kleuters de school binnen. Naast taalproblemen is er ook een culturele afstand; een afstand die niet alleen door het lage opleidingsniveau, maar ook door de religie (de islam) wordt gevoed. Opvattingen over de opvoeding van kinderen, 
over de verhouding tussen mannen en vrouwen of over joden en homofielen staan vaak haaks op wat er in Nederland gebruikelijk is dan wel wenselijk wordt geacht. Dat levert in de dagelijkse omgang de nodige spanningen en conflicten op, die lange tijd met de mantel der multiculturele liefde zijn bedekt. Sinds de aanslagen op 11 september 2001 in Manhattan en Washington en de opkomst van Pim Fortuyn heeft zich niet alleen in de publieke opinie, maar ook in het beleid een belangrijke verschuiving in het denken voorgedaan. Inmiddels heeft de diversiteitsideologie (koesteren van verschillen) plaatsgemaakt voor het burgerschapsdenken (wat ons bindt). Het integratiebeleid is minder vrijblijvend geworden (verplicht leren van de Nederlandse taal), het immigratiebeleid een stuk terughoudender (bijvoorbeeld strengere eisen t.a.v. huwelijksmigratie).

In het onderwijs maakt men zich zorgen om een toenemende segregatie. In de grotere steden zijn veel scholen de afgelopen jaren in rap tempo verkleurd. De scheiding van kinderen uit verschillende sociale en etnische bevolkingsgroepen bemoeilijkt de inpassing van jongeren uit andere culturen in de Nederlandse samenleving.

\section{Probleemgedrag van jongeren}

Normoverschrijdend gedrag van jongeren komt zowel binnen als buiten de school voor. Voor beide situaties geldt dat het wangedrag niet alleen vaker voorkomt, maar dat ook de ernst ervan is toegenomen (Zeijl et al. 2003). Bij een deel van de jeugd is assertiviteit doorgeschoten naar agressiviteit (Van den Brink 2001). Binnen de school gaat het om zaken als pesten, vernielingen, stelen en allerlei vormen van agressief gedrag, variërend van brutaliteit, schelden en bedreigen tot daadwerkelijk fysiek geweld. Vormen van wangedrag die het schoolklimaat in negatieve zin beïnvloeden. Voor leraren vormt het vaak een van de redenen om het onderwijs vaarwel te zeggen. In het voorbereidend middelbaar beroepsonderwijs en het secundair beroepsonderwijs zijn de problemen het grootst. Ook buiten de school is sprake van toenemend probleemgedrag. Daar manifesteert het zich in de vorm van overmatig alcohol- en drugsgebruik en in verschillende vormen van delictgedrag (vandalisme, vermogens- en geweldsmisdrijven). Gedrag dat de samenleving veel overlast en schade berokkent.

Spijbelen, schorsingen en voortijdig de school verlaten vormen belangrijke signalen dat het met jongeren niet goed gaat op school. Het zijn signalen die vaak samenhangen met probleemgedrag binnen de school; tegelijkertijd zijn ze meestal een voorbode van probleemgedrag buiten de school. Omdat de maatschappelijke effecten van voortijdig de school verlaten zo negatief zijn (geen diploma, werkloosheid of onaangenaam werk, langdurige uitkeringssituatie, weinig inkomen, een grotere kans op criminaliteit), is er van overheidswege het nodige beleid ontwikkeld om ongeoorloofd schoolverzuim en voortijdig de school verlaten tegen te gaan.

De achtergronden van het probleemgedrag bij jongeren zijn divers. Individuele factoren zoals intelligentie, maar ook kenmerken als hyperactiviteit of aandachts- 
stoornissen kunnen een rol spelen. Leeftijd en sekse zijn van belang, terwijl ook de gezinsachtergrond (ouders met problemen of armoede) en de opvoeding van invloed zijn (Junger-Tas 200o). Over de vraag in hoeverre het toegenomen probleemgedrag moet worden toegeschreven aan tekorten in de opvoeding door ouders, aan de invloed van vrienden of de leerlingenpopulatie op school (groepsdruk), aan maatschappelijke ontwikkelingen als individualisering en welvaartsgroei, aan de toegenomen invloed van de media dan wel aan persoonlijke frustraties als gevolg van de steeds hogere eisen die er in het onderwijs worden gesteld, lopen de meningen uiteen.

Probleemgedrag gaat vaak samen met slechte schoolprestaties en met een zekere weerzin tegen de school. Zwakke en ongemotiveerde leerlingen maken zich er vaker schuldig aan dan beter presterende leerlingen die het op school wel naar hun zin hebben. Dat roept de vraag op of jongeren zich gaan misdragen omdat het slecht gaat op school of dat het slecht gaat op school omdat jongeren zich misdragen. Vermoedelijk is er sprake van een wisselwerking.

\subsection{WAARDEN EN NORMEN: AANKNOPINGSPUNTEN IN HET ONDERWIJS}

Onderwijs biedt in principe tal van aanknopingspunten voor persoonlijke, sociale en morele vorming van kinderen en jongeren. Sociologen gebruiken in dit verband vaak de term 'socialisatie', een proces waarin kinderen en jongeren door de vele rollen die ze moeten leren spelen geleidelijk aan de belangrijkste morele, cognitieve en affectieve codes van onze maatschappij krijgen ingeprent. De inhoud van de socialisatie wordt beïnvloed door het gezin, door de verschillende groepen waarin kinderen en jongeren verkeren en door ervaringen in onderwijs en beroep. De nadruk ligt in deze visie sterk op de sociale beïnvloeding van de persoonlijkheidsvorming. Psychologen spreken meestal over de vorming van een 'zelfconcept' dat zich naarmate de ervaringswereld uitbreidt, gaandeweg ontwikkelt tot een eigen identiteit.

Naast het gezin vormt de school de belangrijkste omgeving waarin het socialisatieproces zich voltrekt. Dit gebeurt op verschillende manieren: via de onderwijsinhouden, door de pedagogisch-didactische aanpak en de omgangsvormen op school (het schoolklimaat), langs de weg van het schoolbeleid en de wijze waarop het onderwijs op school wordt georganiseerd (vestigingsbeleid, contacten met ouders, de wijze van groepering van leerlingen, inschakeling van externe deskundigen), via het zogenoemde verborgen leerplan (de impliciete boodschap die van inhouden, leraarsgedrag en schoolorganisatie uitgaat) of door functieverbreding van de school in de vorm van allerlei activiteiten buiten de reguliere lestijd.

\section{Overdracht van waarden en normen via onderwijsinhouden}

Waardeopvoeding via het onderwijs is in veel landen een belangrijk thema. In de 
literatuur worden bij waardeopvoeding drie didactische modellen onderscheiden: waardeoverdracht, waardecommunicatie en waardeverheldering.

Bij waardeoverdracht krijgen kinderen de waarden en normen overgedragen die gelden in een bepaalde gemeenschap of voortkomen uit een bepaalde traditie. Daarbij beperkt men zich in de regel alleen tot waarden waarover consensus bestaat. De eerder aangehaalde 'universele waarden', zoals die door het Platform Pedagogische Opdracht werden genoemd, passen in deze gedachtegang. Voorstanders van waardecommunicatie benadrukken dat het voor de (morele) ontwikkeling van kinderen van belang is dat ze leren reflecteren op en communiceren over waarden. Bij waardeverheldering staat de bewustmaking van waarden, normen en opvattingen centraal. Het gaat om een proces waarbij leerlingen worden aangezet tot een kritisch doordenken van hun eigen (bewuste of onbewuste) waardestelsel en tot het ontwikkelen van een persoonlijke mening. Docenten maken in het algemeen geen onderscheid tussen waardecommunicatie en waardeverheldering.

Niet alleen de wijze van waardeoverdracht, ook de inhoud van de waardeopvoeding kan sterk uiteenlopen. In westerse samenlevingen richt men zich vooral op civiele waarden die de relatie tussen individu en gemeenschap regelen (rechten en plichten). In andere samenlevingen worden bijvoorbeeld politieke waarden (de voormalige communistische wereld) of religieuze waarden (sommige islamitische landen) centraal gesteld. In Nederland is overigens lang niet iedereen voorstander van aandacht voor waardeopvoeding op school.

In 1998 zijn in het Nederlandse basisonderwijs naast nieuwe kerndoelen voor de verschillende vakken en leergebieden voor het eerst ook zogenoemde 'leergebiedoverstijgende' kerndoelen geïntroduceerd. Daarmee wilde de overheid een impuls geven aan de vorming van kinderen op het gebied van waarden en normen. Er werden zowel doelen geformuleerd om leerlingen weerbaarder te maken, als doelen ter bevordering van sociaal gedrag. Bij de eerste categorie gaat het erom dat leerlingen leren om met hun eigen mogelijkheden en grenzen om te gaan (zelfvertrouwen hebben, gedragsimpulsen beheersen, opkomen voor zichzelf en anderen); de tweede categorie is erop gericht dat leerlingen een positieve bijdrage leveren in een groep (bijvoorbeeld respectvol met anderen omgaan, handelen naar algemeen geaccepteerde normen en waarden, rekening houden met gevoelens en wensen van anderen). Bij de leergebiedoverstijgende doelen gaat het dus eigenlijk meer over het pedagogisch en didactisch handelen van de leerkracht - waarover later meer - dan over de inhoud van het onderwijs.

In de doelen voor de verschillende vakken en leergebieden zitten diverse elementen die benut kunnen worden voor waardeoverdracht. Zo wordt er in het basisonderwijs bij het leergebied geschiedenis bijvoorbeeld kennis gevraagd van de ontwikkeling van de multiculturele samenleving na 1945. Bij het leergebied samenleving wordt ingegaan op verschijnselen als tolerantie en discriminatie. De door de overheid vastgestelde kerndoelen worden door verschillende uitgeve- 
rijen in methoden (bijvoorbeeld leerboeken en werkboeken) omgezet. Deze methoden zijn in de praktijk het meest richtinggevend voor de inhoud van het onderwijs. De Inspectie van het onderwijs gaat tijdens het schooltoezicht na of het leerstofaanbod dekkend is voor de kerndoelen. Bij ruim tachtig procent van de basisscholen voldoet het leerstofaanbod aan de eisen. In het voortgezet onderwijs geldt dit slechts voor één op de drie scholen (Inspectie 2003). ${ }^{2}$

Het godsdienstonderwijs en het levensbeschouwelijk vormingsonderwijs, waarin de religieuze en morele waardevorming centraal staan, nemen een speciale positie in. In het bijzonder onderwijs vormt het een cruciaal onderdeel van de wijze waarop de school inhoud geeft aan haar identiteit en daarmee aan de vrijheid van onderwijs. Met het oog daarop stelt de onderwijsinspectie zich dan ook uiterst terughoudend op. De inspectie neemt het godsdienstonderwijs alleen onder de loep wanneer daar aanleiding toe bestaat. Het godsdienstonderwijs maakt onderdeel uit van het onderwijsprogramma en valt onder de verantwoordelijkheid van het bevoegd gezag. In het openbaar onderwijs geeft het bevoegd gezag (de gemeente) enkel gelegenheid tot het volgen van godsdienstonderwijs; de verantwoordelijkheid voor de inhoud ligt niet bij het bevoegd gezag, maar bij de leraar die door de kerkelijke of geestelijke instelling wordt aangewezen.

In de kerndoelen voor de basisvorming gedurende de eerste leerjaren van het voortgezet onderwijs wordt eveneens een aantal vakoverstijgende thema's genoemd, bijvoorbeeld 'het kennen van en omgaan met eigen en andermans normen en waarden' en 'het functioneren als democratisch burger in een multiculturele samenleving'. Vakken als geschiedenis, maatschappijleer of het literatuuronderwijs bieden eveneens de nodige aanknopingspunten voor waardeoverdracht of -communicatie. Tot op heden worden die mogelijkheden onvoldoende benut. Door de overladenheid van het curriculum en de exameneisen die hun schaduwen vooruitwerpen is daarvoor vaak onvoldoende gelegenheid.

In internationaal verband wordt met enige regelmaat gepleit voor invoering van een vakgebied als burgerschapsvorming om de sociale samenhang en de integratie van minderheden te bevorderen. In het Engelse nationale curriculum is citizenship een van de vakken. In Frankrijk is er sinds 1999 voor alle leerlingen van vijftien tot achttien jaar van het Lycee een verplicht programma éducation civique, juridique et sociale, dat voortbouwt op de éducation civique voor jongere leerlingen (Onderwijsraad 2002: 40). In Nederland bestaat er geen apart vak burgerschapsvorming voor de jeugd. In het vak maatschappijleer komen overigens verwante thema's aan bod. Sinds enkele jaren zijn er wel verplichte inburgeringscursussen voor volwassen immigranten.

Een belangrijke vraag die beantwoord moet worden is bij wie de verantwoordelijkheid voor de kwaliteit van de waardevorming op school moet worden gelegd: bij de individuele docent, bij de school, bij het schoolbestuur als drager van de identiteit van de school of bij de overheid (via kerndoelen, exameneisen, toetsen of inspectiebeoordeling)? Overheidsinvloed op het punt van waarden en normen 
wordt in Nederland al snel gezien als een inbreuk op de in de grondwet neergelegde vrijheid van onderwijs (artikel 23). Dit neemt niet weg dat er in de van overheidswege voorgeschreven kerndoelen heel wat waarden en normen zijn neergelegd. Kennelijk bestaat daarover voldoende consensus.

De laatste tijd is er in dit verband een discussie op gang gekomen over de wenselijkheid en mogelijkheid van inspectieonderzoek naar het godsdienstonderwijs op, bijvoorbeeld, islamitische scholen; dit naar aanleiding van signalen dat er door de imams op die scholen waarden zouden worden overgedragen die haaks staan op waarden van de Nederlandse rechtsstaat. Tot dusverre geldt het uitgangspunt dat de inspectie zich alleen buigt over het godsdienstonderwijs als daar aanleiding toe bestaat.

Wil waardevorming in het onderwijs serieus worden genomen, dan zal ook moeten worden nagegaan of leerlingen er iets van geleerd hebben. Bij toetsen en examens komen in het algemeen echter alleen de cognitieve aspecten aan de orde. Als er correcte antwoorden worden gegeven, betekent dit nog niet dat de waarden ook daadwerkelijk zijn geïnternaliseerd.

De hamvraag is natuurlijk of kennis, inzicht en oordeelsvorming uiteindelijk leiden tot het internaliseren van waarden en tot een socialer gedrag. Weten, begrijpen (kennis) en kunnen (vaardigheden) impliceren immers nog geen doen (gedrag). Uit onderzoek is bekend dat informatie- en voorlichtingsprogramma's er weliswaar aan kunnen bijdragen dat de kennis over een probleem toeneemt of dat attitudeverandering plaatsvindt, maar dat ze meestal weinig of geen invloed hebben op het feitelijke gedrag. Junger-Tas maakt in dit verband melding van evaluatieonderzoek van programma's als 'politie op school', die in de Verenigde Staten populair zijn en ook in ons land worden toegepast. Alle evaluatiestudies uit de vs wijzen uit dat er geen of nauwelijks effect is op het gedrag van leerlingen (Junger-Tas 2002: 37).

Er kan op school ook aan bevordering van sociaal gedrag gewerkt worden zonder dat er sprake is van overdracht van kennis en inzicht of van eigen oordeelsvorming over achterliggende waarden en normen. Bij jonge kinderen ligt dat sowieso meer in de rede.

\section{Het belang van de pedagogisch-didactische aanpak en de omgangsvormen op school}

De manier van lesgeven door leerkrachten en de omgangsvormen op school hebben in de regel meer invloed op het gedrag van leerlingen dan boekenwijsheid, informatie en voorlichting. In beschouwingen over de taak van het onderwijs op het gebied van waarden en normen wordt dan ook vooral naar het schoolklimaat en het gedrag van de verschillende partijen binnen de school gekeken.

Docenten oefenen door hun wijze van lesgeven, maar ook door hun persoonlijkheid (voorbeeldfunctie) grote invloed uit op de motivatie en de schoolprestaties 
van leerlingen. Zij kunnen zelfvertrouwen en interesse kweken, maar ook faalangst en antisociaal gedrag genereren. Een belangrijk aspect is bijvoorbeeld de manier waarop de vorderingen en prestaties van leerlingen worden beoordeeld. In de regel is dat weinig motiverend voor leerlingen, omdat vooral de fouten en niet de vorderingen worden vermeld.

Werkvormen als klassikaal onderwijs, samenwerken in kleine groepen en individuele opdrachten doen een beroep op uiteenlopende vaardigheden en persoonlijkheidskenmerken. Klassikaal onderwijs vereist concentratievermogen en zelfcontrole (stil zijn en luisteren, niet door elkaar heen praten), het samenwerken in groepen vraagt om sociale vaardigheden (elkaar helpen, rekening houden met elkaar, conflicten kunnen oplossen), het uitvoeren van individuele opdrachten vraagt om eigen initiatief en doorzettingsvermogen. In de afgelopen decennia is er zowel in het basisonderwijs als in het voortgezet onderwijs het nodige veranderd in de onderwijskundige inrichting en didactische aanpak. In het basisonderwijs is het accent verschoven van klassikaal onderwijs naar groepswerk en individuele opdrachten. In het voortgezet onderwijs wordt geprobeerd een omslag te maken van 'onderwijs door de docent' naar 'actief en zelfstandig leren door de leerling'. Er wordt minder dan voorheen een beroep gedaan op discipline en concentratievermogen en meer op de zelfstandigheid en eigen verantwoordelijkheid van leerlingen. De onderwijskundige en didactische vernieuwingen kunnen een pedagogische aanpak op school echter ook in de weg staan (zie par. 5).

Het schoolklimaat wordt in belangrijke mate bepaald door de wijze waarop docenten en leerlingen onderling en met elkaar omgaan. Begin jaren negentig bleek uit onderzoek dat er op scholen veel werd gepest en dat er sprake was van allerlei vormen van geweld (Mooij 1992; Mooij 1994). Sindsdien is de aandacht voor de veiligheid op school aanzienlijk toegenomen. Er werden allerlei methodes ontwikkeld om het pesten tegen te gaan (bijvoorbeeld een omgangsprotocol) en er werd een landelijke campagne gestart onder de noemer 'De veilige school'. In 2001 is de situatie opnieuw onderzocht. Uit dat onderzoek komt naar voren dat leerlingen in het voortgezet onderwijs, tien jaar na de start van de campagne, evenveel pestgedrag ervaren en in vergelijkbare mate gewelddadig gedrag vertonen als in het begin van de jaren negentig. Vanwege het ontbreken van een controlesituatie is het echter niet mogelijk vast te stellen hoe de situatie zonder de campagne zou zijn geweest (Mooij 2001).

In de praktijk zijn scholen vaak meer bezig met het tegengaan van antisociaal gedrag dan met het bevorderen van sociaal gedrag. Op scholen waar duidelijke normen, verwachtingen en regels over het gewenste gedrag van de leerlingen worden gehanteerd en waar die regels ook consequent worden gehandhaafd, is het schoolklimaat prettiger en gedragen leerlingen zich ook beter. Indien leerlingen zelf bij het opstellen van de regels in de school worden betrokken, worden deze meer geaccepteerd en meestal ook beter nageleefd. Er hoeft in dat geval ook niet voortdurend opnieuw over de regels te worden onderhandeld. 
Het lijkt zo voor de hand te liggen, maar toch is de praktijk vaak weerbarstig. Op scholen voor voortgezet onderwijs is consequente handhaving vaak moeilijk, omdat leerlingen wekelijks met heel veel verschillende (vak)docenten contact hebben. De opvattingen van docenten over de reikwijdte van hun pedagogische taak kunnen sterk uiteenlopen. In het basisonderwijs vallen regels makkelijker te handhaven. De leerlingen zijn er jonger en wat meer gezeglijk, basisschoolleerkrachten kennen de kinderen in hun groep goed en hebben in het algemeen ook een meer uitgesproken pedagogische taakopvatting. Leerlingen vinden het belangrijk dat docenten goed kunnen uitleggen, eerlijk en rechtvaardig zijn en interesse tonen in hun persoonlijke omstandigheden en belevenissen. Leerlingen willen persoonlijke aandacht, ze willen geen nummer zijn. Elkaar kennen en gekend worden, daar draait het om. Op basisscholen met één of hooguit enkele docenten per groep valt dat makkelijker te realiseren dan op scholen voor voortgezet onderwijs.

De omgangsvormen op school zijn zeer bepalend voor het gedrag. Dat geldt zeker voor de zwakkere en meestal minder gemotiveerde vbo-leerlingen, maar ook voor oudere leerlingen in het secundair beroepsonderwijs (ROC's). Zij hebben het op school het minst naar hun zin (Bronneman-Helmers et al. 2002). Onderzoek onder schooluitvallers leert dat een slecht schoolklimaat de belangrijkste reden is voor vertrek. Van de spijbelaars meldde maar liefst driekwart dat de school hun spijbelgedrag niet eens opmerkte of er niet op reageerde (Inspectie van het Onderwijs 200o). Een dergelijke opstelling van de school wordt door leerlingen niet alleen ervaren als gebrek aan controle, maar ook als gebrek aan interesse en betrokkenheid.

Enigszins haaks op de hiervoor gesignaleerde gedragsproblemen staat de constatering van de Inspectie van het onderwijs dat het pedagogisch klimaat op 99 procent van de basisscholen en op 98 procent van de scholen voor voortgezet onderwijs veilig en structurerend is. Ook het schoolklimaat wordt door de Inspectie op vrijwel alle scholen voor voortgezet onderwijs positief beoordeeld. Van de scholen met veel achterstandsleerlingen voldoet volgens de Inspectie 96 procent aan dit kwaliteitskenmerk voor goed onderwijs. Vermoedelijk kijkt de Inspectie vooral naar het pedagogisch gedrag van de leraar tijdens de les en wordt er minder gelet op het gedrag van de leerlingen in de pauzes en rondom de school.

\section{De invloed van het schoolbeleid en van de organisatie van het onderwijs}

Via het schoolbeleid en de organisatie van het onderwijs worden de voorwaarden geschapen die het mogelijk moeten maken om aan de pedagogische opdracht vorm te geven.

Het zijn de schoolbesturen die namens een religieuze, levensbeschouwelijke of pedagogische stroming (bijzonder onderwijs) of namens de samenleving (openbaar onderwijs) scholen stichten en instandhouden. Het schoolbestuur bepaalt formeel de identiteit van de school. In de praktijk is de schoolleiding verantwoordelijk voor de dagelijkse gang van zaken op school. Schoolbestuur en schoollei- 
ding geven dan ook samen inhoud aan de identiteit van het onderwijs. Zij scheppen als het ware de voorwaarden voor een goed schoolklimaat.

Opmerkelijk genoeg worden schoolbesturen veel minder aangesproken op het punt van de waarden en normen die in het onderwijs worden uitgedragen dan schoolleiders. Opmerkelijk, omdat schoolbesturen niet alleen zeggen de dragers te zijn van de vrijheid van onderwijs, maar in de praktijk ook in belangrijke mate de voorwaarden bepalen waaronder schoolleiders en docenten hun pedagogische taak moeten vervullen. Het schoolbestuur komt tot dusver eigenlijk alleen in beeld indien er zich incidenten of problemen voordoen, bijvoorbeeld bij de recente discussie over het godsdienstonderwijs op islamitische scholen en bij eerdere signalen over discriminatie van homofiele docenten op gereformeerde scholen. Op grond van hun positie in het onderwijsbestel zou van schoolbesturen een meer actieve waardevormende opstelling kunnen worden verwacht.

De huisvestingssituatie waarin scholen verkeren loopt sterk uiteen. Sommige scholen zijn gehuisvest in nieuwe en goed onderhouden gebouwen. Er zijn echter ook heel wat scholen, vooral in de oude stadswijken, die met veel achterstallig onderhoud kampen. Een slechte huisvestingssituatie lokt vandalisme uit en leidt gemakkelijk tot verloedering, waardoor het schoolklimaat verslechtert en leerkrachten vertrekken. In zo'n neergaande spiraal kunnen gedragsregels moeilijk worden afgedwongen. Schoolbesturen zijn verantwoordelijk voor het onderhoud van het schoolgebouw. Gemeenten zijn sinds 1997 verantwoordelijk voor de huisvesting van basisscholen en scholen voor voortgezet onderwijs.

Schoolbesturen beslissen of scholen die onder hun bevoegd gezag vallen al dan niet fuseren. In de jaren negentig zijn in het voortgezet onderwijs op instigatie van de rijksoverheid veel kleine categorale scholen samengevoegd tot grote brede scholengemeenschappen. Door (neven)vestigingen in stand te houden konden er voor schooltypen als het praktijkonderwijs, het vbo en soms ook het mavo aparte locaties gehandhaafd blijven. Met zo'n fysieke scheiding van groepen leerlingen kwamen scholen niet alleen tegemoet aan de wensen van middelbaar en hoger opgeleide ouders, die hun kinderen het liefst naar een school sturen met leerlingen uit eenzelfde of vergelijkbaar milieu. Ook docenten hebben in het algemeen een voorkeur voor homogene groepen. Het proces van schaalvergroting heeft dan ook, geheel tegen de bedoelingen in, de sociale en culturele segregatie in het voortgezet onderwijs versterkt. Leerlingen komen er overwegend in aanraking met kinderen uit vergelijkbare milieus (Bronneman-Helmers et al. 2002). In het basisonderwijs wordt de aard van de leerlingenpopulatie in de eerste plaats bepaald door de bevolkingssamenstelling van de buurt waar de school gevestigd is. In sommige (achterstands)wijken in de grote steden is er onder de beter opgeleide ouders wel sprake van vluchtgedrag naar witte scholen in andere wijken. Toch is het segregatieproces er minder ver voortgeschreden dan in het voortgezet onderwijs, omdat in het basisonderwijs alle kinderen in principe bij elkaar zitten en de meeste ouders nog steeds kiezen voor de dichtstbijzijnde school. 
Scholen zijn tot op zekere hoogte vrij een eigen toelatings- en selectiebeleid te voeren. In de publieke discussie over de integratieproblematiek van minderheden wordt steevast het argument naar voren gebracht dat bijzondere scholen allochtone leerlingen zouden weigeren. In de praktijk doet zo'n selectief toelatingsbeleid zich maar in beperkte mate voor. Algemeen bijzondere scholen en gereformeerde scholen zijn naar verhouding het minst gemengd. Bij dergelijke scholen is eerder sprake van zelfselectie.

De toegenomen gedragsproblemen in het voortgezet onderwijs worden vaak toegeschreven aan de schaalvergroting in die sector (RMO 2000). Uit onderzoek onder leerlingen blijkt echter dat de schoolgrootte als zodanig geen effect heeft op het welbevinden van leerlingen. Veel belangrijker zijn individuele kenmerken van leerlingen en het schooltype. Meisjes, autochtone en jonge leerlingen gaan met meer plezier naar school dan jongens, allochtone en oudere leerlingen. Vmbo-leerlingen hebben het op school in het algemeen slechter naar hun zin dan havo/vwo-leerlingen. Op grote scholen wordt wel veel vaker gespijbeld dan op kleine (Herweijer en Vogels 2003).

Inmiddels is schaalvergroting van scholen niet langer een doelstelling van het overheidsbeleid. Het tweede kabinet-Balkenende wil kleinschalig onderwijs bevorderen en zal hiertoe het fuseren en vormen van grotere scholen afremmen.

De pluriformiteit in waarden en normen is de afgelopen decennia sterk toegenomen. Met name maatschappelijke processen als immigratie, secularisatie en individualisering liggen hieraan ten grondslag. Het onderwijs sluit daardoor niet meer als vanzelf aan op de opvoeding thuis. Dit komt ook doordat sommige ouders niet in de eerste plaats kiezen voor de basisschool die het beste aansluit bij de eigen opvoedingsdoelen, maar voor de dichtstbijzijnde school. Hoger opgeleide ouders laten zich bij de schoolkeuze vooral leiden door de pedagogische kwaliteit van het onderwijs. In scholen met een heterogene leerlingenpopulatie is het niet langer vanzelfsprekend dat ouders en school bondgenoten zijn bij de opvoeding. In het voortgezet onderwijs is de schoolkeuze meestal beperkter, niet alleen omdat er minder scholen zijn, maar ook omdat het geadviseerde schooltype begrenzingen oplegt.

De betrokkenheid van ouders bij het onderwijs loopt sterk uiteen. In het basisonderwijs hebben ouders en docenten frequent contact, zeker in de eerste leerjaren als de kinderen nog gebracht en opgehaald worden. Veel ouders verrichten activiteiten ten behoeve van de basisschool. In het voortgezet onderwijs zijn ouders wat meer op afstand. Hoogopgeleide ouders zijn in het algemeen sterker betrokken bij de school dan laagopgeleide ouders. Allochtone ouders voelen zich minder vaak actief betrokken bij de school; zij hebben vaker het gevoel niet welkom te zijn en zijn het ook vaker dan autochtone ouders niet eens met de school (Vogels 2002). 
Ouders en docenten zitten met hun opvattingen over opvoeding dus lang niet altijd op één lijn. Docenten hebben vaak nogal wat kritiek op de wijze waarop ouders opvoeden. Ouders zouden te weinig eisen stellen en hun kinderen opzadelen met te veel sociale verplichtingen. Kinderen zouden thuis onvoldoende leren om zich aan regels te houden. Ouders vinden daarentegen dat de school te weinig met hen in gesprek gaat over waardeopvoeding. Het pedagogisch beleid komt in hun ogen pas aan de orde als er problemen zijn, bijvoorbeeld in de vorm van pesten of spijbelen.

Hoewel zowel ouders als docenten in het algemeen redelijk tevreden zijn over het schoolklimaat, beoordelen ze het wel vanuit een heel verschillend perspectief. Voor ouders staat de bescherming van het eigen kind voorop; bij docenten staat de groep meer centraal. Leerkrachten hebben immers niet met één maar met veel kinderen te maken. Volgens docenten zijn ouders onvoldoende op de hoogte van wat er op school gebeurt. Ouders op openbare scholen zijn gemiddeld wat minder tevreden over het schoolklimaat, ouders met kinderen op algemeen bijzondere scholen zijn het meest tevreden (Klaassen en Leeferink 1998; Veugelers en De Kat 1998).

In de relatie tussen ouders en school ontbreekt het, naar het lijkt, niet zozeer aan informatie. Die wordt voldoende gegeven via de schoolgids, via voorlichting en ouderavonden en in gesprekken met docenten of schoolleiding. De communicatie tussen ouders en school schiet daarentegen vaak tekort. Dat blijkt bijvoorbeeld uit evaluatieonderzoek naar de werking van de wettelijke klachtenregeling die sinds 1998 in het basis- en voortgezet onderwijs van kracht is (Vermaas en Wiersma 200o). Daaruit komt naar voren dat ouders vaak het gevoel hebben dat er onvoldoende naar hen geluisterd wordt en dat er na een klacht niets gebeurt. Scholen voelen zich vaak geschoffeerd door een formele klacht, vinden veel klachten futiel en de drempel om ze in te dienen te laag. De boodschap uit het onderzoek is dan ook dat de meeste klachten door middel van een betere communicatie gewoon binnen de school zouden kunnen worden opgelost.

De Inspectie van het onderwijs beoordeelt niettemin vrijwel alle basisscholen (99\%) positief op het kwaliteitskenmerk 'contacten met ouders'. Alleen in de grote steden en bij scholen met veel allochtone leerlingen zijn de contacten bij zo'n tien procent van de scholen beneden de maat.

In veel scholen bestaat het idee dat opvoedings- en gezinsproblemen steeds meer op de school worden afgewenteld. Die gedachte leeft, blijkens een kranteninterview, ook bij de huidige minister van Onderwijs, Cultuur en Wetenschap, mevrouw Van der Hoeven (de Volkskrant 12 juli 2003). Zij merkt daarover op dat ouders vaak te veel van de school verwachten en dat ze hun problemen niet zomaar over de schutting van de school kunnen kieperen in de verwachting dat de school het wel oplost. "Als de school dan ingrijpt omdat het fout gaat met een kind, komen ze met hoge poten op de leerkracht af om verhaal te halen. Dat soort gedrag ondermijnt het gezag." 
De minister betoont zich in het interview een groot voorstander van oudercontracten. Daarin moeten scholen en ouders expliciet afspreken wat ze van elkaar verwachten. Het gaat om elementaire dingen als geen wapens mee naar school nemen, geen petjes in de klas, niet je kinderen thuis houden omdat je eerder met vakantie wilt, niet met de vuist verhaal komen halen na een slecht rapport. "Met zo'n contract maak je duidelijk dat het geen vrijblijvende afspraken zijn. In het ergste geval moet een school kunnen zeggen niet door te willen met een kind.”

Het voorstel riep, zoals te verwachten, gemengde reacties op. Hoewel er algemene instemming is met het signaal dat ouders zich weer meer verantwoordelijk moeten gaan voelen voor de opvoeding van hun kinderen, maken vooral de ouderorganisaties bezwaar tegen de eenzijdigheid van het contract. Niet alleen de plichten van ouders en leerlingen zouden moeten worden vastgelegd, maar ook die van de school. Ouderorganisaties geven in het algemeen de voorkeur aan een partnerrelatie met de school boven een contractrelatie. Een contractrelatie zou goed partnerschap zelfs in de weg kunnen staan. Ook uit andere reacties blijkt een zekere angst voor averechtse effecten. Het voorstel genereert niet alleen nieuwe regels, maar werkt ook een verdere juridisering van de relatie tussen ouders en school in de hand. Het aantal juridische procedures tegen scholen over zaken als pesten, lesuitval en tegenvallende schoolprestaties zou er wel eens sterk door kunnen toenemen.

Eén ding is duidelijk: de communicatie tussen ouders en school(bestuur) moet en kan beter. Meer communicatie en een grotere betrokkenheid van ouders zijn bovendien niet alleen vanuit een pedagogisch gezichtspunt wenselijk. Uit onderzoek is bekend dat leerprestaties van kinderen beter worden naarmate ouders meer bij het onderwijs betrokken zijn. De mate van betrokkenheid van ouders wordt sterk beïnvloed door het schoolbeleid. Scholen zullen vooral voor de lager opgeleide autochtone en allochtone ouders extra initiatieven moeten ontplooien. Deze ouders blijven nu vaak afzijdig. Verbetering van leerprestaties vergroot niet alleen de kans op maatschappelijk succes en daarmee op sociale integratie, maar vermindert ook de neiging tot antisociaal gedrag op school.

Bij ernstige gedragsproblemen moeten scholen een beroep kunnen doen op externe deskundigen. Dat kan het schoolmaatschappelijk werk zijn indien er problemen zijn in het gezin, de jeugdhulpverlening in geval het kind of de jongere individuele problemen heeft waaraan de school weinig kan doen, of politie en justitie wanneer jongeren zich schuldig maken aan ernstige overtredingen, delicten of misdrijven. Veel scholen hebben inmiddels een uitgebreid netwerk van contacten opgebouwd. Niet alle instanties zijn echter even toegankelijk en effectief. Vooral de samenwerking met de jeugdhulpverlening laat vaak te wensen over.

\section{Het verborgen leerplan}

In het onderwijs worden ook onbewust heel wat waarden en normen overgedragen. Onbewust gedrag en ongeschreven regels zijn voor de waardeoverdracht wellicht zelfs belangrijker dan het instructiegedrag van de docent of de officiële 
schoolregels. Het verborgen leerplan kan zich op drie manieren manifesteren: via de school als organisatie (bijvoorbeeld in de indeling van leerlingen in prestatiegroepen), via de dominante onderwijsideologie (denk bijvoorbeeld aan de huidige nadruk op de eigen verantwoordelijkheid van de leerling, ook voor mislukken) en via het gedrag van leraren (die het formele leerplan als het ware filteren via hun eigen opvattingen en verwachtingen) (Reijnders 1976). Door het verborgen leerplan leert de leerling wie hij is in relatie tot anderen en wat zijn plaats is in de wereld. Het verborgen leerplan representeert als het ware de dominante waarden in de samenleving en wordt dan ook meestal 'ontdekt' door tegenmachten die zich tegen die dominante waarden verzetten.

Sinds de jaren zestig heeft er het nodige onderzoek plaatsgevonden naar de werking van het verborgen leerplan (Van der Hoeven 1990; Jungbluth 2003). Daaruit blijkt bijvoorbeeld dat leerkrachten het niveau van hun lessen afstemmen op de leerlingenpopulatie die zij voor zich hebben. Groepen van wie minder wordt verwacht (bijvoorbeeld kinderen uit lagere sociale milieus) krijgen onderwijs op een lager niveau aangeboden. Leerlingen in die groepen worden als gevolg daarvan soms onvoldoende uitgedaagd. Vanuit de veronderstelling dat meisjes nu eenmaal niet goed zijn in de bètavakken worden ze tijdens de les, maar ook bij de vak- of profielkeuze, vaak anders behandeld dan jongens. Ook een onderwijsdoelstelling als sociale competentie wordt in de praktijk heel verschillend ingevuld. Op vmbo-scholen wordt de aandacht ervoor meestal ingegeven door de behoefte aan orde, rust en veiligheid. Leerkrachten komen door het storende gedrag van kansarme jongeren anders nauwelijks aan lesgeven toe. Vmbo-leerlingen wordt dan ook in de eerste plaats geleerd zich aan te passen aan de gangbare maatschappelijke codes. Havo/vwo-leerlingen daarentegen worden niet alleen voorzien van kennis over de samenleving, ze krijgen ook democratische waarden als gelijkwaardigheid en rechtvaardigheid overgedragen en worden zo, als het goed is, opgevoed tot kritisch burgerschap.

Aan het formele leerplan wordt dus op heel verschillende manieren invulling gegeven; soms bewust, maar vaak ook onbewust. Beleidsmakers, scholen en leraren geven zich in de regel onvoldoende rekenschap van de onbedoelde gevolgen van de verborgen boodschappen die zij uitdragen.

\section{Functieverbreding van de school}

De 'brede school' is inmiddels een bekend fenomeen in het basisonderwijs en is ook in het voortgezet onderwijs in opmars. Kenmerkend voor brede scholen is dat zij samenwerken met andere instellingen (welzijn, zorg, jeugdhulpverlening, maatschappelijk werk, politie, cultuur en sport) om op die manier de ontwikkelingskansen van kinderen te verbeteren.

In 2001 waren er 450 brede basisscholen operationeel. Verwacht wordt dat dit er aan het eind van dit decennium ongeveer 1.0oo zullen zijn; één op de zeven basisscholen zal dan breed zijn (Oberon 2002). In veel gemeenten is het verminderen van onderwijsachterstanden het belangrijkste doel. In andere gemeenten 
ligt het accent meer op het bieden van gelegenheid voor naschoolse opvang en op het aanbieden van culturele en sportieve activiteiten buiten schooltijd.

In het voortgezet onderwijs kan ongeveer een kwart van de scholen (9o scholen op ruim 100 locaties) als brede school (in wording) worden aangemerkt. De activiteiten richten zich vooral op leerlingen in de eerste twee leerjaren en op vmboleerlingen (Oberon 2003). Veiligheid en sociale participatie zijn in het voortgezet onderwijs belangrijke doelen.

Steeds meer scholen organiseren na schooltijd allerlei activiteiten voor hun leerlingen. Deze activiteiten vervullen twee functies. In de eerste plaats houden ze jongeren van de straat waarmee de gelegenheid voor wangedrag buiten de school afneemt. Sportieve en culturele activiteiten kunnen daarnaast, mits goed begeleid, ook een belangrijke vormende waarde hebben. Door middel van huiswerkklassen na schooltijd wordt aan verbetering van de schoolprestaties gewerkt.

Er is sinds enkele jaren zowel bij de scholen als bij gemeenten veel aandacht voor het bevorderen van de sociale competentie van kinderen en jongeren. Toch is de sociale competentie niet als doelstelling in het nieuwe Landelijk beleidskader voor het gemeentelijk onderwijsachterstandenbeleid (LBK 2002-2006) opgenomen. Dat had voor een deel te maken met het normatieve karakter van het begrip (voor welk soort samenleving willen we leerlingen eigenlijk sociaal competent maken?), maar ook met het ontbreken van een heldere definitie en operationalisering en van goede evaluatie- en meetinstrumenten om de vorderingen van leerlingen en scholen op het gebied van de sociale competentie te kunnen vaststellen. ${ }^{3}$

Inmiddels worden er onder de noemer 'sociale competentie' allerlei experimenten, programma's en projecten uitgevoerd, variërend van experimenten en programma's om de sociale competentie van basisschoolleerlingen te verbeteren (bijvoorbeeld het Kleinschalig Experiment Onderwijsontwikkeling Sociale competentie (KEOS) in Rotterdam en programma's als Taakspel en Cool Down) tot projecten in het voortgezet onderwijs als Werktuig, waarbij een groep toneelspelers met leerlingen aan sociale vaardigheden werkt, en allerlei programma's na schooltijd (voetbal, basketbal, street-dance, video-art, web-design, filmclub, fotoclub, computerclubhuis) met het doel de binding van de leerlingen met de school te versterken en zo ook de motivatie om te leren te vergroten (Ten Dam et al. 2003).

Er wordt dus op vele fronten gewerkt aan het bevorderen van sociaal gedrag. Het probleem is echter dat het vaak om tijdelijke projecten en programma's gaat. Ze worden in de regel niet goed geëvalueerd en in geval van succes vaak ook niet goed geïmplementeerd (Junger-Tas 2002).4 Daardoor dreigt het risico dat een instantie als de Algemene Rekenkamer op termijn zal concluderen dat al het beleid en alle initiatieven uiteindelijk weinig hebben opgeleverd. 


\subsection{BEPERKINGEN BIJ DE INVULLING VAN DE PEDAGOGISCHE TAAK VAN DE SCHOOL}

Hoewel er in het onderwijs in principe dus heel wat aanknopingspunten liggen voor het overdragen en inprenten van waarden, normen en gedragsregels zijn er in de praktijk ook de nodige beperkingen. Enkele ervan zijn verbonden met het onderwijs zelf en in het voorgaande al aangestipt. Belangrijker zijn echter de beperkingen die de omgeving oplegt. Kinderen en jongeren brengen maar een beperkt deel van hun tijd op school door; jaarlijks niet meer dan zo'n twintig procent. De opvoeding in het gezin is veel belangrijker. Vanaf een jaar of tien neemt de invloed van vrienden en leeftijdgenoten toe. Ook de buurt en de samenleving als geheel bieden niet altijd een context waarin het vanzelfsprekend is om zich te houden aan algemeen geaccepteerde waarden en normen. In andere bijdragen aan deze bundel wordt uitvoerig ingegaan op die omgevingsfactoren. De bekende zinsnede The school cannot compensate for society kan in dit verband dan ook alleen maar worden onderschreven.

Basisscholen en scholen voor voortgezet onderwijs krijgen na een periode van toenemende overheidsbemoeienis met de inhoud van het onderwijs (kerndoelen) en met het proces (een nieuwe didactische aanpak) sinds enkele jaren weer wat meer vrijheid om het onderwijs naar eigen inzicht in te richten. Een ontwikkeling die de komende jaren naar verwachting zal doorzetten. In het Hoofdlijnenakkoord dat ten grondslag ligt aan het tweede kabinet-Balkenende is nog eens uitdrukkelijk vastgesteld dat er meer ruimte zal worden geboden voor de inrichting van het onderwijs (zoals studiehuis en basisvorming).

"Ouders, docenten en leerlingen moeten meer invloed op de inrichting van het funderend onderwijs krijgen. Daartoe moeten besturen meer verantwoording afleggen en meer inzicht geven in bestedingen en de kwaliteit van het onderwijs."

Er wordt dus verwacht dat ouders en scholen samen inhoud zullen geven aan de pedagogische opdracht. Dat roept de vraag op hoe ouders en leraren aankijken tegen de pedagogische taak van de school. In het voorgaande is al gewezen op problemen in de communicatie tussen ouders en school en op verschillen van inzicht tussen ouders en leerkrachten. Die verschillen kunnen een goede invulling van de pedagogische opdracht in de weg staan.

\section{Ouders en hun opvattingen over de pedagogische taak van de school}

Ouders zijn in het algemeen heel tevreden met de kwaliteit van het onderwijs op de school van hun kinderen. Dat blijkt zowel uit onderzoeken van het ITS (de jaarlijks verschijnende Onderwijsmeter) als uit onderzoek van het SCP (waarover in het Sociaal en Cultureel Rapport 2002 is gerapporteerd).

Aan een aspect als veiligheid werd in 2002 volgens meer dan 90 procent van de ouders door de school voldoende aandacht besteed (basisonderwijs $96 \%$, voortgezet onderwijs 92\%). Ouders zijn in meerderheid ook te spreken over de 
persoonlijke aandacht die hun kind op school krijgt (basisonderwijs 85\%, voortgezet onderwijs $74 \%)$.

Hoewel ouders dus redelijk tevreden zijn over de school van hun kind, hebben ze ook weleens zorgen. In de eerste plaats over het tekort aan personeel (basisonderwijs $82 \%$ en voortgezet onderwijs $83 \%$ in 2002). Daarnaast maken veel ouders zich weleens zorgen over de gedragsproblemen in het onderwijs ${ }^{5}$ (respectievelijk $67 \%$ en $75 \%$ ) en over het gebrek aan individuele aandacht ( $47 \%$ in het basisonderwijs en $52 \%$ in het voortgezet onderwijs) (Wartenbergh-Cras et al. 2002).

Ander onderzoek onder ouders geeft enig zicht op het belang dat ouders hechten aan verschillende pedagogische doelstellingen van het onderwijs (nog te verschijnen SCP-onderzoek). Eind 2000 is aan ouders met kinderen in het basisonderwijs de vraag voorgelegd welke kenmerken zij heel belangrijk of juist minder belangrijk vinden bij de keuze van een basisschool. Verreweg het belangrijkst vinden ouders dat er een goede sfeer is op school: bijna 95 procent vindt dit (zeer) belangrijk. Op de tweede plaats komt 'het hebben van veel aandacht voor sociale vaardigheden van het kind' (iets minder dan 9o\%). Daarmee vergeleken wordt minder belang gehecht aan aansluiting bij de opvoeding thuis: een kleine 70 procent vindt dit (zeer) belangrijk. Dit geldt nog sterker voor het belang dat wordt gehecht aan de aansluiting bij het eigen geloof of levensbeschouwing: nog geen 40 procent van de ondervraagde ouders vindt dit (zeer) belangrijk.

Aan dezelfde ouders is ook de vraag voorgelegd hoe ze aankijken tegen de taakverdeling tussen school en gezin. Maatschappelijke en sociale doelstellingen als 'respect bijbrengen voor mensen uit andere culturen' en 'rekening houden met elkaar' zijn volgens een ruime meerderheid van de ouders zowel een taak voor de school als voor het gezin (respectievelijk $75 \%$ en $70 \%$ ). Meer persoonsgerichte doelstellingen als 'kinderen vormen tot evenwichtige mensen' en 'kinderen goede manieren bijbrengen' worden door respectievelijk bijna de helft en ruim 70 procent van de ouders overwegend of uitsluitend als een taak voor het gezin gezien.

Hoger opgeleide ouders ${ }^{6}$ beschouwen persoonsgerichte opvoedingsdoelen meer als een taak voor het gezin, terwijl laagopgeleide ouders daarin vaker ook een taak voor de school zien weggelegd. Bij ouders met kinderen in het voortgezet onderwijs slaat de balans in de taakverdeling tussen school en gezin in het algemeen wat meer door naar het gezin.

Kennelijk ligt voor de doorsneeouder de pedagogische taak van de school eerder in de maatschappelijke en sociale aspecten van de opvoeding (respect voor mensen uit andere culturen, rekening houden met elkaar) dan in de meer persoonsgerichte doelstellingen (zoals vorming tot evenwichtige mensen en bijbrengen van goede manieren). De school heeft bij de sociale vorming van leerlingen ook een duidelijke meerwaarde ten opzichte van het gezin. Persoonlijke vorming zien ouders eerder als een taak voor zichzelf. $\mathrm{Zij}$ kennen hun eigen kind 
ook het best. Over de vraag wat er onder goede manieren moet worden verstaan, zullen ouders en docenten bovendien nog weleens van mening verschillen.

Docenten stellen vanuit hun verantwoordelijkheid voor een goed verloop van het onderwijsproces en het leefklimaat op school vermoedelijk andere en wellicht strengere eisen dan ouders.

In het eerdergenoemde onderzoek onder ouders komen allochtone ouders nauwelijks aan het woord. Ze hebben in het algemeen weinig of geen onderwijs genoten en zijn de Nederlandse taal vaak slecht of in het geheel niet machtig. Uit onderzoek onder verschillende groepen allochtone ouders komt naar voren dat de opvattingen nogal uiteenlopen. In het algemeen geldt dat allochtone ouders onderwijs zeer belangrijk vinden en hoge aspiraties koesteren voor hun kinderen. Bij gebrek aan kennis van het Nederlandse onderwijs zijn die aspiraties echter niet altijd realistisch. De opvoedingscultuur in allochtone gezinnen is vaak restrictief en autoritair. De gezagsverhoudingen zijn er overigens wel aan het veranderen. Allochtone ouders kijken ook anders aan tegen de taakverdeling tussen school en gezin. Er is minder dan in Nederlandse gezinnen sprake van voorbereiding op en ondersteuning van het kind bij het onderwijs en er wordt ook minder gedacht in termen van gedeelde verantwoordelijkheid tussen school en gezin; onderwijs en opvoeding tijdens schooltijd zijn een verantwoordelijkheid voor de school (Eldering 2002).

Een veelgehoorde klacht onder allochtone ouders is dat het Nederlandse onderwijs te weinig prestatiegericht is en de pedagogische aanpak te slap en te egalitair. Er wordt naar hun mening onvoldoende recht gedaan aan culturele en religieuze verschillen. Allochtone ouders voelen zich vaak niet serieus genomen door de leerkrachten; vaak is onduidelijk wat er van hen verwacht wordt (Smit en Driessen 2002).

\section{Leerkrachten en hun opvattingen over de pedagogische taak van de school}

Leerkrachten in het basisonderwijs hebben in het algemeen een wat andere taakopvatting dan docenten in het voortgezet onderwijs. In de beroepsopvatting van leerkrachten in het basisonderwijs staat het zorgperspectief centraal. De overwegend vrouwelijke leerkrachten zijn sterk leerlinggericht: het kind hoort centraal te staan en niet de leerstof. Het vormen van kinderen tot evenwichtige volwassenen en het begeleiden van leerlingen in hun leerproces - de opvoedende taak - worden belangrijker gevonden dan het bereiken van een zo hoog mogelijk leerresultaat (Hoogeveen 1999). Deze taakopvatting leidde een aantal jaren geleden tot forse kritiek: het basisonderwijs zou er onvoldoende op gericht zijn goede resultaten te behalen op het gebied van de kernvakken. Dat zou vooral ten koste gaan van kinderen uit kansarme gezinnen, die het voor het verwerven van basisvaardigheden vooral van de school moeten hebben. De persoonsgerichte cultuur zou dan ook moeten worden omgevormd tot een opbrengstgerichte cultuur (Commissie Evaluatie Basisonderwijs 1994). Sindsdien is er sprake van een duidelijke toename in het belang dat wordt gehecht aan het toetsen en het meten van leerresultaten. Dit zeer tegen de zin van dat deel van de leerkrachten dat de 
mening is toegedaan dat toetsen hooguit inzicht geven in de cognitieve vaardigheden, maar niet in de sociaal-emotionele ontwikkeling van het kind.

In het voortgezet onderwijs heersen andere beroepsopvattingen. In de professionele oriëntaties van docenten in het voortgezet onderwijs wordt wel een onderscheid gemaakt tussen de docent als vakdidacticus, de docent als pedagoog en de docent als organisator van het leerproces. Het merendeel van de docenten in het voortgezet onderwijs plaatst zichzelf tegenwoordig vermoedelijk in de derde categorie. Vakdidactici zijn de afgelopen decennia in de minderheid geraakt. De taakopvatting van docenten hangt sterk samen met het schooltype waarin men lesgeeft: docenten in het voorbereidend beroepsonderwijs (vbo) zullen zichzelf vermoedelijk eerder als pedagoog bestempelen dan docenten die lesgeven aan gymnasiumleerlingen.

Over de kwaliteit van het lerarencorps is weinig bekend. De Inspectie was er een aantal jaren geleden in haar evaluatieonderzoek naar de uitvoering van de basisvorming in het voortgezet onderwijs maar matig over te spreken (Inspectie van het onderwijs 1999). Het onderwijs kent geen verplichting tot periodieke bijscholing. Scholen hebben nauwelijks mogelijkheden om personeel dat slecht functioneert te ontslaan. Bij het huidige lerarentekort zijn ze vaak gedwongen genoegen te nemen met minder kwaliteit. De ingezette ontwikkeling naar meer functiedifferentiatie leidt ertoe dat er vooral lager opgeleid (en goedkoper) ondersteunend personeel bij komt. Daardoor neemt het gemiddelde opleidingsniveau van het personeel af; een ontwikkeling die haaks staat op de verhoging van het opleidingsniveau van de bevolking.

Hoewel de verschillende vakken en leergebieden in principe tal van aanknopingspunten bieden voor een discussie over waarden en normen, gebeurt dit lang niet altijd. Het lesprogramma is overladen, waardoor er nauwelijks gelegenheid is om, bijvoorbeeld naar aanleiding van de actualiteit, eens wat dieper op een onderwerp in te gaan. Er is bovendien een zekere 'methodedwang'. Het boek moet aan het eind van het schooljaar behandeld zijn. Met leerkrachten die aan parallelklassen lesgeven zijn afspraken gemaakt over de data waarop proefwerken worden gegeven. Deze tijdsdruk beperkt de gelegenheid voor pedagogische uitstapjes. Ook de nieuwe didactiek van het meer individueel en zelfstandig leren verkleint volgens docenten de mogelijkheden om de opvoedende taak vorm te geven. Klassikale momenten zijn vervangen door individuele studie-uren. Leerlingen worden bij zo'n aanpak veel meer als individu aangesproken dan als lid van een groep. Daarnaast doet zich ook een zekere spanning voor tussen de behoefte aan eensgezind optreden van het hele docententeam en het belang van een meer persoonlijke invulling van de pedagogische opdracht (Veugelers en De Kat 1998).

\section{Verschillen tussen scholen}

Scholen verschillen in de samenstelling van hun leerlingenpopulatie. Sommige scholen trekken een heel gevarieerd publiek, bij andere scholen is de leerlingenpopulatie in sociaal en cultureel opzicht homogener. Die verschillen hangen niet 
alleen samen met de vestigingsplaats van de school of - in het voortgezet onderwijs - met het schooltype, maar ook met verschillen in denominatie of richting.

Openbare basisscholen, die van overheidswege (dat wil zeggen de gemeente) worden bestuurd, zijn voor iedereen toegankelijk. De leerlingenpopulatie is er in de regel veel meer gemengd dan in het bijzonder onderwijs. De morele vorming is er mede als gevolg van het facultatieve karakter van het godsdienstonderwijs of humanistisch vormingsonderwijs beperkt. 7 De meeste openbare scholen stellen zich op het punt van de waardevorming tamelijk passief en neutraal op. Sommige scholen besteden in hun onderwijs uitdrukkelijk aandacht aan de multiculturele aspecten van de samenleving (bijvoorbeeld in de vorm van aandacht voor islamitische feestdagen, via onderwijsprojecten met een sociaal karakter of door bezoeken aan buitenschoolse culturele instellingen). Openbare scholen stemmen hun onderwijs in de praktijk in hoge mate af op de omgeving waarin ze functioneren (Braster 1996).

Het algemeen bijzonder onderwijs gaat, net als het openbaar onderwijs, uit van gelijkwaardigheid van alle levensbeschouwelijke en maatschappelijk stromingen. Veel algemeen bijzondere scholen hebben een speciale onderwijskundige of pedagogische identiteit (bijvoorbeeld montessori, jenaplan, dalton etc.). Omdat vooral hoogopgeleide ouders voor dergelijke scholen kiezen is de leerlingenpopulatie er een stuk homogener dan in het openbaar onderwijs (Vogels 2002). Er is weinig bekend over de wijze waarop de waardevorming er wordt ingevuld. ${ }^{8}$

Vergeleken met andere confessionele richtingen is de identiteit van het roomskatholieke onderwijs het meest diffuus (Vreeburg 1997). In het protestantschristelijke onderwijs is de religieuze vorming minder sterk verwaterd dan in het rooms-katholieke onderwijs. Maar ook hier is het karakter van het godsdienstonderwijs in de loop der jaren duidelijk veranderd: er is minder sprake van overdracht van religieuze waarden en normen (bijbelonderricht) en er wordt meer ingespeeld op algemene zingevings- en levensvragen van de leerlingen zelf. Het merendeel van de rooms-katholieke en protestants-christelijke scholen praktiseert momenteel een gematigde vorm van levensbeschouwelijkheid. Daardoor zijn deze scholen ook voor buitenkerkelijke ouders aantrekkelijk, temeer daar veel ouders een confessionele identiteit vaak associëren met een zekere kwaliteit (op protestants-christelijke scholen heerst rust en orde, katholieke scholen scoren beter op de Cito-toets). Bovendien vinden veel buitenkerkelijke ouders het belangrijk dat de school enige aandacht besteedt aan levensbeschouwelijke vragen.

In het reformatorisch en gereformeerd onderwijs is nog sprake van dagelijks gebed. Er is ruime aandacht voor het godsdienstonderwijs en de identiteit van de school werkt sterk door in de andere schoolvakken en (buiten)schoolse activiteiten. Leerkrachten zijn in het algemeen uit de eigen kerkelijke achterban afkomstig en scholen nemen alleen leerlingen aan die de grondslag van de school onderschrijven. 
In 1988 werden de eerste islamitische basisscholen opgericht. Inmiddels zijn dat er eenenveertig (op een totaal van ongeveer zevenduizend basisscholen). Islamitische scholen verschillen nogal in de wijze waarop ze invulling geven aan de religieuze vorming. Op sommige scholen wordt strikt vastgehouden aan de islamitische regels (hoofddoeken voor meisjes en gescheiden (gymnastiek)lessen in de hogere groepen), op andere scholen is dat veel minder het geval.

De verschillende denominaties binnen ons onderwijsbestel bieden al met al een breed spectrum aan religieuze en morele waardevorming. Bij sommige scholen beperkt het zich tot een facultatief uurtje godsdienstonderwijs, bij andere worden het gehele onderwijs en het schoolklimaat door de identiteit van de school bepaald. ${ }^{9}$ Scholen met een homogene leerlingenpopulatie kunnen hun onderwijs veel gemakkelijker afstemmen op de opvoeding thuis dan scholen die hun leerlingen uit zeer uiteenlopende milieus betrekken.

\section{Verschillende manieren van afstemming tussen school en gezin}

Ouders en leerkrachten kijken begrijpelijkerwijs vanuit een verschillend perspectief naar de pedagogische opdracht van de school. Ze zijn het erover eens dat opvoeding in de eerste plaats een verantwoordelijkheid is voor de ouders. Dit neemt niet weg dat ook de school een pedagogische taak heeft. Vanuit die gedeelde verantwoordelijkheid wordt vaak gepleit voor een betere afstemming tussen de opvoeding in het gezin en het onderwijs op school. Daarbij gaat men er in de regel van uit dat afstemming betekent dat ouders en school vanuit eenzelfde referentiekader inhoud geven aan hun pedagogische taak. De grondwettelijke vrijheid van onderwijs is ook op dit gezichtspunt gebaseerd. Hiervoor is al opgemerkt dat een inhoudelijke afstemming in de praktijk lang niet altijd kan worden gerealiseerd.

Behalve aan inhoudelijke aansluiting kan bij afstemming ook gedacht worden aan een taakverdeling tussen school en gezin, waarbij de school zich op andere pedagogische doelen richt dan het gezin. Daarbij ligt het gezien de eerder aangegeven voorkeuren van ouders voor de hand dat de school het accent legt op de maatschappelijke en sociale doelen en dat het gezin meer de persoonlijkheidsvormende aspecten van de opvoeding voor haar rekening neemt. Bij een dergelijk model is het van belang dat er helderheid is over de verdeling van taken en dat ouders en school afspraken maken en met elkaar in gesprek blijven over die aspecten van de opvoeding die zowel in de school als in het gezin aan de orde zijn, zoals fatsoenlijke omgangsvormen, op tijd komen, zich aan de regels houden, rekening houden met elkaar en dergelijke.

De pedagogische afstemming tussen school en gezin hoeft dus niet noodzakelijk via inhoudelijke aansluiting plaats te vinden, maar kan ook worden gerealiseerd door duidelijke afspraken te maken over de taakverdeling tussen school en gezin. Bij de kleinere richtingen valt zo'n inhoudelijke afstemming makkelijker te realiseren dan in bijvoorbeeld het katholiek of het openbaar onderwijs. Scholen die uitsluitend kinderen trekken uit eigen kring hebben in pedagogisch opzicht minder uit te leggen dan scholen met een meer heterogeen publiek. Scholen die 
openstaan voor groepen met uiteenlopende sociale en culturele achtergronden moeten niet alleen meer duidelijkheid verschaffen over de wijze waarop zij hun pedagogische opdracht invullen, maar ook meer met ouders communiceren over pedagogische kwesties. Het maken van heldere afspraken over een pedagogische taakverdeling ligt hier eerder voor de hand. Diversiteit heeft ook voordelen: zij biedt meer mogelijkheden om aandacht te schenken aan de maatschappelijke en sociale aspecten van de pedagogische opdracht (bijvoorbeeld kinderen respect bijbrengen voor mensen uit andere milieus of met andere geloofsovertuigingen). Docenten moeten daarin dan wel beter worden geschoold dan tot dusver gebruikelijk is.

\subsection{DE ROL VAN DE OVERHEID}

Scholen hebben bij de overdracht en handhaving van waarden, normen en gedrag met twee overheden te maken: de rijksoverheid en de gemeente.

\section{De rol van de rijksoverheid}

Overheidsbeleid is niet waardevrij: er worden impliciet dan wel expliciet belangrijke waarden en normen uitgedragen, zo bleek in paragraaf 10.2. Deze weerspiegelen de tijdgeest in een bepaalde periode en zijn op hun beurt weer van invloed op het gedrag van burgers. De calculerende burger is in zekere zin een product van overheidsbeleid. ${ }^{10}$ Momenteel staan voor scholen en instellingen waarden als autonomie en verantwoording hoog genoteerd. Ten aanzien van ouders en leerlingen staan keuzevrijheid en eigen verantwoordelijkheid centraal. Scholen en ouders moeten in goed overleg samen invulling geven aan het onderwijs en dus ook aan de pedagogische opdracht. In het voorgaande is betoogd dat een dergelijke dialoog geenszins vanzelfsprekend is en evenmin spontaan op gang komt. Er wordt bovendien van uitgegaan dat alle ouders en leerlingen ook in staat en bereid zijn om de gewenste constructieve bijdrage te leveren. Dit is maar zeer ten dele het geval. Daar komt nog bij dat de positie van de schoolbesturen - een belangrijke gesprekspartner in dit verband - op dit moment zeer onduidelijk is. Schoolbesturen staan weliswaar voor de identiteit van de school en vervullen een belangrijke voorwaardenscheppende functie maar zijn voor ouders in het algemeen onzichtbaar en ontoegankelijk. De komende jaren zal de afstand als gevolg van een van overheidswege gestimuleerde schaalvergroting en professionalisering onder schoolbesturen alleen nog maar toenemen. Democratische controle van schoolbesturen door ouders, leerlingen en personeel is nauwelijks mogelijk, ook al vanwege de toegenomen complexiteit van de regelgeving. Bij het openbaar onderwijs vervult de gemeenteraad in principe nog een controlerende functie.

De rijksoverheid is in verband met de grondwettelijke vrijheid van onderwijs van oudsher zeer terughoudend bij het geven van richtlijnen voor onderwijsinhouden en pedagogisch-didactische aanpak. De jaren negentig vormden in dit opzicht een uitzondering. De overheid stelt zich ten aanzien van het onderwijs overwegend neutraal en instrumenteel op. De Nederlandse overheid voert geen 
cultuurpolitiek, maar laat noodzakelijke keuzes ten aanzien van onderwijsinhoud en didactische aanpak door (vak)deskundigen en belanghebbenden voorbereiden. Binnen de algemene kaders die zo totstandkomen, hebben scholen de nodige vrijheid voor een eigen invulling. Die gang van zaken resulteert weliswaar in een grote variëteit aan onderwijspraktijken en ruime keuzemogelijkheden, maar biedt weinig mogelijkheden voor bijsturing in geval zich ongewenste (neven)effecten voordoen.

Welke rol zou de rijksoverheid dan wel kunnen vervullen om overdracht en handhaving van waarden en normen via het onderwijs te bevorderen en ongewenst gedrag tegen te gaan? De overheid zou scholen meer tijd en ruimte moeten geven om aan hun pedagogische opdracht vorm te geven. Docenten zullen daarvoor wel moeten worden toegerust (bijscholing, aanvullingen op methodes). Het bieden van ruimte verdient de voorkeur boven invoering van nieuwe vakken en leergebieden, zoals media-educatie of burgerschapsvorming, die het onderwijsprogramma alleen nog maar voller zouden maken.

De Inspectie zou een eerlijk inzicht moeten geven in de omvang en aard van de gedragsproblematiek die zich binnen scholen voordoet. ${ }^{11}$ De toename van het aantal schorsingen valt moeilijk te rijmen met positieve geluiden over het pedagogisch klimaat. Indien de pedagogische situatie op een school niet in orde is, moeten er duidelijke afspraken worden gemaakt over een verbetertraject. Iets dergelijks gebeurt momenteel al wel bij tekortschietende leerprestaties (het zogenoemde onderwijskansenbeleid).

De didactische aanpak en de pedagogische opdracht moeten niet langer als afzonderlijke aspecten worden behandeld, maar in samenhang worden ontwikkeld. Veel gedragsproblematiek komt voort uit frustratie over slechte schoolprestaties of gebrek aan persoonlijke aandacht. Het onderwijs aan lastige leerlingen wordt te vaak gekenmerkt door een negatieve benaderingswijze (straf) of door onverschilligheid (bijvoorbeeld bij regelmatig verzuim). Onderwijskundigen, didactici en pedagogen zullen rond de tafel moeten om de samenhang tussen didactiek en pedagogiek te herstellen.

Leerlingen moeten medeverantwoordelijk worden voor de formulering en handhaving van de regels op school en in de klas. Die medeverantwoordelijkheid zou zich in het voortgezet onderwijs ook kunnen uitstrekken tot de beoordeling van leerkrachten. Leerlingen zijn in het algemeen heel goed in staat om een afgewogen oordeel te geven. Hun oordeel zou een rol moeten spelen bij beslissingen over aanstelling en salariëring.

Risicoleerlingen (bijvoorbeeld kinderen uit probleemgezinnen of kinderen met ADHD) moeten in een vroeg stadium worden opgespoord, extra worden ondersteund en nauwkeurig worden gevolgd. ${ }^{12}$ Binnen de kinderopvang en de voor- en vroegschoolse educatie zou al met het afleren van agressief gedrag moeten worden begonnen. Kinderen die als gevolg van gedragsproblemen op school 
moeilijk in een groep te handhaven zijn, moeten (tijdelijk) apart kunnen worden opgevangen. Laagopgeleide ouders (allochtoon en autochtoon) moeten meer bij de school worden betrokken. Dat zal de nodige inspanningen vergen waarvoor scholen wel wat externe hulp kunnen gebruiken. De pedagogische afstemming tussen ouders en school zal bij een zeer diverse leerlingenpopulatie anders moeten worden ingevuld dan bij een homogene. Scholen moeten hiervoor eigen oplossingen kunnen ontwikkelen. Ze zullen daarover wel publiekelijk verantwoording moeten afleggen, niet alleen aan ouders en leerlingen, maar ook aan de Inspectie.

Er valt, last but not least, ook nog het nodige te verbeteren in de sfeer van de voorwaarden: de organisatie van het onderwijs (waaronder vestigingsbeleid), de lerarenopleidingen, de bijscholing van docenten, de huisvesting en het onderhoud van schoolgebouwen.

\section{De rol van de gemeente}

Gemeenten hebben als lokale overheid belangrijke taken op het gebied van het onderwijs. In het kader van het gemeentelijk onderwijsachterstandenbeleid wordt er in overleg tussen gemeente en schoolbesturen gewerkt aan een verbetering van de leerprestaties van kinderen uit lagere sociale milieus en uit etnische minderheidsgroepen. Gemeenten zijn sinds enkele jaren ook verantwoordelijk voor de huisvesting van scholen. Ze hebben bovendien een belangrijke taak op het gebied van de handhaving van de leerplicht en het tegengaan van voortijdige schooluitval. Gemeenten richten zich vooral op maatschappelijke problemen en op zaken die de spankracht van de afzonderlijke scholen te boven gaan. Ze proberen integraal beleid te voeren, waarbij er verbindingen worden gelegd tussen verschillende beleidsterreinen: het jeugdbeleid, het veiligheidsbeleid, het grotestedenbeleid, het inburgeringsbeleid en het onderwijsachterstandenbeleid. Naast het verbeteren van de leerprestaties wordt ook veel belang gehecht aan het bevorderen van de sociale competentie van jongeren (Turkenburg 2003). Er is in dat verband de afgelopen jaren veel werk gemaakt van de ontwikkeling van eerdergenoemde brede scholen.

Op papier is er in toenemende mate sprake van 'een sluitende aanpak'. In de praktijk zijn er nog tal van barrières die een goede samenwerking tussen de verschillende instanties (scholen, kinderopvang, jeugdzorg, maatschappelijk werk, welzijn, sport en culturele vorming) in de weg staan.

Het tweede kabinet-Balkenende heeft in het Hoofdlijnenakkoord aangekondigd dat het gemeentelijk budget voor het onderwijsachterstandenbeleid zal worden overgeheveld naar de schoolbesturen. Tegelijkertijd zal er op dit beleid flink worden bezuinigd. Beide beleidsvoornemens zullen de komende jaren voor de nodige bestuurlijke onrust en personele onzekerheid zorgen. De bestuurlijke verhoudingen op lokaal niveau waren net enigszins uitgekristalliseerd. Er was een begin gemaakt met het wegnemen van de schotten tussen de verschillende beleidsterreinen. Gevreesd moet worden dat als gevolg van deze koerswijziging 
de school overstijgende maatschappelijke component van de waarden, normen en gedragsproblematiek de komende jaren minder aandacht zal krijgen. Het zal de nodige tijd kosten om de verantwoordelijkheidsverdeling tussen de verschillende instanties opnieuw te definiëren. De bredeschoolontwikkeling zal als gevolg van de bezuinigingen vermoedelijk stagneren.

\subsection{TEN SLOTTE}

De voorgaande beschouwingen zouden mogelijk het beeld kunnen oproepen dat de gedragsproblemen en de spanningen tussen culturen dermate groot zijn dat de taakstelling van het onderwijs ingrijpend zou moeten veranderen. Dit beeld is onterecht. De problemen en spanningen moeten ook weer niet overdreven worden. Ouders en leerlingen zijn in het algemeen heel tevreden met de kwaliteit van het onderwijs (SCP 2002). De verandercapaciteit van het onderwijs is bovendien beperkt, omdat kinderen jaarlijks hooguit eenvijfde deel van hun tijd (gemiddeld ongeveer duizend uur) op school doorbrengen.

Leerlingen die in het onderwijs moeilijk kunnen meekomen, raken daardoor gedemotiveerd en gefrustreerd. Dat uit zich in veel gevallen in gedragsproblemen. Vaak zijn het kinderen en jongeren die ook nog kampen met persoonlijke problemen of beperkingen, afkomstig zijn uit problematische gezinnen en van huis uit weinig meekrijgen. Was het vroeger gebruikelijk om dit als een onvermijdelijke vorm van sociale reproductie te beschouwen, tegenwoordig domineert de meritocratische norm: wie in het onderwijs niet mee kan komen heeft dat in de eerste plaats aan zichzelf te wijten. Het is dan ook niet verwonderlijk dat met het stijgen van de opleidingseisen (het niveau van de startkwalificatie als minimum) en met de toename van het belang dat wordt gehecht aan persoonlijke kenmerken (initiatiefrijk, flexibel, sociaal, zelfbewust, assertief) de groep die in de problemen raakt, in omvang toeneemt. Voor het merendeel van het normoverschrijdende gedrag geldt echter dat de jeugd gewoon het slechte voorbeeld van volwassenen volgt.

Wat kan het onderwijs dan eigenlijk nog doen? In voorgaande paragrafen is aangegeven dat er via de onderwijsinhouden, maar vooral langs de weg van de omgangsvormen op school nog de nodige winst te boeken valt. Daarbij gaat het niet zozeer om toevoegen van nieuwe vakken of leergebieden of om een sterke toename van tijd en aandacht die aan de opvoedende taak moet worden besteed, maar meer om een andere aanpak. De nu vaak gepraktiseerde negatieve benadering (tegengaan van antisociaal gedrag) zou moeten worden vervangen door een positieve (bevorderen van sociaal gedrag). Leerlingen willen serieus genomen worden en dat kan het beste door ze medeverantwoordelijk te maken voor het opstellen en handhaven van de gedragsregels op school. Een vergelijkbare omslag van negatief naar positief zou moeten plaatsvinden bij de beoordeling van leerresultaten: aangeven wat de vorderingen zijn in plaats van wat leerlingen niet kunnen. Dit wil niet zeggen dat er in de toekomst geen hoge eisen meer mogen 
worden gesteld of dat er niet langer corrigerend moet worden opgetreden. Normoverschrijdend gedrag zal nooit helemaal kunnen worden uitgebannen. De mogelijkheden van de school zijn beperkt. Maar in ieder geval moet worden voorkomen dat het onderwijs(beleid) zelf de gedragsproblemen veroorzaakt.

Via buitenschoolse activiteiten (muziek, toneel, sport) kan ook het nodige worden gedaan aan het bevorderen van sociaal gedrag. Leerlingen die moeite hebben met schoolse taken kunnen dan ook succeservaringen opdoen. Risicoleerlingen moeten zo snel mogelijk worden opgespoord en extra worden ondersteund, desnoods in een aparte setting.

De pedagogische opdracht hoeft dus niet te worden uitgebreid, maar moet anders worden ingevuld. Een positief pedagogisch klimaat levert niet alleen tijdwinst op, maar leidt ook tot betere leerprestaties. De kerntaak van de school (overdracht van kennis en vaardigheden) mag in geen geval in het gedrang komen.

Ook ouders moeten regelmatig op hun opvoedingsverantwoordelijkheid worden aangesproken, door de rijksoverheid, maar ook door schoolbesturen en gemeenten. Schoolleiders kunnen zich beter met de pedagogisch-didactische vernieuwing van het onderwijs en de verdere professionalisering van het docentencorps bezighouden.

Van de rijksoverheid mag worden verwacht dat ze zich bij bestuurlijke of onderwijsinhoudelijke vernieuwingen bewust is van verborgen signalen en mogelijk averechtse effecten. Ze zou in ieder geval duidelijk moeten aangeven hoe in verschillende situaties de verantwoordelijkheid voor de pedagogische opdracht het beste kan worden verdeeld: tussen de rijksoverheid, schoolbesturen, scholen, ouders, leerlingen, gemeenten en instanties die ondersteuning dan wel aanvullende activiteiten kunnen bieden. De Inspectie van het onderwijs zou periodiek een realistisch inzicht moeten geven in de pedagogische situatie, zowel binnen de scholen als in de directe omgeving ervan. Overheden hebben verder vooral een voorwaardenscheppende functie: zorgen voor een toereikende bekostiging, kwaliteitszorg ten aanzien van de lerarenopleidingen en het personeel, goede huisvesting, het stimuleren en goed laten evalueren van experimenten met nieuwe werkwijzen, zorg dragen voor een veilige omgeving bij scholen, voor een snelle en goede ondersteuning bij persoonlijke of gezinsproblemen, enzovoorts. Uitvoerders binnen scholen, maar ook bij andere instanties die met de jeugd in aanraking komen zouden, ten slotte, niet voortdurend met beleidswijzigingen en nieuwe maatregelen moeten worden geconfronteerd. 


\section{NOTEN}

In deze bijdrage beperk ik me tot het basis- en voortgezet onderwijs. Dat betekent overigens niet dat aandacht voor waarden en normen in het daaropvolgende beroeps- en hoger onderwijs onbelangrijk zou zijn.

Dat laatste hangt samen met problemen die zijn ontstaan als gevolg van de verbreding van de basisvorming. Inmiddels zijn er enkele wijzigingsvoorstellen aangenomen die scholen de ruimte geven om kerndoelen te laten vallen of slechts gedeeltelijk aan te bieden.

Het begrip 'sociale competentie' is inmiddels nader onderzocht. Het blijkt een containerbegrip te zijn dat vele invullingen kent. In de regel wordt het vanuit twee invalshoeken benaderd: vanuit de psychologische ontwikkeling van kinderen en vanuit het perspectief van sociale participatie en kritisch burgerschap (Ten Dam et al. 2003). Het dekt daarmee vrijwel de gehele problematiek van waarden, normen en gedrag.

Meestal zijn de doelstellingen nogal vaag of wordt alleen de tevredenheid van de school gemeten maar wordt niet gekeken of het gedrag van de leerlingen veranderd is.

De gemiddelde Nederlander is overigens veel zorgelijker over de gedragsproblemen in het onderwijs dan de ouders. Waarschijnlijk laat de doorsneeburger zich leiden door berichten in de media, terwijl ouders vermoedelijk vooral afgaan op ervaringen met de school van het eigen kind.

Vooral ouders met kinderen in het algemeen bijzonder onderwijs.

7 Dit onderwijs wordt door de gemeente gesubsidieerd; er wordt echter steeds vaker op bezuinigd.

Islamitische en Vrije scholen zijn soms ook bij de algemeen bijzondere koepelorganisatie aangesloten; bij deze scholen ligt het onderwijs duidelijk in het verlengde van het geloof of de levensbeschouwing.

Zo verplichten sommige scholen voor voortgezet onderwijs hun leerlingen uit de bovenbouw om gedurende een aantal uren per jaar maatschappelijke activiteiten te verrichten, variërend van vrijwilligerswerk in een bejaardentehuis tot begeleiding van brugklassers of het meewerken aan de schoolkrant. Een tiental scholen heeft sinds kort in het kader van een experiment een maatschappelijke stage ingevoerd.

De recente fraude met studentenaantallen in het hbo kan bijvoorbeeld niet los worden gezien van de bekostigingswijze van hogescholen.

De Inspectie beoordeelt tot dusver alleen of aan de basisvoorwaarden voor goed onderwijs is voldaan.

2 Uit recent ontwikkelingspsychologisch onderzoek blijkt dat fysieke agressie al heel vroeg in het leven (vanaf zes maanden) zichtbaar wordt en daarom ook al vroeg moet worden afgeleerd. Wordt fysieke agressie op jonge leeftijd niet gecorrigeerd, dan vormt dat een belangrijke risicofactor voor toekomstig antisociaal gedrag en andere sociale problemen (Junger 2003). 


\section{LITERATUUR}

Braster, J.F.A. (1996) De identiteit van het openbaar onderwijs, Groningen: WoltersNoordhoff.

Brink, G. van den (2001) Geweld als uitdaging, Utrecht: NIZW.

Bronneman-Helmers, H.M. et al. (2002) Voortgezet onderwijs in de jaren negentig, Den Haag: Sociaal en Cultureel Planbureau.

Commissie Evaluatie Basisonderwijs (1994) Zicht op kwaliteit. Eindrapport, Den Haag: Sdu.

Dam, G. ten, et al. (2003) Sociale competentie langs de meetlat. Het bestrijden van onderwijsachterstand. Het meten en evalueren van sociale competentie, Den Haag: Transferpunt Onderwijsachterstanden.

Eldering, L. (2002) Cultuur en opvoeding. Interculturele pedagogiek vanuit ecologisch perspectief, Rotterdam: Lemniscaat.

Herweijer, L., en R. Vogels (2003) Mammoetscholen: monster of mythe?, blz. 6o-65 in: Het theorema van Thomas, Nieuwjaarsuitgave 2003 van het Sociaal en Cultureel Planbureau, Den Haag: SCP.

Hoeven, A.A. van der (1990) Effecten van leerlingbeelden en streefniveaus op schoolloopbanen, dissertatie, Nijmegen: ITS.

Hoogeveen, K. (1999) 'Het kunnen allemaal je eigen kinderen zijn'. Leerkrachten basisonderwijs over hun beroep, Utrecht: Uitgeverij Jan van Arkel.

Inspectie van het onderwijs (1999) Werk aan de basis. Evaluatie van de basisvorming na vijfjaar, Utrecht: Inspectie van het onderwijs.

Inspectie van het onderwijs (2000) Van wie is de school? Jongeren over de invloed van het schoolklimaat op het voortijdig schoolverlaten, rapport 2000-6, Utrecht: Inspectie van het onderwijs.

Inspectie van het onderwijs (2003) Onderwijsverslag over het jaar 2002, Utrecht: Inspectie van het onderwijs.

Junger, M. (2003) Gedragsproblemen en gezondheidsimplicaties in een ontwikkelingsperspectief, Utrecht: Universiteit Utrecht.

Junger-Tas, J. (200o) Diploma's en goed gedrag. De maatschappelijke functie van het onderwijs vanuit justitieel perspectief, Den Haag: Ministerie van Justitie.

Junger-Tas, Josine (2002) Diploma's en goed gedrag II. Preventie van antisociaal gedrag in het onderwijs, Den Haag: Ministerie van Justitie.

Jungbluth, P. (2003) De ongelijke basisschool. Etniciteit, sociaal milieu, sekse, verborgen differentiatie, segregatie, onderwijskansen en schooleffectiviteit, Nijmegen: ITS.

Klaassen, C., en H. Leeferink (1998) Partners in opvoeding in het basisonderwijs. Ouders en docenten over de pedagogische opdracht en de afstemming tussen gezin en school, Assen: Van Gorcum.

Mooij, T. (1992) Pesten in het onderwijs, Nijmegen: ITS.

Mooij, T. (1994) Leerlinggeweld in het voortgezet onderwijs, Nijmegen: ITS.

Mooij, T. (2001) Veilige scholen en (pro)sociaal gedrag. Evaluatie van de campagne 'De veilige school' in het voortgezet onderwijs, Nijmegen: ITS/KUN.

Onderwijsraad (2002) Verkenning Samen leren leven.

Reijnders, M. (1976) Op zoek naar het verborgen leerplan, Amsterdam. 
RMO (2000) Aansprekend burgerschap. De relatie tussen de organisatie van het publieke domein en de verantwoordelijkheid van burgers, Den Haag: Raad voor Maatschappelijke Ontwikkeling.

SCP (2002) Sociaal en Cultureel Rapport 2002. De kwaliteit van de quartaire sector, Den Haag: Sociaal en Cultureel Planbureau.

Smit, F., en G. Driessen (2002) Allochtone ouders en de pedagogische functie van de basisschool, Nijmegen: ITS.

Turkenburg, Monique (2003) Het gemeentelijk onderwijsachterstandenbeleid halverwege de eerste planperiode (1998-2002). Het beleidsproces in vijftien gemeenten, Den Haag: Sociaal en Cultureel Planbureau.

Veugelers, W., en E. de Kat (1998) Opvoeden in het voortgezet onderwijs. Leerlingen, ouders en docenten over de pedagogische opdracht en de afstemming tussen gezin en school, Assen: Van Gorcum.

Vermaas, J., en H. Wiersma (2000) De klachtenregeling in het primair en voortgezet onderwijs: spiegel of bliksemafleider, Tilburg: IVA.

Vogels, R. (2002) Ouders bij de les. Betrokkenheid van ouders bij de school van hun kind, Den Haag: Sociaal en Cultureel Planbureau

Volkskrant (2003) 'Onderwijs vernieuwt zichzelf', interview met Maria van der Hoeven, de Volkskrant, 12 juli 2003.

Vreeburg, B.A.N.M. (1997) Religieuze socialisatie en onderwijsverzuiling, in: Dijkstra, Anne Bert, et al. (red.). Verzuiling in het onderwijs. Actuele verklaringen en analyse, Groningen: Wolters-Noordhoff

Wartenbergh-Cras et al. (2002) Onderwijsmeter 2002, Nijmegen: ITS. 


\title{
11 NORMOVERSCHRIJDING EN ALLOCHTONE JONGEREN
}

\author{
S. Harchaoui
}

\subsection{INLEIDING}

In de Nederlandse samenleving wordt al geruime tijd een publiek debat gevoerd over normen en waarden. De termen die in dit debat worden gebruikt, suggereren dat er sprake is van ernstig verval. Normen en waarden in de samenleving zouden vooral worden bedreigd omdat deze niet door alle groepen en binnen alle sociale klassen in de samenleving worden gedeeld of op zijn minst onderschreven. Tekenend voor het huidige discours is dat het 'allochtonenvraagstuk' in verschillende gedaanten het middelpunt of het vertrekpunt vormt voor dit debat (vgl. Cliteur 2002; Lucassen en De Ruijter 2002 en Jaspers en Outshoorn 2002). Het zijn op dit moment vooral allochtone jongeren, in het bijzonder de Marokkaanse, die in toenemende mate de verbeelding van de teloorgang van een zeker - maar onvoldoende geëxpliciteerd - beschavingspeil vormen.

Allochtone jongeren en hun culturele achtergronden worden in verschillende bewoordingen in meerdere of mindere mate ervoor verantwoordelijk gehouden als een soort voorhoede te fungeren in het verzet tegen de heersende normen en waarden in de maatschappij. Daarbij zou het sociaal-culturele milieu waarin deze jongeren wortelen (ouders, gezinnen en gemeenschappen) normafwijking onvoldoende remmen en soms zelfs bevorderen. Deze stellingen worden vaak geadstrueerd door in absolute termen en (morele) kwalificaties te wijzen op de onmiskenbare oververtegenwoordiging van deze jongeren in de criminaliteitsstatistieken. De verklaring voor de jeugdcriminaliteit en overlast in het publieke domein door allochtone jongeren wordt gezocht in 'hun' cultuur of 'hun' culturele achtergronden.

De aard van het publieke debat over normen en waarden in relatie tot de multietnische samenleving heeft aanzienlijke gevolgen. Wanneer collectieve normen en waarden in een direct verband worden gepresenteerd en bediscussieerd met etniciteit, ontstaat er een stil proces van onontkoombaarheid. Een self-fulfilling prophecy is dan in de maak. Om deze reden acht ik het van belang stil te staan bij een aantal kenmerken van dit debat (par. 11.2). Dat debat is niet uniek - het vindt ook in de ons omringende landen plaats - en wordt gevoerd vanuit een ethische inslag op basis van negatieve emoties. De rol van empirie en de inbreng van allochtone burgers daarin is gering, terwijl de rol van religie zonder meer wordt benadrukt. De paradoxale werking is dat emancipatie hierdoor juist wordt afgeremd in plaats van gestimuleerd.

Jeugdcriminaliteit en overlast in het publieke domein gelden als de belangrijkste manifestatie van normafwijking (par. 11.3). Het criminaliteitsbeeld dat hieraan 
ten grondslag ligt, is echter eenzijdig en niet vrij van stereotypering of ideologische vooronderstellingen. De relatie tussen aard en omvang van deze jeugdcriminaliteit en de door de jongeren gehanteerde normen en waarden is minder vanzelfsprekend dan wordt gesteld. Het kan dienstbaar zijn ook andere criminaliteitsbeelden bij onze overwegingen te betrekken als we op zoek gaan naar gemeenschappelijke normen en waarden. Het zijn niet alleen notoire harddrugsverslaafden die om te voorzien in hun dagelijkse behoefte het verschil tussen 'mijn' en 'dijn' niet maken, maar het betreft - om maar wat te noemen - ook frauderende vastgoedhandelaren die de fiscus (en dus de maatschappij) tillen. Het verschil tussen bevolkingsgroepen zal verder afnemen als we ook aandacht hebben voor gedeeld dader- en slachtofferschap. Ondanks de relatieve massaliteit van normoverschrijdingen schieten culturele verklaringen tekort. Een culturele integratieparadox dient zich aan: betere culturele integratie leidt op korte termijn tot meer criminaliteit.

Een andere illustratie van normafwijking betreft vormen van religieus conservatisme en, meer recent, zelfs extremere religieuze opvattingen (par. 11.4). Hier gaat het vooral om de gestelde onverzoenbaarheid tussen 'hun' en 'onze' waarden en normen. In deze bijdrage concentreer ik mij op dit onderwerp, waarbij vooral vormen van verzet onder allochtone (moslim)jongeren aandacht krijgen. Het thema van 'de hoofddoek' en dergelijke krijgt als het om voorbeelden van verzet gaat naar mijn mening disproportioneel veel aandacht.

Belangrijker lijkt mij de constatering dat het debat over normoverschrijding van allochtone jongeren plaatsvindt binnen een context van ingrijpende veranderingen in de gehele samenleving. Veranderingen die fundamentele onzekerheid bewerkstelligen. Naast een poging de kenmerken hiervan te begrijpen, wil ik vooral de averechtse effecten van het debat duiden die op lange termijn mogelijk nijpende nieuwe en complexere problemen voor de samenleving tot gevolg hebben (par. 11.5). Een effectieve dialoog wordt geblokkeerd, stigmatisering leidt tot onderbenutting van maatschappelijk kapitaal en zelfisolement en verschillende vormen van verzet openbaren zich.

Ten gevolge van het niet-gestroomlijnde debat worden positieve autopoëtische (zichzelf scheppende) maatschappelijke processen binnen allochtone gemeenschappen doorkruist (par. 11.6). Het gaat dan juist om processen die uit kunnen monden in integratie of zelfs assimilatie van bepaalde groepen of individuen. Stille en moeilijk zichtbare emancipatieprocessen worden onvoldoende herkend en onvoldoende aangemoedigd. Dit doorkruisende proces is niet bevorderlijk voor 'de' sociale cohesie. Het draagt niet bij aan de afname van groepstegenstellingen en op lange termijn ontstaat een nauwelijks gedeeld draagvlak voor de (sociale) rechtsstaat. De ontwikkeling van allochtone jongeren tot individuele burgers wordt gedeeltelijk ook belemmerd door de welhaast tirannieke werking van een aanhoudende collectivisering van hun persoon en gedrag. Zonder een stroomlijning van het politiek-maatschappelijke debat - waarin problemen zorgvuldig worden benoemd en burgers niet worden vervreemd - zal de effectiviteit 
van overheidshandelen onder de nieuwe generaties allochtone jongeren niet toenemen. Al met al voldoende urgente redenen om te concluderen dat het debat op een andere wijze moet worden gevoerd (par. 11.7). Als dit niet gebeurt, zullen aangedragen oplossingen - hoe goed ook - weinig zoden aan de dijk zetten.

\subsection{KENMERKEN VAN HET NEDERLANDSE DEBAT}

Publieke debatten over normen en waarden zijn niet eigen aan Nederland. In diverse Europese en westerse landen worden discussies gevoerd over multiculturalisme, sociale cohesie en nationale identiteit. De gekozen thema's zijn per land verschillend en hebben betrekking op diverse facetten van domeinen van beleid: asiel, nationaliteitswetgeving, integratie of antiracisme (Prins en Slijper 2002). De aard en toon van de discussies is onmiskenbaar verbonden met een wisselvallige conjunctuur van politieke gebeurtenissen. Zo hebben de aanslagen in de Verenigde Staten op 11 september 2001 de debatten een buitengewoon gevoelige lading gegeven, waarin de nuance het eerst is gesneuveld. De nationale culturele traditie bepaalt verder in aanzienlijke mate de invulling. In Duitsland wordt de problematiek van multiculturaliteit besproken in termen van 'Leitkultur', wat dienstig moet zijn aan het creëren van bindende factoren tussen verschillende burgers gebaseerd op beginselen van democratie, tolerantie en de rechten van de mens.

\section{De ethische inslag in het Nederlandse debat}

In Nederland domineert in het debat over multiculturalisme en nationale identiteit een zekere ethische inslag. Op zichzelf is dit niet verwonderlijk. 'De' Nederlandse cultuur kent duidelijke moralistische trekken, althans er zijn betrekkelijke constanten in die cultuur aan te wijzen: burgerlijke waarden, individualisme, afkeer van extreme politieke ideologieën en feminiteit (Couwenberg 2001: 24). Deze constanten hebben natuurlijk geen eeuwigheidswaarde. Discussies over normen en waarden in relatie tot de eigen identiteit werden ook in het verleden regelmatig gevoerd. De behoefte aan onder meer ontzuiling maakte in de jaren zestig en zeventig van de vorige eeuw het zoeken naar andere gemeenschappelijkheden noodzakelijk. Dit proces werd versneld door de jeugdbewegingen. Maar in tegenstelling tot eerdere perioden werd het collectieve en het bindende tussen verschillende bevolkingsgroepen benadrukt. Omwille van pacificatie moest het conflict immers vermeden worden om harmonie te kunnen bereiken. Consensus en compromis waren sleutelwoorden. De bekroning was het opgaan van katholieken en protestanten in één politieke partij (CDA). De wederzijdse bevruchting bleek bestendig. "Alleen fundamentalisten (...) zouden de partij kunnen doen splijten”, aldus Zijderveld (1993). Dwars door de zuilen heen is het zogenaamde poldermodel in feite ook een vorm van pacificatie en overbrugging geweest. Te denken valt ook aan de vorming van de FNV. In de jaren negentig kantelde de discussie door de toenemende invloed van Europa, de globalisering en hiermee gepaard gaande migratiegolven. In de huidige tijd slaat de slinger de andere kant op: alles wat riekt naar consensus en harmonie ligt aan de wieg van de ellende. 


\section{Het debat wordt beheerst door negatieve emotie: weerstand tegen verandering}

Het zijn vooral Nederlandse (rechts)filosofen en antropologen die zich intensief buigen over vraagstukken van al dan niet met elkaar in te wisselen begrippen als multiculturaliteit, multiculturalisme of diversiteit. De discussies zijn - zeker voor een buitenstaander - verwarrend en vaag, en heel vaak gaan ze over ideologieën. De toon van publicaties die doorsijpelen in het publieke debat is (cultuur-) pessimistisch. Gemeenschappelijke waarden in de samenleving functioneren nauwelijks nog of hebben onvoldoende draagvlak. Traditionele mechanismen die integratie bewerkstelligen, boeten aan kracht in en de maatschappelijke cohesie dreigt te eroderen. De stabiliteit van het democratische systeem komt op het spel te staan. Of deze visies onderschreven kunnen worden, kan in het midden blijven. Vastgesteld moet in ieder geval worden dat in dit debat argumenten de boventoon voeren. In het publieke debat daarentegen zijn stellingen en opinies doorgaans gebaseerd op emoties en smaken, op een hemeltergend herhalen van stereotiepe beelden over migranten en hun kinderen.

Negatieve emotie beheerst de discussies tussen intellectuelen, namelijk de angst voor identiteitsverlies. Daarmee is de primitiefste vorm van weerstand tegen verandering gegeven. De manier waarop het huidige debat over normen en waarden wordt gevoerd, lijkt Zijderveld gelijk te geven. Autochtone intellectuele fundamentalisten en vooral islamitische fundamentalisten zijn het met elkaar eens in hun opvatting dat de verschillen te groot zijn, de culturen onverzoenlijk. Rest confrontatie en strijd. Het meest opvallende in het huidige debat is immers de uitvergroting en essentialisering van het verschil en het geschil, vooral het religieuze.

\section{In het debat speelt empirie nauwelijks een rol van betekenis}

Een van de oorzaken daarvan is de bescheiden rol die de empirie speelt in deze discussies. Het gaat op dit moment vooral om het doorbreken van taboes (Prins en Slijper 2002: 252). Het heeft inmiddels tot bekentenisliteratuur geleid (Werdmölder 2002, geciteerd in Bovenkerk 2003b). Feiten, context of dynamische ontwikkelingen zijn minder relevant geworden. De focus op moslims of allochtonen is veelal gebaseerd op stereotypering (Shadid en Van Koningsveld 1997). Natuurlijk, aan stereotypen ligt een feitelijke component ten grondslag en het gaat niet aan reële problemen te omzeilen of erger: te bagatelliseren (Boutellier 2002). Voor een gedeelte is beeldvorming immers gegrondvest in reële problemen. Eigen aan beeldvorming - ook in relatie tot werkelijke problemen - is echter ook selectiviteit, subjectiviteit en blikvernauwing. Daar waar empirie ontbreekt en het debat wordt gevoerd op basis van strategische overwegingen (bijvoorbeeld in tijden voor verkiezingen) worden vanzelfsprekend alleen de verschillen benoemd en geproblematiseerd. Het 'slaan van bruggen' wordt moeilijker als de nadruk alleen komt te liggen op sociaal-culturele achtergronden ten koste van sociaal-economische, waarbij het etnische of het religieuze alleen dient om 'de ander' te markeren. De 'antiburgers' zijn geboren. 


\section{In het debat zijn allochtone burgers slechts object van onderzoek}

Een ander belangrijk kenmerk van het Nederlandse debat is de afwezigheid of geringe inbreng van allochtonen zelf. Het kan gerust getypeerd worden als een debat tussen autochtone intellectuelen onderling. Een elite die elkaar over de hoofden van allochtonen heen blijft bekritiseren en ideologisch geladen argumenten aandraagt. De kritiek op multiculturaliteit of 'de' multiculturele samenleving gaat op die wijze gepaard met 'afrekeningen' - op politiek correcten, relativisten of veronderstelde linkse machthebbers (Prins 2000). Dit discours dient in feite vooral om politieke opvattingen, posities en onderlinge verhoudingen te herdefiniëren en is niet gericht op het bereiken van consensus om problemen op te lossen. De participatie van allochtonen is dan ook in deze zin niet relevant. Allochtonen die 'mainstream'-opinies niet willen onderschrijven voelen zich kwetsbaar in het debat, omdat zij veelal de impliciete verwachting ondervinden dat zij zich tegen de eigen culturele achtergrond uitspreken. Andere allochtonen reageren zelden, omdat zij zich - terecht of onterecht - niet serieus bejegend voelen. De convergentie tussen het intellectuele debat en 'de roep in de straat' - de samensmelting ervan - maakt een tegengeluid, een nuancering, een diversiteit aan gedachten of meningen veel moeilijker. De bijdragen van allochtonen zijn summier en blijven vooral beperkt tot ingezonden opinies in de landelijke dagbladen of zijn aan te treffen op de drukbezochte internetsites. Ten slotte ontbreekt bij velen gewoonweg de nodige bagage om op een bepaald abstractieniveau aan het filosofische of politieke debat deel te nemen.

\section{In het debat ligt de nadruk op religie: splijtzwam aller tijden}

Paradoxaal genoeg benadrukken seculiere intellectuelen vooral de religieuze dimensie en niet de politieke en sociaal-culturele mechanismen. In de debatten van de jaren zestig en zeventig die juist hebben bijdragen aan integratie van verschillende delen van de Nederlandse samenleving werd religie juist naar de achtergrond verdrongen. Religie is in de geschiedenis van de mensheid zelden een basis geweest voor eenheid, eendracht en integratie. Zou het niet de voorkeur verdienen ook thans juist de universele normen en waarden vanuit een positieve grondhouding te benadrukken: humanisme, gerechtigheid, tolerantie? In het huidige debat lijkt echter vooral het specifieke en het particularistische op de voorgrond te worden geplaatst. Wellicht ligt hieraan het paradigma van Huntingtons Clash ofCivilisations ten grondslag. Ook binnen het denkpatroon van deze Amerikaanse politicoloog is de religie van moslims niet te verzoenen met waarden van moderniteit, rechten van de mens en democratie. Angst, uitvergroting van verschillen en de nadruk op religie zorgen er echter mede voor dat maatschappelijke debatten over normen en waarden uiteindelijk uitmonden in pessimisme, moedeloosheid en perspectiefloosheid. Het is dan ook niet vreemd dat de jarenlange debatten geen werkbare oplossingen hebben opgeleverd om complexe integratievraagstukken aan te pakken. De opvattingen van de opinieleiders kunnen niet vertaald worden in methoden voor sociale verandering of instrumenten van beleid. Daarmee is het debat een proclamatiedebat. Het is niet constructief, zorgt voor een maatschappelijk gespannen sfeer, blokkeert de politiek en het meest vervelende: het heeft soms een averechtse werking op emancipatoire processen. 


\section{Paradoxale werking van het debat: rem op emancipatie}

Het hiervoor gekarakteriseerde debat gaat namelijk dwars door het emancipatieproces van sommige groepen en door de generaties heen. In plaats van het onderkennen en waarderen van positieve ontwikkelingen, wordt bijvoorbeeld de Marokkaanse gemeenschap alleen en collectief geproblematiseerd. Deze gemeenschap heeft een zeer snelle sociaal-culturele verandering doorgemaakt vanaf het moment van gezinshereniging in de jaren zeventig en tachtig van de vorige eeuw. Gezinnen raakten vanaf dat moment langzaamaan ontwricht. Die ontwrichting had onder meer de val van het traditionele gezag van de vaders tot gevolg. Tegelijkertijd werd de gerichtheid van Marokkaanse jongeren op de Nederlandse cultuur almaar groter en werd de traditie steeds minder belangrijk voor het individuele gedrag van deze jongeren. Een individuele geloofsbeleving werd gewoner. Uniek voor Nederland was dit proces overigens niet. Er kan bijvoorbeeld een opvallende parallel worden getrokken tussen het aanpassingsproces van Marokkaanse migranten uit het Rifgebied in Nederland en Marokkaanse joden uit het Atlasgebergte in Israël (Deshen en Shokeid 1974).

De pragmatiek deed zijn intrede met als gevolg dat jongere, hoger opgeleide generaties (jongens en meisjes) wat oriëntatie betreft geruisloos dichter bij de Nederlandse samenleving kwamen te staan (Pels 1998 en 2000). Het gevolg was een ontluikend emancipatieproces medio jaren negentig van de vorige eeuw (Commissie Marokkaanse Jeugd 1998) waarin openlijk verzet werd gepleegd tegen de bemoeienis van het herkomstland met het integratieproces in Nederland (Rabbae 1993). Onafhankelijkheid van het land van herkomst, participatie en individualisering waren de sleutelwoorden. $\mathrm{Na}$ een lang proces van desintegratie binnen gezinnen en de fragmentering van de gemeenschap leek de situatie in zijn algemeenheid te stabiliseren. De Marokkaanse jongeren vonden hun weg naar en in de Nederlandse samenleving, en nieuwe organisaties, netwerken en studentenverenigingen kwamen van de grond (Kraal en Van Heelsum 2002; Van Heelsum 2001; Engberts 1997). Marokkaanse moeders doorliepen een stille revolutie (Jonkers 2003). Deze ontwikkelingen betekenden niet dat er een einde kwam aan hardnekkige achterstanden in het onderwijs of op de arbeidsmarkt. Evenmin werd een einde gemaakt aan normoverschrijding door Marokkaanse jongeren. Maar door de eenzijdige aandacht voor de criminaliteit van allochtone en meer in het bijzonder van Marokkaanse jongeren, lijkt de niet onderkende en zeker niet benoemde emancipatoire ontwikkeling thans te haperen. Relevante ontwikkelingen zoals de generatiestrijd en de machtsontkenning van jongere generaties tegenover oudere generaties gaan gewoon door, maar de snelheid neemt af. Op zich niet veel nieuws. De huidige criticasters zijn nog altijd trots op hun deelname aan een ander generatieconflict, namelijk dat in de jaren zestig en zeventig. Anderen die in dezelfde conflicten verzeild zijn geraakt, kunnen evenwel op weinig clementie rekenen. 


\subsection{ALLOCHTONE CRIMINALITEIT ALS MANIfESTATIE VAN NORMAFWIJKING}

Achter het debat over de normoverschrijding van allochtone jongeren schuilt een criminaliteitsbeeld dat allesbehalve evenwichtig is. De aard, omvang en ernst van de gepleegde delicten van allochtone jongeren worden in onderzoek, media en de politiek gepresenteerd als zijnde criminaliteitsprobleem nummer één in de Nederlandse samenleving. Deze presentatie is op zich niet onlogisch. Het onbehagen over criminaliteit en overlast in de grote steden betreft immers vooral zichtbare vormen van onmaatschappelijk gedrag (intimidatie in het publieke domein, diefstal met geweld etc.). En het zijn juist deze delictsoorten die allochtone jongeren (vooral Antilliaanse en Marokkaanse) veelvuldig plegen. Van andere vormen van criminaliteit, die in potentie wellicht schadelijker zijn voor de economische orde of de rechtsorde, heeft 'de' burger in de straat nu eenmaal minder last. Bovendien vindt een zekere criminalisering van hanggedrag plaats. Criminologen zien het 'hangen' tegenwoordig als een voorportaal van 'echte' criminaliteit. De definities worden telkenmale opgerekt, waarbij de tolerantie van volwassenen ten opzichte van jongeren duidelijk afneemt. Het argument van de zichtbaarheid rechtvaardigt echter nog geen eenzijdige benadering. Andere vormen van criminaliteit worden zakelijk, functioneel en op een nuchtere toon beschouwd. Zij leveren dan ook geen noemenswaardige ophef of sensatie op. Alsof bij andere, minder zichtbare vormen van criminaliteit geen sprake zou zijn van een tekort aan normbesef of normverval. Het eenzijdige criminaliteitsbeeld dat op onze netvliezen is gebrand, betekent bovendien een ontkenning van allochtoon slachtofferschap. Belangrijker echter is dat de selectiviteit in 'het morele oordeel' ons verwijdert van het benoemen van gedeelde belangen van burgers. Belangen (strijd tegen verloedering in de publieke ruimte bijvoorbeeld) die noodzakelijk zijn voor solidariteit tussen burgers (in de strijd tegen onmaatschappelijk gedrag). Ten slotte raakt gaandeweg de beschermende functie van het recht op de achtergrond als het om allochtone jongeren gaat (Harchaoui en Siesling 2003).

\section{Relatieve massaliteit van daderschap}

Bij het beschrijven van de oververtegenwoordiging van allochtone jongeren in de criminaliteitsstatistieken wordt, ondanks bezwaren van onderzoekers tegen het gebruik van onder meer het Bedrijfsprocessensysteem (BPS) van de politie, doorgaans gebruikgemaakt van politiële en justitiële gegevens (De Haan en Bovenkerk 1993). De registratie van etnische afkomst was en is nog steeds een heet hangijzer. Het argument dat door registratie van etnische afkomst beter maatwerk kan worden geleverd, zien we thans weer terug bij de discussie over de (ontluikende) derde generatie. Het is echter de vraag welke oplossingen we tot dusverre hebben verzonnen dankzij een verbeterd inzicht in de etnische afkomst. Meestal blijft het bij de statistische proclamatie van het gekleurde criminaliteitsprobleem om vervolgens bij de oplossingen slechts generieke maatregelen te vermelden. De toegevoegde waarde van de kennis dat iemands grootvader elders is geboren, is voor effectieve interventies nihil, terwijl het gevaar op misbruik blijft bestaan. Zelfs als het gaat om gemeenten met zeer specifieke problemen- 
zoals de zogenaamde Antillianengemeenten - is het resultaat van de registratie bijzonder mager. Het levert vaak niet meer op dan een onderstreping van het probleem of de beeldvorming.

\section{De culturele verklaring}

Dit neemt niet weg dat ondanks alle - ook statistische - bezwaren (Korf 2001) de omvang van de allochtone jeugdcriminaliteit al jaren zorgwekkend is. Ik vrees dat onze zorgen, mede gelet op het demografische profiel van de jeugd in de grote steden, de komende jaren niet zullen afnemen. De oververtegenwoordiging is in onderzoek en beleid meermalen vastgesteld, evenals de zeer jonge leeftijden (onder twaalf jaar) en de hogere recidive (Wartna 1999). De sociaal-culturele achtergronden werden voor het eerst klemmend met criminaliteit verbonden in de nota Criminaliteit in relatie tot de integratie van etnische minderheden (Ministeries van Binnenlandse Zaken en Justitie 1997). Sindsdien is de culturele verklaring niet meer weg te denken uit onderzoek en beleid. De cultuurverklaring is dominant geworden.

Veel criminologisch onderzoek wordt gedaan door cultureel-antropologen onder de grote vier: Turken, Marokkanen, Surinamers en Antillianen. Dit onderzoek is over het algemeen zeer essentialistisch van aard. Cultuur en culturele achtergronden worden een dwingendheid en onveranderlijkheid toegeschreven die nauwelijks in overeenstemming is met de grillige werkelijkheid. De werkelijkheid van jonge mensen is dat zij hun culturele achtergronden naar bevind van zaken construeren en in sommige opzichten zelfs manipuleren (Harchaoui 2001). De criminaliteit wordt door professionals 'verculturaliseerd' of 'veretniseerd' op grond van lang vervlogen beelden. Het dynamische en constructivistische karakter van culturele opvattingen raakt hiermee uit het zicht. Ondanks het feit dat het merendeel van de allochtone jongeren inmiddels in Nederland is geboren en getogen, rijzen nog maandelijks allerlei vertegenwoordigers van justitiële en maatschappelijke instellingen naar Marokko of Turkije om te zien hoe men het daar doet! In de situatie dat cultuur wordt geconstrueerd raakt het zodanig verweven met 'andere culturen' (de Nederlandse, de hiphopcultuur of de straatcultuur, etc.) dat een geïsoleerde bestudering van culturele achtergronden zonder rekening te houden met nieuwe ontwikkelingen in Nederland algauw leidt tot nietszeggende stereotypen. Jongeren herkennen zich daar allang niet meer in en de instellingen voeren in deze zin achterhoedegevechten. Bij de allochtone jongeren lijkt het - gegeven de gerichtheid op Nederland - tegenwoordig vooral om identiteitsvraagstukken te gaan, waarbij wij onvoldoende zicht hebben op hun symboliek van het 'trekken van grenzen' (Verkuyten 1999). Deze constatering rechtvaardigt een fundamentele herziening van het instrumentarium dat instellingen hanteren om tot gedragsinterventies te komen. Diversiteit dient in het teken van effectiviteit te staan.

\section{De culturele integratieparadox}

De zorgen over criminaliteit zijn er al jaren. De cijfers zijn genoegzaam bekend. Interessant is de grondgedachte die uit beleidsnota's spreekt: niet alleen een 
betere sociaal-economische (werk, woning, scholing), maar ook een betere sociaal-culturele integratie leidt tot minder jeugdcriminaliteit. Op deze gedachte valt het een en ander af te dingen. Onderzoek heeft immers aangetoond dat nieuwkomers van de eerste generatie - die strikt gezien minder sociaal-cultureel zijn geïntegreerd - juist minder crimineel gedrag vertonen dan volgende generaties (Haen-Marshall 1997). Ook is het een gegeven dat in alle (westerse) landen de vertegenwoordiging van bepaalde minderheidsgroepen in de criminaliteit of in detentie groter is dan die van de meerderheidsgroep (Tonry 1997).

Een betere sociaal-culturele integratie (taal, uitgaansleven, mondigheid, assertiviteit) in een situatie van achterblijvende sociaal-economische structurele omstandigheden leidt dus kennelijk juist tot hogere criminaliteitscijfers. Dat blijkt ook uit Amerikaans onderzoek (Waters 1999). Dat heeft te maken met de consumptieve cultuur waarin 'wie je bent' vooral wordt afgemeten aan 'wat je hebt'. Allochtone jongeren met achterstanden in sociaal-economisch opzicht hebben minder kansen hun economische en materiële wensen langs normale weg, zoals werk, te vervullen. Hun relatieve deprivatie is het probleem (Bovenkerk 2003b). Vooral die jongeren die in cultureel opzicht buitengewoon goed geïntegreerd zijn, staan onder spanning toch hun wensen vervuld te zien; als het moet op illegale wijze. Het zijn deze jongeren die veel in contact komen met de 'buitenwereld' en zich daaraan willen meten. Diefstal (met geweld) van gsmtoestellen, scooters en merkkleding komt onder hen dan ook frequent voor. De toverwoorden zijn geld en status. Zo bezien is het dus niet vreemd dat de in sociaal-cultureel opzicht beter geïntegreerde Marokkaanse jongeren meer vermogenscriminaliteit plegen dan de minder geïntegreerde Turkse jongeren (vgl. Dagevos 2001). De econoom Veenman (2001) ontdekte een soortgelijk patroon waar het om Molukse jongeren gaat en de conclusie van de criminoloog Bovenkerk (2002: 228) luidt dan ook dat de criminaliteitscijfers het hoogst zijn onder de snelst geassimileerde groep: de Marokkanen.

\section{Is de omvang relevant voor het debat over normen en waarden?}

De voorgaande paradoxale bevinding levert de vraag op wat de relevantie van sociaal-culturele integratie of assimilatie is voor de preventie en bestrijding van jeugdcriminaliteit. Uit mijn betoog tot nu toe volgt dat het vruchtbaarder is de criminaliteit als mislukte insluiting van jongeren te zien. Bij gedragsbeïnvloeding zou het moeten gaan om te laten zien dat zelfwaarde ontleend kan worden aan 'wie je bent' en niet 'wat je hebt'. Het individu en zijn eigen verantwoordelijkheid komen dan centraal te staan. Culturele integratie is belangrijk, maar in deze zin is sociaal-economische integratie belangrijker. Er lijkt een ontwikkeling waarneembaar waarin afstand wordt genomen van de verklaringskracht van cultuur en culturele achtergronden als zodanig. Sociaal-economische structurele achtergrondfactoren krijgen - zonder de relevante culturele achtergronden te veronachtzamen - meer aandacht. De jeugdcriminologe Junger-Tas (2002; zie ook Junger-Tas et al. 2003) concentreert zich dan ook op het indirecte verband dat via bindingsprocessen aan sociale instituties loopt. Voorts zien we in theorievorming meer aandacht voor het sociaal-economisch model. Dat model kenmerkt 
zich door de indeling in risico- en protectieve factoren. De relevante factoren zijn uitputtend beschreven en op deze plaats kan volstaan worden met de verwijzing naar het onderzoek van Driessen et al. (2002). Het onderzoek naar criminaliteit van allochtone jongeren is daarin op voortreffelijke wijze handzaam samengebracht. Er is een grote hoeveelheid verklaringen voorhanden: selectieve migratie, cultuurconflict, deprivatie, gebrek aan sociale controle, subcultuur, persoonlijkheid enzovoorts. In de kern gaat het echter nog steeds om woning, werk en 'wederhelft'. Daarnaast is er een reeks van etnografisch onderzoek dat in meer of mindere mate wijst op verschillende normpatronen en opvattingen (Sansone 1992; Van San 1998; Van Gemert 1998; Van de Port 2001; Bovenkerk 2002; Yesilgöz 1995). Voor een beoordeling van al deze culturele verklaringen, het aanwijzen van verschillen en het zoeken naar mogelijke oplossingen is het instructief een aantal complicerende feiten in ogenschouw te nemen alvorens we een verband leggen tussen normoverschrijdend gedrag en een (ander) stelsel van normen en waarden.

1 In de eerste plaats is de hoge vertegenwoordiging relatief. Reeds dit gegeven stelt onze stelligheid over een afwijkend normenpatroon op de proef. In absolute omvang komt de meeste jongenscriminaliteit voor rekening van autochtone jongeren. Een geculturaliseerde probleemvisie is dus niet toereikend. De overeenkomsten tussen de autochtone en de allochtone jongeren zijn bij nadere beschouwing groter dan het verschil.

2 Een tweede gegeven dat aan de stelligheid over afwijkende normenpatronen (door een hele gemeenschap of groep jongeren heen) knaagt, ligt ook in de relatieve omvang besloten. Het staat immers vast dat de overgrote meerderheid van de Marokkaanse, Turkse, Antilliaanse en Surinaamse jongeren geen criminaliteit pleegt. De meeste allochtone jongeren met eenzelfde culturele achtergrond plegen geen criminaliteit. Indien de verklaring voor afwijking wordt gezocht in 'hun' cultuur, dan rijst de vraag of de verklaring voor normconform gedrag ook in 'hun' gepercipieerde culturele achtergrond gezocht moet worden. Of heeft succes geen culturele moeder? Deze vraag wordt zelden gesteld in culturalistische literatuur. Anders gezegd: als de verklaring voor afwijking van allochtone jongeren wordt gezocht in een bepaalde opvoedingsstructuur, wat is de verklaring voor de niet-afwijking van een groter gedeelte allochtone jongeren die eenzelfde opvoeding meekrijgen?

3 Ten derde moeten we vaststellen dat de aandacht gefixeerd is op de traditionele grote vier (Marokkanen, Antillianen, Turken en Surinamers). Ook 'nieuwe allochtonen' zijn in meer of mindere mate oververtegenwoordigd in criminaliteitsstatistieken. Van San et al. (20O2) rapporteerden inmiddels over woninginbrekers uit voormalig Joegoslavië. Er is documentatie over personen uit voormalig Joegoslavië en de voormalige Sovjet-Unie (Snel et al. 20oo; Integrale Veiligheidsrapportage), Ethiopiërs en Somaliërs voor wat betreft vermogensdelicten (Dominquez Martinez et al. 2002). Daarnaast werd de overlevingscriminaliteit van illegalen bestudeerd (Engbersen et al. 1999), evenals crimina- 
liteit gepleegd door asielzoekers (De Haan en Althoff 2002) en alleenstaande minderjarige asielzoekers (Kromhout en Van San 2003).

Deze oververtegenwoordiging van nieuwe groepen maakt de culturele verklaringskracht er niet groter op. Een verschil in cultuur is theoretisch eenvoudiger te funderen met betrekking tot Marokkanen of Somaliërs dan voor personen afkomstig uit voormalig Joegoslavië. Nog ingewikkelder wordt het als we het onderzoek van Kromhout en Van San (2003) bij de hand nemen. Daaruit blijkt namelijk dat jeugdigen uit Frankrijk, België, Polen, Duitsland, Groot-Brittannië en Italië ook enigszins oververtegenwoordigd zijn: "In 2000 was het percentage 12- tot en met 24-jarige verdachten in deze groepen maximaal twee maal zo hoog als gemiddeld. Opvallend veel Italiaanse meisjes en jonge vrouwen zijn aangemerkt als verdachte" (2003: 13).

Of het nu Chinezen, Soedanezen of Afghanen zijn: elke groep blijkt in meerdere of mindere mate cijfermatig oververtegenwoordigd. De enige constante in al dit onderzoek is dus dat in vergelijking tot de autochtone Nederlander bijna elke andere groep frequenter in aanraking komt met het strafrechtelijk systeem. Deze opsomming leidt ertoe dat we in de omvang van de criminaliteit als zodanig weinig houvast hebben voor het benoemen van afwijkende normen die zodanig zijn te veralgemeniseren dat in de preventie van criminaliteit daarmee een substantieel voordeel behaald kan worden. De indeling in westerse en nietwesterse allochtonen blijft op andere terreinen relevant, maar zij zegt niet alles. Zo wordt in literatuur over niet-westerse allochtonen vaak ruimte gelaten voor een beschrijving van islamitisch-culturele achtergronden. Tegelijkertijd worden Indonesiërs (in Indonesië wonen de meeste moslims) door het CBS tot de westerse allochtonen gerekend.

De voorlopige conclusie die ik op basis van deze gegevens trek, is dat de verklaringen voor normoverschrijdend gedrag door allochtone jongeren in de grote steden op zijn minst niet eenzijdig in de culturele achtergrond dient te worden gezocht. Dat blijkt overigens ook wel uit onderzoek naar groepscriminaliteit. Een ervaren onderzoeker als Van Gemert die meermalen onderzoek naar 'de harde kern' in verschillende wijken van Rotterdam en Amsterdam heeft gedaan, lijkt thans te berusten in het feit dat groepsvorming niet op basis van ideologische, maar eerder groepsdynamische basis geschiedt (Van Gemert en Fleischer 2002) en dat jeugdbendes in Nederland niet aanwezig zijn. Dat er bij de harde kern of de zogenaamde veelplegers sprake is van asociaal en normoverschrijdend gedrag met een hoge resistentiegraad tegen effectief interventiebeleid is niet verbazingwekkend. Daarom is het ook een harde kern! Een vergelijkbare situatie doet zich bijvoorbeeld voor bij 'voetbalhooligans' (Van der Torre en Spaaij 2003).

\section{Miskenning van andere vormen van criminaliteit}

De verwijzing naar allochtone jeugdcriminaliteit is niet voldoende om een evenwichtig debat over normen en waarden te kunnen voeren. Vooral als het gaat om te delen normen dienen wij vanuit hetzelfde morele vertoog andere vormen van 
criminaliteit te bezien. Hiermee wordt vanzelfsprekend op geen enkele wijze de ernst of de omvang van de allochtone jeugdcriminaliteit gebagatelliseerd. Die is zorgwekkend, en dat zal zo blijven. Maar je kunt het morele vertoog niet slechts eenzijdig en selectief toepassen in die zin dat normafwijking alleen wordt gegrondvest in het afwijkende of 'de ander'. De reden om het vertoog te verbreden is om de overeenkomsten bloot te leggen die individuen of groepen in staat stellen bruggen te slaan en tot onderlinge solidariteit te geraken. Daarvoor moet echter eerst de muur van 'wij' (normen) en 'zij' (geen normen) beslecht worden. Zonder het neerhalen van deze muur van wederzijdse verwijten is ontmoeting, vertrouwen en een effectieve dialoog niet mogelijk. De kans dat verschillende groepen - interetnisch - zich samen verantwoordelijk maken voor gezamenlijke problemen moet op deze wijze worden vergroot.

\section{Fraude}

In sommige vormen van criminaliteit 'excelleren' autochtone Nederlanders. Onderzoeker noch beleidsmaker heeft tot dusverre fraude expliciet in verband willen brengen met 'de' Nederlandse cultuur of 'de volksaard'. Leven we echt in een graaicultuur? Is er sprake van een doorgeschoten streving naar geldelijk gewin ten koste van de maatschappij? Het oplichten van de Belastingdienst is volkssport nummer één, terwijl in het buitenland honderden miljoenen euro's zijn geparkeerd door individuen van wie we vinden dat hun normbesef buitengewoon goed ontwikkeld is. De parlementaire enquête Bouwfraude leert dat van incidenten geen sprake is. Het morele verwijt dat een valsheid in geschrift plegende en bijklussende uitkeringsgerechtigde wordt gemaakt in de publieke beeldvorming staat in schril contrast met kwalificaties van boerenslimheid bij topondernemers. Het zijn opvallend vaak ook deze laatsten die zich belasterd voelen als iemand deze boerenslimheden aanmerkt als criminele daden.

Fraude in de zorg, op de aandelenmarkt of in het beroepsonderwijs zijn allemaal vormen van groepsgewijs door leden van gerespecteerde organisaties of beroepsgroepen gepleegde criminaliteit. Deze criminaliteit wordt vaak contextueel benaderd, waarbij het falen van de overheid veelal als strategie gehanteerd wordt om persoonlijke verantwoordelijkheid te ontlopen. Van 'veretnisering' bij fraude met BTW, accijns, sociale premies en wat dies meer zij is geen sprake. Dat geldt ook voor allerlei vormen van organisatiecriminaliteit ondanks de grensvervaging tussen illegale en legale markten (Huisman en Niemeijer 1998). Arbeidsrechtelijke trajecten worden vaker ingezet dan strafrechtelijke. Onze morele projectie op allochtone jongeren als het gaat om normoverschrijding moge dan soms juist zijn, de volwassenen en hun instellingen komen er te eenvoudig van af.

\section{Drugshandel}

De duizenden van Curaçao afkomstige drugskoeriers (bolletjesslikkers of bolletjesduwers) brachten de overheid en het publiek in beroering. De culturele achtergrond van de bolletjesslikkers, vooral waar het ging om het excessieve geweld dat met de drugseconomie gepaard gaat (Bovenkerk 2001), was een veelgenoemd feit. 
Dat de koeriers bij nadere beschouwing van verschillende origine waren, deed niets af aan het feit dat in de publieke beeldvorming het beeld van 'de Antilliaan' werd gecultiveerd. Bij andere vormen van drugscriminaliteit (precursoren, xtc, heroïne, cocaïne en hennep) blijkt de culturele factor toch minder stellig te worden geponeerd. Bovenkerk (2003a) heeft de sociale organisatie waarin hennepteelt plaatsvindt beschreven en hem is opgevallen dat - van Nederlandse boerenfamilies afstammende (Cottaar 1996) - woonwagenbewoners hierin een prominente plek innemen (Van der Poel 1999). Dat de Nederlander substantieel aanwezig is als het om georganiseerde hasjhandel gaat, bleek eerder al uit onderzoek van Klerks (2000).

Betreft het de smokkel van drugs via de haven van Rotterdam, dan spreekt men in het publieke debat - bijna bewonderend - over geraffineerde smokkelmethoden of over de economische repercussies die nog intensievere controle van containers zullen hebben. In de periode 2000-2001 werd in de Rotterdamse haven maar liefst 14,9 ton cocaïne in beslag genomen (Brink en Brodie-Barendrecht 2002: 48). De Nederlandse link is ook duidelijk als het gaat om de distributie van drugs uit Spanje waarbij opvallend veel Nederlanders betrokken zijn, terwijl de etnische diversificatie zeer groot is (Zaïtch 2002).

Zowel Bovenkerk als Zaïtch stelt dat Antillianen geen doorslaggevende rol spelen in de handel van cocaïne, die gedomineerd wordt door Colombianen en Nederlanders. De Antilliaan is onderaan de ladder te vinden als koerier of straathandelaar, maar wel weer het meest zichtbaar. Gaat het om het gebruik van cocaïne, dan is op ons publiek netvlies 'de' Surinaamse verslaafde die zich bezondigt aan het 'basen' (crackverslaving) of 'de' Antilliaanse gettocultuur gebrand. De andere waarheid is dat 2,9 procent van de Nederlandse bevolking ooit cocaïne heeft gebruikt, terwijl in de leeftijdsgroep 20-24 jaar dit gebruik tot ruim 8 procent steeg. Vooral in het uitgaansleven speelt het gebruik een rol (Korf et al. 2002). Ook het gebruik van xtc is niet geproblematiseerd. Dat heeft iets te maken met de gebruikers, die vaak ook afkomstig zijn uit de Nederlandse middenklasse. Marokkaanse, Turkse en Surinaamse jongeren blijken minder te drinken, te slikken en te snuiven (Korf et al. 2003).

De Nederlander lijkt de spil te zijn van het feit dat Nederland inmiddels bekend staat als productie- en distributieland nummer één. Volgens de Unit Synthetische Drugs (2001) in Eindhoven werden in 2001 ruim 25,6 miljoen MDMA-tabletten in beslag genomen. Opvallend overigens is ook de activiteit van orthodoxe joden in de internationale handel in xtc (CIROC 2OO2) en de illegale diamanthandel (Siegel 2002b). Datzelfde geldt voor de illegale activiteiten van Russen (Siegel 2002a) en Britten en Nederlanders met betrekking tot sigarettensmokkel en milieucriminaliteit (Kernteam Noord- en Oost-Nederland 2001).

\section{Vuurwapenhandel}

Een eenduidige etnische factor is ook niet te vinden als we het criminaliteitsbeeld over vuurwapens bestuderen. Dat beeld is voornamelijk gedomineerd door 
Nederlanders en Joegoslaven. In mindere mate geldt dat ook voor Turken (Kernteam Noord- en Oost-Nederland 2002). De wapenhandel, met inbegrip van het onduidelijke exportbeleid van Nederland, is terra incognito (Kleemans 2001), maar dat de invoer van handvuurwapens vanuit de voormalige Oostbloklanden een ernstig probleem is, valt moeilijk te ontkennen (Spapens en Bruinsma 2002), evenmin als de risico's voor bedrijven en onderzoeksinstellingen in het kader van de proliferatie van massavernietigingswapens.

\section{Mensensmokkel en mensenhandel}

Bij mensensmokkel en mensenhandel is de diversificatie in het 'verdachtenaanbod' wederom groot. Colombianen, Turken, Somaliërs, Turkse Koerden, Chinezen, Russen, Nederlanders; iedere etniciteit levert een bijdrage.

Deze vorm van criminaliteit staat hoog op de politieke agenda, omdat bestrijding ervan een van de methoden is om een stringenter immigratiebeleid te voeren. De gesmokkelden komen dan ook van heinde en verre (IAM 2002). Tot dusverre is betrekkelijk weinig aandacht besteed aan de culturele achtergronden van personen die zich hieraan schuldig maken. In het publieke debat vernemen we vaak dat bepaalde allochtone jongeren een voorbeeld moeten nemen aan de Chinese bevolkingsgroep. Ondertussen voltrekt zich de ene na de andere persoonlijke tragedie en worden vele Chinezen door hun landgenoten (slangenkoppen) emotioneel en soms ook fysiek gegijzeld (Soudijn 2000 en 2001). Ook bij mensenhandel is de mate van geweld enorm groot.

De variatie in criminaliteit en de in die criminaliteit betrokken personen kunnen nog veel uitgebreider worden beschreven. Het punt dat het criminaliteitsbeeld in het debat over normen en waarden erg eenzijdig is, moge wat mij betreft reeds op grond van de voorgaande selectie duidelijk zijn.

\section{Het ontkende allochtone slachtofferschap}

Naast de selectiviteit in het benoemen van de cultuur van daders bij bepaalde strafbare feiten, valt het op dat er weinig aandacht is voor allochtoon slachtofferschap. Er is buitengewoon veel aandacht voor de persoon van het slachtoffer (Boutellier 2002; Zijderveld 2003), maar deze persoon is zelden gekleurd. Daarmee wordt het gemeenschappelijke van burgers en het gedeelde belang veronachtzaamd. Op deze wijze kan geen solidariteit ontstaan tussen burgers met verschillende culturele achtergronden. Het slachtoffer roept immers sympathie of medeleven bij ons op. Ook op het institutionele vlak is er geen aandacht voor allochtoon slachtofferschap, met uitzondering van het fenomeen loverboys, van wie allochtone meisjes slachtoffer zijn. Hanrath (2002), die onderzoek heeft gedaan naar slachtofferhulp en culturele diversiteit, heeft opgemerkt dat allochtonen minder vaak een beroep doen op slachtofferhulp, hetgeen leidt tot minder adequaat gebruik van specifieke mogelijkheden binnen het (strafrechtelijke) proces. Er is sprake van grote afzijdigheid (Lempens et al. 1998). Vooral in de grote steden zijn (ook) allochtonen in aanzienlijke mate slachtoffer van delicten, terwijl de beleefde onveiligheid tussen autochtonen en allochtonen nauwelijks 
verschilt (Bervoets en Stol 2002). Ook wat dit aspect betreft zijn de overeenkomsten tussen verschillende groepen - met een verondersteld verschillend normenstelsel - veel groter dan de verschillen.

\subsection{RELIGIEUS CONSERVATISME TER ILLUSTRATIE VAN NORMAFWIJKING}

Degenen die het probleem van cultuurgebonden normoverschrijding benadrukken, wijzen onder meer op de problemen rondom de hoofddoek, het uithuwelijken en de vrouwenbesnijdenis. Opmerkelijk is dat deze voorbeelden stuk voor stuk te maken hebben met de positie van de vrouw. De vrouw zou bij allochtone groeperingen een minderwaardige en onderdrukte positie hebben. Kijkend naar de omvang van deze drie verschijnselen onder allochtone jongeren kan men vaststellen dat de relevantie daarvan vrijwel nihil is. Het aantal Marokkaanse meisjes dat de hoofddoek draagt is beduidend laag. Het uithuwelijken van jonge meisjes is een snel verdwijnende praktijk in vergelijking met de eerste jaren na de gezinshereniging medio jaren tachtig. En de vrouwenbesnijdenis doet zich op geen enkele wijze voor onder Turken of Marokkanen. Het is een relatief niet vaak voorkomende praktijk bij moslims uit de Hoorn van Afrika (Somalië, Soedan, etc.). Maar het multicultureel debat wil dat de bovengenoemde drie praktijken zich massaal voordoen onder de moslimmigranten en dat deze derhalve een probleem vormen voor de integratie. Hoofddoek, uithuwelijken en vrouwenbesnijdenis zijn praktijken die vooral een symbolische functie hebben om te laten zien dat onze cultuur en beschaving worden bedreigd door primitieve opvattingen en praktijken.

Door incidenten uit te vergroten ontstaat het beeld dat er sprake zou zijn van verspreiding van deze praktijken onder allochtonen. Dit beeld komt echter niet overeen met de religieuze praktijk van Marokkanen. Ook onder de Marokkanen varieert de mate van religiositeit met de leeftijd. Veel Marokkanen van de eerste generatie zijn thans godsdienstig georiënteerd. Dat waren zij niet in hun jeugdjaren toen zij in de jaren zestig naar Nederland kwamen. Zij dronken bier en vertoonden een vrij seksueel gedrag (Theunis 1979). Dat heeft te maken met de leeftijd. Veel van de ouderen, net als hun kinderen nu, hebben in hun jeugd hun religieuze plichten verzaakt en wensten eenmaal ouder geworden een goede moslim te zijn. Nu zijn zij ietwat religieuzer geworden (Kemper 1996).

Door heel Europa leken jonge moslims op grote schaal met de traditionele islamitische gemeenschap te breken. Hoewel veel moslimjongeren zich moslim voelen en trots zijn op hun islamitische identiteit (Vertovec 2001), beschouwen zij zichzelf niet altijd als gelovig en blijken zij opvallend weinig kennis te hebben van de islamitische geloofsleer. Zij reageren ook vaak afwijzend op de beperkingen die het geloof hun oplegt als het gaat om voedselvoorschriften (drinken) en seksualiteit. De deelname aan religieuze groepsactiviteiten is ook niet groot. Tegelijkertijd levert de nadruk van de ontvangende samenleving op hun identiteit de para- 
doxale situatie op dat zij tegen wil en dank zichzelf alleen op basis van die identiteit kunnen definiëren.

Zowel de moreel conservatieve rurale (plattelands)beleving van de islam bij de eerstegeneratie-Marokkanen als de symbolische en identitaire islam van de tweede generatie is duidelijk te onderscheiden van de 'strijdbare' islam van fundamentalisten. Juist als reactie op het emancipatieproces en de liberale omgang van oude en jongere Marokkanen met religie is een conservatieve reactie ontstaan uit militante Salafistische kringen. Deze poogt de oude religieuze orde te herstellen zoals zij dat voor ogen heeft. De militant-Salafistische beweging uit Saudi-Arabië, die naar terugkeer naar de bron streeft, begint langzamerhand haar ingang te vinden binnen de Marokkaanse gemeenschap. Met de hulp van buitenlandse geldschieters worden infrastructuren opgezet voor politieke indoctrinatie, waarbij de nadruk ligt op de overdracht van zeer conservatieve, antidemocratische en intolerante opvattingen als zijnde de ware islamitische identiteit. Hierbij wordt misbruik gemaakt van de positieve identiteitsgevoelens bij jongeren als moslims. Opvallend in de werkwijze van genoemde militante groeperingen is het feit dat zij veelvuldig en zelfs dankbaar gebruik (en misbruik) maken van uitsluitingstendensen waar vooral Marokkaanse jongeren de laatste jaren mee geconfronteerd worden. De militante Salafisten proberen deze jongeren een alternatief houvast te bieden en gebruiken daarbij angstscenario's om hun het gevoel te geven te behoren tot de verworpenen van de Nederlandse samenleving.

Sociaal-economische omstandigheden, onderwijskansen en maatschappelijke participatie beïnvloeden sterk de identiteitsvorming van jongeren en de omgang met hun geloof. Uitsluiting en discriminatie versterken de aantrekkingskracht van rechts-extremistische ideologieën met een religieuze inslag. Hiermee worden jongeren blootgesteld aan politiek misbruik door groeperingen die de islam willen gebruiken als instrument voor een wereldwijde strijd tegen het Westen. De opstelling van de omringende samenleving met ongebreidelde maatschappelijke debatten over normen en waarden draagt bij aan de verwijdering tussen jongeren en hun omgeving. De jongeren worden afhankelijk van de boodschapper de ene keer gepresenteerd als 'schuim der natie' en de andere keer als 'de verworpenen der natie'. Ziehier een onbedoeld effect van een onderneming die juist was bedoeld om integratie te bevorderen.

\subsection{GEVOLGEN VAN EEN NIET IN GOEDE BANEN GELEID DEBAT}

Ook in procedureel opzicht voldoet het debat over waarden en normen niet aan de criteria om tot een effectieve dialoog te komen. Immers, het debat is zelden gericht op het bereiken van overeenstemming. In de tegenstrijdig veronderstelde normen- en waardensystemen van autochtonen en allochtonen wordt geen helder alternatief geboden om tot die consensus te geraken. Het gaat vooral om het benoemen van verschillen en problemen en niet om het oplossen van proble- 
men. De meeste argumenten stellen de culturele of etnische achtergrond en de individuele drager daarvan centraal. Daardoor voelen mensen zich snel vernederd en gekleineerd.

\section{Negatieve beeldvorming, stereotypering en stigmatisering}

Natuurlijk, vrijwel elke groep nieuwkomers heeft te maken met negatieve beeldvorming: Chinese zeelieden, joodse Amsterdammers, Antillianen, Turken en Marokkanen. Het wordt echter lastig als het proces van sociale en politieke definiëring (etikettering) vooral uit stereotypen bestaat die niet meer functioneel zijn, in de zin dat het kennispakketjes blijven om gedragingen en kenmerken van bepaalde groepen te kunnen beoordelen (Hagendoorn 1998). De filosoof Hoogerwerf (2002: 16) schaart het gebruik van stereotypen onder zijn scenario's van onverdraagzaamheid. Hardnekkige stereotypen worden gevaarlijk op het moment dat er een 'collectief' is (zoals de moslims, de allochtonen of de Marokkanen) tegen wie ongenoegens en frustraties geuit kunnen worden. Dit zondebokmechanisme ligt vooral op de loer als de samenleving van slag is, zoals Nederland dat was na de aanslagen van 11 september 2001 of de moord op de politicus Pim Fortuyn op 6 mei 2002. Juist in zulke situaties ontstaan sociaal-psychologische impasses die met morele paniek kunnen worden geduid (Cohen 1972). Boutellier (2003) drukt dat gevaar met betrekking tot Marokkanen als volgt uit: "Het stigma 'Marokkaan' biedt een grote psychologische bevrediging door de mogelijkheid om een herkenbare groep verantwoordelijk te maken voor het postmoderne onbehagen." Het projecteren van negatieve emoties en angsten of het creëren van zondebokken is een mechanisme dat bijvoorbeeld in Frankrijk erg zichtbaar is geworden. Terwijl in Frankrijk Marokkanen en Algerijnen op zichzelf beschouwd veel beter zijn opgenomen in het maatschappelijk en cultureel systeem (Nair 1992: 84).

Het komt mij voor dat op dit moment door vooral de media en politieke gezagsdragers aanhoudend rampscenario's worden aangedragen ('de integratie is volledig mislukt', etc.) die er mede toe hebben geleid dat we ons bevinden in een fase van nauwelijks omkeerbare stigmatisering van bevolkingsgroepen, in het bijzonder Marokkaanse jongeren. Vooral deze laatsten voelen zich eenzijdig aangesproken op een collectieve eigenschap (crimineel, extremist, etc.), een sociale identiteit die hen bij voorbaat diskwalificeert (het stigma). Dat is een bijzonder ongemakkelijke positie. Negatieve voorbeelden zijn er immers altijd te vinden in de hardnekkige gemarginaliseerde jeugdgroepen in de grote steden.

\section{De sociaal-psychologische reactie van zelfisolement}

Terwijl de autochtonen denken met de culturele verklaringen aan te tonen waarom men doet zoals men doet, ervaren de allochtonen deze verklaringen als een aanval op wat men is, hun identiteit. Moslims en Marokkanen ervaren het publiek debat daarom als een vloek die rust op hun bestaan als bijvoorbeeld moslims. Dit leidt in de eerste plaats tot onbehagen en een lagere mate van welbevinden onder allochtonen. Kernvraag zal blijven hoe jongeren met hun geschonden en zelfs afgekeurde identiteiten omgaan (Goffman 1963). De sociaal- 
psychologische reacties en gevolgen zijn vooralsnog onvoldoende voorwerp van onderzoek, maar uit onderzoek blijkt inmiddels wel een zekere verwijdering en isolering uit de omringende maatschappij. Het feit dat allochtone jongeren zich niet herkennen in het debat over normen en waarden, dat ze niet als individu worden aangesproken, leidt ertoe dat steeds meer jongeren zich niet thuis voelen. Zij voelen zich vreemdeling; niet geaccepteerd om wie ze als individu zijn; uitgesloten en soms zelfs uitgekotst. Het gevaar is dat jongeren zichzelf uitsluiten: "Ik mag er niet bij horen, dus wil ik er niet (meer) bij horen” (Schuyt 200o). "Bekijk het verder maar.” Gevaarlijk, omdat jongeren - óók in een veranderende wereld altijd ergens bij 'willen horen' en 'moeten horen'. Om deze reden zal binding aan de maatschappij altijd van belang blijven.

De sociaal-psycholoog Verkuyten (2003: 87) schrijft in dit verband over de individuele strategie van het zich terugtrekken in eigen kring het volgende: “De psychische gemoedsrust krijgt voorrang op maatschappelijke participatie en ambities. De sociale uitsluiting leidt tot zelfuitsluiting en de nadruk op slachtofferschap. Sociaal-psychologen zien deze reactie als voorbeeld van psychologische verdediging die op korte termijn begrijpelijk is en nuttig kan zijn, maar die op lange termijn meer nadelen dan voordelen heeft."

\section{Stigma's kosten geld en creëren een voedingsbodem voor geweld}

Stigmatisering leidt in de tweede plaats tot maatschappelijke (economische) kosten wegens de structurele onderbenutting van het allochtone talent in een vergrijzende Nederlandse samenleving (Veenman 2003). Ten slotte is de stigmatisering - indien niet op tijd gekeerd - de voorbode van geweld. Op lokaal niveau nemen de confrontaties en interetnische spanningen toe. Veelal wordt teruggegrepen op symboliek die nogal eens overeenkomt met geweldsgolven in de afgelopen decennia (Witte 2003). Witte heeft in zijn onderzoek naar racistisch geweld in de afgelopen vijftig jaar laten zien dat het geweld tegen gestigmatiseerde groepen in een verhit politiek klimaat in omvang en ernst toeneemt, evenals de kans op tegengeweld (Witte 1996).

\section{Schelden doet wel pijn: vernedering}

De schaduwzijden van de 'alles moeten kunnen zeggen'-mentaliteit leiden tot schelden en verbale vernedering van mensen. Het is een misverstand te denken dat schelden geen pijn doet. Zo blijkt schelden bijvoorbeeld opvallend vaak de katalysator tot fysiek geweld te zijn (Middelhoven en Driessen 2003). Allochtone jongeren voelen zich vaak uitgesloten en vernederd, hetgeen onverschilligheid en passiviteit genereert. Daarnaast voedt het niet alleen wederzijdse vijandigheid, maar wordt ook een voedingsbodem gekweekt op de lange termijn voor acceptatie of vergoelijking van geweld.

De als een collectieve vernedering ervaren toon in het debat over normen en waarden leidt in sommige gevallen tot regelrecht neofundamentalisme onder - in dit geval - moslimjongeren. De schreeuw om respect houdt natuurlijk verband met de - terecht of onterecht - ervaren vernedering. De ervaren vernedering gaat 
gepaard met het gevoel gestigmatiseerd te worden. Allochtone jongeren voelen zich niet alleen geschonden in hun imago, maar vooral in kwesties rond hun identiteit.

Het is juist het overgrote deel van de jongeren dat geen problemen veroorzaakt, maar onvoldoende aandacht krijgt (de ontluikende middenklasse) waar we deze psychologische verwijdering en mentale isolatie kunnen waarnemen. Allochtone jongeren voelen zich bovendien minder gelukkig, zijn vaker bang en hebben last van depressieve symptomen. Volgens de cross-cultureel pedagoge Vollebergh (2002) leidt deze veronachtzaming ertoe dat we terechtkomen in een spiraal van toenemende (wetenschappelijke) onwetendheid. We blijven onwetend over de psychosociale problematiek, de leefwereld van jongeren en het feit dat hun gedrag contextueel is bepaald. Tot die context behoren ook uitsluiting, discriminatie en vijandigheid.

Op het collectieve niveau werkt de verscherping van het debat polarisatie in de hand. Het constant afbeelden van mensen als fundamenteel afwijkend in hun gedrag, hun culturele en politieke aspiraties en levensstijlen om ze vervolgens af te schilderen als vijand leidt slechts tot politieke en maatschappelijke polarisering. Jongeren voelen zich aangevallen, ook al is dat niet zo bedoeld. Een en ander vergroot de kloof tussen de jongeren en de samenleving. Zij zullen zich in hun isolement terugtrekken, agressief reageren, passiviteit en radicalere opvattingen ontwikkelen.

\section{Verzet}

Een van de opvallende (collectieve en individuele) reacties tegen de ervaren druk op de identiteit en de ervaren vernedering, is dat veel allochtone jongeren - al dan niet in georganiseerd verband (vgl. de Arabische Europese Liga), zich steeds vaker verzetten. Vanuit de criminologie is bekend dat verzet, vooral wanneer het niet effectief is, ertoe bijdraagt dat duurzame vormen van afwijkend gedrag ontstaan. Dit kan zelfs zover gaan dat de gemarginaliseerde delen van allochtone jeugdgroepen een crimineel zelfbeeld aanvaarden. Gestigmatiseerden gedragen zich soms in overeenstemming met het maatschappelijke stigma (secundaire deviantie). Daarmee leidt stigmatisering juist tot gedrag dat we willen voorkomen (Becker 1963). Het risico zichzelf buiten de sociale orde te plaatsen is dan levensgroot aanwezig. Maar ook op andere niveaus komen we verzetsvarianten tegen: in de publieke ruimte tegen gezagsdragers of in de justitiële setting waar jongeren zich tegen psychiaters verzetten in hun poging de institutionele machtsverhoudingen te wijzen (Komen 2003). Deze confrontaties worden door sommigen gezien als teken van voortschrijdende emancipatie. Er zijn naast vermelde vormen van verzet ook andere die thans bijzonder relevant zijn. Deze hebben te maken met het verzet van jongeren tegen islamvijandigheid die zij menen te herkennen. Zij verwijzen in hun argumentatie vaak naar de anti-moslimreacties na 11 september 2001, maar ook geregeld naar de Tweede Wereldoorlog. "Wij zijn de joden van toen" (de Volkskrant van 8 maart 2003) is een veelgehoorde uitspraak, die de intensiteit van de ervaren dreiging weergeeft. De discussie over 
de anti-integratietendensen binnen het islamitisch onderwijs wordt met argusogen gevolgd, omdat ook deze discussie als een dreiging wordt ervaren (Inspectie van het onderwijs 2002). Inmiddels heeft de Inspectie in een vervolgonderzoek - met verbreding van de gebruikte onderzoeksmethoden - de eindconclusie getrokken dat er geen bevindingen zijn gedaan die tot onrust of ernstige ontevredenheid zouden moeten leiden (Inspectie van het onderwijs 2003: 7).

\section{Een bijzondere vorm van verzet: radicalisering}

De huidige beeldvorming laat (te) weinig ruimte voor de individualiteit van allochtone jongeren. Het onvermogen van de overheid om voldoende helder te formuleren wat aanpassing aan de Nederlandse normen en waarden inhoudt, veroorzaakt vooral bij jongeren uit de (ontluikende) middenklasse nog meer onzekerheid. Deze onzekerheid gaat in toenemende mate over in een stille woede over wat zij ervaren als assimilatiedrift van de zijde van de overheid. Jongeren op weg naar volwassenwording verkeren bijna per definitie in allerlei emancipatieslagen, waarbij hun verschillende loyaliteiten (aan ouders, samenleving, etc.) moeten worden gecombineerd. Zij bezitten noodzakelijkerwijs hybride identiteiten. Doordat zij weinig compassie, geduld en inlevingsvermogen ervaren voor hun problemen (van hun ouders, van de samenleving), zijn deze jongeren kwetsbaar en te beïnvloeden als je 'de juiste snaar raakt'. De kernvraag is hoe zij omgaan met stress in een context vol vijandigheden. Indien de reacties niet worden gekanaliseerd, is de kans op externe attributie, identificatie met de eigen groep een mix die uiteindelijk haatgevoelens kan oproepen. Vooral bij die jongeren die in sociaal-economisch opzicht successen hebben geboekt, maar niettemin naar hun mening worden gefrustreerd in hun ontwikkelingen en te weinig waardering voelen. De kans op krenking is dus groot. In de criminologie staat krenking bekend als omstandigheid die een acute reden kan vormen, een legitimatie, om 'de knop om te draaien' (Katz 1988/1998).

Het gevoel nergens bij te horen, het isolement en de achterdocht jegens de beweegredenen van de Nederlandse samenleving (of overheid) kunnen al snel leiden tot een gevoel van anomie. Een situatie waarin eerder gewortelde jongeren ontworteld raken. Een proces van radicalisering als daad van verzet is vervolgens niet denkbeeldig meer (Buijs en Harchaoui 2003; Buijs 2002; Haddad 1998; Springzak 1991). Overigens zijn processen van radicalisering ook in sommige christelijke of joodse groepen aan te treffen (Kepel 1991), en ook elders in WestEuropa zijn deze voor andere moslimjongeren beschreven (Seitmeyer en Müller 1997; Sunier 1997; Landman 1997). Voor duiding van dat proces is het van belang niet alleen te letten op identiteitsconflicten, de slechte sociaal-economische positie van migranten en hun kinderen of de wijze waarop de ontvangende samenleving reageert (uitsluiting of insluiting). Belangrijker is te bezien hoe veranderingen onder Nederlandse moslimjongeren interfereren met ontwikkelingsprocessen in de gehele samenleving op het culturele, sociaal-economische, religieuze en politieke niveau (Buijs en Harchaoui 2003: 102-103). Het intense onbehagen en de frustratie van in potentie kwetsbare jongeren worden uitvergroot door de woede over negatieve berichtgeving in de media. Wat betreft dit 
laatste is tekenend dat vooral hoogopgeleide moslimjongeren de media bevooroordeeld vinden. Dit gaat gepaard met een machteloosheid op het persoonlijke niveau om de eigen identiteit te vrijwaren van assimilatiedruk en op het collectieve niveau om de beeldvorming evenwichtig te maken. Deze omgeving interfereert met allerlei nationale en internationale ontwikkelingen. Extremisten bezitten kennelijk de feilloze timing de teleurstelling van deze jongeren te combineren met vermeende achterstelling en vermeende immoraliteit van de Nederlandse samenleving (euthanasie, homohuwelijk, pro-Israëlpolitiek). Persoonlijke rechtvaardigingen voor verzet worden omgezet in neutralisatietechnieken (Sykes en Matza 1957) waarmee de eerste stap kan worden gezet in de vervreemding van de samenleving. Om tot die toestand te geraken worden jongeren doelbewust ook van hun ouders geïsoleerd om langzaamaan geestelijk afstand te kunnen nemen, zodat de betrokkenheid bij de omringende samenleving minimaal zal zijn. De loyaliteit wordt in stappen uitgehold (Manouzi 1997). Al-Berry (2002: 72) vertelt als insider die het proces van rekrutering heeft doorleefd over het aanmeten van een nieuwe identiteit en het provocatieve gedrag in het publieke domein. ${ }^{1}$

\footnotetext{
"Maar in de scherpzinniger ogen van mijn vader was de djellaba een teken van ergens bij horen, bij iets nieuws. De familie waar ik uit voortkwam, de waarden waarin ik was opgevoed, het milieu dat het mijne was, werden hierdoor verworpen. Door van uiterlijk en manieren te veranderen probeerde ik allen die ik tegenkwam een boodschap over te brengen om hun mijn nieuwe identiteit kenbaar te maken."
}

\subsection{CONVERGERENDE PROCESSEN: STILLE EN ONGEZIENE EMANCIPATIEPROCESSEN}

In de publieke beeldvorming van vandaag moet vooral 'de Marokkaan' het ontgelden. Hij is welhaast 'uitschot der natie' geworden. Mede om deze reden zal ik het volgende deel dan ook de emancipatieprocessen van vooral deze groep behandelen. 'De Marokkaan' is bij uitstek degene die steeds meer op 'de' Nederlander gaat lijken, zoals ook Dagevos in zijn studie over de sociaal-culturele en structurele integratie van etnische minderheden in Nederland constateert (Dagevos 2001: 58). De individualisering is binnen de Marokkaanse gemeenschap goed zichtbaar, evenals de sociaal-economische stijging als gevolg van betere arbeidsprestaties en een hogere arbeidsdeelname. Op tal van terreinen zijn positieve veranderingen waarneembaar bij deze jongeren.

\section{De miskende sociale mobiliteit}

Allochtone jongeren menen over het algemeen dat zij voldoende zijn geïntegreerd en begrijpen de ongeduldige roep om aanpassing niet. Dit jaar bracht het Verwey-Jonker Instituut een trendstudie uit over de maatschappelijke positie van de allochtone jeugd in de periode 1989-1998 (Keune en Van Horssen 2003). Op grond van de trend is pessimisme niet nodig. Allochtone jongeren liggen goed op koers, zoals de sociologen Gowricharn en Duyvendak schrijven. En, voegen zij 
eraan toe, de indrukwekkende opwaartse sociale mobiliteit hebben ze helemaal zelf bereikt.

De meest recente cijfers ondersteunen deze positieve grondhouding (Martinez et al. 2002), ook met betrekking tot het onderwijs (SCP 2003). De onderwijsresultaten van allochtone jongeren zijn nog steeds te laag. Er moet op vele fronten hard gewerkt worden, maar het niveau gaat aanzienlijk vooruit. Zo is de leerwinst van allochtone leerlingen in de bovenbouw van de basisschool groter dan de winst van autochtone leerlingen. De doorstroom naar het hoger onderwijs van nietwesterse allochtone jongeren met een havo- of vwo-diploma is groter dan van hun autochtone medegeslaagden. En in het voortgezet onderwijs hebben allochtone achterstandsleerlingen inmiddels zelfs een voorsprong op autochtone achterstandsleerlingen. Ondanks de grote zorgen zijn dit toch bemoedigende gegevens. De meeste allochtone jongeren spreken goed of acceptabel Nederlands, hebben veel kennis van de maatschappij, bezitten een hoge ambitie en voelen zich verbonden met Nederland.

\section{De miskende emancipatietrend}

Uit onderzoek blijkt dat in sociaal en cultureel opzicht de integratie in Nederland van Marokkaanse jongeren snel gaat. Een gunstige sociaal-economische positie gaat gepaard met een hogere culturele integratie (Dagevos 2001). De aanpassingssnelheid is groot, maar lijkt thans te stokken uit onvrede met de assimilatiedrift. Het verklaart ook de behoefte aan autonomie. In vrijwilligheid passen mensen zich sneller aan dan in onvrijwillige situaties. Dwang leidt tot verzet. Zelfs die groepen waarmee het volgens de publieke opinie goed gaat, weten hun culturele eigenaardigheden te behouden (Gowricharn 2002).

Allochtone jongeren verzelfstandigen ook binnen het gezin, maar anders dan bij de vrouwen en arbeiders van weleer zijn er weinig maatschappelijke sociale bewegingen die deze emancipatie in goede banen kunnen leiden. De samenleving is dezelfde niet meer. Allochtone jongeren zijn vooral op zichzelf gewezen om het wiel uit te vinden. Dit is geen eenvoudig proces: je losmaken van het gezin en zonder noemenswaardige houvast een solide sociaal netwerk opbouwen. Deze dubbele emancipatieslag is een zware opgave voor kwetsbare jongeren (Schuyt 1995). Alles wat door vrouwen en arbeiders ooit al eens is bevochten, moeten zij nu opnieuw doen: de instituties toegankelijk maken, zeggenschap verkrijgen en eigen verantwoordelijkheid nemen. Door de ontzuiling en de afbraak van allerlei maatschappelijke organisaties komen jongeren er vaak alleen voor te staan. Dat geldt niet alleen voor Turkse of Marokkaanse jongeren. Zo beschrijft Veenman dat Molukse jongeren er ook vaak alleen voor komen te staan. Zonder vaste voorbeelden moeten ook zij in een tijd van individualisering en dynamisering hun weg vinden. Ook bij hen is sprake van 'knutselbiografieën' (Veenman 2001: 41).

De dubbele emancipatieslag is afhankelijk van de mate van ondersteuning in het gezin. Ouders die voor kinderen een veilige en warme omgeving creëren, belangstelling tonen, hen liefdevol bejegenen en emotioneel ondersteunen hebben een 
positieve invloed. Recent onderzoek onder kleine groepen laagopgeleide Nederlandse, Marokkaanse en Turkse moeders én vaders (12-18 jaar) vond geen verschillen in de mate van ondersteuning van ouders. Deze was in alle onderzochte groepen hoog. Ook de mate van uitleg verschilde niet. Marokkaanse ouders bleken wel vaker te straffen dan Nederlandse ouders. Nederlandse ouders daarentegen hielden vaker toezicht dan Turkse en Marokkaanse ouders (Oosterwegel, Vollebergh, Pels \& Nijsten 2002). Niettemin concluderen de onderzoekers dat het meer straffen en minder toezicht houden niet tot probleemgedrag leidt. Dit gegeven komt overeen met een ander onderzoeksgegeven: namelijk dat opvoeding niet de oorzaak is van asociaal gedrag. Wel is de opvoeding onmisbaar gebleken om gerezen problemen effectief op te lossen; dus een einde te maken aan asociaal gedrag (Heiden-Attema en Bol 200o). Het is in feite een gebrek aan een effectief sanctie-instrumentarium dat ouders parten speelt. Allochtone ouders moeten de in het gezin spelende desintegratieprocessen lijdzaam aanzien die mede het gevolg zijn van de openheid van de ontvangende samenleving. Emancipatie naar buiten van de kinderen levert eenzaamheid naar binnen voor de ouders. Om deze reden dient de aansluiting van de ouders bewerkstelligd te worden en het beste vehikel voor hun emancipatie is hun kind.

\section{De miskenning van de funderende individualiteit}

Onder Marokkaanse jongeren zijn processen van een ontluikend individualisme gaande waarbij sprake is van het ontstaan en de ontwikkeling van de kerningredienten van een liberaal denken en handelen. Het individualisme in het algemeen wordt gerelateerd aan een aantal beginselen en waarden zoals de waardigheid van de mens, autonomie, privacy en zelfontwikkeling (Lukes 1973: 45-72). Deze waarden vormen naast de vrijheid het fundament van het liberalisme.

De relatieve verzelfstandiging van allochtone jongeren ten opzichte van hun sociale omgeving is duidelijk aanwijsbaar, maar krijgt onvoldoende wetenschappelijke aandacht. We doen net alsof de Nederlander is geïndividualiseerd, maar de allochtoon nog steeds een representant is van een collectief. De burgerschapsstijlen, zoals actief, afwachtend, afhankelijk of afzijdig (Van den Brink 2002), zouden toch ook moeten opgaan voor de allochtone jongeren. De WRR (2002: 90) vat het individualiseringsproces op als een serie feitelijke sociale veranderingen. De stijgende onderwijsdeelname die voor 'de Nederlander' als factor wordt gezien voor verschuivende (economische) afhankelijkheid, doet zich thans ook voor onder 'de allochtoon'.

Doornbos (2001) beschrijft de beleving van de islam door Marokkaanse meisjes. Zij constateert dat sommige regels en verboden, zoals die met betrekking tot de consumptie van alcohol en varkensvlees, bijna unaniem navolging krijgen. Op de overige aspecten scheppen de meisjes voor zichzelf een ruime marge. Ze doen dit voornamelijk door hun geloof te definiëren als een individuele, een persoonlijke opdracht tot zelfontwikkeling. Het resultaat is individueel en niet eenduidig. Dat de jonge vrouwen de symbolen delen, betekent niet noodzakelijkerwijs dat zij ook de interpretaties daarvan met elkaar gemeen hebben. De uitkomsten lijken 
paradoxaal. Enerzijds is sprake van individualisering en aanpassing aan de "verleidingen' van het moderne leven, waarin individuele keuzes en zelfbeschikking centraal staan. Anderzijds wordt de islam, althans een individuele geloofsbeleving, belangrijker als element van de individuele identiteit. Zo blijkt uit ander onderzoek dat Marokkaanse meisjes de maagdelijkheid niet meer zien als een zaak van de gemeenschap in haar geheel, maar als een persoonlijke verantwoordelijkheid en eisen daarbij hun individuele privacy (Buitelaar 2002: 482). De op internet gevoerde discussies tussen de jongeren laten overigens hetzelfde beeld zien. Allen tasten zij de culturele, maar persoonlijk ingevulde grenzen af. Ook hier zien we interessante tendensen die op een individualiseringsproces wijzen (Brouwer 2002: 131).

Al met al kan gesteld worden dat er onder Marokkaanse jongeren (jongens en meisjes) een proces van emancipatie en verzelfstandiging gaande is. Religieuze opvattingen krijgen een persoonlijke invulling. De manier waarop jongeren invulling geven aan hun geloof, zeker de meisjes, verschilt duidelijk van hun ouders. Jongeren voeren hierin hun eigen strijd en hebben eigen dilemma's. Zij beleven hun religiositeit als een persoonlijke weg met eigen leermomenten en uitdagingen. Er is sprake van individualisering van het geloof en losmaking van traditionele en regelgeleide opvattingen die zowel binnen hun directe omgeving als in hun eigen gevoelswereld een belangrijke rol spelen (Doornbos 2001: 202).

De veranderingen in het gedrag en de denkwijzen van de jongeren hebben thans betrekking op omgang met geloof, seksuele normen, huwelijk, positie van de vrouw, privacy, scheiding privé en publiek, etc. Deze kunnen zich op termijn uitstrekken tot andere normen. Zo bezien zijn er geen fundamentele verschillen (religieuze of culturele) die op individueel niveau onverenigbaar zijn met de eisen die de omringende samenleving aan hen stelt. Daarenboven vormt geen enkele culturele inhoud een onvermijdelijk obstakel tot acculturatie. Religie, moraal, taal of gewoonte: alles is in principe veranderbaar (Kozakai 2000: 227).

Het stelselmatige verzet van allochtone jongeren in reactie op uitsluiting en gebrek aan zelfrespect is niet het verzet dat het publieke debat domineert. Daar wordt het verzet als reactie tegen integratie of 'de' Nederlandse cultuur gezien. Deze laatste stelling gaat echter niet op in de situatie dat individualiteit en autonomie tot ontwikkeling lijken te komen. Dat individu is het fundament voor emancipatie. Hiermee gaan we juist voorbij aan ongeziene funderende processen die we dienen te stimuleren. Jongeren ontwikkelen thans nieuwe strategieën van leven buiten de dwang van de collectiviteit, zonder noodzakelijkerwijs 'daaruit te stappen'. Het lijkt erop dat deze jongeren de kunst van het zich overwogen en vreedzaam isoleren van hun gelijken goed verstaan (De Tocqueville 1961: 143). Zij gaan selectief om met hun culturele repertoires, kiezen voor bepaalde elementen en negeren andere (Buitelaar 2002: 483). Aldus is hiermee ook het belang onderschreven van een dynamische en constructivistische beschrijving van de culturele achtergronden. De kernvraag behoort te zijn hoe deze processen van losmaking ondersteund kunnen worden, waarbij de regie gelaten wordt aan de 
jongeren teneinde een evenwichtige keuzes op basis van eigen verantwoordelijkheid te maken.

\subsection{CONCLUSIE: TIJD VOOR EEN EVENWICHTIG EN HELDER DEBAT}

Er is nog steeds zonder meer een ernstig probleem van jeugdcriminaliteit en normoverschrijding door allochtone jongeren in het publieke domein. Door de zichtbaarheid van straatcriminaliteit is de aandacht hiervoor ook logisch. Het is van belang dat de grenzen van het toelaatbare helder worden gemarkeerd en sancties snel en consequent worden toegepast. In feite gaat het hier om handhaving van wetten. Niet meer en niet minder. Het debat over jeugdcriminaliteit dreigt echter te ontaarden. Dat is mede inherent aan de kenmerken van dat debat: weinig op empirie berustend en vanuit een negatieve invalshoek benaderd. Daarbij ligt de nadruk zeer eenzijdig op culturele elementen en dan steeds vaker op het religieuze. De relevantie hiervan is echter marginaal. Vooral die jongeren die niet behoren tot het gemarginaliseerde gedeelte ondervinden hiervan steeds meer hinder in hun emancipatie en zelfontplooiing. Door de koppeling met normen en waarden wordt de onzekerheid van deze jongeren vergroot in plaats van verkleind. De overheid en maatschappelijke instellingen zijn niet bij machte voldoende helder het gemeenschappelijke te benoemen. Het verschil - vooral het gecollectiviseerde - vermag niet tot enige vorm van consensus te leiden, waardoor de sociale afstand toeneemt en de kans op vervreemding aan het groeien is.

Nederland verandert in rap tempo. Structurele ontwikkelingen in de voorbije decennia hebben tot een enorme culturele hybriditeit geleid, maar we hebben moeite met de hiermee gepaard gaande culturele en normatieve diversiteit. Omwille van sociale cohesie en bestaande traditionele machtsstructuren is steeds vaker een roep om homogeniteit van de samenleving te horen. Inperking van variëtiteit en het collectiviseren van jonge Nederlanders - met een andere achtergrond - tot één identiteit (moslim, allochtoon) is evenwel onvoldoende om nieuwe sturing te vinden. Het leidt tot afnemende tolerantie, de basis van onze rechtsstaat.

Het is wenselijk dat de overheid oog krijgt voor stille processen die mede het gevolg zijn van de aard van het publieke debat over allochtone jongeren. Het zijn immers de gezagsdragers die aan de basis ervan staan. Dat publieke debat doorkruist door zijn eenzijdigheid positieve ontwikkelingen en miskent andere maatschappelijke problemen. De gevolgen van een niet in goede banen geleid debat zijn zorgwekkend. Het bereiken van consensus, gedeeld burgerschap en het nemen van gezamenlijke verantwoordelijkheid voor gemeenschappelijke problemen zullen onder deze omstandigheden een illusie blijken. Fenomenen van zelfisolement, interetnische vijandigheid, groepstegenstellingen en verzet liggen op de loer. Het publieke debat over waarden en normen in relatie tot normoverschrijding heeft op deze wijze weinig zin. Het vinden van oplossingen en het 
betrekken van eigen gemeenschappen bij problemen die jongeren veroorzaken zal moeilijker worden. Om deze reden heb ik in deze bijdrage niet stilgestaan bij mogelijke oplossingen voor de gesignaleerde problemen. Wegens de averechtse werking van het proclamatiedebat is deze bijdrage vooral hieraan gewijd. Het in betere banen leiden van dit debat is volgens mij een conditio sine qua non voor elke mogelijke oplossing voor de zorgwekkende problemen. 


\section{NOTEN}

Een andere relatieve insider is de broer van Zacaraias Moussaoui - de twintigste kaper - die over zijn ervaringen een boek heeft geschreven (Moussaoui en Bouquillat 2003).

2 Veenman gebruikt de term die door hem is ontleend aan de Duitse socioloog Ulrich Beck (Veenman 2001: 141). 


\section{LITERATUUR}

Al-Berry, K. (2002) De aarde is mooier dan het paradijs, Amsterdam/Antwerpen: De Arbeiderspers.

Becker, H.S. (1963) Outsiders: Studies in the sociology of deviance, New York: The Free Press of Glenco.

Bervoets, E. en W. Stol (2002) 'Marokkanen en Nederlanders over hun wijk - gedeelde problemen als mogelijkheid voor buurtactivisme', Tijdschrift voor Criminologie, 3, 44: 247-261.

Boutellier, H. (2002) De veiligheidsutopie. Hedendaags onbehagen en verlangen rond misdaad en straf, Amsterdam: Boom.

Boutellier, H. (2003) 'De gekleurde veiligheidsutopie. Aantekeningen bij een verscheurend vraagstuk', in: S. Harchaoui en C. Huinder (red.), Stigma: Marokkaan! Over afstoten en insluiten van een ingebeelde bevolkingsgroep, Utrecht: Forum.

Bovenkerk, F. (2001). Misdaadprofielen, Amsterdam: Meulenhoff.

Bovenkerk, F. (2002) 'Essay over oorzaken van allochtone misdaad', blz. 209-246 in: J. Lucassen en A. de Ruijter (red.), Nederland multicultureel en pluriform? Amsterdam: Aksant.

Bovenkerk, F. (2003a) Hennepteelt in Nederland. Het probleem van de criminaliteit en haar bestrijding, Zeist: Kerkebosch.

Bovenkerk, F. (2003b) 'Paniekreacties op de criminaliteit van allochtone jongeren in Australië en Nederland', in: S. Harchaoui en C. Huinder (red.), Stigma: Marokkaan! Over afstoten en insluiten van een ingebeelde bevolkingsgroep, Utrecht: Forum.

Bovenkerk, F., M. Komen en Y. Yesilgöz (red.) (2003) Multiculturaliteit in de strafrechtspleging, Amsterdam.

Brink, G.J.M. van den (2002) Mondiger of moeilijker? Een studie naar de politieke habitus van hedendaagse burgers, WRR Voorstudies en Achtergronden nr. V115, Den Haag: Sdu.

Brink, H.M.A., en M.J. Brodie-Barendrecht (2002) Criminaliteitsbeeld Rotterdamse haven, Rotterdam: Kernteam Rotterdam-Rijnmond.

Brouwer, L. (2002) 'Marokkaanse jongeren en virtuele discussies', Sociologische Gids, $49,2$.

Buijs, F.J. (2002) Democratie en terreur. De uitdaging van het islamitisch extremisme, Amsterdam: Uitgeverij SwP.

Buijs, F.J., en S. Harchaoui (2003) 'Islamitisch radicalisme en rekrutering in Nederland. Een verkenning', PROCES, 2: 98-108.

Buitelaar, M.W. (2002) 'Negotiating the rules of chaste behaviour: re-interpretations of the symbolic complex of virginity by young Moroccan descent in the Netherlands', Ethnic and Racial Studies, 25, 3.

CIROC (2002) Nieuwsbrief 2002, 3.

Cohen, S. (1972) Folk devils \& Moral panics, London: MacGibbon and Kee.

Commissie Marokkaanse Jeugd (1998) Samen vol vertrouwen de toekomst tegemoet. Perspectieven voor de Marokkaanse jeugd in de Nederlandse samenleving in de XXI eeuw. 
Cottaar, A. (1996) Kooplui, kermisklanten en andere woonwagenbewoners: Groepsvorming en Beleid 1870-1945, Amsterdam: Het Spinhuis.

Cliteur, P. (2002) Moderne papoea's. Dilemma's van een multiculturele samenleving, Amsterdam/Antwerpen: Uitgeverij De Arbeiderspers.

Couwenberg, S.W. (2001) 'Nationale identiteit: van Nederlands probleem tot Nederlandse uitdaging', in: S.W. Couwenberg (red.), Civis Mundi jaarboek, Budel: Uitgeverij Damon.

Dagevos, J. (2001) Perspectief op integratie. Over de sociaal-culturele en structurele integratie van etnische minderheden in Nederland, WRR werkdocumenten W 121, Den Haag: Sdu.

Deshen, S., en M. Shokeid (1974) The Predicament of Homecoming. Cultural en Social Live of North African Immigrants in Israel, Ithaca/London: Cornell University Press.

Dominquez-Martinez, S., S. Groeneveld en E. Kruisbergen (2002) Integratiemonitor 2002, Rotterdam: ISEO/EUR.

Doornbos, A. (2001) 'Tussen traditie en verleiding: Dilemma's in het dagelijkse leven van jonge moslimvrouwen', Sociologische Gids (2001, 2).

Driessen, F.M.H.M., B.G.M. Völker, H.M. op den Kamp, A.M.C. Roest en F.J.M. Moolenaar (2002) Zeg me wie je vrienden zijn. Allochtone jongeren en Criminaliteit, Zeist: Kerkebosch.

Engbersen, G., J.P. van der Leun, R. Staring en J. Kehla (1999) Inbedding en uitsluiting van illegale vreemdelingen, Amsterdam: Boom.

Engberts, M. (1997) Voet aan de grond. Over de integratie van Marokkanen in Nederland 1980-1997, Utrecht: SMT

Gemert, F. van (1998) Ieder voor zich. Kansen, cultuur en criminaliteit van Marokkaanse jongens, Amsterdam: Het Spinhuis.

Gemert, F. van, en M. Fleisher (2002) In de greep van de groep: een onderzoek naar een Marokkaanse problematische jeugdgroep, internetmanuscript, Amsterdam: Regioplan.

Goffman, I. (1963) Stigma. Notes on the management of spoiled identity, New York: Prentice Hall.

Gowricharn, R. (2002) Het omstreden paradijs. Over multiculturaliteit en sociale cohesie, Tilburg: Universiteit van Tilburg.

Haan, W. de, en M. Althoff (2002) Vreemd en verdacht. Een verkennend onderzoek naar criminaliteit in en om asielzoekerscentra, Groningen: Rijksuniversiteit Groningen.

Haan, W. de, en F. Bovenkerk (1993) 'Moedwil en misverstand. Overschatting en onderschatting van allochtone criminaliteit in Nederland', Tijdschrift voor Criminologie, 35, 3: 277-300.

Haddad, Y.Y. (1998) 'Towards the Carving of Islamic Space in the West', ISIM Newsletter 1998, 1.

Haen-Marshall, I. (red.) (1997) Minorities, Migrants and Crime, Thousand Oaks etc: Sage.

Hagendoorn, L. (1998) 'Stereotypen over etnische minderheden in Nederland', in: C.H.M. Geuijen (red.), Multiculturalisme, Utrecht: Uitgeverij Lemma.

Hanrath, J. (2002) Slachtofferhulp en culturele diversiteit, Utrecht: Willem Pompe Instituut voor Strafrechtswetenschappen.

Harchaoui, S. (2001) 'Hedendaags kwaad revisited; kanttekeningen bij de Marokkaanse 
criminaliteit in Nederland', Justitiële Verkenningen, 27, 5: 99-113.

Harchaoui, S., en M. Siesling (2003) 'Openbaarheid en multiculturele strafrechtspleging', blz. 181-198 in: A. Beijer, C. Brants, L. van Lent en C.M. Pelser, Openbare strafrechtspleging, Deventer: Kluwer.

Heelsum, A. van (2001) Marokkaanse Organisaties in Nederland; een netwerkanalyse, Amsterdam: Het Spinhuis.

Heiden-Attema, N. van der, en M.W. Bol (200o) Moeilijke jeugd; risico- en protectieve factoren en de ontwikkeling van delinquent gedrag in een groep risicojongeren, Den Haag: woDc.

Hoogerwerf, A. (2002) Wij en Zij. Intolerantie en verdraagzaamheid in 21 eeuwen, Budel: Uitgeverij Damon.

Huisman, W., en E. Niemeijer (200o) Zicht op organisatiecriminaliteit. Een literatuuronderzoek, Den Haag: Sdu.

IAM (2002) Mensensmokkel. In beeld 2000-2001, Landelijk Parket Rotterdam, Zeist: Kerkebosch.

Inspectie van het Onderwijs (2002) Islamitische scholen en sociale cohesie, Inspectierapport nr. 2002-8, Utrecht.

Inspectie van het Onderwijs (2003) Islamitische scholen nader onderzocht, Inspectierapport nr. 2003-17, Utrecht.

Jaspers, T., en Y. Outshoorn (red.) (2002) De bindende werking van concepten. Reflecties over participatie, binding en betrokkenheid in opvoeding $\mathbb{\&}$ onderwijs, arbeid en zorg, Amsterdam: Aksant.

Jonkers, M. (2003) Een miskende revolutie. Het moederschap van Marokkaanse vrouwen, Amsterdam: Aksant.

Junger-Tas, J. (2002) 'Etnische minderheden, maatschappelijke integratie en criminaliteit. Een theoretisch raamwerk', blz. 247-278 in: J. Lucassen en A. de Ruijter (red.), Nederland multicultureel en pluriform? Amsterdam: Aksant.

Junger-Tas, J., M.J.L.F Cruyff, P.M. van de Looij-Jansen en F. Reelick (2003) Etnische minderheden en het belang van binding. Een onderzoek naar anti-sociaal gedrag van jongeren, Den Haag: Koninklijke Vermande.

Katz, J. (1998/1998) Seductions of crime. Moral and Sensual Attractions in Doing Evil, Basic Books.

Kemper, F. (1996) Religiositeit, etniciteit en welbevinden bij mannen van de eerste generatie Marokkaanse moslimmigranten, Nijmegen: Katholieke Universiteit Nijmegen.

Kepel, G. (1991) De wrake gods. Christelijk, joods en islamitisch fundamentalisme, Baarn: Ambo.

Kernteam Noord- en Oost-Nederland (2001) Criminaliteitsbeeldanalyse Oost-Europa, Zwolle.

Kernteam Noord- en Oost-Nederland (2002) Criminaliteitsbeeldanalyse Turkije, Zwolle.

Keune, M., en C. van Horssen (2003) Trendstudie: Allochtone jeugd: vooruitgang of stilstand? Maatschappelijke positie, beleid en onderzoek in de periode 1989-1998, Utrecht: Verwey-Jonker Instituut.

Kleemans, E. (2001) 'Wapenhandel: terra incognita', Tijdschrift voor Criminologie, 43, 1: $25-27$.

Klerks, P.P.H.M (200o) Groot in de hasj. Theorie en praktijk van de georganiseerde misdaad, Alphen aan den Rijn: Samsom. 
Komen, M. (2003) 'Naffers en psychiaters', in: S. Harchaoui en C. Huinder (red.), Stigma: Marokkaan! Over afstoten en insluiten van een ingebeelde bevolkingsgroep, Utrecht: Forum.

Korf, D.J. (2001) 'Witte allochtonen en zwarte autochtonen: etniciteit en criminaliteit in Nederland', Delikt en Delinkwent, 31: 230-259.

Korf, D.J., T. Nabben en A. Benschop (2002) Antenne 2001: Trends in alcohol, tabak, drugs en gokken bij jonge Amsterdammers, Amsterdam: Rozenburg Publishers.

Korf, D.J., T. Nabben en A. Benschop (2003) Antenne 2002: Trends in alcohol, tabak, drugs en gokken bij jonge Amsterdammers, thema: etniciteit, Amsterdam: Rozenburg Publishers.

Kozakai, T. (2000) L'étranger, l'identité: essai sur l'intégration culturelle, Paris : Editions Payoit \& Rivages.

Kraal, K., en A. van Heelsum (2002) Een Dynamisch Mozaïek. Nieuwe trends bij Marokkaanse organisaties, Utrecht: SMT.

Kromhout, M., en M. van San (2003) Schimmige werelden. Nieuwe etnische groepen en jeugdcriminaliteit, Den Haag: Boom/wodc.

Landman, N. (1997) 'Islamisme in de West-Europese context', Justitiële Verkenningen, 23, 6: 95-106.

Lucassen, J., en A. de Ruijter (red.) (2002) Nederland multicultureel en pluriform? Een aantal conceptuele studies, Amsterdam: Aksant.

Lempens, A., L. Assa, G. Öntas en F. Bovenkerk (1998) 'U ziet er gezond en niet al te gedaan uit'. Een onderzoek naar Slachtofferhulp en allochtone slachtoffers, Utrecht: Willem Pompe Instituut voor Strafrechtswetenschappen.

Lukes, S. (1973) Individualism: Key concepts in the Social Sciences, Oxford: Basil Blackwell.

Manouzi, A.B.L. (1997) 'Moslims in de Nederlandse samenleving; herbezinning op de islam en loyaliteit aan de democratie', Justitiële Verkenningen, 23, 6: 118-129.

Martinez, S.D., S. Groeneveld en E. Kruisbergen, Integratiemonitor 2002, Rotterdam: Instituut voor Sociologisch-Economisch Onderzoek Erasmus Universiteit (ISEO).

Middelhoven, L.K., en F.M.H.M. Driessen (2003) 'Schelden in het (semi-)publieke domein; een onderzoek onder verschillende beroepsgroepen', Justitiële Verkenningen, 29, 3: 65-74.

Ministerie van Binnenlandse Zaken en van Justitie (1997) Criminaliteit in relatie tot de integratie van etnische minderheden, Den Haag.

Nair, S. (1992) Le regard des vainqueurs: les enjeux français de l'immigration, Paris: Graset.

Oosterwegel, A., W. Vollebergh, T. Pels en C. Nijsten (2003) 'Parenting and adolescent development in Dutch, Turkish and Moroccan families in the Netherlands', blz. 91-111 in: L. Hagendoorn, J. Veenman en W. Vollebergh (red.) Integrating Immigrants in the Netherlands. Cultural versus Socio-Economic Integration, Aldershot/Burlington: Ashgate.

Pels, T. (1998) Opvoeding in Marokkaanse gezinnen. De creatie van een nieuw bestaan, Assen: Van Gorcum.

Pels, T. (200o) Opvoeding en integratie. Een vergelijkende studie van recente onderzoeken naar gezinsopvoeding en de pedagogische afstamming tussen gezin en school, Assen: Van Gorcum.

Poel, S. van der (1999) 'Onder en boven de wet. Woonwagenbewoners in Noord- 
Brabant', blz.75-99 in: Morele kwesties in het strafrecht, Deventer: Gouda Quint. Port, M. van de (2001) Geliquideerd. Criminele afrekeningen in Nederland, Amsterdam: Meulenhoff.

Prins, B. (200o) Voorbij de onschuld. Het debat over de multiculturele samenleving, Amsterdam: Van Gennep.

Prins B., en B. Slijper (2002) 'Inleiding van het themanummer: Hoe tolerant zijn wij eigenlijk?’, Migrantenstudies, 4: 194-210.

Rabbae, M. (1993) Naast de Amicales nu de UMmon. De mantelorganisaties van de Marokkaanse autoriteiten in Nederland, Utrecht: Nederlands Centrum Buitenlanders.

San, M. van (1998) Stelen of steken. Delinquent gedrag van Curaçaose jongens in Nederland, Amsterdam: Het Spinhuis.

San, M. van, E. Snel en R. Boers (2002) Woninginbrekers en zware jongens. Daders uit voormalig Joegoslavië in beeld, Rotterdam/Apeldoorn: Risbo/Politie en Wetenschap.

Sansone, L. (1992) Schitteren in de schaduw. Overlevingsstrategieën, subcultuur en etniciteit van creoolse jongeren uit de lagere klasse in Amsterdam 1981-1990, Amsterdam: Het Spinhuis.

Schuyt, C.J.M. (1995) Kwetsbare jongeren en hun toekomst, Rijswijk: Ministerie van Volksgezondheid, Welzijn en Sport.

Schuyt, C.J.M. (200o) 'Essay: sociale uitsluiting', in: Sociale Uitsluiting, Amsterdam: Stichting Leger des Heils Welzijns- en Gezondheidszorg/Uitgeverij swP.

Shadid, W., en P. van Koningsveld (1997) Moslims in Nederland. Minderheden en religie in een multiculturele samenleving, Houten: Bohn Stafleu Van Loghum.

Siegel, D. (2002a) Russian biznes in the Netherlands, Utrecht: Willem Pompe Instituut voor Strafrechtswetenschappen.

Siegel, D. (2002b) 'De Joodse gemeenschap en de Antwerpse diamantsector in historisch perspectief', Tijdschrift voor Criminologie, 44, 4: 338-350.

Sociaal en Cultureel Planbureau (SCP) (2003) Rapportage minderheden 2003, Den Haag: SCP

Snel, E., J. de Boom, J. Burgers en G. Engbersen (2000) Migratie, integratie en criminaliteit. Migranten uit voormalig Joegoslavië en de voormalige Sovjet-Unie in Nederland, Rotterdam: Risbo.

Soudijn, M.R.J. (200o) De TAO van mensensmokkel, Rotterdam: Politie Rotterdam-Rijnmond.

Soudijn, M.R.J. (2001) 'Gijzeling. Een onderbelichte kant van mensensmokkel bij Chinezen', Tijdschrift voor Criminologie, 43, 4: 360-367.

Spapens, T. en M. Bruinsma (2002) Smokkel van handvuurwapens vanuit voormalige Oostbloklanden naar Nederland, Tilburg: IVA.

Springzak, E. (1991) 'The process of delegitimation: Towards a linkage theory of political terrorism', Terrorism and Political Violence, $3,1$.

Sunier, T. (1997) 'Islamitisch integreren? Visies van Turkse jongens op integratie en Islam', Justitiële Verkenningen, 23, 6:107-118.

Sykes, G.M., en D. Matza (1957) ‘Techniques Neutralisation. A theory of Delinquency’, American Sociological Review, 17.

Tocqueville, A. de (1961) La démocratie en Amérique. Préface d’ André Jardin (oorspr. 1835), Parijs. 
Tonry, M. (red.) (1997) Ethnicity, Crime and Immigration, Chicago: University of Chicago Press.

Torre, E.J. van der, en R.F.J. Spaaij (2003) 'Rotterdamse hooligans'. Aanwas, gelegenheidsstructuren, preventie, Deventer: Kluwer.

Theunis, S. (1979) Ze zien liever mijn handen dan mijn gezicht, Baarn: Het Wereldvenster. Unit Synthetische Drugs(2001) Jaarverslag 2001, Eindhoven.

Veenman, J. (2001) Molukse jongeren in Nederland. Integratie met de rem erop, Assen: Van Gorcum.

Veenman, J. (2003) 'Stigmatisering en onbegrepen eigenbelang', in: S. Harchaoui en C. Huinder (red.), Stigma: Marokkaan! Over afstoten en insluiten van een ingebeelde bevolkingsgroep, Utrecht: Forum.

Verkuyten, M. (1999) Etnische identiteit: Theoretische en empirische benaderingen, Amsterdam: Het Spinhuis.

Verkuyten, M. (2003) 'Sociaal-psychologische gevolgen van stigmatisering', in:

S. Harchaoui en C. Huinder (red.), Stigma: Marokkaan! Over afstoten en insluiten van een ingebeelde bevolkingsgroep, Utrecht: Forum.

Vertovec, S. (2001) 'Moslimjongeren in Europa: vermenging van invloeden en betekenissen', blz. 95-116 in: Naar een Europese Islam?, Amsterdam: Mets \& Schilt.

Vollebergh, W. (2002) Gemiste kansen. Culturele diversiteit en de jeugdzorg, oratie, Nijmegen: Katholieke Universiteit.

Wartna, B.S.J. (1999) Recidiveonderzoek in Nederland, Den Haag: WoDC.

Waters, M.C. (1999) Crime and Immigrant Youth, Thousand Oaks etc: Sage.

Witte, R. (1996) Racist Violence and the State, London: Addison Wesley Longman.

Witte, R. (2003) 'Gewelddadige stigmatisering', in: S. Harchaoui en C. Huinder (red.), Stigma: Marokkaan! Over afstoten en insluiten van een ingebeelde bevolkingsgroep, Utrecht: Forum.

Wetenschappelijke Raad voor het Regeringsbeleid (2002) De toekomst van de nationale rechtsstaat, Rapporten aan de regering nr. 63, Den Haag: Sdu.

Yesilgöz, Y. (1995) Allah, Satan en het recht, Arnhem: Gouda Quint.

Zaïtch, D. (2002) Trafficking Cocaine. Colombian Drug Entrepreneurs in the Netherlands, Den Haag/Londen/New York: Kluwer Law International.

Zijderveld, A.C. (2003) 'De wisselende aandacht voor slachtoffers. Enkele cultuursociologische overwegingen. Preadvies voor de Nederlandse Juristen-Vereniging', blz.3-32 in: Het opstandige slachtoffer. Genoegdoening in strafrecht en burgerlijk recht, Handelingen Nederlandse Juristen-Vereniging, 2003-I, Deventer: Kluwer.

Zijderveld, A.C. (1993) 'De katholieke en de calvinistische cultuur', in: De parvenucultuur en andere essays, Kampen: Kok Agora. 


\title{
12 DE WAARDE VAN WAARDEN
}

\author{
W. Groot en H. Maassen van den Brink
}

\subsection{INLEIDING}

Economen wijzen er graag op dat vermeende nieuwe maatschappelijke inzichten al in het werk van de grondlegger van de economische wetenschap, Adam Smith, terug te vinden zijn. Dit geldt zeker voor het belang van normen en waarden. In zijn 'Lecture on the influence of commerce on manners' uit 1766 signaleert Adam Smith verschillen tussen landen in de 'rechtschapenheid' en de 'punctualiteit' van de bevolking. Zo beweert Smith bijvoorbeeld dat van alle volkeren de Nederlanders het meest betrouwbaar (“... the most faithful to their word”) zijn (a.w. in Zak \& Knack 2001: 295).

De verwijzing naar Adam Smith is niet toevallig. Smith was in de eerste plaats een moraalfilosoof. Normen en waarden en de relatie met individueel gedrag - het onderwerp van deze bijdrage - vormen een belangrijk onderwerp in het werk van Adam Smith. De vraag welke mechanismen zorgen voor samenhang in een samenleving staan centraal in zijn denken. In hedendaagse terminologie geformuleerd vraagt Adam Smith zich af hoe sociale cohesie totstandkomt. Hoe komt het dat een samenleving die bestaat uit burgers die vooral hun eigenbelang najagen, niet uit elkaar valt? Hoe worden individuele belangen in overeenstemming gebracht met maatschappelijke belangen? In zijn bekendste boek The Wealth of Nations geeft hij hierop een antwoord. Dit antwoord ligt in de onzichtbare hand waardoor de individuele belangen en overtuigingen ('passions') van burgers in de richting worden geleid die het meest overeenkomt met de belangen van de gehele samenleving: "By pursuing his own interest he frequently promotes that of the society more effectually than when he really intends to promote it" (Smith 1976 [1776]: 456). Eigenbelang drijft burgers ertoe datgene te doen wat waardevol is voor de samenleving. In een vaak aangehaald citaat omschrijft Smith het aldus: "It is not from the benevolence of the butcher, the brewer, or the baker that we expect our diner, but from their regard to their self-interest" (Smith 1976 [1776]: 26-27). ${ }^{1} \mathrm{De}$ maatschappelijke samenhang ontstaat doordat het najagen van eigenbelang wordt gereguleerd door concurrentie. Concurrentie voorkomt exorbitante zelfverrijking, extreem hoge prijzen en winsten. Marktwerking, zo kunnen we Smith interpreteren, leidt tot sociale cohesie en voorkomt dat eigenbelang ontaardt.

Centraal in deze bijdrage staat de vraag naar de relaties tussen normen en waarden, 'het economisch marktdenken' en het gedrag van burgers. Het 'economisch marktdenken' is daarbij een metafoor voor opvattingen waarbij de nadruk ligt op eigenbelang, concurrentie en het geloof in de gunstige effecten van marktwerking. In hoeverre dit juist is, zal later worden onderzocht. Zoals hierboven is aangegeven, zijn normen en waarden nauw verbonden met sociale samenhang in de samenleving. 
Het begrip 'normen' kent verschillende definities. In grote lijnen kan een onderscheid worden gemaakt in positieve en normatieve definities van normen. In de positivistische definitie wordt een norm omschreven als een regel die wordt ondersteund door een systeem van informele sancties. Een voorbeeld van een normatieve definitie van 'normen' - waarin wordt benadrukt dat een norm een verplichting in zich bergt - is die in Cooter (1998). Sociale normen worden door hem omschreven als een 'effectieve consensusverplichting'. Een norm bestaat als bijna iedereen in een samenleving het erover eens is dat men zich in bepaalde situaties op een bepaalde manier moet gedragen, en deze overeenstemming bepaalt wat burgers werkelijk doen, aldus Cooter. In deze bijdrage zullen wij normen - in aansluiting bij Cooter - opvatten als een consensusverplichting. Echter, wij zullen vooral aandacht besteden aan situaties waarbij de verplichting niet wordt nagekomen: normen kunnen worden overtreden.

Definities kunnen verhelderend zijn, maar met een definitie van 'normen' is nog niet bepaald over welke 'normen en waarden' we het eigenlijk hebben. Elster (1989) betoogt dat sociale normen moeten worden onderscheiden van wettelijke normen, morele normen en persoonlijke normen. Hoewel dit onderscheid conceptueel verhelderend kan zijn, is het om twee redenen niet bevredigend. Ten eerste is het onderscheid empirisch moeilijk te maken. Een voorbeeld maakt dit duidelijk. Als ik in mijn auto door een woonwijk rijd en ik houd me dan aan de maximumsnelheid van dertig kilometer per uur, doe ik dat dan omdat alle andere automobilisten dat ook doen (sociale norm), omdat dertig kilometer de wettelijke snelheidslimiet is (wettelijke norm) of omdat ik kinderen die in de buurt spelen niet in gevaar wil brengen (morele norm)? Een tweede reden is dat sociale normen vaak ook wettelijke of morele normen zijn of dat na verloop van tijd worden. Een voorbeeld hiervan is handel met voorkennis. Hierbij zijn sociale normen in de jaren tachtig de morele en wettelijke normen van de jaren negentig geworden.

Een onderscheid tussen sociale, morele en wettelijke normen beantwoordt niet de vraag over welke normen we het hebben. Een volledige omschrijving van normen en waarden is een moeilijke taak. Het wordt eenvoudiger als we de andere kant van de medaille nemen: normafwijkend gedrag. Van normafwijkend gedrag kunnen we ons een betere voorstelling maken. We zullen in deze bijdrage betogen dat - in tegenstelling tot hetgeen soms wordt gedacht - normafwijkend gedrag juist veroorzaakt wordt door het ontbreken van marktwerking. Onvolledige informatie, gebrek aan transparantie en marktmacht zijn kenmerken van het ontbreken van volledige marktwerking en voorwaarden voor het ontstaan van normafwijkend gedrag.

Het is goed om kort stil te staan bij de vraag wat onder normafwijkend gedrag moet worden verstaan. Normafwijkend gedrag verwijst naar handelingen die gericht zijn op het behalen van eigen voordeel, maar die schade en kosten voor de organisatie of de samenleving met zich meebrengen. Normafwijkend gedrag wordt in deze bijdrage breed opgevat. Het verwijst enerzijds naar overtredingen, 
delicten en andere strafbare feiten. Anderzijds gaat het bij normafwijkend gedrag om handelingen die afwijken van gemaakte (contractuele) afspraken. Normafwijkend gedrag kan derhalve worden gezien als een vorm van moral hazard. Hiermee dienen zich ook de mogelijkheden aan om normafwijkend gedrag te voorkomen. Evenals bij andere vormen van moral hazard kan normafwijkend gedrag worden beperkt door toezicht en inspectie van gedrag, risicodeling (de veroorzaker van de schade laten delen in de schadelast), sancties en beloningen, en door het bieden van een langetermijnperspectief.

In deze bijdrage zullen wij verder betogen dat sociale normen een economische waarde kunnen hebben. ${ }^{2}$ Normafwijkend gedrag is daarentegen vrijwel altijd schadelijk voor de economische ontwikkeling. Fraude, bedrog en omkoping zijn drie voorbeelden van normafwijkend gedrag. Meer in het algemeen kan worden gesteld dat normafwijkend gedrag een vorm is van wat in de economische literatuur wordt omschreven als rent seeking behavior. Rent seeking behavior is gedefinieerd als pogingen van individuen om hun persoonlijk kapitaal of vermogen te vergroten, terwijl tegelijkertijd een negatieve bijdrage wordt geleverd aan het nettokapitaal van de samenleving (zie Buchanan, Tollison \& Tullock 1980). Baumol (2002) omschrijft rent seeking als: “... any activity whose objective is the acquisition of some monopoly profit or the other economic rents currently generated or potentially available in the economy" (Baumol 2002: 61). Daarmee kunnen bijvoorbeeld ook de excessief hoge salarissen van managers in het be drijfsleven en bij semi-overheidsinstellingen als een vorm van rent seeking behavior worden gezien. Hiermee is tevens aangegeven dat normafwijkend gedrag gezien kan worden als een vorm van rent seeking behavior, maar dat het omgekeerde niet geldt: niet alle vormen van rent seeking behavior zijn normafwijkend.

Normen verminderen transactiekosten. Als de norm luidt 'Vrouwen gaan voor', dan vermindert dat de onderhandelingskosten - een vorm van transactiekosten over wie het eerst door de deur gaat. Normen dienen om verwachtingen die partijen hebben op elkaar af te stemmen en verminderen onzekerheid omtrent het gedrag van de andere partij in de transactie. Normen creëren met andere woorden vertrouwen. De norm 'Vrouwen gaan voor' creëert de verwachting dat zonder onderhandeling de kamer te verlaten niet tot botsing der seksen bij de deur leidt. Vervolgens vertrouwt iedereen erop dat vrouwen voor mannen gaan. Ten slotte kunnen normen aan de ene kant zelfversterkend zijn: als de meerderheid zich aan de norm houdt, is het voor de minderheid ook voordelig om zich hieraan te conformeren. Aan de andere kant kan in sommige gevallen door normafwijkend gedrag individueel voordeel te behalen zijn.

Het eerste onderwerp dat in deze bijdrage aan de orde komt is de vermeende dominantie van het economisch marktdenken. Wij vragen ons af in welke betekenissen het begrip 'economisch marktdenken' wordt gebruikt en wat de betekenis ervan is voor de ontwikkeling van waarden en normen. Hier zullen wij betogen dat economische welvaart het ontstaan en de ontwikkeling van 
maatschappelijke waarden als vertrouwen, solidariteit en altruïsme niet tegenwerkt maar juist bevordert. Zo zullen wij betogen dat vertrouwen een belangrijke economische waarde heeft. Veel sociale normen bevorderen samenwerking en vertrouwen onder burgers en dragen daardoor bij aan productiviteit en economische groei. Vertrouwen in de overheid en vertrouwen in de werkgever bepalen in hoge mate het sociale gedrag van burgers in de samenleving. Overheid en bedrijfsleven hebben daarbij een voorbeeldfunctie. Economisch marktdenken, gedefinieerd als 'Voor wat hoort wat', wordt ons inziens vooral bepaald door de toename van kortdurende relaties. Hogere mobiliteit - zowel op de arbeidsmarkt als geografische mobiliteit (verhuizen) en mobiliteit in relaties (echtscheiding) bevordert economisch marktdenken en kan normen en waarden zowel binnen bedrijven en organisaties als binnen gezinnen en gemeenschappen eroderen.

Het tweede onderwerp betreft het normafwijkend gedrag in het bedrijfsleven en bij de overheid. Normafwijkend gedrag is een vorm van rent seeking behavior en is nadelig voor de economische ontwikkeling. Bovendien heeft rent seeking behavior een eroderend effect op normen en waarden.

Het derde thema betreft de invloed van het economisch marktdenken buiten de markt, in het bijzonder de invloed van het marktdenken op relaties binnen huishoudens. Kortdurende relaties en monetarisering van activiteiten binnen huishoudens zijn uitkomsten van veranderende waarden en normen binnen het gezin. Omgekeerd beïnvloedt de bekorting van de duur van relaties als gevolg van de toename in echtscheiding de normen en waarden over de rol en de betekenis van het gezin.

In de conclusies gaan we in op de stelling dat normen en waarden luxegoederen zijn en dat normafwijkend gedrag een gevolg is van imperfecte marktwerking, gebrek aan informatie en transparantie of van marktmacht.

\subsection{HET DOMINANTE ECONOMISCH MARKTDENKEN}

Calculerend gedrag wordt vaak gezien als een uiting van de economisering van de samenleving en als een belangrijk negatief effect van de toenemende dominantie van het economisch marktdenken. Het vooropstellen van het eigenbelang bij calculerend gedrag ten koste van maatschappelijke belangen en van minder zelfzuchtige of altruïstische overwegingen wordt beschouwd als een bedreiging voor de sociale cohesie en structuur van de samenleving. Calculerend gedrag wordt hierbij tegenover solidariteit met de zwakkeren in de samenleving geplaatst.

Economisering van de samenleving gaat gepaard met individualisering en normvervaging, zo is de vrees. Hierbij wordt onder economisering verstaan dat in het handelen de nadruk ligt op eigenbelang en calculerend gedrag. Het vooropstellen van eigenbelang kan ten koste gaan van anderen en betekent in elk geval dat minder rekening wordt gehouden met de belangen van anderen. In die zin wordt 
calculerend gedrag tegenover altruïstisch gedrag geplaatst. ${ }^{3}$ Het is de vraag of dit een valide redenering is. Altruïstisch gedrag en solidariteit kunnen heel goed samengaan met calculerend gedrag en eigen belang. De Franse filosoof Derrida drukt dit in extreme mate uit wanneer hij stelt dat echt altruïstisch gedrag niet bestaat. Elster (1989) beweert dat normen door eigenbelang worden gevormd: "Norms, in turn, are partly shaped by self-interest, because people often adhere to the norms that favour them" (Elster 1989: 150).

De econoom Gary Becker (1996) laat zien dat altruïstisch gedrag en solidariteit heel goed samengaan met calculerend gedrag en eigenbelang. Altruïsme en solidariteit kunnen worden gezien als een vorm van inkomensoverdracht van personen die goed af zijn naar personen die minder goed af zijn. ${ }^{4}$ Altruïsme en solidariteit kunnen Pareto-efficiënt zijn, dat wil zeggen dat ze zowel de welvaart van de ontvanger als de welvaart van de gever kunnen vergroten. ${ }^{5}$ Becker (1996) geeft hierbij het voorbeeld van het geven van geld aan bedelaars. We geven geld aan bedelaars omdat het zicht op en de confrontatie met verloederde bedelaars ons onaangenaam is en onze welvaart aantast (en misschien geven we geld om van opdringerige bedelaars af te zijn). Om dezelfde reden hebben we belang bij een goed functionerende gezondheidszorg. De gedachte dat - bij gebrek aan middelen - verstandelijk gehandicapten naakt aan een verwarming worden geketend druist in tegen onze maatschappelijke waarden en normen. We zijn bereid om extra geld te besteden aan de zorg voor verstandelijk gehandicapten, niet omdat we daar zelf van profiteren of dat we verwachten dat we ooit mogelijk zelf in een dergelijke situatie verzeild raken, maar omdat leven in een samenleving waar verstandelijk gehandicapten voldoende zorg krijgen onze welvaart vergroot. ${ }^{6}$

Daarnaast vormen altruïsme en solidariteit een vorm van verzekering. Zeker in landen met een beperkter socialezekerheidsstelsel - zoals bijvoorbeeld in de Verenigde Staten - zijn mensen altruïstischer en vrijgeviger tegenover bedelaars, omdat ze weten dat er een kans bestaat dat ze zelf ook in dergelijke omstandigheden verzeild kunnen raken.

In de afgelopen vijftig jaar is de solidariteit tussen hogere en lagere inkomens, tussen mensen die gezond zijn en zij die dat niet zijn, tussen mensen die over veel vaardigheden beschikken en zij die meer hulp in hun persoonlijke ontwikkeling nodig hebben, groter geworden. Dit uit zich in de toename van de sociale zekerheid, de collectief gefinancierde gezondheidszorg en het onderwijs. Nog nooit in de geschiedenis waren de inkomens- of solidariteitsoverdrachten tussen groepen in de samenleving zo groot. Het sterk toegenomen aandeel van de collectieve sector en de inkomensoverdrachten in de economie zijn hiervan het bewijs. Dit alles is mogelijk gemaakt door de toegenomen welvaart. Een grotere welvaart leidt tot meer altruïsme en solidariteit in de samenleving. De waarden die aan solidariteit en altruïsme ten grondslag liggen zijn, zoals economen zouden zeggen, luxegoederen. De uitgaven voor solidariteit en altruïsme - zowel vrijwillig als afgedwongen door belasting- en socialepremieheffing - nemen meer dan evenredig toe met de toename van de welvaart. 
Om te kunnen bepalen wat de effecten zijn van het dominante marktdenken dient eerst de vraag te worden beantwoord wat precies onder 'het dominante marktdenken' wordt verstaan. In het algemeen wordt het begrip 'marktdenken' in twee betekenissen gebruikt. In de eerste plaats wordt het gebruikt om de - al dan niet vermeende - toename van het najagen van eigenbelang en calculerend gedrag mee aan te duiden. Voorbeelden hiervan zijn de berichten over zelfverrijking onder managers van grote bedrijven door het zichzelf toekennen van optieregelingen en bonussen en de hoge salarissen van bestuurders van (semi-) publieke instellingen als ziekenhuizen en universiteiten. ${ }^{7}$ Deze opties en hoge salarissen worden meestal door managers zelf gerechtvaardigd met een beroep op de markt ('marktconforme beloning').

Het dominante marktdenken verwijst daarnaast naar de opvatting dat organisatie van activiteiten via de markt betere (lees: efficiëntere) uitkomsten oplevert dan organisatie door centralisatie en hiërarchische sturing. Met andere woorden: de markt presteert beter dan de overheid. Marktwerking wordt hierbij zowel als analytisch middel gebruikt ('marktwerking is efficiënter') als als normatief principe ('efficiënter is beter').

De markt biedt mogelijkheden tot normafwijkend gedrag, maar beperkt daarnaast ook de mogelijkheden tot normafwijkend gedrag zoals fraude en bedrog (cheating and shirking). De transparantie van de markt beperkt de mogelijkheden tot normafwijkend gedrag en zorgt ervoor dat normafwijkend gedrag aan het licht komt en wordt gecorrigeerd. Normafwijkend gedrag gedijt slechts in situaties van onvolkomen informatie. Hier staat tegenover dat de decentrale beslissingsbevoegdheid in de markt leidt tot een groter aantal mensen dat normafwijkend gedrag vertoont.

Marktwerking veronderstelt tegelijkertijd ook waarden als integriteit en vertrouwen. Zonder deze positieve waarden is marktwerking niet mogelijk. Daarnaast creëert, bevordert en beloont de markt ook positieve waarden als integriteit en vertrouwen.

In de volgende twee paragrafen worden de positieve en negatieve waarden die door de markt worden bevorderd en ontwikkeld nader tegen het licht gehouden. Eerst gaan we in op de rol van de markt bij het scheppen van vertrouwen. In de daaropvolgende paragraaf komen de gevolgen van normafwijkend gedrag aan de orde.

\subsection{DE ECONOMISCHE BETEKENIS VAN NORMEN: DE WAARDE VAN VERTROUWEN EN INTEGRITEIT}

Vertrouwen en integriteit vormen een belangrijke waarde in het economisch verkeer. Integriteit verwijst naar de betrouwbaarheid van mensen. Vertrouwen verwijst naar de bereidheid om de eigen welvaart te laten bepalen door beslissin- 
gen van anderen. De mate waarin de medemens wordt vertrouwd, bepaalt in belangrijke mate of de burger bereid is leningen te verstrekken of af te gaan op het advies en de handelingen van anderen. Vertrouwen verlaagt de transactiekosten. Hierdoor kunnen samenlevingen waarin veel vertrouwen heerst efficiënter produceren en transacties afsluiten, dat wil zeggen: tegen lagere kosten.

Arrow (1972) en Fukuyama (1995) argumenteren dat de mate waarin in een samenleving vertrouwen heerst een belangrijke determinant is van economisch succes. In de woorden van Fukuyama (1999): “All societies have some stock of social capital; the real differences among them concerns what might be called the 'radius of trust'” (Fukuyama 1999: 17). Het begrip positive radius of trust is hetgeen economen opvatten als de positieve externe effecten van vertrouwen.

Yamagishi \& Yamagishi (1994) onderscheiden twee typen van vertrouwen. Het ene is gebaseerd op afschrikking (deterrence) en het andere op 'goedwilligheid' (benevolence). Het eerste type komt in grote lijnen overeen met vertrouwen dat wordt gegenereerd door formele instituties en door informele sancties zoals uitsluiting, terwijl het tweede type gebaseerd is op sociale cohesie of homogeniteit.

De economische waarde van vertrouwen is groot. Vertrouwen verlaagt de transactiekosten van economische activiteiten (bijvoorbeeld doordat aanbieders bereid zijn goederen te leveren voordat betaling plaatsvindt, of doordat producenten meer zekerheid hebben dat geleverde producten ook betaald worden). Welvaart is op vertrouwen gebaseerd. Verschillen in de mate waarin burgers elkaar vertrouwen vormen een verklaring voor welvaartsverschillen tussen landen.

In West-Europa hebben burgers sinds de Renaissance hun belangen gebundeld in organisaties - gilden, bedrijven, verenigingen, vakbonden, steden, naties, et cetera - die een vanzelfsprekende band van vertrouwen hebben gecreëerd. Deze vertrouwensbasis zorgt ervoor dat mensen bereid zijn risico's te nemen (Ik lever goederen vandaag en vertrouw erop dat jij volgende week betaalt).

In Oost-Europa is deze vertrouwensbasis met de val van het communistische systeem grotendeels verdwenen. Bestaande instituties - de communistische partij, het staatsapparaat - zijn ontmanteld en er zijn (nog) niet altijd nieuwe instituties voor in de plaats genomen die het vertrouwen van de burgers hebben. Een belangrijke rol hierbij speelt de politieke instabiliteit in veel Oost-Europese landen. Regeringen wisselen elkaar in snel tempo af en elke nieuwe regering begint met het ongedaan maken van de maatregelen die door de vorige regering zijn genomen. Naast de politieke instabiliteit vormt ook het ontbreken van een juridische infrastructuur een belangrijk obstakel voor het ontwikkelen van vertrouwen en daarmee voor economische ontwikkeling.

Veel landen in Oost-Europa en de voormalige Sovjet-Unie kenden bijvoorbeeld lange tijd geen deugdelijke faillissementswetgeving. Hierdoor is het mogelijk dat 
bedrijven die eigenlijk niet meer aan hun financiële verplichtingen kunnen voldoen, economisch actief blijven. Dit belemmert in hoge mate het opbouwen van vertrouwen: als er grote onzekerheid is of het bedrijf waarmee je zaken doet wel aan zijn verplichtingen kan voldoen, zul je niet snel bereid zijn om met het bedrijf in zee te gaan. Door deze onzekerheid over de betrouwbaarheid van bedrijven komen er minder transacties tot stand dan eigenlijk zou kunnen. Als er minder zaken worden gedaan, leidt dit tot daling van de economische ontwikkeling.

Als mensen elkaar vertrouwen functioneren grote organisaties beter, werken overheden efficiënter en hoeven minder middelen te worden besteed aan controle en repressie. Zo vinden Knack \& Keefer (1997) dat een stijging van één standaarddeviatie in de mate van vertrouwen in een land leidt tot een toename van de economische groei met meer dan de helft van één standaarddeviatie. Vertrouwen is hierbij gemeten aan de hand van het percentage van de bevolking dat het eens is met de stelling 'De meeste mensen vallen te vertrouwen'. Zak \& Knack (2001) vinden dat het aandeel van investeringen in het bruto nationaal product (BNP) met bijna één procentpunt toeneemt bij een toename van het vertrouwen met zeven procentpunten in een land. $\mathrm{Zij}$ vinden verder dat een toename van de mate van vertrouwen met één standaarddeviatie tot een toename van de economische groei met bijna één procentpunt leidt. Landen waarin het onderlinge vertrouwen groter is, hebben een structureel hogere economische groei.

Zak \& Knack (2001) analyseren verder de determinanten van vertrouwen. Zij vinden dat vertrouwen wordt bepaald door de sociale, economische en institutionele omgeving waarin transacties worden uitgevoerd. Zo blijkt dat het vertrouwen daalt als er sprake is van beloningsdiscriminatie op basis van niet-economische factoren: vertrouwen is groter in rechtvaardige samenlevingen. Vertrouwen neemt verder toe naarmate de inkomensongelijkheid in een land kleiner is en eigendomsrechten beter beschermd worden door de overheid. Vertrouwen is minder naarmate de sociale afstand tussen bevolkingsgroepen in een land groter zijn.

Glaeser et al. (1999) stellen dat de bereidheid anderen te vertrouwen wordt bepaald door: 1) de overtuiging over de betrouwbaarheid van anderen; 2) voorkeuren voor anderen iets over te hebben; 3) de capaciteit om vertrouwen bij anderen te wekken. Overtuigingen, altruïstische voorkeuren en de capaciteit vertrouwen te wekken worden alle in meer of mindere mate door onderwijs en opleiding bepaald.

Glaeser et al. (200oa) vinden dat hoger opgeleiden meer vertrouwen hebben in anderen dan lager opgeleiden. Naast opleiding wordt het vertrouwen in de medemens ook vergroot door leeftijd en inkomen. Verder hebben mannen, mensen die getrouwd zijn en personen met een sterke religieuze overtuiging meer vertrouwen in anderen. Glaeser et al. (1999) vinden dat mensen met een academische 
opleiding dertig procent meer kans hebben om 'ja' te zeggen op een vraag of anderen te vertrouwen zijn dan voortijdige schoolverlaters. Een cross-nationale vergelijking geeft aan dat in landen waar het gemiddeld opleidingsniveau hoger is, de mate van vertrouwen in de medemens groter is. In Glaeser et al. (1999) wordt verder gevonden dat het opleidingsniveau van de ouders een positief effect heeft op de mate waarin kinderen anderen vertrouwen.

Alesina \& La Ferrara (2000) vinden dat de belangrijkste factoren die leiden tot minder vertrouwen zijn: 1) traumatische gebeurtenissen in het recente verleden, 2) behoren tot een groep die vindt dat ze gediscrimineerd wordt (allochtonen, vrouwen), 3) economisch niet succesvol zijn in termen van inkomen en opleiding en 4) wonen in een buurt met veel verschillende bevolkingsgroepen of in een buurt met grote inkomensverschillen. Verder wordt in dit onderzoek gevonden dat hoger opgeleiden meer vertrouwen hebben in hun medemens.

Onderwijs is een belangrijke bron van vertrouwen. Volgens de Wereldbank draagt onderwijs op drie manieren bij aan de vorming van sociaal kapitaal: leerlingen en studenten praktiseren sociaal-kapitaalvaardigheden zoals participatie en reciprociteit, scholen vormen een forum voor gemeenschapsactiviteiten en door burgerschapskunde (civic education) leren jongeren hoe ze verantwoordelijke burgers in de samenleving worden. Knack \& Keefer (1997: 1270) verklaren de relaties tussen onderwijs en vertrouwen aldus: "Education may strengthen trust and civic norms, for example, if ignorance breeds distrust, or if learning reduces uncertainty about the behavior of others, or if students are taught to behave cooperatively." Glaeser et al. (200o) geven twee mogelijke verklaringen voor het effect van opleiding op vertrouwen. Hoger opgeleiden hebben vaker sociale contacten met andere hoogopgeleiden die, om de een of andere reden, betrouwbaarder zijn. Onderwijs creëert individueel sociaal kapitaal doordat het de sociale vaardigheden vergroot of doordat een hogere status de mogelijkheid vergroot om anderen te belonen (voor vertrouwen) of te straffen (als het vertrouwen wordt geschonden).

Vertrouwen en integriteit zijn positieve waarden. Integriteit is op betrouwbaarheid gebaseerd. Donaldson (2001) richt zich vooral op integriteit als waarde en tracht meer algemene ethische normen en waarden te formuleren die landen een concurrentievoordeel opleveren ('an ethical advantage of nations'). Donaldson (2001) onderscheidt vier kenmerken. Elk van deze kenmerken draagt bij aan een welvarender economie. Deze vier zijn: 1) een rechtvaardigere verdeling van goederen, 2) een betere overheid, 3) een samenleving die meer doortrokken is door sociale samenwerking en 4) het inprenten van economische 'plichten' bij burgers. Donaldson (2001) betoogt verder dat veel ethische succesfactoren dienen als een middel om falen en imperfecties van de markt te omzeilen. Hiervoor is wel vereist dat deze ethische succesfactoren de status hebben van intrinsieke waarde, dat wil zeggen mensen moeten een onafhankelijke waarde aan deze ethische factoren toeschrijven, onafhankelijk van de economische bijdrage van deze factoren. Een voorbeeld in de vorm van een citaat uit Donaldson (2001) ter illu- 
stratie: "In daily life we prefer doing business with people who show independent concern for values. Think of integrity. If we believe that our lawyer or banker is constantly lying in wait, looking for the moment he can abandon integrity, and that he is routinely seeking the hidden moment when acting unscrupulously will fatten his advantage and decrease ours, then we suppose it is time to hire a new lawyer or banker. Most of us prefer doing business with a lawyer or banker who places some intrinsic value on integrity" (Donaldson 2001: 33). Ten slotte betoogt hij dat, als deze claim van ethische succesfactoren juist is, landen zich moeten richten op morele educatie.

\subsection{NORMAFWIJKEND GEDRAG IN HET BEDRIJFSLEVEN EN BIJ DE OVERHEID}

De bekendste voorbeelden van normafwijkend of onethisch gedrag in het bedrijfsleven zijn de boekhoudschandalen die zich in de afgelopen jaren hebben voorgedaan. Het voorbeeld van Enron is het meest bekend. In ons land hebben zich onder andere boekhoudschandalen voorgedaan bij Baan Automatiseerders en bij Ahold. Cohan (2002) analyseert de interne dynamiek en de voorwaarden die bij Enron hebben geleid tot grootschalige boekhoudfraude. Uit zijn analyse blijkt dat bij Enron het hogere management geïsoleerd van het uitvoerende personeel functioneerde; individuele medewerkers streefden doelstellingen na die in strijd waren met de doelstellingen van de organisatie als geheel; de informatievoorziening was beperkt en negatieve informatie bereikte het hogere management niet; er bestond een organisatiecultuur van intimidatie; het uiten van twijfel of scepticisme werd ontmoedigd, wat leidde tot onwilligheid om hogere managers te confronteren met onwelkome feiten; en de ethische en juridische grenzen aan het handelen werden verlegd.

Drie aspecten springen bij de analyse van het Enron-schandaal in het oog. Het eerste is het grote belang van informatie. Fraude en bedrog zijn altijd een vorm van onvolledige (en soms valse of verkeerde) informatie. Het tweede aspect vormen de beperkingen van het zogenaamde stakeholder-model. Het stakeholdermodel wordt vaak gezien als alternatief voor het shareholder-model en als een voorbeeld van verantwoord ondernemerschap. De laatste jaren zijn opvattingen over 'maatschappelijke verantwoord ondernemen' en het stakeholder- versus shareholder-model van de organisatie meer in de belangstelling gekomen. Het aantal stakeholders bij het bedrijf wordt meestal ruim gedefinieerd: aandeelhouders, managers, werknemers, leveranciers, klanten, belangengroepen, vakbonden, concurrenten, etc. Een belangrijk punt van kritiek op de stakeholder-benadering is dat door het aantal stakeholders zo groot mogelijk te definiëren het voor het management makkelijker wordt zijn eigen opvattingen door te drukken. ${ }^{8}$ Uit de analyse van Cohan (2002) blijkt duidelijk dat de problemen bij Enron voor een belangrijk deel veroorzaakt werden doordat sommige stakeholders belangen hadden die in strijd waren met het belang van de organisatie. Het derde aspect dat bij de Enron-analyse opvalt is het correctieve vermogen van bedrijfsschandalen. 
In de woorden van Cohan (2002): "In the wake of Enron corporations may simply have no choice but to meet increased demands by workers, shareholders, customers and the government for greater accountability."

Economische prikkels kunnen niet alleen normafwijkend gedrag aanmoedigen, maar kunnen ook een middel zijn om niet-integer gedrag te ontmoedigen. In een overzicht van empirische studies over ethische beslissingen binnen bedrijven vinden Loe, Ferrell \& Mansfield (2000) dat in een meerderheid van de onderzochte studies wordt gevonden dat in organisaties waar (on)ethisch gedrag wordt beloond en ondersteund, dergelijk gedrag vaker voorkomt. Een belangrijke stok achter de deur is de reactie van de aandelenmarkten op onethisch gedrag. Een aantal studies toont aan dat beurskoersen dalen nadat bedrijven mededelingen doen over onethisch gedrag (Gunthorpe 1997; Rao \& Hamilton 1996). Hierbij moet wel worden aangetekend dat een negatieve reactie van de aandelenmarkt voor bedrijven een stimulans vormt om onethisch gedrag niet naar buiten te brengen.

De boekhoudschandalen in de vs en Nederland roepen de vraag op hoe wijdverspreid normafwijkend en onethisch gedrag in het bedrijfsleven is. In Collins (2000) wordt een overzicht gegeven van onderzoek naar de prevalentie van onethische praktijken in het bedrijfsleven. Hieruit komt een gemengd beeld naar voren. Aan de ene kant is er onderzoek waaruit blijkt dat zo'n tachtig procent van de managers van mening is dat hun bedrijf er hoge morele standaarden op na houdt (Posner \& Schmidt 1987) en zeggen de meeste leidinggevenden dat het onwaarschijnlijk is dat ze zich ooit met onethische praktijken zullen bezighouden (Eastman et al. 1996). Aan de andere kant blijkt dat de meeste mensen hun eigen morele standaarden hoger inschatten dan die van hun leidinggevenden of van anderen in hun directe omgeving (zie bijvoorbeeld Cole \& Smith 1996 en Ford \& Richardsen 1994). Ongeveer de helft van de managers zegt verder weinig problemen te hebben en akkoord te kunnen gaan met een frauduleus financieel verslag (Brief et al. 1996).

In de afgelopen jaren is het aantal meldingen over fraude toegenomen. Bekende voorbeelden zijn - naast de hierboven genoemde boekhoudschandalen bij grote bedrijven in Nederland en de vs - de bouwfraude, de fraude met studentinschrijvingen bij hogescholen, de fraude in de gezondheidszorg en de gevallen van aandelenhandel met voorkennis. Het valt niet vast te stellen of fraude tegenwoordig vaker voorkomt dan vroeger of dat fraude vaker aan het daglicht treedt en meer aandacht krijgt van de media en justitie. Sennett (2003) beweert van niet: "Corrupte en incompetente managers hebben altijd geprobeerd om belastend cijfermateriaal te verbergen. Nieuw aan een schandaal als dat van Enron Corporation is het aantal 'pottenkijkers' van buiten en de snelheid waarmee de boekhoudkundige fraude werd onthuld” (Sennett 2003: 181). Meer transparantie leidt tot snellere ontdekking. Naast snellere ontdekking is ook duidelijk dat door verscherping van de normen sommige activiteiten tegenwoordig als frauduleus worden bestempeld die vroeger wel toelaatbaar werden geacht. Een voorbeeld 
hiervan is de in de inleiding genoemde handel met voorkennis. Tot in de jaren tachtig was handel met voorkennis niet strafbaar. Door aanpassing van de wetgeving wordt handel met voorkennis tegenwoordig als fraude bestempeld.

Niet alleen in het bedrijfsleven wordt gefraudeerd. Sommige gevallen van fraude die de afgelopen tijd bekend zijn geworden, speelden zich af bij (semi-)publieke instellingen (hogescholen, gezondheidszorginstellingen). In andere gevallen waren ambtenaren bij fraude betrokken (bouwfraude). Fraude is een vorm van normafwijkend gedrag dat in alle gevallen veroordeeld dient te worden, omdat zij schade toebrengt aan het algemeen belang of het bedrijfsbelang: fraudeurs trachten zichzelf op oneigenlijke wijze te bevoordelen ten koste van de samenleving of het bedrijf (rent seeking behavior). Toch kan worden gesteld dat fraude met overheidsgeld kwalijker is dan fraude in het bedrijfsleven. Hiervoor zijn drie argumenten te geven. Ten eerste worden burgers verplicht - via belastingheffing - bij te dragen aan de financiering van collectieve goederen. In het bedrijfsleven kunnen financiers - aandeelhouders of banken - besluiten geen geld in een onderneming te stoppen als de indruk bestaat dat dit geld wordt gebruikt voor frauduleus handelen. Bij de overheidsfinanciering bestaat deze vrijheid niet. Het verplichte karakter van de financiële bijdrage legt een grotere morele verplichting op een juiste besteding van de middelen. Een tweede argument is dat in het bedrijfsleven financiers vaak juist worden aangetrokken door de snelle en hoge winst die door onoorbare praktijken wordt verkregen. Zo werden beleggers in Ahold aangetrokken door de koersstijgingen die het gevolg waren van geflatteerde winstcijfers. Een derde argument is dat frauduleus gedrag van de overheid algemeen geaccepteerde normen in de samenleving ter discussie stelt en daarmee burgers aanzet tot normafwijkend gedrag onder het motto 'Waarom zij wel en wij niet?’

Een regelmatig voorkomend probleem bij normafwijkend gedrag is dat de normen en waarden van de betrokkenen zelf - de insiders zou men kunnen zeggen - afwijken van die van de buitenstaanders (de outsiders of de 'pottenkijkers' zoals Sennett ze noemt) die zich een oordeel over het gedrag van de insiders vormen. De insiders zoeken de oorzaken van normafwijkend gedrag vaak niet bij zichzelf, maar in externe factoren, vooral bij onduidelijke, formalistische of bureaucratische regels of handhaving van de regels. Een voorbeeld hiervan is te vinden in het onderzoek van Jesilow et al. (1991) naar fraude onder medici met declaraties bij sociale ziektekostenverzekeringen in de Verenigde Staten. In deze studie wordt medici die veroordeeld zijn wegens fraude gevraagd naar hun beweegredenen. Hoewel deze medici veroordeeld zijn, zijn ze er vrijwel allemaal van overtuigd dat ze niets verkeerd hebben gedaan: "[they] saw themselves as sacrificial lambs hung out to dry because of incompetent or backstabbing employees, stupid laws, bureaucratic nonsense, and a host of similar reasons." In veel gevallen is normafwijkend gedrag het gevolg van een subcultuur waarin dergelijk gedrag niet alleen wordt goedgepraat maar - na verloop van tijd - ook niet meer als verkeerd wordt gezien. Hyman (2001) voegt daaraan toe dat de sociale context waarin normafwijkend gedrag plaatsvindt invloed heeft op het oordeel over 
dergelijk gedrag: "Broadly speaking, physicians view such behavior (d.w.z. fraude - WG\&HMvdB) as essential to ensure high-quality care; program administrators view it as the price of the program; fraud control personnel view it as criminal misconduct; and the public's view depends greatly on who is benefitting" (Hyman 2001: 531).

Zoals hierboven al kort werd aangegeven, speelt de cultuur een belangrijke rol bij het vóórkomen van fraude en andere vormen van normafwijkend gedrag. Cultuur is ook belangrijk bij de vraag hoe met fraude wordt omgegaan. Een goed voorbeeld van dat laatste is het onderzoek Frauderisico-analyse in de Gezondheidszorg dat begin 2003 in opdracht van het ministerie van vws is gemaakt. Aanleiding voor dit onderzoek was een uitzending van het televisieprogramma Nova. Hierin werd melding gemaakt van twee rapporten naar fraude in de zorg. In deze rapporten - die waren opgesteld in opdracht van Zorgverzekeraars Nederland en van het Openbaar Ministerie - werd gesteld dat in de gezondheidszorg mogelijk voor honderden miljoenen euro's gefraudeerd wordt. In de Verenigde Staten - waar veel onderzoek naar fraude in de gezondheidszorg is gedaan gaat men er algemeen van uit dat vijf tot tien procent van alle declaraties frauduleus is.

Onder druk van de Tweede Kamer besloot de minister van vws om twee externe deskundigen een onderzoek te laten doen. De teneur van hun rapport was dat het met de fraude in de gezondheidszorg reuze meevalt. De argumenten die zij hiervoor geven zijn illustratief voor de manier waarop in Nederland met berichten over fraude wordt omgegaan. Drie reacties zijn hierbij te onderscheiden: het bagatelliseren van het probleem, het vergoelijken ervan en de aandacht verleggen.

Bagatelliseren gebeurt door de aandacht te vestigen op ondergeschikte onderdelen. Zo wordt in de samenvatting van het rapport de fraude met buitenlandse declaraties uitdrukkelijk genoemd. De omvang van de buitenlandse declaraties is maar vijftien miljoen euro per jaar. De omvang van deze fraude kan dus nooit veel zijn. Veel mensen lezen alleen de samenvatting en denken vervolgens: een paar procent van vijftien miljoen euro is niet iets om je druk over te maken. Het vergoelijken gebeurt door op te merken dat “... een deel van de fraude niet onder de noemer zelfverrijking valt”. Fraude is niet zo erg, zo wordt gesuggereerd, want “... de zo verworven middelen blijven wel binnen de gezondheidszorg en binnen de instelling”. Hoe de onderzoekers dat zo zeker weten is niet duidelijk. Ze hebben immers zelf geen onderzoek verricht. De derde manier om fraude onder tafel te houden is door de aandacht te verleggen. In het rapport wordt gewezen op de complexe budgetteringsystemen in de zorg, de hoge administratieve lasten en de tekorten en de wachtlijsten in de zorg. Vervolgens schrijven de onderzoekers: "Deze problematiek is voor de toekomst van de gezondheidszorg wellicht belangrijker dan de fraudeproblematiek." Een weinig subtiele poging om de aandacht af te leiden. 
Furubotn \& Richter (2000) betogen dat er een belangrijk verband is tussen rent seeking behavior en de werkwijze van de overheid: "Historically, the king, as the locus of public authority, could give exclusive rights to natural resources or other assets to favored individuals or groups. The latter could then capture the established monopoly rents. What developed therefore, was a system in which it became adventageous for people seeking government favors (e.g., aspiring monopolists) to make expenditures in order to lobby the king or other authorities and thus improve their chances of acquiring valuable rights. Such lobbying expenditures in the form of legal fees, bribes, and related expenses are, however, wasted resources from a social standpoint” (Furubotn \& Richter 2000: 105).

Baumol (2002) betoogt dat de economische groei en ontwikkeling in de westerse wereld vooral is veroorzaakt doordat rent seeking behavior werd verdrongen door productieve activiteiten: "Destructive wars and rent-seeking activities as means to enhance wealth and power, of course, continued through the Renaissance and, indeed, they manifestly continue today. The idea that productive activity is disgraceful continued to guide continental European nobility well into the nineteenth century. But at least in Italy, the Low Countries, and England things began to change, roughly in the thirteenth to fifteenth centuries. As capitalistic activity rose in these countries, the relative ease of wealth attainment through banking, commerce, and production seems to have become irresistable" (Baumol 2002: 64-65).

\subsection{ECONOMISERING VAN NORMEN EN WAARDEN BINNEN HUISHOUDENS}

Kennis van de economische theorie - met haar nadruk op keuzes die burgers moeten maken en de (financiële) offers die zij daarvoor moeten brengen - is van invloed op ons wereldbeeld. Naarmate de kennis van de economische theorie zich verder verspreidt in de samenleving, wordt de economische kijk op de wereld en de interpretatie van de werkelijkheid in termen van kosten en baten groter. Echter, door de hele geschiedenis heen hebben economische motieven een belangrijke plaats in het dagelijkse leven ingenomen. Normen en waarden in de samenleving zijn altijd nauw verbonden geweest met economische overwegingen en belangen (Groot \& Maassen van den Brink 2000).

Zo betoogde de zeventiende-eeuwse Leidse jurist Hugo de Groot dat vrouwen die slachtoffer waren geworden van een verkrachting financieel gecompenseerd behoorden te worden voor zowel de financiële als de morele schade. De morele schade van verkrachting ontstond - naar de opvatting van Hugo de Groot - door de schending van haar eer: door de verkrachting was ze ontmaagd of was haar seksuele reputatie aangetast. Doordat de schending van haar eerbaarheid nadelige gevolgen kon hebben voor haar huwelijkskansen, leidde verkrachting ook nog tot financiële schade (zie Van der Heijden 1998). Tegenwoordig beschouwen we verkrachting - terecht - als een zwaar misdrijf en niet meer als een vorm van 
kapitaalvernietiging. Normen en waarden veranderen. Wat dit voorbeeld ook illustreert is dat door de toegenomen welvaart de invloed van het economisch marktdenken - in de vorm van financiële compensatie - op normen en waarden minder wordt. Wij vinden het tegenwoordig hoogst ongepast een oordeel te geven over schending van normen en waarden in de vorm van verkrachting in termen van geld. Aan de andere kant wordt in onze samenleving steeds vaker getracht om psychische schade langs juridische weg financieel gecompenseerd te krijgen. Een voorbeeld hiervan is het bedrag dat een rechtbank onlangs heeft toegekend vanwege wrongful life van de geboorte van een verstandelijk en lichamelijk gehandicapt kind.

Opvattingen over normen en waarden hebben altijd sterk samengehangen met de economische situatie. Vaak wordt het Romeinse Rijk in de derde eeuw na Christus gezien als een voorbeeld van decadentie en verval van normen. Deze periode was er echter ook een van stabiliteit en voorspoed. De grenzen van het Romeinse Rijk waren relatief zeker, er waren weinig oorlogen en interne conflicten en er was economische voorspoed. Tijden van relatieve rust en economische voorspoed zijn een goede voedingsbodem voor liberale seksuele opvattingen.

Ten opzichte van de jaren voor de Eerste Wereldoorlog waren de jaren twintig een periode van stabiliteit en economische voorspoed. Na de beurskrach van 1929 begonnen de crisisjaren. De jaren dertig waren ook een periode waarin op het gebied van de normen en waarden de teugels weer wat werden aangetrokken. $\mathrm{Na}$ de Tweede Wereldoorlog was Europa verwoest en verarmd. De jaren vijftig waren jaren van wederopbouw. De handen werden uit de mouwen gestoken om Europa weer op te bouwen. Geen tijd voor liberale opvattingen over normen en waarden. In de jaren zestig was de opbouw voltooid. Nederland was welvarend geworden. De basis voor liberalisering van normen en waarden was daarmee gelegd.

In breder perspectief is er een historische band tussen het huwelijk - of meer in het algemeen relaties tussen twee individuen - en economie. Huwelijken werden - en worden in sommige landen nog steeds - gesloten op grond van economische overwegingen. In haar boek Huwelijk in Holland over de seksuele moraal in de zestiende eeuw schrijft Manon van der Heijden: "Zolang een familie bezit of inkomen had, speelden zakelijke belangen ook in lagere maatschappelijke kringen een belangrijke rol bij de huwelijkssluiting. De toestemming van de ouders, voogden of andere belanghebbenden was weliswaar geen vereiste, maar in de praktijk behielden ouders en familieleden hun zeggenschap." De verdeling van geld en bezit binnen relaties creëert afhankelijkheid en is van invloed op de (intieme) verhoudingen binnen het gezin. Er zijn door de geschiedenis heen vele voorbeelden van financiële overeenkomsten binnen families. In de negentiende eeuw was het vooral in de lagere sociale milieus normaal dat grootouders werden betaald voor het oppassen op de kinderen. Tot 1961 droegen kinderen financiële verantwoordelijkheid (zorgplicht) voor hun gepensioneerde ouders. Voor de invoering van de basisbeurs in het hoger onderwijs kregen ouders voor stude- 
rende kinderen kinderbijslag en waren zij financieel verantwoordelijk voor hun studerende kinderen. In veel ontwikkelingslanden zijn kinderen nodig om verzekerd te zijn van verzorging als men oud en hulpbehoevend is (Groot \& Maassen van den Brink 2000, 2001).

Nog altijd geldt dat los van vriendschap, (naasten)liefde en romantiek een huwelijk of relatie niet veel meer is dan een economische overeenkomst tussen personen. Een relatie, huwelijk of familieband verzekert tegen risico's in het leven. Als er geen inkomen meer is, zal een partner met een eigen inkomen uitkomst bieden. De gevolgen van een ziekte of ongeval zijn minder dramatisch als er een partner is die de zorg op zich kan nemen. Een relatie in deze zin biedt garanties op inkomen en verzorging. Een ander voordeel van een meerpersoonshuishouden is de gezamenlijke productie en het gebruik van goederen. Door woning, wasmachine en koelkast te delen met anderen kan op deze kosten worden bespaard. Een verbintenis is niet alleen gericht op het gezamenlijk voortbrengen van nageslacht. Het is ook een contract voor financiële steun en zorg voor elkaar.

Binnen het gezin wordt meestal zonder geld gerekend, daarbuiten wordt geld gevraagd. Verpleging voor een ziek familielid wordt zonder geld geregeld. Voor hetzelfde werk in een ziekenhuis moet worden betaald. Als geld zou worden gevraagd voor liefde binnen het gezin, zou raar worden opgekeken. Betaalde liefde komt alleen buiten het gezin voor, nemen we aan. Toch geldt ook binnen het gezin vaak 'Voor wat hoort wat'. Leden van het gezin worden meestal niet in geld betaald, maar krijgen op andere wijze iets terug voor wat ze doen.

Gezinsleden zijn door formele en informele afspraken met elkaar verbonden. Formeel door het huwelijks- of samenlevingscontract. Informeel door verwantschap en onderlinge banden. Relaties tussen gezinsleden zijn in de afgelopen veertig jaar zowel informeler als formeler geworden. De omgangsvormen binnen het gezin - en daarbuiten - zijn informeler geworden. Kinderen tutoyeren hun ouders en spreken ze bij de voornaam aan. Relaties binnen het gezin zijn daarnaast ook formeler geworden. Er wordt onderhandeld tussen gezinsleden. Niet zelden gebeurt dat op basis van eigenbelang: 'Ik doe voor jou dit als jij dat voor mij doet.' Wat krijg ik ervoor terug, is niet alleen buiten het gezin maar ook daarbinnen steeds vaker het motto. Rent seeking behavior wordt ook binnen het gezin steeds minder geaccepteerd: in het moderne onderhandelingshuishouden is het minder acceptabel dat gezinsleden iets ontvangen of ergens recht op hebben zonder dat daar een tegenprestatie tegenover staat.

Naarmate binnen het gezin zaken vaker geregeld worden via onderhandeling en op basis van eigenbelang, treedt de economie ook steeds verder het gezin binnen. Een logisch gevolg is dat geld binnen het gezin een steeds grotere rol krijgt. Geld zorgt ervoor dat transacties snel en gemakkelijk verlopen.

In een onderhandelingshuishouden ontstaat een behoefte aan een objectieve rekeneenheid en een makkelijk ruilmiddel. Zeker als de onderlinge banden losser 
worden, kan het zijn dat men liever direct geld voor geleverde diensten heeft dan de toezegging dat op een later tijdstip een wederdienst zal worden verricht. De overheid stimuleert dit afrekenen binnen het gezin ook. Bijvoorbeeld door het Persoonsgebonden Budget (PGB) in de gezondheidszorg. Het PGB kan worden gebruikt om professionele thuiszorghulp te kopen, maar het kan ook worden gebruikt om familie of kennissen in te huren om zorg te verlenen. Door het PGB bevordert de overheid de monetarisering van het gezin. Hetzelfde geldt voor de nieuwe wettelijke mogelijkheden om familieleden, vrienden en kennissen te betalen voor oppas en verzorging van kinderen. Onbetaalde hulp door familie of vrienden wordt betaalde verzorging. Dit heeft zowel voor- als nadelen. Waardering kan met het PGB worden omgezet in iets tastbaars. Nadeel is dat relaties er formeler door worden: ik bied je geld als jij mij verzorgt of helpt. Hulp bieden zonder dat daar direct iets tegenover staat, geeft vele mensen voldoening. Je doet iets goeds en zonder eigenbelang voor anderen. Door daar geld voor te bieden wordt dit minder. Een beloning in geld heeft gevolgen voor de intieme relaties tussen gezinsleden. Verhoudingen worden zakelijker. Geld lokt calculerend gedrag uit: word ik wel voldoende beloond voor wat ik doe? Bij handelingen uit vriendschap, sympathie of (naasten)liefde wordt deze vraag waarschijnlijk niet gesteld.

Het realiseren van eigen wensen heeft een grotere nadruk gekregen in het gezin.

Vroeger werd het normaal gevonden als de oudste dochter in het gezin thuis bleef om voor haar ouders te zorgen. $\mathrm{Zij}$ offerde zich op voor de zorg voor haar ouders. Het recht van de dochter om een eigen leven op te bouwen - een baan te zoeken, te trouwen en kinderen te krijgen - werd daarmee vaak ondergeschikt gemaakt aan het recht op verzorging van de ouders. Gelukkig denken we er tegenwoordig heel anders over en vinden we het normaal dat iedereen een eigen leven leidt. Voorzieningen als thuiszorg en verpleeghuiszorg hebben dit ook mogelijk gemaakt. Wel heeft dit ertoe geleid dat onbetaalde dienstverlening in de vorm van zorg van kinderen voor hun ouders is vervangen door betaalde hulp door ziekenverzorgenden en verpleegkundigen.

Een andere factor die de monetarisering van activiteiten binnen het meerpersoonshuishouden bevordert, is de toegenomen mobiliteit. Kinderen wonen vaak ver weg en kunnen niet altijd bijspringen als ouders verzorgd moeten worden. Door de daling van het kindertal moet de zorg ook door minder kinderen worden gedeeld. Dit betekent een grotere last per kind. Hierdoor wordt het sneller aantrekkelijk om professionele zorg in te huren in plaats van zelf voor een zieke moeder of vader te zorgen.

Hoewel velen hiertegen een natuurlijke weerstand hebben, heeft de economisering van het gezin ook voordelen. Behalve dat zij de waarde zichtbaar maakt biedt economisering mensen ook meer vrijheid hun leven naar eigen inzicht in te richten. De economisering van het gezin past in het streven naar zelfbeschikking en autonomie van mensen. Nadeel is dat geld ongelijkheid creëert. Zonder geld zijn mensen afhankelijk van (naasten)liefde (mantelzorg) en naarmate (naasten)liefde schaarser wordt, neemt de afhankelijkheid van geld toe. 
Een van de terreinen waarop de behoefte aan autonomie en zelfbeschikking het sterkst tot uiting komt, is dat van de levensbeëindiging. Euthanasie maakt van de dood een keuze. De dood zelf is geen keuze. Het moment van overlijden is dat in toenemende mate wel. Euthanasie biedt de mogelijkheid om het moment van overlijden zelf te kiezen. In de discussie over euthanasie wordt vaak het belangrijkste element ervan over het hoofd gezien, namelijk dat beëindiging van het leven door euthanasie een kosten-batenafweging wordt. Wegen de resterende levensverwachting en de kwaliteit van het leven nog wel op tegen het ondraaglijke lijden en de toenemende ontluistering van het bestaan? Een dergelijke kosten-batenafweging kan waardevol zijn. Je wilt niet leven tegen elke prijs. Er zijn echter ook gevaren. Het gevaar bij euthanasie zit er in dat kosten-batenafwegingen een te grote rol gaan spelen. Dat niet alleen wordt meegewogen of er sprake is van uitzichtloos lijden, maar ook of de medische zorg niet beter besteed is aan patiënten met grotere overlevingskansen. Om te voorkomen dat buiten ondraaglijk lijden ook andere kosten en baten van invloed zijn op de beslissing om tot euthanasie over te gaan, is euthanasie met regels omgeven. Belangrijk is dat steeds kan worden getoetst of de arts met voldoende zorgvuldigheid te werk is gegaan. Het probleem is echter dat de controle hierop tekortschiet.

Sinds 1998 moet euthanasie worden gemeld bij een regionale toetsingscommissie. Deze toetsingscommissie - bestaande uit een jurist, een ethicus en een arts bekijkt of de arts zich aan de wettelijke regels heeft gehouden. Voor 1998 werd dit door het Openbaar Ministerie onderzocht. Een belangrijk verschil is dat voor 1998 euthanasie in principe stafbaar was. Het Openbaar Ministerie had de mogelijkheid om niet tot vervolging over te gaan als de arts zorgvuldig had gehandeld. Sinds 1998 is euthanasie in principe niet meer strafbaar, maar kan de regionale toetsingscommissie aangifte doen bij het Openbaar Ministerie als de arts niet zorgvuldig heeft gehandeld. De wet is veranderd van 'strafbaar, tenzij...' in 'niet strafbaar, mits...' Sinds de invoering van de regionale toetsingscommissies is het totale aantal meldingen van euthanasie jaarlijks afgenomen, van 2216 in 1999 tot 1882 in 2002. Uit onderzoek van Van der Wal en Van der Maas blijkt verder dat slechts iets meer dan de helft van de euthanasiegevallen wordt gemeld bij de regionale toetsingscommissies. Bijna nooit komen de regionale toetsingscommissies tot de conclusie dat de arts onzorgvuldig heeft gehandeld. Dit kan natuurlijk komen doordat alle artsen de regels goed toepassen. Er kan ook iets anders aan de hand zijn.

Het is mogelijk dat artsen alleen die gevallen aanmelden waarvan ze zeker zijn dat ze zorgvuldig hebben gehandeld. Het feit dat maar de helft van de gevallen van euthanasie wordt gemeld maakt dat aannemelijk. Daarnaast zitten de toetsingscommissies met een groot dilemma. Als ze te streng oordelen zijn artsen minder geneigd euthanasie te melden. Als ze te mild oordelen wordt het een papieren tijger. Niet alleen hollen ze daarmee hun eigen functie uit. Artsen gaan zich afvragen waarom ze gevallen nog langer moeten melden bij een instantie die alles goedkeurt. Zowel strenge als milde toetsingscommissies leiden er uiteindelijk toe dat artsen minder vaak gevallen van euthanasie melden. De indruk is 
overigens dat regionale toetsingscommissies vooral niet te streng willen zijn om het melden van euthanasie niet af te schrikken. Artsen melden steeds minder gevallen van euthanasie. De regionale toetsingscommissies schieten tekort. Evenals op veel andere terreinen wordt bij euthanasie te veel vertrouwd op zelfregulering en is echte controle taboe. Op de vraag of gebrek aan controle tot ontsporingen kan leiden rust vaak eveneens een taboe. Hier is een analogie met het gebrek aan controle dat aanleiding geeft tot fraude bij de overheid en in het bedrijfsleven, dat in de vorige paragraaf aan de orde is gekomen.

Betaalde arbeid levert een belangrijke bijdrage aan het ontwikkelen van normen en waarden bij individuen en binnen het gezin. Veel jongeren leren elementaire normen en waarden - zoals beleefdheid, luisteren, doen wat gezegd wordt, op tijd komen - vooral tijdens hun eerste baantje op zaterdag in de supermarkt.

Betaalde arbeid neemt bij vrijwel iedereen tegenwoordig een zeer centrale plaats in zijn - en steeds vaker ook haar - leven in. Een groot deel van het leven wordt immers besteed aan (betaalde) arbeid. Betaalde arbeid is niet alleen een bron van normen en waarden, opvattingen over betaalde arbeid en het arbeidsproces zelf worden in hoge mate door normen en waarden bepaald. Elster (1989) omschrijft het aldus: "The work place is a hotbed of norm-guided action (...) There is a social norm against living off other people and a corresponding normative pressure to earn one's income from work" (Elster 1989: 121).

\subsection{CONCLUSIE}

Vooral bij niet-economen bestaat soms de vrees dat er sprake is van economisering van de samenleving en dat 'het dominante economisch marktdenken' tot een erosie van normen en waarden leidt. De economisering van de samenleving zou daarbij tot uitdrukking komen in een formalisering van relaties en gedrag dat gebaseerd is op directe kosten-batenafwegingen. Economisering van de samenleving is naar onze mening niet zozeer het gevolg van 'het dominante marktdenken', maar een direct resultaat van de toegenomen mobiliteit in de samenleving. Zowel arbeidsrelaties als gezinsrelaties zijn korter geworden. Werknemers veranderen vaker van baan, huwelijken eindigen vaker in echtscheiding. Daarnaast is de geografische mobiliteit toegenomen, waardoor mensen minder dan vroeger langere tijd op één plek wonen en vaker de plaats en de regio verlaten waar ze zijn opgegroeid en waar ouders en naaste familie wonen. De toename van de mobiliteit en de kortere duur van relaties leidt tot formalisering van relaties. Dit komt doordat voor het opbouwen van informele relaties vertrouwen nodig is, vertrouwen gebaseerd is op reputatie en het tijd kost voordat een betrouwbare reputatie is opgebouwd. Formalisering van kortdurende relaties werkt in de hand dat mensen hun gedrag meer laten leiden door een directe kosten-batenafweging. De oorzaken van economisering van de samenleving liggen voor een belangrijk deel buiten het economisch domein. 
Economisering van de samenleving leidt in onze ogen niet tot een erosie van normen en waarden. Productie, handel en transacties worden beïnvloed door de waarden en normen van de samenleving waarin deze economische activiteiten plaatsvinden. Normen en waarden vormen - om het in economische termen uit te drukken - restricties op het handelen van economische actoren. Niet alleen bepalen normen en waarden het economisch handelen, bij het ontwikkelen van normen en waarden spelen economische overwegingen als efficiëntie een belangrijke rol: normen en waarden worden gevormd om het economische proces doelmatig te doen verlopen. De aanwezigheid van waarden als integriteit, betrouwbaarheid en vertrouwen zijn noodzakelijke voorwaarden voor een efficiënt verloop van het economisch proces. Als gevolg hiervan bevordert en beloont het economische marktproces ook de ontwikkeling van deze positieve waarden.

Waarden en normen kunnen een grote economische waarde hebben en de welvaart vergroten. Een samenleving met grotere en breder gedragen normen en waarden kan een hogere economische groei realiseren. Omgekeerd draagt een grotere welvaart bij aan versterking van normen en waarden. Waarden als altruisme en solidariteit gedijen beter in een welvarende samenleving. Welvaart is een voorwaarde voor maatschappelijke waarden als solidariteit en altruïsme. In economische termen zijn normen en waarden een luxegoed.

De positieve bijdrage van het economische marktproces aan de ontwikkeling van normen en waarden in de samenleving laat onverlet dat ook in een markteconomie normafwijkend gedrag kan voorkomen. In deze bijdrage hebben wij betoogd dat normafwijkend gedrag een gevolg is van imperfecte marktwerking - gebrek aan informatie en transparantie of van marktmacht. Controle en inspectie van gedrag dragen bij aan vergroting van informatie en transparantie. In deze bijdrage hebben wij betoogd dat op verschillende terreinen - variërend van fraude in het bedrijfsleven en in de zorg tot euthanasie - gebrek aan controle normafwijkend gedrag in de hand werkt.

Verder is gewezen op de rol van cultuur bij normafwijkend gedrag. Hierbij valt op dat normafwijkend gedrag, zoals fraude, in Nederland vaak wordt gebagatelliseerd en vergoelijkt. De rol van de overheid is hierbij belangrijk. Niet alleen heeft de overheid een taak bij het bestrijden van fraude, zij heeft ook een belangrijke voorbeeldfunctie. De overheid onttrekt zich aan de markt. Het gevaar voor normafwijkend gedrag bij de overheid is daardoor groter. Correctiemechanismen die op de markt wel werken, werken bij de overheid vaak niet. 


\section{NOTEN}

1 Dit citaat wordt nog begrijpelijker als men bedenkt dat het werk van een slager door Smith wordt omschreven als 'brutal and odious' (Smith 1976 [1776]: 117).

2 Daarmee is overigens niet gezegd dat sociale normen overal en altijd leiden tot vergroting van de welvaart. Sociale normen kunnen negatieve externe effecten hebben. Een voorbeeld van normen en waarden met een negatief welvaartseffect is de multiculturele samenleving. Normen over de multiculturele samenleving hebben lange tijd remmend gewerkt op de inburgering van allochtonen. Zo werden allochtonen onvoldoende aangemoedigd en verplicht zich de Nederlandse taal eigen te maken. Het gevolg van het gebrek aan inburgering was hoge werkloosheid onder allochtonen. De geringe inzetbaarheid van allochtonen op de arbeidsmarkt brengt hoge maatschappelijke kosten met zich mee en leidt tot welvaartsverliezen. Elster (1989: 139-150) geeft meerdere voorbeelden van sociale normen met een negatieve invloed op de sociale welvaart.

Posner (1998) plaatst een opmerkelijke en enigszins cynische kanttekening bij de relatie tussen eigenbelang en normen: “... I do not myself believe that many people do things because they think they are the right thing to do unless they have first used the plasticity of moral reasoning to align the 'right' with their selfinterest" (Posner 1998: 560).

4 Vanzelfsprekend hoeft altruïsme niet altijd gepaard te gaan met de directe overdracht van geld. Echter, ook als altruïsme de vorm heeft van handelingen en acties die tot doel hebben de situatie van minderbedeelden te verbeteren, kan worden gesproken over het opofferen van tijd. De alternatieve kosten van de tijdsbesteding kunnen worden gezien als een vorm van inkomensoverdracht. Zoals bij veel economische theorieën zijn ook voor dit inzicht aanwijzingen te vinden in het werk van Adam Smith. Echter, ditmaal niet in The Wealth of Nations maar in een eerder werk, The Theory of Moral Sentiments (Smith 1790). In dit laatstgenoemde werk - waarvan de eerste editie verscheen vóór The Wealth of Nations - betoogt Smith dat sympathie of medeleven met anderen de basis voor moreel handelen is. Voor een nadere uitwerking van deze gedachte, zie Groot \& Maassen van den Brink (2003).

Voormalig minister-president Kok sprak in dit verband van 'exhibitionistische zelfverrijking'. Ogenschijnlijk leek hier sprake te zijn van een verspreking en bedoelde Kok 'exorbitante zelfverrijking'. De vraag is of het probleem vooral te maken heeft met zelfverrijking of met het exhibitionistische karakter ervan. Een recent voorbeeld hiervan is de beloning van de nieuwe voorzitter van de Raad van Bestuur van Ahold, Moberg. Zijn salaris werd in onderhandeling met de voorzitter van de Raad van Commissarissen vastgesteld zonder dat de aandeelhouders hierover konden beslissen. 


\section{LITERATUUR}

Alesina, A., \& W. La Ferrara (2000) The determinants of trust, NBER Working Paper 7621. Arrow, K. (1972) 'Gifts and exchanges', Philosophy and Public Affairs, 1: 343-362.

Baumol, W. (2002) The Free-Market Innovation Machine. Analyzing the Growth Miracle of Capitalism, Princeton: Princeton University Press.

Becker, G. (1996) Accounting for Tastes, Cambridge (MA): Harvard University Press.

Brief, A., J. Dukerich, P. Brown \& J. Brett (1996) 'What's wrong with the treadway commission report? Experimental analysis of the effects of personal values and codes of conduct on fraudulent financial reporting', Journal of Business Ethics, 15: $183-198$.

Buchanan, J., R. Tollison \& G. Tullock (red.) (1980) Toward a Theory of a Rent Seeking Society, College Station: Texas A\&M University Press.

Cohan, J. (2002) “'I didn't know” and “I was only doing my job”: has corporate governance careened out of control? A case study of Enron's information myopia', Journal of Business Ethics, 40: 275-299.

Cole, B., \& D. Smith (1996) 'Perceptions of business ethics: students vs. business people', Journal of Business Ethics, 15: 889-896.

Collins, D. (2000) 'The quest to improve human conditions: the first 1500 articles published in Journal of Business Ethics', Journal of Business Ethics, 26: 1-73.

Cooter, R. (1998) 'Expressive law and economics', Journal of Legal Studies, 27: 585.

Donaldson, T. (2001) 'The ethical wealth of nations', Journal of Business Ethics, 31: $25-36$.

Eastman, K., J. Eastman \& A. Eastman (1996) 'The ethics of insurance professionals: comparison of personal versus professional ethics', Journal of Business Ethics, 15: 951-962.

Elster, J (1989) ‘Social norms and Economic Theory', Journal of Economic Perspectives, 3 (4): 99-117.

Elster, J. (1989) The Cement of society: A Study of Social Order, Cambridge: Cambridge University Press.

Ford, R., \& W. Richardson (1994) 'Ethical decision making: a review of the empirical literature', Journal of Business Ethics, 13: 205-221.

Friedman, M. (1970) 'The social responsibility of business is to increase its profits', The New York Times Magazine, $13^{\text {th }}$ September.

Fukuyama, F. (1995) Trust, New York: Free Press.

Fukuyama, F. (1999) The Great Disruption: Human Nature And The Reconstitution of Social Order, Londen: Profile Books.

Furubotn, E., \& R. Richter (200o) Institutions and Economic Theory. The Contribution of the New Institutional Economics, Ann Arbor: The University of Michigan Press.

Glaeser, E., D. Laibson, J. Scheinkman \& C. Soutter (1999) What is social capital? The determinants of trust and antitrust, NBER Working Paper 7216.

Glaeser, E., D. Laibson, J. Scheinkman \& C. Soutter (2000a) 'Measuring trust', Quarterly Journal of Economics, 115: 811-846.

Glaeser, E., D. Laibson \& B. Sacerdote (200ob) The economic approach to social capital, NBER Working Paper 7728. 
Groot, W., \& H. Maassen van den Brink (2000) Lusten en Lasten. Over Economie en Emotie, Amsterdam: Prometheus.

Groot, W., \& H. Maassen van den Brink (2001) 'Het Gezin BV’, Trouw, december 2001.

Groot, W., \& H. Maassen van den Brink (2003) 'Sympathy and the value of health: the spill-over effects of migraine on household well-being', Social Indicators Research, 61: 97-120.

Gunthorpe, D. (1997) 'Business ethics: a quantitative analysis of the impact of unethical behavior by publicly traded corporations', Journal of Business Ethics, 16: 537-543.

Heijden, M. van der (1998), Huwelijk in Holland, Amsterdam: Bert Bakker.

Hyman, D. (2001) 'Health care fraud and abuse: market change, social norms, and the trust "reposed in the workmen"', Journal of Legal Studies, 30: 531-567.

Jelisow, P., G. Geis \& H. Pontell (1991) 'Fraud by physicians against meicaid', JA MA, 3318: 3320-3321.

Knack, S., \& P. Keefer (1997) 'Does social capital have an economic payoff? A cross-country investigation', Quarterly Journal of Economics, 112: 1251-1288.

Lindbeck, A., S. Nyberg \& J. Weibull (1999) 'Social norms and economic incentives in the welfare state', Quarterly Journal of Economics, 114: 1-35.

Lindbeck, A. (2001) 'Incentives and Social Norms in Household Behavior', A EA Papers, and Proceedings, 87 (2): 370-377.

Loe, T., L. Ferrell \& P. Mansfield (2000) 'A review of empirical studies assessing ethical decision making in business', Journal of Business Ethics, 25: 185-204.

Posner, R. (1998) 'Social norms, social meaning, and economic analysis of law: a comment', Journal of Legal Studies, 27: 553-565.

Posner, B., \& W. Schmidt (1987) 'Ethics in American companies: a managerial perspective', Journal of Business Ethics, 6: 383-391.

Rao, S., \& B. Hamilton (1996) 'The effect of published reports of unethical conduct on stock prices', Journal of Business Ethics, 15: 1321-1330.

Sennett, R. (2003) Respect in een Tijd van Sociale Ongelijkheid, Amsterdam: Uitgeverij Byblos.

Smith, A. $(1976,1776)$ An Inquiry into the Nature and Causes of the Wealth of Nations, Oxford: Oxford University Press.

Smith, A. (1974, 1790) The Theory of Moral Sentiments, Oxford: Oxford University Press.

Wereldbank, http://www.worldbank.org/poverty/scapital/

Yamagishi, T., \& Yamagishi, M. (1994) 'Trust and commitment in the United States and Japan', Motivation and Emotion, 18: 129-166.

Zak, P., \& S. Knack (2001) 'Trust and growth', Economic Journal, 111: 295-321. 


\title{
13 WAARDEN DOEN ERTOE IN DE ECONOMIE
}

\author{
A. Klamer
}

\subsection{INLEIDING}

"Intellectuals in the year 2000 - philosophers or social scientists, literary critics or economists have inherited a family of problems about the idea of Rationality and its relations to those of necessity and certainty. But they tend to ignore the more practical, complementary idea of Reasonableness, or the possibility of living, as in pre-modern times, without any absolute necessities or certainties" (Stephen Toulmin 2001: 1).

De overheid handelt nooit vrij van waarden. Wanneer ze energiebedrijven liberaliseert, stelt ze de waarden van de markt boven de waarden van de publieke sfeer. Voorzover een dergelijke ingreep een verschuiving teweegbrengt in sociale en economische omgangsvormen, beïnvloedt de overheid tevens de normen van onze samenleving - zoals in de norm van loon naar prestatie. Ook bedrijven opereren in een sfeer van waarden en kunnen met hun operaties die sfeer beïnvloeden. Het maakt wat uit wanneer het management de winst boven zijn maatschappelijk verantwoordelijkheid stelt of wanneer het eerder taakgericht dan mensgericht opereert. Waarden doen ertoe in de economie.

Sterker nog, geen (economische) handeling is waardevrij. En dan gaat het niet alleen om het al dan niet kopen van Max-Havelaar-koffie. Werken versus zorgen, economische versus sociale ambities, luxevakanties versus goede doelen: steeds weer gaat het om de afweging van wat wij belangrijker, waardevoller vinden. Er is geen ontkomen aan. Waarden bepalen ons leven en het samenleven, ook in de economie.

In die zin is een aparte discussie over waarden en normen bevreemdend. Alsof anders waarden en normen er niet toe doen. Iedere discussie, of deze nu gaat over de liberalisering van de energiemarkt, de WAO of beloningen van topbestuurders, gaat uiteindelijk over waarden en (her)waarderingen. Dus waar hebben we het over? Gaat het soms vooral over fatsoen en goede manieren? Of staat er meer op het spel? Onze beschaving misschien?

Ik bedoel met de beschaving het tapijt van waarden en normen dat door de eeuwen heen geweven is, dus inclusief de waarden en normen die het economisch handelen bepalen. Kenmerkend voor de Nederlandse beschaving zou bijvoorbeeld kunnen zijn dat zelfverrijking onbetamelijk, solidariteit iets goeds en overleg wenselijk is. Zien we een ontrafeling van dat weefsel, dan hebben we een goede reden om waarden en normen op de politieke en sociale agenda te zetten en het te hebben over wat het goede leven en samenleven voor ons in deze samenleving inhoudt. ${ }^{1}$ 
Een discussie over waarden en normen gaat meestel over een verlies daarvan. Mensen hebben het over waarden wanneer ze verontrust raken door verschuivingen in waarden en herwaarderingen, wanneer ze kampen met het gevoel iets waardevols te verliezen. Waar anderen winst prediken, ervaren zij verlies. Zij die het momentum hebben, kunnen doen alsof het om iets economisch, iets zakelijks gaat, dus niet om iets wat met waarden te maken heeft - ook al is dat wel degelijk het geval. Zij die verlies ervaren, willen het juist wel over de voor hen belangrijke waarden en normen hebben.

Het is een ongelijke strijd. De minister die inzet op het economische, pleit voor een zakelijke aanpak en wijst op het begrotingstekort, trekt aan het langste eind. Althans, zo is de situatie vandaag de dag. Een discussie over waarden en normen lijkt alleen een kans te krijgen in een economische luwte met overschotten. Zodra de economie weer de aandacht opeist, waait deze discussie snel over. De economie is hard en concreet; waarden zijn zacht en vaag en ongrijpbaar. Het is gemakkelijker de economische groei te benoemen en een begrotingsnorm vast te stellen dan waarden als zorgzaamheid en respect bespreekbaar te maken. Daarom zijn de meeste discussies over waarden en normen impliciet: we hebben het erover zonder dat direct te erkennen. Of het nu over efficiëntie of over solidariteit gaat, het gaat om waarden en waarderingen.

Laat dat duidelijk zijn: ook degene die betoogt dat het tijd wordt voor een zakelijke aanpak van, pakweg het onderwijs of de cultuur, gaat een discussie over waarden aan. Blijkbaar vindt deze persoon de heersende waarden bedenkelijk, zoals de waardering van overleg en consensus. "Neen”, aldus het betoog, "we moeten knopen durven doorhakken, ondernemingslust tonen, met als doel meer winst." Het is een zakelijk betoog, maar daarom niet gespeend van waarden. Een overheid die een dergelijk betoog steunt, waardeert. Dat is ook het geval wanneer ze de creatie van werk boven aan de agenda zet. 'Werk, werk, werk!' impliceert een waardering. Of het nu gaat om loon naar prestatie, meer concurrentie in de taximarkt, een eigen bijdrage in de ziektekosten of een tolheffing, iedere keer weer staan waarden op het spel.

\subsection{HET CULTUREEL-ECONOMISCH PERSPECTIEF}

In deze bijdrage is het voornaamste doel het belichten van een cultureel-economisch perspectief, omdat deze mijns inziens het meeste zicht biedt op de rol van waarden en normen in economische context. Dit perspectief komt voort uit een eerbiedwaardige traditie in de economische wetenschap die ongeveer begint met Aristoteles en via Thomas van Aquino, Adam Smith, John Maynard Keynes wellicht, en in het heden voeding krijgt in de werken van onder anderen Deirdre McCloskey. In deze traditie staan waarden centraal; steeds weer gaat het om de vraag of een economische orde, handeling en uitkomst bijdragen aan het goede leven en samenleven. Ze maakt intensief gebruik van discussies in verwante sociale wetenschappen alsmede de filosofie, vooral de 
deugden-filosofie (vgl. Granovetter, Zelizer, Etzioni, MacIntyre, Taylor, Nussbaum).

Dit cultureel-economisch perspectief is niet wat de student economie in de handboeken krijgt aangereikt. Daar gaat het eerder om de vraag welk arrangement, welke prikkel, welk beleid bijdraagt tot de maximalisering van de economische groei, de winst dan wel het individuele nut. Het beeld is dat van rationele individuen die met gegeven voorkeuren, of preferenties, en met immer schaarse middelen het beste proberen te bereiken. Alle aandacht gaat vervolgens naar de efficiëntie van markten en de doelmatigheid van publieke diensten. Het uiteindelijke criterium is de economische groei. Waarden en normen komen niet aan bod in een dergelijke verhandeling. Ze zijn in ieder geval geen onderwerp voor het economisch handboek (Klamer 2003c).

De verleiding is groot om het 'waarden-loze' van de dominante economische denkwijze bloot te leggen en te laten zien hoe beperkend en misleidend de eng economische zienswijze is. Dergelijk kritisch werk is belangrijk, temeer omdat zovele niet-economen deze eng economische zienswijze etaleren zonder zich bewust te lijken zijn van hun inspiratiebron. ${ }^{2}$ Desalniettemin geef ik er de voorkeur aan het cultureel-economisch perspectief te benadrukken, omdat dit meer te bieden heeft aan beleidsmakers die zich een beeld willen vormen van de waarden en normen die hun beleid versterken dan wel ontkrachten. Het laat zien dat de economie meer is dan iets praktisch en doelmatigs, dat waarden ertoe doen en dus dat ingrepen in de economische orde consequenties hebben voor de aard van onze beschaving.

\subsection{MET BETREKKING TOT WAARDEN}

Waarden zijn overal en nergens. Ze zijn overal omdat geen handeling zonder waarde is. Ze zijn nergens omdat ze niet tastbaar zijn en vrijwel nooit expliciet benoemd worden. Weet $\mathrm{u}$ uw belangrijkste waarden op te noemen? Ik niet. Is het eerlijkheid? Waarachtigheid? Wetenschappelijke integriteit misschien? Wanneer is iemand dan oneerlijk? Moet iemand zijn baas vertellen wat hij precies van hem vindt 'omdat dat eerlijk is'? Sommige bedrijven maken er werk van om hun kernwaarden te benoemen. Dus weten we dat het hun gaat om 'integriteit', 'respect,' 'resultaatgerichtheid' en nog andere waarden. De vraag is hoe de werknemers met die waarden omgaan in hun dagelijkse bezigheden. Zouden ze ermee werken? Of zijn die waarden eerder bedoeld voor een goed gevoel en de pr? Wetenschappers zeggen graag dat het hun om de waarheid te doen is, maar het lijkt in de alledaagse wetenschappelijke praktijk eerder te gaan om zaken als aandacht, erkenning, status, betekenis en het belang van de wetenschap in het algemeen en de eigen wetenschap in het bijzonder. Eerlijkheid? Waarachtigheid?

En toch handelen we naar onze waarden. Iedere handeling houdt een waardering in. Ik ben nu aan het schrijven en heb dus even geen tijd voor de kinderen, voor 
facultaire aangelegenheden, voor gesprekken met studenten etc. Door te schrijven geef ik aan dat ik het vervullen van een opdracht hoger waardeer dan al het andere dat ik zou willen doen. Wie zal kunnen zeggen welke waarden allemaal meespelen? Verantwoordelijkheidsgevoel wellicht? Een economische waarde misschien? Status? Of toch gewoon liefde voor het vak? Betekent dit dat die liefde sterker is dan de liefde voor mijn kinderen? Misschien verzaak ik mijn verantwoordelijkheid als vader wel door hier te zitten en denkt mijn vrouw er het hare van. Wie weet?

Waarden worden gauw bijzonder en verheven in een discussie over waarden en normen. Bepaal ik me tot de economische context, dan gaat het over zaken als fraude, al dan niet milieubewust opereren, maatschappelijk verantwoord ondernemen en rechtvaardigheid. Dit zijn allemaal bijzondere en grote waarden. Daar valt veel over en voor te zeggen. Volg de economische discussie en je ziet in dat het huidige accent op efficiëntie ten koste zal gaan van de rechtvaardigheid (Okun 1975; Hausman \& McPherson 1996). Meer marktwerking zou grotere ongelijkheid in de hand kunnen werken. Daar staat tegenover dat een genereus sociaal beleid ten koste kan gaan van de economische productiviteit en daarmee van de welvaart. Economen, voorzover ze waarden en normen bespreken, bevorderen deze verbijzondering van waarden tot veelomvattende, globale begrippen. Schrijft de econoom McPherson samen met de filosoof Daniel Hausman over Economic analysis and moral philosophy (1996), dan gaat het juist over de grote en abstracte waarden van rechtvaardigheid en billijkheid. Daar zou economisch beleid op gericht moeten zijn, zo beweren zij. Terecht, maar er is zoveel meer waar het beleid mee rekening dient te houden, met zoveel meer waarden vooral.

Om duidelijk te maken hoe waarden het handelen kunnen beïnvloeden, geef ik twee voorbeelden. Het eerste voorbeeld schetst een persoonlijke situatie waarin sommige lezers zich wellicht kunnen herkennen.

\subsection{TWEE VOORBEELDEN}

De zoon zou oppassen. Dat was duidelijk afgesproken. Een week van tevoren zelfs. Een dag voor de bewuste avond komt hij met de mededeling dat hij niet kan. De buren hebben gebeld dat hij diezelfde avond bij hen kan oppassen. Sorry. Een discussie tussen de ouders volgt. Ze zien hun lang voorgenomen avond uit in rook opgaan. Ouder 1 stelt voor zoon te betalen wat hij bij de buren zou verdienen. Ouder 2 is faliekant tegen en wil zoon aan zijn afspraak houden. Waarop ouder 1 tegenwerpt dat hij dan nooit meer zal willen oppassen. Ouder 2 waarschuwt dat zoon voortaan altijd geld wil zien voor een oppasbeurt en heeft het vervolgens over verantwoordelijkheidsbesef, loyaliteit en wederkerigheid. De discussie is heftig en emotioneel. Ouder 2 slaat met de deur en roept iets over verloedering.

Je zou kunnen zeggen dat deze situatie over belangen gaat en wel de belangen van zoonlief, van de ouders die een avondje uit willen en die van de buren die blijk- 
baar ook iets moeten. Je zou ook kunnen zeggen dat het over schaarste gaat en dan vooral de schaarste aan oppassen die op afroep beschikbaar zijn en dus op de prijs van een oppas. Maar het gaat ook over waarden. Voor de zoon is het duidelijk waar het om gaat en dat is geld. Thuis blijven is kostbaar vanwege het inkomen dat hij dan misloopt: hij benadrukt wat economen zijn opportunity costs noemen. Ouder 1 gaat daarin mee en ziet de oplossing in een marktachtige deal: zoonlief blijft thuis in ruil voor de geldende marktprijs. Je zou kunnen zeggen dat deze ouder het marktmodel volgt. Er is erkenning voor de prijs van oppassen, de opportunity costs van de zoon en wellicht ook wel waardering voor de ondernemingslust en onderhandelingsstrategie van zoonlief. Mijn ervaring in de vs suggereert dat deze ouder in dit opzicht zich goed zal thuis voelen in een Angelsaksisch klimaat. Want daar staan waarden als ondernemerslust, initiatief en een goede deal voorop.

Ouder 2 zal zich wellicht eerder gesteund weten in een Franse omgeving waar, zo vertellen informanten mij, de zoon buiten de orde is door zelfs maar te suggereren zijn verplichting op te geven voor het geld van de buren (zie de bijdrage van Pessers). In een dergelijke omgeving is iedere vorm van onderhandeling onbetamelijk, laat staan de verwachting van betaling voor een taak; zoon zal doen wat hem opgedragen wordt. Het gaat nu om waarden als loyaliteit, plicht, verantwoordelijkheid, autoriteit (van de ouders dan) en het primaat van het gezin, de familie. De situatie zoals beschreven is typisch Nederlands, want er wordt natuurlijk weer overlegd. Er is geen sprake van dat de vader zoonlief subiet terechtwijst, of dat een deal vanzelfsprekend is. De ouders overleggen, waarbij de zoon ongetwijfeld een kans krijgt een duit in het zakje te doen. (De typisch Nederlandse oplossing is het compromis. In dit geval regelt de zoon een vriendin om op te passen, zodat hij zelf het geld kan verdienen. De ouders moeten dus toch betalen voor de oppas.)

Het voorval is onbetekenend in het grote geheel. Maar ze tekent hoe waarden opereren. Laat me een paar punten maken.

Een 'waarden-loze' positie is ondenkbaar. De kans is groot dat ouder 2 tijdens de discussie, dan wel in gesprekken met vrienden, zal klagen over het verval van waarden en normen: "Moet je nou eens horen, wij moesten onze zoon betalen om op te passen. Dat was wel anders vroeger. Waar moet dit heen?” Ouder 2 merkt dat zijn waarden minder vanzelfsprekend zijn dan de waarden waar ouder 1 zich op beroept. Net als degenen die momenteel voor meer markt, meer individuele keuze, meer privatisering en minder genereuze sociale voorzieningen pleiten, kan ouder 1 volstaan te wijzen op dat wat prudent, efficiënt dan wel praktisch is. Dat zijn allemaal waarden, maar omdat zij de tijdgeest van nu bepalen, hoeven ze niet als waarden benoemd te worden. Dat neemt niet weg dat in iedere discussie, in iedere afweging waarden bepalend zijn. Ook wanneer de oplossing van het probleem de markt is. (Dus geen economische benadering is 'waardenloos', houd ik mijn collega-economen voor.) 
Waarden manifesteren zich gewoonlijk in de vorm van morele gevoelens. Al gaat het in de discussie om waarden als individuele keuze, ondernemerschap, verantwoordelijkheid en betrouwbaarheid, ouders behoeven die waarden niet expliciet te benoemen in hun discussie. Zijn die waarden evenwel belangrijk voor hen, dan merken ze dat in de vorm van gevoelens. U kent het waarschijnlijk wel: de woede die u voelt omdat de ander niet meegaat, of de teleurstelling, of het immense gevoel van tevredenheid wanneer de discussie uw kant opgaat. Je ziet ouder 2 kwaad weglopen en hoort de deuren slaan wanneer blijkt dat zoonlief met geen mogelijkheid thuis te houden is. De Schotse verlichtingsfilosofen, onder wie Adam Smith, spraken daarom van morele gevoelens. Zij bepalen onze reactie; eventuele woorden zijn secundair. Willen we morele gevoelens onderdrukken met een beroep op redelijkheid, dan kan het effect averechts zijn. Hoewel Nederlanders over het algemeen vatbaar zijn voor een beroep op redelijkheid, de beide ouders in ons voorval zouden wel eens uit hun slof kunnen schieten wanneer de ander dat beroep doet. "Wie is hier onredelijk?"

De beïnvloeding van de overheid is indirect. Geen wet of voorschrift geeft aan of een zoon betaald moet worden voor een huiselijke taak of niet. De ouders zijn niet strafbaar wanneer ze hem verplichten thuis te blijven. Dat wil niet zeggen dat de ouders alles kunnen doen wat hun goeddunkt. Krijgen alle kinderen betaald om thuis op te passen, dan moeten de ouders van goeden huize komen om de zoon niet te betalen. Gaat loyaliteit boven alles in een samenleving, dan riskeren ouders sociale afkeur mochten zij hun zoon liever betalen. Het gaat dus om het klimaat waarin de ouders opereren. In dit land is het klimaat nu aanzienlijk anders dan toen ik opgroeide. Ik betwijfel dat mijn vrienden zelfs ook maar op de gedachte gekomen zouden zijn geld te vragen, laat staan dat ze het kregen. Is het klimaat voor een belangrijk deel bepalend voor de uitkomst van dit soort discussies, dan blijft de vraag wat de overheid kan bijdragen aan dan wel afdingen op dit klimaat. Wellicht is de overheid onderdeel van het klimaat en verwoorden politici wat onder de mensen leeft (want anders zouden ze niet gekozen zijn). Ik houd het er voorlopig op dat de overheid met haar beleid en haar retoriek bepaalde waarden bevestigt en daarmee kan versterken, terwijl ze andere waarden ontkent dan wel afzwakt.

De betekenis van topoi (gemeenplaatsen) en personages ('characters'). Hoe bepalend huiselijke discussies zijn in de vorming van sociale en maatschappelijke waarden, is moeilijk te zeggen. De huiselijke discussies worden natuurlijk ook beïnvloed door de discussies die de huisgenoten meemaken rond hen heen, in de media, in de soaps, in boeken, onder vrienden en op het werk. Ik onthoud me van causale verklaringen. Ik wil alleen wijzen op de rol van topoi en personages. In de hitte van de strijd vallen discussianten terug op de formules, de uitspraken, die steeds weer in hun situatie voor hun betoog gebruikt worden. In de retorica heten dat de topoi, letterlijk de plaats waar je naar argumenten zoekt. Voor ouder 1 zijn dat de topoi van prudentie, eerlijkheid ("Als hij elders betaald krijgt, dan moeten wij hem ook betalen") en eigenbelang ("Luister eens, wij willen toch gewoon lekker uit? Laten we hem dan toch gewoon wat betalen; dan zijn we eraf”). 
Ouder 2 gaat eerder te raad bij de topoi van verantwoordelijkheid, gemeenschap en dergelijke. ("Wat voor gezin wordt dit, als iedereen alleen aan zichzelf denkt, als we alleen tegen betaling iets van de kinderen gedaan krijgen?”) Met een goede antenne zou je kunnen opmerken dat de lucht zoemt van dit soort opmerkingen. Het vermoeden is dat de topoi van ouder 1 sterker in volume worden. Want waarom anders zouden ouder 2 c.s. klagen over het verval van normen en waarden?

Het tweede voorbeeld geeft aan hoe economische transacties ingebed zijn in waarden en zelf waarden versterken dan wel afzwakken.

De bibliotheek kampt met tekorten. De politieke bereidheid om de tekorten aan te vullen uit gemeenschappelijke middelen neemt af. De kersverse directrice stelt voor meer marktgericht te werken. Zij wil differentiatie in tarieven, met scherpe prijzen voor cd-roms, video's en andere dergelijke 'producten'. Iedereen moet meer klantgericht zijn en dus de eigen werkzaamheden afbreken zodra een 'klant' in zicht komt. Ze is in gesprek met bedrijven voor sponsorafspraken. Een elektronisch bedrijf heeft al een reclamebord in de hal mogen aanbrengen. Tegen betaling natuurlijk. Een groot deel van de staf wil van deze aanpak evenwel niets weten. "De bibliotheek is geen bedrijf", is hun topos. Volgens hen dient de bibliotheek een gemeenschappelijk belang en is daarom een publieke zaak. Ze protesteren tegen de tarifering van sommige van hun diensten met als belangrijkste argument dat deze oneerlijk is; mensen met lagere inkomens kunnen zich geen video veroorloven en om die mensen gaat het toch. Ze zijn ronduit verontwaardigd over het reclamebord in de hal. Ze gaan liever de straat op om te protesteren bij het stadhuis dan dat ze een knieval maken voor de commercie. Na hevige conflicten beseft de directrice dat ze geen vertrouwen meer heeft van haar staf en stapt op.

De directrice denkt als ouder 1 in het eerste voorbeeld. Ze bezigt de retoriek van de markt, ziet zichzelf als ondernemer en manager, de bibliotheekdiensten als 'producten' en de bezoekers als 'klanten'. Zij ziet de tarifering als een goede zaak. Door duidelijk te prijzen communiceer je a) dat de diensten schaars zijn en b) wat ze waard zijn. Het is ook goed dat voorzover mogelijk de gebruiker betaalt voor de verleende diensten. Het binnenhalen van sponsors ziet ze als een uitdaging die bij haar rol als ondernemer past. Ze wil proberen of ze de bibliotheek als 'merk' kan neerzetten op zo'n manier dat bedrijven er baat bij hebben om hun naam met het merk van de bibliotheek te verbinden. In haar kennissenkring oogst ze veel bewondering voor haar ondernemingslust en haar zakelijke aanpak. Ze is dan ook verbolgen over de onwil van de medewerkers. Als ze eerlijk is, vindt ze hen een ingedutte groep die aan het verleden hangt. Waarschijnlijk is haar uiteindelijke beoordeling, zoals ze deze zal delen in haar vriendenkring, zelfs nog minder diplomatiek.

De medewerkers hebben op hun beurt weinig goeds te zeggen over de directrice. $\mathrm{Na}$ eerst overdonderd te zijn door haar enthousiasme, realiseerden ze zich dat haar marktgerichte aanpak de integriteit van de bibliotheek kan aantasten. Het voelde alsof de directrice hun de bibliotheek wilde ontnemen. Ze waren aangetast 
in hun professionaliteit. De tarifering strookte niet met hun opvatting dat al hun diensten voor iedereen die het lidmaatschap had betaald, zonder betaling uitgeleend konden worden. (Ze hadden al met een bezwaard hart een uitzondering gemaakt voor de bestsellers, maar waren gezwicht omdat anders te veel mensen te lang moesten opwachten om een bestseller te kunnen lenen.) Zij willen zich graag zien als mensen die werken voor een collectief belang. Hun personage is dat van sociaal werkers of dienaars van het collectief. Meegaan in de wereld van de directrice betaamt hen niet. De waarden botsen.

Dit soort waardeconflicten doet zich op allerlei niveaus en in allerlei situaties voor. Ze doen zich vooral voor waar er sprake is van een verschuiving dan wel een verandering van de cultuur. Zie de conflicten binnen de Nederlandse Spoorwegen, waar de cultuur van machinisten, conducteurs en treinliefhebbers botst met de managementcultuur die de verzelfstandiging bewerkstelligde. Ook de universiteiten maken een dergelijke verandering mee. Steeds meer komt de nadruk te liggen op marktgericht en klantgericht onderzoek en onderwijs. Net als de bibliotheek dient de universiteit haar producten duidelijk te positioneren, efficiënter te werken, meer rekening te houden met de wensen van studenten en werkgevers (zoals in het project 'studeerbaarheid'), onderwijsprogramma's dienen beter georganiseerd te worden en zowel het onderwijs als het onderzoek beter meetbaar (daarom meer accreditatie en research assessments). In de culturele wereld krijgen marketeers en managers een steeds belangrijkere rol toebedeeld. Kunstenaars krijgen te horen dat ze 'culturele ondernemers' dienen te worden en dus meer aan marketing, relatiemanagement en andere commerciële activiteiten moeten doen. Met een terugtrekkende overheid zullen culturele instellingen de markt op moeten en dus, net als de directrice van de bibliotheek, potentiële sponsors benaderen en scherper prijzen.

Daarmee lijkt zich een waardeomslag voor te doen. Economische waarden zijn gaan prevaleren. Sterker nog, economische waarden zijn het doel van het beleid geworden met als hamvraag voor ieder voorstel: is het goed voor de economie?

\subsection{ECONOMISCHE, SOCIALE EN CULTURELE WAARDEN}

De prevalentie van economische waarden doet zich voor in tal van discussies. Dat moge duidelijk zijn wanneer het gaat om de Tweede Maasvlakte of de Betuwelijn, maar het bevreemdt als het gaat over de uitbreiding van het Stedelijk Museum of extra geld voor de universiteiten. Maar ook in culturele discussies zijn economische argumenten veelal doorslaggevend. Bepalend is of de investering economische waarde toevoegt, in de vorm van extra banen, meer inkomsten uit toerisme en de vestigingen van bedrijven. Extra geld voor de universiteiten mag als de arbeidsmarkt en het bedrijfsleven daarvan profiteren. 
Economische waarden zijn de waarden die direct met het economische proces te maken hebben. Het zijn de waarden van inkomen, rijkdom, winst, economische groei, efficiëntie, productiviteit. De bron van deze waarden is het economisch kapitaal.

Het vooropstellen van economische waarden doet denken aan kinderen die op de vraag waar het hun om te doen is antwoorden: "Geld verdienen"- en als de ondervrager hen enigszins vreemd aankijkt, toevoegen: "Nee, laat ik dat corrigeren, het gaat om heel veel geld verdienen." Een dergelijk antwoord is onzinnig, zoals de mythe van koning Midas wil aangeven. Het hebben van geld is geen doel op zich, maar een middel om andere waarden te realiseren. Vraag door en zelfs de zo-even geciteerde kinderen zien gauw in dat het hun om mooie huizen, snelle auto's en dergelijke zaken te doen is en dat die zaken er weer voor dienen om een goed leven te hebben met goede vrienden, een goed gezin, om vrij te zijn in de keuzes, om te kunnen wonen waar ze willen. Het gaat dan eerder om persoonlijke en sociale waarden. Zelfs een kind ziet in dat het hebben van geld (dus economische waarden) niet voldoende is voor goede vriendschap, een goed gezin, goede smaak, liefde. Verantwoordelijkheidsgevoel, inlevingsvermogen, vertrouwen, compassie en dergelijke sociale waarden komen op een andere manier tot stand; ze zullen een andere bron hebben dan het economisch kapitaal (oftewel het vermogen economische waarden te genereren).

Sociale waarden zijn de waarden die het sociale kapitaal van een individu, organisatie, gemeenschap of samenleving vormen, oftewel het vermogen met mensen samen te leven. Denk aan vriendschap, verantwoordelijkheidsgevoel, solidariteit, zorgzaamheid, gezelligheid en liefde.

Het vermoeden bestaat dat het najagen van veel geld deze sociale waarden eerder ondermijnt dan versterkt. De werkelijkheid blijkt weerbarstig. Zoals Lane (1991) en McCloskey (1994, 1996, 2003) overtuigend betogen draagt het genereren van economische waarden via de markt bij aan de vorming van specifiek sociaal kapitaal. Denk aan de deugden van prudentie, waaronder de vooruitziende blik, ondernemerschap, redelijkheid, een beschaafde omgang met onbekenden en vreemdelingen ("Het geld van hen is immers zo goed als het geld van ieder ander”). Het handelen in de markt is dus niet zonder sociale waarden. Sterker nog, de markt als instituut heeft bijgedragen aan de beschaving die wij kennen. Maar daarmee is niet gezegd dat de markt waarden als compassie en liefde cultiveert. Om misverstand te voorkomen, dien ik erop te wijzen dat economen als eersten zullen erkennen dat economische waarden niet meer dan middel zijn. Daarvoor bevatten de economische modellen preferentiefuncties van individuen en sociale welvaartsfuncties voor samenlevingen. Het gaat om de bevrediging van behoeftes. Het is evenwel niet de gewoonte om in het economische vertoog in te gaan op de inhoud van die preferentie- en sociale welvaartsfuncties. Het gaat om de procedurele rationaliteit en niet om de substantieve rationaliteit, om een onderscheid van Max Weber te hanteren. Het cultureel perspectief laat even- 
wel zien dat de substantieve rationaliteit er terdege toe doet, ook in economisch verband. Mensen zijn morele wezens omdat ze in hun handelen steeds weer waarderen, evalueren, beoordelen en veroordelen. Vandaar het onderscheid tussen economische en sociale waarden. "Dat is niet loyaal!" "Neem je verantwoordelijkheid." "Dat ik tien miljoen euro verdien is een zaak tussen mij en de commissarissen; daar heeft de rest van Nederland niks mee te maken.” Je moet erover mee kunnen praten, weten wat wel en wat niet gezegd kan worden, om je in een waardedebat staande te houden.

Met de benoeming van economische en sociale waarden zijn we er nog niet. De behoefte aan een derde categorie waarden doet zich vooral voor in discussies over kunst, wetenschap en religie. Dat er economische waarden gemoeid zijn met kunstzinnige, wetenschappelijke en religieuze activiteiten moge niet iedereen direct duidelijk zijn, maar laat zich toch gemakkelijk raden. Kunstwerken brengen geld op, wetenschap kan een bijdrage aan de economie leveren en ook de kerken kennen een financiële huishouding. De sociale waarden van de kunst staan voorop in zoverre het om integratie van allochtonen en educatie gaat. Kunst kan blijkbaar binden en voedt soms ook een nationale identiteit. De sociale functie van religies staat buiten kijf. Maar daarbij blijft het niet, zoals vele auteurs hebben proberen duidelijk te maken. Binnen het economische vertoog hebben onder meer Bourdieu (1984, 1993) maar vooral ook David Throsby (2001) gewezen op de culturele waarden van culturele goederen en activiteiten. Te denken is hier aan esthetische, spirituele en transcendentale waarden. (Throsby rekent ook een reeks sociale waarden onder deze categorie, maar die behoren eerder bij het sociaal kapitaal.) Je zou kunnen zeggen dat de culturele waarden inspireren, zonder dat het gaat om economisch gewin of een persoonlijk of sociaal oogmerk.

Culturele waarden zijn de waarden die het culturele kapitaal van een individu, organisatie, gemeenschap of samenleving vormen. Het gaat nu om het vermogen te inspireren dan wel geïnspireerd te worden.

Bourdieu dicht aan cultureel kapitaal vooral economische betekenis toe. Hoogopgeleiden zijn uitgerust met het culturele kapitaal dat hen in staat stelt om zich op te houden in het betere milieu en daarmee hun economisch voordeel te doen. Goede smaak heeft economische waarde. Dit lijkt momenteel de gangbare gedachte: investering in cultureel kapitaal is goed voor toegevoegde economische waarde. Alsof het daarom te doen zou zijn. Maar dit is de wereld op zijn kop.

Economische waarden zijn altijd ondergeschikt aan andere waarden, aan waarden die het goede leven en samenleven bepalen. Net als een auto en een ijskast is geld instrumenteel om andere waarden te realiseren. De associatie met Maslows hiërarchie aan behoeftes is hier onvermijdelijk, maar de vraag is of die hiërarchie wel klopt. Het is niet onvermijdelijk dat een dak boven het hoofd vooraf moet gaan aan een beleving van zelfverwezenlijking. Hoe de verschillende waarden zich tot elkaar verhouden is gecompliceerd. Sociale waarden kunnen bijdragen 
aan economische waarden (zie de bijdrage van Groot en Maassen van den Brink) en culturele waarden kunnen dat ook. Het Rijksmuseum brengt met zijn culturele waarden geld in het laatje van het Rijk, de stad en het bedrijfsleven. Daarmee is niet gezegd dat het doel de economische waarden zijn. De vraag is eerder wat economische waarden bijdragen aan het sociale en culturele kapitaal.

De verleiding is groot om vooral te kijken naar de economische consequenties van een activiteit. De reden is dat deze het beste gemeten worden. We weten vrij goed wat de winst is van een bedrijf, wat we verdiend hebben en met welk percentage de economie gegroeid is. We kunnen zelfs redelijk goed de kosten en baten van de Betuwelijn tegen elkaar afzetten. Dat doen we door te meten in termen van geld en vervolgens aan boekhouding te doen. Die boekhouding is overigens vrij recent ontwikkeld (de nationale boekhouding dateert van de jaren twintig en dertig van de vorige eeuw) en blijft bewerkelijk. Recentelijk is men begonnen met het ontwikkelen van indicatoren voor sociaal kapitaal. Het serieuze denken over cultureel kapitaal moet nog beginnen. Indicaties van de ontwikkelingen in het sociaal en cultureel kapitaal zijn vooral belangrijk wanneer ze niet parallel lopen met de ontwikkelingen in het economisch kapitaal (Klamer 2003b).

Is het denkbaar dat een groei in het economisch kapitaal ten koste gaat van sociaal en cultureel kapitaal? Vraag de topmanagers. Wat hun economisch kapitaal betreft, doen ze het voortreffelijk, maar gezien het wantrouwen en de verontwaardiging die hun topsalarissen teweegbrengen, is het minder goed gesteld met hun sociaal kapitaal. Bekend zijn de sociale problemen van loterijwinnaars. In eerste instantie schiet hun geluk omhoog om vervolgens te dalen en veelal te eindigen beneden het niveau van voor de grote klapper (Frey \& Stutzer 2002). De problemen doen zich vooral in de relationele sfeer voor. Oude vriendschappen blijken bijvoorbeeld moeilijk houdbaar wanneer de een zoveel meer geld heeft dan de ander.

De afweging is het duidelijkste in het bedrijfsleven. Zoals Robert Frank (2004) laat zien, betalen ideële bedrijven minder dan commerciële bedrijven voor gelijksoortig werk. Salarissen voor universitaire medewerkers liggen flink beneden het niveau van salarissen van academici in het bedrijfsleven. Blijkbaar zijn mensen bereid economische waarden op te offeren in ruil voor meer sociale en ook culturele waarden. De relatie kan ook anders lopen. Iemand die vanuit de bijstand een baan krijgt, kan sociale meerwaarde ontlenen aan het eerste loon. Een salarisverhoging voelt goed, zeker ook in sociaal opzicht. Een goede beloning kan bijdragen aan het verantwoordelijkheidsgevoel en andere sociale waarden. Bruno Frey (200o) spreekt in dergelijke gevallen van het crowding in-effect: een hogere economische waarde levert meer sociale en culturele waarden op. Het crowding out-effect doet zich voor wanneer meer economische waarde ten koste gaat van sociale en culturele waarden. Wanneer een vriend die u net uit hoofde van vriendschap een gunst hebt verleend, $\mathrm{u}$ daarvoor wil betalen, dan genereert $\mathrm{u}$ economische waarde (de betaling), maar u zult waarschijnlijk ook beseffen dat 
die vriendschap minder is dan wat $u$ gedacht had. Het is immers niet zo gek om die betaling als verraad aan de vriendschap te beschouwen. U verliest dus ook, vriendschap vooral.

Moet ik een conclusie uit het voorafgaande trekken, dan is dat de volgende: economische waarden zijn instrumenteel en zijn ondergeschikt aan sociale en culturele waarden. Wanneer zij centraal staan in de discussie, is de impliciete veronderstelling dat een toename in economische waarden bijdraagt aan een toename van het sociaal en cultureel kapitaal. Dit hoeft niet het geval te zijn. Verrijking kan bijvoorbeeld ten koste gaan van vriendschap en vertrouwen.

\subsection{DE MARKT EN DE OVERHEID}

De directrice van de bibliotheek probeerde meer aandacht te krijgen voor economische waarden. Zij bezigde daartoe de retoriek van de markt met termen als 'product', 'klantgericht werken', 'concurrentie', 'efficiëntie', 'vraag en aanbod', 'prijs'. De ouder die wilde betalen voor het oppassen van de zoon deed min of meer hetzelfde. Zij zetten de toon. Want de markt spreekt momenteel tot de verbeelding. Ook de overheid ziet de markt als oplossing van tal van problemen, met als gevolg dat instellingen als de NS, de universiteit, het ziekenhuis, het energiebedrijf 'de markt op moeten'. Daarmee worden bepaalde waarden geprivilegieerd, terwijl andere waarden gedevalueerd worden, in het publieke debat alsook in discussies thuis, zoals we zagen.

Vanuit het eng economische perspectief ziet de markt eruit als een efficiënt allocatiemechanisme dat vooral stoelt op het prijsmechanisme. Een vlot lopend marktsysteem zou dan superieur zijn aan welk ander allocatiemechanisme ook (zoals een verdeling via de overheid). De eng economische benadering is louter instrumenteel met als belangrijkste vraag: hoe kan de markt beïnvloed worden om gewenste uitkomsten te realiseren? (zie hiervoor de bijdrage van Groot en Maassen van den Brink).

Vanuit een cultuur-economisch perspectief is de markt een waardesfeer. De sociologe Zelizer spreekt van een 'circuit' van waarden. Het is een aparte sfeer of een circuit vanwege een specifieke logica, een aparte manier van praten. De markt noopt tot instrumenteel en doelgericht denken. In marktgerichte organisaties praat men over wat de klanten willen, over efficiëntie, prestatie en uiteindelijk de winst. De neiging bestaat individuele belangen voorop te stellen en daarmee sociale belangen weg te drukken. Wanneer de markt een jaarlijks salaris van tien miljoen euro aangeeft, dan zij dat zo. Wat anderen daarvan vinden is hun zorg. Alles dient het doel van het maximaliseren van economische waarden. De klanten, de collega's, de concurrenten, de cultuur, waarden, ze zijn allemaal middelen daartoe. 
De markt is een complexe sfeer met een breed spectrum aan waarden. McCloskey en Lane benadrukken de positieve waarden die een markt cultiveert, zoals ondernemingslust, redelijkheid, vrijheid. McCloskey betoogt dat in de handelsgerichte Nederlanden van de zeventiende eeuw burgerlijke deugden tot hun recht kwamen en dat is wat haar betreft een goede zaak. Haar betoog is gericht tegen de zogenoemde culturalisten (literatoren, kunstenaars, sociaal werkers, theologen en anderen die culturele waarden hooghouden) die gefixeerd zijn op de negatieve waarden van de markt. Daarmee levert ze een belangrijke bijdrage. Want het is goed te beseffen dat de markt niet alleen welvaartsverhogend werkt, maar dat ze ook een toevluchtsoord is voor degenen die zich willen ontrukken aan een stroperige overheidssfeer of welke naargeestige en onderdrukkende omgeving ook. De markt betekent vrijheid van keuze, een kans op een ander leven.

Maar de markt kan ook onzekerheid, instabiliteit, ongelijkheid, verlies en een moordende concurrentie betekenen. Dat zijn de negatieve waarden waar de culturalisten op hameren. In de markt kan het fortuin keren en met het oog op de aandeelhouders en de concurrentie willen managers dan de bijl hanteren. Dan win je en dan verlies je. Je zult ermee moeten leren leven, wil je je gelukkig voelen in de sfeer van de markt. Je zult ook moeten willen leven met de ongelijkheid die in een markt kan ontstaan. Noem het zelfverrijking of noem het eerlijk verdiend, grote verschillen in beloning zorgen voor afgunst en ontevredenheid. (In een bekend experiment kiezen mensen eerder voor een algehele verlaging van het salaris dan voor een salarisverhoging die achterblijft bij wat anderen krijgen.)

In de markt kunnen zich grote machten vormen, de internationale bedrijven die zo machtig zijn dat zij de macht van overheden kunnen ondermijnen. De markt kan wonderen verrichten; meer markt, oftewel meer vrije handel, werkt veel beter voor de derde wereld dan al de ontwikkelingshulp bij elkaar. Dat neemt niet weg dat ook daar een al te ver doorgevoerde markt ondermijnend kan werken. $\mathrm{Na}$ twaalf jaar heeft het voormalige Oostblok zich nog steeds niet aangepast aan het regime van de markt. De prijs van de snelle invoering daarvan is hoog geweest. Sociale verbanden zijn ontwricht, de onzekerheid is groot en de gemiddelde levensverwachting is gekelderd. De markt is niet de oplossing van alle problemen. Daarvoor is haar sfeer van waarden te beperkt en te specifiek.

De sfeer van de overheid dient ervoor om het collectieve domein inhoud te geven en de tekortkomingen van de markt te compenseren. Ook dat gaat gepaard met een spectrum aan waarden. Tegenover het private belang van de markt komt het collectieve belang te staan. In plaats van vrijheid van keuze en eigen verantwoordelijkheid heersen in de overheidssfeer waarden als rechtvaardigheid, solidariteit en collectiviteit. In deze sfeer is het anders praten en denken. Het is niet voor niets dat een ambtenaar het moeilijk heeft te werken in een marktgerichte organisatie en dat een commercieel iemand gek kan worden van een overheidsorganisatie. Het zijn twee totaal verschillende werelden, met verschillende waarden. Dan blijkt ook dat wat voor de één een positieve kwaliteit is, voor de ander negatief is. Een ambtenaar kan een democratische besluitvorming met alle belanghebbende 
partijen aan tafel waarderen omdat de uitkomst in het publieke belang dient te zijn. Een marktgeoriënteerd persoon ziet vooral inefficiëntie, omslachtigheid en een gebrek aan daadkracht. Wil de laatste regels aan de laars lappen 'omdat die alleen maar lastig zijn', dan benadrukt de ambtenaar het belang van zorgvuldigheid en het gevaar dat andere partijen benadeeld worden. Produceert de markt een tweedeling, dan zou een herverdeling in het publiek belang kunnen zijn. Het tegengaan van machtsconcentraties kan dat ook zijn.

\section{Tabel 13.1 De sfeer van waarden van de markt en van de overheid}

\section{De sfeer van waarden van de markt}

$+$

vrijheid van keuze

consumentensoevereiniteit

onafhankelijkheid

prestatiegericht

ondernemingslust

objectieve waardering via prijzen

individugericht

individuele verantwoordelijkheid

De sfeer van waarden van de overheid

$+$

rechtvaardigheid

solidariteit

het collectieve belang

regelgeving

overleg

gelijkheid

democratische procedures

objectiviteit machtsconcentratie

manipulatie via reclame

onzekerheid en instabiliteit

prestatiedwang

hebzucht

idem

anonimiteit

asociaal en immoreel

meedogenloos, harteloos

belastingen

nationalisme

dwang en regelzucht

stroperigheid

verkeerde prikkels

inefficiëntie

onpersoonlijk

Het terugdringen van de overheid betekent dus het terugdringen van haar sfeer van waarden. Meer ruimte voor de markt en het individu betekent minder nadruk op het collectief belang, op waarden als solidariteit, een zorgzame samenleving, (sociale) zekerheid ten bate van waarden als keuzevrijheid, efficiëntie, prestatie, maar ook die van ongelijkheid, hebzucht, onzekerheid en instabiliteit. Na jaren geopereerd te hebben in een samenleving die beheerst werd door de sfeer van de overheid, geeft die omschakeling problemen. Belangrijke groeperingen onder de bevolking ervaren vooral een verlies. Privatisering en liberalisering leveren onverwachte problemen op, omdat blijkbaar niet rekening gehouden is met de noodzakelijke waardeomslag. Klantgericht en prestatiegericht werken klinkt goed, maar niet als het ten koste gaat van waarden als zekerheid, stabiliteit, gelijk- 
heid en het collectieve belang. Als gevolg daarvan neemt het verzet tegen zaken als de liberalisering van de energiemarkt en de 'exorbitante zelfverrijking' van de bestuurlijke top toe. Rampen in Enschede en Volendam doen realiseren dat een goede en doelmatige overheid onontbeerlijk is. De markt is ten minste niet zaligmakend. Wellicht dat de balans weer richting overheid aan het verschuiven is.

\subsection{DE OIKOS EN DE DERDE SFEER}

De pendule die tussen de sfeer van de markt en de overheid zwaait, lijkt zo hypnotiserend dat er geen aandacht is voor mogelijke andere waardesferen. Het is alsof die niet bestaan. Ik maak er een punt van ernaar te vragen in discussies en krijg vrijwel nooit een suggestie. Mijn wetenschap, de economische, is wellicht voor een deel deze kortzichtigheid aan te rekenen, want in die wetenschap gaat het over niets anders dan over de markt versus de overheid, oftewel het private belang versus het collectieve belang. ${ }^{3}$ Maar met de aandacht voor waarden en het realiseren daarvan, geeft het cultureel-economisch perspectief zicht op een andere, derde sfeer (Klamer \& Zuidhof 1998.) Dit is geen nieuws voor antropologen en sociologen (Gudeman 2001; Putnam 2000), maar door rekening te houden met deze derde sfeer verandert het zicht op de economie aanzienlijk en wordt duidelijk waarom sociale en culturele waarden zo in de verdrukking kunnen raken wanneer alleen in termen van markten en overheden gedacht en gesproken wordt.

De derde sfeer is de sfeer van informele interacties, van ideële organisaties, van gezinnen, clubs, partijen, vrienden- en kennissenkringen. Verreweg de meeste van onze interacties met anderen vinden in deze sfeer plaats. Ga maar na: de enkele keren dat een gemiddeld persoon opereert in de sfeer van de markt - door iets te kopen, te handelen in aandelen, over een beloning te onderhandelen - of die van de overheid - door een belastingformulier in te vullen, een subsidie aan te vragen, zich te houden aan de regels - staat in geen verhouding tot de eindeloze interacties met collega's, vrienden en vooral gezinsleden. Zelfs op het werk zijn de informele interacties talrijk. Het gaat dus om die interacties waarvan de waarde niet gemeten wordt met een prijs en die niet op een of andere manier geregeld zijn in een contract of een bureaucratische procedure. De informele interacties blijken bepalend te zijn voor tal van waarden.

De basis van de derde sfeer is wat Aristoteles de oikos noemde, het thuis waar het vuur brandt. In onze samenleving is dat meestal een gezin, maar in sommige gevallen kan dat ook Nederland als geheel zijn (zoals voor Nederlanders die in het buitenland in de problemen geraken). De oikos is de sfeer waar een mens thuis is. Het is de sfeer waarin wij leren wat liefhebben, zorgen, delen, loyaal zijn en verantwoordelijkheid nemen betekenen. Leden van de oikos rekenen niet af, ze ruilen niet op basis van quid pro quo, zoals in de markt, en houden elkaar niet aan een contract (nou ja, soms misschien wel); ze delen een gemeenschappelijk belang en dragen ieder op een eigen manier daaraan bij. 
Als dat allemaal te positief klinkt, de oikos staat ook voor negatieve waarden zoals uitbuiting, onderdrukking, afhankelijkheid, kleinzieligheid. De oikos kan verstikkend werken. Dat is een goede reden voor mensen om de vrijheid van de markt op te zoeken, op zichzelf te willen leven, het eigen ik te bevestigen en de hulp van de overheid in te roepen om afhankelijkheid van de eigen oikos te voorkomen. Zowel de markt als de overheid biedt dus een tegenwicht voor de negatieve kanten van de oikos. (Zij die allergisch reageren op de oikos, houd ik voor dat geen sociaal instituut zo dynamisch en veranderlijk is als het moderne gezin: een gezin is nog niet gevormd of de ontbinding begint reeds vanwege sterfte, het vertrek van kinderen, een scheiding. En wie kent twee gezinnen die precies eender zijn?) Dat neemt niet weg dat de oikos de brandhaard blijft van tal van positieve waarden die het tapijt van onze beschaving kleur en warmte geven.

Is de oikos allesoverheersend in een traditionele samenleving, in een moderne samenleving zien we een ver ontwikkelde derde sfeer, ook wel aangeduid als civil society. Net als in de oikos overheersen in deze sfeer de informele, sociale interacties. Het is in deze sfeer dat mensen zich verenigen, clubs vormen, vriendenkringen onderhouden en collegialiteit realiseren. Belangrijke dragers zijn, behalve clubs, partijen en verenigingen, sociale organisaties, ook wel 'non-profit'en 'non-gouvernementele' organisaties genoemd. De laatste benamingen geven al aan dat deze organisaties noch in de sfeer van de markt, noch in die van de overheid opereren. Dit zijn de organisaties die ideële doelstellingen vooropstellen en veelal afhankelijk zijn van donaties en vrijwilligerswerk.

\section{Tabel 13.2 Waarden van de oikos en de derde sfeer}

$\begin{array}{ll}+ & - \\ \text { verantwoordelijkheid } & \text { plichtmatig } \\ \text { loyaliteit } & \text { onderdrukking } \\ \text { verbondenheid } & \text { afhankelijkheid } \\ \text { zorgzaamheid } & \text { betutteling } \\ \text { generositeit } & \text { liefdadigheid } \\ \text { gemeenschappelijkheid } & \text { idem }\end{array}$

De gift is de vorm van transactie die de derde sfeer kenmerkt, tegen het quid pro quo van de markt en de contractuele rechten en plichten van de overheid. De gift onderscheidt zich door de ambiguïteit van haar condities. Geef en u zult ontvangen, alleen ligt niet vast wat, wanneer en in welke vorm. De gift, zo wijst modern onderzoek uit, is het middel bij uitstek om verbindingen te realiseren (Komter 1996). Door middel van giften realiseren mensen relaties met elkaar. Vrienden rekenen niet met elkaar af, althans niet expliciet. Collega's helpen elkaar. Het principe is dat van wederkerigheid: ik doe wat voor jou en jij voor mij, maar het hoe, wat en wanneer laten we in het midden. De gift is ook de manier om deel uit te maken van iets gemeenschappelijks. Door onze tijd, aandacht en eventueel 
geld te geven aan een instelling voelen we ons eraan verbonden; we zijn een deelnemer. Jonge mannen uit Puerto Rico zijn bereid hun leven in Irak op te offeren om Amerikaan te mogen zijn.

Zoals het onderzoek naar sociaal kapitaal laat zien, is de derde sfeer cruciaal voor de vorming van sociale waarden. In hun informele interacties ontwikkelen mensen verantwoordelijkheidsgevoel, het gevoel ook verbonden te zijn met iets gemeenschappelijks. Een democratisch bestel functioneert beter al naar gelang de kwaliteit van de derde sfeer (Putnam 1992, 2000). Wellicht geldt hetzelfde voor de markt. De derde sfeer genereert iets als vertrouwen. Mensen die elkaar kennen van de vereniging, de kerk of andere instituten uit de derde sfeer, zullen elkaar eerder vertrouwen en daarom gemakkelijker met elkaar handelen dan mensen die totale vreemden van elkaar zijn. Sociale waarden doen ertoe en daarom doet de derde sfeer ertoe.

Veel 'goeds' komt tot stand in de derde sfeer. Veel nieuwe kunst ontstaat door middel van een informele samenwerking onder kunstenaars; wetenschappers komen bijeen om hun ideeën te bespreken; buurtgenoten organiseren een sportclub, een radiozender en een buurtcomité, zonder dat er geprijsd en gerekend wordt en zonder dat eerst contracten gesloten worden. De gift is het instrument bij uitstek om verantwoordelijkheidsgevoel en verbondenheid uit te drukken en te realiseren. Ik heb het sterke vermoeden dat niet alleen sociale waarden maar vooral ook culturele waarden juist in de derde sfeer tot hun recht komen. Kunst krijgt waarde doordat mensen eraan willen bijdragen. De bijdrage staat voorop, de eventuele economische waarde van de kunst is een afgeleide (Klamer 2003b). Vandaar ook dat in de werelden van de kunsten, religie en de wetenschappen de markt problematisch is en voorzover mogelijk op afstand gehouden wordt. Gaat het om de werkelijk belangrijke waarden, dan is het instrumentele van de markt ongepast. Dat geldt ook voor de objectivering waaraan de overheid niet ontkomt. Liefde is geen zaak van de overheid, noch van de markt.

\subsection{VERMENGING VAN DE SFEREN}

In de praktijk lopen de sferen in elkaar over en duiken in elkaar op. De waarden en de retoriek van de markt laten zich bijvoorbeeld gelden in de oikos, zoals we zagen. Ouders betalen kinderen voor verleende diensten en partners sluiten contracten af om de aan elkaar bewezen diensten vast te stellen (vooral handig in verband met een eventuele scheiding). De markt steekt verder steeds meer de kop op in de overheidssfeer. Tal van (semi-)overheidsorganisaties opereren alsof ze marktinstellingen zijn. Universiteiten doen aan marketing en rekenen hun afdelingen af op het aantal studenten dat ze binnenhalen en afleveren. Onderzoek dient steeds meer marktgericht te zijn. Gesubsidieerde culturele instellingen kopen zich in in de markt en ontwikkelen marktstrategieën om het aantal 'klanten' te verhogen in verband met de subsidievoorwaarden. Ideële organisaties huren professionele fondsenwervers aan, maken gebruik van commerciële 
consultants en willen zich als merk profileren waardoor het onderscheid met commerciële organisaties verwatert.

Daartegenover staat dat de derde sfeer haar invloed ook in de sfeer van de markt en van de overheid laat gelden. De manager probeert de werknemers te inspireren door hen voor te houden dat ze een familie zijn, dat het om loyaliteit gaat en om betrokkenheid en dat hij goed voor hen wil zorgen - alle waarden, begrippen en topoi van de derde sfeer. De straatverkoper houdt de argeloze voorbijganger voor dat ze vrienden zijn en dat hij daarom een zeer speciale prijs voor hem heeft; het is de derde sfeer in de markt. Maar ook zakenmensen willen elkaar een gevoel geven vrienden te worden alvorens tot een deal te komen - hoe zuidelijker je komt, hoe sterker die invloed van de derde sfeer is. De overheid wordt gemakkelijk gemodelleerd naar de metafoor van de oikos. Het wordt dan vadertje staat en het vaderland, of het wordt de zorgzame moeder, de overheid die over ons waakt en goed voor ons zorgt. Want dat begrijpen mensen; met die metaforen zijn ze groot gegroeid (zie ook de bijdrage van Pessers).

Ten slotte herkennen we de waarden van de overheid in de bureaucratische organisaties in de wereld van de commercie en sociale organisaties. Vooral grote private organisaties uit de derde sfeer, zoals het Rode Kruis en tal van fondsen, zijn moeilijk te onderscheiden van overheidsorganisaties, omdat ze net zo bureaucratisch en objectiverend te werk gaan, met regels en de topoi van billijkheid en rechtvaardigheid. Alleen de directe inbedding in een politiek (democratisch) stelsel ontbreekt.

Al deze vermengingen en wederzijdse invloeden maken het onderscheid tussen de drie sferen niet overbodig (zie ook Van Staveren 200o). Het blijft van belang te erkennen dat wij opereren in verschillende waardesferen die in tal van situaties met elkaar in conflict zijn. Daarom kan ik van u uw auto kopen en misschien ook uw jas, maar begin ik over uw kind of partner, dan ben ik althans in deze beschaving buiten de orde. Dat geldt ook als ik een bod uitbreng op uw nier. Dat kan gewoonweg niet. De meeste mensen zouden dat zelfs als immoreel bestempelen. Een dergelijke ruil botst met de waarden van de derde sfeer. We zouden ook gek opkijken wanneer een winkelier broodjes uitdeelt met als reden dat hij zo veel van ons, zijn klanten, houdt. Zou hij dat doen in zijn oikos, dan zou dat eens tijd worden; in de markt past dergelijk gedrag niet. Rechtvaardigheid, de kernwaarde in de sfeer van de overheid, voldoet niet in de oikos. Mijn familie zou het niet pikken wanneer ik onze spullen ga verdelen onder armlastige mensen in de buurt. Hoe rechtvaardig dergelijk gedrag ook zou zijn, het botst met de zorgzaamheid en het verantwoordelijkheidsgevoel die van mij in mijn oikos verwacht worden. Liefde is niet te koop en vriendschap ook niet. Ik moet de ouders nog ontmoeten die hun kinderen de rekening presenteren voor alles wat ze aan hen gespendeerd hebben.

Hoe vermengd ook, de sferen zijn onderscheidend en min of meer afzonderlijk te herkennen. In de onderliggende voorstelling staat de oikos aan de basis. Dat is de 
constellatie die vrijwel iedereen het beste kent omdat het van huis meegegeven is. De derde sfeer is een vertaling van de oikos in het sociale veld van informele relaties. Het zou me niet verbazen als Weber, maar ook sociologen als Granovetter en de economische historicus Karl Polanyi gelijk hebben wanneer ze stellen dat de effectiviteit van een markteconomie bepaald wordt door de kwaliteiten van de derde sfeer. Het onderzoek naar de betekenis van het sociale kapitaal heeft deze hypothese tot nu toe bevestigd.

De markt en de overheid zijn en blijven oneigenlijke constructies in het licht van de oikos. Wij mensen zijn sociale wezens die moeten leren opereren in sferen waar zorgzaamheid, vriendschap en liefde niet tellen, waar het gemeenschappelijke een illusie is of een voorwendsel om profijt te halen. Velen wennen daar nooit aan en proberen daarom de oikos op een of andere manier te recreëren met gezellige huiskamers op het werk en een taal van vriendschap, loyaliteit en wederkerigheid. Vanuit het perspectief van de oikos kan een overheid, hoe rechtvaardig ze ook is, harteloos en meedogenloos overkomen. De familie Gümüs, die jarenlang illegaal in Nederland een goed bestaan had opgebouwd en ingeburgerd was in Amsterdam, moest weg op grond van gelijke behandeling; voor degenen die deze familie een warm hart toedroegen, was deze opstelling van de overheid meedogenloos. Maar hoe oneigenlijk de markt en overheid ook mogen zijn, zij die deel uitmaken van de westerse beschaving weten er goed mee te leven, zozeer zelfs dat de markt en overheid als natuurlijk ervaren kunnen worden.

\section{Figuur 13.1 Vermenging van de sferen}

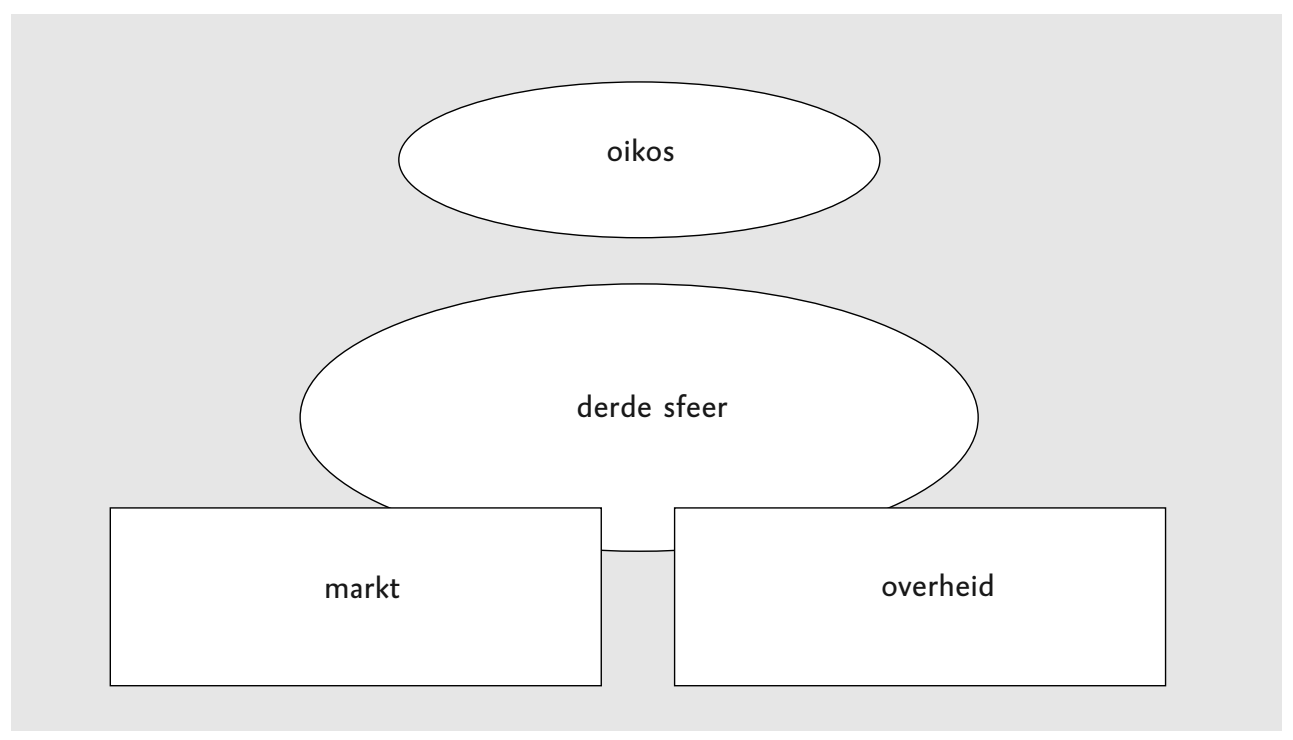

Uiteindelijk gaat het om een goede verhouding tussen de drie sferen. Problemen ontstaan wanneer de ene dan wel een andere sfeer te dominant wordt. Te veel overheid verdringt de markt en de derde sfeer en te veel aan markt verdringt de overheid en wederom de derde sfeer. Een te dominante derde sfeer zal ook niet 
werken, want we hebben in onze moderne samenleving een sterke overheid nodig en een vitale markt. Scheve verhoudingen zijn goed voor waardediscussies. Wanneer de markt te veel gaat overheersen, hoor je al snel verontwaardigde geluiden over monopolies, hebzucht, zelfverrijking en uitbuiting. Overheerst de overheid, dan gaat het gauw over te hoge belastingen, bureaucratie en regelzucht. De overheid heeft goede redenen om zich daar rekenschap van te geven, want zij speelt een belangrijke rol in een eventuele herschikking. Daarbij zal ze rekening dienen te houden met de specifieke constellatie van de samenleving waarin ze opereert.

\subsection{DE NEDERLANDSE CONSTELLATIE}

De Nederlandse samenleving heeft iets eigens. Een belangrijk onderscheidend kenmerk zou wel eens de manifestatie van de derde sfeer kunnen zijn in de sferen van de markt en de overheid. Denk aan het belang dat Nederlandse politici en zakenlieden hechten aan 'samenwerking', 'overleg' en 'partnerschap'. Het typisch Nederlandse gaat onder de naam van het poldermodel, dat natuurlijk niet van begin jaren tachtig dateert, maar sinds mensenheugenis bestaat. Reeds ten tijde van de gilden waren Nederlanders die hetzelfde vak uitoefenden gewend om met elkaar te overleggen en afspraken te maken. In het geval van conflict is het gewoonte hier om de dingen uit te praten en te regelen. De consensus is essentieel. Deze praat- en overlegcultuur domineert tot op de dag van vandaag. Voor buitenstaanders werkt deze cultuur bevreemdend. Amerikanen (die ik toevallig wat beter ken) kunnen er gek van worden en niet alleen zij. Dat eindeloos masseren..."Laten we knopen doorhakken, laten we stemmen.” Het is voor buitenstaanders ook onbegrijpelijk dat werkgevers en werknemers elkaar als sociale partners zien en voortdurend met elkaar in overleg zijn en gezamenlijk verschillende sociale organisaties beheren (Klamer 1990). Laatst probeerden de Duitsers het eens met een dergelijk overleg. Het lukte niet. Zij ontberen dan ook de overlegcultuur waar Nederlanders mee opgroeien.

De overlegcultuur brengt met zich mee dat de verschillen niet al te ideologisch kunnen zijn. De partijen moeten met elkaar kunnen onderhandelen. Van belang is het gemeenschappelijke gevoel. Samen dienen de partijen sterk te zijn om de buitenlandse concurrentie het hoofd te bieden of het water te bedwingen. De vakbondsleider die agressief de loononderhandelingen ingaat, krijgt onherroepelijk te horen dat de eisen in strijd zijn met het gemeenschappelijke belang. Roep iets over de concurrentiepositie en de partners gaan al door de knieën. Het is een topos waarmee je in landen als Engeland of Amerika weinig bereikt. Hier des te meer. Ook degenen die hun hoge salarissen proberen te rechtvaardigen, hebben te maken met de Nederlandse eigenheid. Men probeert met de waarden van de markt - "De man is het waard in de internationale markt” - maar krijgt te maken met het Nederlandse familiegevoel. Daarvoor gelden egalitaire waarden, het "Doe maar normaal”. Een uitzonderlijke beloning past niet, hoe de markt ook is. Daar wordt men ongelukkig van en wellicht 
jaloers. In een kleine gemeenschap kunnen de verschillen niet al te groot zijn. Grootverdieners passen zich aan of doen er beter aan hun toevlucht elders te zoeken. Ze hebben te maken met de macht van de derde sfeer.

Links en rechts horen we geluiden dat deze overlegcultuur voorbij dient te zijn. Nederland moet mee in de vaart der volkeren, oftewel de markt moet de vrije ruimte krijgen. Het beleid is er ook naar. Het mededingingsbeleid dat op last van de Europese Unie wordt doorgevoerd, breekt hardhandig in op de overlegcultuur. De vele initiatieven tot vergaande marktwerking in sectoren als die van de taxi's, het notariaat en het openbaar vervoer geven aan dat het de overheid menens is. De markt staat model voor haar handelen. De vraag is of met dit beleid de waarden van de derde sfeer ondergesneeuwd dreigen te geraken.

Neem de bouwfraude. In een overlegcultuur is het denkbaar dat bouwondernemers grote projecten met elkaar bespreken om afspraken te maken. Dat is goed voor de spreiding van risico en uit hoofde van kennisdeling. Gebeurt een dergelijk overleg in alle redelijkheid en met waardering voor de eventuele belastinggelden die met het project gemoeid zijn, dan is daar weinig fouts mee. Zo opereren kenmerkt de Nederlandse samenleving. Nu bepaalt het mededingingsbeleid dat iedere vorm van overleg strafbaar is. De bondgenoten wordt opgedragen om met elkaar te concurreren. Afgezien van de vraag of deze aanpak tot lagere prijzen en efficiëntere aanbestedingen leidt, kunnen we ons afvragen of de consequenties in termen van waarden wenselijk zijn. Ging het in de overlegsituatie over waarden als samenwerking, gemeenschappelijkheid, redelijkheid en stabiliteit, nu worden waarden als eigenbelang, winst en efficiëntie gepromoot. Willen we dat? Wordt onze beschaving daar beter van?

Maar niet alleen de dominantie van de marktsfeer bedreigt de derde sfeer. De dominante overheidssfeer gedurende de laatste vijf decennia is net zo goed verantwoordelijk voor de veronachtzaming en onderwaardering van de derde sfeer. Het instituut van de gift staat bijvoorbeeld zwaar onder druk, omdat de overheid de rol van gever heeft overgenomen. Voor de Tweede Wereldoorlog kochten particulieren en verenigingen in onbruik geraakte molens, stichtten musea en bibliotheken en steunden orkesten en theatergezelschappen. De overheid heeft deze verantwoordelijkheden overgenomen met als gevolg dat de klad is gekomen in het instituut van de gift. Nederlanders geven nog volop, maar een kritische blik leert dat de belangrijkste gevers kerkgangers zijn en juist die groep slinkt razendsnel (Schuyt 2001). Andere Nederlanders willen nog wel geven, maar alleen als ze de kans hebben op grote prijzen. $\mathrm{Zij}$ kopen loten van goede-doelen-loterijen die vervolgens ongeveer zestig procent van de inleggelden doorsluizen naar ideële organisaties. De belangrijkste donoren zijn evenwel bedrijven, maar hun giften nemen eerder het karakter van een markttransactie aan, zeker wanneer ze het instrument zijn om klanten te werven, een reputatie op te bouwen en de werknemers te motiveren. In het algemeen geldt dat Nederlanders, in tegenstelling tot hun voorouders, niet meer de sociale plicht en verantwoordelijkheid voelen om met hun generositeit activiteiten en instellingen te steunen. Zijn culturele instellingen in het overgrote 
deel van de wereld vooral afhankelijk van de inzet en het geld van betrokkenen, hier worden zij in de handen van het bedrijfsleven gedwongen wanneer de overheid de handen terugtrekt. De vraag is of een dergelijke ontwikkeling wenselijk is. Het antwoord hangt af van welke waarden de voorkeur hebben.

\subsection{BELEIDSCONSEQUENTIES}

Belangrijk is oog te hebben voor de verschillende waardesferen. Van groot belang is bijvoorbeeld om meer zicht te hebben op de rol en de betekenis van de derde sfeer. Zou het kunnen zijn dat deze sfeer in verdrukking komt vanwege een te dominante overheid aan de ene zijde en een oprukkende markt aan de andere? Het beleid zou gericht kunnen zijn op een versterking van de derde sfeer (denk aan belastingaftrek van giften, versterking verenigingscultuur, minder subsidies en meer matching). Het beleid kan rekening houden met het belang van gezinnen, scholen, kerken, clubs, fondsen en andere instellingen die in de derde sfeer opereren.

De invloed van de overheid komt niet alleen via haar maatregelen. Bij monde van de politici en de ambtelijke inbreng heeft ze ook invloed op het klimaat. De gebezigde retoriek kan een bepaalde sfeer versterken, zoals momenteel die van de markt. Door de taal van de markt te hanteren, bevestigen politici en ambtenaren de waarden van de markt ten koste van andere waarden. Zo kan het gebeuren dat waarden als solidariteit en gemeenschappelijkheid devalueren. De gebezigde taal zorgt er ook voor dat Nederlanders zich steeds meer individu, klant en consument voelen en steeds minder burger en lid van een gemeenschap, met als gevolg dat mensen veeleisend worden en op de eigen strepen gaat staan, zonder zich af te vragen hoe ze kunnen bijdragen aan het gemeenschappelijke. Dus als ik recht op wachtgeld heb, dan pak ik dat toch, ook al ben ik steenrijk? Dat dergelijk gedrag ten koste van de gemeenschap gaat, het zij zo. Laat een ander zich daar maar druk over maken. Solidariteit? Kunnen ze niet voor zichzelf zorgen, zelf verantwoordelijkheid nemen? En zo schrijdt de afkalving van het sociale kapitaal ras voort.

Het is niet aan de wetenschap de overheid het beleid voor te schrijven. Door de derde sfeer te benoemen impliceer ik wel dat deze sfeer veronachtzaamd wordt en dat een correctie wenselijk is. Voor deze stelling vind ik steun in de opleving van waardediscussies. Zoals ik eerder opmerkte, zouden die wel een reactie kunnen zijn op een te dominante markt. De verontwaardiging over de vermeende zelfverrijking in de commerciële sector is tekenend. Het geeft aan dat de oude vertrouwde waarden die de Nederlandse beschaving bepaalden, zoals de waarden van redelijkheid en gelijk(waardig)heid, nog steeds van kracht zijn.

De overheid zou helpen door in de formulering van haar beleid duidelijk te maken dat de economie niet meer dan een middel is om belangrijke waarden te realiseren en dat de markt een hulpmiddel is. Ze zou verder aandacht kunnen 
besteden aan het belang van een vitale en ontwikkelde derde sfeer als alternatief voor haar eigen activiteiten en die van de markt. Zou de overheid beslissen mee te willen werken aan een herwaardering van de derde sfeer, dan is een aanpassing in de publieke retoriek noodzakelijk. Want dan gaat het om een herwaardering van waarden als (sociale) verantwoordelijkheid, zorgzaamheid, maatschappelijk ondernemen, solidariteit, burgerschap en gemeenschappelijkheid. 


\section{NOTEN}

Zie ook het initiatief Stop de Uitverkoop van de Beschaving dat met zijn manifest kwam op 1 mei 2001 met als belangrijkste doelwit het verregaande vertrouwen van beleidsmakers in de markt. Ondergetekende was onder de opstellers van dat manifest tezamen met onder meer Dorien Pessers, Huub Oosterhuis, Wouter van Dieren en Jan Marijnissen. De stichting is nog steeds actief.

2 De bijdrage van Maassen van den Brink en Groot laat zien hoe die eng economische benadering met waarden kan omgaan. Staan waarden centraal in een cultureel-economisch perspectief, in een eng economische benadering moeten ze erbij gedacht worden.

3 De derde weg, die sociaal-democraten als Tony Blair wilden volgen, is een combinatie van de overheid en de markt en heeft daarom weinig weg van de derde sfeer zoals ik deze hier benoem. 


\section{LITERATUUR}

Bourdieu, P. (1984) Distinction : a social critique of the judgement of taste, Londen: Routledge.

Bourdieu, P. (1993) The field of cultural production: essays on art and literature, Cambridge (UK): Polity Press.

Frank, R.H. (2004) What price the moral high grounds? Ethical dilemmas in competitive environments. Princeton: Princeton University Press.

Frey, B.S. (2000) Arts $\&$ economics: analysis $\&$ cultural policy, Berlijn/New York: Springer.

Frey, B.S., \& A. Stutzer (2002) Happiness and economics: how the economy and institutions affect well-being, Princeton: Princeton University Press.

Gudeman, S. (2001) The anthropology of economy: community, market, and culture, Malden (MA): Blackwell.

Hausman, D.M., \& M.S. McPherson (1996) Economic analysis and moral philosophy, Cambridge: Cambridge University Press.

Klamer, A. (1990) Verzuilde dromen: 4O jaar SER. Amsterdam: Balans.

Klamer, A. (2003a) 'Economisch, sociaal en cultureel kapitaal', blz. 50-51 in: Sturen op statistieken, Utrecht: Centraal Bureau voor de Statistiek.

Klamer, A. (2003b) 'A pragmatic view on values in economics', Journal of economic methodology, 10(2): 191-212.

Klamer, A. (2003c) Speaking of Economics: How to be in conversation with economists, Unpublished, see www.klamer.nl.

Klamer, A., \& P.W. Zuidhof (1998) The role of the third sphere in the world of the arts, Erasmus Paper, Rotterdam: Erasmus University of Rotterdam.

Komter, A.E. (red.) (1996) The Gift: An Interdisciplinary Perspective, Amsterdam: Amsterdam University Press.

Lane, R.E. (1991) The market experience, Cambridge: Cambridge University Press.

McCloskey, D.N. (1994) 'Bourgeois Virtue', American Scholar, 63 (2): 177-191.

McCloskey, D.N. (1996) The Vices of Economists; The Virtues of the Bourgeoisie, Amsterdam: Amsterdam University Press.

McCloskey, D.N. (2003) Bourgeois Virtue, unpublished.

Okun, A.M. (1975) Equality and efficiency: the big tradeoff, Washington (DC): The Brookings Institution.

Pessers, D. (2003) Big Mother: over de personalisering van de publieke sfeer, Den Haag: Boom Juridische Uitgevers.

Putnam, R.D. (1992) Making democracy work: civic traditions in modern Italy, Princeton (NJ): Princeton University Press.

Putnam, R.D. (200o) Bowling alone: the collapse and revival of American community, New York: Simon \& Schuster.

Schuyt, T.N.M. (red.) (2001) Geven in Nederland 20o1: giften, legaten, sponsoring en vrijwillegerswerk, Houten/Diegem: Bohn Stafleu Van Loghum.

Staveren, I. van (2000) Caring for economics: an Aristotelian perspective. Londen: Routledge

Throsby, D. (2001) Economics and culture, Cambridge: Cambridge University Press.

Toulmin, S.E. (2001) Return to reason, Cambridge (MA): Harvard University Press. 


\title{
14 ONDERZOEK HET GOEDE: WAARDEBEHEER IN DE GEZONDHEIDSZORG
}

\author{
A. $\mathrm{Mol}^{1}$
}

\subsection{INLEIDING}

Werd er vijfentwintig jaar geleden een moreel appèl op de inwoners van Nederland gedaan, nu heet het dat er iets mis is met onze geneigdheid tot het naleven van waarden en normen - of althans met die van sommigen van ons: de anderen. De continuïteit is minstens zo opvallend als de breuk, want ook nu vertoont de verontrusting een hoog appèlgehalte. Individuen worden opgeroepen zich waardiger te gedragen. De reflectie richt zich op de redenen waarom die individuen dat na zouden laten. Gebreken in de opvoeding worden breed uitgemeten. Zijn onze medemensen al te zeer geseculariseerd om zich de tien geboden te herinneren? Materialistisch, consumentistisch, individualistisch geworden misschien? Of - maar deze verdenking geldt vreemd genoeg alleen (nazaten van) voormalige buitenlanders - niet voldoende geïntegreerd? Hoe dit ook zij, ergens, buiten ons, deugt er iets niet. Ja, ook het morele karakter van het appèl op de ander is de afgelopen decennia constant gebleven.

Hoe komt het toch dat het moralisme in de diverse publieke debatten in Nederland - dat over normen en waarden niet in de laatste plaats - zo hardnekkig is? In plaats van het antwoord op die vraag af te wachten, zal ik in mijn bijdrage aan deze Verkenning een theoretisch repertoire presenteren dat helpt om eraan te ontsnappen. Moralistische appèls zijn immers niet zonder risico. De 'anderen' op wie het appèl gedaan wordt, kunnen daar vast door geïnspireerd raken, maar waarschijnlijker is het dat de suggestie dat ze het goede niet altijd al, op hun eigen manier, nastreven, hen pijnlijk treft, ergert, of opstandig maakt. Annie M.G. Schmidt, vlijmscherp chroniqueur van alledaagse moralisme, reageerde daarop niet voor niets met een: "Ik ben lekker stout!" Haar waarschuwing wordt in de wind geslagen. Het lijkt erop of degenen die moralismen de wereld in blijven slingeren, zich niet serieus bekommeren om de effecten die dat met zich meebrengt. Wat doe je als je een ander vertelt hoe het hoort; wat doe je als je verzucht dat zovelen falen? Breng je dan het goede teweeg of bevestig je slechts de morele superioriteit van de spreker en wellicht een stuk of wat instemmende luisteraars?

De logica van het moralisme maakt van een twijfelaar of tegenspreker al vlug iemand die zelf wellicht niet deugt. En toch valt eraan te ontkomen. Het is mogelijk de maatschappelijke thema's die in onze publieke debatten spelen, wel aan de orde te blijven stellen, maar met andere woorden, zodat het verhaal anders gaat klinken en we op een andere manier over onszelf, elkaar en de wereld gaan nadenken. Daar zijn zelfs vele manieren voor, waarvan ik er hier één zal beproeven. Wat ik hier voorstel is een meer gedetailleerde en geduldige interesse in waardebeheer. In plaats van te betreuren dat anderen falen of te bepleiten dat 
iedereen het goede doet, stel ik voor dat we het goede onderzoekend benaderen. Hoe worden waarden in alledaagse praktijken eigenlijk gekoesterd, betwist, veranderd, verworpen? Hoe doen we het goede eigenlijk, dat wil zeggen: welke zaken gelden in deze en gene context als goed (dan wel als slecht of als kwaad); wie of wat krijgt het recht dan wel de taak daarover te oordelen; op wat voor andere manieren dan via 'het oordeel' verhouden we ons tot het goede (denk aan werkwoorden als: verlangen, nastreven, meten, opgeven); welke manieren van doen verbinden we aan transgressies, falen en mislukkingen; en op welke diverse manieren bestaan uiteenlopende versies van 'het goede' naast elkaar (om slechts de meest urgente vragen te noemen)?

Wat onderzoek gevoed door deze vragen ook precies te zien zal geven, een belangrijke opbrengst zit al in de methode ingebakken: de aandacht verschuift van individuen die al dan niet moreel verantwoord handelen, naar praktijken waarin diverse, soms strijdige tradities, instituties en voorwerpen een rol spelen bij het genereren, instandhouden dan wel ondermijnen van diverse soorten 'goed'. Dat we met een pluraliteit aan 'goeden' leven, wordt daarbij niet benepen betreurd, maar evenmin vrijblijvend bezongen. Het vormt aanleiding om te trachten te begrijpen hoe die veelvuldigheid werkt en tot welke harmonieuze klanken en dissonanten ze aanleiding geeft. Om u een kleine proeve te bieden van wat nader onderzoek naar waardebeheer zou kunnen behelzen, zal ik hieronder een voorbeeld presenteren uit het domein van de gezondheidszorg. Daarbij ligt een bijzonder accent op de verwevenheid van alledaags waardebeheer met medische kennis en technieken. Dat is niet voor niets. Dat waardebeheer verweven is met kennis en technieken maakt immers duidelijk dat het niet louter een zaak van individuen is, maar hen (ons) aan alle kanten overstijgt.

Er is nog een reden om in een onderzoek naar waardebeheer juist kennis en techniek ter sprake te brengen. Zoals iedereen weet, leven we in een kennisintensieve, hoogtechnologische samenleving. Maar wat dit precies behelst, welke verstrekkende consequenties het heeft, dat is nog nauwelijks tot ons doorgedrongen. Daar hebben we nog nauwelijks woorden voor. In veel (sociaal-wetenschappelijk dan wel juridisch geïnspireerde) reflecties op de samenleving komen zelfs amper dingen voor; of ze spelen een ondergeschikte rol; of ze komen uit de lucht vallen; of ze vormen slechts het decor voor intermenselijke (mis)communicatie. Maar toch valt er wel degelijk van alles over dingen op te merken: er is de laatste twee decennia zelfs uitgebreid historisch en antropologisch onderzoek naar wetenschap en techniek gedaan. ${ }^{2}$ Juist ook als het om waarden gaat, zo leert dat onderzoek, is aandacht besteden aan materialiteiten, feiten, apparaten en wat dies meer zij onontbeerlijk.

Behalve dat het een voorbeeld biedt van onderzoek naar waardebeheer waarin kennis en technieken ter sprake komen, vormt dit essay ook een gerichte interventie in het hedendaagse Nederlandse debat over de gezondheidszorg. Daarin circuleren domeinspecifieke moralismen. Die miskennen niet alleen de pogingen van diverse betrokkenen om (op hun manier) naar het goede te streven, maar 
gaan bovendien voorbij aan de vraag hoeveel grip zij hebben op de situatie waarin ze verkeren. Zo klinkt, wanneer de gezondheidszorg als te duur wordt afgeschilderd, daarin (soms stilletjes, soms luid en duidelijk) de ondertoon mee dat dat komt doordat patiënten te veel verlangen. Zieken zijn te gretig naar zorg. Ze zouden bescheidener moeten wezen. Dit idee kan alleen bestaan tegen de achtergrond van de veronderstelling dat het patiënten zijn die in de zorg de cruciale morele afwegingen maken. Aan de bescheiden patiënt gaat de kiezende patiënt vooraf: de patiënt die zelf beslist over ingrepen in het eigen leven. Is die patiënt nog geen werkelijkheid? Dan valt dat de hulpverleners te verwijten. In allerlei toonaarden krijgen professionele hulpverleners nu al jaren te horen dat ze de waardegeladen keuzen in de zorg aan hun patiënten moeten overlaten. Hun eigen taak dient eruit te bestaan om neutrale informatie te verschaffen en de (technische) middelen aan te reiken die de doelen van patiënten dichterbij brengen. En als ze iets anders doen, doen ze het fout.

Maar wat als het niet kán? Wat als zowel de verwijten aan patiënten als die aan dokters de plank misslaan? Want dat is wat ik hier beoog te adstrueren. Een nadere verkenning van het waardebeheer in de gezondheidszorg leert dat neutrale informatie niet bestaat en dat doelen en middelen niet uit elkaar te halen zijn. Daarom, zo zal ik betogen, is het onverstandig om te proberen beslissen en handelen uit elkaar te halen. Als waarden inherent zijn aan kennis en technieken, dan begint waarderen lang voor er informatie op tafel ligt en komt er, heel de therapie lang, heel het leven lang, geen einde aan. Dan is professionaliteit niet waardevrij maar evenmin ooit (op enig moment van 'keuze') buitenspel te zetten. In waardevrije informatie geloven én dokters vragen om hun mond te houden als het om waarderen gaat, behelst een miskenning van de aard van professionaliteit. Het dreigt bovendien die professionaliteit te eroderen. Patiënten schieten daar niets mee op. Het biedt hun immers geen toegang tot de waarden die in kennis en technieken vervat zitten, terwijl het wel de last van alles dat misgaat, op hun schouders schuift.

\subsection{ACHTERGROND}

Onderzoek naar waardebeheer kan voortbouwen op een waaier aan eerdere intellectuele tradities - te veel om hier uitputtend te bespreken. Ik beperk me tot een paar schetsmatige aanduidingen. Om te beginnen zijn er in de filosofie manieren ontwikkeld om niet louter stellig over normen en waarden te praten, maar ook redenerend, onderzoekend en verbaasd. Daarbij gaat het niet alleen over anderen: de ware filosoof zet ook zichzelf op het spel. In de ethiek worden normatieve vragen gethematiseerd vanuit het perspectief van het handelend individu: 'Wat moet $i k$ doen?' In de politieke filosofie wordt de wij-vorm gehanteerd en vormt niet het private maar het publieke leven de horizon van de discussies: 'Hoe moeten wij onze samenleving inrichten?' In de discussies over deze kwesties is een verschil gemaakt tussen 'normen' en 'waarden' (een verschil dat overigens elders in diezelfde filosofie weer ondergraven is). ${ }^{3}$ Diverse normen en waarden 
zijn vervolgens onderscheiden, geordend, tegen elkaar afgewogen en ga zo maar door. Deze tradities hebben dan ook een rijke schakering aan termen te bieden waarmee het mogelijk is om verschil te maken - tussen deontologische en utilitaristische verdedigingen van het goede bijvoorbeeld; of tussen rechtvaardigheid en respect als leidende maatschappelijke norm. Daarbij komt dat ze het besef voeden dat er erg veel verschil te maken valt: van eenvormigheid (van meningen) en eenduidigheid (van termen) is immers geen sprake.

Maar hoe rijk aan inzichten ethiek en politieke filosofie ook zijn, ze vertonen weinig nieuwsgierigheid naar waar het handelende individu dan wel het handelende politiek collectief zich eigenlijk bevindt en hoe het precies komt dat we daar onze vraag 'Wat te doen?' stellen, en niet ergens anders. De aandacht gaat uit naar de te maken keuzen en niet naar de situatie van het kiezen. ${ }^{4}$ Ethiek en politieke filosofie nemen de zaken die zich als gegevenheden voordoen aan het individu dan wel aan het collectief dat voor een normatieve keuze staat, zelf ook als gegeven aan: hulpbronnen, technische mogelijkheden en beperkingen, problemen, opdrachten en ga zo maar door. Voor wie het reëel bestaande waardebeheer wil leren kennen, zijn die gegevenheden echter juist de moeite van het onderzoeken waard: waar komen ze vandaan; welke goeden en kwaden zitten erin vervat; doen zich (elders, eerder) in vergelijkbare situaties wellicht net iets andere keuzes voor, of zijn er zelfs situaties die aan geen van de deelnemers aanleiding geven tot kiezen?

Terwijl de filosofische traditie een rijk vocabulaire te bieden heeft voor het benoemen van normen en waarden, geeft de sociologische traditie voeding aan gearticuleerd intellectueel wantrouwen tegen elk beroep op het goede. De geboorte van de sociologie in de negentiende eeuw kenmerkte zich immers door een uitgesproken afkeer, niet alleen van moralismen, maar van alle moraal (ethische en politiek-filosofische theorieën inbegrepen). Sociologen trachtten, in verschillende toonaarden, aan te tonen dat mensen niet handelen op grond van de waarden die ze aanhangen of zeggen aan te hangen. In plaats daarvan werden andere verklaringsschema's ontwikkeld. Zelfmoord plegen hing niet samen met waar mensen precies wel en niet in geloofden, onthulde Durkheim, maar met de mate van onderlinge cohesie die hun (geloofs)gemeenschap hun bood: vooral losgeslagen of juist al te sterk aan hun groep gebonden mensen doden zichzelf. Marx trachtte aan te tonen dat niet de culturele bovenbouw maar de economische onderbouw de geschiedenis voortstuwt. En om ook Nietzsche in een zin te parafraseren: niet de geneigdheid tot het goede drijft de mens, maar de wil tot macht. Religies en theologen hadden het over waarden. Sociologen, in hun pogingen zich daar scherp van te onderscheiden, (dus) niet. ${ }^{5}$

In de twintigste eeuw zijn er vele nieuwe manieren bij gekomen om bij het bedrijven van sociale wetenschap elk beroep op waarden te omzeilen. In de (neoklassieke) economie worden menselijke gedragingen verklaard uit ons vermogen diverse soorten winst en verlies van elkaar af te trekken. De sociobiologie trachtte ons er eerst van te overtuigen dat ons handelen niet voortkomt uit nobele motieven of aardigheid, maar slechts het succes van onze genen beoogt. Vervolgens 
werd 'altruïsme' wel weer in de verklaringsschema's opgenomen, maar ditmaal als iets wat het succes van onze genen bevordert en daarom in die genen ingebakken zit. De gedragspsychologie bracht onder onze aandacht dat gedrag dat stelselmatig (of liever nog: intermitterend) beloond wordt, daardoor bevestigd wordt en ingesleten raakt. En de speltheorie ontwikkelde bepaald complexe modellen om de indrukwekkend ingewikkelde calculaties te analyseren die mensen zouden maken bij het najagen van hun eigenbelang.

Terwijl ethiek en politieke filosofie ons goede raad trachten te geven over de manier waarop we onze normen en waarden het best kunnen schragen, of zelfs over wat te doen, hebben al deze vormen van sociale wetenschap (overigens onderling strijdige) manieren ontwikkeld om ons gedrag achteraf te verklaren zonder het woord 'waarden' ook maar één keer te laten vallen. Een bezwaar van het weglaten van alle referenties aan 'waarden' uit de sociale wetenschappen is echter dat daarmee flinke stukken van de werkelijkheid simpelweg niet te begrijpen zijn. Als alle mogelijke mensen immers ruzie maken over God en gebod, of zich daar groepsgewijs gezamenlijk op beroepen, en de sociale wetenschappen hebben daar niets anders over te melden dan dat dat epifenomenen zijn, zonder verklarende kracht, dan is dat bepaald armoedig. Als mensen in hun alledaagse leven onrechtvaardigheden aan de kaak stellen, zich met hart en ziel aan hun werk wijden, goed voor kun kinderen proberen te zorgen, hun leven voor hun vaderland geven of zelfs maar toegewijd hun huis schoonhouden, en sociale wetenschappen zien louter calculaties, dan schieten die sociale wetenschappen tekort. Als alles en iedereen zich op de raarste momenten druk maakt over goed en kwaad, alleen de sociale wetenschappen niet, dan duidt dat op een manco in die sociale wetenschappen.

$\mathrm{Nu}$ zijn er ook stromingen in de sociale wetenschappen die waarden wel als deel van de sociale werkelijkheid zijn blijven analyseren. De poging van Weber om aan te tonen dat de opkomst van het kapitalisme mede te danken was aan de kracht van protestant-christelijke waarden, zoals hard werken en spaarzaamheid, is er het bekendste voorbeeld van. Een ander intrigerend voorbeeld biedt de sociologie van Parsons, in wiens lijvige werk over de feedback-mechanismen in het sociale systeem de gezondheidszorg een belangrijke case vormde. In een tijd waarin de pathofysiologie (en andere biomedische disciplines) exclusief recht van spreken hadden als het over ziekte ging, bracht Parsons te berde dat het oordeel 'ziek' niet alleen een verwijzing naar de toestand van een lichaam is, maar ook een sociale interventie. Zeggen dat iemand 'ziek' is, betekent immers dat die persoon niet hoeft te werken. Zo iemand mag in bed gaan liggen, sterker, moet in bed gaan liggen, of althans: alles ondernemen wat vereist is om zo vlug mogelijk beter te worden. (Deze sociologie stamt uit de jaren vijftig: bij 'ziek' moeten we hier denken aan een wond, een botbreuk, een longontsteking of andere forse infectieziekte die heftig is, kort duurt en zo goed als restloos geneest.) Omdat 'niet hoeven werken' voor veel mensen aantrekkelijk is, aldus nog steeds Parsons, kan het recht om het oordeel 'ziek' te vellen, niet zomaar aan iedereen toevallen. In moderne samenlevingen is het voorbehouden aan artsen. Zij moeten diagno- 
sen stellen die, juist omdat ze grote sociale gevolgen hebben, niet op sociale waarden gebaseerd mogen zijn. Artsen moeten hun oordelen op hun biomedische kennis funderen en het verschil tussen 'gezond' en 'ziek' aan de hand van biomedische criteria maken. Die immers zijn niet-sociaal en daarom kunnen we er genoeg op vertrouwen om ons er collectief aan over te leveren.

Latere medisch sociologen hebben deze redenering niet weerlegd maar empirisch ondergraven. Bij nader onderzoek bleken medische oordelen in de praktijk wel degelijk sociale waarden te bevatten. In de jaren zestig kreeg de (toenmalige) diagnose 'homoseksualiteit' veel aandacht als manier waarop gedrag dat door velen 'onzedelijk' of 'zondig' werd bevonden, opnieuw negatief werd gelabeld, maar nu als 'neurose'. Ook andere psychiatrische categorieën (schizofreen, verslaafd) werden in die tijd als sociale veroordelingen van sociale onaangepastheid te kijk gezet. (Het etiket 'ziek' werd in dit verband niet langer gezien als een prettig excuus om niet te hoeven werken, maar als een vorm van sociale uitstoting.) Ook in biomedische oordelen kunnen sociale oordelen doorklinken, heette het. 'Gij zult niet roken' bijvoorbeeld mag dan wel een epidemiologische rationale hebben, deze aansporing is tegelijk een naadloze voortzetting van het burgerlijk fatsoen van eerdere decennia dat ook al leerde dat nette meisjes niet roken. Maar hoezeer in dit type medische sociologie Parsons empirisch ook werd weerlegd (artsen bleken, tegen zijn overtuiging in, wel degelijk sociale waarden mee te laten wegen in hun werk), zijn theoretische schema bleef overeind. Immers: er klonk verontwaardiging door in de medische sociologie wanneer ze artsen 'betrapte' op het vellen van sociale oordelen: hier gebeurde iets verkeerds. Eigenlijk zouden het louter biomedische normen moeten zijn die de gezondheidszorg richting gaven.

In Parsons' theoretische schema stonden biomedische normen en sociale waarderingen tegenover elkaar. Juist omdat oordelen over ziekte en gezondheid grote sociale gevolgen hebben, moesten die oordelen op louter biomedische criteria gebaseerd zijn. Latere sociologen verweten de geneeskunde dat in de praktijk niet alleen de gevolgen, maar ook de gronden van medische oordelen vaak sociaal zijn. Daar kwam bij dat medische oordelen niet alleen de huidige toestand van patiënten betreffen, maar ook de toekomstige. Medisch handelen is erop gericht mensen beter te maken, maar wat is beter? Naarmate de te behandelen ziekten minder vaak acuut (en geneesbaar) en vaker chronisch (en ongeneeslijk) werden, werd deze kwestie prangender. Waar bij een behandeling precies naar streven: een langer leven of een leven met meer kwaliteit? Wat is minder erg: de lasten dragen van dagelijkse trainingen of die van driemaal daags pillen? En hoe de kans op verbetering door een operatie te wegen tegen het risico op tafel dood te blijven? De waarden die bij dergelijke beslissingen de doorslag geven, zeiden de medisch sociologen, zijn niet biomedisch, maar sociaal.

Ethici waren in eerste instantie wel gecharmeerd van de figuur van de medicuspracticus die het antwoord op de vraag 'Wat te doen?' niet in de wetenschap kan vinden. Deze trof hen als een uitzonderlijk goed voorbeeld van een individu dat 
voor gewichtige keuzes staat (keuzes over leven en dood nog wel) en ze namen het met genoegen op zich om over die keuzes mee te denken en medici goede raad te geven. ${ }^{6}$ Maar na enige tijd gingen ethici een bondgenootschap aan met de verontwaardigde sociologen en gezamenlijk stelden ze de vraag aan de orde waarom dokters zich eigenlijk in de positie bevinden om over de levens en de dood van hun patiënten te beslissen. Bij Parsons was de rationale voor de medische macht duidelijk: die gaf een neutrale grond aan lastige sociale beslissingen en voorkwam zo sociale conflicten. Maar als de neutraliteit van medische oordelen illusoir was, viel die rationale weg. Wat overbleef waren paternalistische dokters die zich vanuit hun eigen parti-pris met de levens van hun patiënten bemoeiden en er de baas over speelden. ${ }^{7}$ Dat moest afgelopen wezen. Medici moesten zich voortaan beperken tot wat werkelijk neutraal is: hun kennis over het lichaam en het ziekteverloop, hun vaardigheid in het hanteren van medische technieken. Aan patiënten het recht hun eigen waarden in stelling te brengen en zelf te kiezen tussen de diverse mogelijke ingrepen in eigen lijf en leven.

Deze voorstelling van zaken domineert (of domineerde?) niet alleen de medische sociologie en de medische ethiek, maar is ook geïncorporeerd geraakt in het beleid ten aanzien van de gezondheidszorg. Dat artsen neutrale informatie moeten aanleveren, zodat patiënten zelf hun keuze kunnen bepalen, waarop artsen hun de middelen aanreiken die hun doelen dichterbij brengen, heeft in Nederland zelfs kracht van wet gekregen. ${ }^{8}$ Wat die wet en de pogingen haar te implementeren in de praktijk ook precies veranderd hebben, ze hebben in elk geval de ideologische ruimte vergroot waarin het mogelijk is om patiënten -immers degenen die de keuzen 'mogen' maken - voor van alles en nog wat verantwoordelijk te houden (zoals voor de stijging van de kosten van de gezondheidszorg). .9 In de sociale wetenschappen en de ethiek echter is intussen een nieuwe denklijn ontwikkeld. Daarin wordt het parsoniaanse schema eindelijk verlaten. Niet langer wordt het alleen empirisch tegengesproken, het voedt ook geen verwijten meer. Dat dokters waarderen als ze werken, wordt hun niet langer aangerekend omdat het onvermijdelijk is. Biomedische wetenschap en medische technieken, zo luidt de nieuwe les, zijn niet waardevrij, maar door en door sociaal.

Er is gedurende het afgelopen decennium 'post-parsoniaans' veldwerk gedaan in IVF-klinieken, ICT-werkplaatsen, revalidatieklinieken, huisartspraktijken, kraamkamers, PET-scan-centra, neurochirurgische operatiezalen, verpleeghuizen en ga zo maar door. ${ }^{10}$ Daarbij is veel aandacht uitgegaan naar de waarden vervat in biomedische kennis en technieken en naar de diverse manieren waarop die gekoesterd, bediscussieerd en getransformeerd worden. Enkele van de inzichten die in deze onderzoekslijn ontwikkeld zijn, zal ik hieronder presenteren. Ter wille van de overzichtelijkheid doe ik dat aan de hand van voorbeelden ontleend aan eigen onderzoek naar de behandeling van diabetes. ${ }^{11}$ Wat hier volgt zijn lessen uit recent etnografisch onderzoek naar medische praktijken die in de eerste plaats relevant zijn voor de (Nederlandse) gezondheidszorg waaraan ze zijn ontleend, maar die bovendien aanknopings- en afzetpunten bieden voor onderzoek naar waardebeheer op andere plaatsen en tijden. ${ }^{12}$ 


\section{$14 \cdot 3$ BIOMEDISCH EN SOCIAAL}

De recente etnografische studies naar het waardebeheer in de gezondheidszorg laten zien dat biomedische feiten en sociale waarden zo onlosmakelijk met elkaar verbonden zijn dat proberen ze van elkaar los te maken een weinig productieve strategie is. Het probleem met het model van de informerende arts en de beslissende patiënt, is dus niet alleen dat patiënten 'kiezen' niet altijd even aantrekkelijk vinden en op heel wat momenten in hun bestaan-als-zieke een beroep blijven doen op de professionaliteit van hun hulpverleners. ${ }^{13}$ Er is nog iets anders aan de hand: de 'informatie' waarover artsen beschikken is nooit zo puur biomedisch dat alle sociale waarden eruit weggewassen zijn. Het waardebeheer in de gezondheidszorg begint niet pas vanaf het moment dat er in de spreekkamer informatie ter tafel ligt, maar lang daarvoor. Er zitten waarden vervat in medische feiten.

Neem de behandeling van diabetes. De lichamen van mensen met diabetes zijn niet in staat om insuline te maken (dit is het geval bij mensen met, zoals dat heet, diabetes 1) of hun cellen zijn er ongevoelig voor geworden (dit heet diabetes 2). De instructie 'suiker opnemen' die insuline aan lichaamscellen hoort te geven als de suikerspiegel in het bloed stijgt, blijft dus uit of komt niet aan. Zonder behandeling zou de suikerspiegel in het bloed van iemand met diabetes na een maaltijd enorm stijgen. Is die suikerspiegel dankzij flinke inspanning eenmaal te laag, dan blijkt dat ook de tegenregulatie bij mensen met diabetes gebrekkig is: ze maken de glucagon die hun suikeropslag ertoe aan moet zetten suiker vrij te geven, slecht aan. Is dit nu de informatie, zijn dit de feiten: dat het bloedsuiker van mensen met diabetes, als er niet van buitenaf in hun suikerregulatie wordt ingegrepen, of te hoog wordt of te laag? Zeker, maar er zit wel waardering in die zin vervat en geen puur biologische. Wat is namelijk precies te hoog en wat te laag?

Laten we beginnen met de ondergrens: te laag. Wat is een te laag bloedsuiker, waar begint, om de medische term te gebruiken, hypoglykemie? In het Nederlandstalige handboek Diabetes Mellitus lezen we: “Bij personen zonder diabetes mellitus varieert de plasmaglucosespiegel tussen 3 en $8 \mathrm{mmol} / \mathrm{l}$, afhankelijk van de tijd die verstreken is na de laatste maaltijd. In het algemeen wordt bij diabetespatiënten als criterium van een hypoglykemie een bloedglucose onder 3,5 mmol/l gehanteerd" (Van Haeften 1995: 142). Het staat niet in dit citaat, maar bij een bloedsuikerspiegel beneden de 3,5 $\mathrm{mmol} / \mathrm{l}$ beginnen de meeste mensen last te krijgen (ze gaan zich draaierig voelen en vaak geïrriteerd bovendien). Daarom markeert dat getal hier het verschil tussen normaal en te laag. In het proefschrift van Ter Braak echter, dat aan hypoglykemie gewijd is, figureert een ander getal: "Hypoglycaemie kan worden gedefinieerd als een bloedglucosegehalte lager dan $3,9 \mathrm{mmol} / \mathrm{l}$ omdat beneden deze waarde bij gezonden de glucosetegenregulatie op gang komt” (Ter Braak 200o: 188).

Deze definities komen niet uit verschillende werelddelen: de auteurs werkten op het moment van schrijven in dezelfde kliniek. Maar de getallen die ze noemen zijn wel verschillend. De rationale erachter ook: krijg je beneden de 3,5 $\mathrm{mmol} / \mathrm{l}$ 
last, gezonden maken al bij 3,9 mmol/l de glucagon aan die opgeslagen suikers uit hun cellen vrij moet maken. Hier en nu wil ik geen discussie over de kracht van deze beide definities voeren, maar laten zien dat er ruimte voor zo'n discussie bestaat. De deskundigen onder elkaar houden die ruimte zorgvuldig open door hun getallen niet al te stellig te poneren, maar uitdrukkingen als 'over het algemeen' en 'kan worden' te gebruiken. Zij weten heel goed dat er rek zit in de feiten en ervaren dagelijks dat kennis waardering veronderstelt. Bij dergelijke waarderingen plegen allerlei typen afwegingen door elkaar te lopen: waar is het getal voor nodig (in een onderzoekscontext zijn vaak andere grenzen van belang dan in de dagelijkse praktijk); door wie moet het worden gebruikt; wat is de nauwkeurigheid van de meetapparatuur; wat kost meten; wat zijn (en voor wie) de gevolgen van het te ruim of juist te krap definiëren van hypoglykemie - en ga zo maar door. Dergelijke afwegingen zijn nauwelijks onder te brengen in afzonderlijke rijtjes 'biologisch' en 'sociaal' en er passen bovendien nog wel meer bijvoeglijke naamwoorden bij: praktisch, technisch, juridisch, financieel, psychologisch - en ga zo maar door - allemaal door elkaar.

Ook het vaststellen van de bovengrens van het normale gebied is geen eenduidige biologische kwestie. Wanneer is een bloedsuikerspiegel te hoog? $8 \mathrm{mmol} / \mathrm{lmag}$ volgens het handboek Diabetes Mellitus de hoogste waarde zijn die de bloedsuikerspiegels van mensen zonder diabetes pleegt te bereiken, mensen met diabetes hebben daar weinig aan. Omdat zij hun bloedsuiker extern moeten reguleren, is een 'bovengrens' in hun geval geen gegeven ijkpunt, maar een nader te bepalen streefwaarde. Wat is een goede streefwaarde? Het zou, opnieuw, $8 \mathrm{mmol} / \mathrm{l}$ kunnen zijn. Maar dat vereist wel dat het inspuiten van insuline nauwkeurig wordt afgestemd op het moment van eten en op de hoeveelheid voedsel die men eet. Het vereist ook dat kortwerkende insuline wordt gespoten en is dus pas mogelijk sinds er kortwerkende insuline bestaat, en alleen bij mensen die daarop zijn overgestapt. Als aan een van deze vereisten niet voldaan is, is het onmogelijk $8 \mathrm{mmol} / \mathrm{l}$ als bovengrens te hanteren. Wellicht lukt $10 \mathrm{mmol} / \mathrm{l}$ wel. Maar ook dat vereist dat de afstemming van geneesmiddel, maaltijd en inspanning (zijn dit biologische grootheden? sociale?) goed is. Zo niet, dan komt de bloedsuikerspiegel van iemand met diabetes onherroepelijk herhaaldelijk boven de $10 \mathrm{mmol} / \mathrm{l}$.

Grootschalige clinical trials hebben laten zien dat voor mensen van wie de bloedsuikerspiegels regelmatig flink boven de $10 \mathrm{mmol} / \mathrm{l}$ komen, de risico's op het ontwikkelen van complicaties groter zijn dan voor anderen wier bloedsuiker, zoals dat heet, strakker gereguleerd wordt. Die complicaties zijn lichamelijk: slechte ogen, slechte bloedvaten, slechte zenuwgeleiding. Maar daarmee zijn ze ook sociaal: iemand die weinig ziet, kan niet meer lezen of autorijden of televisiekijken; iemand wiens bloedvaten zo slecht zijn dat ze tot ernstig falen van de nieren leiden, moet aan de dialyse, met alle sociale gevolgen van dien, enzovoort: er is een keur aan ellende mogelijk die, dat moge duidelijk zijn, mét het lichaam het leven treft. Strakke regulatie is sinds de betreffende trials dus tot ideaal verheven. In de hoop nooit boven de $10 \mathrm{mmol} / 1$ te komen, houden sommige mensen als bovengrens van hun streefwaarde zelfs een bloedsuikerspiegel van $6 \mathrm{mmol} / 1$ 
aan. Maar dat heeft ook zo zijn bezwaren. Iemand die erop mikt nooit boven de 6 $\mathrm{mmol} / \mathrm{l}$ te komen, loopt meer kans af en toe weg te zakken naar een bloedsuiker beneden de $3 \mathrm{mmol} / \mathrm{l}$. En ook een serieuze hypoglykemie vormt tegelijk een lichamelijk en een sociaal probleem. Het beschadigt niet alleen de hersenen, maar vloert ook de persoon: eerst word je draaierig, dan geïrriteerd en als je daarop niet snel reageert door iets te eten, val je flauw. Dat is erg vervelend als je een vergadering bijwoont en nog vervelender als je in de auto zit, achter het stuur.

Wat een te hoge en wat een te lage bloedsuikerspiegel is, valt niet te formuleren in eenduidige, biomedische termen die slechts het lichaam betreffen. Want hoe erg het is dat er juist dit met iemands lichaam misgaat (later blind worden) of juist dat (nu flauw vallen), is onverbrekelijk verknoopt met de sociale situatie van de betrokkenen en wat daaraan te waarderen valt. Maar louter sociaal zijn de relevante waarderingen evenmin - ze vereisen inzicht in de mechanismen van de bloedsuikerregulatie en veranderen met het veranderen van biomedische en klinisch-epidemiologische kennis. Ook het vergaren van de betreffende kennis is intussen geen louter lichamelijke zaak: het vereist op zijn minst grote groepen patiënten die bereid zijn volgens diverse tegen elkaar af te wegen regimes te leven; het vereist eindpunten die gelden als parameter van het succes dan wel het falen van een ingreep. Wanneer is uw diabetesbehandeling goed geweest: als $u$ jaren gewoon uw werk hebt kunnen doen, zonder last van hypoglykemieën; of als $\mathrm{u}$, met nog verrassend goede ogen, uw zeventigste verjaardag haalt? Bij dergelijke vragen gaat het niet om het afwegen van een goede kwaliteit van leven tegen een slechte, maar om een veel lastiger confrontatie van verschillende kwaliteiten die het leven hebben kan.

Om meer inzicht te krijgen in het waardebeheer in de gezondheidszorg, zullen we de medische kennis in moeten duiken. In plaats van aan dokters om 'neutrale informatie' te vragen, zullen we de niet-neutraliteit van alle feiten onder ogen moeten te zien. Welke vragen staan in het huidige biomedische en klinischepidemiologische onderzoek eigenlijk voorop? Welke parameters doen er de ronde? Welke alternatieven concurreren daarbij met elkaar? Wie is er bij de discussies over deze kwesties betrokken en wie niet? Welk beeld van 'het belang van de patiënt' en van 'het goede leven' wordt in onderzoeksdesigns ingebouwd? Tot welke conclusies zouden andere representaties van patiënten en dagelijkse levens leiden ${ }^{14}$ Over dergelijke kwesties is al van alles bekend, wat akelig slecht doordringt op de plekken waar het verschil zou kunnen maken - wat valt daaraan te doen? Veel ook is niet bekend: de medische wetenschappen, rijk en heterogeen, verdienen beslist nader onderzoek. Wat staat, is dat we met een scherp besef van de complexiteit van het waardebeheer op een kennisintensief gebied als de gezondheidszorg meer gediend zijn dan met de algemene stelling dat de biomedische feiten een zaak zijn voor artsen, terwijl het sociale waarderen aan patiënten toekomt. 


\subsection{DOELEN EN MIDDELEN}

Voor wie geïnteresseerd is in het waardebeheer in de gezondheidszorg zijn niet alleen onze oordelen over de werkelijkheid maar ook onze ingrepen in die werkelijkheid van belang. De vraag naar het goede van ingrepen wordt in de meeste gangbare theoretische talen opgesplitst in twee typen vragen: die naar het doel en die naar het middel. Vragen naar het beoogde doel van ingrepen komen in ethische en politieke theorieën aan bod. 'Wat te doen?' wordt vereenvoudigd tot 'Wat te bereiken?': waar willen we heen? Soms heerst daarbij het idee dat, als het doel eenmaal is vastgesteld, anderen, technici, daartoe de middelen maar moeten ontwikkelen. Soms ook is de ethische dan wel politieke discussie bescheidener, en beperkt ze zich ertoe bestaande middelen tegen elkaar af te wegen vanuit de vraag welk middel het beste doel dient. In de wereld van de techniek intussen, waar middelen worden ontwikkeld en geëvalueerd, klinkt het woordje 'goed' ook. De vraag wat een goede techniek is, wat een goed middel, wordt daar echter verengd tot een kwestie van effectiviteit en efficiency. Een effectief middel, zo heet het dan, is een middel dat een tevoren gesteld doel zo dicht mogelijk weet te naderen met zo min mogelijk bijwerkingen. Als het ook nog weinig moeite en geld kost, is het middel bovendien efficiënt.

Het aantrekkelijke van dit soort schema's is dat ze overzichtelijke taakverdelingen mogelijk lijken te maken. Ze suggereren dat een patiënt voorzien van informatie zelf de eigen doelen stellen kan, waarop een arts, neutraal, deskundig, de middelen zal aanleveren die dat doel onderdanig dienen. Ze suggereren bovendien dat het parlement of een ander beslissend gremium kan discussiëren over de vraag waar het heen moet (met de dijken, de WAO, de voortplanting) en dat de ingezette middelen zich vervolgens aan die doelen zullen onderwerpen. $\mathrm{Ze}$ suggereren dat, als iets ethisch of politiek als goed is aangemerkt, de realisering ervan weliswaar soms lastig is (met het ontwikkelen van de benodigde middelen kunnen veel hoogopgeleide mensen en veel geld gemoeid zijn), maar dat het au fond eenvoudig is, want slechts waardevrij regelen en meten vereist. Onderzoek naar het waardebeheer in dagelijkse praktijken waarin technieken ontwikkeld en gebruikt worden, laat echter zien dat het, opnieuw, ingewikkelder ligt. Technieken dienen doelen niet alleen, maar doen er veel meer mee. De verknopingen zijn slechts met reeksen werkwoorden weer te geven. Technieken vestigen, vormen, vermenigvuldigen en veranderen doelen, net zo goed als ze er op hun beurt door gevestigd, gevormd, vermenigvuldigd en veranderd worden. Waardebeheer en het ontwikkelen en inzetten van technieken zijn dan ook niet uit elkaar te halen.

Daar inzicht in verwerven vereist onderzoek naar waardebeheer dat zich in de techniek mengt, dat technisch wordt. Dat technieken meer effecten hebben dan hun doelen alleen, zal ik hier illustreren aan de hand van een eenvoudige techniek: suikervrij eten. Ter wille van een goede suikerregulatie werd aan mensen met diabetes vroeger aangeraden om zo min mogelijk suiker te eten. Snoep, limonade, pudding, ijs en gebakjes waren verboden. Hun dieet week daarmee duidelijk af van dat van de meeste mensen in hun omgeving. En hoewel het doel, een 
goed gereguleerde bloedsuikerspiegel, onomstreden was, werd juist dit neveneffect, manifest anders zijn, als onplezierig ervaren. Met de introductie van suikervrije varianten van allerlei zoete heerlijkheden op de markt verminderde dit iets, maar niet veel. Want hoewel het prettig was mee te kunnen genieten van 'iets lekkers', bleven deze producten mensen met diabetes apart zetten. Zij aten anders dan hun naasten en waren dus ook anders.

Groot was bij vele betrokkenen dan ook de vreugde toen suikervrij eten niet langer hoefde. Het regime veranderde. In plaats van het streng beperken van de totale suikeropname kwam de taak om evenwicht te bewaren. De hoeveelheid gegeten koolhydraten, de inspanning en de gespoten insuline moeten nu nauwkeurig op elkaar worden afgestemd. Als het evenwicht maar gehandhaafd blijft, kan een gebakje best een keer; en wie flink ver gaat fietsen doet er zelfs goed aan iets te snoepen mee te nemen. Niet langer valt aan het voedsel op ieders bord te zien wie er anders is. Maar alleen maar voordelen heeft deze verandering niet. Vroeger, zo vertelde een van onze informanten die al jaren diabetes heeft, kochten ze ter gelegenheid van een verjaardagsfeestje een apart gebakje voor je en daarmee was je een uitzondering. Nu sta je niet meer apart, maar nu gaan ze zich met je bemoeien. Ze zeggen: neem toch een gebakje, dat deed je vorige keer toch ook, dat mogen jullie nu toch? Ze zeggen: doe niet zo ongezellig! Het ingewikkelde verhaal van het evenwicht is lastiger uit te leggen dan het simpele verhaal dat alle suiker taboe is. Sinds het 'suikervrije dieet' heeft plaatsgemaakt voor het 'bewaren van evenwicht' is de grens tussen zieken en gezonden niet langer manifest. Maar in plaats van dat suikervrije gebakjes dat voor hen doen, moeten mensen met diabetes die grens nu zelf bewaken.

Suikervrij voedsel had de bloedsuikerregulatie als doel, niet het vrijwaren van mensen met diabetes van de al te grote bemoeizucht van hun naasten. Dat dat een van de effecten ervan was, blijkt pas achteraf, nu het dieet veranderd is. Evalueren hoe zwaar de verbeteringen wegen en wat precies de last van de onvoorziene bezwaren is, is hier de bedoeling niet. Het gaat me erom te illustreren dat de effecten van medische interventies op het alledaagse leven zo complex zijn dat ze niet in een doel-middelschema passen. Wie verwacht het waarderen te kunnen beperken tot het moment dat de doelen gewogen worden, en van technici vraagt de middelen aan te leveren om die doelen dichterbij brengen, komt dan ook bedrogen uit. Technieken blijken grillig in het gebruik. Wat ze teweegbrengen is ook voor hun ontwikkelaars vaak onverwacht. ${ }^{15}$ In plaats van, zelf louter middel, onze doelen te dienen, dragen technieken er veeleer toe bij dat onze doelen veranderen.

Dat doelen onder de invloed van nieuwe technieken kunnen veranderen, valt goed te illustreren aan de hand van de geminiaturiseerde bloedsuikermeter. Dit is een apparaatje waarmee mensen met diabetes zelf thuis hun bloedsuikerspiegel kunnen bepalen. Toen dit apparaatje nog niet bestond, was het in de Nederlandse diabeteszorg gangbaar dat mensen eens in de drie maanden, vlak voor ze bij hun specialist op controle kwamen, bloed lieten prikken: 's morgens vroeg, voor het 
ontbijt. Die nuchtere bloedsuikerspiegels moesten onder de $10 \mathrm{mmol} / \mathrm{l}$ blijven en als ze dat niet deden, kon op het consult de behandeling worden bijgesteld. Als iemand helemaal ontregeld was, was een ziekenhuisopname vereist. In het ziekenhuis kon dan om de paar uur een bloedsuiker geprikt worden en met veel gepas en gemeet kon de patiënt opnieuw worden ingesteld. De geminiaturiseerde meter maakte het patiënten mogelijk regelmatig zelf om de paar uur hun eigen bloedsuikerspiegels te controleren, tussen hun dagelijkse activiteiten door. Dat maakt een fine-tuning van de instelling mogelijk. Als de gemeten getallen regelmatig te hoog zijn, kunnen dieet, inspanning of insuline worden aangepast. Zo werd de streefwaarde, $10 \mathrm{mmol} / \mathrm{l}$ nuchter, bereikbaarder. Maar daar bleef het niet bij. Met een bloedsuikermeter thuis was het ideaal al vlug niet langer om enkel nuchter onder de $10 \mathrm{mmol} / \mathrm{l}$ te blijven, maar om dat altijd te doen, de hele dag. ${ }^{16}$ Zo veranderde het metertje de waardering van de bloedwaarde die het meten moest.

De bloedsuikermeter is geen dienstig middel. Hij mengde zich zelfs op nog een manier in zijn eigen doel. Het meten van de eigen bloedsuikerspiegels was geïntroduceerd om hoge bloedsuikers te voorkomen. Om te beginnen via de hierboven beschreven weg en bovendien, van dag tot dag, op meer onmiddellijke wijze. Dat gaat zo: als iemand met diabetes zich beroerd begint te voelen, kan dat een goede reden zijn om iets te eten: een hypoglykemie dient immers te worden voorkomen. Maar als je bloedsuikerspiegel van, pakweg, $15 \mathrm{mmol} / \mathrm{l}$ naar $8 \mathrm{mmol} / 1$ zakt, voel je je ook beroerd. Eten is dan echter niet raadzaam: dat zou immers met zich meebrengen dat je bloedsuikerspiegel opnieuw naar de 15 mmol/l zou klimmen. Met een bloedsuikermeter bij de hand kan iemand die zich beroerd voelt, nagaan of eten nu wel of niet geboden is. Dat voorkomt 'voor niets' eten en dus het te hoog oplopen van de eigen bloedsuikerspiegel.

Het strakke reguleren dat met de bloedsuikermeter (en snelwerkende insuline en indrukwekkende trial-resultaten) zijn intrede had gedaan, bleek intussen echter tot nieuwe problemen te leiden. Het aantal hypoglykemieën nam erdoor toe. Als bloedsuikerspiegels gemiddeld lager zijn, zijn ze vaker te laag: vreemd is dat niet, vervelend is het wel. Maar terwijl bloedsuikermeters de te frequente hypoglykemieën mede veroorzaken, dienen ze zich ook aan als deel van de oplossing. Iemand met diabetes die zich extra heeft ingespannen of die wat weinig gegeten heeft, en die de eigen suikervoorraad wellicht heeft opgebruikt, kan met zo'n metertje onder handbereik immers de eigen bloedsuikerspiegel checken, om na te gaan of die inderdaad aan de lage kant is en het dus nodig is iets te eten. En zo heeft dit apparaatje niet alleen de bloedwaarden veranderd die het helpt nastreven, maar ook zichzelf. Van een techniek bedoeld om te hoge bloedsuikerspiegels te vermijden, veranderde het in een techniek die evenzeer dient om te lage bloedsuikerspiegels tegen te gaan.

Technieken zijn geen gehoorzame doosjes die dienstig onze wil ten uitvoer brengen; interventies zetten meestal meer in beweging dan aanvankelijk de bedoeling was. ${ }^{17}$ Een goed doel heiligt de middelen dan ook niet. De waarde van een middel 
ligt immers niet louter in het doel besloten, maar hangt ook af van onvermoede gunstige effecten en onverhoopte nadelen die eraan verbonden zijn. Hoe die te achterhalen? Met effectiviteitsonderzoek lukt dat niet. Om met een trial effectiviteit te kunnen meten, moet het doel, in de vorm van 'parameters voor succes', immers aan het begin van het onderzoek worden vastgelegd. $\mathrm{Nu}$ is de vraag of een techniek het beoogde doel al dan niet dichterbij brengt, beslist interessant. Maar effectiviteitsonderzoek helpt niet om de diversiteit aan waarden te leren kennen die technieken in het gebruik aankleven. Het helpt niet om zicht te krijgen op de eigenaardigheden van apparaten en manieren van doen; op de creativiteit van alles en iedereen die bij het implementeren van een techniek betrokken is. Wie het met een techniek geassocieerde waardebeheer wil leren kennen, moet onderzoek doen dat niets vooraf vastlegt, maar open oog heeft voor het variëren van alle mogelijke variabelen in, om en aan de betreffende techniek. ${ }^{18}$ Technieken zijn nu eenmaal geen instrumenten. Ze onderwerpen zich niet aan wat we van ze willen, maar interfereren met wie we zijn.

\subsection{DELIBEREREN EN DOEN}

In ethiek en politieke filosofie zijn 'waarden' kwesties om over na te denken en te discussiëren. Bij dat delibereren worden argumenten 'voor' en 'tegen' tegen elkaar afgewogen, nieuwe invalshoeken aangedragen, aanbevelingen of regels geformuleerd en, door anderen, elders, weer verworpen. Omdat de betrokken theoretici zich in het debat thuis voelen als vissen in het water, veronderstellen ze maar al te gemakkelijk dat ook in de rest van de wereld het beheren van waarden een kwestie van delibereren is. Wie in dagelijkse praktijken op zoek gaat naar deliberaties vindt er ook meer dan genoeg: op tal van plekken praten mensen in tal van talen over wat goed (waardevol, belangrijk, rechtvaardig, verstandig, juist) is om te doen. Parlementen, vergaderzalen, leslokalen, televisieprogramma's, krantenkolommen, cafés en verjaardagsfeestjes: ze gonzen van de debatten waarin waarden gewogen worden. En de plek waar patiënten bij hun artsen op consult komen, heet niet voor niets de spreekkamer. Er wordt in onze wereld heel wat afgepraat, maar als het hier bepleite onderzoek naar waardebeheer zich tot het analyseren van die deliberaties beperken zou, dan miste het veel. Behalve delibereren omvat het beheren van waarden in de alledaagse praktijk immers ook nog andere manieren van doen.

Opnieuw een voorbeeld uit de praktijk van de diabeteszorg. In de spreekkamer overlegt een internist met een patiënt over diens behandeling. De internist legt het verhaal nog eens uit dat $u$ hierboven las: dat strak reguleren complicaties op lange termijn kan helpen voorkomen, maar dat het wel vereist dat de patiënt af en toe de eigen bloedsuikerspiegels meet. Zeker. Ja dokter. De patiënt knikt. In deze ruimte, deze spreekkamer, lijkt het hem een goed idee. Dat wil hij wel: betere bloedvaten zien te houden, betere ogen, minder zenuwuitval. Dat zijn allemaal goede zaken, die grif opwegen tegen het nadeel van het meten. Bij de eerstvolgende afspraak vertelt de betrokken patiënt echter dat het hem niet gelukt is. Hij 
heeft zijn bloedsuikers niet vaak genoeg gemeten. Wat hier goed klonk, bleek daarbuiten niet te werken. Dergelijke mislukkingen zijn in de gezondheidszorg aan de orde van de dag. Ze zijn er echter geen eindpunt. Daar zit ie immers weer, op het spreekuur, de patiënt. En hij wil het nog steeds, heus, strak reguleren, als het tenminste te doen valt. Wat nu?

$\mathrm{Nu}$ is het zaak om alles wat met 'meten' verband houdt, uit elkaar te rafelen om na te gaan of er iets aan valt bij te stellen zodat het wel lukt. Misschien mist de patiënt de vaardigheid die vereist is om zelf te meten. Dan gaat hij bij de diabetesverpleegkundige langs om alles nog eens na te lopen: in je vinger prikken, het stickje erbij houden, bloed uit je vinger op het stickje duwen, stickje met bloed in de meter steken, getal aflezen en opschrijven in het bijbehorende notitieboekje. Terwijl hij dat oefent, kan de verpleegkundige merken dat het metertje dat de patiënt heeft, niet goed bij hem past. Daar zit het probleem: de schroefdop op het doosje met de stickjes is te lastig open te maken, of het display geeft de uitkomst in te kleine cijfertjes weer, of het meetapparaat is juist aan de grote kant, zodat het onhandig is om mee te nemen. In dergelijke gevallen kan een ander apparaatje worden uitgeprobeerd. Maar ook de specifieke kenmerken van iemands dagelijkse leven kunnen de belemmerende factor blijken. De patiënt werkt in de wegenbouw. Hoe krijg je daar je vingers schoon genoeg om hygiënisch te prikken? Hoe doe je er überhaupt iets zonder dat al je collega's er met hun neus bovenop staan? De enige plek in de wijde omtrek met enige privacy, de wc, is precies ook het smerigst. En wie zich alsmaar terugtrekt, lijkt zich van het werk te drukken. Maar aan 'vijf keer per dag meten' valt van alles te variëren. Is het wellicht een oplossing om niet één dag vijf keer, maar vijf dagen één keer te prikken, telkens op een ander tijdstip, zodat er toch een dagcurve te maken valt? Enzovoort.

Het gesprek in de spreekkamer is geen deliberatie over een doel dat losstaat van het middel dat wordt ingezet om het doel bereiken. Een groot deel van de tijd bespreken patiënten en hun hulpverleners technische zaken. Het precieze tijdstip van het meten, de voor- en nadelen van diverse soorten insuline, de beste voorzorgsmaatregelen ter voorkoming van een hypoglykemie na het sporten, trucjes voor het bijstellen van je dagritme als je in een vliegtuig een tijdzone passeert, enzovoort. In de klinische praktijk bestaat heel wat dagelijks werk van zowel hulpverleners als patiënten uit het achterhalen van de precieze voorwaarden waaronder technieken in het leven van alledag werkbaar te maken zijn. Ook het in de gaten krijgen van 'bijwerkingen' van ingrepen, is niet altijd eenvoudig. Maar door ze op te sporen en te articuleren, kunnen ze beter hanteerbaar worden gemaakt of worden bijgesteld. En na elke aanpassing blijken er dan onherroepelijk nieuwe verschuivingen op te treden die op hun beurt weer tot nieuwe vreugdes en nieuwe ellende leiden. Dat is waardebeheer op de vierkante centimeter en in de vleselijke realiteit van het alledaagse leven. Het goede willen is één ding: maar hoe het te doen?

Bij het praktisch realiseren van idealen zijn technieken voor deskundigen geen vaste gegevenheden. Weten hoe de voorwaarden waaronder technieken werken, 
de gevolgen die ze met zich meebrengen en de apparaten die er het glanzende hart van uitmaken, in het gebruik te kalibreren: dat is nu juist deskundigheid. Deze deskundigheid is niet aan artsen en verpleegkundigen voorbehouden, ook veel mensen met een chronische ziekte verwerven haar; zij het meestal vooral gecentreerd rond de eigen behandeling. Er zijn zelfs allerlei elementen uit de omgang met technieken waarin patiënten beter bedreven raken dan hun hulpverleners. Zo hoeft een arts die geen diabetes heeft, nooit bij zichzelf insuline spuiten, in de eigen vinger te prikken om een bloedsuikerspiegel te meten of voedsel mee te dragen om zo nodig een hypoglykemie te voorkomen. Voorzover er een kloof gaapt tussen deskundigen en leken, is dat dan ook geen kloof tussen artsen en patiënten. Het relevante onderscheid is veeleer dat tussen mensen die weet hebben van de omgang met deze of gene ziekte, diabetes bijvoorbeeld, en anderen, die daar buiten staan. Tussen mensen die weten dat het er bij het leven met een chronische ziekte op aankomt allerlei stukjes en beetjes dagelijks leven telkens opnieuw zo hanteerbaar mogelijk op elkaar af te stemmen, en anderen, die denken dat waarderen een kwestie van delibereren is, terwijl doen 'maar gedoe' is. ${ }^{19}$

Waardebeheer is geen kwestie van delibereren alleen, maar onlosmakelijk met allerlei praktische zaken en taken verbonden. Delibereren is bovendien zelf een praktijk. Er is tijd voor nodig, rust, ruimte. Als het leven te hectisch is of het consult te gehaast verloopt, lukt het niet. Positieve en negatieve aspecten van een gebeurtenis, een toestand of een handeling op een rijtje zetten en overwegen, vereist behalve tijd bovendien de nodige vaardigheden. Neem opnieuw de behandeling van diabetes. Voorzien van een eigen bloedsuikermeter kan een moderne patiënt een deel van het werk doen dat vroeger aan laboranten was voorbehouden, namelijk de eigen bloedsuikerspiegels meten en de uitkomsten noteren in een schriftje. Wie dat schriftje meeneemt naar het spreekuur verschaft de arts meer en betere gegevens ter wille van het voorschrijven van nauwkeuriger afgestemde doses insuline. Het is echter ook mogelijk om als patiënt een deel van de taak over te nemen die vroeger aan de dokter was voorbehouden: de therapie bijstellen. Moderne patiënten kunnen in voorkomende gevallen besluiten om iets meer eenheden insuline te spuiten of juist iets minder, al naar gelang dat - gegeven hun inspanning, eetplannen en bloedsuikerspiegel verstandig is.

Het bijstellen van de eigen therapie vereist echter denkwerk. Het gedelibereer dat nodig is om te kunnen beslissen wat, hier en nu, in deze omstandigheden, precies verstandig is, is niet makkelijk om te doen. Er zijn allerlei cursussen voor ontwikkeld. Er wordt geëxperimenteerd met achterwachten die je op kunt bellen als je het even niet meer weet en met internetconsulten. De statistieken leren dat strak reguleren op termijn complicaties voorkomt en een bloedsuikerspiegel blijft het meest constant bij mensen die van dag tot dag, van uur tot uur, hun behandeling weten bij te stellen. Maar eenvoudig is het niet. Het lukt dan ook niet altijd en het lukt niet iedereen. Luister, ik wil best meten, zeggen sommigen van onze informanten luid en duidelijk, maar ook nog eens over die getallen nadenken: 
daar begin ik niet aan. Daar word ik helemaal mesjoche van. Dat laten ze dus liever aan hun dokter over. Je moet er immers zo veel voor weten: over koolhydraten en inspanning en eenheden insuline. Je moet er ook veel voor kunnen: rekenen en onthouden en de eenheden aanpassen die je spuit. Beslissen over je eigen behandeling is in de praktijk niet alleen een kwestie van je waarden doen gelden, het is ook technisch ingewikkeld. Je moet er kalm, weldoordacht en consequent van alles en nog wat voor doen.

In technieken en de details van hun dagelijks gebruik zijn sociale waarden vervat. Dat is een goede reden om de ontwikkeling, de implementatie en de bijstelling ervan niet aan technici, in casu artsen, over te laten. Het is alleszins op zijn plaats daar gepaste vormen van openbaarheid voor te zoeken. Maar wat voor vormen? Met louter deliberatie over de in onze technieken ingebouwde (of in te bouwen) waarden kan immers niet worden volstaan. Wie wil delen in de beslissingsmacht die in deskundigheid geïmpliceerd is, moet - in de een of andere vorm - deskundigheid verwerven. In het leven van mensen met diabetes wordt dat op dit moment al scherp, soms pijnlijk, duidelijk. Deelnemen aan het beheer van de voor onze dagelijkse levens relevante waarden, vereist, in een kennisintensieve en hoogtechnologische samenleving, veel kennis en tal van technische vaardigheden.

\subsection{CONCLUSIE}

Waarden zijn niet statisch en van God gegeven. Ze zijn in de loop van de geschiedenis, in specifieke sociale constellaties, in vele vormen en variëteiten, totstandgekomen. We dragen ze mee in onze gewoonten en hebben ze in onze voorwerpen ingebouwd. Maar als ze niet gekoesterd worden, kwijnen ze weg. Waarden verdienen het bovendien van tijd tot tijd te worden bijgesteld en als ze botsen zijn er afwegingen, bijstellingen of compromissen nodig. Het is een complexe sociale taak om waarden te beheren. Hierboven heb ik van dat beheer enkele voorbeelden gepresenteerd. Ze zijn afkomstig uit de Nederlandse gezondheidszorg, in het bijzonder uit de behandelpraktijk voor mensen met diabetes. Uit die voorbeelden vallen enkele lessen te destilleren. De eerste les is dat de waarden die een praktijk als de gezondheidszorg schragen, niet in individuen zitten opgesloten, maar door uitgebreidere netwerken (van mensen, gebruiken en dingen) worden gedragen. Die waarden zijn dan ook niet louter sociaal, maar zitten even goed vervat in kennis (ook in biomedische kennis) en in technieken (van diëten via bloedsuikermeters tot aan de meer spectaculaire technieken die vaker krantenkoppen halen). De waarden die inherent zijn aan kennis en technieken blijven op de achtergrond als we louter (enthousiast dan wel veroordelend) naar de keuzen van individuen kijken. Ze verdienen het echter dat we ze in onderzoek naar waardebeheer naar de voorgrond halen.

De tweede les betreft het op elkaar afstemmen van botsende waarden, van handelwijzen met fricties ertussen. Dit kan op een aantal manieren. Daar waar 
doelen en middelen uit elkaar getrokken worden en delibereren wordt onderscheiden van doen, domineert de bestuurlijke stijl voor het zoeken naar compromissen. Die tracht van niet tot elkaar te reduceren waarden toch één rekening op te maken. Het model is dat van de boekhoudbalans die een debet- en een creditkant kent. De ideaaltypische bestuurder, de manager, streept ook voor- en nadelen die niet in geld zijn uit te drukken, op een zo verstandig mogelijke wijze tegen elkaar weg. Hier een rijtje met diverse mogelijke doelen en wat ze wegen, daar een ander rijtje waarin gewicht wordt toegekend aan de voor- en nadelen van de potentiële middelen. Enerzijds, anderzijds. Zo blijkt na een zorgvuldige deliberatie één kant het zwaarst te wegen. Dat moet ook, want daarna kan er tenminste gehandeld worden. Na afloop valt dat handelen, opnieuw enerzijdsen en anderzijdsen afwegend, dan weer te evalueren.

De andere stijl van het op elkaar afstemmen van botsende waarden is professioneel. In een professionele stijl van werken zijn zowel doelen als middelen tot op zekere hoogte veranderbaar. In welk opzicht en in welke mate ze veranderbaar zijn, valt niet al delibererend te beslissen, maar alleen al doende te bemerken. Het is een kwestie van kundig kalibreren, van uitproberen. Het opmaken van een balans is hier onmogelijk: optellen en aftrekken vereist immers variabelen die vaststaan. In de professionele stijl gaat het er dan ook niet om afgewogen te managen, maar komt het eropaan creatief te dokteren. Wie doktert, vraagt niet 'Wat is voor deze gegeven persoon in deze gegeven omstandigheden de beste van deze gegeven interventies?' Zowel persoon als omstandigheden als interventies worden in deze stijl niet als gegeven beschouwd, maar als veranderbaar. Niet afwegen maar afstemmen vormt de kern van dokteren. En terwijl een goede manager ingrepen vooraf afweegt en eventueel achteraf evalueert, blijft een goede dokter al doende alsmaar aan het bijstellen en verbeteren. ${ }^{20}$

Het onderzoek naar waardebeheer dat ik hier bepleit, is beschrijvend, maar daarmee niet neutraal. De moraal van dit verhaal is dat het, gezien de aard van het waardebeheer in kennisintensieve en van de techniekafhankelijke praktijken zoals de gezondheidszorg, onverstandig is om te trachten waarderen aan de ene kant en feiten verzamelen aan de andere kant uit elkaar te halen; of beslissen en uitvoeren te verdelen over verschillende plaatsen, tijden en mensen. Dergelijke separaties vereenvoudigen wellicht het managen, maar ondermijnen het dokteren. ${ }^{21}$ Beter is het om te proberen de waarden die in de feiten worden ingebakken, meer openlijke aandacht te geven. Wat willen we weten, waarom, en wie zijn 'we'? Wat doen we als we meten en welke parameters representeren ons het best? Luid roepen om 'transparante informatie' helpt alleen maar om dergelijke cruciale vragen te verdonkeremanen. We doen er beter aan ze aan de orde te stellen.

Delibereren en doen elk een eigen plek geven, stagneert intussen de creativiteit van het kalibreren. Als elke gegeven patiënt, autonoom, in een gegeven levenssituatie moet kiezen tussen verschillende gegeven middelen, dan verhindert dat een gedurige afstemming van de middelen op de patiënt, de omstandigheden op de middelen, of, zo nodig, al deze elementen op elkaar (de patiënt incluis - en de 
hulpverlener bovendien). Als we hulpverleners vragen hun handelen achteraf te verantwoorden met rekensommen die vereisen dat hun activiteiten telbaar zijn, dan dwingen we hen om allerlei voorheen vloeibare variabelen te fixeren. Dat frustreert het dokteren. Kwantitatieve controle op de zorg belemmert zo het kwalitatieve verbeteren van de zorg. Dat wil niet zeggen dat we professionals ongestoord hun gang moeten laten gaan, maar wel dat we professionaliteit serieus moeten nemen. Kennisintensieve en van de techniek afhankelijke praktijken vereisen eigen, geëigende vormen van openbaarheid. ${ }^{22}$

Een goede gezondheidszorg is er niet een waarin alle waarden tevoren worden afgewogen en alle handelingen achteraf worden verantwoord, maar een waarin subliem en subtiel wordt gedokterd. Nee, niet door dokters alleen. 'Hoe willen we leven?' en 'Waar willen we dood aan gaan?’ zijn beslist vragen die iedereen aangaan. Maar de mogelijke antwoorden op deze vragen interfereren met de inhoud van onze kennis en de details van onze technieken. Hoe die te democratiseren? Regelen, sturen en managen van kennis en technieken (in welke variant van democratisch dan ook) biedt de oplossing niet. Democratische bemoeienis met het waardebeheer in kennis en technieken vereist immers dat we ons er niet boven plaatsen, maar erin duiken. Dat we geen enkele vorm van kennis schuwen en waar nodig technisch worden. Hoe? Misschien valt ook op dit punt iets te leren van mensen met diabetes, die immers tegelijk deskundig zijn en ziek, die hun zorg niet alleen ondergaan maar ook zelf uitvoeren en die in de spreekkamer luisteren en spreken. 


\section{NOTEN}

Met dank aan Mieke Aerts, Bernard Kruithof, John Law, Peter van Lieshout, Geertje Mak, Jeannette Pols, Rita Struhkamp, Tsjalling Swierstra en Dick Willems voor hun intellectuele steun en inspiratie en/of hun scherpe commentaar op eerdere versies. De meest geëigende noot keert een boekenkast om en dat zal ik u besparen. Maar zie in elk geval: Shapin \& Schaffer (1985) Latour (1988) Pickstone (2000) en Law (2002). In plaats van zelf vast te stellen wat (nu eenmaal) een norm en wat een waarde is, zou ik liever op diverse terreinen onderzoeken wat tot de normen en wat tot de waarden gerekend wordt en wat daaraan vastzit. Juist centrale termen dienen in etnografisch onderzoek niet tevoren in een eigen definitie te worden geconsolideerd, maar aan een nader onderzoek onderworpen te worden. Binnen het bestek van dit essay gaat een dergelijk onderzoek echter te ver. Ik voeg me daarom naar mijn veld en gebruik de term 'waarde' hier als brede, overkoepelende term, omdat in de gezondheidszorg de term norm primair een biologische connotatie heeft (en verwijst naar het verschil tussen normaal en pathologisch).

Van een specifieke situatie kunnen abstraheren wordt vaak zelfs gezien als noodzakelijke voorwaarde voor waarlijk rationeel moreel redeneren. En een veil of ignorance aangaande praktische omstandigheden zou mensen kunnen helpen objectief, dat wil zeggen zonder uit te gaan van hun eigen situatie, hun afwegingen te maken.

5 Voor een goede analyse van de verhouding van de sociologie tot 'waarden' en een poging het tij te keren door te onderzoeken hoe mensen hun handelen rechtvaardigen en bovendien hoe ze handelen vanuit agapè, met een toewijding die verder gaat dan te rechtvaardigen valt, zie: Boltanski (1990).

Volgens Toulmin (1986) kon de academische ethiek zichzelf enkel nog vitaliseren door zich op 'toepassingen' te richten en kwamen alle dilemma's in de gezondheidszorg haar geweldig goed uit.

Op de achtergrond van deze verschuiving transformeerde een heel wereldbeeld. Het oude beeld van een wereld vol (mogelijke dan wel feitelijke) sociale conflicten waarin dokters, als neutrale derden, bemiddelen, vervaagde. Daarvoor in de plaats kwam een nieuw beeld: dat van een wereld waarin het meest prangende sociale conflict dat tussen deskundigen en leken is: dokters botsten met patiënten.

In de loop van de jaren negentig is een serie 'patiëntenwetten' van kracht geworden met deze strekking. Zie voor een goede analyse van de manier waarop dergelijke wetten met de inhoud van professioneel handelen (kunnen) interfereren: Pols (2003).

Overigens is patiënten verdenken van 'te veel vragen' even oud als de zorgverzekeringen die het patiënten mogelijk maken om zonder dat ze dit rechtstreeks in hun portemonnee merken, hulp te vragen. In de late jaren veertig en de vroege jaren vijftig van de twintigste eeuw gonsde het in (medisch) Nederland van discussies over de wenselijkheid van remgeld. 
Zie bijvoorbeeld de bijdragen aan Berg \& Mol (1998), Lock, Young \& Cambrosio (2000) en Dodier (1993) en Berg (1997).

Voor hun financiering van diverse delen van dat onderzoek dank ik Nwo, Ethiek en Beleid; en zoN-MW, Verbinden en Vernieuwen. Voor hun medewerking dank ik de patiënten, artsen en verpleegkundigen die mij toestonden hun dagelijkse bezigheden te observeren en hen daarover te interviewen. Dank ook aan Claar Parlevliet en Efanne Bok die aanvullende interviews deden en aan de mensen die hen te woord wilden staan.

Op mijn beurt ben ik ook geïnspireerd door onderzoek dat niets met de gezondheidszorg van doen heeft. Voor de radicaliteit van sociaal-culturele verschillen tussen vormen van waardebeheer, zie de bijdragen aan: Howell (1997). Voor een poging geschiedschrijving met een analyse naar waardebeheer te verbinden zie: Todorov (1991). En voor een inspirerend voorbeeld van een studie waarin de verwevenheid tussen waarden en dingen/technieken (hier: een autoweg door de Pyreneeën) geanalyseerd wordt: Thévenot (2002).

3 Dit wordt vaak afgedaan als een tekort van de betrokken patiënten, een onvermogen. Nadere analyses van de situaties waar het om gaat, leren echter iets anders. Zo heeft het bijvoorbeeld ook te maken met de aard van de keuzen, die nooit louter sociaal zijn, maar ook biomedische aspecten hebben (zie verderop); en die vol zitten met onzekerheden die een gevolg zijn van het statistische karakter van veel 'medische informatie'. Dit uitwerken hoort beslist bij het onderzoek naar waardebeheer dat ik hier bepleit. Ik heb er in dit essay echter voor gekozen de andere lijn uit te diepen, die van de waarden vervat in de kennis, omdat die in het Nederlandse debat tot nu toe nog sterker onderbelicht is gebleven.

4 De aids-epidemie heeft voorbeelden te zien gegeven van indrukwekkende verschuivingen in dit patroon: mensen met aids, HIV-positieven en andere leden van de getroffen risicogroepen gingen zich vergaand met de onderzoeksdesigns bemoeien en onderzoekers hadden dat ook nodig om hun trials kans van slagen te geven. Zie voor deze ontwikkeling in de vs Epstein (1996) en in Frankrijk Bardot (20O2). Ook in andere gevallen hebben zich fascinerende verschuivingen voorgedaan waar (delen van) de zeggenschap over onderzoek verschoof in de richting van georganiseerde patiënten (zie bijv. Rabeharisoa \& Callon 1999). Voor een Nederlands pleidooi om patiënten meer systematisch een rol te geven in het vormgeven van onderzoek, zie Blume \& Catshoek (2003).

5 Dat de grilligheid van technieken hun ethisch-politieke beheersing tot een illusie maakt, wordt uitgebreider betoogd in Latour (2002), die in dit verband, met een woordspeling op het Engelstalige ends-means-onderscheid, van the ends of the means spreekt.

Het is veel vaker zo dat nieuwe diagnostische mogelijkheden de precieze definiëring veranderen van de ziekte die ze moeten helpen diagnosticeren; en dat interventiecategorieën veranderen onder invloed van de technieken waarmee ze worden afgebakend. Zie bijvoorbeeld Pasveer (1992). Voor de radicale consequenties van de techniekafhankelijkheid van onze kennis (namelijk de meervoudigheid van de werkelijkheid; en de verwevenheid van ontologie en politiek) zie Mol (2002).

Ook het omgekeerde geldt: het succesvol 'toepassen' van een techniek is afhanke- 
lijk van veel meer voorwaarden dan veelal voorzien. Zie voor een goed voorbeeld daarvan de studie van Lock (2002) waarin zij in detail traceert waarom transplantaties in Japan zo veel minder makkelijk tot een gangbare interventie geworden zijn dan in Noord-Amerika

18 Zie voor een verzameling Nederlandstalige voorbeelden van dergelijk onderzoek Berg \& $\mathrm{Mol}$ (2001).

19 Een van de indrukwekkendste (en bruikbaarste!) boeken uit de rijke verzameling van door 'patiënten' geschreven teksten, is in mijn ogen dan ook de open brief vol praktische adviezen (met verstrekkende consequenties) geadresseerd aan haar collega-vakpatiënten, te vinden in Miltenburg (1998). Voor een iets andere versie van deze tegenstelling, zie Law \& Mol (2002). Daarin wordt toegelicht hoe de stijl van het dokteren (daar: tinkering) er slecht vanaf dreigt te komen in een rechtszaak, omdat ze, bij gebrek aan niet alleen optelbaarheid, maar meer algemeen discreetheid, ook minder verbaal is. Voor het argument dat het heilige geloof in de autonome kiezende patiënt in heel de zorg (niet alleen de medische) tot ellende leidt omdat het de specificiteit van professionaliteit miskent, zie Tonkens (2003). In plaats van sturen, zijn er andere metaforen nodig voor een gepaste omgang met technieken. In een studie naar de ontwikkeling van een openbaarvervoerstechniek waarbij het niet lukte de verschillende variabelen uiteindelijk op elkaar af te stemmen, beproeft Latour de metafoor van het koesteren, het liefhebben. Zie Latour (1996). 


\section{LITERATUUR}

Bardot, J. (2002) Les malades en mouvements. La médecine et la science à l'épreuve du sida, Parijs: Balland.

Berg, M. (1997) Rationalizing medicine: decision support techniques and medical practices, Cambridge (MA): MIT Press.

Berg, M., \& A. Mol (eds.) (1998) Differences in Medicine. Unravelling practices, techniques and bodies, Durham: Duke University Press.

Berg, M., \& A. Mol (red.) (2001) Ingebouwde normen. Medische technieken doorgelicht, Utrecht: Van der Wees.

Blume, S., \& G. Catshoek, 'De patiënt als medeonderzoeker. Van vraaggestuurde zorg naar vraaggestuurd onderzoek', Medische antropologie, 15 (1): 183-204.

Boltanski, L. (1990) L’Amour et la Justice comme compétences, Parijs: Métailié.

Braak, E. ter (200o) Insulin Induced Hypoglycemia and Glucose Counterregulations: Clinical and Experimental Studies, proefschrift, Utrecht.

Dodier, N. (1993) L'expertise médical, Parijs: Métailié.

Epstein, S. (1996) Impure Science. Aids, activism and the politics of knowledge, Berkeley: University of California Press.

Haeften T. van (1995) 'Acute complicaties - hypoglykemische ontregeling', blz. 142-150 in: E. van Ballegooie \& R. Heine (red.), Diabetes Mellitus, Utrecht: Wetenschappelijke Uitgeverij Bunge.

Howell, S. (red.) (1997) The Etnography of moralities, Londen: Routledge.

Latour, B. (1988) The pasteurization of France, Cambridge (Mass.): Harvard University Press.

Latour, B. (1996) Aramis or the love of technology, Cambridge (Mass.): Harvard University Press.

Latour, B. (2002) 'Morality and Technology: The End of the Means', Theory, Culture $\mathbb{8}$ Society, 19 (5/6): 247-26o.

Law, J. (2002) Aircraft stories. Decentering the object in technoscience, Durham: Duke University Press.

Law, J. \& A. Mol (2002) 'Local entanglements or utopian moves: an inquiry into train accidents', blz. 82-105 in: M. Parker (red.), Utopia and organization, Oxford: Blackwell Publishing/The Sociological Review.

Lock, M. (2002) Twice dead. Organ transplants and the reinvention of death, Berkeley: University of California Press.

Lock, M., A. Young \& A. Cambriosio, (200o) Living and working with the new medical technologies. Intersections of inquiry, Cambridge: Cambridge University Press.

Miltenburg, R. (1998) Over ziek zijn. Een leidraad voor zieke mensen, Utrecht: Kosmos.

Mol, A. (2002) The body multiple. Ontology in medical practice, Durham: Duke University Press.

Pasveer, B. (1992) Shadows of knowledge. Making a representing practice in medicine: Xray pictures and pulmonary tuberculosis, 1895-1930, proefschrift, Amsterdam.

Pickstone, J. (2000) Ways of knowing. A new history of science, technology and medicine, Manchester: Manchester University Press.

Pols, J. (2003) 'Enforcing patient rights of improving care? The interference of two 
modes of doing good in mental health care', Sociology of Health and Illness, 25 (4): 320-347.

Rabeharisoa, V., \& M. Callon, (1999) Le pouvoir des malades, Parijs: Presse de l'École de Mînes.

Shapin, S., \& S. Schaffer (1985) Leviathan and the air-pump. Hobbes, Boyle and the experimental life, Princeton: Princeton University Press.

Thévenot, L. (2002) 'Which road to follow? The moral complexity of an 'equipped' humanity', blz. 35-87 in: J. Law \& A. Mol (red.), Complexities. Social Studies of Knowledge Practice, Durham: Duke University Press.

Todorov, T. (1991) Les morales de l'histoire, Parijs: Grasset.

Tonkens, E. (2003) Mondige burgers, getemde professionals, Utrecht: NIZW.

Toulmin, S. (1998) 'How medicine saved the life of ethics', blz. 265-281 in: J. DeMarco \& R. Fox (red.), New directions in ethics: the challenge of applied ethics, Londen: Routledge and Kegan Paul. 


\title{
15 WAARDESTELSELS IN EN ROND DE MEDIA
}

\author{
A. van den Berg en H. Sleurink
}

\subsection{INLEIDING}

Journalisten hebben niet eerder zo veel mogelijkheden gehad om hun werk goed te doen als tegenwoordig het geval is. Ze zijn hoger opgeleid dan voorheen en werken ook voor een publiek waarvan de gemiddelde scholing toeneemt. Moderne communicatiemiddelen maken het onderhouden van contacten makkelijker dan ooit en internet blijkt een informatiebron te zijn die journalisten in een uur meer kan opleveren dan vroeger een dag in de bibliotheek. Niettemin zijn veel publicaties die op dit moment verschijnen over de media, in het bijzonder over de journalistiek, pessimistisch van toon. Zo zou overal de commerciële druk op de redacties toenemen, verdwijnen er krantentitels en zoekt de tv-journalistiek steeds meer naar een grootste gemene deler. Bovendien zou er het een en ander aan te merken zijn op de journalistieke ethiek. Een tekort aan objectiviteit en handjeklap met politici aan de macht zijn daarbij genoemde gebreken.

Voor een discussiebijdrage als deze over 'waarden en normen in de media' is het van belang eerst enige afstand van het onderwerp te nemen. Studie ervan is namelijk niet goed mogelijk zonder te begrijpen hoe de media functioneren. En dit inzicht blijkt maar beperkt voorhanden te zijn. Gedeeltelijk in samenhang hiermee liggen er complicaties in bestaande vaagheden en misverstanden over en rond de media. Deze constatering maakt het onvermijdelijk deze beschouwing daarmee te beginnen. Wat is er zo mistig in het beeld van de media en wat zou opheldering kunnen verschaffen?

Dat wat vandaag is, is meestal gebouwd op dat wat daarvoor tot stand werd gebracht. Beschrijven wat vandaag is, wordt daarom lastig als niet vastgelegd of onderzocht is hoe het kon ontstaan. Maar juist bij een onderwerp als de media valt op dat er weinig geschreven mediageschiedenis beschikbaar is, in Nederland en ook daarbuiten. De Britse hoogleraar James Curran, die zich wel in het onderwerp heeft gespecialiseerd, zegt daarover: “... mediageschiedenis wordt gereduceerd tot technologisch-deterministische studies over de invloed van de diverse media op de samenleving, die veelal door niet-historici - zoals Marshall McLuhan - zijn geschreven. Hoewel deze beschouwingen interessant zijn, behandelen zij slechts één aspect van de mediageschiedenis en geven zij nauwelijks een indruk van de reikwijdte ervan" (Curran 2002: 485). Curran heeft in zijn werk getracht de Britse mediageschiedenis te beschrijven vanuit verschillende visies: een liberale visie, een feministische, populistische, libertaire, antropologische en een radicale visie. Hoewel waardevol voor het begrip, kan geen deze verhalen pretenderen dé mediageschiedenis te zijn, concludeert Curran. Er moet een synthese komen. Dat kan het best door het opzetten van een historisch overzicht van de ontwikkeling van de maatschappij, waarin een betoog over de ontwikkeling van 
de media wordt ondergebracht, in plaats van andersom zoals gewoonlijk gebeurt. De media opereren immers nooit in een vacuüm; ze maken nu juist een onlosmakelijk onderdeel van de samenleving uit. Een onderdeel dat bovendien is opgebouwd uit talloze verschillende partijen met eigen doelstellingen en wensen. Toch wordt met groot gemak in discussies, analyses en beschouwingen gesproken en geschreven over 'de media', alsof het zou gaan om een eenduidige en volkomen zelfstandige categorie entiteiten. Zulk taalgebruik heeft de term doen verworden tot een containerbegrip. Ons meest bekende woordenboek omschrijft dat als een begrip "zonder afgebakende betekenis, waaraan de taalgebruiker zelf nadere invulling kan geven en dat op veel verschillende toestanden, gebeurtenissen of zaken wordt toegepast”.

Enigszins verwonderlijk is het ontstaan van dit containerbegrip wel, want als er íets duidelijk in het oog springt, is het de grote verscheidenheid in de mediawereld. Zo kan er al direct verschil worden gemaakt tussen publieke en commerciële media. Bovendien bestaat er ook onderscheid naar het soort werk dat media hebben te verrichten. Amusementsmedia hanteren andere doelstellingen en daarmee meestal ook andere waarden en normen dan nieuwsmedia. Er kan zelfs sprake zijn van sterke tegenstellingen in ethisch handelen. Zo vormen journalisten een apart staande groep professionals met belangen die soms tegengesteld zijn aan die van de bedrijven waarvoor ze werken.

Dit medialandschap is niet toevallig zo ontstaan en dat maakt een cultuurhistorische benadering noodzakelijk om de plaats, de betekenis en de invloed van de media in de huidige samenleving op samenhangende wijze te kunnen bepalen. Nederlandse onderzoekers hebben nooit uitgeblonken in een dergelijke integrale aanpak. Deze omstandigheden leveren als probleem op dat zelfs schemerig blijft op welke terreinen noodzakelijke inzichten ontbreken. Een fundamentele maar onbeantwoorde vraag is bijvoorbeeld in hoeverre de media zich lenen voor het kritiekloos doorgeven van propaganda. En als het waar is dat de journalistiek macht bezit, waaruit bestaat die macht dan precies? Hoeveel macht heeft het publiek dan weer als mediaconsument?

De bestaande kennis over het functioneren van de media schiet zozeer tekort dat het claimen van voldoende overzicht op het onderwerp ijdel zou zijn. Noodgedwongen zullen wij in dit betoog daarom eerder vragen oproepen en nieuwe vraagstukken aanwijzen dan dat wij in staat zijn antwoorden te geven. Als benadering kozen we voor het beschrijven van de vier niveaus die samen het ethisch besef van de individuele journalist of programmamaker vormen. Deze niveaus zijn:

1 het geheel aan waarden en normen binnen een samenleving;

2 de normen van de organisatie waarvoor iemand werkzaam is;

3 de mores binnen de journalistiek;

4 de privé-normen van het individu. 
Op deze niveaus bevinden zich de omstandigheden en ontwikkelingen die van invloed zijn op de waarden en normen in de media. Soms direct, maar veel vaker indirect.

\subsection{WAARDEN EN NORMEN BINNEN DE SAMENLEVING}

Eeuwenlang moest iemand die op de hoogte wilde blijven daarvoor zijn huis uit. Maar dat gebeurde dan ook altijd massaal, zo betoogt Mitchell Stephens in het boek De geschiedenis van het nieuws (1989). Daarin staat een aardige opsomming van de manier waarop door de tijden heen mensen elkaar opzochten om de laatste nieuwtjes te horen: van de drukte die de apostel Paulus aantrof op de markt in Athene tot de zeventiende-eeuwse klacht dat het universiteitspersoneel in Cambridge zijn tijd verbeuzelde met nieuwtjesjagerij en citaten van antropologen die signaleren hoezeer mensen eeuwig en overal een onbedwingbare belangstelling hebben om te weten wat er in het volgende dorp gebeurt.

Steeds opnieuw geïnformeerd willen worden over de laatste stand van zaken is een hoogst menselijke eigenschap. Waarbij ook een constatering mag zijn dat het immer profijtelijk was die nieuwsgierigheid te bevredigen. Waar de verteller aan het kampvuur van de jagers het misschien nog doen moest met een gratis maal, wisten zelfs de allereerste drukkers er al geld aan te verdienen. Daarbij zijn er steeds weer voorbeelden te geven waarbij entertainment als verpakking voor de informatie werd gebruikt.

\section{Goede en slechte effecten}

Tegenwoordig worden onvatbare stromen nieuws en amusement tegen geringe vergoeding thuisgebracht. Dat is zo normaal dat het meteen als een gemis voelt als de krant niet wordt bezorgd of de televisie stuk gaat. Deze verandering heeft zo zijn gevolgen, maar welke zijn dat precies?

De beantwoording van deze vraag blijkt ingewikkeld te zijn, omdat alle functies van de media steeds zowel goede als slechte effecten kunnen hebben. Positief is bijvoorbeeld dat volwassenen die allang de school hebben verlaten via de media kennis en cultuur kunnen worden aangereikt. Maar een negatief effect kan dan weer zijn dat alleen een schoongewassen versie van die cultuur wordt doorgegeven, waar delen van de bevolking zich onvoldoende in kunnen herkennen.

Tegenover de positieve eigenschap dat de media ontspanning bieden, staat als negatief aspect dat ze daarmee ook de passiviteit en apathie bij het publiek kunnen vergroten.

Media kunnen rust en zekerheid brengen in tijden van paniek; de regionale omroepen in Nederland hebben zelfs een wettelijke taak als calamiteitenzender. En tegelijkertijd kunnen ze net zo goed meehelpen om angst te zaaien. Volgens verschillende Britse onderzoeken heeft de bevolking daar het idee dat de onveiligheid de laatste jaren is toegenomen en dat bijvoorbeeld seksueel kindermis- 
bruik steeds vaker voorkomt. Misdaadstatistieken laten evenwel een ander beeld zien. Dit verschil tussen beleving en werkelijkheid zou vooral door de tabloids komen, die al te gretig verhalen over criminaliteit publiceren. Nu is er wel wat af te dingen op zo'n conclusie. Zou het Britse publiek zijn beeld over het functioneren van politie en justitie werkelijk alleen ontlenen aan wat daarover in de media komt of er misschien ook zelf ervaring mee hebben? Deze vraag wijst op een lastig probleem in het bestuderen van de manier waarop media maatschappelijk functioneren: de boodschappers zullen vaak een factor van betekenis zijn, maar zelden toch de enige.

\section{Het Nederlandse medialandschap}

Wie de beschikbare literatuur over media onderzoekt, komt een aantal opvallende zaken tegen. Zo blijkt vrijwel niemand ooit onderzoek te doen naar de positieve effecten van het werk van de media. Als uit research een keer blijkt dat televisiekijken niet slecht is voor peuters, komt dit zelfs breed in het nieuws. Opmerkelijk is ook dat de meest invloedrijke literatuur nog altijd uit Groot-Brittannië en de Verenigde Staten komt. Deze landen kennen een wetenschapstraditie die de onze niet altijd is. En omdat in deze landen in de media overwegend één taal wordt gebruikt, blijft de invloed van taal daar meestal buiten beschouwing. Het zonder meer overnemen van theorieën die daar zijn ontwikkeld, heeft meer bezwaren dan doorgaans wordt onderkend.

Een andere complicatie bij een beschouwing over de Nederlandse media is dat veel mediaproducten onversneden uit het buitenland worden gehaald. Op dit moment is ook hier de populaire muziek goeddeels Engelstalig en brengen de televisiezenders dagelijks talloze series uit de vs. De ruime aandacht voor het Amerikaanse rechtssysteem in speelfilms en televisiefictie maakt zelfs dat sommige bezoekers aan een Nederlandse rechtbank verbaasd opkijken dat hier geen jury's zijn. Maar al die series waren waarschijnlijk nooit bedoeld voor export; ze richten zich allereerst op de binnenlandse markt. Daarmee zullen ze bovendien vooral Amerikaanse waarden en normen tonen. En hoewel sommige daarvan niet vreemd zijn, wordt in de Verenigde Staten wel anders gedacht over solidariteit met de zwakkeren in de samenleving of over vuurwapenbezit.

Toch valt pas echt op dat al die import of buitenlandse zenders andere normen hanteren als er ineens protest tegen komt. Zo kleurden de Amerikaanse tvzenders hun berichtgeving met patriottisme tijdens de oorlog met Irak in het voorjaar van 2003. Een patriottisme bovendien met het harde uitgangspunt dat wie niet voor de vs was wel tegen moest zijn. Dit leidde in Nederland bij de programmaraad voor Groningen en Drenthe tot de aanbeveling de nieuwszender CNN uit het standaardpakket voor de kabel te schrappen. De berichtgeving zou te tendentieus zijn geweest. De programmaraad ontmoette meteen stevige kritiek. Daarbij viel op dat velen gepikeerd waren dat anderen voor hen hadden gedacht en besloten. De raad werd zelfs belachelijk gemaakt en streepte het voorstel uiteindelijk weg. Kabeltelevisie heeft in Nederland dus zo'n nutsfunctie dat er publieke raden voor zijn ingesteld om te bepalen wat erop te zien moet zijn. 
Daarbij zijn de waarden en normen van deze beperkte groep bepalend voor wat hele provincies mogen zien - al mogen ze ook weer niet te veel pretenties hebben.

Een ander probleem bij het beschouwen van de media is dat er veel ontwikkelingen tegelijk en door elkaar heen spelen. Daardoor maken al die verschillende organisaties binnen de mediawereld tal van veranderingen door. Mediatechnologie ontwikkelt zich bijvoorbeeld razendsnel. Tegelijk neemt ook de concurrentie tussen de media toe, al was het maar omdat het publiek zijn tijd en aandacht maar op één ding tegelijk kan richten. Er komen ook steeds weer nieuwe vormen van vrijetijdsbesteding bij.

De overheid heeft op sommige terreinen een aantoonbaar sturende invloed. Tien jaar gesteggel over de plaats van commerciële radio in de ether leidde er uiteindelijk pas in mei 2003 toe dat de stations een permanente FM-frequentie met landelijke dekking konden krijgen. Daardoor verdwenen er plotseling zenders, maar kwamen er ook weer nieuwe bij. Tien jaar gesteggel over FM betekende ook dat de ontwikkeling van digitale etherradio volkomen genegeerd werd door de politiek en waarschijnlijk ook de komende jaren weinig aandacht zal krijgen. Andere Europese landen hebben op dit terrein een voorsprong en zullen deze alleen maar vergroten.

Het Nederlandse medialandschap is door deze en nog weer andere omstandigheden in meer dan één opzicht uniek. Zo verschijnen hier in vergelijking met de omringende landen nog altijd opvallend veel dagbladen, ook al staat de markt op dit moment onder druk. Die kranten worden bovendien vrijwel allemaal bij de lezers thuis bezorgd. En onder die kranten zijn geen tabloids te vinden. De oplage van de tijdschriften is hoog. Alleen in Denemarken komen meer boeken uit, omgerekend naar bevolkingsaantal. Vrijwel nergens hebben meer huishoudens toegang tot internet. Bovendien is het abonnement op de kabeltelevisie en -radio hier vanouds veel goedkoper dan elders. Tot onvrede van de exploitanten trouwens, die weliswaar allemaal een monopolie hebben, maar gedwongen zijn zich te houden aan de prijsafspraken die zij maakten bij de overname van de gemeentelijke kabelnetten.

Nederland kent ook nog maar sinds de jaren negentig op de binnenlandse markt gerichte commerciële tv. Deze relatief korte duur betekent dat ook in die sector tal van ontwikkelingen nog niet zijn uitgekristalliseerd. Zo zouden er volgens sommigen op dit moment te veel televisiezenders zijn om van reclame-inkomsten te kunnen bestaan. Maar visionair ingestelde deskundigen stellen juist dat er meer op Nederland gerichte themazenders bij zullen komen zodra de kabel volwaardige infrastructurele concurrentie krijgt van satelliet en digitale ethertelevisie.

\section{Het hypnotiserende oog}

Nieuwe zendgemachtigden moeten hun inkomsten op andere manieren verwerven dan de traditionele publieke omroep kon. Nu verkoopt seks bijna altijd, op 
welke manier dan ook. Van het Duitse RTL en het Nederlandse SBS6 is bekend dat ze erotische films gingen vertonen opdat kijkers aan hun kabelaanbieders zouden vragen deze zenders in het pakket op te nemen. Maar omdat veel adverteerders niet geassocieerd willen worden met dergelijke programma's, ontstond daarmee tijd en ruimte voor reclame van bedrijven die zelf iets aan seks hadden te verkopen. Zoals de dienst om prikkelberichtjes te versturen via sms, een nieuwe vorm van media die en passant pas heel recentelijk ontstond. Maar als zo'n televisiezender eenmaal goed bekeken wordt, treedt er ineens schaamte op. Dan wordt verloochend dat het uitzenden van seks ooit nuttig was en komt met enig aplomb de aankondiging dat alle bloot in de ban gaat. Meestal om geruisloos na een halfjaar weer in het zendschema te worden opgenomen.

Een vraag is daarom wat er gebeurt als er daadwerkelijk zo veel kanalen bij komen als wordt verwacht. Moet er dan met nog sterkere prikkels dan voorheen geconcurreerd gaan worden? Dat zowel radio als televisie het vooral van amusement moet hebben roept sowieso een fundamentele vraag op. In hoeverre beogen deze media eigenlijk nog communicatie? In de permanente concurrentieslag tussen zenders gaat het tegenwoordig vooral om kijk- en luistercijfers, omdat die de inkomsten uit reclame bepalen. Zendgemachtigden zijn daarom vooral gebaat bij de hypnose van hun publiek en daardoor niet of nauwelijks gericht op de vraag of een eventuele boodschap nu aankomt of niet. De aandacht krijgen en nooit meer afstaan, lijkt het enige parool te zijn geworden.

$\mathrm{Nu}$ moet televisie het niet zelden van trucs hebben om de aandacht vast te houden. Het beeld dient duidelijk iets toe te voegen aan het geluid, anders verslapt de aandacht bij de hedendaagse kijker snel. Daarom kijkt zelfs de nieuwslezer van het televisiejournaal zo af en toe in een andere camera. Dat is een beeldwisseling die instinctief een reactie oproept bij het publiek en daarmee aanzet tot verder kijken. Televisiereclame maakt ook van een foefje gebruik. Het geluid van commercials is zo afgestemd dat het luider lijkt dan van de normale programma's. Door het grote aantal klachten van kijkers hierover is de STER zelfs geluidsdempers gaan inzetten op de publieke netten. Een ander handigheidje om het publiek over langere tijd vast te houden, bestaat eruit het deelgenoot te maken van een geheim. Soapseries zijn volkomen op dit gegeven gebaseerd. Ingewijden kunnen geen aflevering missen, omdat ze willen weten hoe het verder gaat. Terwijl buitenstaanders die toevallig eens een aflevering zien, zich er vooral van bewust zijn te veel voorinformatie te missen.

Ook in de nieuwsvoorziening valt op dat de media het aandurven heel wat bekend te veronderstellen. Geen enkele krant brengt nog een echt verslag van een voetbalwedstrijd, maar veeleer meningen over het vertoonde spel. Het is alsof journalisten ervan uitgaan dat iedereen met belangstelling eerder wel iets op televisie heeft gezien van die wedstrijd. Televisiejournaals kunnen maar een beperkte hoeveelheid informatie doorgeven en moeten er daarbij op vertrouwen dat kijkers de achtergrondgegevens elders hebben opgedaan. Pas bij het zien van het Jeugdjournaal valt op hoeveel basale kennis andere nieuwsbulletins weglaten. 
Alleen aan kinderen wordt bij nieuws elders in de wereld getoond waar het land zich bevindt en hoe groot het is in verhouding tot Nederland. Goed leren omgaan met de nieuwsmedia vraagt, kortom, gewenning en bewustwording van het publiek. Een conclusie mag zijn dat zo'n toegangsdrempel er bij amusement nauwelijks is. Als het maar beweegt, kan het motto hier grofweg zijn. En vooral sterke prikkels blijken goed te werken om de aandacht van de kijker gevangen te houden. Moord en doodslag nodigen veel mensen meteen tot verder kijken uit, net als explosies en blote lijven.

\section{Bemoeienis van de overheid}

De overheid hanteert als norm dat kinderen maar beter geen seks kunnen zien op televisie en dat omroepen daarom pas bloot mogen brengen als de jeugd is gaan slapen. Precies zo mogen gewelddadige series of films niet al te vroeg worden uitgezonden. Mede daarom kennen de zendgemachtigden inmiddels een vorm van zelfregulering om te bepalen wat kinderen kunnen hebben. Daartoe worden uitzendingen door het instituut NICAM op leeftijdniveau gewaardeerd en van indicatieve logootjes voorzien. NICAM heeft in 2000 de taken van de Filmkeuring overgenomen; met de komst van zelfregulering hoefde de overheid zich niet langer als zedenmeester op te stellen. Al leidde dit besluit wel tot protest van enkele christelijke partijen. Maar de rol van de overheid als censor of zedenmeester in een democratie is altijd problematisch geweest.

Het duidelijkste voorbeeld voor Nederland van een periode waarin de media massaal de verkeerde waarden verspreidden, was de Tweede Wereldoorlog. Zo luidt tenminste het oordeel achteraf. Op het moment zelf kozen vrijwel alle uitgevers van kranten voor bedrijfscontinuïteit, ook al was er dan censuur en gaven ze voortaan Duitse propaganda door. Tijdens de perszuivering van na de oorlog bleek hoe moeilijk het is om de media ethisch gedrag op te leggen. De Persraad noch een Adviescommissie Perswet slaagde erin daar afdoende regels voor te formuleren. Steeds stuitten zij op de normen uit de grondwet dat er vrijheid van drukpers is, naast vrijheid van meningsuiting (Heuvel 1981: 115-120). Dergelijke afwegingsprocessen maken het meerkoppige karakter van veel mediabedrijven duidelijk zichtbaar. De journalistiek mag dan door zijn controlerende taak een belangrijke immateriële waarde voor de democratie vertegenwoordigen, feit blijft dat de meeste dagbladen en tijdschriften worden uitgegeven door bedrijven die winst moeten maken om voort te bestaan.

De overheid heeft zijdelings weer wel iets te zeggen over wat de publieke omroep moet brengen, al was het maar omdat die voor een groot deel met belastinggeld wordt betaald. Er bestaan derhalve verschillen tussen organisaties met staatssteun en commerciële mediabedrijven. Die tweedeling roept op zich al ethische vragen op. Zo kan de publieke omroep een onlinenieuwsvoorziening bouwen en aldus met staatssteun concurreren tegen de plannen die uitgevers voor hun eigen websites hadden. De uitgevers hebben daar dan ook inmiddels bij de Europese Commissie tegen geprotesteerd. 


\section{Waakhond met beperkte blik}

Uit het voorgaande is als voorlopige conclusie te trekken dat het bij de ethiek en de media in Nederland steeds weer gaat om het beschrijven van ontwikkelingen op verschillende niveaus. Op het meest elementaire niveau zijn dat de waarden en normen die journalisten en programmamakers zelf hanteren om de kwaliteit en geloofwaardigheid van hun werk te garanderen. Deze ethiek kan onder economische druk veranderen, zoals heel extreem tijdens de Tweede Wereldoorlog duidelijk werd. In het verlengde daarvan ligt de vraag welke waarden en normen in de berichtgeving of programma's worden doorgegeven. Dit is het onderdeel waar doorgaans het meeste debat over ontstaat. De meest uiteenlopende discussies bovendien: variërend van de uitroep dat de media Pim hebben vermoord tot een dispuut over de vraag of een voetbalverslaggever nu altijd voor Ajax is of niet.

Vanuit cultuurhistorisch oogpunt bekeken bestaat er nog een hoger niveau van ethiek, waarbij geloofs- en levensovertuigingen - vaak weer beïnvloed door de tijdgeest - waardestelsels laten ontstaan. Het is op dit niveau dat de functie van de media, in het bijzonder die van de journalistiek, binnen een democratie aan de orde komt. In dit ethische vraagstuk bestaat op dit moment het minste inzicht. Er zijn eigenlijk alleen buitenlandse voorbeelden te geven van onderzoek waarin de media in de sociaal-culturele en politieke werkelijkheid van hun tijd zijn geplaatst en dat mag toch wel een omissie worden genoemd (vgl. Herman en Chomsky 1998). Zo is bijvoorbeeld een regelmatig terugkerend punt van kritiek op de Nederlandse journalistiek dat zij zich meer interesseert voor meningen dan voor feiten, een interesse die ook gegrondvest zou zijn in de nationale politieke cultuur. In een groter onderzoek naar waarden en normen in de media zou dit verwijt zeker nadere aandacht verdienen.

Een breed gedragen opvatting luidt dat de journalistiek een functie heeft als waakhond van de democratie. De vraag of de pers daarin slaagt is alleen te beantwoorden vanuit een breed kader, met uitgebreide aandacht voor het functioneren van de politieke partijen in Nederland. Alleen zo valt te zien of datgene waar de journalistiek aandacht voor heeft overeenkomt met de werkelijkheid, of dat zij er eerder een te beperkt of vertekend beeld van geeft. Op dit gebied zijn overigens al direct enige waarnemingen te doen. Conservatief geschat komt op dit moment zestig procent van de Nederlandse wetgeving uit Brussel. Alleen wordt hier volgens de meeste journalisten hoogstens in Den Haag politiek bedreven en wel door enkele ministers en een stuk of wat leden van het parlement. Dus krijgt de EU amper aandacht in de berichtgeving, terwijl deze organisatie door het ontbreken van directe aansprakelijkheid nu juist door de pers bewaakt zou moeten worden. Een ander controlemechanisme is er niet.

Daarbij mag het misschien nog een geluk heten dat Haagse politici weleens aandacht nodig hebben, al was het maar rond de verkiezingen. Of zoals D66-fractievoorzitter Dittrich opmerkte toen zijn partij in het voorjaar van 2003 onverwachts toch bereid bleek met CDA en VVD te regeren: in het kabinet komen onze 
standpunten meer aan bod dan als kleine oppositiepartij. Door dit wederzijdse belang treedt er nog enige wisselwerking op tussen de macht en zijn kritische volgers. Maar er zijn in Nederland tal van andere machtsblokken actief, waarvan het functioneren zelden in het nieuws komt. Neem de rechtspraak, die hier volledig aan professionals is uitbesteed. Elk van onze buurlanden kent een of andere vorm van juryrechtspraak, maar Nederland niet. Dus zou er voor de journalistiek een uitgelezen taak liggen die gesloten juridische macht op zijn ethisch functioneren te controleren. Of dat merkwaardige kartel van verzekeraars en zorginstellingen in de medische zorg. Structurele aandacht daarvoor ontbreekt.

Een interessante onderzoeksvraag is daarmee waarom de journalistiek zichzelf zo'n beperkte onderwerpkeuze oplegt. Nader onderzoek zou ook moeten verduidelijken of de Nederlandse journalistiek niet een veel te gunstig beeld van zichzelf heeft. Het idee dat de professionele journalistiek de democratie bewaakt, blijkt vrijwel onomstreden te zijn. Onlangs nog pleitte de Raad voor Maatschappelijke Ontwikkeling (RMO 2003) er in het rapport Medialogica voor om journalisten eenmaal per jaar in het openbaar verantwoording te laten afleggen over hun berichtgeving. Dit zou de kwaliteit van hun werk ten goede komen. Alleen het Genootschap van Hoofdredacteuren keerde zich bij monde van Pieter Broertjes in eerste instantie categorisch tegen dit plan. Volgens hem ondermijnt het publiekelijk te kijk zetten van journalisten hun gezag als waakhonden van de democratie (Broertjes 2003).

\section{Propaganda voor derden}

Onderzoek naar het verschil tussen wat journalisten zeggen te doen en wat er werkelijk gebeurt, zou ook kunnen verduidelijken in hoeverre de Nederlandse media als spreekbuis voor de propaganda van derden fungeren en bij welke onderwerpen dit mogelijk het geval is. Propaganda dan vooral bedoeld om de macht van gevestigde belangen te beschermen. Waarbij het om de wezenlijke vraag gaat in hoeverre er kritiekloos waarden en normen worden doorgegeven.

De nieuwsvoorziening in Nederland kent eigenschappen die kwetsbaar maken voor beïnvloeding. Zo is een aantal grote mediabedrijven in handen van zeer weinigen. Daarnaast kan de overheid in principe altijd beperkende maatregelen opleggen aan de media en die moet daartoe zeker niet verleid worden. Tegenover het maatschappelijke belang dat de journalist dient, staat telkens evenzeer het belang zijn werkgever niet te schaden. Bovendien heeft de journalistiek ook gewoon iets parasitairs. Om hun werk goed te kunnen doen zijn journalisten vaak afhankelijk van de welwillende medewerking van anderen. En die medewerking moet wel steeds weer verworven kunnen worden. Een vraag is daarom in hoeverre die groep professionele nieuwsmakers niet onderdeel van de machtsstructuur uitmaakt die zij juist zou moeten controleren. Tijdens de verzuiling hadden vele media duidelijker de eigenschap propaganda te maken dan die van nu. Maar dit betekende ook dat een deel van hun waarden- en normenpatroon tenminste bekend was. De media staan ook nu nog onder druk om gekleurde informatie door te geven. Aandacht kan namelijk enorme waarde hebben. 
Telkens weer spelen politici beleidsplannetjes door aan bevriende journalisten, omdat de reacties op zo'n idee in de media informatief zijn. Wetenschappelijke onderzoekers willen aandacht voor hun vindingen of ideeën om subsidiëring voor hun werk veilig te stellen. Bedrijven hebben producten aan te bieden. Muzikanten willen dat het publiek weet dat er een nieuwe cd uit is. Filmmaatschappijen oogsten gratis reclame in programma's met showbizznieuws. Op iedere mediaredactie komen dagelijks tientallen persberichten binnen. Er zijn in Nederland vele malen meer persvoorlichters en communicatiemedewerkers actief bij overheden, instellingen en bedrijven dan dat er journalisten zijn.

\section{Overheid als bron en distributeur}

Inmiddels heeft de overheid zich er rekenschap van gegeven dat de media niet per se nodig zijn als intermediair om informatie door te geven. Althans, dat was de teneur in twee door het kabinet gevraagde adviezen over de modernisering van de overheidscommunicatie (Commissie ICT en Overheid 2001; Commissie Toekomst Overheidscommunicatie 2001). Daarin stond onder meer dat de Nederlandse overheden internet zouden kunnen benutten om zelf een volwaardig nieuwsmedium op te zetten. Verder zouden overheidsinstellingen sneller moeten reageren op fouten in de berichtgeving van de onafhankelijke pers; zelfs al vereist dit een continue analyse, 24 uur per dag. Indien nodig zou de overheid voor haar communicatie ook van amusementprogramma's gebruik moeten maken.

Deze aanbevelingen komen voort uit het idee dat de nieuwsmedia het publieke debat meer sturen dan politici en bestuurders doen. Ongenoegen daarover kwam ook in 2003 uitgebreid aan bod in het eerdergenoemde rapport Medialogica van de Raad voor Maatschappelijke Ontwikkeling (2003). Inmiddels heeft de Raad voor het openbaar bestuur (Rob) zich eveneens over deze kwestie uitgelaten. In het advies Politiek en media. Pleidooi voor een LAT-relatie (2003) constateert de Rob dat overheid en politiek de media voor hun eigen belangen gebruiken, net zoals het omgekeerde gebeurt. Dit 'Haagse Huwelijk' moet ontbonden worden, want door de gebruikte tactieken van partijstrategen en voorlichters verdwijnt het eigenlijke doel van de communicatie - betrouwbare informatie van een aanspreekbare overheid doorgeven - naar de achtergrond. De Rob vindt dat het politieke debat hier te veel in de media plaatsvindt. Terwijl volksvertegenwoordigers juist eigen afwegingen moeten durven maken, om zo het debat terug te halen naar het parlement.

\section{Beperkingen in de vertelvorm}

Volgens de Raad voor Maatschappelijke Ontwikkeling lijdt de journalistiek in Nederland aan een aantal slechte eigenschappen. Daarbij wordt een reeks klachten genoemd die, ondanks alle veranderingen in de bedrijfstak, inmiddels al enige decennia terugkeren. Journalisten jagen in meutes op hetzelfde; ze berichten te snel en met te weinig kennis over hun onderwerpen; de dagelijkse actualiteit wordt vooral aan personen opgehangen; nieuws kan door voortdurende herhaling veel belangrijker lijken dan het is; en er worden erg simpele indelingen 
gehanteerd om ontwikkelingen te verduidelijken; politici zijn bijvoorbeeld altijd links of rechts of neigen tot een van beide kanten.

Enkele van deze klachten hebben betrekking op de vertelvormen die in de media zijn ontwikkeld om het nieuws te brengen. Die kunnen inderdaad tekortschieten. Journalisten hebben de taak actualiteiten en ontwikkelingen begrijpelijk te maken. Ze richten zich daarbij vrijwel altijd op een zo groot mogelijk publiek. Maar om dit te kunnen doen moeten ze meestal versimpelen en vaak ook vergroven en meestal gebeurt dit op dezelfde manier. Maar zelfs als er iets aan die ingeslepen werkmethoden verandert, kan dat weerstand oproepen. Alweer enige jaren worden talloze vaak nogal negatief getoonzette beschouwingen gewijd aan de opkomst van 'infotainment' - zoals op dit moment de al eeuwen bestaande methode heet om informatie in entertainment te verpakken. Het woord 'infotainment' duikt telkens weer op in heel verschillende debatten: van discussies over media en populaire cultuur tot die over mediabeleid en ook weer bij het signaleren van trends in de hedendaagse journalistiek. Wat daarbij opvalt is dat iedereen iets anders onder infotainment lijkt te verstaan en dat de eigen waarden en normen de onderzoeker behoorlijk kunnen dwarszitten. Alleen al de mening over wat kwalitatief goede media brengen moeten, kleurt het oordeel. En in beschouwingen over infotainment wordt hard actueel nieuws leveren vaak als hoogste taak gezien en al het andere als minder (Deuze 200o).

$\mathrm{Nu}$ vinden er op dit moment wel degelijk verschillende ontwikkelingen tegelijk plaats in de mediawereld. Zo is de markt de laatste decennia aanmerkelijk competitiever geworden. Televisie- en radiozenders, tijdschriften en kranten moeten meer moeite doen om publiek te winnen. Mede daarom ook zijn ze meer aandacht gaan besteden aan onderwerpen waarvoor grote belangstelling wordt vermoed. Daarbij worden niet zelden zachtere verteltechnieken ingezet dan die in de harde nieuwsvoorziening gebruikelijk waren. Actualiteitenrubrieken zetten ineens muziek onder hun beelden; een techniek die toch eerder uit de filmwereld afkomstig is. Of in programma's treedt een muziekgroep ter ontspanning op tussen de interviews door. Dat dagbladen in de weekenden extra katernen of zelfs magazines brengen, moet ook in die ontwikkeling worden gezien.

Een Amerikaans onderzoek naar de invloed van dit verschijnsel op de journalistiek heet de Changing definition of news (Committee of Concerned Journalists 1998). Daaruit bleek dat in twintig jaar tijd veel meer aandacht was gekomen voor nieuws over bekende persoonlijkheden, entertainment en voor misdaad en schandalen. Dit ging ten koste van ruimte voor verslagen over de politiek en het buitenlands nieuws. Ook wordt nieuws veel vaker als verhaaltje gebracht, waarbij alles aan een persoon is opgehangen en abstracties zoveel mogelijk zijn vermeden. Vergelijkbare gegevens over Nederland zijn er niet. Daarbij speelt mee dat commerciële televisie hier pas sinds 1989 bestaat. Sindsdien vonden er vele veranderingen tegelijkertijd plaats. Bovendien is het op zich niet eens zo interessant om alleen te kijken of er verschuivingen in de onderwerpkeuze optreden. Een fundamenteler vraag is of en in hoeverre de kwaliteit van de totale nieuws- 
voorziening lijdt onder de opkomst van infotainment. En ook of redacties niet altijd al belangrijke ontwikkelingen hebben laten passeren, omdat ze er geen vertelvorm voor konden vinden. Een journaalredacteur gaf bijvoorbeeld aan dat dit de reden is dat er zo weinig over de EU wordt bericht. De redactie kan te zelden aansprekende voorbeelden vinden om het verhaal goed te kunnen vertellen (Laroes 2003). Voor het mogelijk is een kwalitatief oordeel over de opkomst van infotainment uit te spreken, is het derhalve eerst nodig inzicht te krijgen in de kwaliteit van de gehele nieuwsvoorziening. Van belang daarbij is vooral de vraag of er vroeger wel aandacht was voor onderwerpen die nu blijven liggen.

\section{Commerciële druk}

Traditioneel stellen onderzoekers dat de media drie functies hebben: informeren, amuseren en onderwijzen. Maar bij die drie functies hoort een duidelijk aanwijsbare vierde, namelijk die van het bieden van advertentieruimte aan derden. Deze functie is de laatste decennia sterk in betekenis toegenomen en alles wijst erop dat die tendens de komende jaren zal doorzetten. Dat leidt ertoe dat naast de indirecte economische invloed vanwege toenemende concurrentie ook de directe commerciële druk op de media toeneemt. Adverteerders kunnen tegenwoordig gewoon programma's kopen bij de commerciële omroepen. Waar de ene bouwmarkt een klusprogramma op de ene zender sponsort, doet de concurrent dat bij een ander. Reclame wordt daarbij gebracht alsof het objectieve informatie is, en in een vertelvorm die het publiek uit journalistiek verantwoorde producties kent.

Kranten en tijdschriften bieden weleens advertorials aan. Maar als het goed is, worden die anders opgemaakt dan de redactionele pagina's en staat erbij dat het geheel reclame is. Op websites wordt zo'n onderscheid niet zelden minder duidelijk aangebracht. Journalisten en programmamakers gaan als vanzelf mee in de ontwikkeling informatie gebruiksvriendelijker te verpakken. De meeste van hen hanteren daarbij geen andere uitgangspunten dan altijd al golden; een streven naar objectiviteit blijft steeds de maat. Maar in het bijzonder voor de journalistiek brengt die commerciële druk een reeks gevaren mee die elkaar meestal aanvullen en versterken. Dit kan ertoe leiden dat de redactionele onafhankelijkheid onder druk komt te staan.

Bovendien kunnen puur economische ontwikkelingen de kwaliteit van de berichtgeving bedreigen. Wanneer de concurrentie binnen een bedrijfstak sterk toeneemt of de onderneming meer winst wil maken dan wel als er economische malaise heerst, zullen de arbeidsomstandigheden voor de journalist niet zelden verslechteren. Redacties krimpen in, hetzelfde werk moet door minder mensen worden gedaan en specialismen verdwijnen. Niettemin wordt aan journalisten permanent de eis gesteld om de kwaliteit van hun berichten te waarborgen. Informatie dient verantwoord, objectief en betrouwbaar verzameld en verspreid te worden om geloof te vinden bij een publiek. Niet één keer, maar iedere dag weer. En dit proces kan toch al door talloze oorzaken bemoeilijkt en ontregeld worden. 


\subsection{DE NORMEN VAN DE ORGANISATIE WAARVOOR IEMAND WERKZAAM IS}

Nogal wat strategische keuzes van mediaorganisaties worden gedicteerd door economische wetten en ontwikkelingen. Die hebben invloed op allerlei niveaus. Mondialisering zorgt er bijvoorbeeld voor dat Rupert Murdoch ineens met radio actief is op de Nederlandse markt. En schaalvergroting heeft ertoe geleid dat nog maar twee bedrijven alle grote landelijke dagbladen uitgeven. Verder zijn adverteerders de laatste tien jaar machtiger en veeleisender geworden.

\section{Auteursrecht en consumentenvrijheid}

Een factor van belang ligt ook in de snelle ontwikkeling van mediatechnologie. Opmerkelijk daarbij is dat lang niet alles wat technisch kan, ook door het publiek in gebruik wordt genomen. Dat kan komen door gebrek aan belangstelling, maar het kan ook een gevolg zijn van weerstand bij partijen met gevestigde belangen. Zo werd in de Verenigde Staten in het voorjaar van 2003 een rechtszaak gevoerd over het recht van kijkers om reclame tijdens en tussen tv-programma's over te slaan. De grote Amerikaanse televisiemaatschappijen vinden dat dit niet kan. Ze beschouwen het als een aantasting van hun auteursrecht op de manier waarop programma's worden gebracht. En met dit argument voerden ze een juridische aanval uit op het bedrijf dat persoonlijke digitale videorecorders leverde; apparaten die zo te programmeren zijn dat de reclame op tv overgeslagen kon worden. Dit bedrijf, SonicBlue, is inmiddels mede failliet gegaan aan de hoge kosten die de rechtszaak met zich meebracht.

Waarom dit voorbeeld genoemd? Omdat de Verenigde Staten steeds een paar jaar voorlopen in deze ontwikkelingen en Europa - en daarmee ook Nederland telkens weer onderdelen blijkt over te nemen uit wetgeving die in Amerika ontstaat. Ook in onze nieuwe Auteurswet, waar de Tweede Kamer in 2004 over zal stemmen, staan duidelijk elementen die verdacht veel lijken op wat Amerikaanse mediabedrijven door een kapitaalkrachtige lobby in de vs hebben bereikt. Omstreden bepalingen uit de Digital Millenium Copyright Act (DMCA) maken het dan waarschijnlijk ook in ons land verboden kopieerbeveiligingen op digitale informatie te verwijderen. Voor consumenten zou het dan illegaal worden een reservekopie te maken van een favoriete cd of $\mathrm{dvd}$.

Een eventueel succes van de persoonlijke digitale videorecorder - die het bijvoorbeeld nu al mogelijk maakt dertig uur televisie op te nemen - zal van grote invloed zijn op de manier waarop het publiek tv kijkt. Mensen zullen zelf meer gaan bepalen op welke momenten ze tv-uitzendingen willen zien. Daardoor zullen de afwegingen van zenders voor het maken van aantrekkelijke avondprogramma's er steeds minder toe doen. En als het normaal wordt dat het publiek tvreclame overslaat, heeft dit desastreuze gevolgen voor de inkomsten van de stations. Waarschijnlijk zullen de adverteerders er alles aan doen om te voorkomen dat hun nu nog groeiende invloed taant. In de vs is nu al zichtbaar dat bedrijven meer aan directe sponsoring binnen programma's willen doen. Het beleid 
van de overheid zal waarschijnlijk mede bepalen op welke termijn zulke nieuwe technologie ook hier wordt ingevoerd en wat die technologie dan vermag. Rond dit spanningsveld valt op dat overheden, zowel Europese als nationale, twee beleidslijnen volgen die op gespannen voet met elkaar staan. Enerzijds krijgt het intellectueel eigendom extra bescherming en gaan daarin economische belangen voor. Anderzijds wordt gestreefd naar het gebruik van open standaarden in de communicatie en interactie via tv, wat vooral het publiek ten goede komt.

\section{De groeiende macht van adverteerders}

Vanaf het moment dat de Nederlandse overheid schoorvoetend commerciële televisie toestond, kwam er een grote hoeveelheid zendtijd voor reclame bij. En meer nog: commerciële omroepen boden adverteerders keuzevrijheid. Voortaan werd het mogelijk reclame te plaatsen bij de programma's die de doelgroep waarschijnlijk bekijken zou. Die mogelijkheid had de STER op de publieke netten nooit willen bieden. Daar was het altijd maar afwachten geweest wanneer een commercial werd uitgezonden. Behalve zendtijd boden de commerciële omroepen de adverteerders daarom ook invloed. En de privileges die de ene zendgemachtigde toestond, moesten de andere wel overnemen om te kunnen blijven concurreren.

De totale bestedingen aan advertenties zijn in tien jaar tijd tweeënhalf keer zo groot geworden, mede geholpen door economische bloei en de strijd tussen telecombedrijven om mobiele bellers te winnen. Van die groei aan reclame profiteerden de dagbladen het minst. Weliswaar verdubbelden de advertentie-inkomsten ook voor hen in tien jaar tijd, maar de kranten hadden in 2002 slechts 20 procent van de advertentiemarkt in handen, tegen 25 procent in 1992. De grote winnaar is de televisie; dit medium strijkt in Nederland meer dan de helft op van alle uitgaven aan reclame in de media. Adverteerders konden ook nooit bij de dagbladen navragen welk nut hun investeringen hadden gehad. Pas sinds een jaar wordt een meetsysteem gebruikt dat inzicht biedt in het bereik van de reclamebestedingen; hoeveel mensen de advertentiepagina's achter in het vijfde katern op zaterdag nog bekijken bijvoorbeeld.

De dagbladwereld vormt van oudsher een branche met kartelachtige eigenschappen, die in hoge mate een eigen cultuur voortbracht met vele onderlinge afspraken. De advertentietarieven waren altijd gekoppeld aan de oplage, reden waarom sommige kranten tot enkele jaren terug sjoemelden met hun oplagecijfers (Alberts 1997). En nog altijd kennen bijvoorbeeld de Volkskrant en NRC Handelsblad geen extra goedkope abonnementen voor studenten. Hoewel het wederverkopers inmiddels wel is toegestaan de vaste verkoopprijs los te laten voor een stunt.

Het duidelijkst is de directe invloed van de commercie zichtbaar op televisie. Daar heerst bittere concurrentie en dan vooral om grote publiekstrekkers te krijgen. In de competitie tussen commerciële en publieke omroep zijn de rechten om een sport als voetbal te mogen brengen, exorbitant duur geworden. Dit gaat 
noodzakelijkerwijs ten koste van geld dat voor eigen producties beschikbaar is. Maar ook speelfilms en succesvolle series kunnen alleen via koppelverkoop worden aangeschaft, samen met vele minder goede producties die dan toch maar worden uitgezonden. Het Commissariaat voor de Media (2002, 2003) constateert mede hierom dat, hoewel er steeds meer televisiezenders bij komen in Nederland, het eigenlijke aanbod verschraalt. Er is daarmee sprake van marktfalen, omdat de toegenomen concurrentie voor het publiek geen winst oplevert. Alleen de aandeelhouders van de commerciële zenders profiteren (Van Cuilenburg 2003).

\section{Extern en intern toezicht}

Het Commissariaat is in 1988 door de overheid ingesteld om achteraf toezicht te houden op de regels die in de Mediawet staan voor uitzendingen op radio en televisie. Daarnaast bewaakt dit zelfstandige bestuursorgaan de kwaliteit, diversiteit en de onafhankelijkheid van de nieuwsvoorziening. In die hoedanigheid bestaan er bij het Commissariaat voor de Media zorgen over de druk op de programmatische onafhankelijkheid bij de televisie. Al die beschikbare zendtijd moet gevuld worden en televisie maken is schrikbarend duur. Op de commerciële netten zijn tal van informatieprogramma's te zien waarvan de inhoud volledig wordt gesponsord. Volgens een schatting uit 2002 zou van de totale uitgaven aan reclame vijftien tot twintig procent naar het kleuren van informatie in de programma's gaan. Non-spot advertising heet dat dan in het jargon. Sponsoring van informatieprogramma's bij de publieke omroep is verboden. Toch zijn er opvallende samenwerkingsverbanden te zien tussen deze omroepen en een aantal ideële organisaties. Bovendien is de scheiding tussen commerciële en redactionele verantwoordelijkheid ook bij de publieke omroep nauwelijks geregeld, aldus het Commissariaat voor de Media.

Er bestaat een typisch Nederlands voorbeeld van afspraken waarin de redactionele onafhankelijkheid wel duidelijk is vastgelegd. Binnen de dagbladwereld verplicht de CAO sinds de jaren zeventig de aanwezigheid van een redactiestatuut. Dit statuut stelt de vrijheid van een redactie ten opzichte van de hoofdredacteur vast en daarmee ook tegenover het management. Zo hoort de advertentieverkoop tot een ander onderdeel van een krant, waar de redactie niets mee te maken heeft. Dit zou commerciële druk van buitenaf om gekleurde informatie te brengen in principe moeten uitsluiten. Het Commissariaat voor de Media zou daarom graag redactiestatuten zien ingevoerd bij alle omroepen. Maar een vraag is hoeveel daarmee wordt opgelost.

Zelfs bij de kranten houdt een redactiestatuut geen stand onder directe economische druk. Redacteuren zullen moeten toestaan dat collega's ontslagen worden als het enige andere alternatief is dat de uitgave verdwijnt. Maar ook tegen kleine bezuinigingen biedt zo'n statuut geen verweer. Terwijl ook die de kwaliteit en objectiviteit van de nieuwsvoorziening wel degelijk kunnen beïnvloeden. Als er geen ruimte is om experts in dienst te nemen of te betalen, moeten bijvoorbeeld ingewikkelde zaken steeds door nauwelijks ingevoerde leken worden uitgelegd. 
Dit is iets waarover vooral binnen de wetenschap zorg bestaat. Wezenlijke maatschappelijke discussies met ingrijpende ethische aspecten, zoals de ontwikkeling van biotechnologie, kunnen door dit gebrek aan kennis makkelijk vertekend worden met als gevolg een gebrek aan nuancering.

Geldgebrek op redacties wordt ook zichtbaar in de onderwerpkeuzes. Omdat het zo veel geld kost een verslaggever of een cameraploeg op pad te sturen, moeten deze noodzakelijkerwijs ook met een goed verhaal terugkomen. De veiligste keuze is dan zogeheten agendanieuws te brengen. Daarbij gaat het om evenementen waarvan tevoren vaststaat waar en wanneer ze plaatsvinden: persconferenties, politieke debatten, sportwedstrijden en andere manifestaties. Vooral regionale tv-omroepen besteden vrijwel alleen aan deze zaken aandacht, naast een beetje achtergrond bij nieuws dat anderen al brachten. Dit heeft tot gevolg dat hun journaals maar een zeer beperkt deel van de dagelijkse actualiteit tonen. Ook het Nos-journaal heeft overigens al eens de wens uitgesproken minder aan agendanieuws en meer aan eigen nieuwsgaring te willen doen (Boom 2000). $\mathrm{Nu}$ vermelden dagbladen in hun redactiestatuten vaak nog wel welke onderwerpen zij belangrijk genoeg achten om extra aandacht te geven. Maar bij die beginselverklaring blijft het ook; over alle puur praktische overwegingen bij de nieuwsselectie staat nooit iets op papier. Bovendien is ook al gebleken dat het statuut niet kan belemmeren dat een krant verdwijnt of in een groter concern opgaat. De afgelopen twintig jaar is de dagbladwereld in Nederland beheerst door sanering, concentratie en monopolievorming.

Op dit moment wordt negentig procent van de markt voor landelijke en regionale kranten door drie grote uitgeversconcerns gecontroleerd. Van alle grote landelijke dagbladen wordt alleen de Telegraaf niet uitgegeven door uitgever PCM. Het Commissariaat voor de Media vindt deze machtsconcentratie zorgwekkend. PCM heeft weliswaar ook de maatschappelijke taak de pluriformiteit van de pers te bewaken, maar die komt in de knel als de concernleiding er niet in slaagt de onderneming goed in stand te houden. En de uitgever heeft enkele peperdure miscalculaties op het gebied van internet gemaakt.

Meer dan de helft van de Nederlandse krantenlezers geeft overigens op dit moment nog altijd de voorkeur aan een regionaal dagblad. Maar in deze sector vindt al evenzeer een verschraling plaats. Titels verdwijnen, lokale redacties worden opgeheven en berichtgeving van buiten het eigen gebied komt tegenwoordig bij vrijwel elke krant van de Geassocieerde Pers Diensten (GPD) of persbureaus als het ANP. In de meeste plaatsen in Nederland is nog maar één dagblad te krijgen met aandacht voor de lokale ontwikkelingen, of soms zelfs dat niet eens meer. Dit wordt door velen als een zorgelijke ontwikkeling gezien. Er kan hierdoor een grens overschreden worden, waarna de regionale pers er niet meer in slaagt alle landelijke en internationale ontwikkelingen in een begrijpelijk lokaal perspectief te plaatsen. De regelmatig terugkerende uitspraak dat het publiek zoveel meer keuze aan media heeft, moet daarom misschien wel worden gerelativeerd. De komst van de gratis dagbladen Metro en Sp!ts, het aanbod van nieuws 
op Nederlandstalige websites en de opkomst van technologie als WAP en $i$-mode, hebben samen vooral gemaakt dat dezelfde nieuwsberichten van het persbureau ANP nu werkelijk via elk medium te lezen zijn. Het is overigens opmerkelijk dat er alleen maar verschraling van het aanbod plaatsvindt en dat er nauwelijks geconcurreerd wordt door de kwaliteit van het gebodene te verbeteren. Oudhoofdredacteur van Het Parool Sytze van der Zee constateert bijvoorbeeld dat de dagbladen op het moment enorm hun best doen om meer jongeren te bereiken. Maar in die vernieuwingsdrift wordt het trouwe vaste lezersbestand volgens hem volkomen ten onrechte genegeerd (Haak 2003).

Op zich is die wens om vooral jongeren te willen lijmen wel verklaarbaar. Uit de marketing blijkt dat mensen gewoontedieren zijn, die na hun dertigste zelden nog van voorkeuren veranderen. Dus moeten ze voor die tijd gegrepen worden. Maar wat steeds weer opvalt aan de pogingen die media doen om hun bereik te vergroten, is dat ze daarbij steevast op de hurken gaan zitten voor de te werven doelgroep. Als te weinig jongeren naar de publieke zender Radio 3 luisteren, wordt de programmering aan hen aangepast. Dat de bestaande luisteraars of de programmamakers daarmee misschien geschoffeerd worden, doet er dan niet toe. Nico Haasbroek wilde als hoofdredacteur de Nos-journaals aanpassen aan het profiel van de zender waarop ze werden uitgezonden. Dit was vooral bedoeld om meer jongeren en lager opgeleide kijkers te bereiken. Maar in plaats daarvan werden alle nieuwsuitzendingen op alle zenders populairder gemaakt; een trend die overigens op het moment al weer enigszins gekeerd lijkt.

Het Commissariaat voor de Media heeft de afgelopen jaren meermalen de vrees geuit voor ontwikkelingen die de pluriformiteit van de media bedreigen, of deze nu door de directe druk van de commercie veroorzaakt worden of door indirecte economische ontwikkelingen als schaalvergroting. Maar deze angst bestaat al langer en was in de jaren zeventig reden om het Bedrijfsfonds voor de Pers in te stellen. Hoewel dit fonds steeds meer bevoegdheden en geld krijgt, is het toch de vraag of het met succes functioneert. Zo kan het Bedrijfsfonds geen financiële steun verlenen aan kranten die onderdeel zijn van een groter concern, ofwel aan meer dan negentig procent van de markt. Verder wordt pas sinds kort subsidie gegeven aan initiatieven om via internet groepen te bereiken die niet door de reguliere media worden bediend. Deze maatregelen zorgen weliswaar voor meer pluriformiteit in de marge, maar veranderen niets aan de commerciële keuzes van de grote mediabedrijven.

\section{Nieuwe spelers in de mediawereld}

De huidige Mediawet houdt ook weinig rekening met machtsconcentraties binnen andere segmenten van de mediaproductie. De wet kent maar enkele bepalingen over cross-ownership, die moeten voorkomen dat de informatievoorziening te veel in één hand terechtkomt. Zo mag De Telegraaf geen groter belang in S BS Broadcasting hebben dan de dertig procent die de krant nu bezit. Maar toen kabelexploitant UPC in 2000 SBS wilde overnemen en daar geen wettelijke belemmeringen voor bleken te zijn, was er even grote paniek onder politici. Dat 
een kabelexploitant als UPC een omroep wilde kopen, is niet toevallig. Het tvproductiebedrijf Endemol werd tenslotte ook door een telefoonbedrijf overgenomen. Naast de traditionele partijen als uitgevers en omroepen krijgen de exploitanten van de communicatie-infrastructuren er namelijk steeds meer belang bij een aantrekkelijk pakket te kunnen bieden. Dit komt omdat hun traditionele bronnen van inkomen op den duur sterk zullen teruglopen.

Telecombedrijven verdienen op dit moment vrijwel alleen aan het transport van informatie. Maar de opbrengsten van dit transport dalen, omdat er steeds meer communicatienetwerken bij komen. Onderzoeksbureau Ovum heeft al voorspeld dat informatieoverdracht verreweg het goedkoopste element in communicatie gaat worden. Dit maakt het bijvoorbeeld op termijn te duur om nog langer de kosten van ieder afzonderlijk telefoongesprek in rekening te brengen. De bandbreedte die zo'n gesprek vraagt, valt dan volkomen weg tegen de capaciteit die beschikbaar is. Daardoor ontstaat de noodzaak nieuwe bronnen van inkomen te vinden. Telecombedrijven hebben nooit een kerntaak gehad in het produceren van 'content', dus moet die van elders worden gehaald. Allianties met grote bedrijven zijn daarbij voor beide partijen het aantrekkelijkst, omdat deze elkaar werk uit handen kunnen nemen. Voor sommige experts is daarmee nu al uitgemaakt dat telecombedrijven de poortwachters tot informatie gaan worden. Al was het maar omdat in deze sector meer geld omgaat dan in traditionele mediabedrijven.

Overigens kunnen telecombedrijven ook op dit moment al een direct belang bij bepaalde televisie-uitzendingen hebben. Zo pleiten zowel Holland Media Groep (HMG), Endemol als KPN er bij Justitie voor om telefoonspelletjes op televisie binnen de kansspelwet te blijven gedogen. Tijdens deze belspelletjes wordt kijkers fraaie prijzen beloofd voor het oplossen van een uiterst eenvoudige puzzel. Alleen krijgt de sukkel die opbelt vrijwel nooit de kans die simpele vraag te beantwoorden. Eerst moeten nog wat andere opgaven opgelost worden, zonder dat duidelijk is hoe. Dit maakt het belspel plots geen puzzel meer, maar een kansspel waar een vergunning voor nodig zou zijn. Justitie zal deze niet afgeven. En vermoed mag worden dat een verbod op de belspellen de telecombedrijven miljoenen aan inkomsten gaat schelen.

Een ander voorbeeld is de talentenjacht Idols, die de Holland Media Groep een groter kijkerspubliek opleverde dan ooit. De volledige uitslag van deze talentenjacht bleef evenwel geheim, omdat die informatie concurrentiegevoelig is. Het publiek stemde per telefoon of sms voor zijn favorieten en betaalde daar fors voor. Zelfs voor het bedankje dat sms-stemmers kregen toegestuurd moesten ze nog betalen, zonder dat dit hun was verteld. Hypes als Idols creëren is daarom op meerdere manieren profijtelijk en al helemaal als verschillende partijen daar de vruchten van kunnen plukken. Alleen al vanuit dit besef zou het goed zijn als het Commissariaat voor de Media en de Nederlandse Mededingingsautoriteit het toezicht op mediaconcentraties niet alleen tot de producenten zou beperken, maar ook op de distributeurs zou gaan letten. 


\section{Niet-zichtbare macht}

Er zijn binnen de media meer dwarsverbanden mogelijk waarin van belangenverstrengeling sprake kan zijn. Zo blijkt in de vs het mediaconcern Clear Channel vrijwel alle lokale radiostations te bezitten, terwijl het ook de kaartjesverkoop voor muziekconcerten in handen heeft. Dit maakt het niet moeilijk te raden welke muziek de meeste radiostations daar uitzenden. In Nederland kreeg ID\&T in mei 2003 een FM-frequentie voor commerciële radio toegewezen, hoewel het bedrijf ook bestaat van het organiseren van festivals en het uitgeven van bladen. Een overweging bij de licentietoekenning kan zijn geweest dat ID\&T een van de vele organisatoren en uitgevers in Nederland is en vooral een relatief kleine doelgroep met liefhebbers van dance-muziek bedient. Toch geven de voorbeelden van Clear Channel en ID\&T aan dat er situaties zijn waarin nevenactiviteiten van mediabedrijven moreel aanvaardbaar zijn, maar ook dat hiervoor grenzen bestaan. Een vraag is daarom of voorkomen kan worden dat het publiek geleid en misleid wordt door commerciële ondernemingen en al helemaal in hoeverre de overheid daar iets tegen kan doen.

Uit studies naar mediaconcentraties blijkt dat het Commissariaat van de Media maar met moeite een beeld kan krijgen van alle activiteiten van de grote mediabedrijven. Evenmin heeft het Commissariaat bijvoorbeeld kunnen bewijzen dat de publieke omroep gesponsord wordt door ideële organisaties; iets wat illegaal is. Toch krijgen veel van deze organisaties nogal prominent aandacht in sommige programma's. Het is dus niet uitgesloten dat er meer van dergelijke profijtelijke verbanden bestaan dan op dit moment zichtbaar is. Daaronder kunnen ook verbanden zijn die direct raken aan de keuzevrijheid van het publiek of aan de objectiviteit van de informatievoorziening en daarmee aan de vrijheid van de journalist of de programmamaker.

\subsection{DE MORES BINNEN DE BEROEPSGROEP}

Iedereen in Nederland kan en mag zich journalist noemen. Het is geen beschermd beroep. De grondwet staat bescherming in de weg vanwege de vrijheid van meningsuiting en de vrijheid van drukpers. Maar dat er minder speelruimte is dan wel lijkt, wordt al geillustreerd door het grote aantal journalistieke opleidingen in Nederland. Bovendien kent de sector een eigen vorm van tuchtrecht. Dit zijn twee duidelijke kenmerken van een vak dat zich heeft geprofessionaliseerd.

\section{Vrijheid en conformisme}

De beroepsgroep van journalisten heeft een eigen waarden- en normenstelsel ontwikkeld in de vorm van ethische regels die vooral beogen de neutraliteit en daarmee de geloofwaardigheid van de journalist te waarborgen. Zo wordt in een bericht altijd verduidelijkt wie de bron van het nieuws is. En behalve in columns komt de journalist in principe zelf niet aan het woord. Er vindt hoor en wederhoor plaats als er erg kritische uitspraken van een kant komen. Feiten worden geverifieerd. 
De ethiek van de beroepsgroep legt de journalist dus een wijze van werken op, maar omgekeerd ontstaan uit ingeslepen werkpatronen ook weer normen. Een nogal dominante beroepsnorm komt van de journalisten die zich met verslaggeving over de harde actualiteit bezighouden. Het hoogste dat zij kennen is de eer om als eerste over iets te kunnen berichten. Als het maatschappelijke belang van dit nieuws maar groot genoeg wordt geacht, wijken daar zelfs de normale ethische afspraken voor. Dan mag het nieuws ineens wel van een anonieme bron afkomstig zijn. Wie iets als eerste brengen kan en daarbij exclusiviteit bezit, moet wel door alle andere media als bron worden genoemd. Beter kan een journalist nauwelijks presteren.

In het verlengde van het enorme belang dat aan scoops gehecht wordt, bestaat er grote vrees te laat over actuele gebeurtenissen te berichten of om onderwerpen te missen. Heel lang konden journalisten van andere bladen niet anders dan wat smalend over het dagblad Trouw spreken, omdat de krant het nieuws vaak net wat later bracht. Dat zo'n aanpak ook de kwaliteit ten goede kan komen, omdat er zo misschien meer tijd is alle feiten op hun waarde te wegen, was voor de criticasters nooit een overweging.

Deze twee ongeschreven regels van de beroepspraktijk leiden ertoe dat de professionele journalistiek een fundamentele kwetsbaarheid bezit. De angst om iets te missen zorgt ervoor dat overal en voortdurend wordt opgelet wat andere kranten, journaals of actualiteitenrubrieken brengen. Dit is een beroepskwaal die makkelijk conformisme in de hand werkt en daardoor ook snel tot hypes kan leiden. Als iedereen maar tegelijk hetzelfde belangrijk vindt, dan wordt het ook belangrijk. Bovendien is het verslavend om dagelijks in de frontlijn van de nieuwsverslaggeving te staan en daardoor immer meer te weten dan een ander. De actualiteit overschrijdt voortdurend de grens van al het weetbare. Nieuws is vaak ook letterlijk iets nieuws. En deze kwaliteit gekoppeld aan de angst niets te mogen missen maakt de dagelijkse journalistiek merkwaardig jachtig. Hierdoor treedt ook regelmatig het fenomeen op dat een onderwerp wekenlang alle dagbladen en nieuwsuitzendingen kan beheersen, maar er dan ineens uit verdwijnt zonder ooit een goede afronding te hebben gekregen.

\section{Angst voor openbaar debat}

Als de beroepsgroep over de beroepsethiek discussieert, gaat dat zelden over hun ingeslepen werkmethoden en de gevolgen daarvan. Dat onderwerp wordt altijd van buitenaf opgelegd, door een wetenschappelijke publicatie of een scriptie. Terwijl een kritische blik op de eigen beroepsmethoden toch van groot belang zou zijn. Zo maken internet en andere elektronische media de dwang om eeuwig actueel te zijn alleen maar groter. Websites kunnen ieder moment van de dag worden bijgewerkt en ook telefoons bieden iedereen overal al toegang tot deze informatie.

Vanouds waren er klassieke momenten op een dag om nieuws te consumeren: als de krant werd bezorgd of tijdens het avondjournaal. Die traditie staat onder 
druk. Voor een nieuwsorganisatie betekent meegaan in de jacht op actualiteit daarom beginnen aan een zeer kostbare race, waarin nooit meer tussenstops mogelijk zijn. Gedebatteerd wordt er onder journalisten hoogstens over ethische problemen uit de praktijk. Zoals over de vraag wat het juiste woordgebruik is om het conflict te beschrijven tussen de Israëlische overheid en de Palestijnse bevolking. Of over de kwestie of de journalistiek werkelijk zo negatief over de politicus Pim Fortuyn berichtte als een aanzienlijk deel van de bevolking dacht. Opmerkelijk aan die discussies is dat de resultaten daarvan zelden op papier verschijnen. En dat valt toch al op aan de mores binnen de journalistiek. Er bestaat een duidelijk normen- en waardestelsel, maar daarvan is maar een gering deel opgetekend. Het is alsof er angst heerst om die ethische plichten vast te leggen, omdat anderen daar rechten aan zouden kunnen ontlenen.

Twee voorbeelden kunnen dit probleem illustreren. Iedere krant kent een pagina voor ingezonden brieven van lezers. Toch kan geen lezer ervan op aan dat zijn brief wordt gepubliceerd. Een redacteur oordeelt namelijk of kritiek op de berichtgeving van zijn werkgever het waard is in de krant te komen. Toch maakt elke journalist weleens fouten, al was het maar in de haast om nieuws zo snel mogelijk te brengen. Ook verdwijnen er bij de opmaak van de pagina weleens stukken tekst. De meeste gedrukte media hebben daarom een rubriek waarin vergissingen worden rechtgezet. Alleen heeft die rubriek altijd een weinig opvallende plek en wordt er minimaal uitleg gegeven. De vergissing krijgt weliswaar aandacht, maar vervolgens moet de lezer zelf de ingewikkelde mentale connectie maken tussen de gemelde fout en het oorspronkelijke stuk.

Of het publiek voldoende mogelijkheid heeft om te klagen over het functioneren van de media is op dit moment een belangrijke ethische kwestie. De Europese Commissie heeft al in 1989 de richtlijn Televisie zonder grenzen opgesteld, die onder meer een wettelijk kader biedt om de groei van de media in het digitale tijdperk te stimuleren. Tegelijkertijd tracht deze richtlijn ook het algemeen belang te beschermen. Daarvoor zijn zaken als de vrijheid van meningsuiting en het recht op weerwoord een grondbeginsel. Uitgangspunt hierbij is een verdragstekst van de Raad van Europa uit 1974 (Council of Europe 1974). België kent zelfs al langer een recht op weerwoord. Het houdt onder meer in dat een beledigde partij zonder meer ruimte kan opeisen in de media om zijn standpunt weer te geven. Daarbij hoeft niet eens bewezen te worden dat de eerder gebrachte informatie onjuist was of schade toebracht. Binnen de gedrukte media krijgt een klager dan maximaal duizend letters ruimte, die op ongeveer dezelfde plaats moeten worden afgedrukt als het omstreden artikel. Op televisie gaat het om maximaal drie minuten zendtijd. Overigens wordt wel zeventig procent van de aanvragen op een weerwoord afgewezen op procedurefouten vanwege de ingewikkelde vereisten (Decaluwé 2003). 


\section{Arbiter zonder macht}

In Nederland bestaat een wettelijk recht op weerwoord niet, al klinken van tijd tot tijd binnen de politiek wel stemmen die daarvoor pleiten. Bij de Nederlandse Vereniging voor Journalisten (NVJ) bestaat evenwel grote vrees voor de invoering van een dergelijke plicht. Alleen al omdat daarmee wettelijke restricties voor de beroepsgroep zouden worden geïntroduceerd. En de angst van de NVJ is niet onterecht. Uit een internationaal en historisch onderzoek van de UNESCO blijkt dat ethische codes die van buitenaf aan de journalistiek worden opgelegd telkens te ver doorschieten. Zodra een overheid gedragslijnen uitzet, beschermen die de overheid te zeer. Komen de regels bij consumentenorganisaties vandaan, dan geniet de consument overmatige protectie. Dit belemmert het goed functioneren van de nieuwsmedia altijd, zelfs als deze volledig naar de letter van die ethische codes werken (Jones 1980).

Wat is het beste antwoord op zowel de politieke als commerciële druk op de journalistiek? Volgens de UNESCO zal de beroepsgroep zelf een hogere standaard voor professionalisme en ethiek moeten ontwikkelen. Daarvoor zal training nodig zijn en meer bewustzijn over het onderwerp ethiek. Journalisten zijn in deze visie pas vrij als ze het als een hogere taak zien om het publiek te dienen dan de overheid of de aandeelhouders van hun werkgever. En bij die vrijheid hoort ook de plicht om aangesproken te kunnen worden op fouten.

De richtlijnen die de Europese Commissie uitvaardigt, bieden voor lidstaten altijd enige ruimte voor eigen interpretatie. Daardoor is in Nederland geen recht op weerwoord ingevoerd en dat lijkt zo te blijven zolang sprake is van afdoende zelfregulering binnen de bedrijfstak. Daartoe kent ons land al sinds het begin van de jaren zestig eigen tuchtrecht in de vorm van de Raad voor de Journalistiek. Een probleem is evenwel dat dit instrument nooit volledig goed gefunctioneerd heeft, al was het maar door een gebrek aan werkelijke macht. De enige sanctie waarover de Raad beschikt, is om zijn uitspraak over het functioneren van een journalist of nieuwsmedium openbaar te maken op zijn website of in het vakblad De Journalist. De eis tot rectificatie kan een schuldig bevonden medium gewoon naast zich neerleggen. Dit gebeurt ook geregeld, omdat een deel van de media zich helemaal niets van de Raad voor de Journalistiek aantrekt. Zo is het dagblad De Telegraaf pas sinds kort bijgedraaid en afgedwongen rectificaties ook werkelijk gaan publiceren. De NVJ heeft regelmatig de onverschilligheid van dergelijke organisaties met harde woorden veroordeeld, juist omdat die zulke grote gevolgen voor de hele beroepsgroep kan hebben. Mede door het gebrek aan macht van de Raad voor Journalistiek vindt een deel van het debat over het ethisch functioneren van de media in Nederland uiteindelijk in de rechtszaal plaats. Daar zoeken gedupeerden via het strafrecht of een civiele procedure een uitspraak of journalisten gerechtvaardigd hebben gehandeld of niet. Daardoor ontstaat uiteindelijk toch jurisprudentie over het grensgebied tussen journalistieke vrijheid en juridische normen. 


\subsection{DE PRIVÉ-NORMEN VAN HET INDIVIDU}

De speelruimte van de media wordt niet alleen bepaald door de mensen die erin werkzaam zijn of door bedrijfseconomische overwegingen. Evenmin heeft de overheid in Nederland de doorslaggevende stem. Uiteindelijk bepaalt het publiek wat het van de media wil aannemen. Het publiek is daarmee de vierde factor die bepaalt welke waarden en normen de media zullen doorgeven. Maar het is op het oog wel de zwakste factor van allemaal.

\section{Zoekende mediaconsument}

Het publiek bestaat uit een massa individuen die ieder voor zich bijzonder weinig mogelijkheden hebben de media te corrigeren. Hoogstens kunnen ze een passief protest afgeven door een kranten- of tijdschriftabonnement op te zeggen of de televisie uit te zetten. Als dat passieve protest toevallig massaal wordt, valt op hoe slecht de media gewend zijn kritisch naar zichzelf te kijken. Op dit moment vergrijzen bij alle dagbladen de abonneebestanden. Het is zelfs voor hoogopgeleide jongeren geen vanzelfsprekendheid meer om een abonnement op een krant te nemen. Deze ontwikkeling wordt in de branche met zorg gadegeslagen. Niet zelden valt daarbij het gevreesde woord 'ontlezing'. Terwijl er toch duidelijke aanwijzingen zijn dat jongeren niet zozeer tegen het product krant zijn gekant, als wel tegen de tamelijk prijzige verplichting daarvoor een abonnement te moeten afsluiten. In een tijd waarin sms, e-mail, instant messaging services en andere vormen van chatten op internet bloeien, kan bovendien moeilijk volgehouden worden dat tekst voor jongeren in belang afneemt.

De traditie dat kranten hier vooral door abonnementhouders gelezen worden, heeft de uitgevers misschien wat lui gemaakt. Dit heeft voor het Nederlandse medialandschap wel als voordeel dat er nooit tabloids op de markt zijn gekomen, kranten die iedere dag met nieuws in chocoladeletters op het voorblad kopers proberen te lokken. Maar evenmin is er ooit met grote tariefdalingen gestunt, zoals bijvoorbeeld in Groot-Brittannië regelmatig gebeurde. De ongeschreven akkoorden binnen de dagbladwereld staan prijsstunten waarschijnlijk niet toe. De comfortabele positie die krantenuitgevers tot voor kort hadden, heeft ook lang tot ongevoeligheid voor de wensen van het publiek en de adverteerders geleid. En in tijden van recessie wreekt zich dan dat adverteerders uitwijken naar media waarvan duidelijker is welke respons de reclame oplevert.

Het Commissariaat voor de Media ging er in zijn onderzoek naar marktconcentraties van uit dat de verschillende mediatypen op dit moment geen substituut zijn voor elkaar. Radio, televisie, kranten en tijdschriften kennen allemaal eigen karakteristieken, verzorgen ieder voor zich een specifieke bijdrage in de informatievoorziening en beïnvloeden elkaar daarin ook positief. Goede kranten dwingen de televisiejournaals tot adequate berichtgeving en omgekeerd. Het Commissariaat noemt het daarom cruciaal dat iedere sector in de media gezond en sterk is. Maar voor de individuele burger geldt dat al die verschillende mediatypen elkaar wel kunnen vervangen. Gebruik van internet gaat ten koste van de tijd die 
aan televisiekijken wordt besteedt. Er wordt daardoor ook steeds meer van een scherm gelezen en minder in kranten en tijdschriften. De mogelijkheid om met een digitale persoonlijke videorecorder de uitzendschema's van de omroepen te negeren, werd al eerder aangehaald. En het lijkt nog een kwestie van een paar jaar tot het gebruik van internet via de mobiele telefoon normaal geworden is, waardoor de traditie kan verdwijnen om op het nieuws te wachten tot het thuis is bezorgd.

\section{De media als tweewegsysteem}

Internettechnologie zorgt ervoor dat nieuws en informatie steeds meer op maat zijn af te nemen en dat er bovendien direct op kan worden gereageerd. Internet maakt tweewegverkeer tussen media en publiek makkelijker dan ooit. Deze ontwikkeling biedt interessante nieuwe mogelijkheden voor beide kanten. In Zuid-Korea heeft de bevolking internet bijvoorbeeld aangegrepen om de eigen nieuwsmedia te corrigeren. Misschien niet toevallig, omdat dit land het hoogste percentage breedbandaansluitingen in de wereld telt. In Korea biedt sinds vier jaar de website OhmyNews.com een opvallend tegenwicht aan de al te gezagsgetrouwe reguliere nieuwsmedia. In principe kan iedereen er zijn eigen nieuws op plaatsen, omdat een website nu eenmaal geen gebrek aan plaatsingsruimte heeft. Bovendien kunnen lezers meteen op ieder bericht reageren. Dit had bijvoorbeeld tot gevolg dat er opeens een brede discussie over de aanwezigheid van het Amerikaanse leger in Zuid-Korea kon plaatsvinden, een onderwerp dat daarvoor volstrekt taboe was. OhmyNews zou zelfs van bepalende invloed zijn geweest op de verkiezing van de hervormingsgezinde presidentskandidaat Roh Moo Hyun.

In Nederland bestaat onder de naam Indymedia.nl een website met vergelijkbare doelstellingen. Indymedia.nl meldt bovendien geïnspireerd te zijn op het internationale netwerk van Independent Media Centers (IMC's), dus de trend is niet nieuw. Een belangrijk verschil met de Zuid-Koreanen is wel dat OhmyNews.com ook wekelijks een nieuwsbrief laat drukken met de belangrijkste actualiteiten. Bovendien worden de schrijvers van de berichten betaald naar rato van het belang van hun nieuws. Merk op dat dit systeem nog niet eens zo veel afwijkt van wat er voorheen in Nederland bestond. De meeste dagbladen hadden ooit uitgebreide netwerken aan plaatselijke correspondenten, die nieuws en verslagen aanleverden naast hun normale werk. Maar de professionalisering van het vak maakte hen vrijwel geheel overbodig.

\section{Individualiteit in de journalistiek}

De sterk doorgevoerde professionalisering van het vak roept ook de vraag op hoeveel individualiteit de journalist of programmamaker nog rest. De werkgever stelt eisen. De beroepsgroep kent een duidelijke mores. Wat betekent dit in de praktijk? Cruciale posities in de nieuwsvoorziening blijken vooral bezet te worden door mensen die aan een vergelijkbaar profiel voldoen. Volgens onderzoeker Mark Deuze heeft de doorsneejournalist bij nieuwsorganisaties in Nederland als kenmerken dat hij een hoger opgeleide blanke man is, van vijf tot tien jaar hogere leeftijd dan zijn collega's in omringende landen. Hij stemt in de meeste 
gevallen op een linkse partij en ziet een voorname taak voor zichzelf weggelegd in het interpreteren van de actualiteit in plaats van het nieuws sec te brengen. Deze journalist werkt in een vast dienstverband en blijft lang bij dezelfde werkgever plakken. De arbeidsmarkt voor journalisten is daarmee weinig dynamisch (Deuze 2002: 187-197). Deze omstandigheden hebben invloed op de journalistieke praktijk. Doordat er relatief weinig nieuw bloed binnenstroomt, blijven de routines van de ervaren krachten maatgevend. Bovendien dragen de opleidingen aan dit klimaat bij, bijvoorbeeld doordat daar nog altijd onderwezen wordt dat de harde dagbladjournalistiek het grootste belang heeft. Trends als infotainment en internet of de ontwikkeling naar een meer culturen kennende samenleving werden door Deuze node in de lesprogramma's gemist.

$\mathrm{Nu}$ worden kranten, tijdschriften en radio- en televisieprogramma's niet alleen door vaste redacties gemaakt. Er is in Nederland een heel leger freelancers actief. Een enkeling daarvan behoort zelfs tot de goedbetaalde gezichten van zo'n medium. Maar het merendeel kampt niet zelden met onderbetaling, schimmige afspraken en willekeur. De FLA, die de belangen van freelancers behartigt, trof bij een enquête onder leden zelfs 'negentiende-eeuwse toestanden' aan. De meeste freelancers kunnen ook niet van hun werk voor de media leven. Een merkwaardige toestand volgens de FLA, daar bijvoorbeeld dertig procent van de krantenartikelen en zeker vijftig procent van de artikelen in tijdschriften uit het werk van freelancers bestaat. Toch blijft bovenal de harde nieuwsvoorziening het exclusieve domein van de redacties. De toon van de journalistiek blijkt daarmee grotendeels door CAO-bevoorrechten met een vergelijkbare achtergrond te worden bepaald. Het is deze groep die in de afgelopen jaren de hardste verwijten te horen heeft gekregen. Zij zouden zich onder verwijzing naar professionele autonomie aan elke vorm van kritiek onttrekken.

Op die verwijten kwam aanvankelijk als collectieve reflex een categorische ontkenning. Daarin is een kentering te bespeuren. De Journalist publiceert nu geregeld stukken waarin met openheid over journalistieke werkwijzen wordt geschreven. In het ene bericht bekent een oud-journalist dat veel verwijten kloppen. De journalistiek is inderdaad voornamelijk bureauwerk geworden en redactiemedewerkers sluiten zich daarin op als in een ivoren toren. In een ander bericht erkennen de hoofdredacteuren van het NOS-Journaal en SBS Nieuws dat de journalistiek door het poldermodel is beïnvloed. Het is te autoriteiten volgend, behept met politieke correctheid en elitair. Beide hoofdredacteuren vinden nu dat journalisten ook bereid moeten zijn in een achterstandswijk te gaan wonen, om zich beter in de mensen daar te kunnen inleven. Zelf zijn ze overigens te zeer gehecht geraakt aan een prettige woonomgeving (Van Liempt 2003).

\section{Publieksparticipatie}

De media krijgen nog altijd weinig tegenspel van het publiek over wat ze brengen en ze zijn kritiek niet goed gewend. Toch is er de laatste tien jaar wel iets veranderd. Al was het maar omdat internet het de mediaorganisaties mogelijk maakt hun publiek interactie aan te bieden op fora en andere elektronische prikborden. 
Een andere trend ontstond begin jaren negentig in de vs. Daar kwam civic journalism op, wat inhoudt dat het publiek voortaan mee hielp te bepalen waar de nieuwsmedia over berichten. Zo werd getracht de actualiteit op een toegankelijker wijze te brengen. Dit had als voordeel dat er problemen aan bod kwamen die tot dan toe onderbelicht waren gebleven. Voor de hand liggende nadelen bleken evenwel dat het publiek vaak maar een beperkt zicht op de werkelijkheid heeft en niet uit een homogene massa individuen bestaat. Nieuws steeds vanuit een beperkte invalshoek blijven belichten om maar genoeg mensen te bereiken, leidt dan al gauw tot eenzijdigheid. Uit een evaluatie van de University of WisconsinMadison blijkt dat ten minste een op de vijf Amerikaanse dagbladen in de periode 1994-2001 iets met civic journalism heeft gedaan. En de redacties zijn er overwegend goed over te spreken. Volgens de onderzoekers heeft civic journalism als belangrijk positief gevolg gehad dat er meer rust genomen wordt om uit te leggen wat bepaalde ontwikkelingen voor een bevolking betekenen (Friedlander en Nichols 2002).

Iets anders is dat specialisten en praktijkmensen binnen het publiek altijd meer detailkennis hebben dan een intermediair zoals een journalist. Bovendien blijken zij vaak ook ten volle bereid die kennis te delen. De mogelijkheden die dit biedt, worden binnen de journalistiek nog maar amper beseft. Alleen waar het om ingewikkelde onderwerpen ging, zijn er voorbeelden te geven van media die het aandurfden voorlopige versies van een artikel ter commentaar op een openbaar webforum te plaatsen. Jane's Intelligence Review kon daardoor in 1999 een veel beter artikel over computercriminaliteit publiceren dan anders was gelukt en bedankte daarvoor de commentatoren (Gillmor 2003).

Het publiek ziet vaak ook meer dan journalisten kunnen zien. Digitale apparatuur is bovendien inmiddels zo goedkoop dat er meer beelden worden vastgelegd dan ooit. De BBC vraagt het publiek daarom inmiddels al om foto's over actuele gebeurtenissen naar haar nieuwswebsite op te sturen. Na het verongelukken van de spaceshuttle Columbia in februari 2003 deed ruimtevaartorganisatie NASA een vergelijkbare oproep aan iedereen die beelden had om die beschikbaar te stellen. Dit leverde een massale stroom aan extra informatie op. Een grotere inbreng vanuit het publiek kan media dus beter laten functioneren, zonder dat de betrokken redacties en programmamakers overigens alleen op dat mechanisme mogen vertrouwen om tot kwaliteitsverbetering te komen. De vraag is evenwel hoe de bevolking aangezet kan worden het gebodene minder lijdzaam te ondergaan. Of, in het verlengde daarvan, hoe werkelijk een stem kan worden gegeven aan geluiden die op dit moment ten onrechte niet of nauwelijks zijn te horen.

\subsection{AFSLUITEND}

Dat overheden nadenken over de omgang van het publiek met de media en informatie is niet nieuw. Daar komen extreem gesteld alle vormen van censuur uit voort. De gedachte dat het beter is om de bevolking niet blind te willen bescher- 
men maar weerbaarder te maken, ontstond veel recenter. Doorgedrongen tot beleidskringen is dat inzicht nog nauwelijks en dat mag wonderlijk heten (Sleurink en Van den Berg 2000: 58-63).

\section{Media-educatie}

In een waterrijk land moeten kinderen op jonge leeftijd leren zwemmen. Geen politicus zal dat ontkennen. Meestal krijgen kinderen een zwemdiploma en dat levert blije en trotse gezichten op. Op dezelfde wijze worden jongeren met het behalen van een verkeersdiploma geholpen hun weg te vinden in het drukke verkeer. Waarom bestaat er geen mediadiploma? Tegenwoordig is het mediaverkeer alom aanwezig en invloedrijk. Het is daarom, eufemistisch gezegd, geen luxe om kinderen vertrouwd te maken met elementaire media-inzichten. Waarom zegt een plaatje meer dan duizend woorden? Bestaan er ook woorden die meer zeggen dan duizend plaatjes en welke zijn dat? Hoe kun je van iemand in een filmpje van vijf minuten een schurk maken en hoe kun je van dezelfde persoon in dezelfde tijd ook een held maken? Wat is issue-management? En waarom zijn honderden pr-bureaus daar dag in en dag uit mee bezig in opdracht van allerlei bedrijven en instellingen? Wat is er eigenlijk nieuw aan nieuwe media?

We zagen eerder dat het publiek in het mediaverkeer een sturende factor is, maar dan wel de enige zonder agenda en een met duidelijke zwaktes. De Raad van Europa concludeerde in 2000 dat de opleiding en vorming van burgers tot volwaardige informatie- en mediagebruikers een verantwoordelijkheid van de overheid is. Er kan sociale uitsluiting ontstaan, oordeelde de Raad, voor diegenen die het niet lukt de boodschappen van de media kritisch op hun waarde te beoordelen. Daarbij komt dat iedereen die de vaardigheden mist om nieuwe communicatiemiddelen te gebruiken eveneens de kans loopt buitengesloten te raken. Daarom adviseerde de Raad aan de lidstaten media-educatie als een belangrijk aandachtspunt te beschouwen en programma's voor zowel kinderen, jongeren als volwassen te ontwikkelen.

Iedere burger moet geleerd worden een kritische en scherpzinnige houding tegenover de media in te nemen, zo stelt de Raad van Europa. Het moet eenieder mogelijk zijn een eigen oordeel te vormen over de informatie die via de media beschikbaar komt. Dit is een basisvoorwaarde voor democratie (Council of Europe 2000).

Al jaren eerder, in 1996, bracht de Raad voor Cultuur een soortgelijk advies uit aan het ministerie van Onderwijs, Cultuur en Wetenschappen. Daarin werd gesteld dat de introductie van media-educatie in het onderwijs een noodzakelijke voorwaarde is voor de verdere ontwikkeling van de kennis- en communicatiemaatschappij. Volgens deze Raad vraagt het omgaan met de media specifieke vaardigheden en kennis. Media-educatie kan daarin voorzien en moet daarom in het curriculum van de scholen worden opgenomen. Daarbij hoeft het overigens geen speciaal vak te worden. $\mathrm{Nu}$, eind 2003, moet worden geconcludeerd dat media-educatie in Nederland beleidsmatig nog altijd braakliggend terrein is. 


\section{Betrouwbare informatie is de kern}

In deze bijdrage zijn fundamentele vragen opgeworpen over de kwaliteit van de informatievoorziening in Nederland. Een belangrijke constatering was bijvoorbeeld dat politiek Den Haag relatief meer aandacht krijgt dan objectief nog te verdedigen is. Bovendien komt dit nieuws tot ons via intermediairs die ontwikkelingen liever meteen interpreteren dan sec te willen brengen. Opmerkelijk is ook dat nieuwsmedia vrijwel altijd een zekere achtergrondkennis bij hun publiek veronderstellen. In hun werkwijze wordt er bovendien op vertrouwd dat wat zij niet brengen, wel bij een ander medium te halen valt. Amusement kent zo'n toegangsdrempel niet.

Er zijn verder verschillende ontwikkelingen gaande die de kwaliteit van de informatievoorziening kunnen aantasten. Het feit bijvoorbeeld dat er steeds meer kanalen bij komen waarlangs informatie en amusement te halen is, maakt het medialandschap competitiever dan ooit. Daarbij gaat het niet alleen om het winnen van aandacht, maar in de stagnerende economie van het moment ook om het verkrijgen van advertentie-inkomsten. In Nederland worden nu meer journalisten ontslagen dan er werk krijgen. Blijkbaar is het niet interessant genoeg om op kwaliteit te willen concurreren of daarin extra te investeren. Hoewel kritiek op mediaorganisaties dus mogelijk en nodig is, wil deze bijdrage ook tonen dat het weinig zin heeft alleen beschuldigend naar de media te wijzen. Mediabedrijven opereren niet in een vacuüm. Ze verspreiden weliswaar waarden, maar worden op hun beurt van buitenaf - economisch, politiek, religieus, sociaal en cultureel - bewerkt, gemasseerd en geïnfiltreerd in een poging externe waarden in de nieuws- en informatievoorziening en zelfs in het amusement mee gedistribueerd te krijgen.

Mediabedrijven zijn ook niet de enige die nieuws en informatie verspreiden. Overheden doen dat ook, evenals tal van bedrijven en instellingen. De levering van betrouwbare informatie - hier genoemd als cruciale voorwaarde voor het functioneren van de democratie - overschrijdt de grenzen van de mediawereld en is een zaak van de samenleving in de breedte. In een recent vraaggesprek heeft Paul van den Hoven, directeur van het Instituut voor Media en Representatie in Utrecht, erop gewezen dat de samenleving steeds afhankelijker wordt van uiteenlopende soorten informatie, afkomstig uit allerlei bron. Twijfel over de betrouwbaarheid van die informatie kan uitgroeien tot een maatschappelijk knelpunt (Sleurink 2003). Hij opperde de gedachte dat de overheid een Keuringsdienst voor Informatie in het leven zou moeten roepen, al was hij zich bewust van de haken en ogen die aan de realisatie van zo'n instituut vastzitten. 


\section{LITERATUUR}

Alberts, Jaco (1997) 'Oplage instituut wil betrouwbare cijfers', NRC Handelsblad 23 oktober 1997.

Boom, Joeri (200o) 'Ik speel met de journalistiek', interview in: De Groene Amsterdammer, 22 juli 2000.

Broertjes, Pieter (2003), Jaarrede 2003, uitgesproken op de 44ste jaarvergadering van het Nederlands Genootschap van Hoofdredacteuren, te Amsterdam, 25 april 2003.

Committee of Concerned Journalists (1998) Changing definitions of news, z.p.

Commissariaat voor de Media (2002) Mediaconcentratie in beeld. Concentratie en pluriformiteit van de Nederlandse media 2001, Hilversum: Commissariaat voor de Media.

Commissariaat voor de Media (2003) Mediaconcentratie in beeld. Concentratie en pluriformiteit van de Nederlandse media 2002, Hilversum: Commissariaat voor de Media.

Commissie ICT en Overheid (2001) 'Burger en overheid in de informatiesamenleving', Advies aan het kabinet, Den Haag.

Commissie Toekomst Overheidscommunicatie (2001) 'In dienst van de democratie', Advies aan het kabinet, Den Haag.

Council of Europe (1974) 'On the Right of Reply - Position on the Individual in Relation to the Press', Resolution (74) 26, Straatsburg.

Council of Europe (2000) 'Report. Media Education', Doc. 8753, Straatsburg.

Cuilenburg, Jan van (2003) Concurrentie in de omroep, waartoe en voor wie?, bijdrage aan het symposium 'Van omroepmonopolie naar -concurrentie, en verder' te Amsterdam, 16 januari 2003.

Curran, James (2002) 'Mediageschiedenis en ideologie', blz. 465-481 in: J. Bardoel et al., Journalistieke cultuur in Nederland, Amsterdam: Amsterdam University Press.

Decaluwé, Carl (2003) 'Tussenkomst naar aanleiding van de bespreking van het voorstel van decreet houdende het recht op informatie via radio en televisie en houdende instelling van een recht op antwoord en een recht van mededeling ten aanzien van radio en televisie', Plenair debat in het Vlaams parlement, te Brussel, op 8 juli 2003.

Deuze, Mark (200o) Implicaties van Infotainment voor Journalistenonderzoek: Definities, Steekproef en Questionnaire, working paper, Amsterdam.

Deuze, Mark (2002) Journalists in the Netherlands. An Analysis of the People, the Issues and the (Inter-)national Environment, Amsterdam: Aksant.

Friedlander, Lewis A., en Sandy Nichols (2002) Measuring Civic Journalism's Progress. A report Across a Decade of Acitivity, A study conducted for the Pew Center for Civic Journalism.

Gillmor, Dan (2003) 'We the Media', Columbia Journalism Review, 33, 1.

Haak, Kees (2003) 'De wanhoop regeert in krantenland', interview in: Nieuwspoort Nieuws, 41, september: 3 .

Herman, E.S. en N. Chomsky (1998) Manufacturing Consent. The Political Economy of the Mass Media, New York: Pantheon.

Heuvel, Hans van den (1981) De vrijheid van de pers. De overheid en het commerciële handelen van de pers. 1944-1949, Baarn: Ambo.

Jones, J. Clement (1980) Mass media codes of ethics and councils: a comparative internatio- 
nal study on professional standards, Parijs: Unesco.

Laroes, Hans (2003) 'Een pleidooi voor journalistieke onbevangenheid', lezing voor het CDA-symposium ‘Botsende Belangen', Den Haag, 5 september 2003.

Liempt, Paul van (2003) 'Ook journalisten zijn door het poldermodel beïnvloed', De Journalist, 16 mei 2003: 23.

Raad voor Cultuur (1996) Advies Media-educatie, Den Haag.

Raad voor Maatschappelijke Ontwikkeling (2003) Medialogica. Over het krachtenveld tussen burgers, media en politiek, Den Haag: Sdu.

Raad voor het openbaar bestuur (2003) Politiek en Media. Pleidooi voor een LAT-relatie, z.p.

Sleurink, Hans (2003) 'Keuringsdienst voor Informatie nodig', Staatscourant, 18 juli 2003.

Sleurink, Hans, en Arjen van den Berg (200o) Media-educatie. Een kennisinventarisatie. Een geschiedkundige, geografische, bestuurlijke en onderwijskundige ontdekkingstocht, Assen: Van Gorcum.

Stephens, Mitchell (1989) Geschiedenis van het nieuws. Van de tamtam tot de satelliet, Utrecht: Het Spectrum. 


\title{
16 ALS DE LEUGEN REGEERT, WIE BRENGT HAAR DAN IN OMLOOP? MEDIA, OVERHEID EN HET DEBAT OVER WAARDEN EN NORMEN
}

\author{
O. Scholten
}

\subsection{INLEIDING}

De laatste jaren is sprake van telkens terugkerende uitbarstingen van kritiek op 'de media'. Die kritiek concentreert zich op de politieke journalistiek. Het kernverwijt is steeds dat de media hun klassieke rol van informeren over wat in politiek en samenleving gaande is, verloochenen en als zelfstandige actor in het politieke proces gaan functioneren. In het meest extreme geval nemen 'de media' de rollen van aanklager, rechter en uitvoerder van het vonnis op zich: nog voor de betrokken gezagsdrager de gelegenheid heeft gehad zich te verdedigen, moet hij al het veld ruimen. De negatieve beeldvorming maakt verder functioneren immers onmogelijk.

Dergelijke verwijten worden doorgaans kracht bijgezet door te refereren aan allerlei affaires van de afgelopen jaren waarin de media een belangrijke en soms zelfs beslissende rol gespeeld zouden hebben in de afloop van kleine en grote crises in politiek en samenleving. De voorbeelden liggen voor het oprapen: burgermeester Ouwerkerk van Groningen, minister van Binnenlandse Zaken Peper, VvD-campagneleider Van Baalen, het dagelijks bestuur van de Gereformeerde Kerken in Nederland, super-PG Docters van Leeuwen - moesten ze niet stuk voor stuk onder druk van de media het veld ruimen? Achteraf bleek dat de rol van de media in sommige gevallen zacht gezegd vragen opriep en dat in andere gevallen de media gebruikt waren om een machtsstrijd te beslissen. Een hoofdrolspeler in één van de affaires geeft naderhand een lang interview met daarin de onnavolgbare spagaat "hoewel de media niets te verwijten valt, hebben ze zich wel laten gebruiken” (Docters van Leeuwen 1998).

Maar alle discussie en commotie die de genoemde affaires teweegbrachten, vallen in het niet bij de gebeurtenissen van voorjaar 2002. Op 10 april 2002 maakt het NIOD het langverwachte rapport over Srebrenica openbaar. De kritiek op de media (te veel emotie en te weinig feiten, te veel opvattingen en te weinig analyse) is stevig. Een dag na het verschijnen van het NIOD-rapport barst de discussie over de rol van de media al los, waarbij opvalt dat de media een tot nu toe ongekend vermogen tot zelfreflectie aan de dag leggen (De Graaf 2003; Klaassen en Klein 2002). Terwijl de discussie nog loopt, eist een volgende schokkende gebeurtenis alle aandacht op. Pim Fortuyn, lijsttrekker van de LPF en als geen ander de media beheersend, wordt op het Mediapark in Hilversum vermoord. De woede daarover treft niet alleen politieke tegenstanders maar ook (een deel van) de media. Journalisten worden bedreigd en een aantal van hen wordt dag en nacht bewaakt. De antimediastemming komt zeer scherp tot uiting bij de uitvaart 
van Fortuyn: “Nu je zin, Wouke en Wim?” luidt de vraag op een bord dat uit de menigte omhoogsteekt. ${ }^{1}$

Debatten over de kwaliteit van de openbare informatieverschaffing worden met enige regelmaat gevoerd, maar zo heftig en omvangrijk als de laatste jaren is het debat nog niet eerder geweest. En niet te vergeten: de roep om maatregelen klonk nog nooit zo luid. Wat is er aan de hand en vooral wat staat ons te doen, dat zijn de centrale vragen in deze beschouwing. We beginnen met een schets van de veranderingen in medialandschap en journalistiek. Daarna gaan we in op de discussie over de maatschappelijke verantwoordelijkheid van media in samenhang met de roep om verantwoording af te leggen. En tot slot staan we stil bij de rol van de overheid in deze kwesties.

\subsection{JOURNALISTIEK: DRIE OBSERVATIES VAN WEBER}

In 1919 publiceerde de Duitse socioloog Max Weber een essay dat al snel gerekend werd tot de klassiekers en beroemd is geworden door het onderscheid tussen Gesinnungsethik (handelen uit overtuiging zonder acht te slaan op (voorzienbare) gevolgen) en Verantwortungsethik (handelen wordt mede bepaald door (voorzienbare) gevolgen). Het hoofdthema van zijn verhandeling is het ontstaan van het beroep politicus en de verantwoordelijkheden die dat beroep met zich meebrengt. Weber wijdt ook enkele pagina's aan de (politieke) journalistiek. De verleiding is groot deze pagina's integraal over te nemen, maar laten we ons beperken tot de observaties die ook ruim tachtig jaar later nog steeds treffend genoemd kunnen worden en waarin de dilemma's en vragen waar de journalistiek anno 2004 mee geconfronteerd wordt, al volop aanwezig zijn.

\footnotetext{
"De journalist", schreef Weber, "deelt met alle demagogen en trouwens ook (...) met de advocaat en de kunstenaar het lot, dat hij geen vaste plaats in de maatschappelijke hiërarchie heeft. Hij behoort als het ware tot een kaste van paria's die door 'de maatschappij' steeds op het sociale niveau van haar bedenkelijkste vertegenwoordigers wordt geplaatst." Weber betreurde dat overigens. Een werkelijk goede journalistieke prestatie vereiste in zijn ogen minstens evenveel hersenwerk als welke wetenschappelijk arbeid dan ook, vooral omdat journalisten onmiddellijk prestaties moeten leveren. En bovendien: “Dat de verantwoordelijkheid veel groter is, en ook dat het verantwoordelijkheidsgevoel van iedere fatsoenlijke journalist in doorsnee niet minder groot is dan dat van de geleerde (juist groter, zoals de oorlog ons geleerd heeft) wordt vrijwel nooit geapprecieerd, omdat onvermijdelijk juist de onverantwoordelijke journalistieke producten, wegens hun vaak afschuwelijke uitwerking, in het geheugen blijven hangen” (Weber 1999: 59).
}

Een tweede observatie betreft de invloed van politieke en economische krachten op de dagbladjournalistiek.

"Bij ons", noteerde Weber een jaar na het einde van de Eerste Wereldoorlog, "hebben de grote kapitalistische krantenconcerns in het algemeen vooral onverschilligheid voor de politiek aangekweekt. Immers, aan zelfstandige politiek was niets te verdienen, en men zou er de economische 
begunstiging door de politiek heersende machten mee verspeeld hebben. Door advertentieruimte te kopen heeft men tijdens de oorlog een poging gedaan om de pers op grote schaal te beïnvloeden, hetgeen men thans, naar het schijnt, wil voortzetten" (Weber 1999: 61).

Weber sluit zijn paragraaf over de politieke journalistiek af met een schets van de 'bijzonder zware innerlijke eisen' die aan journalisten gesteld worden. "Het is zeker geen kleinigheid, om op schijnbare voet van gelijkheid in de salons van de machtigen der aarde te verkeren, en daar gevleid (want gevreesd) te worden, - en daarbij te weten dat wanneer men de deur nog nauwelijks uit is, de gastheer zich tegenover zijn gasten moet verontschuldigen wegens zijn omgang met 'persmuskieten'. En het is zeker geen kleinigheid dat men zich onmiddellijk en ook nog overtuigend moet uitspreken over alles en nog wat dat 'de markt' interesseert, over alle denkbare levensproblemen, zonder daarbij in uiterste oppervlakkigheid te vervallen niet alleen, doch vooral ook op onwaardige wijze zijn talenten te verkwisten, met alle gevolgen van dien. Niet dat er zoveel menselijk ontspoorde of ontaarde journalisten zijn is verbazend, maar wel dat juist deze beroepsgroep een zo groot aantal waardevolle en echte mensen kent, - meer dan buitenstaanders vermoeden” (Weber 1999: 63).

\subsection{JOURNALISTIEK ANNO 2004}

Bijna een eeuw later is er veel en soms ook weinig veranderd. Zo heeft het beroep 'journalist' nog steeds een even diffuse maatschappelijke status als in Webers dagen. De een waardeert het beroep zeer hoog (en heeft wellicht de alom gerespecteerde en erudiete hoofdredacteur van een kwaliteitskrant voor ogen), de ander minacht het bijna (en heeft wellicht de alom verguisde en aan seks, drugs en rock-'n-roll ten onder gaande medewerker van een roddelblad voor ogen) (Kaiser 1985: 77).

Deels wel, deels niet veranderd is de beroepsideologie van journalisten, de set van regels die voor de meeste journalisten essentieel is voor het beroep 'journalist' (zie tekstbox 16.1).

\section{Tekstbox 16.1 Beroepsideologie van Nederlandse journalisten samengevat}

Journalisten zijn dienstverleners ten opzichte van het publiek, bijvoorbeeld als 'waakhonden' en 'boodschappers'. Journalisten zijn onpartijdig, neutraal, objectief en (dus) geloofwaardig. Journalisten moeten autonoom, vrij en onafhankelijk hun werk kunnen doen. Journalisten werken met het nieuws, de actualiteit, hetgeen aan het werk een essentieel aspect van tijd en snelheid geeft. Journalisten hebben een zeker gevoel voor ethiek.

Bron: Deuze (2001: 11- 17 en 235)

De sterke oriëntatie op de publieke zaak, werken met nieuws en een zeker gevoel voor ethiek zijn al bij Weber herkenbaar, al worden ze anno 2004 (deels) anders 
ingevuld. Journalisten lijken - net als in Webers dagen - niet opvallend minder of meer verantwoordelijkheidsgevoel te hebben dan andere beroepsbeoefenaren. De Nederlandse journalist is - zo concludeert Deuze - "een buitengewoon ambitieuze 'duider'. Dat blijkt ook uit wat hij of zij ervoor overheeft om een verhaal te krijgen: publieke figuren worden stevig op de huid gezeten, er wordt soms een valse identiteit aangenomen en politieke of economische informatie wordt zonder toestemming gebruikt. Aan de andere kant is de Nederlandse journalist huiverig om de persoonlijke levenssfeer van de 'gewone' mens te schenden en zal hij of zij in principe weigeren om voor informatie te betalen. De Nederlandse journalist is (...) met een grote variatie in de ethische opvattingen tamelijk 'ruimdenkend' (als het gaat om het toelaten van twijfelachtige methoden van nieuwsgaring)" (Deuze 2001: 234).

De andere elementen (neutraliteit, onpartijdigheid, objectiviteit, onafhankelijkheid) zijn vanaf de tweede helft van de negentiende eeuw - in 1848 werd de vrijheid van drukpers verankerd in de grondwet - deel gaan uitmaken van de journalistieke beroepsideologie. Ze zijn bijvoorbeeld in de Gedragscode voor Nederlandse Journalisten van het Genootschap van Hoofdredacteuren moeiteloos terug te vinden (Bakker en Scholten 2003: 283-284). Dit proces is onlosmakelijk verbonden met het vanaf het midden van de negentiende eeuw ontstaan van een parlementair-democratisch stelsel waarin een steeds groter wordende kring van burgers kiesrecht kreeg en langzaam maar zeker een kritische openbaarheid ontstond die (politieke) machthebbers beperkingen oplegt (Scholten 1982: 9 e.v.).

Wel sterk veranderd is de maatschappelijke context waarbinnen de journalistiek functioneert. Dat blijft uiteraard niet zonder gevolgen voor de journalistiek in het algemeen en voor de normen en waarden in de journalistiek in het bijzonder. De belangrijkste factoren zijn de technologische ontwikkelingen (ICT/internet), de multiculturele samenleving, de dominantie van het marktdenken en de roep om transparantie.

\subsection{MAATSCHAPPELIJKE CONTEXT: ICT/INTERNET EN JOURNALISTIEK}

De huidige technologie maakt een ongekende snelheid van berichtgeving mogelijk. Bijna als een natuurwet gaat dan gelden: 'Wat kan, moet'. Gevolg is dat allerlei filters geheel of gedeeltelijk wegvallen en nieuws zowel bij geschreven als bij audiovisuele media met steeds minder tussenschakels in de krant of op het scherm komt. In augustus 1992 gingen de beelden van een uitgehongerde Bosniër achter prikkeldraad in een mum van tijd de wereld rond, tien jaar eerder zouden we deze beelden hooguit met een vertraging van enkele dagen te zien gekregen hebben. In 1992 deden de beelden in ongekend korte tijd hun werk: een golf van morele verontwaardiging sloeg over Europa en in brede kring was de conclusie duidelijk: dit was een Servisch concentratiekamp. Het good guys, bad guys- 
schema was geboren, twijfel over de rolverdeling was er nauwelijks, de Serviërs waren de schurken. Naderhand bleken de beelden grotendeels bedrog, Trnopolje - beter bekend als kamp Omarska - was geen concentratie- maar een vluchtelingenkamp waar niemand opgesloten zat achter prikkeldraad. Ironisch genoeg was de Britse cameraploeg die de opnamen maakte, door de Serviërs uitgenodigd om in Trnopolje te komen filmen. Dit in een poging om de al langer rondgaande geruchten over Servische concentratiekampen te ontzenuwen. Of snelheid en tijdsdruk in dit geval een rol gespeeld hebben bij het uitzenden van beelden die achteraf niet waren wat ze leken te zijn, is onduidelijk. Wel duidelijk is dat de kans op dergelijke missers toeneemt naarmate snelheid van berichtgeving en tijdsdruk toenemen. Dergelijke missers kunnen enorme gevolgen hebben. Het NIOD-rapport laat zien dat de beelden uit Omarska een ommekeer in de publieke opinie bewerkstelligden: ze maakten de geesten rijp voor enigerlei vorm van (militaire) interventie in voormalig Joegoslavië. Gezien de ernst van de mogelijke gevolgen, is er dus alle reden om de kans op missers waar mogelijk te verkleinen.

'Omarska' maakt ook duidelijk dat door de technologische ontwikkelingen de factor 'afstand' bijna wegvalt. De plaats van handeling doet er steeds minder toe, Omarska, New York, Enschede en Volendam liggen soms even dichtbij en even ver weg. Toch schuilt er ook iets bedrieglijks in dat wegvallen van afstand. We zien op televisie weliswaar (bijna) live de beelden van de tragedies die zich afspelen in Omarska, New York, Enschede en Volendam, maar we blijven toeschouwer aan de zijlijn, we maken geen deel uit van wat zich daar voltrekt, we kijken ernaar vanuit de veilige beslotenheid van eigen huis en haard. We zijn er niet bij, kunnen de gebeurtenissen op geen enkele manier beïnvloeden. Misschien blijven we geroerd, diep onder de indruk en machteloos achter en schrijven nog maar een girootje uit, misschien zappen we verder naar zoiets als Goede Tijden, Slechte Tijden. Dat de Verenigde Staten en Europa zo verschillen in hun reactie op September eleven, is (groten)deels terug te voeren op dit verschil in kijkervaring. Amerikanen identificeerden zich veel sterker met de slachtoffers van de aanslagen dan Europeanen, het was immers hun eigen land dat in vitale delen getroffen werd. In het geval van Omarska was het precies andersom: de uitgemergelde gevangene achter prikkeldraad riep alom in Europa herinneringen op aan de concentratiekampen uit de Tweede Wereldoorlog. Geografisch mag afstand minder belangrijk geworden zijn, in psychologisch opzicht is het nog steeds een factor van belang.

Misschien wel het meest besproken is het probleem om de betrouwbaarheid van de oceaan aan informatie op internet te schatten. Hoe kaf en koren, rijp en groen, verdichting en waarheid, roddel en nieuwsfeit van elkaar te scheiden? In de klassieke opvatting is dat een kerntaak van de journalist. Internet maakt van iedere burger in zekere zin een journalist. En wel in die zin dat het voor iedereen met een minimum aan inspanning mogelijk wordt berichten wereldwijd te verspreiden. Daarin lag zoals bekend ook het begin van wat zou uitgroeien tot de moeder aller affaires, Monica-gate, een zaak die eind jaren negentig media en politiek in de Verenigde Staten een jaar lang beheerste. In dit geval bleek het gerucht achteraf 
een kern van waarheid te bevatten, maar dat doet niets af aan het gegeven dat de hoeveelheid informatie zo immens groot en de bronnen op internet vaak zo oncontroleerbaar zijn dat het in veel gevallen vrijwel onmogelijk is de betrouwbaarheid van de informatie te beoordelen. "De Internetjournalist wil autonoom zijn of haar werk kunnen doen, maar loopt tegen de bijkans onmogelijke verifieerbaarheid van de meeste informatie op het wereldwijde Web aan. Daarnaast bestaat de actualiteit van de Internetjournalistiek veelal uit die van de al eerder door collega's bij de krant of nieuwsdienst ANP gesignaleerde actualiteit, aangezien men vooral het werk van anderen online zet”, concludeert Deuze na een onderzoek onder enkele tientallen internetjournalisten (Deuze 20o1: 235-236).

\subsection{MAATSCHAPPELIJKE CONTEXT: MULTICULTURELE SAMENLEVING EN JOURNALISTIEK}

$\mathrm{Na}$ elf september 2001 en zeker na de moord op Pim Fortuyn kregen media nogal eens het verwijt de problemen die de multiculturele samenleving met zich meebrengt veronachtzaamd te hebben. Kort samengevat kwam de kritiek erop neer dat over de multiculturele samenleving slechts in politiek correcte bewoordingen gesproken en geschreven kon worden. Twee maanden na de aanslagen in de vs verweet Bolkestein journalisten 'agenten van het correcte denken' te zijn: uit angst minderheidsgroepen te stigmatiseren werden spanningen, problemen en fundamentele verschillen in opvatting over in de Nederlandse rechtsstaat verankerde waarden, onbesproken gelaten (de Volkskrant, 10 november 2001). Een verwijt dat meer is dan een slag in de lucht. Onderzoek naar commentaren en opiniestukken over het thema 'multiculturele samenleving' laat zien dat tussen 1990 en 2002 een duidelijke verschuiving heeft plaatsgevonden. Na de aanslagen in de vs en zeker na de moord op Fortuyn wordt de discussie veel opener en minder omfloerst gevoerd (Van Wonderen 2002). Met alle verschillen tussen de drie onderzochte kranten - de Volkskrant, Trouw en De Telegraaf-ondersteunen de uitkomsten het beeld dat tot en met midden jaren negentig het politiek correcte denken overheersend was. Wie zich aan die code onttrok, kon rekenen op beschuldigingen minderheden te stigmatiseren of werd - erger nog - uitgemaakt voor racist en/of fascist. Kwalificaties die Bolkestein - fractieleider van de VVD - halverwege de jaren negentig met enige regelmaat ten deel vielen toen hij de problemen rond asielzoekers, vreemdelingenbeleid en integratie aan de orde stelde. Om nog maar te zwijgen van de beschuldigingen en verwijten aan het adres van Fortuyn toen hij in de aanloop naar de verkiezingen 'de islam' keer op keer en ongekend fel bestreed.

Schrijven over de multiculturele samenleving confronteert journalisten voortdurend met tegenstrijdige eisen. Neutraliteit en objectiviteit staan in de alledaagse praktijk vaak op gespannen voet met waken voor negatieve stereotypering van etnische minderheden. De grens tussen helder en herkenbaar benoemen van problemen en spanningen enerzijds en bijdragen aan versterken van 'wij versus zij'-denken anderzijds is nauwelijks te trekken. De waakhondfunctie vraagt om 
signaleren en aan de kaak stellen van maatschappelijke misstanden, wat in de praktijk leidt tot aandacht voor complexe sociale problemen inclusief criminaliteit en onveiligheid waar met name etnische minderheden bij betrokken zijn. En dat brengt weer grote risico's van negatieve beeldvorming met zich mee (vergelijk Deuze 2001: 125-126 en 235-236). Kortom: de multiculturele samenleving stelt hoge en vaak tegenstrijdige eisen aan de journalistieke beroepsuitoefening.

\subsection{MAATSCHAPPELIJKE CONTEXT: MARKTDENKEN}

Journalistiek is in westerse landen en zeker in Nederland sterk verweven met de politieke en staatkundige ontwikkelingen in de laatste anderhalve eeuw. Dagbladen speelden als spreekbuis van emancipatiebewegingen en als verlengstuk van politieke partijen een cruciale rol in het emancipatie- en democratiseringsproces. Het archetype van de ideale journalist is vooral in die periode gevormd: informatie verstrekkend en commentaar leverend op wat zich afspeelt op het toneel van de macht, sterk georiënteerd op de instituties (overheid, politieke partijen, vakbonden, kerken en allerhande belangengroeperingen in het maatschappelijk middenveld). Tot midden jaren zestig werkten journalisten, zeker bij de in een zuil wortelende dagbladen en televisieprogramma's, vanuit een met de lezers en kijkers gedeeld referentiekader over wat belangrijk en waardevol was. Die min of meer vastomlijnde en met lezers/kijkers gedeelde referentiekaders zijn verleden tijd. Kiezers zweven, kijkers zappen, consumenten shoppen en luisteraars hebben wel oren maar horen niet. Om toch nog enige greep te krijgen op de onvoorspelbare burger in al zijn rollen, verlaten bedrijfsleven, politieke partijen, onderwijs, media-instellingen - kortom: wie niet - zich steeds meer op marketing en marktonderzoek. De aloude vraag 'Was will das Weib?' is vervangen door 'Wat wil de klant?' Ook de overheid gaat in haar communicatie steeds meer uit van het denken in termen van 'de burger als klant' (Commissie Toekomst Overheidscommunicatie 2001; Dewez et al. 2001).

Ook de mediasector blijft niet buiten de greep van dit denken in termen van markt en marketing. Wat dagbladen betreft is dat geen nieuw gegeven. Dagbladuitgeverijen zijn vanouds op commerciële basis werkende ondernemingen: zij worden geacht op de lezers- en advertentiemarkt voldoende inkomsten te verwerven om de continuïteit van hun bedrijf te verzekeren. Maar anders dan bij de drop- en autofabrikant is bij uitgevers van dagbladen tegelijkertijd sprake van een ideële doelstelling, kortweg te omschrijven als het leveren van een bijdrage aan het functioneren van de democratie. Media vormen in de formulering van de Medianota uit 1975 een 'constituerend deel van onze democratie', ze vervullen een sleutelrol in het functioneren van de democratie. Of zoals het toenmalige Kamerlid Van Mierlo bij de behandeling van de wijziging van de grondwet in december 1976 het formuleerde: "Constitutioneel gezien zijn zij de beslissende factor in het democratisch functioneren, maar zij hebben geen enkele constitutionele verplichting, alleen een constitutioneel recht om te doen wat hun goed dunkt, behoudens ieders verantwoordelijkheid voor de wet. (...) Ik meen dat 
Kamer en Regering over deze probleemstelling eens moeten nadenken. Ik meen dat de overheid op dit gebied een zorg kan hebben, hoewel ik niet weet hoe het precies moet worden aangepakt" (Van Mierlo 1976: 2003).

Ook de audiovisuele media leven (deels) met een dubbele opdracht, zij het dat de verhouding tussen commerciële en ideële doelstellingen hier lange tijd anders gelegen heeft. De publieke omroep, gefinancierd uit publieke middelen en op geen enkele manier mede afhankelijk van de markt, heeft in Nederland heel lang zijn monopoliepositie weten te handhaven. Pas in 1989 werd het verbod op commerciële televisie opgeheven. Reclame op de publieke omroep was vanaf 1967 toegestaan, zij het onder allerlei voorwaarden en beperkingen. Al met al kunnen we constateren dat vanaf midden jaren zestig het belang van 'verzuiling' sterk afgenomen en het belang van 'commercialisering' sterk toegenomen is. De ideële, aan levens- en wereldbeschouwing gelieerde doelstellingen van dagbladen en audiovisuele media zijn langzaam maar zeker op de achtergrond geraakt, de mediasector is steeds meer een bedrijfstak geworden waarin de gewone wetten van het gewone bedrijfsleven gelden. Met de daarbij horende rendementseisen, marktaandelen en concurrentie tussen media om lezers en kijkers aan zich te binden. Is op een markt sprake van een heftige concurrentiestrijd, dan is de kans groot dat een 'trek naar het midden' optreedt. Het aanbod kenmerkt zich dan door 'meer van hetzelfde'. Heeft een bepaald programma-aanbod succes, dan zullen concurrerende zenders met een vergelijkbaar aanbod komen. Daarmee komt de diversiteit van het programma-aanbod onder druk te staan. Onderzoek naar de Nederlandse televisiemarkt in de jaren tussen 1988 en 1999 ondersteunt dit beeld (Van der Wurff en Van Cuilenburg 2001).

Toegespitst op de politieke journalistiek is een veelgehoorde klacht dat de toegenomen concurrentie, vooral wat televisie betreft, heeft geleid tot wat wel een papegaaiencircuit of meutevorming wordt genoemd (Bolkestein 2001; Raad voor Maatschappelijke Ontwikkeling 2003: 35). Uit angst iets te missen wat een collega wel heeft, rennen al die journalisten op het Binnenhof achter dezelfde persoon aan, op jacht naar de niet te missen soundbite en benaderen ze het politieke nieuws vanuit één en hetzelfde perspectief. Zoals gezegd: het is een veelgehoorde klacht, die met name geuit wordt als er een affaire of crisis speelt in het politieke domein. En in die omstandigheid ligt meteen een reden om de klacht van een enkele kanttekening te voorzien.

\subsection{POLITIEKE CRISES EN JOURNALISTIEK}

Crises van politieke aard zijn bij uitstek gelegenheden waarin de strijdende partijen via de media hun gelijk proberen binnen te halen. Wie de rug van wie wast blijft voor de geïnteresseerde burger volstrekt duister, de alom zo vurig bepleite transparantie ontbreekt in dergelijke gevallen ten enenmale (Geelen 1998; Scholten 1999a; Peper 2003). Tijdens crises speelt de geloofwaardigheid van de verstrekte informatie een rol, maar ook nauwe contacten met journalisten 
en het vermogen om aan te voelen waar media in een bepaalde situatie achteraan zullen lopen zijn van belang, aldus de auteurs van een studie naar crises in het nieuws. “Daarbij speelt een deel van het werk zich niet af op de front stage van de persconferentie en de officiële communiqués en interviews, maar op de back stage van de deep background briefings, de goed geplaatste off the record opmerking aan de bar, het op het bureau achtergelaten vertrouwelijke document of het voor-wathoort-wat tussen een bestuurder en een journalist die beiden weten dat ze elkaar in de toekomst hard nodig hebben" (Crisis Onderzoeksteam 1997: 39).

Prachtige voorbeelden van de manier waarop dat spel gespeeld wordt levert de reconstructie die de journalisten Van Liempt en Westing schreven over het ontslag van Docters van Leeuwen, voorzitter van het College van ProcureursGeneraal van het OM in januari 1998 (Van Liempt en Westing 200o). In de epiloog van hun boek wijzen ze erop dat de kracht van de journalistiek haar zwakte begint te worden: "Hoe harder ze, voortgestuwd door onderlinge concurrentie, op primeurs jagen en hoe beter ze dus hun werk doen, des te meer worden de journalisten partij en des te minder bekommeren ze zich erom of wat ze melden wel waar is" (Van Liempt en Westing 2000: 217). Ook Brants, hoogleraar politieke communicatie, laat eenzelfde soort ambivalentie zien. Volgens hem heeft de concurrentie in de media geleid tot een "rijk geschakeerd veld van stijlvormen en een journalistieke paradox: politieke journalisten vertonen zowel imitatiegedrag als een drang naar uniciteit. Enerzijds betekent het sterk gegroeide aantal parlementair journalisten - Den Haag kent momenteel meer bij Nieuwspoort geaccrediteerde journalisten dan Kamerleden - dat zij zich sterk aan elkaar spiegelen: men wil vooral niet missen wat de ander heeft. (...) Anderzijds willen journalisten juist hebben wat anderen niet hebben, waardoor zowel het journalistieke ego wordt gestreeld als het medium een opstekertje krijgt. Deze primeurdwang heeft een marktgedreven ondertoon en zou inhoudelijke consequenties kunnen hebben" (Brants 2002: 97).

Die inhoudelijke consequenties laten zich raden. Een bekende definitie van nieuws - nieuws is wat journalisten zeggen dat nieuws is - suggereert de onveranderlijkheid van een rolletje Rang, dat immers ook alleen Rang genoemd mag worden als er Rang op staat. Als het om nieuws gaat een valse suggestie. Wat journalisten als nieuws beschouwen, is sterk gebonden aan plaats, tijd en cultuur. Dat zien we het beste als we afstand nemen in tijd, plaats en/of cultuur. Een journaalaflevering of dagblad uit de jaren vijftig wijkt qua onderwerpkeuze en behandeling van die onderwerpen sterk af van wat we nu gewend zijn. Anders gezegd: de definitie van nieuws is sterk gewijzigd. Zetten de verschuivingen van nu zich door, dan wordt de oriëntatie op het publiek belangrijker en die op de publieke zaak minder belangrijk (Brants 2002: 97; Scholten 1999a: 8). Dan zal niet wat een betrekkelijk kleine journalistieke elite relevant en wetenswaardig vindt maar wat de burger (lees: de markt) wil horen, zien en lezen, beeldscherm en pagina vullen. Dan zullen niet het ingewikkelde machtsspel tussen het woud aan instituties en belangen en hun ingewikkelde beleidsnota's, maar de alledaagse gevolgen van beleid voor de burger en de individuele levensverhalen aandacht trekken. Dan 
zullen niet de abstracte macrobeschouwingen en analyses, maar mannen en vrouwen die in staat zijn vertrouwen te wekken en te behouden, die de illusie in stand weten te houden dat alles onder controle is, de hoofdrol voor zich opeisen.

Keren we nog even terug naar de commotie rond het ontslag van Docters van Leeuwen. Niet alleen de journalistiek, ook de betrokken politici, de ambtelijke toppen van Justitie en oM en de betrokken voorlichtingsdiensten hebben in deze affaire steken laten vallen. Op het hoogtepunt van de crisis gebruikten de media plotseling de kwalificatie 'muiterij op de Schedeldoekshaven' en daarmee waren de uren van Docters van Leeuwen geteld: het behoeft geen betoog dat een minister zoiets niet kan laten passeren. Tot op de dag van vandaag is onduidelijk wie deze kwalificatie in omloop heeft gebracht, ook Van Liempt en Westing hebben die vraag niet kunnen beantwoorden. Naderhand erkende een van de betrokken journalisten dat media soms misleid worden: "Een muiterij die het achteraf niet blijkt te zijn geweest (...), je tuint er toch in, want je kunt op die momenten niet anders doen dan registreren wat er gebeurt" (Dielesen 1998). In dit geval gaat 'De leugen regeert' naar het zich laat aanzien zonder meer op. En dat maakt de vraag wie haar in omloop bracht des te belangwekkender. 'Gij zult registreren wat er gezegd wordt' en 'Gij zult niet liegen' - duidelijker dan in deze observaties is de tegenstrijdigheid in eisen die aan de journalistiek gesteld worden, nauwelijks te illustreren.

\subsection{MAATSCHAPPELIJKE CONTEXT: TRANSPARANTIE EN JOURNALISTIEK}

Consument en burger stellen steeds meer eisen aan bedrijfsleven en overheid. Niet alleen moeten producten en diensten op zich kwalitatief goed zijn en een goede kwaliteit-prijsverhouding hebben, ook de wijze waarop die producten en diensten totstandkomen, moet goed zijn. Dat wil zeggen, voldoen aan een aantal normen op het gebied van mensenrechten, kinderarbeid, milieu, rechtvaardige beloning, en dergelijke. Van bedrijfsleven en overheid wordt sterker dan voorheen verwacht dat ze ook op die punten openheid van zaken geven, dat ze, zoals dat genoemd wordt, transparant zijn. Dat geldt net zo goed voor C\&A (zijn die rokjes soms zo goedkoop door kinderarbeid in derdewereldlanden?) als voor instituties als het Openbaar Ministerie (waarom is de eis tegen de verdachten in de zaak-Tjoelker zo laag, ze sloegen toch iemand zomaar dood?) als voor politici in Den Haag. De maatschappelijke druk op bedrijfsleven, overheid en semipublieke sector om niet alleen aan het eindproduct maar ook aan het productieproces steeds hogere eisen te stellen (maatschappelijk verantwoord ondernemen) in combinatie met de roep om transparantie, maakt dat de reputatie van een organisatie een even kostbaar als kwetsbaar bezit wordt.

Wat maatschappelijk verantwoord ondernemen betreft is in de loop van de jaren een aantal thema's benoemd die in dit kader van belang geacht worden. Maar voor de meeste thema's ontbreekt het aan verder uitgewerkte normen aan de 
hand waarvan vastgesteld kan worden of een organisatie voldoende presteert. Dat brengt met zich mee dat wat maatschappelijk aanvaardbaar wordt geacht, telkens opnieuw ingevuld moet worden. Deze combinatie van omgevingsfactoren - maatschappelijke verantwoordelijkheid, belang van reputatie, roep om transparantie, onduidelijkheid over normen - maakt dat publiciteit voor organisaties steeds belangrijker wordt en tegelijkertijd steeds meer risico's in zich bergt (Scholten 1999b; Van der Zwan 2000). Immers: transparantie zonder media is ondenkbaar, ook al is in de beleving van bestuurders en politici soms sprake van een welhaast ondraaglijke onmisbaarheid. Over steeds meer aspecten van bedrijf en bestuur worden ze geacht verantwoording af te leggen, het domein van de openbaarheid wordt steeds verder uitgebreid. En dit verantwoording afleggen gebeurt niet alleen in de formele gremia als aandeelhoudersvergadering, rechtszaal en parlement, maar in toenemende mate ook ten overstaan van de media. En daar ontbreken de heldere spelregels, vaste gewoonten en rituelen die in formele gremia het verantwoording afleggen in goede banen leiden. Voor camera en microfoon geldt eerst en vooral de vrijheid van drukpers, verankerd in artikel 7 van de grondwet. Organisaties en hun voorlichters hebben soms zichtbaar moeite met deze ontwikkeling. Pijnlijk duidelijk kwam dat aan het licht toen het OM najaar 1998 weigerde om de lage eis in de zaak-Tjoelker op televisie toe te lichten. Pas twee dagen later gaf het OM een uitgebreide toelichting in NRC Handelsblad. In dit geval het verkeerde moment en het verkeerde medium.

De hier beschreven ontwikkeling brengt voor de journalistiek met zich mee dat het politieke en maatschappelijke krachtenveld waarin men functioneert nog complexer wordt dan het al is. Aan de ene kant hebben overheid en bedrijfsleven steeds meer belang bij het verstrekken van informatie aan de burgers, aan de andere kant worden ook de risico's verbonden aan die informatieverstrekking steeds groter. Wat een organisatie kwijt moet, wil en kan zal steeds zorgvuldiger gewikt en gewogen worden. Het leger voorlichters en communicatieadviseurs dat politici en bestuurders omringt zal eerder groeien dan krimpen, risico's zijn er immers om afgedekt te worden. Dat de verhoudingen tussen beide beroepsgroepen doorgaans niet al te best zijn en dat over en weer de waardering voor elkaars werkzaamheden nogal eens te wensen over laat, verbaast dan ook niet (Neijens 2002). Tegen deze achtergrond is het de moeite waard de rol en positie van overheidsvoorlichting nader te bezien.

\subsection{TRANSPARANTIE: OVERHEIDSCOMMUNICATIE}

Natuurlijk kan men redenerend vanuit de informatieplicht van de overheid stellen dat "een journalist en een overheidsvoorlichter aan hetzelfde doel werken. Beiden willen ze de burger informeren hetgeen de overheid doet" (Van der Ploeg, directeur voorlichting Binnenlandse Zaken en Koninkrijksrelaties, december 2000: 8). Maar daarmee wordt de informatieplicht van de overheid schromelijk overschat en wordt al te gemakkelijk voorbijgegaan aan de vaak tegenstrijdige belangen van politiek en media. 


\section{Tekstbox 16.2 Artikel 2 Wet Openbaarheid van Bestuur}

Het overheidsorgaan dat het rechtstreeks aangaat verschaft uit eigen beweging informatie over het beleid, waaronder de voorbereiding en de uitvoering daarvan, zodra dit in het belang is van een goede democratische bestuursvoering.

De Wet Openbaarheid van Bestuur kent weliswaar een actieve informatieplicht (zie tekstbox 16.2). Maar door de ruime formulering gaat het om een 'plicht' op het verzaken waarvan geen sanctie staat, zo die plicht al verzaakt kan worden. Het is immers de overheid zelf die in alle vrijheid kan bepalen wanneer actieve openbaarmaking in het belang is van een goede en democratische bestuursvoering. En maar al te vaak demonstreert de overheid dat zij de openheid die met de mond zo vurig beleden wordt, in de praktijk niet weet te betrachten (Scholten 20o1a: 5-8). De Commissie Toekomst Overheidscommunicatie (naar haar voorzitter doorgaans commissie-Wallage genoemd) pleit wel voor meer actieve openbaarheid, maar verzuimt aan te geven hoe die vorm moet krijgen of doet suggesties en aanbevelingen die de burger nog verder op achterstand zetten dan reeds het geval is. Zo is weliswaar sprake van een 'recht op communicatie' dat de burger zou toekomen, maar dat blijkt bij nadere lezing al net zo'n fopspeen als artikel 2 van de шов: het recht op communicatie is bedoeld als een politiek-bestuurlijk uitgangspunt voor de overheidscommunicatie, niet als een formeel in de wet te verankeren recht (Commissie Toekomst Overheidscommunicatie 2001: 34; Scholten 20o1b: 2-6). Kortom: zelden is over rechten en plichten vrijblijvender geschreven dan hier.

In dit kader zijn verder van belang de aanbevelingen van de commissie om de overheid meer ruimte te geven om over niet-aanvaard beleid voorlichting te verzorgen en om 500 miljoen gulden extra te investeren in overheidscommunicatie. "Hoe meer geld, hoe meer kleuring", en "hoe zwakker de vormgeving van de actieve openbaarheid hoe groter de kans dat openbaarheid een legitimatiefunctie vervult, al dan niet ingegeven door politiek en/of ambtelijk opportunisme", aldus critici (Wagenaar 2001; Schuyt 2002). De eerlijkheid gebiedt te zeggen dat de burger niet helemaal met lege handen achterblijft: de commissie spoort de overheid tevens aan haast te maken met het via internet toegankelijk maken van alle bij de overheid beschikbare informatie, zonder overigens aan te geven op welke wijze dat zou kunnen.

In de tweede plaats staan de belangen van overheid en media vaak haaks op elkaar. Waar media het nieuws van morgen vandaag willen brengen, hangt het gewenste tijdstip van openbaarmaking in de politiek af van de omstandigheden. Soms - en dat geldt vooral bij gevoelig liggende en dus publicitair juist zeer interessante zaken - hebben politici belang bij een min of meer langdurige radiostilte - men zie de wijze waarop premier Kok de verloving van kroonprins WillemAlexander en Máxima voorbereidde en/of de gang van zaken rond de benoeming van minister van Buitenlandse Zaken De Hoop Scheffer tot secretaris-generaal 
van de NAVO. Bij allerlei verschillen van inzicht waarin de manoeuvreerruimte om overeenstemming te bereiken groter is doordat de tegenstelling een veel zakelijker karakter heeft, is er altijd wel een onderhandelende partij die belang heeft bij openbaarheid. In dergelijke omstandigheden lekt er altijd van alles en nog wat uit en duiken in de berichtgeving de bekende 'welingelichte kringen', 'kringen rond de premier' enzovoort op. Dat lekken heeft altijd een oogmerk. Soms gaat het erom in de publieke opinie af te tasten hoe een idee valt, soms is het de bedoeling om de oppositie tegen een idee van de tegenstander alvast te organiseren, soms om de eigen inzet bij de onderhandelingen zo scherp mogelijk te profileren. Maar het meest voorkomende is het zogenaamde 'ego-lek', giving information primarily to satisfy a sense of self-importance. Door al dat anonieme lekken ontstaat wat een voormalig Kamerlid eens een 'off-the-record-democratie' genoemd heeft (Wagenaar 1997: 457). Het grote nadeel daarvan is dat een wezenskenmerk van een gezonde democratie verloren gaat, te weten de betrouwbaarheid en controleerbaarheid van informatie die in ieder geval in de ogen van veel burgers afkomstig is van 'de overheid' dan wel 'de politiek'. Helderheid over wie de afzender is van welke boodschap, is een noodzakelijke zij het niet voldoende voorwaarde voor de vaak zo vurig bepleite transparantie.

\subsection{MEDIA, MAATSCHAPPELIJKE VERANTWOORDELIJKHEID EN VERANTWOORDING AFLEGGEN}

Ook van media wordt steeds vaker en sterker gevraagd verantwoording af te leggen over allerlei aspecten van hun berichtgeving (Bardoel 2003; Brants en Van Praag 2003; Raad voor Maatschappelijke Ontwikkeling 2003). Die eis past in het algemene beeld dat geschetst is. Sterker: het zou vreemd zijn als het niet zou gebeuren, zeker gelet op het gegeven dat politiek en bedrijfsleven in en door media 'op het matje geroepen worden'. In een samenleving waarin waarden als 'transparantie' en 'verantwoording afleggen' steeds belangrijker worden om de legitimiteit van politiek en bedrijfsleven staande te houden, ligt het voor de hand dat ook de media op deze waarden bevraagd gaan worden. En lezers en kijkers zullen meer dan voorheen inzicht willen hebben in de kwaliteit van journalistieke producten en werkprocessen. Op zich is dat geen nieuw gegeven. Welke rollen journalisten en media in een (democratische) samenleving vervullen en de wijze waarop ze die rollen vervullen, is al decennialang onderwerp van wetenschappelijk onderzoek en maatschappelijk debat.

In dat onderzoek en debat spelen de ideeën uit de theory of the social responsibility of the press een belangrijke rol. Die theorie is eind jaren veertig ontwikkeld in de Verenigde Staten naar aanleiding van een toenemend aantal klachten over het partijdige en commerciële karakter van de pers (Commission on Freedom of the Press 1947). De social responsibility kan worden gezien als een reactie op de in de negentiende eeuw geformuleerde free press theory (Siebert, Peterson en Schramm 1956). In die opvatting bestond uitsluitend oog voor de vrijheid van de pers; de oorsprong van de metafoor 'de pers als koningin der aarde' ligt in deze 
opvatting. De theorie van de vrije pers is tegen de achtergrond van de politieke en maatschappelijke omstandigheden van de negentiende eeuw te beschouwen als liberaal in de negentiende-eeuwse betekenis. De pers, zo was de centrale gedachte, diende vrij te zijn van staatsinvloeden en vanuit een onafhankelijke positie te berichten over wat zij in politiek en samenleving waard vond om over te berichten. Een metafoor als 'koningin der aarde' hield in feite in dat de pers aan niemand verantwoording schuldig was, zoals absolute vorsten zich ook niet behoefden te verantwoorden. De vrije markt, het vrije spel der maatschappelijke krachten zou een free and open encounter waarborgen, een invisible hand zou een selfrighting process garanderen (Fagen 1966: 137). Ongelimiteerde vrijheid bleek echter al snel haar schaduwkanten te hebber. Een op commerciële basis georganiseerde pers bleek niet in alle gevallen het ideale platform voor een open en vrije discussie, de waarheid niet de vanzelfsprekende uitkomst van een discussie.

In de theorie van maatschappelijke verantwoordelijkheid van de pers wordt het belang van een open and free market place of ideas ten volle onderschreven, de democratie is gediend met concurrentie tussen uiteenlopende opvattingen. Maar er wordt wel een kanttekening geplaatst. Zo'n free market place of ideas ontstaat niet vanzelf en het is zeker niet zo dat persvrijheid in economische zin daarvoor een 100\%-garantie oplevert. De manier waarop de journalistiek haar taak opvat is cruciaal. De journalistiek heeft een publieke taak toebedacht gekregen en dat schept een maatschappelijke verantwoordelijkheid. Die verantwoordelijkheid verschaft de samenleving het recht eisen te stellen aan de journalistiek. De Commission on Freedom of the Press formuleerde vijf eisen die tezamen een 'measure of performance' voor de pers opleveren (zie tekstbox 16.3).

\section{Tekstbox 16.3 Een measure of performance voor media}

“A truthful, comprehensive and intelligent account of the day's events in a context which gives them meaning.

A forum for the exchange of comment and criticism.

A representative picture of the constituent groups in society.

The presentation and clarification of the goals and values of the society.

Full access to the day's intelligence."

Bron: Commission on Freedom of the Press (1947: 20-30)

Het werk van deze commissie heeft zowel in wetenschap als praktijk diepe sporen achtergelaten. De ontwikkeling van normatieve mediatheorie - formuleren wat in een democratische samenleving van media verwacht kan en mag worden - is sterk beïnvloed door het werk van deze commissie. Ook in recente pogingen deze verwachtingen zo helder mogelijk te formuleren en uit te werken naar praktisch toepasbare normen voor journalistiek handelen, zijn de grondlijnen van deze vijf eisen duidelijk herkenbaar (McQuail 200o: 166 - 188). En wat de praktijk betreft is het niet anders. Codes voor journalistiek gedrag (Traber en Nordenstreng 1993; Nederlands Genootschap voor Hoofdredacteuren 1995) laten 
zich lezen als variaties en aanvullingen op de measure of performance. In het Nederlandse mediabeleid ten slotte wordt veel waarde gehecht aan het begrip 'pluriformiteit'. En ook de gedachtegang die daarachter schuilgaat, is al herkenbaar in de measure of performance, waarin immers van media verlangd wordt dat zij a representative picture of the constituent groups in society geven.

Ongenoegen en heftige discussies over de rol van media in politiek en samenleving vormden in 1947 in de Verenigde Staten de aanleiding voor het instellen van een commissie. Bijna vijftig jaar later kunnen we vaststellen dat alom in de westerse wereld en zeker ook in Nederland ongenoegen en discussie over de rol van media opnieuw aanleiding geven tot verhitte debatten en verstrekkende voorstellen. Maar vandaag de dag gaat de discussie niet zozeer over de vraag wat media zouden moeten doen, maar veel meer over de vraag hoe ze te dwingen te doen wat ze zouden moeten doen. En daarmee zitten we midden in de discussie over verantwoording afleggen: tegenover wie en aan de hand van welke maatstaven kan van media verlangd worden zich te verantwoorden over hun doen en laten?

\subsection{MEDIA EN VERANTWOORDING AFLEGGEN}

Als media in het geding zijn is verantwoording afleggen de confrontatie tussen wat media schrijven of uitzenden enerzijds en de gerechtvaardigde verwachtingen van de samenleving anderzijds. Dat proces kan omschreven worden als: "all the voluntary or involuntary processes by which media answer directly or indirectly to their society for the quality and or consequences of publication, with particular reference to matters of general public good" (McQuail 20oo: 180).

Ideaaltypisch kunnen die processen vanuit twee verschillende invalshoeken vormgegeven worden, namelijk vanuit het 'aansprakelijkheidsmodel' en vanuit het 'verantwoordelijkheidsmodel' (McQuail 20oo: 182). Het aansprakelijkheidsmodel legt de nadruk op de schade die personen, organisaties of de samenleving op zich kunnen lijden als gevolg van publicaties in de media. Om misverstanden te voorkomen: vanuit dit model wordt aan media geen enkele beperking opgelegd, maar media kunnen wel aansprakelijk gesteld worden voor de gevolgen van aantoonbaar onjuiste publicaties. Oud-minister Peper heeft zich bij herhaling groot voorstander getoond van deze benadering. In zijn visie nopen maatschappelijke ontwikkelingen als individualisering en horizontalisering van eertijds sterk hiërarchische verhoudingen, tot aansluiting zoeken bij het Amerikaanse systeem: iedereen mag zeggen wat hij wil, maar hij moet wel de eventuele consequenties van eigen handelen dragen. "Amerikaanse burgers", aldus Peper "wordt geen strobreed in de weg gelegd om van alles en nog wat over elkaar te zeggen, maar wanneer de aantijgingen niet waargemaakt kunnen worden, wacht de beschuldigende partij (een natuurlijk persoon of een instelling, bijvoorbeeld de media) een naar omvang afschrikwekkende boete. Dat vooruitzicht dwingt tot zorgvuldigheid. Want de vrijheid van meningsuiting wordt - ook in ons land - 
begrensd door de wet. (...) De media blijven uiteraard geheel vrij te publiceren wat zij menen te moeten publiceren. Aan dat grondrecht mag nooit, maar dan ook nooit getornd worden, want dat grondrecht zie ik als de moeder van de democratie. Gezien het type samenleving dat ik heb geschetst, gezien de uitwerking naar personen en instituties van aantoonbare missers in de berichtgeving, zullen ongefundeerde beschuldigingen moeten worden vertaald in klinkende munt. Zo wordt een waardeconflict - de beschuldiging heeft al haar verwoestende werking verricht - omgezet in een op geld waardeerbaar belangenconflict" (Peper 2002: 33-34). Terzijde: als er sprake is van aan de samenleving toegebrachte schade, duikt er een complicatie op. In zo'n geval is het onmogelijk een waardeconflict om te zetten in een op geld waardeerbaar conflict: wie zou wat aan wie moeten uitbetalen?

In het verantwoordelijkheidsmodel ligt de nadruk op debat, vrijwilligheid, onderhandelen en dialoog als de beste benadering om conflicten tussen media en hun criticasters op te lossen. In zo'n benadering komen (torenhoge) schadevergoedingen niet in beeld, maar gaat het om rectificaties, publicatie van excuses en recht van weerwoord. De Nederlandse praktijk sluit vooralsnog eerder aan bij het verantwoordelijkheids- dan bij het aansprakelijkheidsmodel, al wordt een enkele keer wel een schadevergoeding toegekend. Denken vanuit het aansprakelijkheidsmodel heeft de kracht van de eenvoud (alles mag gezegd worden, maar hou rekening met forse financiële gevolgen) en brengt het risico van een verdere juridisering van de samenleving en van het aanwakkeren van een claimcultuur met zich mee. Denken vanuit het verantwoordelijkheidsmodel mist de kracht van de eenvoud: het leidt - hoe ook de verdere uitwerking geschiedt - altijd tot een ingewikkelder systeem. Tegelijkertijd worden in dit model de risico's van verdere juridisering en het aanwakkeren van een claimcultuur grotendeels vermeden.

\subsection{VERANTWOORDELIJKHEID EN VERANTWOORDING AFLEGGEN}

Zoals gezegd: het verantwoordelijkheidsmodel mist de kracht van de eenvoud.

Zeker voor media geldt dat een groot aantal partijen in beeld (kunnen) komen bij de verdere uitwerking. De adverteerders en sponsors willen waar voor hun geld, de eigenaren een zeker rendement, de lezers en kijkers een aantrekkelijk product, de beleidsmakers en wetgevers geen overtredingen van allerlei regelgeving, de verschillende bronnen (regering, politici, grote bedrijven enz.) liefst positieve publiciteit en het is aan de krant of het televisiestation om alle partijen tevreden te stellen (McQuail 2000: 182-185).

Het is onmogelijk om voor alle mogelijk betrokken partijen afzonderlijk een schets te geven van criteria en procedures aan de hand waarvan media in het verantwoordelijkheidsmodel verantwoording af zouden kunnen respectievelijk moeten leggen. Zelfs voor de vier belangrijkste clusters (politiek, markt, publiek en professie) is het een complexe zaak, mede omdat tussen media en/of mediumtypen grote verschillen bestaan. Een zeer in het oog springend en terzake 
doend verschil in dit verband is dat tussen dagbladen (private financiering) en een deel van de omroep (grotendeels publieke financiering). We beperken ons daarom tot een korte beschrijving van de vier clusters (zie tekstbox 16.4).

Tekstbox 16.4 Sturing en verantwoording afleggen

$\begin{array}{lll}\text { Sturing } & \text { Regulerend mechanisme } & \text { Verantwoording } \\ \text { Professie } & \text { gedragscodes } & \text { interne reflectie } \\ & \text { peers } & \text { gedragscode } \\ & & \text { Raad voor Journalistiek } \\ \text { Publiek } & \text { dialoog } & \text { panels } \\ & \text { burgers } & \text { hoorzittingen, } \\ & & \text { internet communities } \\ & & \text { ombudsman } \\ \text { Markt } & \text { vraag en aanbod } & \text { marktaandelen } \\ & \text { aandeelhouders } & \text { kijk-, luister- en oplagecijfers } \\ & & \\ \text { Overheid } & \text { begroting } \\ & & \text { jaarverslag } \\ & & \text { (prestatie)contracten }\end{array}$

Bron: McQuail (20oo: 184-187); Bardoel en d'Haenens (2003: 99-146); Raad voor Maatschappelijke Ontwikkeling (2003: 18); Bardoel (2003)

\section{Verantwoording afleggen: de professie}

De journalistiek heeft nooit bekend gestaan om haar ontvankelijkheid voor kritiek. Niet zelden werd met een beroep op de persvrijheid alle kritiek op media en journalisten van tafel geveegd. Die afwerende en wat hautaine houding is de laatste jaren aan het verdwijnen om plaats te maken voor een meer responsieve opstelling jegens criticasters. Het bizarre jaar 2002 heeft die ontwikkeling in een stroomversnelling gebracht. In april 2002 vormde het verschijnen van het NIODrapport over (de val van) Srebrenica aanleiding voor een debat over de rol van media dat niet eerder in deze omvang en met deze openheid in en door media gevoerd was. Van de bekende pavlovreactie was in de discussies en forumbijeenkomsten weinig tot niets te bespeuren. En in de artikelen over het NIOD-rapport bleef de rol van de media niet onbesproken. Integendeel (zie tabel 16.1). 
Tabel 16.1 Aantal artikelen waarin sprake is van zelfreflectie in relatie tot totaal aantal artikelen over NIOD-rapport (periode: maart-juni 2002)

\begin{tabular}{|lcc|} 
Krant & $\begin{array}{l}\text { Aantal artikelen over } \\
\text { NIOD-rapport }\end{array}$ & $\begin{array}{l}\text { Aantal artikelen met } \\
\text { zelfreflectie }\end{array}$ \\
NRC Handelsblad & 122 & 20 \\
de Volkskrant & 127 & 15 \\
Trouw & 127 & 10 \\
Algemeen Dagblad & 61 & 3 \\
De Telegraaf & 62 & 1 \\
\hline
\end{tabular}

Bron: De Graaf (2003: 297)

Een van de meest bekritiseerde dagbladen - de Volkskrant - maakte een eigen evaluatie van haar berichtgeving over Srebrenica openbaar, wat opnieuw aanleiding gaf tot discussie. Dat media en journalisten meer dan tot dan toe gebruikelijk open bleken te staan voor kritiek en bereid bleken te reflecteren, zal waarschijnlijk mede te danken zijn aan de uitvoerige analyse van de berichtgeving over Srebrenica die aan de kritiek in het NIOD-rapport ten grondslag lag (Scholten, Ruigrok en Heerma 2002). Dergelijke omvangrijke studies zijn zo arbeidsintensief en daarmee zo kostbaar dat ze zelden uitgevoerd worden. Dat is jammer, zeker omdat de discussie na het verschijnen van het NIOD-rapport erop wijst dat de journalistiek haar afwerende houding steeds meer laat varen en zich wel degelijk bereid toont in de spiegel te kijken. Als het maar geen lachspiegel is.

\section{Verantwoording afleggen: het publiek}

Toen kort daarop Pim Fortuyn vermoord werd, kregen de media opnieuw een golf van kritiek over zich heen, moesten diverse journalisten dag en nacht bewaakt worden en ontstond een soms beangstigende situatie. "De kloof tussen politiek en burger bleek eveneens een kloof tussen krant en lezer”, blikte de voorzitter van het Genootschap van Hoofdredacteuren naderhand terug, daarmee refererend aan het verwijt dat ook dagbladen totaal verrast waren door de revolte van mei 2002 (Broertjes 2003). De gebeurtenissen van 2002 laten zien dat in de ogen van in ieder geval een deel van de burgers de media deel zijn gaan uitmaken van de Haagse macht en daarmee hun gerichtheid op het publiek veronachtzaamden. De woede na de moord op Fortuyn richtte zich dan ook niet alleen op 'Den Haag' maar evenzeer op de media. Voor velen een sein om de blik minder op 'Den Haag' en meer op de burger te richten.

Het belangrijkste aan een krant zijn haar lezers, placht Kurt Baschwitz te zeggen. ${ }^{2}$ Het is een oude waarheid die de journalistiek opnieuw lijkt te ontdekken. Ombudsmannen en lezersredacteuren zijn al enkele jaren een beproefde methode om het journalistiek handelen te verantwoorden tegenover protesterende lezers (Bardoel en d'Haenens 2003: 147 e.v.). Na de burgerrevolte van mei 2002 valt een intensivering waar te nemen in de pogingen om de keuzes en 
aanpak in de selectie en bewerking van nieuws op zijn minst inzichtelijk te maken en ter discussie te stellen. De ene krant (Trouw) houdt wekelijks telefonisch spreekuur en publiceert elke zaterdag een brief van de hoofdredacteur waarin journalistieke dilemma's worden geschetst en de gemaakte keuzes worden besproken en toegelicht. Een ander dagblad (de Volkskrant) kiest voor een externe deskundige die met regelmaat de manier waarop de krant bericht, kritisch tegen het licht houdt. En steeds meer media zetten internet in om juist over hun eigen berichtgeving in contact te komen met lezers, luisteraars of kijkers. Op de website van bijvoorbeeld het NOs-journaal gaat de hoofdredactie bijna dagelijks in op vragen en opmerkingen vanuit het publiek. Het is een van de methoden om straat en staat weer met elkaar te verbinden, zoals de hoofdredacteur van het Journaal dat zo kernachtig formuleerde (Laroes 2002).

\section{Verantwoording afleggen: markt, overheid en publieke omroep}

De overheid speelt in Nederland ten aanzien van de audiovisuele media een totaal andere rol dan ten opzichte van geschreven media in het algemeen en dagbladen in het bijzonder. Mediabeleid betekent in Nederland vooral omroepbeleid en niet te vergeten een voortdurende worsteling om in de organisatie van de publieke omroep vormen te vinden die aansluiten bij ontwikkelingen in de samenleving. Het meest treffend komt dat naar voren in de jarenlange strijd rond de vraag in hoeverre en onder welke voorwaarden commercie op radio en televisie toegelaten zou moeten worden. Aanvankelijk ging het gevecht om het al dan niet toelaten van reclame op de publieke radio en televisiezenders, naderhand over de vraag of naast de publieke zenders ook puur commerciële radio en televisie mogelijk gemaakt zou moeten worden (Bakker en Scholten 2003: 103-119). De tegenstanders van commercie en reclame hebben in beide gevechten het onderspit gedolven. Nederland kent nu derhalve een nogal complex omroeplandschap met enerzijds puur commerciële omroepen waarop nauwelijks wet- en regelgeving van toepassing is, en anderzijds een publieke omroep die zich geconfronteerd ziet met een uitgebreide wetgeving die bovendien met grote frequentie kleine en grote wijzigingen ondergaat. Bovendien is binnen dat stelsel niet alleen sprake van een wettelijk omschreven publieke taak, maar tegelijkertijd van de verplichting om in de concurrentie met de commerciële omroepen een bepaald marktaandeel te halen. En om het geheel nog wat verder te compliceren hebben de verschillende omroepverenigingen een dubbele opdracht meegekregen. $\mathrm{Ze}$ worden geacht op Nederland 1, 2 of 3 nauw met elkaar samen te werken om het vereiste marktaandeel te realiseren en tegelijkertijd wordt van hen verwacht dat ze zich op de verschillende zenders zo scherp mogelijk profileren; de pluriformiteit moet immers gewaarborgd blijven.

Bekijken we de audiovisuele media in hun geheel, dan kunnen we vaststellen dat in de naoorlogse periode langzaam maar zeker een verschuiving heeft plaatsgevonden in sturingsmechanisme: mede door het beleid van de overheid is de markt veruit het belangrijkste sturingsmechanisme geworden, zowel door de komst van puur commerciële zenders als door het belang dat binnen de publieke omroep aan kijkcijfers gehecht wordt dan wel gehecht moet worden. De positie 
van de (klassieke) omroepverenigingen - in de verzuilde samenleving van weleer representanten van een politieke en/of levensbeschouwelijke stroming en uitgesproken wortelend in het idee van een civic society - is aanzienlijk verzwakt. $\mathrm{Na}$ meer dan tachtig jaar omroepbeleid hebben we nu een uiterst ingewikkeld georganiseerde publieke omroep, grotendeels gefinancierd uit publieke middelen (in 2003 bedraagt de rijksbijdrage 659 miljoen euro op een totale begroting van 886 miljoen euro) met een deels commerciële taakstelling, te weten een bepaald marktaandeel realiseren. Uiteraard maakt dat het verantwoording afleggen niet eenvoudiger, al was het maar omdat de markt (kijkcijfers) doorgaans andere programma's vraagt dan de publieke taakstelling. Met politiek valt geen geld te verdienen, noteerde Weber in 1919 en wat dat betreft is er niets veranderd. De enkele uitzondering daargelaten - Fortuyn was gedurende een korte periode een zeer opvallende uitzondering - staan politici en/of politieke programma's niet garant voor hoge kijkcijfers.

Een apart punt van aandacht vormt bij televisie het fenomeen sponsoring. Uit onderzoek van een krant beek najaar 2003 dat steeds meer ideële organisaties geld beschikbaar stellen om bepaalde programma's mogelijk te maken (NRC Handelsblad, 27 september 2003). Daarmee komt de onafhankelijkheid van de journalist of programmamaker in het geding, zeker als niet bekend is dat een derde partij een bepaald programma 'mede mogelijk gemaakt heeft'.

\section{Verantwoording afleggen: markt, overheid en dagbladen}

Geschreven media en dagbladen in het bijzonder hebben een lange historie waarin markt en overheid een andere rol spelen dan bij de omroep. Dagbladen hebben nooit publieke financiering gekend, zij hebben altijd de staat op zo groot mogelijke afstand gehouden. Sterker: de vrijheid van meningsuiting - deels in en door dagbladen bevochten - moest veroverd worden op de staat. Vanaf halverwege de negentiende eeuw tot in de jaren zestig van de twintigste eeuw hebben dagbladen een belangrijke rol gespeeld in de politieke en maatschappelijke ontwikkeling van Nederland. Voor politieke bewegingen met een protestantse, katholieke, socialistische of communistische achtergrond waren ze onmisbaar als wapen in de strijd voor verdere democratisering en voor emancipatie van bevolkingsgroepen. Mede door die ervaring zijn dagbladen vanouds vertrouwd met de 'dubbele doelstelling': enerzijds een krant maken die economisch exploitabel is, anderzijds strijden voor een ideaal. Die dubbele doelstelling bestaat zeker voor dagbladen nog steeds, zij het dat de vorm waarin ingrijpend veranderd is. De ontzuiling in de jaren zestig van de vorige eeuw heeft de nauwe banden tussen een aantal politieke partijen en dagbladen doen verdwijnen en daarmee ook de context voor de zogenaamd neutrale dagbladen veranderd. Niet het dienen van een bepaald (partij)politiek ideaal maar het dienen van het democratisch proces, the public interest, staat centraal. Veel belangrijker dan de invulling van de ideële doelstelling is dat het soortelijk gewicht van de verschillende doelstellingen veranderd is. In het tijdperk na de ontzuiling zijn dagbladen steeds meer gewone ondernemingen geworden waarin het economische rendement een zwaarder gewicht in de schaal is gaan leggen dan enigerlei ideële doelstelling. En ook al 
heeft de samenleving een belang bij het instandhouden van een economisch gezonde dagbladsector die zo onafhankelijk mogelijk en vanuit verschillende perspectieven bericht over wat in politiek en samenleving gaande is, van publieke financiering is in deze sector geen sprake. Hooguit van een kleine correctie via het Bedrijfsfonds voor de Pers, opgericht in 1974 om de pluriformiteit van de pers, voorzover van belang voor de informatievoorziening en opinievorming, te handhaven en te bevorderen. Waar de publieke omroep zich jaarlijks via begroting en jaarverslag moet verantwoorden voor de besteding van publieke middelen, hebben dagbladondernemingen en commerciële radio- en televisiestations te maken met aandeelhouders. De tucht van de markt geldt hier ten volle.

\section{Verantwoording afleggen: hoe nu verder?}

In bovenstaande hebben we in grote lijnen geschetst tegenover wie media verantwoording afleggen, zowel over de bedrijfsvoering in algemene zin als over het journalistiek handelen. Daarbij is duidelijk geworden dat tussen de eisen die in die verschillende trajecten gesteld worden, dikwijls spanningen bestaan. Zo bestaat tussen de eisen van de markt (rendement, marktaandelen, kijk- en luistercijfers) en de eisen die gesteld worden aan de kwaliteit van journalistieke werkprocessen en van journalistieke eindproducten, vrijwel altijd spanning. En wat die laatste eisen betreft, is lang niet altijd helder wie de kwaliteitseisen namens wie formuleert. Aan wie komt het formuleren van die eisen toe? Aan de professie zelf? Aan de burgers, als afnemers van de informatie? Aan betrokkenen die met grote regelmaat bron zijn van allerlei informatie? Aan wetenschappers die media, samenleving en politiek als object van studie en reflectie gekozen hebben? Wat gerechtvaardigde verwachtingen zijn van een samenleving jegens media, zal uiteindelijk alleen via een min of meer permanente discussie tussen alle betrokkenen geformuleerd kunnen worden. En alleen uitgaande van die, in alle voorlopigheid geformuleerde, gerechtvaardigde verwachtingen, valt een zinnige discussie te voeren over de vraag of media doen wat van ze verwacht mag worden. Over die verwachtingen is waarschijnlijk wel overeenstemming te bereiken, de verschillende gedragscodes voor journalisten bevatten alle denkbare bouwstenen. Het probleem schuilt in de daaropvolgende vraag, te weten wie op welke wijze toeziet op de naleving van een gedragscode en welke sancties aan eventuele schendingen verbonden moeten worden. Dit probleem is principieel onoplosbaar en dat moeten we dus ook niet willen oplossen. We moeten het onder ogen zien en de onoplosbaarheid erkennen. Elke toezichthoudende instantie met de bevoegdheid bindende sancties op te leggen, staat namelijk, zacht gezegd, op gespannen voet met artikel 7 van de grondwet. "Niet verantwoordingsplichtig te zijn, is zowel de kracht van een onafhankelijke journalistiek als haar achilleshiel. Dat is de paradox van de rol van media in een democratie. En voor paradoxen bestaan geen oplossingen” (Brants en Van Praag 2003). Kiezen we niet voor het voluit toepassen van het aansprakelijkheidsmodel - alles mag gezegd en geschreven, hou wel rekening met forse financiële schadeclaims - dan rest slecht één uitweg: de kracht behouden en de achilleshiel beschermen. Het eerste ligt reeds besloten in artikel 7 van de Grondwet, het tweede vergt van alle betrokken partijen de nodige inspanningen. 
De overheid doet er goed aan de grenzen in de overheidscommunicatie scherper te markeren. Communicatie/voorlichting in het kader van de uitvoering van aanvaard beleid is volop het domein van de overheid. Beïnvloeden en verleiden is in dit kader net zo aanvaardbaar als het handhaven van wet- en regelgeving. Omwille van de duidelijkheid over wie de afzender van de boodschap is, verdient het aanbeveling dit deel van de overheidscommunicatie duidelijk te scheiden van de communicatie rond niet-aanvaard beleid. Strikt genomen is dat niet het domein van de overheid, maar van politieke partijen, belangengroepen en actievoerders. Beïnvloeden, overtuigen en verleiden van de burgers is aan hen, niet aan de overheid. Natuurlijk is de grens tussen beide in de praktijk vaak lastig te trekken. Maar dat mag geen excuus zijn om de huidige situatie waarin overheidsvoorlichters meerdere en soms tegenstrijdige belangen moeten dienen (het belang van het departement, van de bewindspersoon, van de regering, van een regeringspartij) te laten voortbestaan (Smits 2001). Een hernieuwde poging de grens te markeren is dringend gewenst. In dat kader is het tevens van belang dat de overheid de burgers als burger aanspreekt, niet als klant. Dat laatste is een vorm van boerenbedrog die bij de burger alleen maar hogere verwachtingen kan wekken dan de overheid ooit waar kan maken. Wie een paspoort of bouwvergunning aanvraagt, bekeurd of gevangengezet wordt, is nu eenmaal geen klant.

Vervolgens en niet geheel los van het voorgaande is meer afstand tussen regering en parlement en tussen politici en journalisten dringend gewenst. Politici verwijten media telkens weer dat ze deelnemers aan het politieke spel zijn geworden. In de ogen van althans een deel van het publiek zijn journalisten deel gaan uitmaken van het 'Haagse establishment'. Het zijn verwijten met een hoog gehalte van 'De pot verwijt de ketel dat hij zwart ziet'. Voorzover journalisten deelnemers aan het politieke spel geworden zijn in plaats van toeschouwers en commentatoren ervan, zijn het toch in hoge mate politici die met al hun (anonieme) lekken dat mede mogelijk gemaakt hebben. En voorzover politiek en media in de ogen van het publiek deel uitmaken van het vermaledijde 'Haagse establishment', doen ze er goed aan zich af te vragen of ze dat beeld niet zelf geschapen hebben. Natuurlijk onderhouden politici en journalisten veel contacten. Maar als dat voor het oog van de camera uitmondt in al te informeel en kameraadschappelijk gedrag, doet dat afbreuk aan de geloofwaardigheid van het daaropvolgende 'kritische' interview. Gepaste afstand is zeker voor het oog van de camera geboden. Kortom: politici en journalisten doen er goed aan hun eigen rol en verantwoordelijkheid weer scherper te definiëren en te onderscheiden.

Dat is overigens makkelijker gezegd dan gedaan. Het vergt aan beide kanten een verandering in de nu bestaande cultuur. Politici moeten zich onafhankelijker opstellen ten opzichte van journalisten, journalisten ten opzichte van politici (vergelijk Raad voor het Openbaar Bestuur 2003). Dat lukt zowel politici als journalisten alleen als ze binnen hun eigen groep gezamenlijk optrekken. En precies daar ligt de zwakke schakel. Meer distantie tussen politiek en media mag dan op lange termijn in het belang zijn van de geloofwaardigheid van beide partijen en 
daarmee in het belang van een goed functioneren van de democratie, op korte termijn lopen de belangen binnen beide groepen helemaal niet parallel. Op korte termijn heeft elke journalist belang bij een primeur en/of pittige uitspraak te leveren door de politicus. En weet de journalist dat als hij de primeur en/of pittige uitspraak niet optekent, de concurrent dat wel doet. En op korte termijn heeft de politicus belang bij het leveren van die primeur en/of pittige uitspraak. Vier jaar lid zijn van het parlement en niet of nauwelijks de media gehaald hebben is immers een garantie voor wachtgeld. Zolang politiek en journalistiek er niet in slagen het langetermijnbelang voorrang te geven boven het kortetermijnbelang en zo de ruimte voor meer afstand te creëren, heeft de burger het nakijken. Die burger heeft ten slotte ook een deel van de oplossing in handen. Als burgers zich weer gaan realiseren dat politiek meer is dan alleen vermaak en daar consequenties aan verbinden voor hun mediagedrag - Nova in plaats van de borreltafel, een dag- in plaats van een roddelblad, om het zo te zeggen - schept dat voor politici en journalisten meer ruimte om het langetermijnbelang te laten prevaleren. Politici, overheidsvoorlichters, journalisten en burgers: gezamenlijk hebben we de situatie doen ontstaan waarin we ons nu bevinden en waarin beeldvorming belangrijker is geworden dan de werkelijkheid. Gezamenlijk hebben we ook de mogelijkheid de balans te herijken. Motto, richtsnoer, leidraad en richtinggevend principe daarbij kan voor alle betrokkenen een dichtregel van Jan Emmens zijn. Hij schreef:

"k Zocht in geen boomstronk ooit naar een kabouter, maar keek gewoon naar wat er werkelijk was." 3 
NOTEN

1

Gericht tegen Wouke van Scherrenburg, verslaggever van Den Haag Vandaag, en premier Kok.

2 In de jaren dertig grondlegger van wat heden ten dage de opleiding Communicatiewetenschap aan de UvA is.

3 Regels uit het gedicht 'Een kind in de tuin', opgenomen in de bundel Kunst en vliegwerk. 


\section{LITERATUUR}

Bakker, P. \& O. Scholten (2003) Communicatiekaart van Nederland; overzicht van media en communicatie, Alphen aan den Rijn: Kluwer, vierde geheel herziene druk.

Bardoel, J.L.H. (2003) Macht zonder verantwoordelijkheid?; Media, mediabeleid en de kwaliteit van de openbare informatievoorziening, oratie, Nijmegen: Katholieke Universiteit Nijmegen.

Bardoel, J.L.H., \& L. dHaenens (2003) 'Media en maatschappelijke verantwoordelijkheid; van theorie naar praktijk', blz. 99-150 in: Raad voor Maatschappelijke Ontwikkeling, Medialogica. Over het krachtenveld tussen burgers, media en politiek, Den Haag, Sdu Uitgevers.

Bolkestein, F. (2001) 'De zeven hoofdzonden van de journalistiek', de Volkskrant, 11 november 2001.

Brants, K. (2002) 'Opgejaagd door Cerberus; de moeizame mediatisering van de politieke communicatie', in: J. Bardoel et al. (red.), Journalistieke cultuur in

Nederland, Amsterdam: Amsterdam University Press.

Brants, K., \& Ph. van Praag (2003) 'Media op het matje (alweer)', de Volkskrant, 29 maart 2003.

Broertjes, P. (2003) 'Aan de schandpaal? Nee dank, u', blz. 12-15, De Journalist, 25 april 2003.

Commissie Toekomst Overheidscommunicatie (2001) In dienst van de democratie, Den Haag: Sdu Uitgevers.

Commission on Freedom of the Press (1947) A free and responsible press, Chicago: University of Chicago Press.

Crisis Onderzoeks Team Rijksuniversiteit Leiden (1997) Crises in het nieuws; samenspel en tegenspel tussen overheid en media, Alphen aan den Rijn: Samsom.

Deuze, M. (2001) Journalists in the Netherlands; an analysis of the people, the issues and the (inter)national environment, Amsterdam: Aksant.

Dewez, B. et al. (red.) (2001) Overheidscommunicatie; de nieuwe wereld achter Postbus 51 , Amsterdam: Boom.

Dielesen, G. (1998) 'Justitie, niet pers, liet rel rond Docters escaleren' (in gesprek met Fokke Obbema), de Volkskrant, 21 februari 1998.

Docters van Leeuwen, A. (1998) 'Wij zijn meer dan de boodschapper van de minister' (in gesprek met Marcel Haenen), in: NRC Handelsblad, 14 februari 1998.

Emmens, J.A. (1957), Kunst en vliegwerk, Amsterdam: Van Oorschot.

Fagen, R.R. (1966) Politics and communication, Boston: Little, Brown and Company.

Geelen, J.P. (1998) Het Haagse huwelijk; hoe pers en politiek tot elkaar veroordeeld zijn, Nijmegen: sun.

Graaf, A. de (2003) 'Een nieuwe dag, een nieuwe krant; een kwalitatief onderzoek naar zelfreflectie bij vijf Nederlandse dagbladen naar aanleiding van het NIOD-rapport over Srebrenica', in: Raad voor Maatschappelijke Ontwikkeling, Medialogica.

Over het krachtenveld tussen burgers, media en politiek, Den Haag: Sdu Uitgevers.

Kaiser, A. (1985), Haagse journalistiek; een empirisch onderzoek naar de relatie tussen journalisten en parlementariërs, Amsterdam: vu Uitgeverij.

Klaassen, J. en Th. Klein (2002) Srebrenica in de Volkskrant 1991-1995, Amsterdam: de 


\section{Volkskrant}

Laroes, H. (2002) Ten aanval (http://www.omroep.nl/nos/journaal).

Liempt, A., van \& G. van Westing (2000) Klem in de draaideur; Arthur Docters van Leeuwen en het Ministerie van Justitie 1995-1998, Amsterdam: Balans.

McQuail, D. (200o) McQuails' Mass Communication Theory: an introduction, Londen: Sage, vierde druk.

Mierlo, H.A.F.M.O. van (1976) Handelingen Tweede Kamer der Staten-Generaal, zitting 1976-1977: 2003.

Nederlands Genootschap van Hoofdredacteuren (1995) Gedragscode voor Nederlandse journalisten (http://www.villamedia.nl/genootschap).

Neijens, C. (2002) 'Actieve communicatie over niet-aanvaard beleid: de kloof tussen overheidscommunicatie en journalistiek', Tijdschrift voor Communicatiewetenschap, Amsterdam: Boom.

Peper, B. (2003) Over klefheid en lafheid; waarheidsvinding, personalisme en consumentisme, Nijmegen: Uitgeverij Valkhof Pers.

Ploeg, J. van der (2000) 'Terug van even weggeweest' (in gesprek met Marcel Smeets), Comma, 2000 (10): 8-10.

Raad voor Maatschappelijke Ontwikkeling (2003) Medialogica; over het krachtenveld tussen burgers, media en politiek, Den Haag: Sdu Uitgevers.

Raad voor het Openbaar Bestuur (2003) Politiek en media; pleidooi voor een lat-relatie, Den Haag.

Scholten, O. (1982) Krant en democratie; een studie naar politieke informatie in landelijke dagbladen, Amsterdam: vu Uitgeverij.

Scholten, O. (1999a) 'Trends en ontwikkelingen in de journalistiek', in: Comma, 1999 (9): 6-9.

Scholten, O. (1999b) 'Publiciteit als omgevingsfactor; over organisaties, media en samenleving', blz. 15-37 in: A.A. van Ruler et al. (red.), Jaarboek Onderzoek Communicatiemanagement, Alphen aan den Rijn: Samsom.

Scholten, O., N. Ruigrok \& P. Heerma (2002) 'In Sarajevo wordt geschoten, in Genève gepraat; een onderzoek naar de berichtgeving in vier landelijke dagbladen over het conflict in voormalig Joegoslavië van januari tot en met december 1993', bijlage bij Nederlands Instituut voor Oorlogsdocumentatie, Srebrenica een veilig gebied. Reconstructie, achtergronden en analyses van de val van een Safe Area, Amsterdam: Boom.

Scholten, O., N. Ruigrok \& P. Heerma, (2002) 'Good guys, bad guys; een onderzoek naar de berichtgeving in vier landelijke dagbladen over het conflict in voormalig Joegoslavië van januari tot augustus 1995', bijlage bij Nederlands Instituut voor Oorlogsdocumentatie, Srebrenica een veilig gebied. Reconstructie, achtergronden en analyses van de val van een Safe Area, Amsterdam: Boom.

Scholten, O. (2001a) 'Tussen richtinggevend ideaal en schone schijn', Comma, 2001 (10): 5-8.

Scholten, O. (2001b) 'Wallage wil grote omslag - maar wil de burger het ook?', in: Comma, 2001 (7): 2-6.

Schuijt, G. (2002) 'Van Open Barend tot Worldwide Wallage', in: Nederlands Juristenblad, 2002 (2): 75-78.

Siebert, F.S., T. Peterson \& W. Schramm (1956) Four theories of the press, Urbana: Univer- 
sity of Illinois Press.

Smits, J. (2001) Meer dan 'bevestigen noch ontkennen'; over rolopvattingen van overheidsvoorlichters, Utrecht: Uitgeverij Lemma.

Traber, M., \& K. Nordenstreng (1993) Few Voices. Many Worlds, Londen: World Association for Christian Communication.

Wagenaar, M. (1997) De Rijksvoorlichtingsdienst; geheimhouden, toedekken, openbaren, Den Haag: Sdu Uitgevers.

Wagenaar, M. (2001) 'Meer openbaarheid is een zaak van gezond verstand', in: NRC Handelsblad, 31 augustus 2001.

Weber, M. (1999) Politiek als beroep, Baarn: Agora.

Wonderen, M. van (2002), Van 'Troetel-turk' tot 'Kut-Marokkaan', doctoraalscriptie Communicatiewetenschap, Amsterdam: Universiteit van Amsterdam.

Wurff, R. van der \& J.J. van Cuilenburg (2001) 'Impact of Moderate and Ruinous Competition on Diversity: The Dutch Television Market', The Journal of Media Economics, 14 (4): 213-229.

Zwan, A. van der (2000) 'Verantwoordelijke onderneming of verantwoordelijke maatschappij?’, in: F. Becker et al. (red.), De toekomst van de democratie, Amsterdam: Arbeiderspers/Wiardi Beckman Stichting. 


\title{
17 CONTEXT EN VERANTWOORDELIJKHEID: BIJDRAGE AAN HET NORMEN-EN WAARDENDEBAT ${ }^{1}$
}

\author{
H.P.M. Adriaansens
}

\subsection{INLEIDING}

De discussie over normen en waarden is lang een machteloze discussie geweest. Wie zich eraan waagde werd door weldenkend Nederland in een van zijn vele verdomhoekjes geplaatst: van ouderwets, jaren vijftig en theemutscultuur tot rechts, religieus, nationalistisch en intolerant. Dat was niet aardig, maar ook niet helemaal onbegrijpelijk. Want verder dan een ongericht moreel appèl kwam de discussie meestal niet en het nare van zo'n appèl is dat het alleen mensen bereikt die er geen boodschap aan (denken te) hebben. En als er al werd 'doorgepakt' naar beleidssuggesties, dan riepen die naast politieke weerstand vooral bestuurlijk medelijden op. Lik-op-stukbeleid, zero tolerance, tit-for-tat, kampementen, herinvoering van de militaire dienstplicht, sociale dienstplicht voor jongeren; het klonk allemaal zo onwerkelijk dat iedereen er gevoeglijk van uitging dat daar inderdaad nooit iets van terecht zou komen.

Toch is de discussie over waarden en normen aan het begin van deze eeuw opnieuw ontbrand. En weer is het gevoel van onveiligheid de 'trigger'. Incidenten in de sfeer van zinloos geweld, inbreuken op de private levenssfeer en vernieling van publieke goederen maken dat gevoel concreet. De roep om maatregelen werd in 2002 verkiezingsthema nummer één; geen politieke partij kon er meer omheen. In het verlengde daarvan kreeg ook het normen- en waardendebat weer actualiteitswaarde. Want zijn normen en waarden immers niet het voorportaal van gevoelens van veiligheid of onveiligheid en waarom zou niet juist ook de 'voorkant' (preventie) van het veiligheidsvraagstuk in plaats van alleen de 'achterkant' (repressie) kunnen worden aangepakt?

Blijft de vraag of het normen- en waardendebat ook ditmaal als een nachtkaars zal uitgaan en zonder gevolgen zal blijven. Eigenlijk zie je dat al gebeuren nu werkloosheid en financieringstekort weer zijn gaan opspelen, de economie in het slop zit en de oorlogen in Afghanistan en Irak de niet-economische binnenlandse problematiek naar het tweede plan hebben verdrongen. Net als eertijds bij het Rotterdamse 'opzoomeren' zijn ook de acties van vandaag - zoals de 'stadsetiquette' en 'Fatsoen moet je doen' - afhankelijk van de enthousiaste inzet van enkelen. Voor de korte termijn is dat enthousiasme prachtig en heeft het ook wel degelijk effect, maar duurzaam zijn zulke acties zelden. De vraag is dus wat er moet gebeuren om deze en dergelijke acties - en daarmee de aandacht voor normen en waarden - wél duurzaam te laten zijn. Alleen dan kunnen blijvende resultaten worden geboekt. 


\subsection{BEGRIPSMATIGE AFBAKENING}

Eerst moeten we weten waarover we spreken: een begripsmatige afbakening dus. Zo moet de noemer 'normen en waarden' tot hanteerbaardere proporties worden teruggebracht. We schieten namelijk niet op zolang de discussie gaat over het vastleggen van een lijst met regels (meestal voor anderen) die we misschien ook zelf nauwelijks in acht nemen. Toch blijkt die neiging moeilijk te onderdrukken. De vele debatten en symposia die inmiddels over dit onderwerp zijn gehouden, gingen vrijwel steeds over wat nu wel en niet hoort en waaraan mensen wel of niet zouden moeten voldoen. Om al te veel ruzies daarover te voorkomen, kon het vrijwel niet anders dan dat met algemene slogans moest worden volstaan. Al te nadrukkelijke specificatie zou onvermijdelijk op problemen stuiten. Maar normbesef heeft wel degelijk ook een minder oppervlakkige kant, een dieperliggende dimensie. Die zorgt ervoor dat het volgen van gedragsregels tot automatisme wordt, wordt verinnerlijkt. Dat heeft weer het grote voordeel dat gedrag minder afhankelijk wordt van expliciete, vaak uit nood geboren afspraken. In een normen- en waardendebat dat de pretentie van duurzaamheid heeft, dient het juist daarover te gaan: hoe zorg je dat normbesef weer een 'vanzelfsprekende', een 'verinnerlijkte' aangelegenheid wordt?

Een ander aspect van de begripsmatige afbakening ligt in de relationele en dynamische aard van de concepten. Normen zijn weliswaar een wezenlijk element van de sociale infrastructuur en kanaliseren een groot deel van het dagelijks verkeer, maar dat wil nog niet zeggen dat ze ook 'vaste waarden' zijn. Normen zijn de vertaling van waarden naar een specifieke situatie, zoals het verkeer, de kerk, het gezin, het werk. Daarmee zijn ze dus ook gevoelig voor veranderingen in die situaties. Wat ooit abnormaal is geweest, kan na verloop van tijd normaal worden en soms zelf normatief. En andersom kan wat ooit normaal was in de toekomst als volstrekt onoorbaar worden beschouwd. Zo roken we tegenwoordig niet meer in openbare ruimtes, terwijl het er nog niet zo lang geleden zelfs tot de mores behoorde dat mensen elkaar sigaretten presenteerden. De verbodsbepaling 'Gij zult niet roken in openbare gebouwen' was overigens een verlate bevestiging van een norm die al lang en breed was uitgekristalliseerd. Zo gaat dat meestal: heel wat officiële normen en gedragsregels volgen nu eenmaal een eerdere informele praktijk.

Waarden liggen een laag dieper en zijn daarmee ook 'duurzamer', minder afhankelijk van (veranderende) omstandigheden. Waar normen de concrete programma's zijn waarlangs het maatschappelijk verkeer loopt, vormen waarden als het ware de programmeertaal van het samenleven. Het probleem dat door het normen- en waardendebat wordt aangekaart, focust dan weliswaar op de overtreding van normen en gedragsregels, maar gaat in feite over de vraag of onze gemeenschappelijke waarden nog wel een passende vertaling hebben naar de dagelijkse praktijk. Als dat niet zo is, kan dat aan twee dingen liggen: de tekortschietende vertaling zelf en/of de langzame verschuiving die in ons waardepatroon kan hebben plaatsgevonden. Waarden vormen daarmee dus het eerste 
probleem, of preciezer: de mate waarin algemeen beleden waarden wel of niet de dagelijkse praktijk kunnen sturen. Dat in de discussie doorgaans de volgorde 'normen en waarden' in plaats van 'waarden en normen' wordt aangehouden, onderstreept hoe verleidelijk het is om aan de verkeerde kant te beginnen.

\subsection{DE OPKOMST VAN INDIVIDUEEL VERANTWOORDELIJKHEIDS- BESEF ALS KERNWAARDE}

Beginnen we aan de waardekant van de discussie, dan is de waarde die er naar mijn oordeel momenteel het meest uitspringt die van het individueel verantwoordelijkheidsbesef. Die waarde is in belangrijke mate kenmerkend voor de fase van maatschappelijke ontwikkeling waarin wij thans verkeren. Bovendien is ze onderscheidend, in de zin dat de normatieve accenten die daaruit voortvloeien een slag anders liggen dan we decennialang gewend zijn geweest. Ik kom daar zo op terug. Een ander voordeel is dat individueel verantwoordelijkheidsbesef ook geen 'partijdige' waarde is: hoe verschillend de concrete invullingen tussen de verschillende bevolkingsgroepen ook mogen zijn, in geen van die groepen zal het belang van individuele verantwoordelijkheid worden ontkend.

Individueel verantwoordelijkheidsbesef is als onderscheidende waarde niet uit de lucht komen vallen. Nadat in de tijd van industrialisatie en groepsemancipatie vooral collectief verantwoordelijkheidsbesef (in kerken, vakbonden, politieke partijen, enzovoorts) tot kernwaarde van de sociale infrastructuur was uitgegroeid, is onder invloed van de kennisintensivering de rol van de individuele burger steeds belangrijker geworden. Kennisintensivering van de productie heeft ervoor gezorgd dat individuele en persoonlijke kwaliteiten steeds belangrijkere productiefactoren zijn geworden. Daarmee is ook de arbeid wezenlijk van aard en kwaliteit veranderd. Dat is een constatering die het niveau van lippendienst te boven zou moeten gaan. Toch hebben belangrijke tv-rubrieken zoals NOSJournaal en Nova nog steeds de neiging om bij een item over arbeid of werkgelegenheid beelden te laten zien van mensen met helmen op die zich in dampende fabriekshallen daadwerkelijk in het zweet huns aanschijns werken. Dat is uiteraard niet meer het beeld dat bij een kennisintensieve economie past. Verreweg het grootste deel van de werkgelegenheid hoort in de categorie kennisintensieve dienstverlening: praten, onderwijzen, adviseren, bedienen, zorgen, onderzoeken, managen, handeldrijven, enzovoorts: allemaal activiteiten die de persoonlijke kwaliteiten van individuele burgers sterker naar voren halen dan in de industriële productiemodus het geval was.

In feite is de burger daarmee uit zijn 'institutionele jas' gegroeid, zonder dat hem tijdig een nieuwe jas kon worden aangemeten. Integendeel, zijn uitbraak uit de wereld van een veel collectievere soort van verantwoordelijkheid werd met een term als 'individualisering' van een sterk negatieve klank voorzien. Gedacht werd namelijk dat met de uitbraak uit de collectieve verantwoordelijkheidsstructuur ook alle besef van verantwoordelijkheid naar de achtergrond zou verdwijnen. 
Met andere woorden: de burger zou nog uitsluitend op eigenbelang uit zijn en alle interesse voor zijn omgeving verliezen. Vanuit die veronderstelling is vooral defensief geopereerd en gepoogd om de ontwikkeling naar individualisering tegen te houden. Zelf herinner ik me nog maar al te goed dat nog in 1991 de toenmalige minister van Sociale Zaken en Werkgelegenheid het WRR-rapport Een werkend perspectief (1990) terzijde schoof - en er ook niets in zijn knipselkrant over wilde lezen - omdat dat rapport 'vrouwen naar de arbeidsmarkt joeg' en de individualiseringtendens zou aanwakkeren.

Door dat soort defensiviteit is veel te weinig aandacht geschonken aan de vraag hoe individualisering maatschappelijk kon worden ingekaderd, dat wil zeggen: tot individuele verantwoordelijkheid kon worden omgeturnd. Het gebrek aan erkenning van het groeiende belang van de menselijke factor, van de behoefte om 'verschil te maken', om 'ertoe te doen', om herkend te worden en verantwoordelijkheid te dragen, heeft de samenleving als geheel op achterstand gezet. Daar ligt dan ook de belangrijkste opdracht voor hedendaags beleid op het terrein van de sociale infrastructuur: maak een maatschappelijke context waarin die nieuwe verantwoordelijkheid juist wél tot haar recht kan komen. Of anders gezegd: zorg dat de ontwikkeling van een op collectieve verantwoordelijkheid geënte verzorgingsstaat naar een civil society van individueel verantwoordelijke burgers op een ordentelijke manier gestalte krijgt.

\subsection{CONFLICT VERSUS ONVERSCHILLIGHEID}

Er is nog een reden waarom de normen- en waardendiscussie moet worden terugbracht tot een discussie over individueel verantwoordelijkheidsbesef. Op die manier kan namelijk de neiging worden onderdrukt om een soort nationale lijst van door iedereen te volgen gedragsregels op te stellen. Dat zou afbreuk doen aan de maatschappelijke diversiteit en aan de individuele behoefte om zich te onderscheiden. Het probleem is immers niet zozeer dat mensen op contrasterende manieren verantwoordelijkheid nemen voor de samenleving, maar veeleer dat ze te weinig verantwoordelijkheid nemen. Onverschilligheid en vrijblijvendheid zijn grotere problemen in het actuele normen- en waardendebat - en in de samenleving überhaupt - dan conflicterende standpunten. In termen van Zijderveld: het is vooral amoralisme dat is uitgegroeid tot 'ethos van de verzorgingsstaat', niet moralisme of immoralisme (Zijderveld 1981). We moeten dus niet denken dat zo'n debat per se consensus moet opleveren en dat conflicten en tegenstellingen altijd op tekortschietend normbesef duiden. Waarden en normen - zeker de laatste met hun grotere omloopsnelheid - komen in de maatschappelijke dynamiek van het samenleven tot stand. Dat leidt per definitie tot fricties en faseverschillen. Waar dynamiek en dialoog ontbreken - bijvoorbeeld doordat groepen in volkomen segregatie op zichzelf zijn aangewezen - kunnen die fricties tot ernstige normverschillen uitgroeien (denk aan zaken als de besnijdenis van meisjes of de eerwraak). Maar zodra die verschillen raken aan de fundamentele waarden van onze samenleving is er altijd nog het strafrecht of uiteindelijk de 
democratisch totstandgekomen grondwet die geen ruimte laat voor misverstand of voor te ver doorgevoerd cultureel relativisme.

\subsection{DUURZAME BEVORDERING VAN INDIVIDUEEL VERANTWOOR- DELIJKHEIDSBESEF}

De centrale vraag van deze bijdrage is dus hoe dit individuele verantwoordelijkheidsbesef bevorderd zou kunnen worden, anders dan via de weinig duurzame weg van het morele appèl. Juist omdat ik zo veel respect heb voor de initiatieven die her en der worden genomen en die mensen verantwoordelijkheidsbesef moeten bijbrengen, vind ik het belangrijk dat initiatieven structureel of duurzaam worden. Hoe doen we dat? Mijn antwoord op die vraag kan kort zijn: het is de doordachte inrichting van de context, de maatschappelijke organisatie waarbinnen dergelijke initiatieven het licht zien, die hen duurzaam kan maken. Mijn stelling is dat er voor het belang van de context te weinig aandacht bestaat. Natuurlijk, niemand zal - in theorie - betwijfelen dat context een belangrijke factor is in de bepaling van menselijk gedrag. Op die gedachte is zelfs een academische discipline gebouwd: de sociologie. Des te verrassender is het dat dit geluid zo zelden wordt gehoord. Zelfs de meeste sociologen laten het op dit punt afweten. Zodra individuele attributen en kwaliteiten aan bod komen - en individueel verantwoordelijkheidsbesef, normen- en waardenbesef zijn daar voorbeelden van -, bestaat de onuitroeibare neiging om die alleen vanuit een individueelpersoonlijke (psychologische of pedagogische) invalshoek te duiden. Daarmee wordt niet alleen het contextperspectief maar ook de interactie tussen beide invalshoeken veronachtzaamd. Het resultaat daarvan is ook maar al te vaak dat 'schuldigen' worden aangewezen (zoals ouders of leraren die het niet goed doen, of leerlingen, studenten en burgers in het algemeen die ongemotiveerd of 'verwend' zijn) en dat te weinig begrip ontstaat voor de omstandigheid dat individuele kwaliteiten door een maatschappelijke context ondersteund moeten worden om effectief te blijven.

Interessant in dit verband is het om te kijken naar juist dat gedeelte van de maatschappelijke infrastructuur waarvoor de overheid een grote verantwoordelijkheid draagt. Juist omdat het (semi-)publieke domein zo'n overheersende rol speelt in het leven van burgers, jong en oud (denk aan het onderwijs of de zorg), ligt het voor de hand te denken dat de daar opgedane ervaringen een belangrijke invloed hebben op de wijze waarop burgers zich gedragen. In een advies uit 2000 heeft de Raad voor Maatschappelijke Ontwikkeling (RMO) precies dat gedaan. De bevindingen waren alarmerend. Eigenlijk zei de raad: "Overheid, je kunt nu wel roepen dat burgers zich verantwoordelijker moeten opstellen, dat ze zich aan waarden en normen moeten houden, maar heb je er wel eens over nagedacht dat je misschien zelf wel - zonder het je te realiseren - de grootste verantwoordelijkheidsvervuiler bent?" Dat was bepaald een forse stellingname, maar tegelijk een die nadrukkelijk overeind gehouden kon worden. Natuurlijk wordt dan in eerste aanleg altijd gedacht aan de praktijk van gedogen (iets officieel toestaan wat offi- 
cieel is verboden) of aan het slechte voorbeeld dat overheidsvertegenwoordigers geven (van frauduleus declareren via onparlementaire uitdrukkingen gebruiken zoals 'kut-Marokkanen', 'lulverhalen' en 'gigantische rotschoppen' tot te hard rijden), maar dat is niet eens het belangrijkste. Veel belangrijker is dat op de drie belangrijkste dimensies van maatschappelijke organisatie - schaal, sturing en samenhang - overheids- en semi-overheidsorganisaties zich nauwelijks hebben aangepast aan ontwikkelingen die de individuele burger en zijn kwaliteiten in het brandpunt van de sociale infrastructuur hebben geplaatst. Terwijl herkenbaarheid en human resources steeds belangrijker zijn geworden met de veranderingen in de economische productie, overheerst in onderwijs, zorg en veiligheid nog steeds de institutionele structuur van een tijdperk waarin meer waarde werd gehecht aan collectieve dan aan individuele verantwoordelijkheid. Om die omslag te duiden zou de beroemde uitspraak van John F. Kennedy als volgt kunnen worden geparafraseerd: 'Vraag niet wat de groep voor mij betekent, maar wat ikzelf voor de groep kan betekenen.'

\subsection{DE DIMENSIES VAN MAATSCHAPPELIJKE ORGANISATIE: SCHAAL, STURING EN SAMENHANG}

Individuele burgers worden dus niet voldoende 'aangesproken' door de organisatorische context waarin zij verkeren. De aard van de context loopt niet werkelijk parallel aan de individuele behoefte om 'verschil te maken', 'ertoe te doen'. Burgers krijgen op die manier weinig kans om het kasplantje van individueel verantwoordelijkheidsbesef te cultiveren en worden welhaast uitgenodigd om tot freeriding over te gaan, dat wil zeggen: normen en waarden uit het oog te verliezen. Ze moeten sterk in hun schoenen staan om niet voor die verleiding te bezwijken. Laten we daarom die context eens nader bezien op drie essentiële dimensies van maatschappelijke organisatie, namelijk schaal, sturing en samenhang.

\section{Schaal}

In de (semi-)publieke sector wordt op het punt van schaal en schaalgrootte haast automatisch aangesloten bij een industrieel model van efficiency. In dat model is grootschaligheid de norm van efficiency, ook op die terreinen waar human resources de belangrijkste productiefactor vormen. Dat daarmee het tegendeel van efficiency wordt bereikt (om maar niet te spreken van het gebrek aan effectiviteit) begint slechts langzaam te dagen. Het paradigmatische karakter van deze praktijk moge blijken uit het feit dat onder de vlag van efficiency en kwaliteit (!) het aandeel niet-onderwijzend personeel in het hoger beroepsonderwijs is gestegen van 10 naar 43 procent. In de universiteiten was die situatie al veel eerder bereikt. En nog steeds zijn fusies aan de orde van de dag en ze worden door de officiële bekostigingsregels gestimuleerd. Ook in het voortgezet onderwijs hebben we de afgelopen decennia zo'n zelfde trend gezien. Was de gemiddelde schoolgrootte in de jaren zestig ongeveer 200-250 leerlingen, thans is die ongeveer 1400 . Het laat zich raden wat dat voor jonge mensen in hun vormende periode betekent. Als het normaal is dat je de meerderheid van je medeleerlingen niet 
kent, en ook de meerderheid van de leraren niet, dan kan dat niet anders dan een gevoel van anonimiteit en vrijblijvendheid opleveren. En dat is precies het tegenovergestelde van de behoefte ertoe te doen en herkenbaar te zijn. Overigens geldt hetzelfde in andere domeinen waar de overheid een flinke vinger in de pap heeft, zoals de zorg (al is daar kortgeleden gelukkig net de fusiepremie voor ziekenhuizen afgeschaft).

De consequentie daarvan is dat burgers in het (semi-)publieke domein niet of te weinig op hun individuele kwaliteiten en verantwoordelijkheid worden herkend en dat dan ook nauwelijks mag worden verwacht dat zij die verantwoordelijkheid zelf gaan nemen. In ieder geval worden ze daar door de context niet toe aangezet. Andersom geredeneerd zou je je er zelfs over kunnen verbazen dat nog zo veel mensen wel die verantwoordelijkheid nemen. Straks zal ik laten zien hoe op de dimensie van schaal de organisatie van de maatschappij beter aan de behoeften van de individuele burger kan worden aangepast.

\section{Sturing}

Iets dergelijks geldt ook voor de gebruikelijke sturingsmodellen. Ook op dat vlak zijn de traditionele oplossingen die van een voorbije periode. Ze passen steeds minder goed bij de behoefte van burgers aan herkenbaarheid. Hiërarchie en bureaucratie maken van de burger vooral een doorgeefluik. In het semi-publieke domein verliest de professional - en de uitvoerder of front office-werker in het algemeen - veel van zijn eigen handelingsruimte. Leraren weten allemaal wel hoe het beter kan, maar blijven ingesnoerd in een keurslijf van goedbedoelde, maar contraproductieve regels. Thuiszorgers moeten volgens haast fordistische principes hun zorg aan de man brengen en het is niet voor niets dat ook vanuit onverdachte hoek het gehele zorgstelsel als 'leninistisch' is gekenschetst. Studenten worden geconfronteerd met een voorgeprogrammeerd aanbod en het feit dat er wel 300 van die voorgeprogrammeerde trajecten zijn, doet daar hoegenaamd niets aan af. En over de hoofden van leerlingen worden onderwijsideologische tegenstellingen uitgevochten. Grootschalige organisaties zorgen ervoor dat de afstand groot wordt - tussen organisatie en cliënt, tussen professionals en hun cliënten, maar ook tussen de medewerkers binnen de organisatie. Daarmee verliest de professional aan handelingsruimte, de organisatie aan identificatievermogen en iedereen aan herkenbaarheid. Cliënt en medewerker worden er niet op hun menselijke kwaliteiten aangesproken, maar op hun functionaliteit, zonder dat men zich realiseert hoe 'functioneel' die human resources zijn geworden. Dat alles wakkert geen verantwoordelijkheidsbesef aan en heeft alleen al daarom een negatief effect op efficiency en kwaliteit.

\section{Samenhang}

Ten slotte wordt ook op het punt van maatschappelijke samenhang (sociale cohesie) gezondigd tegen de gegroeide behoefte aan individuele herkenbaarheid. En natuurlijk gaat het ook hier om institutionele regelingen die hun tijd hebben gehad: regelingen die op zichzelf het resultaat zijn van een proces van emancipatie, maar die nu geleidelijk tot ontwikkelingsbarrières zijn uitgegroeid. Zo is de 
politiek correcte gedachte dat de maatschappelijke samenhang gebaat is bij zoveel mogelijk gelijkheid vanuit sociologisch gezichtspunt net zo min vol te houden als het omgekeerde. De standaardisering uit de industriële productiemodus en de nogal bijzondere opvatting van gelijkheid en gelijke behandeling uit het verzorgingsstaatsdenken hebben ervoor gezorgd dat verschil en diversiteit met argusogen worden bekeken. Hieronder zal ik betogen dat de relatieve afwezigheid van een 'cultuur van verschil' geen recht doet aan de groeiende behoefte aan individuele herkenbaarheid en dat het confectiekarakter van ons gelijkheidsdenken beter voor een maatpakbenadering kan worden ingeruild.

Kortom: zolang de organisatie van het (semi-)publieke domein niet stoelt op de gedachte dat herkenbaarheid en bekendheid van mensen met elkaar in de moderne samenleving een productiefactor van jewelste zijn, blijft het gebrek aan verantwoordelijkheidsbesef hand in hand gaan met suboptimale prestaties, zowel economisch als sociaal. De actualiteit van het normen- en waardendebat is het beste bewijs dat de institutionele structuur achterloopt bij het toegenomen maatschappelijke belang van het individu en zijn verantwoordelijkheid.

17.7 DRIE ONTWIKKELINGSPRINCIPES VOOR SOCIALE INFRASTRUCTUUR

Vervolgens is er de vraag hoe daarin verandering kan worden gebracht. Hoe kunnen herkenbaarheid en menselijke maat in de organisatie van het publieke domein worden teruggebracht, opdat individueel verantwoordelijkheidsbesef wordt bevorderd? Op dat punt formuleerde de RMO al in 2000 drie adagia die dienst kunnen doen als ontwikkelingsprincipes voor een eigentijdse sociale infrastructuur. In verschillende adviezen daarna heeft de RMO die adagia nog eens herhaald. Opnieuw hebben ze betrekking op de dimensies van schaal, sturing en samenhang.

\section{Schaal: klein binnen groot}

Op de dimensie 'schaal' heet het adagium 'klein binnen groot'. In plaats van de gebruikelijke tegenstelling tussen groot- en kleinschaligheid van organisaties, zou de onvermijdelijke, en vaak ook functionele, grootschaligheid zo kleinschalig mogelijk georganiseerd moeten worden. Er is dus geen sprake van een terugkeer naar de romantische 'small is beautiful'-ideologie van Schumacher of van een nostalgisch terugverlangen naar de theemutsgeborgenheid van de jaren vijftig. Nee, de opgave is juist om grootschaligheid en massaliteit zo kleinschalig mogelijk te organiseren. Met andere woorden: zorg dat in grote organisaties herkenbare eenheden ontstaan, dat de primaire taakuitoefening (de front office) altijd op bekendheid met elkaar is gebaseerd en loop niet weg voor rivaliteit tussen die kleine eenheden. Alleen via zulke herkenbare eenheden worden grote scholengemeenschappen weer 'leefbaar', zijn leerlingen en leraren geen nummer, krijgen ziekenhuis en thuiszorg een menselijk gezicht en hebben medewerkers en professionals het gevoel dat ze ook werkelijk 'verschil maken', 'ertoe doen' of verant- 
woordelijk zijn. En natuurlijk kan dat goed samengaan met een grootschalige organisatie van de niet-primaire taken.

De back office van salaris- en personeelsadministratie, van ICT en van andere facilitaire diensten is doorgaans veel minder afhankelijk van herkenbaarheid. Bekendheid met de systeembeheerder, de salarisadministrateur of de leden van de raad van toezicht is nu eenmaal minder nodig dan bekendheid met de onderwijzer, leraar, leerling, student, professor, verpleegkundige of specialist. Aan dit adagium kunnen tal van concrete aanbevelingen worden gehangen. Die variëren van fusiepremies afschaffen via primaire taken herwaarderen en 'laterale' carrières mogelijk maken tot de schoolgrootte verkleinen. Deze aanbevelingen kunnen overigens naar tijd, plaats en omstandigheden sterk verschillen en de eerste resultaten ervan in de publieke sector kunnen slechts geleidelijk worden herkend. Ook zou het sociaal-wetenschappelijk onderzoek zich eens sterker op de dynamiek van 'klein binnen groot' moeten gaan richten. Tot nu toe is er weinig tot geen onderzoek gedaan naar de optimale schaalgrootte van uiteenlopende activiteiten, noch naar de vraag wanneer 'kleine' herkenbaarheid al of niet tot 'grote' betrokkenheid leidt. Een organisatievorm waardoor mensen zich niet gemakkelijk in de anonimiteit willen of kunnen terugtrekken zorgt ervoor dat zij bij voortduring door anderen op hun gedrag worden aangesproken en dat zij dat op hun beurt ook bij anderen doen. Dat is wat wordt bedoeld met 'sociale controle': het soort context waarin gedragsregels of normen ook werkelijk - en in de praktijk - gedeeld worden of ten minste onderwerp van gesprek zijn.

Interessant is in dit verband dat vooral in Angelsaksische landen tal van voorbeelden van dit adagium te vinden zijn. Zo is de Universiteit van Oxford getalsmatig even groot als bijvoorbeeld de Universiteit van Utrecht, maar doordat zij in 39 min of meer gelijksoortige colleges is georganiseerd, biedt ze haar studenten en faculty toch de gevoelswaarde van kleinschaligheid. Datzelfde geldt, zij het op iets ander niveau, voor de networks in de Verenigde Staten, zoals CBS, ABC en $\mathrm{NBC}$, die elk geworteld zijn in een veelheid van lokale en regionale stations. Of voor een van de grootste organisaties van de wereld, de Rotary, die ondanks het enorme ledenbestand van enkele miljoenen toch nergens groter is dan pakweg 35 mensen. Het is verleidelijk om te vermoeden dat de relatieve normaliteit van dit 'congregationalistische' organisatiemodel een godsdienstsociologische geschiedenis kent. Want waren het niet juist de dissenters, low-church people, met hun ingebakken congregationalistisch organisatiemodel die vanuit Engeland (via Leiden!) naar Amerika vertrokken, terwijl op het vasteland van Europa en gedeeltelijk ook in Engeland het high-church of 'episcopaalse' organisatiemodel uiteindelijk in de vorm van de verzorgingsstaat de overhand heeft gekregen? Blijkbaar is een congregationalistisch organisatiemodel - klein binnen groot - beter bestand tegen de gevaren van massificatie (zoals free-riding en anonimiteit) dan het overwegend episcopaalse organisatiemodel van de verzorgingsstaat. Dat laatste heeft nu eenmaal geen ander verweer tegen de anonimiteit van grootschalige verbanden dan het vaak machteloze morele appèl. Een cultuur van 'elkaar 
aanspreken', een civil society dus, vergt behalve mooie woorden eerst en vooral een passende organisatiestructuur, een passende context.

\section{Sturing: ruimte binnen kaders}

Het tweede adagium of ontwikkelingsprincipe betreft een accentverschuiving op het punt van sturing en verantwoording. Het luidt: 'ruimte binnen kaders'. Als de weg is vrijgemaakt voor 'klein binnen groot', ligt het voor de hand dat ook de hiërarchische verhoudingen tussen front en back office worden bijgesteld.

Net als bij het eerste adagium worden ook op deze dimensie van sociale infrastructuur twee historisch tegengestelde opvattingen over sturing met elkaar verbonden. En net als bij 'klein binnen groot' wordt ook hier de tegenstelling tussen 'nut' en 'zin' overbrugd. Dat het traditionele negentiende-eeuwse patroon van sturing - hiërarchie en bureaucratie - wordt gekritiseerd betekent niet dat wordt teruggevallen op de nostalgie of romantiek van bottom-up-sturing. Integendeel: de gedachte is juist dat alleen dan optimale handelingsvrijheid (en dus herkenbaarheid) ontstaat als de kaders van een organisatie volmaakt helder zijn afgebakend. Ruimte of handelingsvrijheid kan eigenlijk alleen maar verantwoord worden geboden als er een heldere en scherp afgebakende missie is die boven elke twijfel verheven is en bovendien streng wordt gehandhaafd. Hoewel de formulering van de missie natuurlijk ook in een democratisch of horizontaal proces tot stand kan komen, is het bestaan van een dergelijke formule in feite het top-down-element en vormt de ruimte die daardoor aan professional, uitvoerders en cliënten wordt geboden het bottom-up-element van deze eigentijdse vorm van sturing.

Onlangs is de RMO daar nog eens nader op ingegaan in zijn advies Bevrijdende Kaders (2003). Hij stelde vast dat juist het gemis van zulke kaders gemakkelijk leidt tot de bestuurlijke praktijken van 'gedogen' en 'polderen' (de kaders bij voortduring aanpassen aan de barrières waartegen in de bestuurlijke praktijk wordt aangelopen). Door die praktijken ontstaat niet alleen een ondoordringbaar woud van elkaar soms tegensprekende regels, maar wordt ook de handhaving van die regels ondergraven. Want zolang brandveiligheidsvoorschriften in Volendam of Enschede dezelfde status hebben als de voorschriften die over dakkapellen gaan, is het geen wonder dat ook met de brandveiligheid weleens de hand wordt gelicht. En waar de brandveiligheidsvoorschriften van bordelen in strijd zijn met de hygiëneregels waaraan diezelfde bordelen moeten voldoen, kan het niet anders dan dat er ten minste één set van regels moet worden overtreden.

Het onderscheid tussen kaders en ruimte maakt nog eens duidelijk wat de verschillende sturingsverantwoordelijkheden zijn van politiek respectievelijk bestuur. Politiek is er om de kaders vast te leggen, om hoofdlijnen van beleid te formuleren en erop toe te zien dat die hoofdlijnen worden ingevuld en de continuïteit van de organisatie wordt gegarandeerd. Bestuur is de feitelijke 'executieve' taak, het invullen van de hoofdlijnen van beleid. Dat is niet anders dan het 'governance'-model zoals dat in bedrijfsleven en geleidelijk ook in delen van de 
quartaire sector is gaan functioneren. Ook in het publieke domein is die lijn nog onlangs gevolgd door de commissie-Elzinga ter voorbereiding van de Wet op de Dualisering van het openbaar bestuur. Gemeenteraden en de Provinciale Staten vormen de politieke gremia die verantwoordelijk zijn voor de vaststelling van en het toezicht op de hoofdlijnen van beleid, de kaders. Tegelijkertijd hebben ze een initiatiefrecht om de hoofdlijnen van beleid te kunnen bijstellen. B en w en Gedeputeerde Staten zijn er vervolgens voor de bestuurlijke invulling van eenmaal vastgestelde hoofdlijnen. Helaas wordt 'dualisering' nogal eens verkeerd uitgelegd. Vanuit de bestaande praktijk wordt de wet soms gezien als een vrijbrief tot 'duellisering', waarbij de politieke gremia gaan meebesturen met de bestuurders en zich niet zelden tot de beste stuurlui aan de wal ontwikkelen. Dan gaan raadsleden zich bemoeien met stoeptegels en lantaarnpalen, zaken die typisch op het bord van de bestuurders en hun diensten horen te liggen. Dat zoiets gebeurt, heeft ook te maken met de omstandigheid dat in de bestuurlijke lijn niet of nauwelijks manieren van democratische verantwoording tot ontwikkeling zijn gekomen. 'Horizontalisering' noemde de RMO dat in zijn advies Bevrijdende Kaders (2003). Het parkeerbedrijf, de plantsoenendienst, de sociale dienst, enzovoorts, leggen maar zelden verantwoording af aan hun directe cliënten, waardoor klachten uiteindelijk alleen maar bij 'de politiek' kunnen worden gedropt. Die moet zich dan vervolgens wel met het bestuur gaan bemoeien, want anders lopen de kiezers straks over naar een protestpartij. Zouden er op grote schaal mogelijkheden zijn van democratische verantwoording in de bestuurlijke lijn, dan ontstaat ook de ruimte voor raadsleden, et cetera, om zich op hun politieke hoofdtaak te concentreren. Overigens zou dan ook de consequentie moeten worden getrokken om de omvang van gemeenteraden en Provinciale Staten enigszins beperkt te houden. Raden van toezicht hoeven nu eenmaal niet zo groot te zijn.

In dit licht wordt ook de discussie over de gekozen burgemeester en de gekozen minister-president interessant. De gedachte dat de politieke leider ook de eerst aangewezene zou zijn om eerste bestuurder te worden, stamt uit een denkpatroon waarin de politiek het bestuur koloniseert. Dat is in feite hetzelfde denkpatroon waardoor een min of meer boven de partijen staande bestuurder zoals de benoemde burgemeester vaak zo weinig bestuurlijke verantwoordelijkheid heeft mogen dragen.

Voor elke overheid - en in breder verband: ook voor elke leiding van een organisatie - betekent dit dat er scherper moet worden gekeken naar wat werkelijk belangrijk is, opdat optimaal kan worden geprofiteerd van de ondernemingsgeest van de individuele werkers in het veld. Dat is dan ook precies de positieve betekenis van 'terugtreden van de overheid': de overheid heroriënteert zich op haar wezenlijke missie: de kaderstelling. Daarbij laat ze burgers of organisaties van burgers binnen die missie zoveel mogelijk ruimte, maar schroomt niet om de vastgestelde kaders ook werkelijk te handhaven. Terugtreden is in dit verband wel degelijk ook 'optreden'. 
Opnieuw is daarmee een context geschapen waarin herkenbaarheid en betrokkenheid van mensen ertoe leiden dat normen en waarden en individueel verantwoordelijkheidsbesef dagelijks worden herbevestigd. Neem de leraar die binnen de doelstelling van zijn school zijn eigen opvattingen over het vak aan de man mag brengen in plaats van als doorgeefluik te moeten functioneren voor wat ergens ver weg wordt bedisseld door onderwijsideologen, politici of bewindspersonen. Die leraar weet dat er over het kader waarin zijn onderwijs totstandkomt niet gemarchandeerd kan worden, niet door hemzelf, niet door de leerlingen en niet door de schoolleiding; zo'n leraar is in ieder geval geen nummer en zal ook van zijn leerlingen geen nummers maken. Of denk aan de politieagent die met de burgers van zijn wijk heeft bepaald waar een lantaarnpaal moeten komen omwille van de veiligheid, en die dat dan ook voor elkaar kan krijgen. Zo'n agent kan vanuit zijn eigen gezag mensen op hun gedrag aanspreken in plaats van vanuit 'de-politiek-diesowieso-niet-te-vertrouwen-is'. Er zijn nog andere mechanismen die in dit verband kunnen worden aangewend en die het uitvoerende werk weer meer gezag geven. Hierboven sprak ik al over het mogelijk maken van zijwaartse carrières: waarom zouden goede verplegers of onderwijzers alleen maar carrière kunnen maken door het management in te duiken? Dit soort van horizontalisering zal er vast en zeker toe bijdragen dat de vlucht uit uitvoerende taken in de richting van het management kan worden gestopt of vertraagd.

Gelukkig is ook dit adagium niet meer geheel vreemd aan het sturingsdenken binnen het (semi-)publieke domein. Ik noemde in dat verband al het werk van de commissie-Elzinga. Daar moet echter wel één kanttekening bij worden gemaakt. Ruimte geven zonder dat de kaders helder zijn afgebakend betekent dat er extra accent komt te liggen op de noodzaak van 'rekenschap'. Toezicht op en controle van het functioneren van organisaties in het publieke domein hebben gedurende de afgelopen decennia een grote vlucht genomen. Meestal hebben ze de vorm aangenomen van 'outputmeting' op basis van kengetallen. Wat daarmee vooral wordt bereikt is dat de voorzichtige tendens om de werkers in het veld meer eigen verantwoordelijkheid te geven, meer ruimte om 'hun ding te doen', onmiddellijk weer wordt gefrustreerd. Al het onderzoek naar de wederwaardigheden van het grotestedenbeleid laat zien dat er van lokaal bepaalde creativiteit weinig overblijft zodra nationale monitors voetstoots gevolgd gaan worden. En die monitors moeten wel worden gevolgd, omdat anders subsidie kan worden misgelopen. Hoe belangrijk rekenschap en verantwoording ook zijn, het kan niet de bedoeling zijn dat de echte verantwoordelijkheid op de werkvloer onmogelijk wordt gemaakt door de protocollen die in dat kader zijn ingericht. Op die manier wordt de geboden ruimte immers onmiddellijk weer 'dichtgeregeld'.

Ten slotte zou ook het bestuurswetenschappelijke onderzoek zich nadrukkelijker moeten richten op de vraag naar de verhouding tussen kaders en ruimte. Wanneer, in welke modaliteiten en in welke omstandigheden wordt de herkenbaarheid van individuele burgers het beste gegarandeerd? Hoe scherp moeten de beleidskaders worden afgebakend, de organisatiemissie worden geformuleerd om optimale handelingsvrijheid voor medewerkers te garanderen? Wanneer is terug- 
treden ook werkelijk optreden en welke verantwoordingsmechanismen horen daarbij? Op die manier kan dit tweede adagium ook een impuls voor het onderzoek betekenen.

\section{Naar een cultuur van verschil}

Het derde adagium - 'naar een cultuur van verschil' - slaat op sociale cohesie of samenhang en betekent al evenzeer een accentwijziging ten opzichte van de beleidspraktijk van de afgelopen decennia. Het verbindt de uitersten van assimilatie en culturele nivellering met segregatie en culturele autarkie. Het benadrukt hoe belangrijk het voor de herkenbaarheid van individuele burgers is om zich te kunnen identificeren met hun omgeving, om een thuisbasis te hebben. Let wel: dat is iets anders dan 'opgaan in de groep'. Het gaat om een thuisbasis vanwaar de individuele burger zich in de samenleving begeeft. Het onderstreept dat in een pluriforme maatschappij - want dat is het - verschillen tussen groepen niet noodzakelijk tot onoverbrugbare tegenstellingen en gebrek aan cohesie hoeven te leiden.

$\mathrm{Nu}$ wordt daarin al in belangrijke mate voorzien door de beide voorgaande ontwikkelingsprincipes. Want waar de context klein genoeg is om elkaar op gedrag te kunnen aanspreken en er ruimte wordt gelaten voor eigen verantwoordelijkheid, worden de kansen op identificatie met de onmiddellijke omgeving alleen maar gunstiger. Desondanks is aparte aandacht voor de dimensie van samenhang op zijn plaats, al was het maar omdat door het adagium 'naar een cultuur van verschil' de kloof tussen beleidspraktijk en maatschappelijke werkelijkheid kan worden overbrugd. We kunnen immers niet genoeg benadrukken dat voor zo'n identificatie redelijk homogene en herkenbare omgevingen nodig zijn, omgevingen die zich op enig criterium onderscheiden van andere omgevingen en waarin mensen zich thuis kunnen voelen. De kans op automatische identificatie is daar nu eenmaal groter dan in omgevingen waarin heterogeniteit van deelnemers van hogerhand en op last van hogere ideologische principes wordt afgedwongen. In dat laatste geval wordt een veel te groot beroep gedaan op de mogelijkheden van mensen om zich over de grenzen van hun groep of omgeving heen te identificeren met mensen op afstand, zoals de Nederlander, de Europeaan of de wereldburger. Het vermogen om zich in virtuele netwerken thuis te voelen hangt sterk samen met opleidingsniveau. In een eerder advies (Aansprekend Opvoeden, 2001) heeft de RMO erop gewezen dat veel van de huidige pedagogische problematiek te maken heeft met de discontinuiteit van opvoedingscontexten: precies op het punt van de mogelijkheden voor jonge mensen om zich met hun omgeving te identificeren is de stap van gezin naar school en van school naar scholengemeenschap vaak te groot. Het is bovendien niet ondenkbaar dat die discontinuïteit voor jongeren uit bepaalde etnische groepen zo mogelijk nog groter is dan voor autochtone jongeren.

Hoe dit ook zij, te vaak wordt vergeten dat identiteit en identiteitsvorming als zodanig belangrijk zijn, ongeacht de groep of omgeving waarmee men zich identificeert. Natuurlijk zijn er ook tal van 'verkeerde' groepen waarmee men zich kan 
identificeren, maar zolang die niet door het strafrecht of de grondwet zijn verboden, geldt de plicht om die zoveel mogelijk in de maatschappelijke dialoog te betrekken. In beginsel zijn identiteit en trots het passe-partout voor deelname aan een pluriforme samenleving.

Die gedachte staat evenwel op gespannen voet met de beleidspraktijk van de laatste decennia, waarin verschil een negatieve en gelijkheid een positieve klank heeft gekregen. De positieve (maatschappelijke en persoonlijke) betekenis van verschil kon zich moeilijk staande houden in een tijd waarin het accent op het streven naar gelijkheid kwam te liggen. Daarbij kwam dat gelijkheid eerder werd begrepen in termen van 'alles over één kam scheren' dan als suum cuique tribuere (ieder het zijne geven). Op die manier wordt evenwel het kind met het badwater weggegooid en worden vooral de mogelijkheden verkleind om burgers op human resources aan te spreken. Als verschil in diskrediet wordt gebracht, raakt immers ook de mogelijkheid om 'verschil te maken', om 'ertoe te doen' of 'verantwoordelijkheid te nemen' in diskrediet.

De angst voor apartheid en de vrees voor verzuiling hebben ons daarmee bij een ander uiterste gebracht: de onherkenbaarheid en anonimiteit van afgedwongen assimilatie. Waarom zouden al die grote onderwijsinstellingen niet uiteengelegd kunnen worden in overzichtelijke en duidelijke herkenbare scholen en schooltypen? In een grote scholengemeenschap zouden de verschillende schooltypen zich ter wille van de trots en werkvreugde van leraren en leerlingen veel sterker kunnen profileren, bijvoorbeeld door een eigen gebouw, een eigen kern van docenten, eigen rituelen en een eigen cultuur. Voor heel wat jonge mensen in hun vormende periode is dit soort herkenbaarheid van groot belang. En dit betekent geenszins dat ze zich niet - nu of later - zullen inlaten met mensen van andere schooltypen, verenigingen of culturen, maar wel dat ze dit kunnen doen vanuit een beter geïnternaliseerd normen- en waardenkader. Want het hoeft geen betoog dat zoiets beter lukt in een school van 200 leerlingen dan in een van 2000 . Kenmerkend in dit verband is de relatieve afwezigheid van een betekenisvol alumnigevoel bij afgestudeerden van scholen en universiteiten. Vergelijken we dat met de Angelsaksische landen, dan valt op dat men daar niet zozeer alumnus is van een grote instelling, zoals Oxford, maar veel eerder van King's of Queen's College, onderdelen van diezelfde universiteit. Binnen de Nederlandse universitaire wereld zijn het eigenlijk uitsluitend de studentencorpora die nog zo'n alumnusgevoel kunnen opwekken; de instellingen zelf zijn dat station allang gepasseerd.

Bovendien: waarom zou het per se verkeerd zijn als een buurt of wijk zo is samengesteld dat mensen er hun leefstijl of sociaal-economische positie delen, een principe dat trouwens ook aansluit bij de wensen van veel bewoners zelf? Dan is er een basis voor de dagelijkse herbevestiging van gemeenschappelijke gedragsregels en ook voor de erkenning dat elders mogelijk andere gedragsregels gelden. Ook zou op die manier de paniek over de groei van het aantal zwarte scholen in een ander licht kunnen komen te staan. Misschien biedt in voorkomende gevallen de homogenisering van de schoolbevolking wel meer soelaas 
(want trots, herkenbaarheid, concurrentie en op het punt van het Nederlands als voertaal een gelijke startpositie) dan de verkrampte mengingsideologie tot nu toe heeft gerealiseerd. Dit alles natuurlijk onder de aanname dat een op pluriformiteit gericht integratiebeleid - dus geen assimilatie- of multicultibeleid - er werk van maakt dat zulke homogene groeperingen met elkaar in contact worden gebracht.

Toch blijkt telkens weer hoe omstreden de 'cultuur van verschil' in ons land is. Nog niet zo lang geleden zag ik een reportage op de televisie waarin een directeur van een woningcorporatie in Almere de gedachte opperde dat bepaalde bevolkingsgroepen wat hem betreft best bij elkaar mochten wonen als ze dat wilden. Meteen daartegenover werd een wethouder gezet die dat een verderfelijke gedachte vond en de directeur fors op de vingers tikte. Dat alles werd in de beste tradities van de medialogica nog verder opgeklopt door de toenmalige minister van Integratie, Roger van Boxtel, als het ware ex cathedra te laten verklaren hoe fout die directeur was. Toen ik niettemin dit voorbeeld voorhield aan een groep van 35 directeuren van welzijnsinstellingen bleken ze het allemaal van harte eens te zijn met de directeur van de woningcorporatie. Het is opvallend dat het sociaal-wetenschappelijke onderzoek in ons land zich de vraag naar het hoe, waarom en wanneer van de integratieve mogelijkheden van een cultuur van verschil zo weinig heeft gesteld.

\subsection{SLOT}

Consequente toepassing van deze drie ontwikkelingsprincipes op de organisatie van het (semi-)publieke domein zal er naar mijn stellige overtuiging toe bijdragen dat een maatschappelijke context totstandkomt die burgerinitiatieven op het vlak van normen en waarden een grotere duurzaamheid bezorgt. Daarin ligt wel degelijk een taak van de overheid, al was het maar omdat veel van de bestaande arrangementen op de dimensies van schaal, sturing en samenhang moeten worden 'ontregeld' of aangepast. Resultaat daarvan zal zijn dat het individuele verantwoordelijkheidsbesef groeit en dat daarmee de publieke ruimte verantwoordelijker wordt gebruikt. Het zal tot gevolg hebben dat burgers vanuit herkenbare identiteiten de openbare ruimte betreden en blijven betreden, dat de discussie over normen en waarden van de oppervlakte van het maatschappelijk discours doordringt tot de software van de sociale infrastructuur en zo gevolg krijgt voor de praktijk. Pas dan ontstaat een situatie waarin een moreel appèl meer is dan bidden om mooi weer en waarin het normen- en waardendebat ook werkelijk beklijft. 
NOOT

1

Dit essay is een bewerking van het eerder door de RMO gepubliceerde advies Geen woorden maar daden (RMO 20O2). 


\section{LITERATUUR}

Adriaansens, H.P.M., en A.C. Zijderveld (1981) Vrijwillig Initiatief en de Verzorgingsstaat, Deventer: Van Loghum Slaterus.

RMO (2000) Aansprekend Burgerschap, RMO-advies 10, Den Haag: Raad voor Maatschappelijke Ontwikkeling.

RMO (2001) Aansprekend Opvoeden, RMO-advies 18, Den Haag: Raad voor Maatschappelijke Ontwikkeling.

RMO (2002) Geen woorden maar daden, RMO-advies 23, Den Haag: Raad voor Maatschappelijke Ontwikkeling.

WRR (1990) Een Werkend Perspectief. Arbeidsparticipatie in de jaren '9o, WRR-rapport no. 38, Den Haag. 


\section{OVER DE AUTEURS}

Prof. dr. H. P.M. Adriaansens is voorzitter van de Raad voor Maatschappelijke Ontwikkeling (RMO) en Dean van de Roosevelt Academy.

Prof. dr. P.T. de Beer is als bijzonder hoogleraar arbeidsverhoudingen verbonden aan de Universiteit van Amsterdam en was coördinator van het WRR-project Waarden, normen en gedrag.

Drs. A. van den Berg is redacteur van Nieuwsdienst Media Update.

Dr. G. van den Brink is medewerker van het Nederlands Instituut voor Zorg en Welzijn (NIZW).

Drs. R. Bronneman-Helmers is hoofd van de onderzoeksgroep educatie en minderheden van het Sociaal en Cultureel Planbureau (SCP).

Dr. R.F.W. Diekstra is wetenschappelijk adviseur van het College van BenW van Rotterdam, lector Jeugd en Opvoeding aan de Haagse Hogeschool en columnist voor de Staatscourant.

Prof. dr.W. Groot is als hoogleraar beleid, economie en organisatie van de zorg verbonden aan de Universiteit Maastricht.

Mr. S. Harchaoui is directeur/bestuurder van FORUM, instituut voor multiculturele ontwikkeling.

Prof. dr. A. Klamer is als hoogleraar culturele economie verbonden aan de Erasmus Universiteit Rotterdam.

Dr. B. Levering is als docent/onderzoeker verbonden aan de Capaciteitsgroep Algemene Pedagogiek en Orthopedagogiek van de Faculteit Sociale Wetenschappen van de Universiteit Utrecht.

Drs. J. van Lidth de Jeude is burgemeester van Deventer.

Prof. dr. H. Maassen van den Brink is als hoogleraar economie verbonden aan de Universiteit van Amsterdam.

Mr. dr. M. Malsch is senior onderzoeker bij het Nederlands Studiecentrum Criminaliteit en Rechtshandhaving te Leiden en rechter-plaatsvervanger bij de Rechtbank Haarlem.

Prof. dr. A.M. Mol is als bijzonder hoogleraar politieke filosofie (Socrates-leerstoel) verbonden aan de Universiteit Twente. 
Dr. L.G.M. Prick is publicist en medewerker Onderwijs van NRC Handelsblad.

Dr. O. Scholten is als universitair hoofddocent communicatiewetenschap verbonden aan de Universiteit van Amsterdam en aan The Amsterdam School of Communications Research (ASCOR).

Prof. dr.mr. C.J.M. Schuyt is lid van de Wetenschappelijke Raad voor het Regeringsbeleid (WRR) en als hoogleraar sociologie verbonden aan de Universiteit van Amsterdam.

Dhr. H. Sleurink is hoofdredacteur bij Nieuwsdienst Media Update.

Prof. dr. ir. G.H. de Vries is als hoogleraar wetenschapsfilosofie en filosofie van de technologische cultuur verbonden aan de Universiteit van Amsterdam.

Prof. dr. H.E.S. Woldring is als hoogleraar politieke filosofie verbonden aan de Vrije Universiteit en is lid van de Eerste Kamer der Staten Generaal voor het CDA. 


\section{RAPPORTEN AAN DE REGERING}

\section{Eerste raadsperiode (1972-1977)}

1 Europese Unie*

2 Structuur van de Nederlandse economie*

3 Energiebeleid

Gebundeld in één publicatie (1974)*

4 Milieubeleid (1974)*

5 Bevolkingsgroei (1974)*

6 De organisatie van het openbaar bestuur (1975)*

7 Buitenlandse invloeden op Nederland: Internationale migratie (1976)*

8 Buitenlandse invloeden op Nederland: Beschikbaarheid van wetenschappelijke en technische kennis (1976)*

9 Commentaar op de Discussienota Sectorraden (1976)*

10 Commentaar op de nota Contouren van een toekomstig onderwijsbestel (1976)*

11 Overzicht externe adviesorganen van de centrale overheid (1976)*

12 Externe adviesorganen van de centrale overheid (1976)*

13 Maken wij er werk van? Verkenningen omtrent de verhouding tussen actieven en niet-actieven (1977)*

14 Interne adviesorganen van de centrale overheid (1977)*

15 De komende vijfentwintig jaar - Een toekomstverkenning voor Nederland (1977)*

16 Over sociale ongelijkheid - Een beleidsgerichte probleemverkenning (1977)*

\section{Tweede raadsperiode (1978-1982)}

17 Etnische minderheden (1979)*

A. Rapport aan de Regering

B. Naar een algemeen etnisch minderhedenbeleid?

18 Plaats en toekomst van de Nederlandse industrie (1980*

19 Beleidsgerichte toekomstverkenning

Deel 1: Een poging tot uitlokking (1980)*

Democratie en geweld. Probleemanalyse naar aanleiding van de gebeurtenissen in Amsterdam op 30 april $1980^{*}$ Vernieuwingen in het arbeidsbestel (1981)* Herwaardering van welzijnsbeleid (1982)*

Onder invloed van Duitsland. Een onderzoek naar gevoeligheid en kwetsbaarheid in de betrekkingen tussen Nederland en de Bondsrepubliek (1982)* 


\section{Derde raadsperiode (1983-1987)}

Beleidsgerichte toekomstverkenning

Deel 2: Een verruiming van perspectief (1983)*

Waarborgen voor zekerheid. Een nieuw stelsel van sociale zekerheid in hoofdlijnen (1985)

Basisvorming in het onderwijs (1986)

De onvoltooide Europese integratie (1986)

Ruimte voor groei. Kansen en bedreigingen voor de Nederlandse economie in de komende tien jaar (1987)

Op maat van het midden- en kleinbedrijf (1987)

Deel 1: Rapport aan de Regering;

Deel 2: Pre-adviezen

Cultuur zonder grenzen (1987)*

De financiering van de Europese Gemeenschap. Een interimrapport (1987)

Activerend arbeidsmarktbeleid (1987)

Overheid en toekomstonderzoek. Een inventarisatie (1988)

\section{Vierde raadsperiode (1988-1992)}

Rechtshandhaving (1988)

Allochtonenbeleid (1989)

Van de stad en de rand (1990)

Een werkend perspectief. Arbeidsparticipatie in de jaren '90 (1990)

Technologie en overheid (1990)

De onderwijsverzorging in de toekomst (1991)

Milieubeleid. Strategie, instrumenten en handhaafbaarheid (1992)

Grond voor keuzen. Vier perspectieven voor de landelijke gebieden in de Europese Gemeenschap (1992)

Ouderen voor ouderen. Demografische ontwikkelingen en beleid (1993)

\section{Vijfde raadsperiode (1993-1997)}

Duurzame risico's. Een blijvend gegeven (1994)

Orde in het binnenlands bestuur (1995) 
Zesde raadsperiode (1998-2002)

55 Generatiebewust beleid (1999)

56 Het borgen van publiek belang (2000)

57 Doorgroei van arbeidsparticipatie (2000)

58 Ontwikkelingsbeleid en goed bestuur (2001)

59 Naar een Europabrede Unie (2001)

60 Nederland als immigratiesamenleving (2001)

61 Van oude en nieuwe kennis. De gevolgen van ICT voor het kennisbeleid (2002)

62 Duurzame ontwikkeling: bestuurlijke voorwaarden voor een mobiliserend beleid (2002)

63 De toekomst van de nationale rechtsstaat (2002)

64 Beslissen over biotechnologie (2003)

65 Slagvaardigheid in de Europabrede Unie (2003)

66 Nederland handelsland. Het perspectief van de transactiekosten (2003)

67 Naar nieuwe wegen in het milieubeleid (2003)

\section{Zevende raadsperiode (2003-2007)}

68 Waarden, normen en de last van het gedrag (2003)

Rapporten aan de Regering nrs $1 \mathrm{t} / \mathrm{m} 67$ en publicaties in de reeks Voorstudies en achtergronden zijn verkrijgbaar in de boekhandel of via Sdu Klantenservice, Binckhorstlaan 403, Postbus 20014, 2500 EA 's-Gravenhage, tel. 070-3789880, fax 070-3789783.

Rapport nr. 68 is uitgegeven bij Amsterdam University Press (www.aup.nl). 


\section{VERKENNINGEN}

\section{Zevende raadsperiode (2003-2007)}

1 Jacques Pelkmans, Monika Sie Dhian Ho en Bas Limonard (red.) (2003) Nederland en de Europese grondwet* 


\title{
VOORSTUDIES EN ACHTERGRONDEN
}

\author{
Hieronder worden de publicaties uit de WRR-serie Voorstudies en achtergronden opgesomd vanaf de \\ vijfde raadsperiode. Een volledig overzicht van de voorstudies is beschikbaar op de WRR-website \\ (http://www.wrr.nl) of aan te vragen bij het bureau van de WRR (070 - 3564625$)$.
}

\section{Vijfde raadsperiode (1993-1997)}

V82

V83

V84

V85

V86

V87

V88

V89

V90

V91

V92

V93

V94

V95

V96

V97

\section{Zesde raadsperiode (1998-2002)}

V104 Krijn van Beek (1998) De ondernemende samenleving. Een verkenning van maatschappelijke verandering en implicaties voor beleid arbeid

W.G.M. Salet (1994) Om recht en staat. Een sociologische verkenning van sociale, politieke en rechtsbetrekkingen J.M. Bekkering (1994) Private verzekering van sociale risico's

C. Lambers, D.A. Lubach, M. Scheltema (1994) Versnelling juridische procedures grote projecten САнОВ (1995) Aspecten van hoger onderwijs. Een internationale inventarisatie het behoud daarvan

L. Hagendoorn e.a. (1995) Etnische verhoudingen in Midden- en Oost-Europa

H.C. Posthumus Meyjes, A. Szász, Christoph Bertram, W.F. van Eekelen (1995) Een gedifferentieerd Europa J. Rupnik e.a. (1995) Challenges in the East

J.P.H. Donner (rapporteur) (1995) Europa, wat nu?

R.M.A. Jansweijer (1996) Gouden bergen, diepe dalen: de inkomensgevolgen van een betaalbare oudedagsvoorziening W. Derksen, W.A.M. Salet (red.) (1996) Bouwen aan het binnenlands bestuur

SEO/Intomart (1996) Start-, slaag- en faalkansen van hoger opgeleide startende ondernemers

L.J. Gunning-Schepers, G.J. Kronjee and R.A. Spasoff (eds.) (1996) Fundamental Questions about the Future of Health Care

H.B.G. Ganzeboom en W.C. Ultee (red.) (1996) De sociale segmentatie van Nederland in 2015

J.C.I. de Pree (1997) Grenzen aan verandering. De verhouding tussen reorganisatie en structuurprincipes van het binnenlands bestuur

M.F. Gelok en W.M. de Jong (1997) Volatilisering in de economie

A.H. Kleinknecht, R.H. Oostendorp, M.P. Pradhan (1997) Patronen en economische effecten van flexibiliteit in de Nederlandse arbeidsverhoudingen

J.P.H. Donner (1998) Staat in beweging ecologische en maatschappelijke risico's in confrontatie en dialoog

W. Zonneveld en A. Faludi (1998) Europese integratie en de Nederlandse ruimtelijke ordening Verslag en evaluatie van de vijfde raadsperiode (1998)

W. Derksen et al. (1999) Over publieke en private verantwoordelijkheden

Henk C. van Latesteijn (1999) Land use in Europe. A methodology for policy-oriented future studies

Aart C. Liefbroer en Pearl A. Dykstra (2000) Levenslopen in verandering. Een studie naar ontwikkelingen in de levenslopen van Nederlanders geboren tussen 1900 en 1970 
V108 Bart Wissink (2000) Ontworpen en ontstaan. Een praktijktheoretische analyse van het debat over het provinciale omgevingsbeleid

V109 H. Mommaas, m.m.v. W. Knulst en M. van den Heuvel (2000) De vrijetijdsindustrie in stad en land. Een studie naar de markt van belevenissen

V110 H. Dijstelbloem en C.J.M. Schuyt, red. (2002) De publieke dimensie van kennis

V111 M.C.E. van Dam-Mieras en W.M. de Jong, red. (2002) Onderwijs voor een kennissamenleving. De rol van ICT nader bekeken

V112 Wendy Asbeek Brusse, Harry van Dalen en Bart Wissink (2002) Stad en Land in een nieuwe geografie. Maatschappelijke veranderingen en ruimtelijke dynamiek

V113 G.A. van der Knaap (2002) Stedelijke bewegingsruimte. Over veranderingen in stad en land.

V114 F.J.P.M. Hoefnagel (2002) Internet en cultuurbeleid. Over de gevolgen van ICT voor het cultuurbeleid van de Nederlandse overheid

V115 Gabriël van den Brink (2002) Mondiger of moeilijker? Een studie naar de politieke habitus van hedendaagse burgers

V116 Willem Witteveen, Bart van Klink, met bijdragen van Wouter de Been en Peter Blok (2002) De sociale rechtsstaat voorbij. Twee ontwerpen voor het huis van de rechtsstaat

V117 Rein de Wilde, Nikki Vermeulen en Mirko Reithler (2003) Bezeten van genen. Een essay over de innovatieoorlog rondom genetisch gemodificeerd voedsel

\section{Overige publicaties}

Voor de eenheid van beleid. Beschouwingen ter gelegenheid van vijftig jaar Ministerie van Algemene Zaken (1987) Eigentijds burgerschap. WRR-publicatie onder leiding van H.R. van Gunsteren (1992)

Mosterd bij de maaltijd. 20/25 jaar WRR (1997)

De vitaliteit van de nationale staat in een internationaliserende wereld (2002) 


\section{Bijdragen aan waarden en normen}

Op tal van maatschappelijke terreinen wordt gediscussieerd over waarden en normen. Dient het onderwijs onze westerse waarden en normen aan te hangen? Hangt de criminaliteit onder allochtonen samen met een 'afwijkend waarden- en normenpatroon'? Welke verantwoordelijkheid hebben de media bij de verspreiding van waarden en normen? Geven ouders wel het goede voorbeeld aan hun kinderen?

In deze bundel geeft een reeks gerenommeerde auteurs op verzoek van de Wetenschappelijke Raad voor het Regeringsbeleid hun visie op de waarden en normen, elk van hen op een specifiek terrein.

Met bijdragen van onder meer Hans Adriaansens, Gabriël van den Brink, René Diekstra, Sadik Harchaoui, Leo Prick en Henk Woldring. 